Facultad de Ciencias Jurídicas y Económicas

Departamento de Derecho Privado

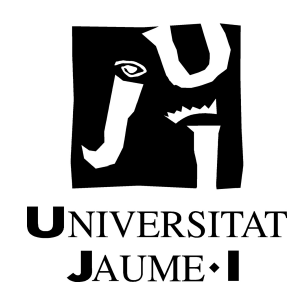

\title{
Tarik Boufous
}

\section{La posición jurídica del destinatario en el transporte de mercancías por carretera}

Tesis doctoral 



\section{ÍNDICE}

ABREVIATURAS

IX

\section{CAPÍTULO I - INTRODUCCIÓN: EL DESTINATARIO COMO TERCERO AJENO A LA RELACIÓN CONTRACTUAL DE TRANSPORTE}

\section{CAPÍTULO II - TEORÍA GENERAL DE LOS CONTRATOS CON ESTIPULACIONES A FAVOR DE TERCEROS}

I. EL PRINCIPIO DE RELATIVIDAD DE LOS CONTRATOS

II. MARCO LEGAL DE LOS CONTRATOS CON ESTIPULACIONES A FAVOR DE TERCERO EN EL ORDENAMIENTO JURÍDICO ESPAÑOL: EL ARTÍCULO 1.257, APARTADO SEGUNDO, DEL CÓDIGO CIVIL

1. Antecedentes normativos

2. Naturaleza jurídica de los contratos que favorecen a terceros $\quad 16$

$\begin{array}{ll}2.1 \mathrm{El} \text { contrato a favor de tercero } & 16\end{array}$

a) La teoría de la oferta $\quad 17$

b) La teoría de la gestión de negocios ajenos 19

c) La teoría de la adquisición directa $\quad 21$

d) La teoría de la declaración unilateral de voluntad 22

e) Recapitulación $\quad 23$

2.2 El contrato con eficacia protectora para terceros $\quad 25$

2.3 Distinción de figuras afines $\quad 32$

a) Estipulación a favor de tercero y cesión del contrato 32

b) Estipulación a favor de tercero y asunción de deuda 35

c) Estipulación a favor de tercero y gestión de negocios ajenos 37

d) Estipulación a favor de tercero y representación 40

e) Contrato a favor de tercero y contrato por persona a designar 43

3. Concepto y caracteres esenciales del contrato a favor de tercero $\quad 47$

3.1 Concepto $\quad 47$

3.2 Caracteres esenciales $\quad 51$

a) El carácter contractual de la estipulación $\quad 52$

b) El tercero es un sujeto extraño al contrato 53

c) El influjo de las voluntades de las partes y del tercero 54

4. Elementos subjetivos de los contratos a favor de tercero 56

4.1 El estipulante $\quad 56$

4.2 El promitente $\quad 58$

4.3 El beneficiario o tercero $\quad 59$

5. Consecuencias jurídicas derivadas del contrato a favor de tercero 62

5.1 La configuración jurídica de las relaciones derivadas de la estipulación a favor de tercero 
a) La relación de cobertura 63

b) La relación de valuta $\quad 65$

c) La relación de ejecución 67

5.2 El contenido de la relación de cobertura y la posición jurídica de las partes contratantes y del tercero beneficiario $\quad 70$

a) La posición jurídica de las partes contratantes $\quad 70$ aa) La posición jurídica del promitente $\quad 70$ bb) La posición jurídica del estipulante y la limitación de su libertad $\begin{array}{ll}\text { contractual } & 72\end{array}$

b) La determinación del tercero beneficiario y su sustitución $\quad 73$

c) La posición jurídica del beneficiario y la función de su aceptación 75

6. Extinción de la estipulación a favor de tercero 77

$\begin{array}{ll}\text { 6.1 La ineficacia del contrato base } & 78\end{array}$

6.2 La revocación del estipulante $\quad 80$

6.3 La renuncia del tercero $\quad 84$

7. La tipificación legal de ciertos contratos a favor de tercero 86

$\begin{array}{ll}7.1 \text { El contrato de transporte } & 87\end{array}$

$\begin{array}{ll}7.2 \text { El contrato de seguro } & 89\end{array}$

a) Seguros de daños 90

b) Seguros de personas $\quad 92$

III. EXCURSO: El CONTRATO A FAVOR DE TERCERO EN EL DERECHO COMPARADO 94

1. En el Derecho alemán 94

2. En el Derecho francés 98

3. En el Derecho italiano 101

\section{CAPÍTULO III - EL CONTRATO DE TRANSPORTE DE} MERCANCÍAS POR CARRETERA 105

$\begin{array}{ll}\text { I. INTRODUCCIÓN } & 107\end{array}$

II. NATURALEZA JURÍDICA Y CARACTERES DEL CONTRATO 108

$\begin{array}{ll}\text { 1. Naturaleza y caracteres } & 108\end{array}$

1.1 Mercantilidad del contrato 109

$\begin{array}{ll}1.2 \text { Carácter consensual } & 111\end{array}$

1.3 Otras características $\quad 112$

2. Definición del contrato de transporte 113

3. Marco legal del contrato de transporte 114

4. Relación del contrato de transporte con otros contratos 116

4.1 Compraventa internacional de mercancías 116

a) Concepto de la compraventa internacional de mercancías 117

b) Régimen jurídico de la compraventa internacional 119

c) Conexión entre los contratos de compraventa y de transporte 120 aa) La entrega de las mercancías 121

bb) La transmisión del riesgo $\quad 122$ 
4.2 El contrato de seguro de transporte 124

4.3 La comisión de transporte $\quad 126$

4.4 El contrato de depósito 129

II. PERFECCIÓN DEL CONTRATO 131

1. Modo y momento de la perfección del contrato 131

2. Las partes del contrato 132

2.1 El cargador o remitente 132

$\begin{array}{lr}2.2 \text { El porteador o transportista } & 134\end{array}$

a) Porteador contractual y efectivo 136

b) Porteadores sucesivos 137

c) El papel de los intermediarios en la contratación del transporte 137

$\begin{array}{ll}2.3 \text { El destinatario } & 139\end{array}$

III. LA DOCUMENTACIÓN DEL CONTRATO DE TRANSPORTE TERRESTRE DE MERCANCÍAS: LA CARTA DE PORTE $\quad 140$

$\begin{array}{ll}\text { 1. Aspectos generales } & 140\end{array}$

2. Naturaleza jurídica de la carta de porte y ejemplares a emitir $\quad 141$

3. Contenido de la carta de porte 144

4. Funciones de la carta de porte 146

5. La carta de porte emitida electrónicamente 151

6. Ausencia, pérdida o irregularidad de la carta de porte 153

6.1 Ausencia o pérdida $\quad 153$

6.2 Irregularidad 154

7. Comprobación de las menciones de la carta de porte con anterioridad a la recepción de las mercancías en el lugar de origen 155

IV. EL DERECHO DE DIPOSICIÓN

1. Concepto 158

2. Naturaleza jurídica del derecho de disposición 161

3. Función del derecho de disposición 163

4. Contenido del derecho de disposición y límites a su ejercicio 165

5. Titularidad del derecho de disposición 170

5.1 El derecho de disposición del cargador o remitente $\quad 170$

a) La impartición de instrucciones en caso de impedimentos al transporte y para la entrega $\quad 172$

aa) Impedimentos al transporte $\quad 172$

bb) Impedimentos para la entrega $\quad 176$

b) La extinción del derecho de disposición del cargador o remitente 181

5.2 El derecho de disposición del destinatario $\quad 183$

5.3 Sobre la posibilidad de transmitir el derecho de disposición a un tercero 


\section{CAPÍTULO IV - LA POSICIÓN JURÍDICA DEL DESTINATARIO EN EL CONTRATO DE TRANSPORTE TERRESTRE DE MERCANCÍAS185}

I. LOS POSICIÓN DEL DESTINATARIO EN LA CONFIGURACIÓN LEGAL DEL CONTRATO DE TRANSPORTE 187

1. Antecedentes históricos de la configuración de las operaciones de transporte 187

2. La aparición del destinatario en las operaciones de transporte 188

3. Consecuencias derivadas de la aparición del destinatario en el contrato de transporte 189

4. El marco estructural de la posición jurídica del destinatario: la estipulación a favor de tercero

190

4.1 La transmisión del derecho de disposición del expedidor al destinatario

190

4.2 La estipulación a favor de tercero

193

II. EL CONCEPTO DE «DESTINATARIO» EN EL DERECHO DEL TRANSPORTE 194

1. Definición del destinatario 194

2. La distinción entre partes y terceros 197

2.1 La noción de «parte» y su posición en el contrato 197

2.2 La noción de «tercero» y su posición en el contrato 199

III. DISTINCIÓN DE FIGURAS AFINES 203

1. El expedidor 203

2. El consignatario de buques 204

3. El transitario 206

IV. EL DESTINATARIO COMO COMPRADOR EN UN CONTRATO DE COMPRAVENTA DE MERCADERÍAS: EL CASO PARTICULAR DE LAS VENTAS EXW Y FOB 208

V. LOS DERECHOS DEL DESTINATARIO 210

1. Aspectos generales 210

2. El contenido y los límites de los derechos del destinatario 211

2.1 El derecho a la entrega de las mercancías $\quad 211$

2.2 El derecho a exigir la entrega del segundo ejemplar de la carta de porte $\quad 214$

2.3 El derecho al resarcimiento de los daños y perjuicios causados 215

2.4 La facultad de rehusar las mercancías $\quad 216$

2.5 El derecho de retención del transportista 218

2.6 Ejercicio del derecho a la comprobación del destinatario después de

la llegada de las mercancías al lugar de destino 220

VI. ObLIGACIONES DEL DESTINATARIO 222

1. La entrega contra reembolso 222

1.1 Concepto y naturaleza jurídica de la entrega contra reembolso 222

1.2 Régimen de responsabilidad $\quad 225$

a) La responsabilidad del cargador $\quad 225$ 
b) La responsabilidad del porteador $\quad 226$

1.3 Cuantía del reembolso y comisión de cobro 227

1.4 Cumplimiento e incumplimiento del encargo de cobrar el reembolso

a) El transportista ha cumplido su encargo de percibir el reembolso del destinatario

b) Incumplimiento del encargo de cobrar el reembolso

231

1.5 El límite indemnizatorio y la prescripción de las reclamaciones por reembolso

1.6 La acción de repetición del porteador frente al destinatario 235

2. Otras obligaciones del destinatario

2.1 Expedición de un justificante que documente la entrega 237

2.2 El pago del precio y de los gastos del transporte 238

a) Las condiciones para la reclamación de portes y gastos 242

b) El contenido de la obligación de pagar los portes y gastos 243

c) La prestación de caución suficiente $\quad 246$

2.3 Desestiba, descarga y manipulación de las mercancías 247

VII. INCIDENCIA DE LOS IMPEDIMENTOS PARA EL TRANSPORTE Y LA ENTREGA 250

1. Los impedimentos para el transporte 250

2. Los impedimentos para la entrega 252

2.1 El transportista no logra localizar el domicilio del destinatario o éste no se encuentra en él

2.2 El destinatario no se hace cargo de la mercancía en las condiciones establecidas en el contrato $\quad 256$

a) El destinatario se retrasa en la aceptación de la entrega $\quad 256$

b) El destinatario rechaza la entrega de las mercancías 257

c) El destinatario se niega a pagar el precio del transporte $\quad 259$

d) El destinatario se niega a pagar los gastos del transporte $\quad 261$

e) El destinatario se niega a pagar el reembolso 262

f) El destinatario pretende aplazar la fecha de entrega 263

2.3 El destinatario se niega a desestibar o a descargar las mercancías 264

$2.4 \mathrm{El}$ destinatario se niega a expedir o firmar el documento de entrega

VIII. LA RESPONSABILIDAD DEL PORTEADOR: HECHOS QUE DAN LUGAR A SU RESPONSABILIDAD FRENTE AL DESTINATARIO

1. Averías

2. Pérdidas

3. Retraso

3.1 Se ha fijado un plazo de entrega

3.2 No se ha pactado plazo de entrega: el plazo «razonable»

3.3 El llamado «deje de cuenta»

a) Ejercicio del derecho

b) Consecuencias 
IX. EFECTOS DE LA ENTREGA Y DE LA FALTA DE ENTREGA DE LAS MERCANCÍAS AL DESTINATARIO 278

1. Efectos para el porteador, en particular, su actuación en caso de impedimentos al transporte o a la entrega

1.1 La petición de instrucciones al cargador $\quad 279$

1.2 El depósito de las mercancías $\quad 281$

a) El depósito judicial y notarial $\quad 284$

b) El depósito ante las Juntas Arbitrales del transporte $\quad 285$

c) Entrega de las mercancías en depósito a un tercero 290

1.3 La venta de las mercancías $\quad 291$

a) Supuestos en los que procede la venta de las mercancías 292 aa) Riesgo de pérdida de la carga por su naturaleza perecedera o por su estado $\quad 292$

bb) Gastos de custodia desproporcionados 293

cc) Falta de instrucciones $\quad 294$

b) Venta judicial o notarial 295

c) Venta por vía arbitral 296

2. Efectos para el destinatario 300

2.1 Aspectos generales 300

2.2 Reservas y reclamaciones 301

2.3 Prescripción de las reclamaciones nacidas del contrato de transporte

a) Supuestos de pérdida parcial, avería de la mercancía y retraso en la $\begin{array}{ll}\text { entrega } & 309\end{array}$

b) Supuestos de pérdida total de la mercancía 311

c) Inicio del cómputo en los restantes supuestos de reclamación 313

d) Problemas derivados de la fijación de un único plazo de prescripción para todas las acciones nacidas del contrato de transporte $\quad 314$

e) Interrupción y suspensión de la prescripción 316

f) La prescripción entre porteadores 321

X. Cuestiones DE LEgITIMACión EN EL CONTRATO DE TRANSPORTE 323

1. Legitimación activa 324

2. Legitimación pasiva 329

2.1 Aspectos generales 329

2.2 La legitimación pasiva en el contrato de transporte sucesivo 331

a) Ejercicio de la acción en el transporte sucesivo 335

b) Acción de repetición entre porteadores sucesivos 336

aa) Consideraciones generales 336

bb) Legitimados pasivos de la acción de repetición 337 
JURISPRUDENCIA

1. JURISPRUDENCIA ESPAÑOLA

1.1 Tribunal Supremo

1.2 Audiencias Provinciales 368

2. JURISPRUDENCIA COMPARADA 369 



\section{ABREVIATURAS}

\begin{tabular}{|c|c|}
\hline AA.VV. & Autores varios \\
\hline$A C$ & Aranzadi Civil \\
\hline$A D C$ & Anuario de Derecho Civil \\
\hline$A D M$ & Anuario de Derecho Marítimo \\
\hline $\operatorname{art}(\mathrm{s})$. & artículo(s) \\
\hline$B G B$ & Bürgerliches Gesetzbuch (Código civil alemán) \\
\hline$B G H$ & Bundesgerichtshof (Tribunal Federal alemán) \\
\hline $\mathrm{CE} / \mathrm{UE}$ & Comunidad Europea / Unión Europea \\
\hline coord. & coordinador \\
\hline $\mathrm{Cc}$ & Código civil \\
\hline Ccom & Código de comercio \\
\hline CCI & Cámara de Comercio Internacional \\
\hline cl. & cláusula \\
\hline COD & cash on delivery \\
\hline CISG & $\begin{array}{l}\text { Convención de las Naciones Unidas sobre los Contratos de Compraven- } \\
\text { ta Internacional de Mercaderías, hecha en Viena el } 11 \text { de abril de } 1980\end{array}$ \\
\hline $\mathrm{CP}$ & Código penal \\
\hline $\operatorname{dir}(s)$ & director(es) \\
\hline DTM & Documento de Transporte Marítimo / Multimodal \\
\hline ed. & edición \\
\hline EXW & ex-works \\
\hline FBL & FIATA Multimodal Transport Bill of Lading \\
\hline FWB & FIATA Multimodal Transport Waybill \\
\hline FETEIA & $\begin{array}{l}\text { Federación Española de Transitarios, Expedidores Internacionales y } \\
\text { Asimilados }\end{array}$ \\
\hline FIATA & $\begin{array}{l}\text { Fédération Internationale des Associations des Transitaires et } \\
\text { Assimilés }\end{array}$ \\
\hline FOB & free on board \\
\hline FOM & Ministerio de Fomento \\
\hline INCOTERMS & $\begin{array}{l}\text { International Commercial Terms de la Cámara de Comercio } \\
\text { Internacional (2010) }\end{array}$ \\
\hline LCA & Ley 12/1992, de 27 de mayo, sobre Contrato de Agencia \\
\hline LCS & Ley 50/1980, de 8 de octubre, de Contrato de Seguro \\
\hline LCTTM & $\begin{array}{l}\text { Ley 15/2009, de } 11 \text { de noviembre, del Contrato de Transporte Terrestre } \\
\text { de Mercancías }\end{array}$ \\
\hline LJV & Ley 15/2015, de 2 de julio, de la Jurisdicción Voluntaria \\
\hline
\end{tabular}


LN

LNM

LOTT

LEC

núm.

cit.

$\mathrm{OM}$

p. / pp.

OTM

POD

RJ

ROTT

$R D M$

$R G D$

RTDciv

RU CIM

S(s)AP

S(s)TS

SS.

T.

Trad.

Traducción

UNCITRAL United Nations Commission on International Trade Law / Comisión de las Naciones Unidas para el Derecho Mercantil Internacional

UNIDROIT Institut pour l'Unification du Droit Privé / Instituto para la Unificación del Derecho Privado

Vid.

Vol.

Ley del Notariado de 28 de mayo de 1862

Ley 14/2014, de 24 de julio, de Navegación marítima

Ley 16/1987, de 30 de julio, de Ordenación de los Transportes Terrestres

Ley 1/2000, de 7 de enero, de Enjuiciamiento Civil

número

obra citada

Orden Ministerial

página / páginas

Operador de Transporte Multimodal

pay on delivery

Repertorio de Jurisprudencia Aranzadi

Reglamento de la Ley de Ordenación de los Transportes Terrestres, aprobado por Real Decreto 1211/1990, de 28 de septiembre

Revista de Derecho Mercantil

Revista General de Derecho

Revue Trimestrielle de Droit Civil

Reglas Uniformes relativas al Contrato de Transporte Internacional de Mercancías por Ferrocarril, Apéndice $\mathrm{B}$ del Convenio relativo a los Transportes Internacionales por Ferrocarril (COTIF) de 9 de mayo de 1980, en la versión dada por el Protocolo de Vilna de 3 de junio de 1999

Sentencia(s) de la Audiencia Provincial

Sentencia(s) del Tribunal Supremo

siguientes

Tomo

Véase

Volumen 


\section{CAPÍtULO I}

\section{INTRODUCCIÓN: \\ EL DESTINATARIO COMO TERCERO AJENO A LA RELACIÓN CONTRACTUAL DE TRANSPORTE}



Conforme a lo dispuesto en la Ley 15/2009, de 11 de noviembre de 2009, del contrato de transporte terrestre de mercancías (en adelante, LCTTM), el contrato de transporte de mercancías es celebrado por dos personas, el cargador y el porteador o transportista ${ }^{1}$. La prestación característica es la del transportista, el cual se compromete a desplazar la carga de un lugar a otro y entregarla al acreedor del transporte. Este último puede serlo tanto el propio cargador como un tercero ajeno al contrato de transporte ${ }^{2}$, aunque lo más habitual es que se designe otra persona para recibir el envío. La persona a la que debe entregarse la mercancía en destino, con independencia de que se trate del propio cargador o de un tercero, se denomina «destinatario» 3 .

Escasos problemas plantean aquellos casos en que el destinatario es el propio cargador, pues es parte él mismo en el contrato de transporte 4 . Ello sucede, por ejemplo, cuando el cargador pacta con el porteador el transporte de sus propias mercaderías desde el establecimiento principal a una sucursal para su comercialización5. No así, en cambio, cuando el destinatario es un tercero ajeno a la relación contractual, único supuesto que será objeto de estudio aquí. En efecto, desde el punto de vista dogmático se trata de una de las cuestiones más controvertidas en relación al contrato de transporte de mercancías.

La posición jurídica del destinatario como sujeto que no forma parte de la relación contractual de transporte ha sido analizada desde diversos puntos de vista, intentándose dar respuesta a la pregunta acerca de la naturaleza jurídica

${ }^{1}$ Así lo establece claramente su artículo 4.1, cuando dispone que «[c]argador es quien contrata en nombre propio la realización de un transporte y frente al cual el porteador se obliga a efectuarlo». Por su parte, el «[p]orteador es quien asume la obligación de realizar el transporte en nombre propio».

${ }^{2}$ En este sentido se expresa ya A. AsQuINI, Del contratto di trasporto, en L. Bolaffio y C. Vivante (coords.), II Codice di Commercio commentato, vol. VI.2, 5. ${ }^{\text {a }}$ ed., UTET, Turín, 1925, pp. 128 y ss.

3 De acuerdo con la amplia definición legal del término «destinatario» en el artículo 4.3 LCTTM, se trata de la "persona a quien el porteador ha de entregar las mercancías en el lugar de destino».

${ }^{4}$ En este caso, debería mencionarse en la carta de porte que el cargador y el destinatario coinciden en una misma persona, para evitar la imposibilidad de conocer a quién debe hacerse la entrega por parte del porteador.

${ }^{5}$ Lo mismo puede suceder en caso de que lo que se contrate sea una mudanza, posibilidad esta que fue admitida expresamente por la STS de 2 de diciembre 1975 (RJ 1975, 4319). 
de su relación con el cargador y el transportista, partes contratantes desde el principio, mientras que aquél no interviene en la conclusión del contrato.

Son muchas las teorías que se han elaborado sobre la posición jurídica del destinatario: desde quienes entienden que el destinatario es representado por el cargador en el momento en el que éste concluye el contrato, hasta quienes defienden que el destinatario adquiere sus derechos por cesión de los que corresponden al cargador. Otros, en fin, consideran que lo que se produce es una delegación de crédito a favor del beneficiario (el destinatario). Con todo, como habrá ocasión de exponer más adelante, la opinión que hoy prevalece es la que se basa en la consideración del contrato de transporte como negocio jurídico que encierra una estipulación a favor de tercero (en Derecho español, art. 1.257 $\left.2^{\mathrm{a}} \mathrm{Cc}\right)^{6}$.

Partiendo de cuanto ha quedado dicho se infiere que la cuestión esencial radica en determinar la posición jurídica del destinatario, esto es, en virtud de qué figura jurídica y de qué forma participa éste en una relación contractual que le es ajena, nacida entre el transportista y el cargador. Esta configuración es, por tanto, un elemento esencial para determinar la adecuada aplicación del régimen jurídico del contrato de transporte a la persona del destinatario, quien de manera definitiva deviene titular de ciertos derechos desde el momento en que acepta la estipulación hecha a su favor por las partes en el contrato de transporte. Ello es especialmente relevante porque, en última instancia, el destinatario puede ostentar legitimación activa para reclamar del transportista la indemnización debida en caso de pérdida o avería de las mercancías, o por una entrega más allá del plazo fijado o razonable. En este sentido, si bien el destinatario es, en los casos aquí contemplados, un tercero ajeno inicialmente a la relación contractual entre transportista y cargador, puede no obstante ejercer en su propio nombre los derechos que deriven del contrato de transporte, adquiriendo legitimación activa para reclamarlos frente al porteador. Para ello será necesario, sin embargo, que previamente manifieste su consentimiento para recibir las mercancías y, en su caso, pagar los portes y gastos.

${ }^{6}$ Véase, entre otros muchos, A. ASQUini, Del contratto.., cit., pp. 129 y ss.; así como A. RECALDE CASTELLS, «La posición jurídica del destinatario en el contrato de transporte de mercancías», RDT, núm. 6, 2010, p. 203. 
A lo largo de las páginas que siguen, se abordarán distintos temas de especial relevancia con respecto a la posición jurídica del destinatario. La primera parte del estudio se consagrará al análisis de aquellos aspectos de la teoría general de las obligaciones y contratos que contemplan la existencia de terceros ajenos a la relación contractual, con especial énfasis en aquellos negocios jurídicos que contengan estipulaciones a favor de tercero, en la medida en que es esta la modalidad contractual en la que suele encuadrarse el contrato de transporte (al menos cuando el cargador y el destinatario sean personas diferentes). A la luz de las conclusiones de esta parte se pondrá de relieve las consecuencias de la consideración del contrato de transporte como contrato a favor de otro. En efecto, ha sido siempre admitido que el contrato de transporte sirve al destinatario, que a través de éste se va a beneficiar de su ejecución.

Además, y como se ha dicho, el destinatario podrá dirigir frente al porteador las acciones de responsabilidad en caso de pérdidas, averías y retrasos en la entrega, aunque no hubiera participado en la celebración de dicho contrato. En particular, tratará de darse respuesta fundada a las siguientes cuestiones: ¿Cómo se traduce jurídicamente el nacimiento de derechos en cabeza del destinatario?; ¿de quién y cómo recibe sus derechos?; y ¿cuáles son esos derechos del destinatario y qué cargas debe asumir para hacerlos efectivos? A ello se dedica el último capítulo de este trabajo. 



\title{
CAPÍtulo II
}

\section{TEORÍA GENERAL DE LOS CONTRATOS CON ESTIPULACIONES}

\author{
A FAVOR DE TERCEROS
}





\section{El principio de relatividad de los contratos}

El sistema contractual actual tiene su punto de partida en la concepción individualista denominada «voluntarismo jurídico», en el que la libertad se configura como un derecho esencial y natural del que surge una obligación derivada. Por lo tanto, la existencia de una relación obligatoria sólo puede surgir de un comportamiento soberano de la voluntad. La naturaleza de esta obligación supone «autoobligarse», cuando la intención de las partes contratantes es someterse a un poder jurídico por consensu7. Así pues, el contrato se explica como fruto de la autonomía privada que se convierte en eje para vertebrar todos los derechos, así como las obligaciones8.

Históricamente, la estructuración de la sociedad civil va surgiendo con la creación de las instituciones de la época romana, de cuya evolución surge el contrato, que se considera como el centro y origen de todos los derechos patrimoniales, dado que - desde el punto de vista jurídico- desempeña un papel instrumental, necesario para intercambiar bienes, a la vez que da lugar al nacimiento del Derecho privado tal y como lo conocemos hoy en día. Así, los bienes y las prestaciones entre los individuos constituyen un motor de la evolución de la sociedad y del desarrollo humano. El ser humano, mediante esta vinculación contractual, se expresa a sí mismo9, es decir, entra a participar en la vida eco-

7 El fundamento de este término se halla en la teoría del «contrato social», cuyo rasgo fundamental radica en la filosofía política moderna de J.J. RouSSEAU, a través del cual podía definirse la relación mutua de los seres humanos como aquel acto de la libre decisión individual dirigido a instaurar efectos legales y obligarse en virtud del mismo. Quien formuló la teoría se limitó, pues, a excluir toda intervención política del gobierno que pueda incidir las libertades privadas o limitarlas. La finalidad es la de establecer una sociedad estructuralmente bien configurada sobre la base de los derechos humanos. Al respecto véase A. TruYol y SERrA, Historia de la filosofía del Derecho y del Estado, 2. Del Renacimiento a Kant, $3^{\text {a }}$ ed., Alianza Editorial, Madrid, 1988, p. 349.

8 L. DíEz-PICAZo, Fundamentos del derecho civil patrimonial. I. Introducción. Teoría del contrato, Thomson-Civitas, Cizur Menor, 2007, p. 140.

9 Así, KANT estableció en su filosofía sobre la autonomía de la voluntad que, cuando nos dirigimos moralmente al fundamento de determinación de nuestra voluntad, no se nos inspira desde fuera, desde el mundo exterior o desde la religión, sino desde nosotros mismos. Quiere decirse con ello que el individuo viene considerado como un fin en sí mismo y no como un instrumento, como una persona apta para ser titular de derechos y obligaciones. Según la afirmación kantiana sobre la práctica de esa razón el ser humano es autónomo porque la ley a la que nos sometemos ya está en nosotros mismos. Cfr. J.I. RODRÍGUEZ GONZÁLEZ, El principio de relatividad de los contratos en el Derecho español, Colex, Madrid, 2000, p. 14. 
nómica y jurídica como manifestación de su libertad. Desde un punto de vista histórico, en el Derecho romano la vinculación jurídica entre las partes contratantes no era vista como un contrato, sino como un «vinculum iuris» que sólo después se conceptuaría de forma contractual ${ }^{10}$. De ahí nació el llamado «principio de relatividad de los contratos», cuyo contenido sustancial se traduce de la siguiente manera: el acto celebrado entre unos no puede ni perjudicar ni beneficiar a otros ${ }^{11}$. Es más, el principio de relatividad es una de las bases sobre las que se construye el concepto mismo de contrato.

En efecto, el alcance de este principio no puede extender su eficacia jurídica más allá de las mismas partes contratantes, ya que el vínculo contractual establece, precisamente, la esfera de las partes contratantes como límite a sus efectos. En este contexto, señala DíEz-Picazo que «la regla contractual así concebida sólo puede vincular a sus autores, si vinculara a otras personas, dejaría de ser verdadera regla de autonomía privada y para los vinculados no autores constituiría un precepto heterónomo». La voluntad es, pues, la piedra angular del principio de relatividad, cuyo objeto es garantizar que las obligaciones y derechos que deriven del contrato sólo vinculen a quienes hayan participado y consentido en su celebración.

La relatividad del contrato viene consagrada en el inciso $1^{\circ}$ del artículo 1.257 del Código civil, que enuncia textualmente que «los contratos sólo producen efectos entre las partes que los otorgan y sus herederos» ${ }^{12}$. En este breve precepto descansa el principio de relatividad ${ }^{13}$ de las obligaciones contractuales. Como éstas derivan del contrato celebrado por las partes, no pueden quedar obligados quienes no expresen su consentimiento y, con ello, se conviertan en parte de la relación negocial. Lo acordado produce efectos entre las partes, el

\footnotetext{
${ }^{10}$ J.I. RodRíGUEZ GONZÁLEZ, El principio de relatividad..., cit., p. 14.

${ }^{11}$ La máxima romana ha llegado a nuestros días a través de la fórmula justiniana «res inter alios acta aliis nec nocere nec prodesse potest», que pone de relieve el origen del principio de relatividad contractual en el Derecho romano.

12 Es obvio que la eficacia del vínculo obligatorio nacido del contrato queda limitada a las partes que han intervenido en su celebración, y ésta se extiende únicamente a los herederos, como consecuencia de la sucesión universal en los derechos y obligaciones del causahabiente que provoca la aceptación de la herencia.
}

${ }^{13}$ En terminología anglosajona se emplea la expresión «privity of contract». 
contrato es res inter alios acta para los terceros, a los que ni daña (nec nocet) ni beneficia (nec prodest) ${ }^{14}$.

Marcado por la impronta romanista reflejada en el primer párrafo del artículo $1.257 \mathrm{Cc}$, el principio de relatividad hace referencia a una eficacia normativa interna del contrato. No obstante, con el desarrollo de la sociedad y el auge comercial, a través de distintas construcciones dogmáticas realizadas en la doctrina y jurisprudencia modernas, esta eficacia se ha interpretado de forma mucho más amplia. Tras someter a revisión el principio de relatividad, se entiende que el contrato produce ciertos efectos en la esfera jurídica ajena al contrato, excepciones $^{15}$, entre las que figuran los efectos externos del contrato ${ }^{16}$. Esta eficacia externa de los contratos se proyecta más allá de los contratantes, ampliándose su alcance para comprender también los actos jurídicos frente a terceros ${ }^{17}$. Así surge el tercero como parte (inicialmente) extraña, pero beneficiario del denominado «contrato a favor de tercero», configurado como una excepción al principio de relatividad del contrato celebrado.

\section{Marco legal de los contratos con estipulaciones a favor de tercero en el ordenamiento jurídico español: el artículo 1.257, apartado segundo, del Código Civil}

\section{Antecedentes normativos}

Tras el análisis comparado por la doctrina científica clásica y moderna consagrada en los códigos francés, italiano y alemán se pone de relieve cómo se pudo integrar en el sistema contractual un genuino cuerpo extraño respecto de su

14 Á. CARRASCO PERERA, Derecho de contratos, Aranzadi, Cizur Menor, 2010, p. 599.

${ }^{15}$ No existe acuerdo sobre el número de excepciones, ni tampoco un criterio acreditado para identificarlas. Con todo, la nota común, como señale I. GonZÁlEZ PACANOWSKA, ha de buscarse en la idea de que un tercero que no ha participado en la formación del contrato adquiere, no obstante, legitimación, por el rigor de la ley o por un segundo acto negocial, para reclamar sus derechos, o bien es obligado de manera directa a su ejecución. Vid. su "Comentario al artículo $1275 \mathrm{Cc}$ », en Aa.V., Comentarios al Código civil y Compilaciones forales, T. XVII, $1^{\circ}$ A, 1993, p. 326.

16 P. JimÉNEZ BlanCo, El contrato internacional a favor de tercero, Universidad de Santiago de Compostela, 2002, p. 33.

${ }^{17}$ J. LÓPEZ RICHART, Los contratos a favor de terceros, tesis doctoral, Alicante, 2001, p. 172. 
configuración dogmática, como es la estipulación a favor de tercero. Cabe señalar que el contrato a favor de tercero representa una novedad introducida en los códigos civiles decimonónicos, dado que bajo el Derecho Romano regía la norma según la cual nem alteri stipulari potest, que prohibía cualquier ampliación de los efectos de un contrato a un tercero que originariamente no había intervenido en su celebración.

La regla aludida impedía también la generación de efectos directos e inmediatos para el representado, es decir, la adquisición de derechos por el tercero ${ }^{18}$. Así, la actividad gestora de un representante debía hacerse siempre de forma indirecta, el representante quedaba obligado o adquiría derechos personalmente frente a la persona con la que pactaba; obligaciones o derechos que aquél debía transmitir después al representado o dominus negotii. De ello queda patente que la idea que subyace a la regla nem alteri stipulari potest impedía que se creasen de manera inmediata derechos a favor de terceros ${ }^{19}$.

La superación de este principio se produjo por las mismas necesidades de la vida económica y social que las que impulsaron la evolución del Derecho canónico ${ }^{20}$, en el que se admitió, en cierta medida, la posibilidad de estipular pactos en beneficio de terceros. Pero este tipo de estipulación -como señala DíEzPICAZO- no es más que un contrato en el que el tercero es un representado y el estipulante un gestor ${ }^{21}$. En efecto, el paso decisivo no se produciría hasta después de la llegada de la escuela de Derecho natural: la obra de Grocio demostró la diferencia conceptual que existe entre el acto de la representación directa y la estipulación a favor de tercero, y reconoció la validez de ambos, inspirándose en el poder omnímodo de la voluntad individual ${ }^{22}$.

${ }^{18}$ I. GonZÁlez PACANOWSKA, «Comentario... », cit., pp. 379 y ss.

${ }^{19}$ L. DíEZ-PicAzo, Fundamentos..., Vol. I., cit., p. 535.

${ }^{20}$ Así, bajo la influencia de la escuela de los glosadores y comentaristas, la admisión de la figura de la representación tuvo cierto reconocimiento en Las Siete Partidas de Alfonso X, que consideraban válida (y no comportaba, por tanto, la nulidad del negocio jurídico celebrado) la representación basada sobre una actuación en nombre ajeno fuera de juicio («personero»), con la condición de que ese «personero» otorgara sus acciones y derechos a aquél en cuyo nombre actuaba. Sobre esta cuestión vide J. LÓPEZ RICHART, Los contratos a favor de terceros, cit., p. 31 y ss.

${ }^{21}$ L. DíEZ-PiCAZO, Fundamentos..., Vol. I, cit., p. 535.

${ }^{22}$ Véase I. GonZÁLEZ PACANOWSKA, «Comentario...», cit., p. 380. 
En esta evolución histórica de la figura de la estipulación a favor de parte ajena marca un punto de inflexión el Código civil francés que, por influencia de las enseñanzas de POTHIER, reflejó en sus artículos $1.119^{23}$ y $1.121^{24}$ (hoy derogados) ${ }^{25}$ la nulidad de la estipulación a favor de tercero, salvo que tal estipulación estuviera ligada con el contrato principal. Así, resultaba nula una estipulación a favor de tercero si no estaba incluida en un contrato «ordinario». Esta estipulación, en suma, no era más que un componente de carácter accidental derivado del contrato ${ }^{26}$, o una prestación accesoria del mismo por la que el promitente quedaba obligado frente al estipulante ${ }^{27}$.

En la práctica, fue la Cour de Cassation francesa la que ayudó a los juristas teóricos a configurar el contrato a favor de tercero como categoría jurídica ${ }^{28}$. El Alto Tribunal, al tratar esta figura, dio el primer paso hacia la admisión general de este tipo contractual en una sentencia de la Sala civil de 16 de enero de 1888, al interpretar las excepciones recogidas en el artículo 1.121 del Code civil. A su juicio, la estipulación a favor de tercero resultaba válida siempre que el estipulante tuviera un interés personal en esta estipulación. Con ello, la Corte anuló la condición restrictiva de que dicho interés fuera de carácter patrimonial y afirmó que era suficiente mostrar un simple interés, incluso moral o afectivo 29.

En la misma línea se posicionó el Codice civile italiano de $1942^{30}$, que contiene una regulación general del contrato a favor de tercero en sus artículos 1.411 a 1.413 y disciplina, a su vez, numerosos casos concretos de este tipo con-

23 «On ne peut, en général, s'engager, ni stipuler en son propre nom, que pour soi-même».

24 Comienza señalando el Code en su art. 1.120 del Code que, «[n]éanmoins, on peut se porter fort pour un tiers, en promettant le fait de celui-ci» y establece, en el art. 1.121, que «[o]n peut pareillement stipuler au profit d'un tiers lorsque telle est la condition d'une stipulation que l'on fait pour soi-même ou d'une donation que l'on fait à un autre».

${ }_{25}$ Como habrá ocasión de señalar, las reglas que disciplinaban la estipulación a favor de tercero han sido objeto de una revisión en profundidad en el año 2016 (infra, sub III.2).

26 J.I. CANO MARTínez DE VELASCO, El contrato a favor de tercero: El seguro de vida, Cálamo, España, 1999, p. 31.

${ }_{27}$ Por ejemplo, «cuando al vender un fundo me hago prometer que una parte del precio será pagada a un tercero». El ejemplo es de J. LÓPEZ RICHART, Los contratos..., cit., p. 73.

28 J.I. CANO MARTínez De Velasco, El contrato..., cit., p. 31.

29 J. LÓPEZ RICHART, Los contratos..., cit., p. 76.

$3^{\circ} \mathrm{El}$ anterior de 1865 aún contenía una regulación prácticamente idéntica a la del Code civil francés en su redacción original. 
tractual31. Sólo genera obligaciones a cargo del promitente y en beneficio del tercero, que adquiere en virtud del contrato un derecho propio y directo frente a aquél (y no frente al estipulante). No obstante, se sigue el criterio establecido en el entonces artículo 1.121 del Código civil francés ${ }^{32}$, en el sentido de que cabe la revocación de la estipulación, siempre que se produzca antes de que el beneficiario haya expresado su voluntad de «volerne profittare» (art. 1.411)33.

Por su parte, en Derecho alemán la regulación jurídica del contrato a favor de tercero se contiene en el $§ 328$ del Bürgerliches Gesetzbuch (BGB)34 como regla general, no por tanto como en el código francés antes de la reforma de 2016, o en el italiano de 1865, que han concebían la estipulación a favor de tercero como una cláusula accesoria o accidental de otro contrato principal. En efecto, el legislador alemán ha configurado el sistema de la estipulación mediante su individualización como un contrato a favor de tercero, en virtud del cual el tercero adquiere un derecho de crédito que surge directamente del contrato y que le legitima para exigir el cumplimiento de la prestación (§ 328.1 BGB) 35 .

En el ordenamiento español, la figura de la estipulación a favor de tercero se mencionaba en la Novísima Recopilación de las Leyes de España (1805)36,

${ }^{31}$ En el Código civil italiano pertenecen a la categoría de los contratos a favor de tercero los siguientes supuestos: el transporte de cosas a favor de tercero (art. 1.689); la renta vitalicia a favor de tercero (art. 1.875); el seguro de vida a favor de tercero (beneficiario) (art. 1.920); el depósito, especialmente bancario, en interés de un tercero que haya prestado su adhesión (art. 1.773); y la asunción de deuda por parte de un tercero a favor del acreedor (art. 1.273). Vid. J. M. MARTín Bernal, La estipulación a favor de tercero, Montecorvo, Madrid, 2002, p. 106.

${ }^{32}$ En este sentido, el segundo inciso del precepto citado establece que «[c]elui qui a fait cette stipulation [au profit d’un tiers] ne peut plus la révoquer si le tiers a déclaré vouloir en profiter».

33 «E' valida la stipulazione a favore di un terzo, qualora lo stipulante vi abbia interesse. Salvo patto contrario, il terzo acquista il diritto contro il promittente per effetto della stipulazione. Questa però può essere revocata o modificata dallo stipulante, finché il terzo non abbia dichiarato, anche in confronto del promittente, di volerne profittare». Vide también J.I. CANO MARTÍNEZ DE VELASCO, El contrato..., cit., p. 33.

34 «Durch Vertrag kann eine Leistung an einen Dritten mit der Wirkung bedungen werden, dass der Dritte unmittelbar das Recht erwirbt, die Leistung zu fordern».

35 Así, C. PÉrez Conesa, El contrato a favor de tercero, Comares, Granda, 1999, p. 54.

${ }^{36}$ Ley I, Título I, Libro X de la Novísima Recopilación, bajo del título «Cumplimiento de la obligación y contrato en el modo que se hiciere, sin embargo de que se le oponga el defecto de estipulación y otras excepciones». En dicha Recopilación se señaló que la Ley del Ordenamiento de Alcalá sancionaba la validez de la estipulación en provecho de tercero en los siguientes términos: «Pareciendo que alguno se quiso obligar a otro por promisión o por el contrato, o en otra manera, sea tenido de cumplir aquello que se obligó, y no pueda 
pero hubo de esperarse al Proyecto de Código civil de 1836 para que aparezca por primera vez una norma que, con carácter general, admitiera la validez del contrato a favor de tercero, en concreto, su artículo 960: «Un contrato puede aprovechar a una tercera persona que no haya intervenido en él, ya se trate de libertarla de alguna obligación o de adquirir para ella algún derecho»37. Posteriormente, el Proyecto de 1851 disponía en el párrafo segundo de su artículo 977 que, «si en el contrato se hubiere estipulado alguna ventaja a favor de tercero, éste podrá exigir el cumplimiento de la obligación, si la hubiere aceptado $y$ hécholo saber al obligado antes de ser revocada» $3^{8}$. Del precepto proyectado se infiere la intención del prelegislador de conceder al tercero una acción directa contra una de las partes contratantes para poder exigir la prestación, sin necesidad de incluirla en una cláusula añadida en el contrato (como podría ser una cláusula penal39), y así lo destacó GARCía GoYENA: «no hay necesidad de cláusula penal, y el tercero podrá exigir el cumplimiento»40.

La configuración actual de la figura del contrato a favor de tercero se encuentra en el artículo 1.275, párrafo $2^{\circ}$, del Código civil, cuyo precedente inmediato ha de verse en el artículo 977 del proyecto de 1851 que se acaba de citar. En efecto, la norma hoy vigente declara que, «[s]i el contrato contuviere alguna estipulación a favor de tercero, éste podrá exigir su cumplimiento, siempre que hubiese hecho saber su aceptación al obligado antes de que haya sido aquélla revocada». El contenido de este artículo no ha modificado mucho el tenor del

poner excepción que no fue hecha estipulación, que quiere decir, prometimiento con cierta solemnidad de Derecho, o que fue hecho el contrato o obligación entre ausentes, o que no fue hecho ante escribano público, o que fue hecha a otra persona derivada en nombre de otros entre ausentes, o que se obligó alguno, que daría otro o haría alguna cosa: mandamos que todavía vala la dicha obligación y contrato que fuere hecho, en cualquier manera que parezca que uno se quiso obligar a otro". $\mathrm{Al}$ respecto puede verse, R.M. ${ }^{\mathrm{a}}$. RocA Sastre y J. Puig-Brutau, Estudios de Derecho Privado, Vol. I, Editorial Revista de Derecho Privado, Madrid, 1948, p. 218; y F. BONET RAMÓN, «Los contratos a favor de tercero», Anales de la Academia Matritense del Notariado, vol. XII, 1961, p. 12.

37 Citado por I. GonZÁLEZ PACANOWSKA, «Comentario...», cit., p. 381.

${ }^{8} 8$ J. LÓPEZ RICHART, Los contratos..., cit., p. 68.

39 Desde el Derecho romano, la cláusula penal era uno de los medios coercitivos para obligar al cumplimiento y así poder asegurar la ejecución de la prestación en interés del beneficiario, facultando al estipulante para justificar su acción contra el promitente para pedir el cumplimiento a favor de tercero. Vid. C. PÉREZ CONESA, El contrato..., cit., p. 81; e I. GONZÁLEZ PACANOWSKA, «Comentario...», cit., p. 381.

40 Citado por C. PÉrez CONESA, El contrato..., cit., p. 81. 
proyecto, aunque sí puede destacarse una innovación de orden terminológico: se sustituye la palabra «ventaja» por la expresión «estipulación», aunque el significado de una y otra viene a ser equivalente. Como puede apreciarse, el precepto recogido hoy en el Código civil no reconoce, en rigor, el contrato sino la estipulación a favor de tercero, admitiendo que éste adquiera directamente el derecho de crédito y se convierta en acreedor una vez que acepte el beneficio estipulado en su favor. Así, el tercero tiene acción para hacer valer sus derechos contra el promitente (podrá exigir el cumplimiento), mas en tanto no manifieste su aceptación de la estipulación, ésta podrá ser revocada.

\section{Naturaleza jurídica de los contratos que favorecen a terceros}

\subsection{El contrato a favor de tercero}

Para explicar la naturaleza jurídica del contrato a favor de tercero ha de hacerse referencia al intenso debate suscitado acerca de esta figura, a través del cual se ha intentado justificar el mecanismo que permite a un tercero ajeno al contrato adquirir un derecho sin que haya intervenido en su celebración. Existen diversas teorías al respecto y, sin ánimo de ser exhaustivos ${ }^{41}$, haremos referencia a aque-

${ }^{41}$ Hay otras teorías como la de las obligaciones subjetivamente alternativas, la de la reducción de la nulidad, la de la delación revocable, la de la adquisición directa, etc. En cuanto a la teoría de las obligaciones subjetivamente alternativas, fue esgrimida por BOISTEL con relación al seguro de vida, aunque la considera aplicable a todo supuesto de estipulación a favor de tercero. Según esta teoría, la contratación se realiza bajo condición alternativa a favor de tercero y a favor propio, es decir, que la idea que subyace a esta teoría es la de dar vida a una obligación alternativa en cuanto a la designación del acreedor. Así, el promitente quedaría obligado a realizar la prestación, alternativamente, al estipulante o al tercero beneficiario. Se intenta recurrir, ante el silencio de la ley, a la aplicación analógica de las normas reguladoras de las obligaciones objetivamente alternativas. La teoría ha sido negada por LAMBERT, que no le encuentra fundamento, y también PACCHIONI afirma la imposibilidad de realizar esa extensión analógica de la ley. Vid. I. NART FERNÁNDEZ, «Notas sobre los contratos a favor de tercero", Anales de la Academia Matritense del Notariado, núm. 5, 1950, p. 484. La teoría de la reducción de la nulidad, por su parte, ha sido sostenida por los autores franceses BAUDRY-LACANTINÉRIE y BARDE, quienes abogan por reducir al mínimo la aplicabilidad del principio alteri stipulari nemo potest y, por el contrario, de extender el círculo de aplicación de las excepciones generales del anterior artículo 1.121 del Code civil. Desde un punto de vista jurídico, la teoría no es suficiente para explicar la naturaleza del derecho del tercero: si bien el hecho de que el estipulante se haya obligado con respecto al promitente representa un requisito esencial en el contrato a favor de tercero, ello no es suficiente para explicar toda la lógica compleja de esta figura jurídica. Vid. M. CASAlS COLlDECARRERA, «El contrato a favor de tercero», en Aa.Vv., Nueva Enciclopedia Jurídica, Seix, Barcelona, 1956-2, p. 367. Con respecto a la teoría de la delación revocable, mantenida por ROCA SASTRE y por DE BUEN [y la acoge el Tribunal Supremo en una sentencia de 9 de diciembre de 1940 (non vidi)], su fundamento está en la 
llas que han contado con un respaldo mayor en la doctrina a la hora de explicar la figura del tercero en el marco del contrato que le favorece ${ }^{42}$.

\section{a) La teoría de la oferta}

En primer lugar, la teoría de la oferta43, seguida por los autores franceses para explicar el mecanismo de la estipulación a favor de tercero, propone la descomposición de la operación en dos contratos. En el primero de ellos, el promitente se obliga frente al estipulante, es decir, el estipulante contrata en primer lugar por sí mismo, así que el crédito ingresa en su patrimonio. Posteriormente, ofrece al tercero la transmisión de su crédito frente al promitente; una oferta cuya aceptación por el beneficiario da vida a un segundo contrato, en virtud del cual se le transmite el derecho de crédito44. En efecto, según esta tesis la aceptación de la oferta (a favor de tercero) que el estipulante había dirigido al promitente da lugar a un primer contrato, mientras que la aceptación del beneficiario de la que se dirigía a él da lugar a un sucesivo o segundo contrato (de cesión). El origen del derecho del beneficiario se halla, en consecuencia, en este nuevo contrato que requiere una declaración de voluntad de su parte, a partir de la cual se le considera titular del crédito estipulado en su provecho45.

Esta teoría plantea, sin embargo, una serie de inconvenientes. Y es que el contrato «a favor de tercero» dejaría de serlo, pues los derechos de este no nacerían con la celebración del contrato entre el promitente y el estipulante, sino

vocación o delación hecha por las partes contratantes al tercero que, para adquirir definitivamente el derecho atribuido a éste, debe prestar su aceptación y, mientras no acepte, puede ser revocada la atribución. Al igual que todas las teorías antes mencionadas, también esta ha sido censurada por PACCHIONI, a cuyo juicio «no hay necesidad de hacer surgir derechos esenciales revocables, a favor de persona que nada sabe y que no se ha pronunciado acerca de ellos». Vid. I. NART FERNÁNDEZ, «Notas sobre...», cit., p. 485; M. CASALS COLLDECARRERA, «El contrato...», cit., p. 367.

$4^{2}$ Con detalle sobre esta cuestión, J. LÓPEZ RICHART, Los contratos..., cit., p. 211.

${ }^{43}$ La teoría es conocida también como la «teoría de la cesión», como ha señalado C. PÉREZ CONESA, El contrato..., cit., p. 103: «esta construcción responde al esquema de la cesión de derechos porque, tal y como ha quedado planteado el proceso por el que el tercero llega a ser titular del derecho, no es más que el efecto de la cesión del crédito del estipulante al tercero mediante un nuevo contrato, si bien se enmarca en la teoría de la oferta porque se precisa que el estipulante emite una oferta dirigida al tercero, con el fin de formalizar el nuevo contrato que crea el derecho de éste». Con detalle sobre la teoría de oferta y sus distintas variantes, vid. J. LóPEz RICHART, Los contratos..., cit., p. 195 y ss.

44 J.M. MARTÍN BERNAL, La estipulación..., cit., p. 213.

45 C. PÉrez CONESA, El contrato..., cit., p. 101. 
desde el momento en que el beneficiario manifiesta su deseo de aceptar la cesión de los derechos nacidos en cabeza del estipulante. Se produce así una falta de eficacia de la estipulación entre estipulante y promitente (relación de cobertura), pues no es ésta la que provoca el efecto deseable -el derecho del beneficiario no nace de este primer contrato-, sino el segundo contrato que requiere de la aceptación del tercero ${ }^{46}$. Además de esta incoherencia conceptual, la teoría de la oferta adolece de los siguientes defectos, que la hace poco útil para dar una explicación correcta sobre la naturaleza del contrato a favor de tercero.

Por una parte, el contenido de esta teoría se contrapone al concepto mismo de contrato a favor de tercero, debido a la descomposición que supone la teoría de la oferta en dos convenciones: el derecho del destinatario no nace sino cuando éste acepta la oferta (de cesión) que le hace el estipulante, pues hasta dicho momento, como ha señalado JossERAND, estaríamos ante una simple policitación. Como consecuencia, la oferta que se dirige al beneficiario es frágil, ya que es susceptible de caducar por el fallecimiento de su destinatario, o la incapacidad sobrevenida de éste o del oferente antes de que se haya perfeccionado el contrato de cesión con la aceptación47. Por otra parte, dado que el crédito del tercero contra el promitente ha ingresado anteriormente en el patrimonio del estipulante y subsiste en él hasta la aceptación de la cesión por el tercero, se convierte en garantía de todos los acreedores de aquél48. Estaría, pues, expuesto a ser objeto de agresión por éstos.

En suma, la teoría de la oferta no satisface la voluntad de las partes, que no persiguen que el estipulante adquiera un derecho, sino que, por la propia virtualidad de la estipulación, lo obtenga el tercero49. La misma crítica fue vertida ya por WINDSCHEID respecto de una teoría parcialmente distinta, en la que la oferta al tercero partía del promitente y no del estipulante. A su juicio, tampoco

\footnotetext{
${ }^{46}$ J.M. MARTÍn BERNAL, La estipulación..., cit., p. 213.

47 En el caso de los seguros de vida, ello tendría consecuencias graves en el momento del fallecimiento, porque es perfectamente posible que el beneficiario no tenga conocimiento de la póliza con anterioridad al siniestro y que se percate de su existencia cuando ya no puede declarar su aceptación al haber caducado la oferta con la muerte del estipulante, cuyo patrimonio queda sujeto a la sucesión de sus herederos (C. PÉREZ CONESA, El contrato..., cit., p. 104 y ss.).

48 J. LÓPEZ RICHART, Los contratos..., cit., p. 199.

49 J. M. MARTÍN BERNAL, La estipulación..., cit., p. 216.
} 
esta teoría respeta la intención de las partes pues, de hecho, supone una vinculación contractual que produce una obligación del promitente respecto del estipulante, pero resulta en vano el derecho estipulado a favor de tercero si el promitente retira la oferta ${ }^{50}$.

\section{b) La teoría de la gestión de negocios ajenos}

Al igual que la teoría de la oferta antes mencionada, también la de la gestión de negocios ajenos, formulada primeramente por POTHIER, intenta explicar el mecanismo a través del cual el tercero adquiere el derecho al beneficio estipulado en su interés. Según esta teoría, el estipulante, al contratar con el promitente, sería un gestor de negocios ajenos, concretamente, de los del beneficiario.

Lo que diferencia a esta teoría de la anterior es el hecho de que la ratificación de la estipulación o la gestión se produce con la mera aceptación del beneficiario, y esta ratificación puede producirse aun después del fallecimiento del gestor o el estipulante. Con la ratificación que presta el tercero al aceptar la gestión, pasa a ocupar retroactivamente la posición jurídica del gestor (el estipulante) desde el día de la operación de gestión (contrato entre el estipulante y el promitente), y así adquiere legitimación activa contra el promitente para exigir el cumplimiento de la obligación estipulada en su provecho51.

Aunque esta teoría ofrece una explicación más satisfactoria que la anterior, también tiene sus inconvenientes, que radican en que las normas que regulan la gestión de los negocios ajenos difieren de las del contrato a favor de tercero, y tampoco coinciden las consecuencias jurídicas derivadas de ambas instituciones. Lo único que comparten es el objeto del beneficio y el hecho de que intervienen tres personas.

Baste recordar que, en el contrato a favor de tercero, el estipulante contrata en beneficio de otro, y no actúa como un gestor de los negocios ajenos. Como ha señalado MARTín BERNAL, el contrato a favor de tercero no es un contrato en nombre de tercero, porque el estipulante no contrata en calidad de ges-

\footnotetext{
50 Véase las referencias en D. DE BUEN LOZANO, «La estipulación en provecho de tercero», Revista General de Legislación y Jurisprudencia, núm. 142, 1923, p. 209.

${ }^{51}$ Vide L.B. PÉREZ GALLARDO, «El contrato a favor de terceros», en Derecho de contratos, Tomo I, Teoría general del contrato, La Habana, 2001, pp. 315-316.
} 
tor ni en nombre de éste52. Además, en la gestión de negocios ajenos53, según lo dispuesto en el artículo $1.893 \mathrm{Cc}$, el dueño del negocio o de los bienes, al obligarse el gestor por su cuenta, debe cumplir las obligaciones asumidas por éste, reembolsando los gastos útiles o necesarios efectuados por él para el desarrollo de su actividad e indemnizando los daños que haya sufrido en el desempeño de su cargo54. Así pues, la gestión de negocios ajenos difiere del contrato a favor de tercero en que el gestor tiene derecho a ser reembolsado por su actuación por cuenta del dueño; algo que no sucede en el caso del estipulante, que no tiene en principio la intención de obtener tal reembolso55.

Así, la diferencia entre ambas instituciones radica en que, en el contrato a favor de tercero, este último es el beneficiario de un derecho dispuesto por el estipulante en su favor. Es decir, el estipulante continúa como parte contratante aún después de la aceptación por el beneficiario, lo que no ocurre en la gestión de un negocio ajeno. Y ello por cuanto el dueño de éste no se considera un tercero, pues esta operación no es más que un medio que convierte en parte contratante a una persona, el dueño, que no ha estado presente en su celebración. De ello se deduce que, en virtud de la representación, a la gestión de negocios concurren sólo dos personas, el dominus negotii y el que contrata con su representante, mientras que el contrato a favor de tercero genera un vínculo triangular entre el promitente, el estipulante y el tercero, aprovechándose éste de un derecho de crédito frente al promitente estipulado a su favor por el estipulante 56 .

Por último, en comparación con la gestión de negocios ajenos, en el contrato a favor de tercero este último tiene la opción de aceptar el beneficio o de rechazarlo, mientras que el dueño del negocio es responsable de las obligaciones contraídas en su interés. De ahí que resulte inadmisible repudiar aquello que le ha resultado útil de la actuación gestora (cfr. art. 1.893 Cc)57.

${ }^{2}$ Teoría de la llamada «gestión representativa» o «representación sin otorgamiento de poderes».

$53 \mathrm{Al}$ respecto, vid. E. BETTI, Teoría general del negocio jurídico, Comares, Granada, 2000, pp. 485 y ss.

54 C. PÉrez CONESA, El contrato..., cit., p. 109.

55 D. DE BUEN LOZANO, «La estipulación...», cit., p. 214.

${ }^{56}$ J. LÓPEZ RICHART, Los contratos..., cit., p. 207.

57 C. PÉrez CONESA, El contrato..., cit., p. 109. 


\section{c) La teoría de la adquisición directa}

La adquisición directa del derecho por el tercero beneficiario desde el momento en que se perfecciona el contrato entre las partes (estipulante y promitente) es el contenido esencial de una teoría de raigambre germánica, según la cual la aceptación del tercero no crea el derecho, sino que éste nace inmediatamente en el patrimonio del tercero, aun sin conocimiento del tercero de tal derecho y aunque no sea una persona determinada.

En efecto, la teoría de la adquisición directa difiere mucho de la teoría de la oferta y de la gestión de negocio y otorga plena validez a los contratos a favor de tercero, superando con ello el anacrónico principio del alteri stipulari nemo potest $5^{8}$. Sin embargo, también ha sido objeto de crítica desde diversos puntos de vista. En este sentido, PACCHIONI opina que: $1^{0}$ es difícil admitir que contractualmente pueda nacer un derecho en favor de una persona sin hacérselo saber y sin que ésta declare su deseo de aprovecharlo; $2^{\circ}$ no hay necesidad de hacer surgir derechos esencialmente revocables en favor de una persona que lo ignore y que no se ha pronunciado acerca de ello; y $3^{\circ}$ resulta desorbitado alegar la analogía con la herencia y los legados, que son disposiciones de última voluntad por causa de muerte, cuando aquí lo que se analiza es un negocio inter vivos. Este último argumento se refuerza si se considera que la aceptación hereditaria no es recepticia y la de la estipulación sí59. También BÄHR combate esta teoría, afirmando que «no se trata de una teoría, sino de una renuncia a toda teoría», que «acredita un resultado, pero no lo explica» (PLANIOL) ${ }^{60}$.

${ }^{8}$ L.B. PÉrez Gallardo, El contrato..., cit., p. 320.

59 Esta crítica ha sido citada en repetidas ocasiones, por ejemplo, por I. NART FERNÁNDEZ, «Notas sobre...», cit., p. 485.

60 Aunque la teoría de la adquisición directa del derecho ha sido objetada por muchos autores, ha sido también saludada positivamente por otros, por ejemplo, entre los escritores franceses por Colin, Capitant, Baudry-Lacantinerie, Brade y Worms; entre los italianos encontramos Tratufari; y entre los germánicos a Unger, Rregelsberger, Garies, Siegel y Windscheid. Para éste último autor, «una vez creado el derecho a que se ha hecho referencia, lo demás depende de la voluntad de las partes, las que pueden querer que el derecho del tercero nazca inmediatamente, o después de un determinado plazo, o someterlo a condición». Vid. J. M. MARTÍN BERNAL, La estipulación..., cit., p. 222; D. DE BUEN LOZANO, «La estipulación...», cit., p. 215. 


\section{d) La teoría de la declaración unilateral de voluntad}

Como derivación de esta teoría se ha desarrollado la llamada teoría de la declaración unilateral de voluntad. A su tenor, la estipulación a favor de tercero representa una subespecie del negocio jurídico unilateral, en el que la sola declaración de voluntad unilateral del promitente se considera suficiente para dar vida a una relación contractual, sin que sea necesaria la intervención de la voluntad de aquél al que va dirigida la promesa ${ }^{61}$. Ciertamente, según la teoría general de las obligaciones, la declaración unilateral de voluntad se considera una fuente de la obligación, al igual que el contrato. Pero tal declaración unilateral de voluntad supone una mayor libertad respecto de la que la ley reconoce en el contrato: mientras que este último requiere el concurso de las voluntades de dos o más personas, en la declaración unilateral -como su propio nombre indicabasta con una sola, siempre y cuando lo prometido sea lícito y se respeten los límites marcados por el orden público. Para obligarse es suficiente, pues, con que se exteriorice un solo consentimiento para obligarse a favor de otro, sin que éste declare su aceptación para aprovecharse del beneficio estipulado en su interés, aunque $a b$ initio sea indeterminado ${ }^{62}$.

Esta teoría ha tenido gran influencia en el Derecho germánico y algunas repercusiones en el francés. Según la perspectiva alemana, la simple promesa goza de plena fuerza vinculante, salvo que se hubiese hecho depender del consentimiento del tercero beneficiario ${ }^{63}$. En este sentido, considera CAPITANT que la promesa unilateral de voluntad del promitente es una fuente autónoma de obligaciones que convierte a éste, por sí sola e inmediatamente, en deudor del destinatario de la promesa ${ }^{64}$.

Para el derecho francés, Josserand sostiene que «el tercero beneficiario es acreedor en virtud de un acto jurídico unilateral, situado en un cuadro con-

\footnotetext{
${ }^{61}$ J. LÓPEZ RICHART, Los contratos..., cit., p. 209.

62 J.E. DUQUe PÉREZ, La declaración unilateral de voluntad como fuente de obligaciones, Medellín, 1953, pp. 487 y ss.

63 Véase las referencias en J. LÓPEZ RICHART, Los contratos..., cit., p. 209.

64 Citado por J.M. MARTín BERNAL, La estipulación..., cit., p. 229.
} 
tractual que le da vida y le asegura eficacia»65. En efecto, esta concepción trata de dar una explicación acerca del mecanismo de adquisición del derecho de crédito por el destinatario, al considerar que el contrato establecido entre el promitente y el estipulante conlleva en sí mismo una declaración unilateral de aquél, obligándose frente al tercero beneficiario a cumplir la operación estipulada en su provecho66.

No obstante, también esta teoría ha sido criticada, por ejemplo, por SALEILLES, quien opina que el vínculo obligacional instaurado entre el estipulante y el promitente no es más que una apariencia, puesto que la promesa unilateral vincula a la persona que se obliga, sin que sea necesario el concurso de voluntades. Lo que se entiende de la crítica de SALEILles es que, cuando se plantea el problema de la generación de una obligación por voluntad unilateral, se supone que esta finalidad de obligarse tiene por fuente una sola declaración de voluntad del deudor. No obstante, la obligación que se analiza aquí resulta de un contrato ${ }^{67}$, o sea, una obligación convencional nacida de la concurrencia de la voluntad del futuro deudor con la de otra persona. Y resulta inadmisible desdoblar la voluntad unipersonal y el contrato, porque ello llevaría a transformar el derecho del tercero en una promesa desligada de su causa, la cual seguiría existiendo aun cuando el contrato fuese nulo, de forma similar a cómo sucede según la concepción alemana de los actos abstractos ${ }^{68}$.

\section{e) Recapitulación}

Recapitulando todas las teorías propuestas para determinar la naturaleza del derecho atribuido al tercero, podemos concluir lo siguiente. La descomposición

${ }^{65}$ L. Josserand, Derecho civil, T. II, Vol. 1, traducción del francés, Ed. Jurídica EuropaAmérica, Buenos Aires, 1950, nota 415, $\mathrm{n}^{\circ} 304$.

66 J. LÓPEZ RICHART, Los contratos..., cit., pp. 209 y ss.

${ }^{67}$ R. SALEILLES, Essai d'une théorie générale de l'obligation d'après le Projet de Code Civil allemand, citado por D. DE BUEN LOZANO, «La estipulación...», cit., p. 216.

68 J.M. MARTín BERNAL, La estipulación..., cit., p. 229. Los contratos abstractos vienen definidos como aquellos por virtud de los cuales se producen efectos por la mera voluntad de las partes, pero sin el elemento de la causa. Algunos autores han intentado trasladar esa concepción del Derecho alemán al español, pero ello resulta inadmisible en un sistema causal como el que prevé el Código civil español. Vid. C. LASARTE ÁlvarEz, Compendio de Derecho civil, trabajo social y relaciones laborales, $2^{\text {a }}$ ed., Dykinson, Madrid, 2005, p. 214. Vid. también, en el mismo sentido, para los contratos causales y abstractos, L. DíEz-PICAZO, Fundamentos..., Vol. I, cit., pp. 277 y ss. 
en dos contratos sucesivos que propone la teoría de la oferta se contrapone a la concepción del contrato a favor de tercero en la práctica. Concretamente, las críticas que se han formulado a esta teoría subrayan la necesidad de concederle al beneficiario un derecho de crédito que no quede a expensas de los sucesores y acreedores del estipulante y que, al mismo tiempo, no quede pendiente de un contrato posterior 69 .

Tampoco la teoría de la gestión de negocios ni la de la declaración unilateral resultan satisfactorias para explicar el mecanismo de atribución del derecho al tercero. Para la primera, existe nada más que un contrato por cuenta de tercero, lo que impide concebirlo como una manifestación concreta de la denominada estipulación a favor de tercero, debido a que tal estipulación es inexistente si es el mismo tercero el que la celebra, aunque sea por medio de su gestor oficioso $^{70}$. Para la segunda, los críticos coinciden en señalar que no se puede desdoblar el negocio en contrato y voluntad unilateral, pues debe evitarse que el derecho del tercero se convierta en mera promesa. En definitiva, el contrato a favor de tercero comporta el nacimiento de una obligación de la concurrencia de dos voluntades, no de una sola. No es, pues - como decía BÄHR - una teoría que busque determinar la naturaleza del contrato a favor de tercero, sino una renuncia a toda teoría que persigue - según PLANIOL - un resultado sin explicarlo.

Como puede fácilmente constatarse, a todas estas teorías subyace una concepción simplista de la figura que se analiza. Si para descubrir el mecanismo sobre el que descansa el contrato a favor de tercero se utilizan instituciones inspiradas en principios inconciliables con dicha figura, resulta imposible lograr un resultado que haga compatible la adquisición del derecho por el beneficiario con el principio de relatividad de los contratos. En este sentido, concluimos citando a WEILL, para quien «la estipulación a favor de tercero es una excepción a la relatividad de las convenciones; una excepción se constata, es inútil relacionarla con otro tipo jurídico [...] una excepción que no puede ser explicada por una identificación con otras categorías, no necesita ser justificada sino por su utilidad y su fin práctico». La naturaleza de la estipulación hecha a favor de ter-

\footnotetext{
69 J. LÓPEZ RICHART, Los contratos..., cit., p. 214.

$7^{70}$ D. DE BuEN LOZANO, «La estipulación...», cit., p. 214.
} 
cero no se explica acudiendo a ninguna otra institución, sino que se considera, sin más, una excepción al principio de relatividad contractual ${ }^{71}$.

\subsection{El contrato con eficacia protectora para terceros}

En relación con el contrato a favor de tercero debe mencionarse, asimismo, la figura del denominado contrato con eficacia protectora para terceros (Vertrag mit Schutzwirkung für Dritte), desarrollada por la doctrina y la jurisprudencia alemanas ${ }^{72}$. Surgida como el resultado de una derivación del avance jurisprudencial de la dogmática de los contratos a favor de tercero en Alemania y de las necesidades singulares de aquel ordenamiento, acabó por tener su eco en la doctrina española73.

Conforme a la doctrina de los contratos con eficacia protectora para terceros, según JAGMANN, están sujetos a los riesgos derivados del cumplimiento del deber de prestación generado por un vínculo obligatorio no sólo los que han celebrado el contrato, sino también ciertos terceros que están en contacto con la conducta prestacional de la otra parte. En consecuencia, estos terceros deben gozar de una protección idéntica a la del propio acreedor frente a los riesgos que dimanan de la relación obligatoria. Por poner un ejemplo, el instalador pone en peligro no sólo a su cliente, sino también a su familia. De la misma forma, las deficiencias de la información sobre la utilización del aparato suministrado resultan peligrosas no sólo para el comprador, sino también para sus empleados74.

La jurisprudencia del entonces Tribunal Imperial (Reichsgericht) tuvo pronto en cuenta esta situación y, forzando la aplicación del § 328 BGB (que se refiere al contrato a favor de tercero), otorgó al tercero perjudicado una preten-

\footnotetext{
${ }^{71}$ J. LÓPEZ RICHART, Los contratos..., cit., p. 215.

${ }^{72} \mathrm{El}$ denominado «contrato con efectos protectores para terceros» aparece por vez primera en 1953, en la primera edición del Manual de Derecho de las obligaciones y contratos de K. LARENZ (Lehrbuch des Schuldrechts). El Tribunal Federal alemán (BGH) la asumió como propia en una sentencia de 15 de mayo de 1959 y, desde entonces, se ha generalizado su uso tanto en la doctrina como en la jurisprudencia. Véase la cita en J. LÓPEZ RICHART, Los contratos..., cit., p. 216.

73 A. CABANILLAS SÁNCHEZ, «El contrato con efectos protectores para terceros en el Derecho alemán», en Aa.Vv., Estudios jurídicos en homenaje al profesor Luis Díez-Picazo, Vol. II, Civitas, Madrid, 2003, pp. 1492 y ss.
}

74 A. CABANILLAS SÁNCHEZ, «El contrato con efectos protectores...», cit., p. 1492. 
sión de resarcimiento de daños y perjuicios fundada en el contrato cuando, en la ejecución de éste, se produjera un daño en su persona o sus cosas por culpa del deudor. Así, por medio de la aplicación del § 328 BGB se trata de ampliar el alcance de la responsabilidad contractual más allá de las partes del contrato, para incluir aquellos supuestos en los que las normas que reglamentan la responsabilidad extracontractual no resultan adecuadas75. La jurisprudencia se ha basado siempre en la interpretación integradora del contrato (§ 157 BGB); una senda que siguió posteriormente el Tribunal Federal (Bundesgerichtshof), confirmando la existencia de deberes de protección ${ }^{76}$ para con terceros, derivados de una interpretación integradora del contrato 77.

Al hilo de esta jurisprudencia, LARENZ afirma que los Tribunales han conferido a la figura del contrato a favor de tercero una extensión improvista, sirviéndose del mismo a fin de otorgar la posibilidad de obtener una reparación pecuniaria por el quebrantamiento de un deber contractual de protección frente a personas que no han intervenido en el contrato pero que, en el caso concreto, se hallan necesitadas de protección 78 .

De entre los casos que la doctrina alemana cita habitualmente como ejemplo de contratos con efectos protectores para terceros destaca el caso del arrendamiento, al objeto de dar una explicación cabal de la responsabilidad contractual del arrendador por los perjuicios sufridos por un familiar, sirviente o cualquier visitante del arrendatario, causados por un mal estado de la vivienda

75 J. LÓPEZ RICHART, Los contratos..., cit., p. 216.

${ }^{76} \mathrm{El}$ tema de los deberes de protección ha sido estudiado de manera pormenorizada por A. CABANILLAS SÁNCHEZ en su monografía Los deberes de protección del deudor en el Derecho civil, en el mercantil $y$ en el laboral, Civitas, Madrid, 2000, donde los deberes de protección, tanto precontractuales como contractuales, son abordados de forma detallada y amplia.

77 La teoría de la interpretación integradora del contrato ( $\$ 157$ BGB) ha sido estudiada por A. CABANILlas como un fundamento jurídico-dogmático del contrato con efectos protectores para terceros: si en virtud del § 328 BGB (que disciplina los contratos a favor de tercero) las partes de un contrato pueden transmitir a un tercero que no interviene en su conclusión un derecho de crédito, debe poder concederse igualmente un derecho de protección, que frente al derecho de crédito es un minus (A. CABANILLAS SÁNCHEZ, «El contrato con efectos...», cit., p. 1510). Vid. también K. LARENZ, que plantea el tema de la interpretación integradora del contrato en su obra Base del negocio jurídico y cumplimiento de los contratos, traducción española a cargo de C. Fernández Pérez, Comares, Granada, 2002, pp. 161 y ss.

78 A. CABANILlas SÁNCHEZ, «El contrato con efectos...», cit., pp. 1492 y ss. 
alquilada. En este contexto, conviene citar un ya antiguo pronunciamiento del Reichsgericht de 1917, en el que se establece que, «cuando una persona celebra un contrato de arrendamiento de vivienda debe tener la intención de proteger también los intereses de los familiares que con él conviven y, por lo tanto, de otorgar a éstos contra el arrendador los mismos derechos que él mismo tiene como consecuencia de los riesgos del estado de la vivienda»79.

No cabe duda de que la jurisprudencia alemana basa sus decisiones en el hecho de que el régimen derivado de las normas que disciplinan la responsabilidad contractual resulta más favorable para el perjudicado que el que se aplica a la responsabilidad delictual. Dicho de otra manera, la jurisprudencia alemana ha encontrado en el contrato con eficacia protectora para terceros un instrumento que permite cubrir las lagunas del régimen de la responsabilidad extracontractual y, en efecto, los esfuerzos hechos por la jurisprudencia para la extensión de la protección referida se comprenden por la distinción fundamental entre la responsabilidad contractual y la aquiliana ${ }^{80}$.

Así, de entre las diferencias de régimen aplicable a las dos responsabilidades en el Derecho alemán, solía mencionarse el plazo de prescripción más exiguo de la pretensión indemnizatoria por responsabilidad aquiliana, que prescribe con el transcurso de tres años, mientras que no sucedía lo propio respecto de las pretensiones basadas en contrato en tanto no transcurriese un plazo diez veces más largo. Obsérvese, sin embargo, que, tras la importante reforma del Derecho de obligaciones y contratos alemán en 2001, el BGB contempla ahora

79 Idéntica solución se ha alcanzado en el ámbito de los contratos de prestación de servicios. Resulta paradigmático el caso decidido por el Reichsgericht en una -igualmente antiguasentencia de 10 de febrero de 1930, que resolvió el conocido caso del «contador de gas». En aquel pleito, la demandante, que servía como asistenta doméstica, resultó herida como consecuencia de una explosión, provocada a su vez por una fuga de gas, debida a la defectuosa instalación de un contador en la vivienda en la que servía. Dicha instalación había sido efectuada por un empleado de la empresa contratada por la inquilina de la vivienda para la reparación de una estufa de gas. En su fallo, el Tribunal Imperial accedió a la pretensión contractual ejercitada por la sirvienta tendente a obtener la indemnización de los daños sufridos, y ello por considerar que el contrato entre la inquilina y la empresa demandada había sido celebrado implícitamente en su favor. Llegó a esta conclusión tras afirmar que de la interpretación del contrato resulta que las partes en el contrato «habrían establecido la responsabilidad directa de [la empresa] por todos los daños [...] en el caso de que en el momento de la celebración del contrato se hubiesen planteado la cuestión». Para ambas sentencias vid J. LÓPEZ RICHART, Los contratos..., cit., pp. 217 y ss.

80 Véase A. CABANILLAS SÁNCHEZ, «El contrato con efectos protectores...», cit., p. 1494. 
un único plazo de prescripción de tres años (§ 195 BGB). En España, en cambio, sigue siendo más extenso el plazo de prescripción de la acción contractual (cinco años: art. 1.964.2 Cc) que el que se aplica a las pretensiones por responsabilidad aquiliana (un año: art. $1.9682^{\mathrm{a}} \mathrm{Cc}$ ). Por otra parte, en lo que se refiere al régimen de la carga de la prueba, para hacerse acreedor de una indemnización por responsabilidad contractual, al acreedor le basta con probar el incumplimiento del deber contractual asumido, y es el deudor quien debe demostrar que éste no le es imputable (§ 280.1 i.f. BGB) ${ }^{81}$. Por el contrario, en la responsabilidad extracontractual es el propio perjudicado quien, por regla general, debe probar la concurrencia de dolo o negligencia en el causante del perjuicio (ex § 823.1 BGB; en España, art. 1.902 Cc).

Ahora bien, para evitar que se desdibuje la frontera entre el alcance de la responsabilidad contractual y la aquilina, el Bundesgerichtshof ha dedicado especial atención a la limitación de la expansión de la protección contractual, alcanzada por virtud del contrato con eficacia protectora para terceros. En efecto, se exige el cumplimiento de algunas condiciones para que los terceros queden incluidos en el ámbito de dicha protección contractual, y para la jurisprudencia y la doctrina alemanas son tres los requisitos para poder extender los deberes de protección más allá de las partes contratantes:

1. ${ }^{\text {a }}$ El tercero debe resultar expuesto con igual intensidad que el acreedor a los riesgos del contrato. Por esta razón, el tercero debe estar próximo de la prestación, es decir, hallarse en el contorno de tal prestación, que es el alcance de riesgo del contrato ${ }^{82}$. Sobre esta base se ha acuñado el término "proximidad a la prestación» (Leistungsnähe) ${ }^{83}$, proximidad que tiene como objeto evitar la expansión de la protección a aquellas personas que entran ocasionalmente en contacto con la ejecución de la prestación.

${ }^{81}$ A. CABANILLAS SÁNCHEZ, El contrato con efectos..., cit., p. 1494. Idéntico resultado alcanza, en España, F. JORDANO FRAGA, La responsabilidad contractual, Civitas, Madrid 1987, pp. 174 y ss.; ID., «Obligaciones de medios y de resultados», $A D C$, vol. 44 (1991), pp. 48 y ss.

82 J.I. RODRÍGUEZ GONZÁLEZ, El principio de relatividad de los contratos en el derecho español, Colex, Madrid, 2000, p. 266; el tema del ámbito de riesgo del contrato ha sido planteado por este mismo autor como una cuestión dogmática, al objeto de distinguir el «ámbito de riesgo contractual» del «ámbito extracontractual» (ibidem, pp. 269 y ss.).

${ }^{8} 3$ Sentencia del BGH de 17 de febrero de 1978 (BGHZ 70, pp. 327 y ss., en p. 329). 
2. ${ }^{\mathrm{a}}$ Que el acreedor tenga un interés especial para asumir la protección del tercero ${ }^{84}$. Así, el cumplimiento del requisito de la proximidad a la prestación resulta insuficiente para extender la protección a los terceros, si no viene acompañada de una relación que liga al tercero con una de las partes del contrato (generalmente de parentesco o de trabajo). Este criterio lo ha tomado el Bundesgerichtshof de LARENZ, exigiendo que el acreedor deba ser en cierta medida responsable del bienestar (Wohl und Wehe) del tercero, de tal manera que sólo los familiares, trabajadores u otras personas a las que el acreedor debe protección y cuidado quedan cubiertos por el ámbito de protección del contrato.

$3 \cdot{ }^{\mathrm{a}} \mathrm{El}$ deudor ha de ser consciente de las circunstancias anteriores en el momento de concluir el contrato (Erkennbarkeit) ${ }^{85}$. Dado que la doctrina del contrato con eficacia protectora para terceros supone una agravación de la responsabilidad que asume el deudor, éste último tiene que conocer y tener en cuenta la existencia del círculo de terceros protegidos. Como señala BROX, el deudor tiene que saber y poder calcular el riesgo asumido en el contrato ${ }^{86}$.

A la vista de las críticas que se formularon (sobre todo por LARENZ) respecto de la interpretación jurisprudencial que fundamentaba la protección del tercero en el $\S 328$ BGB (que, como se decía, regula los contratos a favor de tercero), HADDING propone considerar el contrato con eficacia protectora para terceros una figura jurídica peculiar, derivada de un desarrollo judicial basado en la buena fe (§ $242 \mathrm{BGB})^{87}$. En defensa de su postura alega que el pacto sólo pue-

${ }^{84}$ Sentencias del BGH de 25 de junio de 1971 ( $B G H Z$ 56, p. 273) y de 28 de febrero de 1977 (BGHZ 69, pp. 82 y ss., en p. 86).

85 Sentencias del BGH de 12 de noviembre de 1979 ( $B G H Z$ 75, p. 323) y de 10 de mayo de 1984.

86 Sobre esta cuestión véase, J. LÓPEZ RICHART, Los contratos..., cit., p. 122 y ss; y A. CABANILLAS SÁNCHEZ, «El contrato con efectos...», cit., pp. 1505 y ss.

87 En este contexto, no puede dejarse una más reciente línea jurisprudencial en materia de contratos con eficacia protectora para terceros, iniciada a mediados de los años sesenta del siglo pasado, que arranca con la célebre sentencia de 6 de julio de 1965 «En esta sentencia, el Bundesgerichtshof resolvió el caso de un padre que había acudida a un abogado con la intención de redactar testamento e instituir en él como única heredera a su hija. Debido a una negligencia del abogado, que no procedió a la protocolización notarial del testamento, se declara la nulidad del mismo por lo que se abre la sucesión intestado, resultando de ella que la hija deviene tan solo coheredera de una parte de la herencia. El tribunal accedió a la pretensión de esta última contra el abogado porque 'atendiendo al sentido y la finalidad del contrato, celebrado entre el testador y el demandado (abogado), y según los principios de la confianza y de buena fe, queda plenamente justificado el reconocimiento de un deber de 
de calificarse como contrato a favor de tercero ( $§ 328$ BGB) si al tercero se le concede el derecho a exigir la prestación principal, pero no en los casos en que el tercero beneficiario tiene sólo una pretensión de cumplimiento de deberes de previsión y de protección.

En un sentido similar, otros autores basan su crítica a la postura jurisprudencial que descansa sobre una aplicación del $\S 328$ BGB en que resulta inadmisible, en los contratos con eficacia protectora para terceros, reconocer una voluntad expresa de los contratantes de atribuir un derecho a un tercero. Concretamente, se alega que este precepto y los que le siguen en el BGB (al igual, por cierto, que el art. $1.2572^{\mathrm{a}} \mathrm{Cc}$ ) hacen referencia a aquellos casos en que la prestación al tercero representa el objeto del contrato a favor de tercero; por el contrario, en el denominado contrato con eficacia protectora para terceros, la finalidad estriba en poder servirse de una acción contractual para exigir una indemnización en el caso de que el tercero resulte perjudicado en el momento de la ejecución del contrato ${ }^{88}$. Por esta razón, según LARENZ, no puede hablarse realmente de un contrato a favor de tercero sino de un contrato con eficacia protectora para terceros, que ha adquirido carta de naturaleza en el Derecho alemán como una categoría de plena autonomía e independiente de la de los contratos a favor de tercero ${ }^{89}$.

Si trasladáramos los razonamientos acerca del contrato con eficacia protectora al ámbito del transporte de mercancías, resultaría que se concede protección jurídica al destinatario de las mercancías, incluso aunque no hubiera participado en la conclusión del contrato, desde el momento en que puede resultar afectado en caso de realización imperfecta del transporte. Como se vio, el expediente técnico de los contratos con eficacia protectora para terceros se basa en la extensión de la aplicación de la responsabilidad contractual a las reclamaciones planteadas frente al deudor a quien no es parte en el contrato, esto es, en el transporte de mercancías, el destinatario perjudicado que se encuentra fuera

cuidado también frente a la actora (la hija del testador)'» (J. LÓPEZ RiCHART, Los contratos..., cit., pp. 123 y ss.). Conforme a esta nueva orientación, la protección contractual para terceros descansa ya no sólo en el § 242 BGB, sino que puede plasmarse también en el objeto mismo del contrato.

88 A. CABANILlas SÁNCHEZ, «El contrato con efectos...», cit., pp. 1498 y ss.

89 J. LÓPEZ RICHART, Los contratos..., cit., p. 120. 
de la órbita contractual. En suma, la función de este tipo de contratos consiste en la extensión a dicho tercero beneficiario del régimen de responsabilidad contractual previsto para un negocio jurídico en el que no ha intervenido, de tal manera que el tercero - que, en principio, carece de legitimación para hacerlopuede invocar el cumplimiento del contrato.

Si así fuera, al destinatario como tercero ajeno al contrato celebrado entre el porteador y el cargador se le reconocería el derecho a reclamar del porteador, sobre la base del contrato de transporte concluido entre cargador y transportista, el resarcimiento de los daños y perjuicios causados por un eventual incumplimiento o cumplimiento defectuoso. De esta forma, el destinatario, aunque no forma parte de la relación contractual, gozaría de la posibilidad de invocar el régimen contractual aplicable a las relaciones obligatorias entre las partes del contrato (porteador y cargador) o, incluso, subcontrato de transporte (porteador contractual y porteador efectivo). La idea que subyace a esta atribución de una acción contractual al destinatario frente al porteador sería el hecho de que el destinatario es merecedor de la protección que dimana de dicho contrato. En efecto, la eficacia protectora que despliega el contrato para el tercero implicaría la imposibilidad de negar ante él el contenido de los acuerdos alcanzados por las partes, en la medida en que este tipo de contratos tiene por objeto, precisamente, generar efectos beneficiosos y no dañosos para el tercero ${ }^{90}$.

Ciertamente, como antes se vio, ante las diferencias fundamentales existentes entre los contratos a favor de tercero y los que meramente despliegan efectos protectores para éste, parece imposible su asimilación. Ahora bien, en el ámbito del transporte de mercancías resulta, en línea de principio, innecesario el recurso a la figura del contrato con eficacia protectora para terceros, pues es la propia legislación de transportes la que concede al destinatario una acción contractual para exigir el cumplimiento de la prestación principal (cfr. arts. 13 CMR y 35 LCTTM). Ello sitúa al intérprete, claramente, en el ámbito de los contratos (que contienen estipulaciones) a favor de tercero, y así lo reconoce la doctrina más autorizada en España.

90 Con detalle sobre esta cuestión, A. EMPARANZA SOBEJANO, El concepto de porteador en el transporte de mercancías, Comares, Granada, 2003, pp. 421 y ss. 


\subsection{Distinción de figuras afines}

Resulta frecuente tratar de delimitar las instituciones jurídicas surgidas en la práctica de otras figuras próximas que se presentan semejantes y parecidas, máxime cuando la institución objeto de examen representa una anomalía respecto de las reglas existentes en su ámbito jurídico más inmediato. El ejercicio resulta útil, porque a través de él se consigue matizar la concepción de dicha figura para evitar cualquier confusión y deslindar los límites de su objeto, además de que, con ello, se permite determinar los caracteres propios de esta institución.

Es por ello por lo que se pasará a analizar a continuación, con la debida brevedad, algunas instituciones jurídicas que guardan cierta analogía y afinidad con el denominado contrato a favor de tercero en algunos de sus aspectos, formales o de contenido. Concretamente, se tratará de estudiar las diferencias entre la estipulación a favor de tercero y otras instituciones jurídicas, para al final poder definir qué es el contrato a favor de tercero y alcanzar un concepto acorde con la finalidad y naturaleza de esta figura.

\section{a) Estipulación a favor de tercero y cesión del contrato}

Ante el silencia del Código civil sobre la figura de la cesión del contrato ${ }^{91}$ ha sido la doctrina la que se ha encargado de proporcionar una definición, destacando como elemento más relevante la sustitución en el vínculo contractual de uno de los contratantes por un tercero. De entre estas definiciones destaca la ofrecida por ANDREOLI, que considera la cesión del contrato como «el instrumento que permite realizar la llamada circulación del contrato, es decir, la transferencia negocial a un tercero (llamado cesionario) del conjunto de posiciones contractuales (entendido como resultante unitario de derechos y obligaciones orgánicamente interdependientes), constituida en la persona de uno de los originarios contratantes (llamado cedente); de tal forma que, a través de esa sustitución negocial del tercero en la posición de parte del contrato, en lugar del ce-

\footnotetext{
${ }^{91}$ En efecto, como quiera que no se encuentra ninguna definición expresa de la cesión de contratos en la legislación española, existen varias definiciones doctrinales de esta figura, que es admitida sin reparos por doctrina y jurisprudencia. Su fundamento suele situarse en el art. $1.255 \mathrm{Cc}$, que consagra la libertad de pactos y autonomía privada de las partes: «Los contratantes pueden establecer los pactos, cláusulas y condiciones que tengan por conveniente, siempre que no sean contrarios a las leyes, a la moral, ni al orden público».
} 
dente, dicho tercero subentra en la totalidad de los derechos y obligaciones que en su orgánica interdependencia se derivan del contrato estipulado por el cedente»92. De esta definición se desprende que la cesión de contratos no es sino un negocio jurídico celebrado por las partes contratantes con un tercero, que tiene como objeto sustituir a una de ellas por dicho tercero en la titularidad del vínculo contractual, la cual permanece idéntica en su dimensión objetiva93.

Las diferencias con el contrato a favor de tercero son obvias si se compara la definición de la cesión de contratos con la que señala PACCHIONI para los contratos a favor de tercero. Como se vio, pertenecen a este último tipo de contrato únicamente aquellos negocios en los que la finalidad de las partes contratantes es la atribución directa o indirecta de un derecho de crédito (y no la transmisión de toda la posición contractual del cargador) a un tercero beneficiario que, sin embargo, no ha participado de ninguna manera en la conclusión del negocio y que no se halla, por consiguiente, obligado ni vinculado por él94.

De ambas definiciones se deducen inmediatamente algunas notas diferenciadoras, de entre las que conviene mencionar las siguientes.

1. ${ }^{\text {a }}$ La estructura del consentimiento en la constitución del negocio de la cesión de contratos es tripartita, es decir, dicho negocio requiere el concurso de declaraciones de voluntad de tres partes: del cedente, del cesionario y del contratante cedido, y cada una de ellas se considera un centro autónomo de intereses95. Ello no sucede en el contrato a favor de tercero, que pertenece al grupo de los contratos bilaterales, es decir, la estipulación hecha por las partes contratantes a favor de tercero puede llegar a plantearse "por sorpresa», sin que ese tercero tenga conocimiento de la estipulación hecha en su favor ${ }^{6}$. No obstante, la diferencia aludida puede resultar discutible, ya que hay autores que configuran la cesión de contratos como contrato bilateral, considerando la intervención del

${ }^{2}$ M. ANDreoli, La cesión del contrato, Editorial Revista de Derecho Privado, Madrid, 1956, pp. 2 y ss.

93 M. GARCíA-Amigo, La cesión de contratos en el derecho español, Editorial Revista de Derecho Privado, Madrid, 1964, p. 86.

94 L. DíEz-Picazo, Fundamentos..., Vol. I, cit., p. 532.

95 M. ANDREOLI, La cesión..., cit., pp. 60 y ss.

96 J.M. MARTín BERnAL, La estipulación..., cit., p. 281. 
contratante cedido como un requisito necesario para la eficacia del negocio, pero no para su perfección. De esta configuración se ha deducida una semejanza con la intervención del tercero en el contrato a favor de tercero, dado que sus efectos dependen de la aceptación de éste.

$2 .^{a}$ La eficacia jurídica se plantea de manera distinta en ambos negocios. Para la cesión, consiste en la transmisión al tercero, ajeno al contrato base, de los efectos jurídicos que nacen del contrato. En el contrato a favor de tercero, en cambio, el efecto perseguido es la creación de un derecho a favor de tercero por las partes contratantes. Así, mientras que la cesión tiene carácter traslativo, el del contrato a favor de tercero es constitutivo. En suma, la existencia previa de un vínculo contractual y el común acuerdo de las tres voluntades implicadas acerca de la transmisión configura la estructura normal del negocio de cesión de contratos, cosa que no existe en el contrato a favor de tercero97.

$3 .^{a}$ La diferencia entre el contrato o estipulación a favor de tercero y la cesión del contrato no tiene por qué suscitar gran dificultad, aunque los dos contratos son típicamente dogmáticos y han sido explicados en doctrina y jurisprudencia hasta llegar a entenderse cada uno de ellos como una figura jurídica completa en toda su integridad. En consecuencia, podemos resaltar una nota diferenciadora más: el cesionario del contrato forma parte de la relación negocial, pues su consentimiento es obligatorio, mientras que el tercero en el contrato celebrado en su favor no forma parte de la relación de cobertura que liga a estipulante y promitente - a pesar de ser el destinatario directo de esta estipulación- y se adhiere posteriormente, una vez preste su aceptación, a la relación contractual existente.

Puede, con todo, establecerse dos «puentes recíprocos» entre la cesión de contrato y la estipulación a favor de tercero: por un lado, el contrato a favor de tercero puede servir como criterio que coadyuve a la hora de dar una explicación sobre la figura de la cesión del contrato; por otro, la cesión del contrato, a su vez, puede ser objeto de una estipulación a favor de tercero ${ }^{98}$.

97 M. GARCÍA-AMIGO, La cesión..., cit., pp. 86-87.

98 J.J. Forner Delaygua, La cesión de contrato, Bosch, Barcelona, 1989, p. 14. 


\section{b) Estipulación a favor de tercero y asunción de deuda}

La mayoría de los autores italianos sostienen que la naturaleza jurídica de la asunción de deuda es la de un contrato a favor de tercero (PACCHIONI, BetTi, BLANCA, NiCOLÒ). Naturalmente, tanto la estipulación a favor de tercero como la asunción de deuda muestran elementos de una liberalidad y de una donación, de manera que coinciden en cuanto a su función y finalidad. En efecto, dado que en el contrato de asunción de deuda concluido entre el deudor primitivo y el tercero que asume la obligación ya existe un contrato previo en el que es parte aquél, tiende también a generarse un derecho de crédito a favor de tercera persona que, en principio, no participa en el negocio de asunción, que es el acreedor del deudor primitivo99.

$\mathrm{Al}$ respecto de la semejanza que existe entre ambas instituciones, PACCHIONI sostiene que la asunción de deuda -que, en principio, es cumulativa (es decir, sin efectos liberatorios) ${ }^{100}-$ constituye siempre un contrato a favor de tercero. Obsérvese el siguiente caso: el comprador se obliga, en el acto de la compra y frente al vendedor, a pagar al tercero acreedor una deuda del vendedor, con garantía hipotecaria del fundo que se le vende. Partiendo de que dicha estipulación se realiza por el estipulante y para sí mismo, no hace falta demostrar que las partes (subrogante y subrogado) hayan tenido la específica voluntad de transmitir un derecho al tercero; es suficiente que se haya celebrado válidamente una estipulación a favor de ese tercero, y que éste último haya manifestado su aceptación para querer aprovecharse de tal estipulación ${ }^{101}$.

Sin embargo, esta idea de equiparar la asunción de deuda acumulativa con el contrato a favor de tercero no es compartida por NART FERNÁNDEZ, para

99 J. M. MARTÍn BERNAL, La estipulación..., cit., p. 283.

${ }^{100}$ La doctrina romanística suele diferenciar, en atención a los sujetos, entre obligaciones parciarias, cumulativas y solidarias. Frente a estas últimas, que se caracterizan por tener una pluralidad de sujetos y un objeto único, en las obligaciones cumulativas en sentido propio hay varios sujetos (en este caso, pasivos) que tienen que efectuar una prestación igual, pero que no es la misma, sino que las obligaciones son independientes (cfr. A. GÁLVEZ CRIADO, La asunción de deuda en el derecho civil; asunción liberatoria, asunción cumulativa y supuestos concretos, Tirant lo Blanch, Valencia, 2007, p. 27).

${ }^{101}$ Como puede apreciarse, la opinión de PACCHIONI se funda en el tema de la asunción de una deuda, garantizada hipotecariamente, por el comprador de la finca hipotecada. Con detalle, G. PACCHIONI, Los contratos..., cit., pp. 353 y ss. 
quien la intervención del acreedor aceptante queda reducida a una simple condicio iuris de la adquisición. Y es que, si se piensa en la asunción liberatoria (novatoria) como el resultado de un contrato a favor de tercero, es evidente que quedaría aquélla sujeta a todas las excepciones que se pudieran oponer conforme al contrato principal (el de asunción). Pero el acreedor que consiente en la asunción extingue incondicionalmente su primitivo crédito y lo sustituye por otro, por lo que respecto de este nuevo crédito no deben tener cabida las excepciones que su nuevo deudor pueda oponerle, basadas en una estipulación (la asunción de deuda) en la que aquél no tuvo parte ${ }^{102}$.

Para mejor perfilar las diferencias existentes entre la estipulación a favor de tercero y la asunción de deuda conviene adelantar una definición de ésta ${ }^{103}$. Pues bien, la asunción de deuda viene definida como aquel efecto que dimana de un pacto de voluntades en virtud del cual un tercero se obliga a cumplir una deuda nacida previamente de un vínculo jurídico-obligacional ${ }^{104}$. A la vista de esta definición podemos señalar las siguientes diferencias:

1. ${ }^{a}$ La primera diferencia guarda relación con el surgimiento de la deuda. En el contrato de asunción de deuda hay una sucesión en la deuda mediante «novación», o sea, la deuda del subrogado subsiste y no se extingue, sino que se transmite inalterada al subrogante ${ }^{105}$. Se trata, pues, de una deuda derivada. En el contrato a favor de tercero sucede lo contrario, ya que la deuda que nace en cabeza del promitente tiene carácter originario. En este sentido, MARTín BERNAL señala que, en la estipulación a favor de tercero, la derivación de la prestación (deuda) se efectúa, pero únicamente como un mecanismo posterior a la forma-

${ }^{102}$ I. NART FERNÁNDEZ, «Notas sobre...», cit., pp. 471 y ss.

${ }^{103}$ No existe definición de la asunción de deuda en el Código civil, pero sí de algunas de sus manifestaciones, concretamente, en los arts. 1.203.2 ( Las obligaciones pueden modificarse [...] 2. ${ }^{\circ}$ Sustituyendo la persona del deudor») y 1.205 («La novación, que consiste en sustituirse un nuevo deudor en lugar del primitivo [...]»).

${ }^{104}$ Sobre esta figura puede verse, con detalle, A. GÁlvEZ CRIADO, La asunción de deuda..., cit., passim.

105 Obsérvese, con todo, que el origen de la llamada stipulatio novatoria o «novación» se encuentra en el Derecho romano. En su virtud, la sustitución de un deudor por otro se producía mediante la extinción de una obligación y el nacimiento de otra nueva en su lugar, reafirmándose así la intransmisibilidad inter vivos de las obligaciones en este ordenamiento jurídico. Vid. A. GálvEZ CRIADO, La asunción de deuda..., cit., pp. 35 y ss. 
ción de ese derecho ex novo, mientras que en la deuda emanada de la successio el hecho jurídico que se produce es un traspaso (y no la extinción) de la deuda.

2. ${ }^{\text {a }}$ El objeto esencial en el contrato a favor de tercero es la atribución de un derecho a éste mediante una nueva prestación prometida al estipulante en beneficio del tercero. Así pues, la diferencia con el contrato de asunción de deuda radica en que en este último lo que se produce es un cambio en la persona del deudor, es decir, un nuevo deudo que sucede al antiguo (el subrogado o deudor primitivo) en la deuda ${ }^{106}$.

$3 \cdot{ }^{\mathrm{a}}$ No es conveniente situar la asunción de deuda acumulativa entre los contratos a favor de tercero, si se tiene en cuenta que el derecho del tercero nace inmediatamente y sin cooperación suya con la celebración del contrato entre los sujetos contratantes (promitente y estipulante). Para que se produzca la asunción de deuda son necesarios, por el contrario, la cooperación y asentimiento del tercero, es decir, el acreedor, según lo dispuesto en el artículo 1.205 $\mathrm{Cc}^{107}$. Se entiende que, en los contratos a favor de tercero, para que el derecho del acreedor nazca a su favor, éste ha de aceptarlo; sin embargo, si no muestra interés en conservarlo, obtendrá el derecho para rechazarlo ${ }^{108}$.

\section{c) Estipulación a favor de tercero y gestión de negocios ajenos}

La semejanza entre la estipulación a favor de tercero y la gestión de negocio ajeno ha de buscarse en el cuidado de los intereses de un tercero. En efecto, esta supuesta similitud ha sido planteada doctrinalmente a partir de puntos de vista diferentes, expuestos por autores que han dedicado sus esfuerzos al estudio del fundamento del derecho del tercero y la determinación de la naturaleza del mismo, pretendiendo deslindar los elementos que diferencian la figura de la estipulación a favor de tercero de otras figuras afinas.

${ }^{106}$ J. M. MARTín BERNAL, La estipulación..., cit., p. 284.

107 Conforme a este precepto, «[l]a novación, que consiste en sustituirse un nuevo deudor en lugar del primitivo, puede hacerse sin el conocimiento de éste, pero no sin el consentimiento del acreedor».

${ }^{108}$ E. DANZ, La interpretación de los negocios jurídicos, trad. esp. de la $3^{\mathrm{a}}$ ed. a cargo de W. Roces, Madrid, 1926 (reimpr., Analecta, Pamplona, 2006), p. 302. 
Como se vio, durante un tiempo fue la doctrina francesa la que trataba de identificar ambas figuras. En efecto, se pensaba que la estipulación a favor de tercero es, en realidad, una negotiorum gestio, en virtud de la cual el estipulante efectúa a favor de tercero un acto en calidad de mandatario, atribuyéndose el carácter de ratificación a la aceptación del tercero ${ }^{109}$. Una idea que fue confirmada por POTHIER, quien llegaría a reconocer que toda estipulación a favor de tercero puede considerarse como un acto de gestión de negocios, siempre que haya una ratificación hecha por el principal.

Para comenzar a abordar la distinción entre ambas instituciones, debe señalarse que estaríamos ante una gestión de negocios ajenos cuando actúan dos partes, estipulante y promitente, para concluir un contrato, haciéndose prometer el primero la prestación del segundo en interés de tercera persona, el dueño del negocio, que debe ratificar el contrato110. De ahí que se haya defendido, primero por Pothier y después por DEMolombe, que existe en toda estipulación a favor de tercero un negocio subjetivamente ajeno, colocando en lugar del estipulante la persona del gestor, mientras que se considera al tercero como dominus del negotium que, al final, lo ratifica a través su aceptación, adquiriendo una acción legitima frente al promitente ${ }^{111}$.

En lo que concierne las diferencias entre ambas figuras, conviene poner de manifiesto algunas conclusiones sintéticas, que son las siguientes:

1. ${ }^{\text {a }}$ No es aceptable identificar el contrato a favor de tercero con otro en nombre de tercero ${ }^{112}$, por la sencilla razón de que el estipulante no pacta en calidad de gestor del tercero, ni tampoco en su nombre ${ }^{113}$. No puede hablarse, así, de ninguna injerencia ni de sustitución, por cuanto el estipulante obra en su

109 M. PASQUAU LIAÑo, La gestión de negocios ajenos, Montecorvo, Madrid, 1986, p. 427; más recientemente sobre la gestión de negocios ajenos, M.E. SÁNCHEZ JORDÁN, La gestión de negocios ajenos, Civitas, Madrid, 2000.

${ }^{110}$ J. LÓPEZ RICHART, Los contratos..., cit., p. 68.

${ }^{111}$ C. PÉrez CONESA, El contrato..., cit., p. 21 y ss; I. NART FERnÁNDEZ, «Notas sobre los contratos...», cit., p. 485 .

${ }_{112}$ Que se realizaría en virtud de la teoría de la llamada gestión representativa o de la representación sin otorgamiento de poderes, ya vista.

113 J. M. MARTín BERNAL, La estipulación..., cit., p. 262. 
propio nombre, por sí mismo y por su propia legitimación ${ }^{114}$. La posición del estipulante en la relación contractual es mucho más relevante que la del simple gestor, que desempeña un papel de intermediario o representante en interés del dominus.

2. ${ }^{\mathrm{a}}$ El objeto esencial del contrato a favor de tercero radica en atribuir un beneficio al tercero, pero sin que con ello desaparezca el estipulante, que sigue manteniendo su posición como dueño de la operación, pues dispone de la posibilidad de revocar la estipulación, al menos en tanto el tercero no manifieste su aceptación. Por el contrario, en la gestión de negocios ajenos, la actuación del gestor vincula al dueño, y tampoco puede aquél revocar la gestión, sino que ha de continuarla ${ }^{115}$.

$3 .^{a}$ También Roca SASTRE rechaza la idea de equiparar el contrato a favor de tercero y la gestión de negocios ajenos, pues la ratihabitio o ratificación convierte al dominus en parte contratante ab initio, transmitiéndole todos los derechos y obligaciones del contrato ${ }^{116}$. En consecuencia, el juego de la representación no deja más que dos personas. El tercero en el contrato a favor de tercero, en cambio, permanece ajeno al contrato. Su posición confiere al contrato un carácter tripartito conforme al cual este último se une con posterioridad a las partes contratantes. Su aceptación, al contrario de lo que sucede con la ratificación del dominus negotii, sólo le convierte en titular de un derecho de crédito frente al promitente ${ }^{117}$. En fin, como el tercero (que no es dueño del negocio sino destinatario de una estipulación hecha en su favor), no podrá exigir cuentas al estipulante, de manera que la persona de éste queda más desdibujada que la del gestor en su relación con el dueño, que principalmente origina una relación obligatoria ${ }^{118}$.

Concluyendo puede decirse que, más que una identificación entre las dos figuras jurídicas existe una incompatibilidad, y que los dos contratos se impregnan de un espíritu distinto: el estipulante contrata a favor del beneficiario, pero

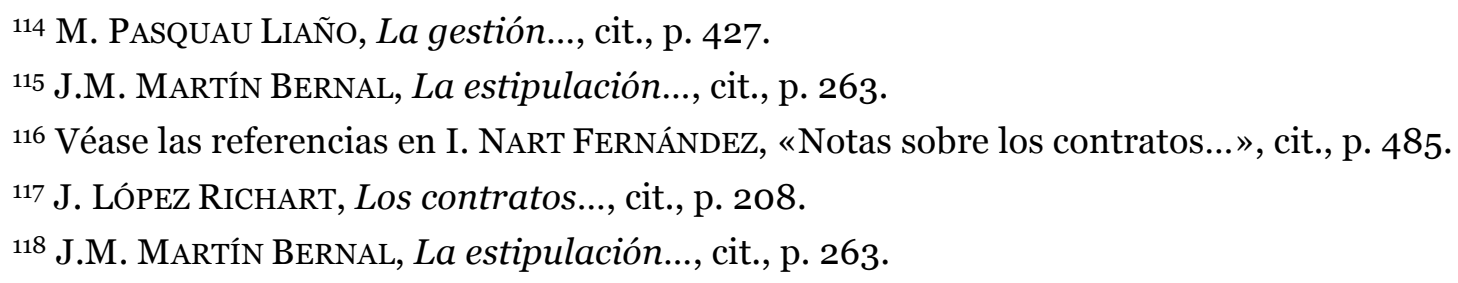


para sí y en su propio nombre; el gestor, en cambio, actúa como intermediario, que tiene que ser reembolsado de los gastos de su gestión en interés del dueño, animado por un espíritu de representación.

\section{d) Estipulación a favor de tercero y representación}

El primer paso para admitir la posibilidad de que se estipulen contratos a favor de tercero consistía en partir de una representación indirecta en la que el tercero sustituye al representado y el estipulante al gestor. Sabido es que en el Derecho romano no se admitía, según la regla prohibitiva alteri stipulari non potest, ninguna representación que pudiera generar efectos jurídicos inmediatos y directos para el representado, y menos aún se aceptaba la validez de ningún negocio estipulado a favor de tercero ${ }^{119}$. No fue hasta que se admitió el principio de la representación directa que ésta pudo ganar autonomía científica, reconociéndose asimismo la validez de la construcción independiente del negoció jurídico por cuenta de otro que se ha conceptuado como un contrato a favor de tercero ${ }^{120}$.

Una vez que se contempla, en el Derecho moderno, junto al contrato celebrado por representación, la estipulación que se realiza para atribuir un derecho de crédito a un tercero por un sujeto que no es su representante, se hace necesaria una distinción entre ambas figuras. Esta necesidad fue puesta de relieve por ZIMMERMANN ${ }^{121}$, a cuyo juicio «tanto en los contratos a favor de tercero como en los celebrados por medio de representante, la intención de las partes es que el tercero adquiera un derecho propiamente suyo; en ambos casos el tercero se halla puesto en seguida in obligatione y no sólo in solutione» ${ }^{122}$.

La distinción entre una y otra figura puede hacerse sobre la base de la consideración de que la estipulación a favor de tercero no da lugar más que a un derecho de crédito a favor de tercero. No asume, en cambio, obligaciones derivadas del contrato, pues jurídicamente no participa en la relación contractual

119 L. DíEz-PiCAZO, Fundamentos..., Vol. I, cit., p. 535.

120 C. PÉrez Conesa, El contrato..., cit., p. 15.

${ }^{121}$ ZIMMERMANN es el autor que ha analizado con mayor cuidado la distinción entre la representación y el contrato a favor de tercero. Vid. su obra Die Lehre von der stellvertretenden Negotiorum Gestio, Strasbourg, 1876 (cit. por G. PACCHIONI, Los contratos a favor de tercero, cit., p. 233).

${ }^{122}$ G. PACCHIONI, Los contratos a favor de tercero..., cit., p. 233. 
celebrada entre las partes contratantes (estipulante y promitente). El carácter que destaca del contrato a favor de tercero es, pues, la espontaneidad, es decir, que el estipulante puede proceder a atribuir un provecho al tercero beneficiario sin éste saberlo ${ }^{123}$. En cambio, el acto representativo genera la legítima expectativa en el contratante de que la gestión se integra en la órbita jurídica del interesado por cuenta del que opera el representante. Eso precisamente es lo que ocurre en la actuación por cuenta ajena, produciéndose directamente la atribución de los efectos jurídicos de esta actuación, siempre y cuando el representante declare formalmente quién es el dueño del negocio (contemplatio domini) ${ }^{124}$.

En el contrato a favor de tercero, por el contrario, el estipulante actúa en su propio nombre y no como representante del tercero. Si así fuera, no existiría en rigor un tercero, sino una parte contratante en la operación, que asume todos los efectos jurídicos del negocio (los beneficiosos y los adversos), es decir, que no necesariamente recibiría sólo un provecho en su favor ${ }^{125}$.

En general puede decirse que el contrato a favor de tercero tiene eficacia jurídica propia para el estipulante, de manera que pueden nacer para él tanto derechos como obligaciones frente al promitente. Mientras que los efectos que emanan del negocio representativo se generan a favor o en contra del representado y de la otra parte contratante, en el contrato a favor de tercero los derechos y las obligaciones se reparten entre el estipulante y el promitente, y únicamente se atribuye un beneficio o derecho al tercero. Por ello, la estipulación a favor de

123 J.M. MARTÍN BERNAL, La estipulación..., cit., p. 267.

124 En este sentido señala C. PÉREZ CONESA que «la representación directa se caracteriza por suponer en el tercero que contrata con el representante un conocimiento de la pertenencia de dicho acto a aquél por quien se gestiona, es donde se evidencia con mayor claridad que los efectos del contrato tienen como destinatario a un sujeto que, aun cuando no ha tenido participación personal, tampoco se puede decir que sea tercero» (El contrato..., cit., p. 17).

125 L. DíEz-PicAzo, Fundamentos..., Vol. I, cit., pp. 536 y ss. En este mismo contexto, el autor plantea la cuestión de si la relación que une el estipulante con el tercero beneficiario puede ser una relación de gestión o no, o sea, si el estipulante puede actuar en beneficio del tercero como un gestor o si el acto de la estipulación exige una causa diferente de la gestión. Finalmente, DíEZ-PICAZO admite el contrato a favor de tercero siempre que el estipulante actúe en nombre propio suyo, con la finalidad de atribuir únicamente un derecho de crédito al tercer beneficiario, así que la eficacia contractual debe recaer sobre las partes, que deberán cumplir o responderán por el incumplimiento del contrato. 
tercero no resulta idónea para imponer obligaciones recíprocas a cargo del tercero beneficiario, lo cual exigiría un contrato en nombre y por cuenta de éste ${ }^{126}$.

Otra diferencia se refiere al vínculo interno entre el representante y el representado, que permite al representado impartir instrucciones a su representante, sea por seguir controlando su actividad o para exigir sus cuentas, pues verdaderamente se considera el dueño del contrato. En cambio, en el contrato a favor de tercero la relación que liga el estipulante con el tercero es una relación independiente, de manera que el estipulante puede revocar la estipulación hecha a favor de tercero siempre que éste aún no haya aceptado el provecho. Ello no sucede en la contratación con representación, pues una vez concluido el contrato por el representante en nombre del dominus, sus efectos quedan irrevocables $^{127}$. De ahí que no deba confundirse las dos instituciones, aunque ambas pertenecen a un grupo de contratos con el mismo objeto ${ }^{128}$, que no es otro que el de contratar por cuenta de otro.

Un criterio más para distinguir ambas figuras radica en la identificación del tercero beneficiario, pues el estipulante puede designarlo no sólo en el momento de la conclusión del contrato, sino puede reservarse esta facultad también para un momento posterior (salvo en aquellos casos en que se exige identificar al destinatario para que éste pueda beneficiarse de la prestación estipulada para él). Por el contrario, en el supuesto de la representación, la designación del representado es imprescindible para que la representación quede clara y caracterizada desde el principio ${ }^{129}$.

${ }^{126}$ C. PÉrez CONESA, El contrato..., cit., p. 17 y ss.

127 J.M. MARTín BERNAL, La estipulación..., cit., p. 268.

${ }^{128}$ En este sentido, señala G. PACCHIONI que, «donde no basta la representación, surge el contrato a favor de tercero» (Los contratos..., cit., p. 243).

129 C. PÉREz CONESA, El contrato..., cit., p. 20, alude a los supuestos de representación directa e indirecta. La diferencia entre ambas se establece en el artículo $1.725 \mathrm{Cc}$, cuando se refiere a la representación directa diciendo que «[e]l mandatario que obre en concepto de tal no es responsable personalmente a la parte con quien contrata sino cuando se obliga a ello expresamente o traspasa los límites del mandato sin darle conocimiento suficiente de sus poderes». Así pues, se entiende de este precepto que la representación directa es solamente una forma de sustitución, por virtud de la cual una persona actúa en nombre y en interés de otra (el representado), pero sin que el representante sea responsable personalmente frente a los con los que contrata. En la representación indirecta, en cambio, el representante actúa frente a la contraparte en el contrato en su propio nombre (y no en el del representado), por mucho que este contrato de representación sea concertado para o 
En suma, no resulta posible construir jurídicamente el contrato a favor de tercero como un caso de representación, en cualquiera de sus modalidades, resultando inadecuada la idea de comparar (y menos aún equiparar) ambas instituciones con base en los argumentos antes aludidos.

\section{e) Contrato a favor de tercero y contrato por persona a designar}

El contrato por persona a designar se conoce como figura jurídica ligada al comercio (compraventa) desde finales de la Edad Media, siendo utilizada primero por venecianos y genoveses ${ }^{130}$. Es también en Italia donde tuvo por vez primera reflejo legal, concretamente, en los artículos 1.401 a 1.405 del Código civil de 1942 ${ }^{131}$. En España, por el contrario, la figura sigue siendo atípica, aunque existe algún precedente legal concreto de aplicación, como el llamado «remate a calidad de ceder a tercero» en las subastas judiciales, previsto en el artículo 1.499 de la (hoy derogada) Ley de Enjuiciamiento Civil de $1881^{132}$.

Al objeto de resaltar las similitudes y diferencias de la figura examinada con el contrato a favor de tercero, conviene primeramente definirla. Se entiende por contrato para persona que se designará (por o para persona a designar o a nominar) aquel contrato en el que una parte contratante, el estipulante o comprador $^{133}$, se reserva la facultad de designar, en un momento posterior y antes de una fecha concreta, a una tercera persona que, en el momento de la conclusión del contrato, es aún indeterminada, la cual ocupará definitivamente la po-

por cuenta de otro (por eso recibe, asimismo, el nombre de «representación oculta o mediata»).

130 L. DíEZ-PiCAZo, Fundamentos..., Vol. I, cit., p. 548.

${ }^{131}$ En el primero de los preceptos indicados se indica en qué consiste la facultad de reserva de la designación de contratante, estableciendo a tal fin que, "[e]n el momento de conclusión del contrato, una de las partes podrá reservarse la facultad de nombrar posteriormente la persona que deba adquirir los derechos y asumir las obligaciones que nacen de dicho contrato».

${ }^{132}$ L. DíEz-PiCAZO, Fundamentos..., Vol. I, cit., p. 548.

${ }^{133}$ En efecto, el ejemplo típico de contrato para persona que se designará es la compraventa. Para simplificar la configuración estructural de dicho contrato, valgo el ejemplo dado por MARTÍN BERNAL: «El comprador que adquiera para sí o por un amigo a elegir, seguido del nombre del amigo, pierde ex tunc la propiedad de la cosa adquirida». 
sición contractual y adquiere los derechos y asume las obligaciones del estipulante frente al promitente ${ }^{134}$.

Como puede observarse, en ambos contratos se emplea la misma nomenclatura para referirse a las partes contratantes (el estipulante y el promitente), que celebran un contrato a favor o para un tercero. Sin embargo, en el contrato a favor de tercero, éste recibe el nombre de «beneficiario», mientras en el contrato por persona a designar es la «persona designada» o «elegida». Por su parte, ambas figuras tienen como finalidad la integración de una parte tercera en el marco de un vínculo jurídico patrimonial. Estas similitudes no impiden, con todo, manifestar que ambas instituciones se diferencian significativamente en muchos puntos. En primer lugar, el contrato por persona a designar no se considera una excepción al principio de relatividad de los contratos, sino como un contrato ${ }^{135}$ que permite al tercero designado entrar en el vínculo contractual. Se convierte en parte contratante en sustitución del estipulante, como si el contrato hubiera sido celebrado por él en persona, y adquiere así todos los derechos y obligaciones derivadas del contrato ${ }^{136}$. Por el contrario, el tercero en el contrato a favor de tercero es una parte extraña, que ni ha intervenido en la celebración del contrato, ni tampoco se convierte en parte contratante, sino que es el acreedor de un derecho de crédito frente al promitente. Por lo tanto, no se le exige cumplir los requisitos de capacidad en el momento de la conclusión del contrato como sí sucede en el contrato por persona a designar ${ }^{137}$.

La segunda diferencia se refiere al contenido esencial de la prestación en cada institución. En el contrato a favor de tercero, la finalidad perseguida con-

134 M. C. GeTe-Alonso y CALERA, «La eficacia del contrato», en L. Puig i Ferriol et al., Manual de Derecho Civil, T. II, Derecho de obligaciones, Responsabilidad civil. Teoría del contrato, $3^{\text {a }}$ ed., Marcial Pons, Madrid, 2000, p. 655.

${ }^{135} \mathrm{Al}$ respecto de la naturaleza jurídica del contrato por persona a designar se ha discutido si se manifiesta a través de un solo contrato o si hay un doble juego de contratos celebrados alternativamente. La segunda opción ha sido defendida por ENRIETTI, a cuyo juicio existe un contrato entre el estipulante y el promitente que está sometido a una condición resolutoria, y un segundo contrato que liga al promitente con el tercero, sometido a una condición suspensiva. No obstante, la doctrina mayoritaria parte de la existencia de un contrato único para lograr la finalidad económica perseguida. Vid. L. Dítz-PiCAzo, Fundamentos..., Vol. I, cit., p. 549.

${ }^{136}$ C. PÉrez Conesa, El contrato..., cit., p. 29.

137 M. NAVARro Michel, El contrato para persona a designar. Nuevas perspectivas, Dykinson, Madrid, 2004, p. 99. 
siste en atribuir únicamente un derecho al tercero que le faculta para exigir su cumplimiento del promitente, pero sin que esta estipulación derive en ninguna obligación a su cargo ${ }^{138}$. En cambio, en el caso del contrato por persona a designar, una vez que se efectúe la designación definitiva del tercero, éste sustituye al estipulante y se convierte en sujeto de la relación contractual, de forma que se le transmite retroactivamente todos los efectos dimanantes del contrato, no sólo los derechos, sino también las obligaciones derivadas de la operación contractual. Tal eficacia retroactiva no cabe predicarla del contrato a favor de tercero, pues éste gira en torno a la adquisición por el tercero de un derecho de crédito a título de acreedor y no como parte contratante, a la que se extenderían todos los efectos del contrato. En consecuencia, el tercero beneficiario sólo tiene derecho a exigir el cumplimiento de su crédito frente al promitente, pero sin que ostente la facultad para, por ejemplo, modificar o terminar el contrato ${ }^{139}$.

La tercera distinción se refiere a la continuidad o desaparición del estipulante como parte contratante. En el contrato por persona a designar, una vez que se realice eficazmente y de manera definitiva la designación o electio del tercero designado, éste sustituye al estipulante en su posición contractual. El estipulante, por su parte, desaparece con la designación y se desvincula del contrato, dando paso al tercero que asume todos los efectos de este contrato con eficacia retroactiva, como si el contrato lo hubiera concluido por sí mismo. Tal sustitución no se produce en el contrato a favor de tercero, donde el estipulante no pierde su condición de parte contratante, que ni se cambia ni se muda, sino que sigue figurando como un sujeto contractual aun después de la aceptación del tercer beneficiario. Y ello debido a que la finalidad de este contrato consiste en atribuir un beneficio a un tercero que, aunque se adhiera posteriormente al contrato con su aceptación, lo hace a título de acreedor beneficiario y no se convierte en parte propiamente contratante ${ }^{140}$. De ahí que DiEz-PicAzo describa la estructura contractual del contrato a favor de tercero como un acto jurídico bila-

${ }^{138}$ J.M. MARTÍn BERNAL, La estipulación..., cit., p. 299.

139 X. Cecchini Rosell, La cláusula 'por sí o por persona que se designará', Tirant lo Blanch, Valencia, 2000, p. 254.

${ }^{140}$ L.B. PÉREZ GALLARDO, El contrato..., cit., pp. 309-310. 
teral en su formación, pero tripartito en sus efectos ${ }^{141}$. Es decir, el contrato se celebra entre dos partes (promitente y estipulante), aunque sus efectos se despliegan de forma triangular: promitente-estipulante (relación de cobertura), estipulante-tercero beneficiario (relación de valuta) y tercero-promitente (relación de ejecución). Por su parte, el contrato para persona a designar es bilateral igualmente en su formación, pero también en sus efectos, pues el estipulante se desvincula contractualmente y desaparece, como si nunca hubiera intervenido en este contrato ${ }^{142}$.

La cuarta diferencia esencial está vinculada al hecho de que, en el contrato a favor de tercero, el nacimiento del derecho de crédito del beneficiario se produce en el momento de la formación del contrato, sin necesidad de que conozca este hecho o que preste su aceptación para dar vida al contrato. La aceptación del tercero de la estipulación hecha en su favor no forma parte, por tanto, de la relación contractual, su aceptación es secundaria, pues sólo conlleva la producción de ciertos efectos determinados contra el promitente. Sucede lo contrario en el contrato por persona a designar: la aceptación de la persona designada se erige en requisito necesario para colocar a esta persona en la posición contractual del estipulante y asignarle todos los efectos derivados del contrato (y no sólo algunos ellos, como ocurre en el contrato a favor de tercero). Así, la ausencia de una declaración de voluntad del tercero elegido (en el sentido de aceptar la prestación una vez hecha la designación) le permite desvincularse totalmente del contrato, es decir, permanece al margen del contrato y los efectos patrimoniales de éste no le alcanzan en tanto no lo permita expresamente ${ }^{143}$.

La última diferencia entre ambas instituciones se refiere al marco estructural. En efecto, señala MARTín BERNAL que es distinto el modo de formación del contrato a favor de tercero en comparación con el del contrato para persona por designar. Mientras que en el primero el contrato se celebra en nombre exclusivamente propio del estipulante, la celebración cumple dos posibles finalidades en el segundo: la primera es una finalidad de gestión, que se enmarcaría en el

${ }^{141}$ L. DíEz-PiCAzO, Fundamentos..., Vol. I, cit., p. 543.

${ }^{142}$ C. PÉrez Conesa, El contrato..., cit., p. 30; L. DíEZ-PiCAZo, Fundamentos..., Vol. I, cit., p. 548; M. NAVARRO MiCHEL, El contrato..., cit., p. 100.

143 M. NAVARRo Michel, El contrato..., cit., p. 100. 
fenómeno representativo ${ }^{144}$; la segunda, una función de mediación, conforme a la cual el estipulante desempeña un papel de intermediario, esperando encontrar la persona a quien otorgar el contrato en su integridad ${ }^{145}$.

\section{Concepto y caracteres esenciales del contrato a favor de tercero}

\subsection{Concepto}

Tras analizar el origen y los antecedentes históricos del contrato a favor de tercero, desde su prohibición en el Derecho romano hasta su plena admisión en la actualidad, se advierte que el contrato a favor de tercero es una institución jurídica de creación reciente por los modernos Códigos civiles ${ }^{146}$ y consagrada por el uso de los negocios en la vida contractual.

El contrato a favor de tercero viene contemplado en el Código civil español en su artículo 1.257, párrafo $2^{\circ}$, de la siguiente forma: «Si el contrato contuviere alguna estipulación a favor de un tercero, éste podrá exigir su cumplimiento, siempre que hubiese hecho saber su aceptación al obligado antes de que haya sido aquélla revocada». La regla establecida por el precepto ha sido calificada de insuficiente ${ }^{147}$, y lo que llama la atención es la utilización (nada desacertada) por el legislador del término «estipulación» para referirse a este fenómeno. $Y$ es que «estipulación» $\mathrm{y}$ «contrato» a favor de tercero son dos instituciones distintas: la estipulación se define como una cláusula añadida a un contrato corriente (que produce efectos entre sus partes), por lo que tal cláusula verdaderamente no es más que una previsión contractual por virtud de la cual

\footnotetext{
$144 \mathrm{El}$ acto representativo en este caso se realiza cuando el estipulante se liga previamente con el tercero, en cuyo interés actúa y del que es gestor o mandatario. El estipulante actúa entonces como un representante del tercero a través de la representación, que en la primera fase de la celebración se queda oculta o encubierta. Vid. L. DíEz-PiCAzo, Fundamentos..., Vol. I, cit., p. 548; J. M. MARTín BERNAL, La estipulación..., cit., p. 298.

145 J.M. MARTín BERNAL, La estipulación..., cit., pp. 298 y ss.

146 A título de ejemplo, la figura del contrato a favor de tercero se halla reconocida legalmente en los arts. 1.411 a 1.416 del Codice civile italiano; en el Derecho alemán, la regulación jurídica del contrato a favor de tercero se contiene en el artículo 328 BGB como regla general; y en el Código civil francés la encontramos en los artículos 1.205 y ss.

147 Cfr. L. DíEz-PiCAzo, Fundamentos..., Vol. I, cit., p. 532.
} 
una de las partes (el estipulante) puede desviar una prestación hacia un tercero frente al otro (el promitente) ${ }^{148}$.

A la luz de esta descripción y frente a la noción de la estipulación, el contrato a favor de tercero tiene como objeto principal producir un efecto jurídico consistente en la atribución de un derecho de crédito al beneficiario. De esta manera, el derecho va a ingresar en el patrimonio de éste, mientras que las obligaciones del contrato permanecen en la esfera de las partes contratantes (estipulante y promitente). El tercero, en virtud del contrato hecho en su favor, adquiere el derecho directamente y desde el momento de la celebración, aun antes de que manifieste su aceptación; es más, la función de la aceptación ha de buscarse en impedir una eventual revocación posterior del derecho por parte del estipulante. Merced a ese derecho el tercero beneficiario deviene legitimado activo para reclamar judicialmente el cumplimiento del promitente, sin necesidad de contar con la cooperación procesal del estipulante.

A pesar de la diferencia conceptual expuesta anteriormente entre «estipulación» $y$ «contrato a favor de tercero», nada impide que, al hablar de contrato a favor de tercero (en sentido amplio, si se quiere), nos refiramos a un contrato en el cual se inserta dicha estipulación, en atención al hecho de que la operación pretende favorecer a un tercero, pues tiene su fundamento en un contrato celebrado entre el estipulante y el promitente; y la estipulación incluida en el contrato afecta decisivamente al régimen jurídico de la relación contractual, confiriendo unas propiedades particulares a los vínculos entre los contratantes, que no es exclusivo del contrato a favor de tercero (siempre y cuando, claro está,

148 J.I. CANO MARTíneZ DE VELASCO, El contrato a favor de tercero..., cit., pp. 29 y ss. También se ha definido el término «estipulación» afirmando que «no es un contrato sino más bien una cláusula, una previsión contractual cuya finalidad consiste precisamente en desviar hacia un tercero la prestación del promitente, atribuyendo a aquél el derecho a exigir directamente su cumplimiento» (J. LóPEZ RICHART, Los contratos..., cit., p. 281). Por esto mismo, ROCA SASTRE y PUIG BRUTAU estiman que «no es acertado hablar de contrato a favor de tercero, sino que resulta preferible usar el concepto clásico de estipulación (no precisamente en el sentido originario de contrato verbal) a favor de tercero, pues la particularidad consiste en el efecto de una cláusula que desvía la prestación hacia un tercero extraño al contrato. La estipulación es la cláusula dirigida a producir dicho efecto» (R. M ${ }^{\mathrm{a}}$. Roca SASTRE y J. PUIG BRUTAU, Estudios..., cit., p. 211). 
que exista una estipulación en beneficio de otro), sino que basta con que la finalidad del contrato sea atribuir un derecho de crédito al tercero ${ }^{149}$.

Así, resulta ocioso el debate sobre cuestiones terminológicas ${ }^{150}$, pues ambas expresiones designan un mismo fenómeno jurídico: la celebración de un contrato que atribuya de manera directa un derecho de crédito a un tercero.

Se puede hablar de un contrato a favor de tercero, como ha señalado PACCHIONI, en dos sentidos distintos: por un lado, en sentido lato o vulgar, por otro, en sentido estricto y técnico. En sentido amplio o lato, son contratos a favor de tercero todos aquellos que son celebrados con la intención de proporcionar una ventaja o cualquier provecho a un tercero'51. En sentido estricto o técnico son contratos a favor de terceros aquellos que se celebran únicamente entre dos partes, pero con la intención de atribuir un derecho de crédito a un tercero que no haya participado de ninguna manera - ni directa ni indirectamente- en la conclusión del contrato, quedando por ello exonerado de cualquiera obligación derivada de él 152 .

Otro es el concepto que sostienen Colin y CAPITANT, quienes afirman que la estipulación es un acto contractual por virtud del cual una de las partes estipula con la otra que se promete a dar o hacer alguna prestación en beneficio de un tercero extraño al contrato y que no está representado en él. En otras pala-

149 J. LÓPEZ RICHART, Los contratos..., cit., p. 282.

${ }^{150}$ En efecto, la expresión «estipulación a favor de tercero» se emplea en muchas ocasiones como sinónimo de un contrato que sea a favor de tercero en su integridad, esto es, para referirse al conjunto del acto jurídico. Por ejemplo, en Francia se conserva el término «estipulación para otro» («stipulation pour autrui»), tomado de POTHIER (cfr. art. 1.205 del Código civil francés). Por el contrario, en aquellos ordenamientos que siguen la estela del pandectismo se habla de «contrato a favor de tercero». Al respecto puede verse J. LóPEZ RICHART, Los contratos..., cit., p. 283.

${ }^{151}$ Como consecuencia, PACCHIONI incluye en este tipo contractual el «contrato celebrado por un representante en nombre de su representado", en tanto que este último no ha sido presente ni ha intervenido de ninguna manera en el momento de la celebración. Y sería también un contrato a favor de tercero en sentido lato, según este autor, aquel que se perfecciona en interés, pero no en nombre, de una persona concreta, incluso si el tercero no adquiere a consecuencia del mismo los derechos contractuales.

${ }^{152}$ La caracterización del contrato a favor de tercero efectuada por PACCHIONI viene referida en muchas ocasiones en la doctrina. Cfr., p.ej., L. DíEz-PICAZO, Fundamentos..., Vol. I, cit., p. 532; C. PÉrez CONESA, El contrato..., cit., p. 3-4; R.M a RoCa SASTRE y J. PUIG BRUTAU, Estudios..., cit., p. 211. Para la definición del contrato a favor de tercero en su sentido amplio y estricto véase G. PACCHIONI, Los contratos..., cit., p. XVII (primera página de la introducción de su obra). 
bras, la operación examinada puede definirse como aquella estipulación, incluida en un contrato y realizada en nombre propio, que desvía la prestación perseguida a favor de tercero, esto es, del titular originario (estipulante) hacia el tercero como titular definitivo153.

Entre los autores españoles que han intentado dar una definición del contrato a favor de tercero encontramos a OsSORIO MORALES, que distingue entre un plano externo y otro interno. En el plano externo, es estipulación a favor de tercero aquel contrato por el cual adquiere un derecho una persona originariamente extraña al contrato. En el plano interno, la estipulación a favor de tercero es un negocio entre los contratantes, cuya consecuencia jurídica consiste en efectuar una prestación a favor de un sujeto que se considera parte ajena al negocio, o sea, que no ha participado en su celebración ${ }^{154}$.

Por su parte, BONET RAMÓN ${ }^{155}$ añade tres requisitos que deben cumplirse para poder constatar la existencia de un contrato a favor de tercero. En primer lugar, que el tercero sea verdaderamente un extraño al vínculo contractual entre estipulante y promitente ${ }^{156}$. En segundo lugar, que la operación contractual quede fuera del ámbito de aplicación de la gestión de negocios ajenos ${ }^{157}$. Y, en tercer y último lugar, que concurra la voluntad de las partes contratantes de dar nacimiento a un crédito del tercero frente al promitente. Son estos, precisamen-

153 R M a Roca Sastre y J. PUig Brutau, Estudios..., cit., p. 211.

154 Véase C. PÉrEz CONESA, El contrato..., cit., p. 5.

${ }^{155}$ F. BONET RAMÓN, «Los contratos a favor de tercero», AAMN, núm. XII, 1961, pp. 6 y ss.

${ }^{156}$ Como es natural, si el pretendido tercero es parte en el negocio, no puede hablarse de estipulación a favor de tercero. En la práctica, esto puede suceder sobre todo en dos tipos de situaciones. Conforme al primero, señala BONET RAMÓN, «Tertius (tercero) había dado a Primus (estipulante) el mandato de estipular en su nombre; en este caso Primus ha obrado como mandatario; no hay más que dos partes en la operación, Tertius y Secundus (promitente) cada uno obrando por cuenta propia». La segunda situación se presenta cuando el tercero es heredero del estipulante y tras el fallecimiento de éste se sitúa en la posición de su causante: se estaría ante un contrato ordinario que, aquí sí, sin más produce efectos para el tercero [«Los contratos sólo producen efectos entre las partes que los otorgan y sus herederos», reza el art. 1.257 $1^{\text {a }}$ Cc (la redonda es nuestra)].

157 Con este requisito, BONET RAMÓN tiene en cuenta la eventualidad de que, en rigor, se esté efectuando una gestión por el estipulante, en los términos clásicos de este negocio, y aclara la situación con el siguiente ejemplo: «el tercero está alejado del centro de sus interés y su casa amenaza ruina. Primus toma la iniciativa de proceder a las reparaciones urgentes: con este fin se dirige a un contratista con el que celebra un contrato; haciendo esto no estipula para Tertius en el sentido jurídico de provecho: el contrato se encuadra en una gestión de negocio, subordinada a la ratificación del dueño». 
te, los rasgos definidores que caracterizan el contrato a favor de tercero y de los que nos vamos a ocupar en el epígrafe siguiente.

Tampoco difiere, en fin, la definición que de la estipulación a favor de tercero efectúa la jurisprudencia: es doctrina consolidada del Tribunal Supremo la que considera que «en sentido estricto o técnico, tiene el carácter de contrato a favor de tercero, aquel que, celebrado válidamente entre dos personas, es dirigido sin embargo a atribuir un derecho a una tercera, que no ha tenido parte alguna, ni directa ni indirectamente en su conclusión y que a pesar de ello, logra efectivamente atribuírselo en su propia persona, sin que pueda estimarse tal derecho como propio del que estipuló el contrato y cedido luego al tercero, o simplemente ejercido por éste en lugar de aquél»158. En definitiva, que la estipulación a favor de tercero «significa en sentido técnico y preciso la atribución de un derecho a quien no ha sido parte en la celebración del negocio» 159 o «una relación contractual en la que el acreedor deriva la prestación del deudor hacia otra persona que no ha intervenido en el contrato» ${ }^{160}$.

\subsection{Caracteres esenciales}

De la definición anterior puede extraerse los caracteres esenciales del contrato a favor de tercero. Resumidamente, tales caracteres son: por un lado, el carácter contractual de la estipulación a favor de tercero; por otro, la posición del tercero como una parte extraña a la relación contractual; y, por último, la finalidad perseguida por las partes, consistente en hacer nacer un derecho de crédito a favor de tercero, que le posibilita para hacerlo valer y reclamar su cumplimiento frente al promitente ${ }^{161}$.

${ }^{158}$ STS de 10 de diciembre de 1956 (RJ 1956, 4126).

${ }^{159}$ STS de 8 de octubre de 1984 (RJ 1984, 4765), con cita de otras anteriores de 28 de junio de 1961 (RJ 1961, 3017); de 18 de diciembre de 1964 (RJ 1964, 5894); y de 7 de junio de 1976 (RJ 1976, 2634).

${ }^{160}$ STS de 6 de febrero de 1989 (RJ 1989, 670), reproducida en este extremo por otra de 26 de abril de 1993 (RJ 1993, 2964).

${ }^{161}$ R. BERCOVITZ RodRíGUEZ-CANO (coord.), Manual de derecho civil, Bercal, Madrid, 2011, p. 70. 


\section{a) El carácter contractual de la estipulación}

De un examen del artículo 1.257 Cc se infiere que la estipulación que otorga un derecho a un tercero que no ha participado en su otorgamiento tiene origen contractual $^{162}$. Ahora bien, cuando se habla de contrato a favor de tercero, es evidente que sus efectos se extienden más allá de los sujetos contratantes. Su eficacia alcanza no sólo a éstos, sino también al tercero que no estaba presente en el momento de la negociación y la perfección del contrato. Y ello por cuanto la intención perseguida por los sujetos originarios es desviar hacia el tercero un derecho de crédito a través de un acuerdo, integrando en el contrato una estipulación (o sea, una cláusula) a favor de tercero. De ello se desprende que esta estipulación, entendida como una operación encuadrada en un contrato, produce un vínculo triangular entre los sujetos del mismo ${ }^{163}$.

En suma, se puede decir que la estipulación a favor de tercero es una operación jurídica accesoria que deriva de un contrato (que podrá ser de cualquier clase: oneroso, remuneratorio, aleatorio o gratuito) por el cual las partes pretenden solucionar a través de un solo negocio una doble composición de intereses, al objeto de atribuir a un sujeto extraño un crédito nacido de un contrato que para él es ajeno. Por lo tanto, el régimen específico de este negocio jurídico se rige por las reglas del contrato fundamental en que se inserta esta operación o estipulación, y por motivos o causas ${ }^{164}$ preexistentes entre el estipulante y el tercero (p.ej., pagar una deuda del estipulante frente al tercero) ${ }^{165}$.

162 Según lo dispuesto en el art. 1257.2 «Si el contrato contuviere alguna estipulación $a$ favor de un tercero...» (la redonda es nuestra).

163 C. PÉrez CONESA, El contrato..., cit., pp. 7 y ss.

164 La causa del contrato a favor de tercero se ha estudiado desde un punto de vista dogmático al objeto de dilucidar si la atribución de un derecho de crédito al tercero es causa suficiente para el contrato establecido entre estipulante y promitente o si la verdadera causa es independiente de aquella atribución y habrá que buscarla en las relaciones preexistentes entre estipulante y tercero o entre las partes del contrato (promitente y estipulante). LóPEZ RICHART analiza ambas propuestas y afirma que lo primero es cierto cuando la estipulación a favor de tercero agota el contenido dispositivo de la relación contractual, mientras que lo es lo segundo cuando, desde un punto de vista estructural, la estipulación conforma un pacto o cláusula accidental dentro del contrato (Los contratos..., cit., p. 284).

165 Á. CARRASCO PERERA, Derecho..., cit., p. 612. 


\section{b) El tercero es un sujeto extraño al contrato}

Como quiera que la verdadera naturaleza del contrato a favor de tercero se explica en atención a su consecuencia jurídica (la transferencia patrimonial en beneficio de alguien que es originariamente extraño al contrato y no ha participado en su celebración), resulta obvio que de entre los rasgos que se empleen para deslindar esta figura contractual se encuentre la falta absoluta de intervención del tercero en la celebración del contrato. Por lo tanto, no es un tercero extraño al negocio el que ha tenido participación de alguna forma en el pacto obligacional: los efectos jurídicos de esta convención le alcanzarán por aplicación de las reglas generales en materia de obligaciones y contratos. La participación del tercero en este caso puede efectuarse expresamente - si manifiesta su consentimiento a la celebración del contrato- o bien de forma sustantiva, cuando sea el centro de imputación de derechos y obligaciones como titular de todos los efectos del contrato celebrado por medio de representante ${ }^{166}$.

Quedan fuera también de la condición de tercero extraño al contrato aquellos supuestos en que éste adquiere un derecho de otro a título derivativo, por herencia, por cuanto el tercero se convierte en parte del contrato por efecto del fenómeno sucesorio. Los causahabientes no tienen la calidad de terceros, aunque no han participado en la conclusión originaria del contrato por sus causantes, pues el heredero se considera una parte continuadora de la personalidad jurídica del fallecido, ocupando la misma titularidad jurídica en el contrato como si lo hubiera celebrado ${ }^{167}$.

A partir de aquí, cabe imaginarse dos situaciones bien distintas que tienen en común la producción de efectos jurídicos en la esfera patrimonial de un tercero, el contrato a favor del tercero y el contrato con «obligación del terce-

${ }^{166}$ C. PÉrez CONESA, El contrato..., cit., p. 11 y ss.

${ }^{167}$ Así, el art. 1257 Cc consagra el principio de la relatividad contractual señalando que sólo produce efectos el contrato entre las partes que lo celebran y sus herederos, con la excepción de que se trata de derechos y obligaciones no transmisibles. De ahí, afirma PÉREZ CONESA, que "estipular a favor de los propios herederos no se puede considerar estipulación a favor de tercero, sino a favor de la propia sucesión, con la salvedad de que el causante haya estipulado a favor de los herederos con la intención de considerarlos al margen de ese carácter» (El contrato..., cit., p. 13). 
ro»168. En el primer caso, la eficacia externa del contrato a favor de tercero se extiende para incluir personas que no han intervenido en modo alguno en su celebración, y su validez se sustenta sobre la idea de que al tercero sólo se atribuye un derecho, pero no las obligaciones correspondientes. Sucede, sin embargo, que a veces se impone al tercero beneficiario una carga junto con el derecho que se le otorga. Es es el caso, señaladamente, de aquellos contratos de transporte en los que la obligación (rectius, la carga) de pagar los portes se atribuye al destinatario («a portes debidos»), de manera que será éste quien deba satisfacer el precio del transporte en aras de obtener la prestación (la entrega de las mercancías). Habrá ocasión de volver sobre este aspecto más adelante en el texto ${ }^{169}$ y baste señalar, por el momento, que ello no convierte necesariamente al tercero en «parte» en sentido estricto, aunque se trata de una cuestión enormemente controvertida. Se trataría, en todo caso, de una adquisición sobrevenida de la posición de parte, que en nada empece la conclusión anterior: es tercero en el sentido de lo previsto en el artículo $1.2572^{\mathrm{a}} \mathrm{Cc}$ aquel sujeto que, en el momento de la celebración del contrato, es ajeno a él.

\section{c) El influjo de las voluntades de las partes y del tercero}

En la ciencia jurídica germánica, sobre todo en las obras de UNGER y de GREIS, toda la teoría del contrato a favor de tercero se basa sobre la voluntad de las partes contratantes, y a la misma voluntad se recurre para resolver todas las dificultades atinentes a ella ${ }^{170}$. Según la teoría germánica basta, pues, para que sea vá-

${ }^{168} \mathrm{El}$ denominado contrato a cargo de un tercero, según MARTín BERNAL, es un contrato de carácter impropio, un negocio por virtud del cual una de las partes (promitente) promete a la otra (promisario) que un tercero extraño, que no ha tenido parte en la celebración del contrato, realizará una determinada prestación. Para ello se requiere, como es natural, un acuerdo previo entre el promitente y el tercero, mas este acuerdo no surte ningún efecto en la relación entre promitente y promisario, lo cual expone a aquél al riesgo de que el tercero no cumpla con éste. En caso de que dicho riesgo se materialice, los daños y perjuicios ocasionados por el incumplimiento del tercero habrán de ser indemnizados por el promitente. Por su parte, para ENNECCERUS y LEHMANN, el llamado contrato a cargo de tercero, "más que a una necesidad, creen que responde al atractivo que sobre la doctrina ejerce la simetría de los conceptos. Por ello se ha intentado hallar un contrato a cargo de tercero que sea la contrapartida del contrato a favor de tercero» (J.M. MARTíN BERNAL, La estipulación..., cit., págs. 157-158).

169 Véase infra, Cap. IV, sub II.2.

${ }^{170} \mathrm{Al}$ contrario de cuanto sucedía (como podrá constatarse infra, sub III.) en Códigos como el francés anterior a la reforma de 2016 o el italiano de 1865, que negaban con carácter ge- 
lida la atribución de un derecho de crédito al tercero, que exista una voluntad genérica de pactar la estipulación correspondiente ${ }^{171}$. Por ello, lo que caracteriza al contrato a favor de tercero es precisamente el nacimiento del derecho en la persona de ese tercero como resultado de la autonomía de la voluntad de las partes contratantes, sin que el consentimiento del tercero sea un requisito decisivo a la hora de la celebración del contracto ${ }^{172}$. La razón de admitir la figura del contrato a favor de tercero es, pues, la intención de atribuir al tercero un derecho de crédito que nace de la voluntad de las partes contratantes ${ }^{173}$. Y así también se comprende que el beneficio que se puede atribuir a un tercero ha de dimanar conscientemente de una acción intencional de las partes contratantes, en el sentido de que la voluntad de atribuir a ese tercero un derecho de crédito es un fundamento esencial en la estructura contractual ${ }^{174}$.

De lo dispuesto en el artículo 1.257 Cc se desprende además que, para que el derecho de crédito del tercero sea irrevocable, basta con la sola aceptación de éste, aunque nada establece la norma sobre al momento de prestar esta aceptación, ni cómo debe ser prestada. A este respecto, las partes del contrato podrán estipular que el tercero beneficiario tenga la posibilidad de prestar de manera inmediata su consentimiento para aceptar la prestación, mas también podrán pactar que el beneficiario sólo podrá declarar su aceptación una vez que se cumpla, bien un plazo fijado o una condición determinada. Esto último es lo que

neral la validez de los contratos a favor de tercero, salvo en ciertos casos expresamente previstos en la ley.

${ }^{171}$ Así, la ciencia jurídica en Alemania interpreta la intención de las partes de forma rigurosa, esto es, "como la verdadera y propia intención de hacer surgir en el tercero un derecho de acción propiamente suyo, inmediatamente o pasado cierto tiempo, de modo absoluto o bajo ciertas condiciones». Vid. G. PACCHIONI, Los contratos..., cit., pp. 212-213. 172 P. JiMÉNEZ BlanCo, El contrato..., cit., p. 32.

173 Así lo señala ENNECCERUS cuando advierte de que el tercero adquiere el derecho en virtud del contrato que los contratantes han celebrado, por la única razón de que así lo han querido la partes. En parecido sentido, PÉREZ y ALGUER exigen que las estipulaciones a favor de tercero deben mantenerse dentro de los límites del art. 1.255 Cc, y OssoRio MORALES defiende al respecto que "es inútil conjeturar explicaciones de que no está necesitada la eficacia de esta institución».Vid. R.M ${ }^{a}$ ROCA SASTRE y J. PUIG BRUTAU, Estudios..., cit., p. 218.

${ }^{174}$ Con mayor detalle sobre el papel de la voluntad de las partes contratantes en atribuir un derecho de crédito a un tercero beneficiario que no ha tenido parte alguna en la relación obligacional, J. LÓPEZ RICHART, Los contratos..., cit., p. 222 y ss. En su estudio, el autor se refiere a los tipos de voluntades que se unen con el objeto de que el tercero adquiera el derecho y pueda hacerlo valer, distinguiendo dos clases: la expresa y la tácita. También establece algunos criterios orientativos para descubrir esos dos tipos de voluntad. 
sucede, precisamente, en el contrato del seguro de vida, en el que la aceptación del tercero se hace depender del fallecimiento del estipulante ${ }^{175}$.

\section{Elementos subjetivos de los contratos a favor de tercero}

Lo habitual en un contrato es que existan y concurra la voluntad de dos partes contratantes para que aquél surta su efecto jurídico Sin embargo, el contrato que contiene una estipulación a favor de tercero involucra a tres sujetos, y eso provoca la complejidad de ese tipo contractual, que encuentra su primera manifestación en la existencia de un titular de un derecho de crédito derivado del contrato que es una parte ajena a éste y diferente de las propias partes contratantes ${ }^{176}$. En la terminología usual, las partes contratantes se designan como «estipulante»y «promitente», mientras que el tercero en cuyo favor se estipula alguna prestación recibe el nombre de «beneficiario».

\subsection{El estipulante}

Es la parte contratante que estipula con el promitente la realización por éste de una prestación a favor de un tercero ${ }^{177}$.. En efecto, el estipulante (o promisario) desempeña el papel del destinatario del valor patrimonial de esta prestación frente al tercero beneficiario, por virtud del cual ese tercero se convierte en acreedor y sujeto con legitimación activa para dirigir una reclamación contra el promitente en caso de incumplimiento de la obligación. En definitiva, es el estipulante quien toma la iniciativa de esta estipulación y es también él quien establece la prestación que ha de efectuarse por parte del promitente frente al tercero $^{178}$. Con todo y con eso, aun siendo el estipulante siempre una parte del con-

175 D. DE BUEN LOZANO, «La estipulación...», cit., p. 124.

${ }^{176}$ P. JIMÉNEZ BLANCO, El contrato..., cit., p. 30.

177 Obsérvese que el estipulante - al igual que el promitente- no tiene que tener ninguna capacidad especial para contratar, pues basta con que goce de capacidad general según lo dispuesto en el artículo $1.263 \mathrm{Cc}$ ( $«$ No pueden prestar consentimiento: $1^{\circ}$. Los menores no emancipados, salvo en aquellos contratos que las leyes les permitan realizar por sí mismos o con asistencia de sus representantes, y los relativos a bienes y servicios de la vida corriente propios de su edad de conformidad con los usos sociales; $2^{\circ}$. Los que tienen la capacidad modificada judicialmente, en los términos señalados por la resolución judicial»). Cfr. L. DíEZ-PICAZo, Fundamentos..., Vol. I, cit., p. 538.

${ }_{178}$ J. M. MARTÍn BERnAL, La estipulación..., cit., p. 182. 
trato convenido con el promitente, no es, al menos inicialmente, acreedor de la prestación a favor del tercero: estipulante y promitente no reciben plenamente todos los derechos y obligaciones por igual, sino que retienen para sí las obligaciones mientras que transmiten de una manera $\mathrm{u}$ otra todos o algunos de los derechos derivados del contrato al tercero favorecido.

El estipulante sigue siendo parte durante todo el proceso de ejecución contractual, incluso después de que el tercero haya manifestado su voluntad de aceptar su derecho de crédito frente al promitente. A pesar de no ser (necesariamente) un acreedor del promitente, se le puede atribuir al estipulante algunas facultades relativas al contrato que, en ocasiones, coinciden con las del tercero, como por ejemplo la facultad de exigir la prestación al promitente (obligado) ${ }^{179}$. Lo que no puede, en principio, es exigir el cumplimiento para sí, porque no es acreedor del obligado. Mas ello no obsta, como es natural, para que, en caso de incumplimiento por parte del promitente, se dirija contra él y pida la resolución del contrato, pudiendo reclamar el resarcimiento de los daños y perjuicios sufridos por él ${ }^{180}$ por el hecho de la inejecución ${ }^{181}$.

Ahora bien, como se ha tenido ocasión de señalar, aunque el estipulante no puede exigir el cumplimiento para sí mismo, sí puede hacerlo para el tercero favorecido. También se le reconocen al estipulante en cuanto parte de la relación obligacional algunos poderes contractuales, tales como la modificación y la revocación del contenido del contrato, al menos en tanto el tercero no declare su intención de querer aprovechar la estipulación hecha en su favor (esto es, que la acepte). La idea de permitir al estipulante exigir el cumplimiento de la prestación para el tercero y no para sí tiene su fundamento en el hecho de que, por un lado, el estipulante no tiene la consideración de acreedor del promitente; por

${ }^{179}$ La exigencia de esta prestación del promitente puede formularse simultáneamente por el estipulante y el tercero, pero ello no significa que los dos compartan el derecho de crédito emanado del contrato. Vid. J. I. CANO MARTÍNEZ DE VELASCO, El contrato..., cit., p. 62.

180 Así lo estima también PÉREz CONESA, cuando señala que «la titularidad de la acción indemnizatoria propia del estipulante tiene aquí justificación por el daño que le puede ocasionar el incumplimiento de la obligación del promitente, si se tiene en cuenta la otra faceta del interés del estipulante, es decir, el interés en el otorgamiento del derecho al tercero que se halla en la relación de valuta donde, incluso cuando la causa sea donandi, el daño no patrimonial sería resarcible» (C. PÉREZ CONESA, El contrato..., cit., p. 214).

${ }^{181}$ F. BONET RAMÓN, «Los contratos...», cit., p. 21. 
otro, que es parte en el contrato para beneficiar al tercero, lo que le faculta para válidamente reclamar el cumplimiento de la prestación que constituye el objeto de dicho contrato. A su vez, el estipulante ha de entregar la contraprestación al promitente, en el caso de que el contrato fuera de carácter oneroso; si fuese gratuito, se estaría ante un contrato unilateral a favor de tercero ${ }^{182}$.

\subsection{El promitente}

El artículo $1.2572^{\text {a }}$ Cc se refiere al promitente como el «obligado» ${ }^{183}$, que ocupa el sitio del contratante deudor de la prestación pactada y que ha de efectuarla en la persona del tercero favorecido ${ }^{184}$. Al igual que sucede con el estipulante, no es necesario que ostente una capacidad especial para celebrar el contrato a favor de tercero, de manera que la capacidad que se le requiere para estipular que se obliga frente al tercero es la misma que la que se exige para pactar el contrato base: por regla general, basta con tener capacidad ordinaria para contratar (art. 1.263 Cc) ${ }^{185}$, dado que el promitente asume frente al tercero la obligación, cuyo origen se halla en el contrato que ha concluido con el estipulante ${ }^{186}$.

$\mathrm{Al}$ prometer la prestación a favor de tercero, el promitente se convierte en legitimado pasivo de la acción de cumplimiento de la obligación frente al estipulante, pero también frente al tercero, en lo que se refiere a la ejecución de la prestación (que puede ser de dar, hacer o no hacer). De ello resulta que la obligación del promitente realmente tiene una doble causa: una que descansa sobre la relación de cobertura con el estipulante; otra que se encuentra fuera de la esfera contractual y tiene que ver con el tercero (por causas preexistentes al contrato, en virtud de las cuales se ha realizado esta estipulación).

A su vez, el promitente no está obligado a mantener la oferta de realizar la prestación si no hay coincidencia de voluntades, esto es, si el tercero no decla-

182 J.I. CANO MARTÍNEZ DE VELASCO, El contrato..., cit., p. 64.

183 J.M. MARTín BERNAL, La estipulación..., cit., p. 182.

184 P. JimÉnEZ Blanco, El contrato..., cit., p. 30.

185 L. DíEz-Picazo, Fundamentos..., Vol. I, cit., p. 538.

186 I. GONZÁLEZ PACANOWSKA, «Comentario...», cit., p. 391. 
ra su aceptación dentro del plazo que se hubiera establecido ${ }^{187}$. No obstante, nada impide que se incluya en el mismo contrato una cláusula que establezca que el promitente quede obligado a mantener la oferta, por lo menos durante un plazo determinado, y resulta inadmisible retirar la oferta por parte del promitente en tanto no transcurra el plazo, porque no puede hacerlo sin causa que lo justifique. El tercero podrá aceptar la oferta aun después de haberse ésta retirado, siempre que manifieste su voluntad para aceptarla dentro del plazo determinado para mantenerla. Una vez verificada la aceptación, surte todos los efectos la estipulación hecha a favor del tercero ${ }^{188}$.

\subsection{El beneficiario o tercero}

Beneficiario ${ }^{189}$ o tercero es quien no es parte en el contrato celebrado, sino un extraño que no interviene de ninguna manera en su celebración. Aunque se convierte en acreedor del promitente al adherirse al contrato mediante la aceptación del beneficio estipulado en su favor, su carácter de extraño se mantiene a lo largo del proceso negocial, y ni siquiera tras la aceptación del provecho se convierte, por regla general, en parte contractual ${ }^{190}$. El beneficiario o tercero, en concreto, es aquel que adquiere el derecho de crédito frente al promitente, razón

187 Citando a otros autores - como WORMS, DEMOLOMBE y PLANIOL-, BONET RAMÓN señala en este mismo sentido que no hay duda de que el plazo indicado por el promitente para mantener su oferta de prestación es eficaz antes de la aceptación, pues la voluntad unilateral obliga.

188 D. DE BUEN LoZANO, «La estipulación...», cit., pp. 223-226.

${ }^{189}$ Con detalle sobre la figura del beneficiario en un ejemplo concreto de contrato a favor de tercero, el seguro de vida, véase C. BOLDó RODA, El beneficiario en el seguro de vida, Bosch, Barcelona, 1998.

190 Este carácter estructural del contrato a favor de tercero no sólo explica su importancia institucional como auténtica excepción al principio de relatividad contractual, sino también sirve para distinguir sus efectos jurídicos de los producidos por otras instituciones o figuras como, por ejemplo, el contrato para persona a designar. Aunque ya se ha estudiado con anterioridad este tema en el epígrafe dedicado a la distinción de figuras afinas, en el contrato para persona a designar tampoco el tercero designado interviene en la celebración del contrato, pero una vez aceptada su designación, se convierte automáticamente en parte contractual, dejando de ser tercero, y así al tercero designado le alcanzan no sólo los derechos sino también las obligaciones establecidas en el contrato a su cargo. Respecto de la posición del tercero una vez declarada la aceptación nos remitimos nuevamente a lo que más adelante se dirá sobre esta cuestión en el contrato de transporte (véase infra, Cap. IV, sub III.2). 
por la cual no se le exige capacidad de obrar ni personarse en la negociación y la celebración del contrato ${ }^{191}$.

En cuanto a la designación del beneficiario, no hace falta que el tercero esté determinado en el momento de la celebración del contrato, y basta con que sea determinable en atención a criterios establecidos en el propio contrato o que se deje al arbitrio de circunstancias futuras o indirectas, o incluso que su determinación se deje al arbitrio del estipulante ${ }^{192}$. Ahora bien, es preciso destacar que, en el caso de la estipulación a favor de tercero, no se puede hablar de adquisición del derecho por el tercero si éste aún no está determinado o no tiene todavía personalidad jurídica193. Ello tiene que ver con el hecho de que la determinación del tercero es necesaria para que éste pueda perfeccionar la estipulación hecha en su favor mediante su aceptación ${ }^{194}$ de querer aprovechar el beneficio derivado del contrato.

De cuanto antecede se comprende sin dificultad que la voluntad del tercero no es para aceptar el contrato en su totalidad (que le convertiría en parte contratante), sino sólo para declarar su deseo de aprovechar la prestación ofrecida por el promitente ${ }^{195}$. La aceptación tiene un valor parecido al de la aceptación de la herencia: es una condicio iuris ${ }^{196}$ para adquirir el derecho y hace que el éste ingrese definitivamente en el patrimonio del tercero aceptante con efecto

${ }^{191}$ M. NAVARRo Michel, El contrato para..., cit., p. 99.

192 Al respecto, PÉREZ y ALGUER, señalan, con base en la autonomía de la voluntad consagrada en el art. $1.255 \mathrm{Cc}$, que «nada obsta a que su determinación se deje al arbitrio de circunstancias futuras por analogía con los artículos 627 y 794 del Código civil, o que su determinación pueda hacerse sólo por circunstancias indirectas-artículos 772 y 773-e incluso, como ya se dijo, por declaración posterior del promisario, si así se hubiere pactado» (citados por J.M. MARTÍN BERNAL, La estipulación..., cit., p. 189).

193 En lo que se refiere a la persona jurídica, admite el Tribunal Supremo en su sentencia de 1 de julio de 1977 (non vidi) que, aunque no esté formada, «lo importante es que esté claramente designada, legalmente constituida y que se identifique como la beneficiaria de la reserva de derecho en el momento de reclamar su cumplimiento" (citada por I. GONZÁLEZ PACANOWSKA, «Comentario...», cit., p. 392).

194 En la doctrina germánica, la aceptación del tercero para adquirir su derecho de crédito tiene una relevancia menor, pues el derecho se atribuye $a b$ initio al tercero una vez que las partes hayan celebrado el contrato. Su aceptación se configura más bien como la concreción de su facultad de renunciar.

195 J. I. CANO MARTínEZ DE VELASCO, El contrato..., cit., p. 100.

196 En el mismo sentido, sostiene BONET que, «más que una aceptación en el sentido contractual, la declaración del tercero no es sino una adhesión elevada por la ley a condicio iuris de la adquisición» (citado por M. CASALS COLLDECARRERA, El contrato..., cit., p. 369). 
retroactivo, de modo que le permite excluir la potestad revocatoria de las partes contratantes ${ }^{197 .}$

Para determinar la función y la verdadera naturaleza jurídica de la aceptación del tercero se han esgrimido muchas opiniones, de entre las que destaca la de PACCHIONI, quien afirma que no es posible considerar la acción de declarar por el tercero la aceptación de una oferta del contrato estipulado, y tampoco es posible descartar su exigencia como un requisito necesario. Por esta razón, PACCHIONI aboga por una vía intermedia, reconociendo que la declaración del tercero es «requisito legal del perfeccionamiento de su derecho»198. Y este derecho se fundamenta en primer lugar en el contrato que, según BonELLI, no llega a ser completo hasta el momento en que el tercero exprese su intención de querer aprovechar la prestación beneficiosa ${ }^{199}$.

Junto a la aceptación del derecho por el tercero, se le reconoce también una libertad para rechazarlo. Pero sucede a veces que el favorecido muere antes de que declare su aceptación o su rechazo, con lo que transmite el derecho de crédito de su patrimonio al patrimonio hereditario. En efecto, la opción de aceptar o rechazar la prestación del promitente pasa a sus herederos ${ }^{200}$, salvo si la

197 Entre los estudios realizados sobre el tema de la aceptación del tercero, conviene citar a PACCHIONI que, al indagar en la naturaleza de la aceptación, se cuestiona si en su fundamento constituye un requisito para poder adquirir el derecho atribuido por el promitente al tercero, o si sólo constituye un medio para que la estipulación hecha en su favor sea revocada por el estipulante (similar la opinión de LAMBERT y BAUDRY). LACANTINÉRIE, por su parte, sostiene que el contrato es la fuente jurídica que confiere inmediatamente un derecho de crédito al tercero y la aceptación de este último no es sino una declaración expresa de hacer valer su derecho, y no se puede decir que esta declaración de aceptación haga que nazca ese derecho; lo que sí tiene es el efecto de privar al estipulante de la posibilidad de revocarlo (vid. M. CASALS COLLDECARRERA, El contrato..., cit., p. 368). En el artículo $1.257 \mathrm{Cc}$, el legislador español no contempla la aceptación como un requisito necesario para el otorgamiento del derecho, sino para facultar al tercero aceptante para reclamar su derecho al cumplimiento de la prestación antes de que la operación estipulada haya sido revocada por las partes contratantes. Vid. C. BOLDó RODA, «El seguro de vida como contrato a favor de tercero", en Estudios jurídicos en homenaje al profesor Vidal Guitarte, Tomo I, Castellón-Valencia, 1999, p. 105.

198 G. PACCHIONI, Los contratos..., cit., p. 199.

199 Citado por M. CASALS COLLDECARRERA, El contrato..., cit., p. 369.

${ }^{200}$ En caso de fallecimiento del beneficiario, nada impide que la facultad de aceptación o rechazo del beneficio sea objeto de adquisición por los herederos, en base al principio de sucesión universal, si esa facultad tiene un valor patrimonial. Vid. J.I. RoDRíGUEZ GONZÁLEZ, El principio..., cit., p. 257. 
prestación es de naturaleza personalísima (es decir, si el efecto jurídico no se produce si el beneficio no llega a la persona determinada) ${ }^{201}$.

La decisión del tecero de aceptar o rechazar la prestación ha de notificarse al obligado (el promitente) según lo dispuesto en el artículo $1.2572^{\mathrm{a}} \mathrm{Cc}$, porque hasta el momento en que el promitente recibe la aceptación del tercero, la estipulación se puede revocar ${ }^{202}$. Si el tercero acepta, esta notificación sirve para iniciar el proceso de ejecución de la prestación. Ello significa que la operación obligacional entra en el proceso final de la ejecución, y desde ese momento el promitente debe cumplir su obligación, sin que la prestación pueda ser modificada o revocada. En el caso de rechazo por el tercero, por el contrario, el derecho de crédito no ingresa en su patrimonio ${ }^{203}$.

En cuanto a la forma de la declaración de voluntad del tercero, el legislador en el artículo $1.2572^{\mathrm{a}}$ no exige forma alguna para la aceptación, y tampoco exige declararla expresamente, por lo cual es admisible hacerlo de forma tácita. No obstante, como señala DíEz-PiCAzo, esta aceptación debe ser tempestiva, al igual que su comunicación al promitente, por lo que ha de realizarse antes de que sea revocado el beneficio por el estipulante 204 .

\section{Consecuencias jurídicas derivadas del contrato a favor de tercero}

\subsection{La configuración jurídica de las relaciones derivadas de la estipulación a favor de tercero}

El contrato a favor de tercero supone, como sostiene JOSSERAND, una operación triangular en cuanto a su consecuencia jurídica, y bilateral en lo que se refiere a su formación ${ }^{205}$. En efecto, el contrato a favor de tercero implica conceder un efecto jurídico (beneficio) por los sujetos del contrato a un tercero ajeno a él,

\footnotetext{
${ }^{201}$ J.I. CANO MARTÍNEZ DE VELASCO, El contrato..., cit., p. 101.

${ }^{202}$ I. GONZÁLEZ PACANOWSKA, «Comentario...», cit., p. 399.

203 J.I. CANO MARTÍNEZ DE VELASCO, El contrato..., cit., p. 101.

204 L. DíEz-PiCAZO, Fundamentos..., Vol. I, cit., p. 543.

205 Citado, p.ej., en J. M. MARTín Bernal, La estipulación..., cit., p. 303; L.B. PÉReZ Gallardo, El contrato..., cit. p. 334; L. DíEZ-PiCAZo, Fundamentos..., Vol. I, cit., p. 543.
} 
excluyendo ${ }^{206}$ al mismo tiempo a una parte contratante, el estipulante, de este beneficio. De ahí la relación tripartita de los sujetos, dos de los cuales intervienen en la celebración del negocio (estipulante y promitente) mientras que el otro se incorpora posteriormente al contrato (tercero beneficiario); existe, por tanto, una «reglamentación legal trimembre»207. En este sentido, debemos destacar la configuración sistemática de las relaciones que plantea la peculiaridad de esta figura contractual, precisando así la relación que une al estipulante con el promitente (relación de cobertura); la que surge entre el estipulante y el tercero (relación de valuta) ${ }^{208}$; y, por último, la relación entre promitente y tercero (relación de ejecución). La conjugación de dichas relaciones tiene trascendencia para solucionar los conflictos que puedan presentarse en los contratos que contienen una estipulación a favor de tercero 209.

\section{a) La relación de cobertura}

La relación establecida entre el estipulante y el promitente es la relación primitiva en la que se concreta originariamente la relación de carácter contractual. Esta relación de cobertura es el núcleo fundamental y la base del contrato a favor de tercero ${ }^{210}$, ya que en ella se fundamenta el procedimiento que dará vida a la obligación del promitente y atribuirá el derecho de crédito al tercero.

Lo anterior supone la primera fase que ha de cumplirse para poder hablar de un contrato a favor de tercero, el vínculo obligatorio y previo que liga al estipulante con el promitente, por virtud del cual se puede explicar la desviación de una prestación hacia un tercero ${ }^{211}$. Como la estipulación a favor de tercero no es

\footnotetext{
${ }^{206} \mathrm{Y}$ es que el estipulante, cuando concluye el contrato con el promitente a favor del tercero, transmite todos o algunos de los derechos derivados de ese contrato al tercero, mientras que retiene para sí el resto de los efectos del contrato, esto es, las obligaciones y algunas facultades relativas al contenido del contrato, tal como la revocación, la modificación y, en su caso, la extinción.

207 J.W. Hedemann, Tratado de Derecho Civil, Vol. II, Derecho de obligaciones, Editorial Revista de Derecho Privado, Madrid, 1958, p. 108.

208 Obsérvese, con todo, que a juicio de ROCA SASTRE y PUIG BRUTAU, la relación entre estipulante y tercero no pertenece al ámbito propio de la estipulación a favor de tercero.

209 Así, I. GonZÁlez PACANOWSKA, «Comentario...», cit., p. 407.

${ }^{210}$ P. JimÉNEZ BlANCO, El contrato..., cit., p. 81.

${ }^{211}$ C. PÉREZ Conesa, El contrato..., cit., p. 132.
} 
un «tipo» contractual propio, se le puede dar cobertura con cualquier contrato, típico o atípico, unilateral o sinalagmático, oneroso o gratuito ${ }^{212}$.

Esta relación que une al promitente con el estipulante permite distinguir el contrato que contiene una estipulación a favor de tercero de la figura de la representación ${ }^{213}$ pues, al contrario de lo que sucede en ésta, aquél se celebra entre estipulante y promitente en nombre propio y surte para ellos todos los efectos jurídicos que le son propios, con la particularidad de que se atribuye un derecho de crédito al tercero favorecido ${ }^{214}$. Por ello, las partes pueden ejercer algunas de las facultades que el contrato les reconoce. Así, las partes quedan libres para poner fin al mismo de mutuo consenso, y también podrán resolver el vínculo obligacional por incumplimiento si es sinalagmático, siempre antes de que el tercero preste su aceptación ${ }^{215}$. Y nada obsta, además, para que el estipulante goce de la facultad de revocar la estipulación a favor de tercero y desviarla hacia sí mismo, siempre y cuando esta facultad derive de la ley o le haya sido otorgada o reservada en una cláusula incluida en el contrato ${ }^{216}$.

El estipulante puede asimismo ejercer una acción legítima frente al promitente para reclamar el cumplimiento a favor del tercero de la prestación pactada, aunque carezca de interés directo en tal acción ${ }^{217}$. Esta facultad se le atribuye en virtud de su posición como parte contratante ${ }^{218}$, por mucho que no sea un verdadero acreedor del derecho de crédito, pues el crédito pertenece al tercero beneficiario de la prestación. Ello no obsta, como es natural, que al tercero como único acreedor de la prestación se le atribuya con pleno derecho la facul-

212 I. GONZÁlEZ PACANOWSKA, «Comentario...», cit., p. 386.

213 J. LÓPEZ RICHART, Los contratos..., cit., p. 290.

214 F. BONET RAMÓN, «Los contratos..., cit., p. 21.

215 J.M. MARTÍN BERNAL, La estipulación..., cit., p. 305.

${ }^{216}$ L. DÍEZ-PiCAZO, Fundamentos..., Vol. I, cit., p. 544.

217 En el Derecho francés, PlANIOL niega en principio la faculta de pedir el cumplimiento de la prestación, que sólo podrá ejercerse cuando el estipulante tenga un interés directo en la reclamación de hacer efectiva la prestación. Sin embargo, otros, como Colin y CAPITANT, siguen un enfoque distinto: como el promitente se ha obligado a efectuar su prestación a favor del tercero, el estipulante a su vez puede exigir el cumplimiento de la obligación, porque éste tiene siempre interés en que se haga efectiva la prestación al tercero, incluso aunque el interés sea afectivo. Vid. las referencias en F. BONET RAMÓN, «Los contratos...», cit., p. 26; D. DE BUEN LOZANO, «La estipulación...», cit., p. 235.

218 Véase, en este sentido, F. BONET RAMÓN, «Los contratos...», cit., p. 25. 
tad de reclamar frente al promitente la ejecución de la prestación ${ }^{219}$. En caso de incumplimiento contractual de una de las partes contratantes ${ }^{220}$, la otra podrá usar su facultad de resolver el contrato, con la indemnización de los daños y perjuicios causados (art. 1.124 Cc).

\section{b) La relación de valuta}

Es la relación existente entre el estipulante y el tercero que motiva la intención de aumentar el patrimonio de éste. En efecto, desde esta relación subyacente ${ }^{221}$ se explica la causa que justifica la atribución al tercero del derecho, esto es, el por qué el promisario busca asegurar que la prestación se efectúe a favor de aquél ${ }^{222}$. La razón jurídica por la que debe justificarse la causa del desplazamiento patrimonial en esta relación descansa sobre intención de evitar que la atribución se considere un enriquecimiento sin causa para el tercero ${ }^{223}$, y también porque en el ordenamiento español se exige precisar la causa de la obligación como un requisito imprescindible para la validez del contrato ${ }^{224}$. Por tanto, el interés del estipulante 225 en la prestación es la causa de la obligación del pro-

219 J.I. CANO MARTÍNEZ DE VELASCO, El contrato..., cit., p. 63.

${ }^{220}$ Aquí la cuestión que se plantea es si el promitente tiene acción para resolver el contrato en caso de incumplimiento y, en efecto, cierta doctrina niega al promitente esa acción resolutoria con el argumento de que no es admisible que el promitente prive al tercero beneficiario del derecho de reclamar el cumplimiento de la obligación en su favor. En cambio, se permite que tal acción resolutoria se ejecute por parte del estipulante, tanto en caso de incumplimiento por inejecución de la prestación al tercero, como en el caso de imposibilidad sobrevenida de ésta. Vid. L. DíEz-PICAZO, Fundamentos..., Vol. I, cit., p. 544. En el mismo sentido señala ENNECCERUS que, «una vez nacido el derecho del tercero, el promisario no puede tener derecho alguno de resolución, por razón de mora o de imposibilidades de la prestación, pues de lo contrario podría privar al tercero de su derecho» (citado por J. M. MARTín BERNAL, La estipulación..., cit., p. 309.

221 Relación subyacente o relación de valuta (Valutaverhältnis), siendo esta última expresión la más extendida en la doctrina alemana, que explica la causa de la atribución al tercero de la prestación deseada por el estipulante frente al promitente. Vid. I. GonZÁLEZ PACANOWSKA, «Comentario...», cit., p. 407.

${ }^{222}$ L. DíEZ-Picazo, Fundamentos..., Vol. I, cit., p. 544; J. M. Martín Bernal, La estipulación..., cit., p. 317.

223 C. PÉrez CONESA, El contrato..., cit., p. 156.

${ }^{224}$ Art. $1.261 .3^{\circ}$ Cc: «No hay contrato sino cuando concurren los requisitos siguientes: [...] $3^{\circ}$ Causa de la obligación que se establezca».

${ }^{225}$ Mucho hay que decir sobre el interés del estipulante. En general, la doctrina italiana, con base en el art. 1.411.1 ${ }^{\circ}$ del Codice («es válida la estipulación a favor de tercero siempre que el estipulante tenga en ello interés») sostiene que el requisito del interés del estipulante es imprescindible para la validez de la estipulación a favor de tercero, aunque el interés del estipulante no tiene por qué ser siempre económico, ya que también puede ser simplemente 
mitente de hacerla efectivo a favor de tercero. Esta causa se puede presentar de diversas formas, pues puede tratarse de una causa donandi que supone una liberalidad por parte del estipulante hacia el tercero, por ejemplo, el supuesto de la donación que se hace mediante una compraventa a favor de tercero ${ }^{226}$; una causa solvendi, que comprende los casos en que el estipulante tiene que saldar una deuda preexistente ${ }^{227}$ para con el tercero a través de la atribución de la prestación del promitente; y, por último, una causa credendi, con la que el estipulante persigue la realización de una prestación a favor de tercero, otorgándole un préstamo y convirtiéndolo en su deudor ${ }^{228}$.

Así pues, la relación de valuta es irrelevante para el promitente, y la causa justificativa hay que buscarla en la persona del estipulante y no en la del promitente ${ }^{229}$. Es decir, el rol que desempeña el promitente se agota en la obligación de atribuir un derecho de crédito directamente al estipulante por virtud de la relación contractual que les une, y el tercero como beneficiario se convierte en acreedor de esta prestación, que se plasma en una atribución patrimonial que debe ser justificada según la intención causal del estipulante ${ }^{230}$.

Como ha sostenido DE BUEN, si la prestación comprende un pago, le serán aplicables, en su caso, las reglas del pago de lo indebido ${ }^{231}$. Si la causa es donan$d i$, resultará de aplicación entre ellos el régimen jurídico de las donaciones en la

moral o de afecto. Vid. J.I. CANO MARTínez DE VELASCO, El contrato..., cit., p. 76. De la jurisprudencia italiana que se ha ocupado del interés del estipulante en la estipulación a favor de tercero resulta significativo notar que nunca se ha fallado desestimando la pretensión o declarando la nulidad de la estipulación a favor de tercero por ausencia o defecto de interés del estipulante [cfr. las sentencias de la Corte di Cassazione $\mathrm{n}^{0} 3413$, de 24 de agosto de 1957, $\mathrm{n}^{\mathrm{O}} 7160$, de 1 de agosto 1994, citadas por J. LÓPEZ RICHART, Los contratos..., cit., p. 133]. Sobre este tema, véase infra, sub III.3.

226 J.I. CANO MARTínEZ DE VELASCO, El contrato..., cit., p. 76.

227 No obstante, se señala en ocasiones que no se puede calificar como contrato a favor de tercero aquél en que el estipulante acuerda con el promitente el pago a un tercero de un débito preexistente del estipulante para con el tercero. Vid. J.M. MARTín BERNAL, La estipulación..., cit., p. 280. Pero existen en la jurisprudencia ejemplos de contratos a favor de tercero en los que parte de la prestación que el promitente debe al estipulante en virtud del contrato base se destina al pago de deudas del estipulante y se configura como asunción de deuda (vid. I. GONZÁlEZ PACANOWSKA, «Comentario...», cit., p. 411).

228 J.M. MARTÍn BERNAL, La estipulación..., cit., p. 317.

229 L. DíEZ-PiCAZO, Fundamentos..., Vol. I, cit., p. 544.

230 J. LÓPEZ RICHART, Los contratos..., cit., p. 299.

${ }^{231}$ F. BONET RAMÓN, «Los contratos..., cit., p. 31. 
medida en que fuese aplicable232 (así, se podrá determinar si la donación es válida o no, porque no habrá que tener en cuenta la cantidad percibida por el tercero, sino la que ha entregado el estipulante al promitente para que éste realice la prestación)233. En fin, si la causa es credendi, se producirán las consecuencias jurídicas que determina la relación preexistente.

En ausencia de causa, la atribución se destinará, como señala DíEzPicAzo, a un proyecto jurídico-obligatorio de creación futura. Sin embargo, cuando tal relación causal no se presente o desaparezca sobrevenidamente, dará lugar a un desplazamiento patrimonial injustificado por carecer de causa, lo que facultará al estipulante para ejercer mediante condictio ${ }^{234}$ una acción frente al tercero con arreglo a las disposiciones del enriquecimiento sin causa ${ }^{235}$. Además, será nula la estipulación a favor de tercero si se demuestra que la causa perseguida a través de ella es ilícita²36.

\section{c) La relación de ejecución}

La relación de ejecución o «de tercero» es la que completa el triángulo que constituye la estructura negocial, ya que supone la consecuencia jurídica en la que la figura descansa, en concordancia con la voluntad de las partes contratantes (relación de cobertura), que pretendieron desviar la prestación de un derecho patrimonial a un tercero beneficiario ${ }^{237}$. A través de esta relación, el tercero ocupa la posición del titular de ese derecho creado en su provecho, configurándose una relación puramente obligatoria, por virtud de la cual el tercero ostentará la cali-

${ }^{232}$ L. DíEz-PiCazo, Fundamentos..., Vol. I, cit., p. 544.

233 F. BONET RAMÓN, «Los contratos..., cit., p. 31.

${ }^{234} \mathrm{O}$ una actio in rem verso por enriquecimiento sin causa. La figura surgió con esta denominación, «acción sobre el provecho obtenido» (in rem verso), en el Derecho romano con la finalidad de restablecer el equilibrio patrimonial destruido por una atribución indirecta. Vid. I. GONZÁlez PACANOWSKA, «Comentario...», cit., p. 413; así como L. DíEZPICAZO, Fundamentos..., Vol. I, cit., p. 110.

235 J.M. MARTín BERNAL, La estipulación..., cit., p. 318.

${ }^{236}$ I.J. CANO MARTÍNEZ DE VELASCO, El contrato..., cit., p. 77, cita el siguiente ejemplo: No será lícita «la compra de un regalo para remunerar a través del promitente servicios prohibidos por la ley prestados previamente por el tercero al estipulante; lo que permitirá anular la atribución del derecho al tercero, no porque el contrato a su favor sea en sí mismo ineficaz, sino por la ilicitud de la causa final».

237 C. PÉrEz CONESA, El contrato..., cit., p. 201. 
dad de acreedor de la prestación y el promitente la del deudor, aunque entre ellos no se haya concluido ningún contrato ${ }^{238}$.

Después de aceptada la prestación, el tercero puede ejercitar en nombre propio la acción para pedir la ejecución forzosa a su favor en caso de mora o de incumplimiento, así como reclamar judicialmente su derecho a ser indemnizado por los daños y perjuicios que se le hayan causado en caso de que dicho incumplimiento o cumplimiento defectuoso de la prestación sea imputable al promitente 239 . Además de las precedentes, DíEz-PICAzo incluye las acciones de carácter conservativo si fuera el caso y las de fraude de acreedores ${ }^{240}$.

Por el contrario, al tercero se le niegan las facultades de resolución o revocación contractual en caso de incumplimiento (v.gr., revocación de la donación por incumplimiento de cargas). Esta posibilidad de resolver o de revocar no se puede ceder al tercero porque simplemente no es una parte contratante, sino un tercero extraño al contrato que se ha adherido a él por virtud como consecuencia de un pacto entre estipulante y promitente. Tampoco puede el tercero (a salvo de lo que más adelante se dirá sobre el derecho de disposición en el contrato de transporte) modificar el contrato, puesto que esa facultad pertenece en exclusiva a las partes contratantes ${ }^{241}$. Sí puede, en cambio, incurrir en mora accipiendi, al ostentar la posición de acreedor, pudiendo el promitente, en su caso, proceder a la consignación de la prestación al objeto de quedar exonerado de la responsabilidad por incumplimiento ${ }^{242}$.

Frente a las acciones del beneficiario para reclamar frente al promitente, este último podrá oponer a la reclamación las excepciones derivadas del contrato inicial concluido con el estipulante (v.gr., la nulidad del contrato por falta de

${ }^{238}$ L. Dítz-PicAzo, Fundamentos..., cit., p. 545.

239 C. PÉrez CONESA, El contrato..., cit., p. 213.

${ }^{240}$ L. DíEz-PiCAZo, Fundamentos..., Vol. I, cit., p. 545.

${ }^{241}$ En concreto, la acción de resolución viene regulada en el artículo $1.124 \mathrm{Cc}$, a cuyo tenor «la facultad de resolver las obligaciones se entiende implícita en las recíprocas, para el caso de que uno de los obligados no cumpliere lo que le incumbe». Respecto de la revocación de la donación, vide C Pérez Conesa, El contrato..., p. 215: «El beneficiario de una carga impuesta al donatario no tiene legitimación para demandar la revocación de la donación por inejecución de la carga modal».

${ }^{242}$ I. GONZÁLEZ PACANOWSKA, «Comentario...», cit., p. 418. 
causa, etc.) ${ }^{243}$. Tanto la doctrina como la jurisprudencia aceptan como válidas estas excepciones que el promitente pueda oponer frente al tercero, por cuanto el fundamento jurídico del derecho del beneficiario reside en el contrato celebrado en su favor.

Con todo, en relación a las excepciones oponibles, se observan discrepancias entre los autores. Algunos rechazan la idea de que se puedan ejercer las excepciones del tipo ex persona stipulatis por el promitente; otros, y son la mayoría, sostienen que el promitente puede hacer valer frente al tercero todas las excepciones que habría podido hacer valer contra el estipulante, salvo en lo referido a la excepción de compensación. Otros muchos, en fin, no consideran posible dar una regla fija o trasladan la resolución del problema a la voluntad de las partes contratantes 244 . Por último, las excepciones derivadas de la relación del tercero con el estipulante (relación de valuta) no se pueden oponer por parte del promitente, dado que la causa de la obligación de éste se obtiene directamente del contrato base, y no es de su incumbencia la finalidad por la que el estipulante persigue la atribución al tercero 245 .

Sea como fuere, el promitente no podrá oponer frente al tercero beneficiario la totalidad de sus relaciones con el estipulante. La cuestión hace referencia de manera concreta, por ser la más polémica, a la excepción de la compensación que pudiera alegar el promitente por un crédito del que, por su parte, dispone frente al estipulante. Dos son las razones por las que la doctrina lo ha denegado. El primer argumento, sostenido mayoritariamente por la doctrina, se basa en que esta excepción no emana del contrato base, sino de otra vinculación diferente, existente entre el estipulante y el promitente ${ }^{246}$. El segundo se fundamenta en la titularidad del derecho atribuido, que corresponde al tercero, por

243 D. DE BUEn LOZANO, «La estipulación..., cit., p. 234.

244 Véase las reflexiones al respecto de G. PACChioni, Los contratos..., cit., p. 118. En sentido, similar, también BONET entiende que no es posible ofrecer una regla única de aplicación general a todas las especies de contrato a favor de tercero (F. BONET RAMÓN, «Los contratos...», cit., p. 29).

245 I. GONZÁLEZ PACANOWSKA, «Comentario...», cit., p. 419.

246 Así lo establecen, incluso, algunos textos legales, como el art. 1.413 del Codice italiano («eccezioni fondate sul contratto dal quale il terzo deriva il suo diritto») o el § 334 BGB («Einwendungen aus dem Vertrag [zugunsten Dritter]»). 
lo que no tendrá que soportar la compensación que se basa en una deuda que en principio no es suya 247.

\subsection{El contenido de la relación de cobertura y la posición jurídica de las partes contratantes y del tercero beneficiario}

Como se ha expuesto con anterioridad, la relación de cobertura constituye una piedra fundamental referente al objeto y la causa del contrato a favor de tercero. El vínculo derivado del contrato base sirve de fundamento para designar la posición de cada parte contratante, uniéndose la iniciativa del estipulante -que se plasma en la oferta - al consentimiento del promitente - en aceptar la oferta-, con la finalidad de aumentar el patrimonio del tercero beneficiario con un derecho que le favorezca. También se ha dicho ya que, para la validez del contrato que contiene una estipulación a favor de tercero, deben concurrir los mismos requisitos que los que se exige para otros contratos, los del artículo $1.261 \mathrm{Cc}$, que se refiere al consentimiento de las partes y la capacidad de éstas para contratar, al objeto y a la causa, siempre referido a la relación de cobertura.

\section{a) La posición jurídica de las partes contratantes}

\section{aa) La posición jurídica del promitente}

Una vez aceptada la oferta contractual del estipulante, surge en cabeza del promitente la obligación de realizar la prestación al tercero. A través de esta aceptación se configura la obligación del promitente, asumida - en todo o en partepor él frente al estipulante. Así, por poner el ejemplo del contrato de transporte, el transportista deberá entregar el envío a un tercero, el destinatario, caso de haberse estipulado la entrega de aquél a éste. En el contrato de seguro, por su parte, el asegurador tendrá que satisfacer al beneficiario el capital asegurado con base en las primas pagadas por el tomador.

\footnotetext{
247 No puede sorprender, por ello, que en España se alegue la ausencia de uno de los presupuestos de la compensación requeridos en el artículo $1.196,1^{\circ} \mathrm{Cc}$, que exige que "cada uno de los obligados lo esté principalmente y sea a la vez acreedor principal del otro», lo que no se daría desde luego en la relación promitente-tercero. Vid. F. BONET RAMÓN, «Los contratos...», cit., p. 29; L. DíEZ-PiCAZO, Fundamentos..., Vol. I, cit., p. 546; I. GONZÁlEZ PACANOWSKA, «Comentario...», cit., p. 419; G. PACCHIONI, Los contratos..., cit., p. 118; C. PÉREZ CONESA, El contrato..., cit., pp. 251 y ss.
} 
En lo que se refiere a la posición jurídica del promitente, se estaría ante dos hipótesis distintas que plantean el problema de si está obligado, o si más bien está facultado, para hacer efectiva la prestación pactada con el estipulante al beneficiario. La primera se presenta cuando el promitente resulta obligado a petición del estipulante a realizar la prestación al tercero, y éste último podrá reclamar el cumplimiento de la prestación que le favorece frente al promitente. Ello no ocurre en la segunda hipótesis cuando el promitente meramente dispone de una facultad de cumplir la prestación al tercero cuando así le convenga ${ }^{248}$. Para saber cuál de estas hipótesis se presenta en cada caso, se tiene en cuenta la finalidad de la cláusula referida al tercero y en interés de cuál de las dos partes ha sido concertada. Por ejemplo, si la estipulación ha sido pactada en interés y a petición del promitente, se entiende que la cláusula le ha atribuido la facultad de liberarse cumpliendo la prestación de esta manera. En cambio, si el interés y la petición descansan en la persona del estipulante, el promitente quedará obligado, como norma, a realizar la prestación al tercero ${ }^{249}$.

Queda por añadir que la posición jurídica del promitente frente al tercero no entraña dificultades ni graves problemas a la hora de realizar la prestación por parte aquél, una vez que se adhiere el tercero por medio de su aceptación. No obstante, se presentan dos cuestiones litigiosas: la causa del derecho del tercero y las excepciones que frente a éste puede oponer el promitente. Mas como quiera que han sido analizadas en otro lugar, nos remitimos a lo que se ha dicho en el momento oportuno ${ }^{250}$.

${ }^{248}$ C. PÉREZ CONESA, El contrato..., cit., p. 146.

249 G. PACChIONI, Los contratos..., cit., p. 185. Para aclarar más la cuestión citamos el ejemplo dado por HELLWIG y citado por PACCHIONI en el lugar indicado: «si el deudor de una suma hubiera obtenido de su acreedor la facultad de poder pagar los intereses debidos a tercera persona residente en el mismo lugar que el deudor, deberá admitirse que con eso no se ha cerrado el camino para pagar válidamente al mismo acreedor directamente. $\mathrm{Y}$ viceversa: si el adquirente de un lote de mercancía hubiera estipulado la consignación de las mismas a un tercero, o se hubiera reservado el derecho de hacerla consignar por el vendedor a persona y lugar determinados, habrá de admitirse que el promitente (aquí el vendedor), estará obligado de modo absoluto a realizar lo convenido directamente al tercero señalado, tanto más cuando resulte que el fin perseguido con aquella cláusula era evitar los gastos de un doble trasporte, u otro análogo».

250 Véase supra, sub 5.1.b) y c). 


\section{bb) La posición jurídica del estipulante y la limitación de su libertad} contractual

Al tratar el tema de la limitación de la libertad contractual, hay que tener presente que la autonomía de la voluntad de las partes contratantes (pero no del tercero) implica la posibilidad de determinar el contenido obligacional del contrato estipulado, así como los efectos que se anuden al incumplimiento de la prestación asumida. En el contrato a favor de tercero, quien toma la iniciativa para concluirlo es el estipulante, es quien tiene un interés propio para que la prestación sea efectuada al tercero a través del promitente. De ahí que este último sea la contraparte instrumental, que desvía el derecho de crédito que sale del patrimonio del estipulante para ingresarlo al patrimonio del tercero.

En cuanto a la responsabilidad del estipulante en el contrato a favor de tercero, está basada sobre el objeto de su interés propio, que consecuentemente se puede buscar en su relación con el tercero o en el motivo causal por virtud del cual se ha atribuido el derecho de crédito al tercero. Poco importa si se trata de un interés pecuniario o de simple afección, como en el caso de donación o cualquier otro contrato de carácter gratuito a favor de tercero (o sea, cuando no esté jurídicamente obligado a ello), lo esencial es que siempre haya un interés, pues sin él no estaríamos ante una estipulación a favor de tercero válida.

La posición del estipulante en el marco del contrato queda delimitada, pues, por el hecho de tener un interés en su celebración que fundamenta el contrato y define su contenido (si se tiene que pagar una deuda preexistente para con el tercero por medio de atribuirle la prestación del promitente, o como consecuencia de una liberalidad que implica una donación del estipulante a favor del tercero, o por último, si se trata de la realización de una prestación a favor de tercero, concediéndole un préstamo de manera que este tercero se convierta en deudor del estipulante). Estas causas son la fuente en que el estipulante basa su iniciativa, y a él se le atribuye la facultad de su revocación o su modificación. De ahí que el estipulante goce de gran libertad para influir sobre la estipulación, siempre que el tercero no la haya aceptado. Una vez aceptada la estipulación, la libertad contractual del estipulante se limita por el mero hecho de tal aceptación, pudiendo el tercero reclamar del promitente el cumplimiento de la que le corresponde realizar. 
En la práctica, el tema del interés del estipulante para fundamentar y determinar su posición jurídica en el contrato a favor de tercero ha preocupado siempre particularmente a la doctrina italiana, en la medida en que el Codice civile contempla el interés del estipulante, según se vio, como un presupuesto de validez de esta figura contractual251. Y ello por cuanto no puede hablarse de contrato a favor de tercero si no existe un interés del estipulante, de manera que, en ausencia de tal interés, no hay verdadero contrato a favor de tercero 252.

En efecto, el interés del estipulante se halla en la relación de valuta. No quiere decirse con ello que éste carezca de interés en su relación con el promitente cuando concluye el contrato. Lo que se quiere expresar es que, cuando el estipulante toma la decisión para contratar con el promitente a favor de tercero, se hace prometer por este último que hará efectiva la prestación a un tercero. El motivo que fundamenta el contrato es el interés del estipulante, que opera en sus relaciones con el promitente y repercute en las que tenga con el tercero, pues a él va dirigida la ejecución de la prestación²53.

\section{b) La determinación del tercero beneficiario y su sustitución}

La determinación del beneficiario se concibe como un acto de carácter unilateral del estipulante, siendo el interés personal de éste el que fundamenta la desviación de la prestación al beneficiario. La persona del beneficiario le es, por ello, indiferente al promitente, aunque nada impide que ese acto pueda también ser bilateral, nacido de la voluntad del estipulante y del promitente, o incluso, según el contenido del contrato, puede haber un interés propio del promitente en la ejecución de prestación prometida.

La determinación del beneficiario es, pues, el acto por el cual el estipulante designa al promitente la persona a la que debe satisfacer la prestación, y a él se reserva la facultad de revocar o sustituir la persona del beneficiario que por su sola voluntad ha determinado. Al no alterarse o causarse, en principio, nin-

\footnotetext{
${ }^{251}$ Recuérdese que el contrato a favor de tercero se regula en el artículo 1.411 del Codice, sobre cuyo contenido la doctrina italiana ha construido la validez de esta figura con base en el interés del estipulante («es válida la estipulación a favor de un tercero siempre que el estipulante tenga en ello interés»).

${ }^{252}$ G. PACChIONI, Los contratos..., cit., p. 179.

253 C. PÉrez CONEsa, El contrato..., cit., p. 151.
} 
guna modificación en la extensión de las obligaciones del promitente, la designación, revocación o sustitución queda al arbitrio del estipulante.

La designación del tercero beneficiario figura entre los requisitos esenciales para la validez de la estipulación, dado que es imprescindible el conocimiento de la persona a a la que irá destinada la prestación estipulada. También hay unanimidad en cuanto al momento de la designación del tercero, en el sentido de que puede tener lugar de forma simultánea a la conclusión del contrato o con posterioridad. En atención a la flexibilidad a la hora de designar el beneficiario se permite que éste sea determinable, indicándose los criterios de determinación por el estipulante, o incluso futuro, sobre todo en materia de seguro de vi$\mathrm{da}^{254}$. La estipulación que se concierta a favor de un beneficiario determinable no ofrece dificultad alguna, pues basta con que su determinación ulterior sea realizada según los criterios derivados del propio contrato. Como sabemos, el tercero no es parte contratante, con lo que nada impide que sea indeterminado o que no haya nacido aún, pero sí ha de ser determinable o llegar a existir ${ }^{255}$.

254 M. Carballo Fidalgo, «El contrato a favor de tercero», Actualidad Civil, núm. 47, 2000, p. 1703.

255 I. GONZÁlEZ PACANOWSKA, «Comentario...», cit., p. 391. En el ámbito de la designación de personas determinables cobra especial interés la que invoca a los herederos del estipulante. La duda que se plantea en este caso es si se trata de una estipulación para los herederos (o sea, para la propia sucesión), o si se puede considerarlos terceros ajenos al pacto concertado. En materia de seguros de vida, donde con mayor frecuencia se plantea la duda, la respuesta a esta pregunta se halla en el artículo 85 LCS, cuando afirma que, «si la designación se hace en favor de los herederos del tomador, del asegurado o de otra persona, se considerarán como tales los que tengan dicha condición en el momento del fallecimiento del asegurado». En caso de que coincidan el beneficiario y el heredero de la prestación en una misma persona, se plantea un conflicto a la hora de determinar la legitimación de esos sujetos. El legislador ha tratado esta cuestión con gran acierto, cuando dedica el inciso final del artículo 85 LCS a la resolución de ese problema de la intromisión, que conlleva la simultaneidad del carácter hereditario y de beneficiario de la estipulación, en el sentido de que resultan beneficiarios de la estipulación los herederos del estipulante una vez que éstos hayan aceptado el beneficio, aun cuando renuncien a la herencia de su causante ( «Los beneficiarios que sean herederos conservarán dicha condición aunque renuncien a la herencia»).

Cuando la estipulación lo sea a favor de persona futura, se admite su validez con un argumento que tiene su base en la importancia de la relación de cobertura: lo relevante es el vínculo contractual entre estipulante y promitente, pero no la declaración de voluntad del tercero, pues no participa en la conclusión del contrato. Ahora bien, sólo cabe admitir la estipulación a favor de quien no ha nacido o no existe y considerarlo como un beneficiario cuando la causa de la relación de valuta sea donandi, porque de ser de carácter oneroso, este tercero habría de existir realmente desde el primer momento, a pesar de no hacérselo saber al promitente hasta un momento posterior. Al respecto puede verse con detalle $\mathrm{C}$. 
En cuanto a la revocación del beneficio o la sustitución del beneficiario, su trata de una facultad que corresponde principalmente al estipulante, por ser el contratante del que parte la iniciativa de la estipulación realizada a favor del tercero y quien tiene interés en que la prestación se realice a éste. No obstante, dicha facultad de revocación y de sustitución por parte del estipulante queda limitada en el supuesto en el que el promitente tenga un interés personal, o si así se hubiera estipulado en el propio contrato, p.ej., haciendo partícipe al promitente en la decisión de la revocación o también la sustitución del tercero beneficiario. Habrá ocasión de volver sobre esta cuestión más adelante en el texto, al tratar la extinción de la estipulación a favor de tercero.

\section{c) La posición jurídica del beneficiario y la función de su aceptación}

Ya hemos visto anteriormente la discusión doctrinal y jurisprudencial para determinar cuál es la verdadera posición jurídica del beneficiario ante la multitud de teorías esgrimidas sobre el particular. También desde el estudio de la naturaleza jurídica del contrato a favor de tercero y su delimitación de figuras afinas se ha podido explicar el mecanismo por el cual se transmite el derecho de crédito al tercero. La finalidad perseguida con este estudio era dilucidar el mecanismo por el cual se crea un derecho a favor de tercero, atribuyéndoselo por la fuerza misma del contrato estipulado originariamente entre el estipulante y el promitente, y encuadrarlo en un marco jurídico en el que se concrete la posición jurídica del beneficiario, por virtud de la cual éste puede actuar para pedir el cumplimiento de la prestación frente al promitente. Conviene recordar, en este contexto, que el derecho de crédito del tercero nace en el mismo momento de la celebración del contrato entre el estipulante y el promitente, desde que se produzca el concurso de la oferta del estipulante y su aceptación por parte del promitente, de que este último ha de realizar la prestación a favor del beneficiario.

En el ámbito, por ejemplo, de los contratos de seguro y de transporte, el asegurado o beneficiario (en el de seguro) o el consignatario (en el de transporte) son terceros en el sentido del artículo 1.257 Cc que se adhieren al contrato

PÉrez CONESA, El contrato..., cit., p. 143-144; M. CARbALlo FIDALGO, «El contrato...», cit., p. 1704; M. CASALS COLLDECARRERA, El contrato..., cit., p. 371. 
mediante la manifestación de su voluntad de hacerlo ${ }^{256}$. De ahí la importancia de la aceptación del tercero beneficiario, que sirve también para diseñar los límites de las facultades de las partes contratantes, sobre todo las del estipulante, que por medio de esta aceptación pierde su facultad de revocar y de modificar el contenido del contrato. El papel de la aceptación en los contratos a favor de tercero se traduce en la adhesión del tercero al contrato, declarando su voluntad de querer aprovecharse del beneficio emanado de la estipulación a su favor. Como se ha señalado, este mecanismo no priva al estipulante de su posición jurídica como parte contratante, hasta el punto de que él mismo podrá pedir el cumplimiento de la prestación, reclamándolo frente al promitente, pero no para sí sino para el tercero.

En efecto, la jurisprudencia española ha prestado gran atención al rol de la aceptación del tercero en relación a la adquisición del derecho, y son varios los pronunciamientos acerca del papel que desempeña esta aceptación y de su naturaleza jurídica a la luz del mecanismo atributivo del derecho al tercero ${ }^{257}$. En la doctrina, a juicio de RocA, la aceptación juega un importante papel en provocar la apropiación del derecho por el tercero beneficiario, matizando su observación en que la estipulación comprende una vocación al tercero equivalente a la delación hereditaria, cuya aceptación tiene el mismo valor que la aceptación de heredero, una condicio iuris, que al propio tiempo pone un límite al poder revocatorio del estipulante. DE BUEN sigue en la misma línea y considera la aceptación como un acto necesario para que el tercero adquiera el derecho que le favorece, y una vez aceptada la prestación ésta se hace efectiva retroactivamente al día de la estipulación ${ }^{258}$.

\footnotetext{
${ }^{256}$ Véase infra, sub 7.

257 Según tiene declarado la STS núm. 644/2008, de 8 de julio (RJ 2008, 3353), la aceptación por el tercero de la estipulación en su favor pactada en un contrato en el que no ha sido parte es «una aceptación de la estipulación y no de todo el contrato». En otras decisiones, por su parte, [SsTS de 31 de enero de 1986 (RJ 1986, 443); de 6 de marzo de 1989 (RJ 1989, 1998); y núm. 1088/2004, de 11 de noviembre (RJ 2004, 6893)], se señala que "[d]icha aceptación puede hacerla el tercero beneficiario en forma expresa o tácita, por palabras o por hechos». Cfr. A. VAQUER ALOY, Derecho europeo de los contratos: libros II y IV del marco común de referencia, Atelier, Barcelona, 2012, p. 638.

${ }^{258}$ Cfr. las referencias en F. BONET RAMÓN, «Los contratos...», cit., p. 21-22; e I. GONZÁLEZ PACANOWSKA, «Comentario...», cit., p. 391.
} 
Así, puede concluirse que la aceptación se considera un requisito necesario para convalidar o ratificar 259 lo que se ofrece al tercero. El fundamento de esta regla se encuentra en el segundo párrafo del artículo $1.257 \mathrm{Cc}$, que vincula la adquisición definitiva del derecho a que el tercero haga saber su consentimiento de aceptar la prestación al obligado antes de que la estipulación haya sido revocada ${ }^{260}$. Así, según el precepto citado, la aceptación del tercero es una declaración de voluntad recepticia, que ha de notificarse al obligado para poder realizar la ejecución de la prestación.

A la vista de esta definición, la aceptación no tiene por efecto la concreción del contenido del provecho pactado a favor del tercero, sino que su objetivo es la adhesión al contrato estipulado a su favor. Así, la aceptación consiste en manifestar la conformidad con la causa que motivó el contrato a favor de tercero, para hacer irrevocable la atribución del derecho de crédito que ingresa en su patrimonio. Al respecto, GonZÁlez PACANOWSKA recuerda que la causa de la atribución del derecho al tercero puede ser donandi, solvendi o credendi, y señala que, salvo en el supuesto de renuncia por su parte, ese derecho ingresa en su patrimonio gratuitamente, pero con carácter claudicante, hasta que se conforme su aceptación de la causa atributiva, que puede ser liberatoria (el pago de una obligación preexistente), o convertir al beneficiario en deudor del estipulante (credendi causa) ${ }^{261}$.

\section{Extinción de la estipulación a favor de tercero}

Con respecto a la construcción de la figura del contrato a favor de tercero aquí estudiada, a partir de que la operación estipulada es perfeccionada nace inmediatamente en cabeza del tercero un derecho de crédito frente al promitente. Sin embargo, la eficacia de este derecho no se consolida en tanto que no se den las condiciones necesarias para su validación. La estipulación resulta definitiva y

\footnotetext{
259 Para Bonet RAMón, la especial naturaleza de la aceptación se asemeja a la de la convalidación y la ratificación, y que por analogía con estos actos deberá tener efectos retroactivos una vez aceptada la prestación, de manera que los efectos de la estipulación se producen a favor del tercero como si hubiera intervenido en ella, aunque no hubiera tenido intervención alguna en la misma. Vid. F. BONET RAMÓN, «Los contratos...», cit., p. 22.

260 Incide en ello, M. CASALS COLLDECARRERA, El contrato..., cit., p. 365.

${ }^{261}$ I. GONZÁLEZ PACANOWSKA, «Comentario...», cit., pp. 395 y 398.
} 
produce plenos efectos a favor del tercero designado cuando el derecho de este último se convierte en irrevocable. Para que así sea, han de presentarse dos requisitos imprescindibles. El primer requisito es, en rigor, una condición negativa, a saber, la falta de revocación de esta estipulación por parte del estipulante. $\mathrm{El}$ segundo es un requisito positivo, consistente en que el tercero manifieste voluntariamente la aceptación del beneficio. En consecuencia, es causa de extinción de la estipulación a favor de tercero la ausencia de cualquiera de esas dos condiciones, para cuyo estudio conviene diferenciar entre la revocación del estipulante y la renuncia del tercero, a las que seguidamente se hará especial referencia ${ }^{262}$. Pero antes de entrar en su análisis, es conveniente entrar brevemente sobre la ineficacia del contrato base, que impide desde el principio que este contrato produzca los efectos en él acordados.

\subsection{La ineficacia del contrato base}

Podemos decir que se está ante un supuesto de ineficacia del contrato cuando dejan de producirse los efectos deseados, y la ineficacia se proyecta de la misma manera sobre la estipulación a favor de tercero que sobre el contrato. El derecho del tercero se extingue por los mismos motivos que los que se aplican como regla general en sede de ineficacia de los contratos privados, ya sea por nulidad, inexistencia, anulabilidad, error, simulación o rescisión ${ }^{263}$.

Lo que ocurre en caso de ineficacia del contrato es que la voluntad del tercero de aceptar el provecho de la prestación se vuelve indiferente, aunque haya manifestado su intención de querer aprovecharse. Así, no puede adquirir ningún derecho si desaparece el fundamento del que nace, dado que la ejecución de la prestación en su favor depende de la validez del contrato estipulado que, por las causas antes mencionadas, resulta ineficaz. De ahí que el tercero pierda su derecho a reclamar la prestación ${ }^{264}$.

Parece lógico, entonces, que no existiría fundamento para que el promitente haga efectivo su cumplimiento frente el tercero, si la causa de la propia

262 M. CARballo FidALGO, «El contrato...», cit., p. 1709.

263 L. DíEz-PiCAzo, Fundamentos..., Vol. I, cit., p. 555.

264 M. CASAls COLLDECARRERA, El contrato..., cit., p. 372. 
obligación no está vigente por ineficacia del contrato-base ${ }^{265}$. Sin embargo, las dudas surgen con respecto al estipulante: ¿qué sucedería si éste hubiera efectuado ya su prestación al promitente? Parece equitativo sostener que el estipulante regrese entonces frente al promitente para recuperar de él lo que le hubiera entregado por virtud del contrato que ha resultado inválido. De negarse el promitente a restituir la prestación hecha por el estipulante y, así, privarlo de su derecho de recuperación, se estaría ante un enriquecimiento indebido del promitente ${ }^{266}$. Otro problema se plantea con respecto a la resolución del contrato base cuando el promitente incumple su obligación frente al beneficiario, particularmente cuando éste ya hubiera aceptado el provecho de la prestación. Y ello por cuanto el incumplimiento que da lugar a la resolución contractual puede tener lugar tanto frente al estipulante ${ }^{267}$ como frente al tercero que está reclamando el cumplimiento de la prestación.

Por un lado, no parece posible que el tercero pueda resolver el contrato base por la simple razón de que no ha tenido parte en su celebración; no es una parte contratante sino un extraño al mismo. Por otro, tampoco por el hecho de estipular a favor de tercero y de aceptar éste la estipulación se puede privar al estipulante de su derecho de exigir del promitente el cumplimiento forzoso o escoger la resolución que le confiere el artículo $1.124 \mathrm{Cc}^{268}$.

Si el estipulante escoge la opción de resolver el contrato base, ello impide, como no puede ser de otra forma, que el tercero adquiera el derecho que se le hubiera atribuido. En efecto, nos encontraríamos ante un conflicto entre el estipulante y el tercero cuando se contrapone la voluntad de aquél de resolver el contrato y el deseo de éste de pretender el cumplimiento forzoso. Son variadas las opiniones doctrinales al respecto. Mientras que algunos quieren dejar la de-

265 L. B. PÉrez Gallardo, El contrato..., cit. p. 346.

266 M. CASAls ColldeCARRERA, El contrato..., cit., p. 372.

${ }^{267} \mathrm{Al}$ estipulante se le otorga la facultad resolutoria, en el caso los contratos sinalagmáticos, cuando se den los presupuestos que la propia ley prevé. Vid. I. GonZÁlEz PaCANOWSKA, «Comentario...», cit., p. 402.

${ }^{268}$ Se dispone en el art. 1.124 Cc que «la facultad de resolver las obligaciones se entiende implícita en las recíprocas, para el caso de que uno de los obligados no cumpliere lo que le incumbe. El perjudicado podrá escoger entre exigir el cumplimiento o la resolución de la obligación [...]. También podrá pedir la resolución, aun después de haber optado por el cumplimiento, cuando éste resultare imposible». 
cisión al arbitrio del estipulante, otros repudian la idea de que el estipulante resuelva el contrato, al sustraer al tercero lo que ya había adquirido irrevocablemente después de su aceptación ${ }^{269}$.

Sea como fuere, en el ámbito de los contratos de transporte resulta difícil que se plantee la disyuntiva. Y es que la propia Ley 15/2009 (a la que habrá de acudirse igualmente en un contexto internacional ante la laguna que al respecto presenta el CMR) regula la mayoría de los supuestos en los que el cargadorestipulante puede declarar la extinción del contrato, con absoluta independencia de la voluntad del tercero beneficiario. Por mencionar alguno de los casos expresamente regulados, el cargador está facultado, por ejemplo, para tener al promitente por desistido del contrato si éste se niega a formalizar la carta de porte a pesar de ser requirido para hacerlo (art. 10.6 LCTTM); y podrá desistir él si existe pacto acerca del día y la hora para la puesta a disposición del vehículo en el lugar de carga y el porteador lo incumple (art. 18 LCTTM). Como puede apreciarse, se trata, en rigor, de supuestos de resolución por incumplimiento (si bien de obligaciones previas o accesorias a la principal de transportar) y no de desistimiento, que no requiere causa especial que lo justifique ${ }^{270}$.

\subsection{La revocación del estipulante}

De entre las demás causas con efectos extintivos para la estipulación merece especial consideración, en primer lugar, la revocación. Por su virtud, se confiere al estipulante un poder unilateral para poner fin al beneficio concedido al tercero, con la condición de que se declare siempre antes de la noticia de la aceptación, es decir, antes de que éste manifieste de una manera u otra su declaración de querer aprovecharse de la prestación constituida en su favor.

El poder revocatorio plantea la cuestión acerca de quién ostenta su titularidad, pues nada se dice expresamente en el artículo $1.257 \mathrm{Cc}$ acerca del legitimado para revocar. Ante este silencio del legislador, para determinarlo habrá que estar en primer lugar al contrato mismo, cuyas cláusulas pueden señalar la

269 Vid. I. GONZÁLEZ PACANOWSKA, «Comentario...», cit., p. 402.

${ }^{270}$ L. DíEz-PiCAZO, Fundamentos del Derecho civil patrimonial. II. Las relaciones obligatorias, $6^{\mathrm{a}}$ ed., Civitas, Cizur Menor, 2008, p. 1086. 
pertenencia a uno de los contratantes o a ambos. Si nada se ha estipulado en el contrato sobre la atribución de este derecho ${ }^{271}$, parece razonable entender que pertenece al estipulante, que podrá usar de él a su arbitrio. De lo contrario, habría de entender que debe tratarse de un acto conjunto de estipulante y promitente, de modo que se estaría más bien ante un supuesto de mutuo disenso y no ante una verdadera revocación ${ }^{272}$.

Como se decía, probablemente, la persona a la que corresponde ese poder es el estipulante, partiendo de que el origen del derecho atribuido al tercero está en la disposición de éste, lo que le convierte en la persona más indicada para negarle el efecto ${ }^{273}$. Esta solución es la sostenida en el ordenamiento francés en el artículo 1.206 del Code civil, que establece que, mientras el tercero no haya declarado su aceptación, el estipulante podrá revocar la disposición y aplicarla entonces en su propio provecho o designarla a otro beneficiario o a sus herede$\operatorname{ros}^{274}$. Y también es esta la conclusión a la que debe llegarse en el ámbito del

${ }^{271}$ Así, podría también el promitente estar facultado a ejercitarlo. Véase L.B. PÉREZ GALLARDO, El contrato..., cit. p. 348; J. L. LACRUZ BERDEJO, Elementos de Derecho civil, T. II, Vol. 1, Parte general. Teoría general del contrato, nueva edición, revisada por Francisco Rivero Hernández, Dykinson, Madrid, 1999, p. 529.

${ }^{272}$ L. DíEZ-PiCAZO, Fundamentos..., cit., Vol. I, p. 546. Esta última es la opinión de GARCía GOYENA, a cuyo juicio, y hasta la aceptación, «[s]erá revocable la obligación por el disenso o contraria voluntad de los que la formaron: si fue uno solo, como generalmente sucede en las donaciones, podrá revocarla el donador. Si fueron dos las partes contratantes, por ejemplo, si yo doy mil duros a Pedro con la condición, o para que se constituya deudor de una renta vitalicia de ochenta a favor de Pablo, será necesario el disenso de Pedro y mío, sin que baste el de uno solo de los dos, porque hay un contrato bilateral» (citado por I. GONZÁLEZ PACANOWSKA, «Comentario...», cit., p. 404).

273 M. CARBALlo FIDALGO, «El contrato...», cit., p. 1709.

274 Ya con anterioridad a la reforma del Code civil en 2016, la jurisprudencia francesa entendía que la facultad de revocación pertenecía al estipulante y no al promitente, pero que nada impedía que en el contrato se estipulase que dicha revocación deberá ejercitarse de común acuerdo. Las dudas surgen, con todo, en aquellos casos en que el promitente tiene un interés personal en que la estipulación produzca su efecto, en los que, como señalan BAUDRY-LACANTINERIE y BARDE, el poder de revocación del estipulante se restringe y no puede ejercerse unilateralmente por él solo, sino que se exige la intervención del promitente. Un ejemplo de una situación en la que el promitente comparte con el estipulante el poder revocatorio sería el siguiente: «se constituye una dote en una transacción de la cual aquella constitución es una condición esencial; sólo podrá ser revocada en tal caso por la conformidad de todas las partes contratantes» (cfr. F. BONET RAMÓN, «Los contratos...», cit., p. 23). Así, también ROCA SASTRE sostiene que sería razonable que el estipulante y el promitente compartan conjuntamente el poder de revocar en aquellos casos en que la estipulación a favor de tercera figura como pacto secundario en un contrato oneroso, salvo en el contrato de seguro de vida, en el que la revocación se atribuye exclusivamente al estipulante (tomador) (art. 87 LCS). La misma opinión la comparten LAMBERT y BUNFOIR, en el sentido de que la revocación por ambas partes 
transporte terrestre, donde la facultad de revocar la prestación -esto es, el llamado «derecho de disposición» que, como habrá ocasión de constatar, faculta inter alia para ordenar la detención el transporte, la devolución de la mercancía a su origen o la entrega a otro desinatario distinto del inicialmente previstopertenece al cargador, salvo que expresamente se pacte que corresponda al destinatario (art. 29 LCTTM). En este último caso, habrá de entenderse que la atribución al destinatario del derecho a la entrega es irrevocable para el cargador.

Por lo que a la forma se refiere, la revocación, que según los casos se considera un derecho personalísimo ${ }^{275}$, no está sometida a requisito formal alguno. Puede, por ello, declararse de forma expresa, cuando el estipulante comunica por medio de una notificación su revocación al promitente o al tercero, en cuyo caso dicha notificación es presupuesto para la plena eficacia de la revocación. Como consecuencia, el promitente queda exonerado de su obligación frente al estipulante si la prestación se cumple, aun después de haberse revocado la estipulación por el estipulante, en ausencia de notificación o antes de que ésta se

contratantes se exige en aquellos casos que impliquen un contrato oneroso, por cuanto el promitente tiene interés en realizar la prestación al tercero por virtud del contrato base (vid. M. CASAls COlLDECARRERA, El contrato..., cit., p. 373).

275 Por ello, no se transmite ni inter vivos ni mortis causa, de modo que su ejecución queda fuera del alcance de los acreedores de su titular. Tampoco pueden éstos subrogarse en la legitimación de tal revocación, por cuanto la acción subrogatoria se reserva por virtud de la ley a la persona del deudor y no a los acreedores del estipulante. Así pues, el derecho de revocar se extingue a la muerte de aquél (C. PÉREZ CONESA, El contrato..., cit., p. 265). Con todo, la transmisibilidad del derecho a revocar del estipulante a sus herederos antes de que el tercero haya manifestado su aceptación de querer aprovechar el beneficio es un aspecto controvertido en la doctrina. Mientras que a juicio de algunos se trata de un derecho de carácter personalísimo que corresponde exclusivamente al estipulante y no propiamente al patrimonio de éste (por lo que no pasaría a sus herederos), para otros este derecho sí puede tener carácter patrimonial, con fundamento en la naturaleza de la estipulación a favor del tercero, que se identifica como una desviación de un derecho de crédito desde el patrimonio del estipulante hacia el del tercero, de manera que la revocación afecta, en rigor, a una prestación que en el fondo se le debe a él. Esta segunda opinión la comparte LAROUMIÈRE, a cuyo juicio el contrato a favor de tercero no se convierte en irrevocable por la muerte del estipulante, porque su facultad de revocación pasa a sus herederos que pueden ejercitarla y, en su caso, apropiarse de la prestación (vid. M. CASALS COLLDECARRERA, El contrato..., cit., p. 374). PACCHIONI, por su parte, basa su opinión en dos puntos: por un lado, reconoce que el derecho de revocación, al tener carácter patrimonial, no se extingue por la muerte del estipulante y pasa por vía sucesoria a sus herederos; por otro, sostiene que, si la prestación no tiene carácter pecuniario o valor patrimonial para el estipulante, y no tiene nada que ver con la prestación que a él se le debe, el derecho de revocación sí que se extingue por la muerte del estipulante (G. PACCHIONI, Los contratos..., cit., p. 210-211; vide también M. CASALS COLLDECARRERA, El contrato..., cit., p. 374). 
produzca ${ }^{276}$. Mas puede también ser tácita, por ejemplo, cuando el estipulante hace cumplir en su favor la promesa del tercero 277.

Como se ha dicho, la revocación puede tener lugar en cualquier momento, al menos en tanto el tercero no confirme al promitente su intención de aceptar la prestación, acto que sustrae al estipulante su facultad de revocar ${ }^{278}$. Según BONET RAMÓN, la revocación puede ser, además, total, en cuyo caso se produce la ineficacia total de la prestación a favor de tercero, debiendo ésta realizarse, en su caso, a favor del estipulante o sus herederos; o parcial, que puede ser de dos formas: la primera consiste en un simple cambio de tercero, sustituyéndose éste por un nuevo beneficiario (lo cual sucede con frecuencia en los seguros de vida y está expresamente previsto en los contratos de transporte ${ }^{279}$ ), sin alterar el modo o el contenido de la prestación; la segunda se refiere a la revocación de una parte del contenido de la disposición ${ }^{280}$. No se excluye, en todo caso, que el estipulante solicite para sí o para sus herederos la prestación, realizándose ésta en su propio beneficio ${ }^{281}$, que es lo que sucede, en el contrato de transporte, si el

${ }^{276}$ J.M. MARTÍN BERNAL, La estipulación..., cit., p. 382.

277 M. CARBALlo FIDALGO, «El contrato...», cit., p. 1711.

${ }^{278}$ Con todo, en algún supuesto excepcional es posible que la revocación se produzca en un momento posterior a la aceptación. Ello puede suceder en los casos en que la prestación debe cumplirse después de la muerte del estipulante, y en aquellos otros en que la estipulación se emplea como vehículo para realizar una donación a favor del tercero. Así, M. CARBALLO FIDALGO, «El contrato...», cit., p. 1710.

279 Concretamente, mediante el ejercicio del referido «derecho de disposición», que faculta al cargador para cambiar la consignación (art. 29.1 LCTTM).

${ }^{280}$ M. CASAlS COLLDECARRERA, El contrato..., cit., p. 373.

${ }^{281}$ J.M. MARTín BERNAL, La estipulación..., cit., p. 385. Con todo, esta última regla debe matizarse, en el sentido de que se halla sujeta a algunas limitaciones importantes, al objeto de resolver la cuestión acerca de la determinación del destinatario de la prestación, teniendo en cuenta los efectos que derivan de la revocación. De entre los criterios apuntados en la doctrina destacan los siguientes: a) Cuando se trate de una estipulación realizada por medio de un contrato accesorio, formando una parte de lo convenido por el estipulante en su propio beneficio, en caso de revocación de este tipo de estipulación la prestación deberá efectuarse al estipulante. Por el contrario, si esta estipulación accesoria no forma parte de la prestación principal debida al estipulante, la revocación en tal caso se atribuiría al promitente, quedando así exonerado de su obligación frente al estipulante (M. CASAls COLLDECARRERA, El contrato..., cit., p. 373; J.M. MARTín BERNAL, La estipulación..., cit., p. 386.); b) Análoga debe ser la consideración cuando se trate de una donación modal, pues los efectos de la revocación se mantienen íntegramente a favor del promitentedonatario, liberándolo de la carga que la existencia del modus suponía; c) Si la prestación debida al tercero consiste en una renta vitalicia (art. $1.803 \mathrm{Cc}$.), en tal caso si el estipulante hubiera revocado en tiempo útil, podría efectivamente percibir para sí la renta vitalicia estipulada inicialmente a favor de tercero, pero como el estipulante no puede por su propia voluntad alterar la extensión de la obligación del promitente (la deuda), el cálculo de la 
cargador, en ejercicio del derecho de disposición, ordena la devolución de las mercancías a su origen (art. 29.1 LCTTM).

\subsection{La renuncia del tercero}

Se entiende por renuncia aquella declaración de voluntad del tercero por la que manifiesta su negativa a aceptar la prestación estipulada en su favor, es decir, el rechazo del derecho atribuido en virtud de la estipulación contractual ${ }^{282}$. La renuncia, siendo también una causa de extinción del derecho a la estipulación, defiere de la revocación en el sentido de que la desaparición del derecho del tercero en tal caso se hace depender de la misma voluntad del beneficiario. Pues bien, resulta obvio que el tercero debe gozar de tal facultad de renuncia, a la vista de la regla general de que nadie está obligado a adquirir derechos en contra de su voluntad, salvo que se hubiera obligado a aceptar la prestación ${ }^{283}$.

La llamada renuncia del beneficiario se analiza con frecuencia al objeto de precisar su naturaleza jurídica. De entre los intentos más destacados en este sentido destaca la opinión de CASAls COLLDECARRERA, a cuyo juicio, en el ordenamiento español, la renuncia tiene carácter "preventivo» siempre que aún no se hubiera producido la aceptación del derecho, y éste tampoco haya ingresado en la esfera patrimonial del tercero a través de una ratificación de su propia voluntad $^{284}$. En este sentido, el carácter preventivo de la renuncia protege al tercero, respetándose la intangibilidad de su esfera privada para que no se le imponga una adquisición a pesar suyo ${ }^{285}$. En cuanto a los efectos de la renuncia, éstos

renta deberá realizarse siempre en atención a la vida del beneficiario (M. CARBALLO FIDALGO, «El contrato...», cit., p. 1712; L. B. PÉREZ GALLARDO, El contrato..., cit., p. 352.); y d) En otras ocasiones, sucede que el mismo contenido de la prestación hace imposible su reversión al estipulante. Es el caso del pacto de respeto al arrendamiento de un colono puesto en la venta de una finca, previsto en el artículo 1.571 Cc: revocada la prestación (o sea, la obligatoriedad de respetar el arrendamiento del colono), será inaplicable la reversión a favor del estipulante-vendedor (M. CASALS COLLDECARRERA, El contrato..., cit., p. 374).

${ }^{282}$ L. DíEz-PICAZo, Fundamentos..., Vol. I, cit., p. 547; L. B. PÉrez GALlardo, El contrato..., cit. p. 347 .

283 C. PÉREZ ConesA, El contrato..., Vol. I, cit., p. 275. Dicha regla general resultará de aplicación, siempre que la renuncia sea legal y no resulte contraria al interés ni al orden público, en perjuicio de terceros. Así, L. DíEZ-PICAZO, Fundamentos..., Vol. I, cit., p. 547.

${ }^{284}$ M. CASAls COLLDECARRERA, El contrato..., cit., p. 373.

285 C. PÉrez CONESA, El contrato..., cit., p. 276. Concretamente, señala la autora que la finalidad referida se consigue atribuyéndole efectos resolutorios a la renuncia, que se 
dependen del caso concreto. Así, según Colin y CAPITANT, la renuncia hace revertir en el estipulante o en sus herederos la prestación pactada a favor del tercero, salvo en el supuesto de la donación modal (sub modo), en la cual la renuncia del favorecido beneficia sólo al promitente (donatario) ${ }^{286}$, sin que de la mismo emane derecho alguno para el estipulante ${ }^{287}$.

La regla general de que todos los derechos son renunciables, siempre que la renuncia no sea contraria al interés u orden público, en perjuicio de tercero, es clara. Sucede, sin embargo, que a veces la renuncia tiene lugar con posterioridad a la aceptación por parte del tercero. En este caso, señala DiEz-PICAZo, la renuncia tiene que enjuiciarse de acuerdo a lo que fue la causa para el estipulante. Así, si la causa es donandi, no hay ningún problema en que el tercero declare la renuncia a su derecho de crédito aun después de haberlo aceptado. Por su parte, si la estipulación es solvendi causa, la renuncia sigue siendo posible, a condición de que se entienda consumada la solutio frente al estipulante.

En cambio, no parece posible ya la renuncia una vez formulada la aceptación en caso de que aquélla implique el incumplimiento de alguna obligación del tercero para con el estipulante, por ejemplo, cuando el consignatario renuncia a recibir la mercancía ${ }^{288}$. Este caso guarda cierta similitud con otro, regulado específicamente en la Ley 15/2009: el llamado «deje de cuenta» o abandono de la

retrotraen al mismo momento en que se considera originada la adquisición por el tercero. Si tuviera efectos ex nunc, el tercero no podría impedir la intromisión en su ámbito jurídico, al menos en el período de tiempo que media entre la conclusión del contrato y el momento de su renuncia.

${ }^{286}$ Véase las referencias en J.M. MARTÍN BERNAL, La estipulación..., cit., pp. 372-373.

287 M. CASAlS COLLDECARRERA, El contrato..., cit., p. 372. En este mismo contexto, Roca SASTRE establece un régimen jurídico diverso, distinguiendo en función de si la estipulación es onerosa o lucrativa: «a) Contrato lucrativo: aquí hay una donación del estipulante al promitente, limitándose el modo a restringir la liberalidad de modo que al repudiar el tercero la transmisión gratuita del estipulante al promitente, se mantendrá íntegramente a favor de éste, quien se verá libre de la carga. b) Contrato oneroso: la infraestructura de esta figura del contrato se construye sobre la base de que la obligación del promitente de efectuar una disposición al tercero, tiene una contraprestación del estipulante al promitente si el tercero renuncia a la atribución intentada a su favor, parece lógico que la prestación la reciba el estipulante o sus herederos, pues de lo contrario habría un enriquecimiento injusto del promitente, desvirtuándose con ello el espíritu de la estipulación, que lo que pretende al final y en definitiva es una reciprocidad y equivalencia de la prestación entre las tres personas que actúan». Vid. también J. M. MARTín BERNAL, La estipulación..., cit., p. 373 .

${ }^{288}$ L. Dítez-PiCAzo, Fundamentos..., Vol. I, cit., p. 547. 
mercancía al porteador ${ }^{289}$. En este caso, el destinatario acepta la prestación realizada en su favor (reclamando la entrega las mercancías), pero decide dejarla de cuenta del porteador (por causa de averías, pérdidas parciales o un retraso excesivo en la entrega), a cambio de la indemnización que corresponda en caso de pérdida total. A pesar de que, en tales casos, parece producirse una «renuncia» a la entrega después de haberse aceptado la estipulación, no existe incumplimiento para con el cargador-estipulante (para quien el abandono es un acto completamente ajeno). Y ello porque, en el caso frecuente de que el transporte se realice en ejecución de un contrato de compraventa, deberá igualmente satisfacerse el precio de las mercancías, a pesar de que no las obtiene finalmente el destinatario, sin perjuicio del derecho a la indemnización por pérdida que le corresponde contra el porteador (art. 54 LCTTM).

Debe preguntarse, por último, cuáles son los efectos de la renuncia sobre la relación contractual que liga al promitente con el estipulante. Como las consecuencias de la renuncia sobre la relación de cobertura no cuentan con ninguna regla general, se entiende que la duda debe resolverse en función del contenido y la naturaleza del contrato. Concretamente, lo que se plantea es si, con posterioridad a la renuncia, el estipulante puede reclamar la prestación para sí o nominar a otro beneficiario, o si queda exonerado el promitente del cumplimiento de su obligación. Lo razonable parece ser la primera solución, al menos cuando el promitente no tuviera un interés especial en el otorgamiento del derecho al tercero, porque de lo contrario se estaría ante un enriquecimiento injusto del promitente 290 .

\section{La tipificación legal de ciertos contratos a favor de tercero}

Como se ha tenido ocasión de señalar, los contratos a favor de tercero encuentran su reflejo legal en el artículo $1.2572^{\mathrm{a}}$ del Código civil. Por su parte, este mismo cuerpo legal contempla algunos supuestos expresamente regulados de estipulaciones a favor de tercero, por ejemplo, el beneficiario en la reversión de

\footnotetext{
${ }^{289}$ Con detalle sobre este supuestos, infra, Cap. IV, sub VIII.3.3.

290 J. LÓPEZ RICHART, Los contratos..., cit., pp. 105-106. Es esta también la solución consagrada de manera expresa en los contratos de seguro de vida y de accidente por cuenta ajena, a los que seguidamente nos referiremos.
} 
una donación a favor de un tercero (art. $641 \mathrm{Cc}$ ); el acreedor en el pacto de pago de deudas (art. $642 \mathrm{Cc}$ ); y el o los beneficiarios en un contrato de renta vital a favor de tercero (arts. 1802 a 1808 Cc). Por su parte, al margen del Código se regulan los derechos del destinatario en un contrato de transporte (art. 35 LCTTM); y los del beneficiario en un seguro de vida (art. 83 de la Ley 50/1980, de 8 de octubre, de contrato de seguro -LCS-)291. Por su interés para el presente estudio, conviene detenerse brevemente en los contratos de transporte y de seguro, los cuales pertencen, según una opinión doctrinal hoy consolidada, a la categoría de los contratos a favor de tercero. Todo ello sin perjuicio de que, como no puede ser de otra forma, el contrato de transporte será objeto de una atención detallada en los Capítulos III y IV.

\subsection{El contrato de transporte}

Como precedente de la tipificación legal del contrato de transporte puede mencionarse la solución romana sobre la base de un texto de Ulpiano, que examina el caso en que uno se compromete con otro a llevar una cosa a un tercero. En tal supuesto, el tercero es el destinatario de la cosa transportada, y a este destinatario se le atribuye la acción contra el transportista ${ }^{292}$. Al respecto, WINDSCHEID opinaba que la acción otorgada al destinatario frente al porteador constituía una excepción a la regla general de la nulidad de los contratos a favor de tercero; por el contrario, Cogliolo, Eisel y PACCHIONI afirman que tal acción del tercero se basa en una actio negotiorum gestio y no deriva del contrato concluido entre el transportista y el remitente, razón por la cual rechazan la posibilidad señalada por WinDSCHEID de que el Derecho romano hubiera previsto una excepción al principio general de nulidad de las estipulaciones a favor de tercero ${ }^{293}$.

A su vez, NART ve en el hecho de forzar la aplicación de la negotiorum gestio invocada por PACCHIONI una verdadera discriminación, dentro de un

\footnotetext{
${ }^{291}$ Para más contratos típicos pertenecientes a la categoría de los contratos a favor de tercero vid. Á. CARRASCO PERERA, Derecho de contratos, cit., pp. 610 y ss.; así como P. JIMÉNEZ BLANCO, El contrato..., cit., pp. 70 y s.

292 I. NART FERNÁNDEZ, «Notas sobre los contratos a favor de tercero», Anales de la Academia Matritense del Notariado, núm. 5, 1950, p. 457.

293 Véase M. CASAls COLLDECARRERA, «El contrato a favor de tercero», en Aa.Vv., Nueva enciclopedia jurídica, Seix, Barcelona, 1956-2, p. 348.
} 
mismo negocio, de dos campos diferentes, el de las partes contratantes y el de los terceros. A su juicio, en Derecho español, el cargador que celebra con el porteador un contrato para trasladar cosas a una persona designada como consignatario no es más que un mandatario-representante sin poder, y lo ilustra con el siguiente ejemplo: «cuando yo compro una cosa a un comerciante de distinta residencia, le encargo (explícita o implícitamente) que me la facture a mi nombre; y la cosa es mía por título de compra y entrega 'sobre vagón': la compañía de ferrocarriles conoce que soy yo o puedo ser el dueño, ya que el transporte es para mí: y acepta, como consecuencia normal, que yo recoja la mercancía o la deje de cuenta (en su caso), que no son más que actos de ratificación inequívoca (expresa)»294.

A partir de aquí, NART advierte de que los derechos del consignatario, en comparación con los del tercero favorecido, no se caracterizan por la sustantividad y la independencia, sino que se consideran como derechos de parte contratante y no de tercero; por ello, tiene también obligaciones como la de pagar los gastos y portes del transporte 295 (art. 374 Código de Comercio). A su juicio, mantener que se trata de una estipulación a favor de tercero (art. $1.2572^{\mathrm{a}} \mathrm{Cc}$ ) que únicamente atribuye derechos al destinatario resulta incompatible con la imposición de algunas de las obligaciones propias de las partes ${ }^{296}$. Como colofón, y siguiendo una construcción dogmática similar a la adoptada por PACCHIONI, niega que el contrato de transporte lo sea a favor de tercero y entiende que el derecho del consignatario emana de la propia ley, que lo condiciona ope legis al cumplimiento de las obligaciones impuestas, como es, señaladamente, la de hacerse cargo de los portes y gastos.

Frente a la opinión reseñada, creemos que los mejores argumentos abogan por incluir el contrato de transporte entre los negocios a favor de terceros; una conclusión que es compartida en la mayoría de los países de nuestro en-

294 I. NART FERNÁNDEZ, «Notas...», cit., p. 459.

295 En apoyo de su tesis cita el -hoy derogado- art. 374 Ccom, a cuyo tenor «[l]os consignatarios a quienes se hubiere hecho la remesa no podrán diferir el pago de los gastos y portes de los géneros que recibieron, después de transcurridas las veinticuatro horas siguientes a su entrega, $y$, en caso de retardo en este pago, podrá el porteador exigir la venta judicial de los géneros que condujo, en cantidad suficiente para cubrir el precio del transporte y los gastos que hubiese suplido».

296 I. NART FERNÁNDEZ, op. y loc. últ. cit. 
torno más próximo. En efecto, el destinatario adquiere un derecho en virtud del contrato frente al porteador, pudiendo reclamar en su propio nombre la reparación de los perjuicios ocasionados durante el transporte297. No es óbice para ello el hecho de que el destinatario soporta, en ciertos casos, el deber de satisfacer los portes, pues - como habrá ocasión de comprobar más adelante en el textono se trata de una obligación en sentido jurídico-técnico (su infracción no faculta per se para reclamar el cumplimiento por vía judicial) sino, únicamente, comporta una desventaja para quien no la respeta (aquí, la imposibilidad de reclamar la entrega de la mercancía en el lugar de destino). Más que de una obligación se trata, por tanto, de una carga.

La inclusión del contrato de transporte en la categoría de los contratos a favor de tercero tiene como objeto determinar el régimen jurídico aplicable al destinatario en el marco del vínculo negocial entre las partes contratantes del transporte 298 , habida cuenta de que el destinatario es una parte ajena al contrato de transporte, y no interviene ab initio en la relación celebrada contractualmente entre cargador y transportista, obligándose éste frente a aquél (y no frente al destinatario) a entregar la mercancía en el lugar pactado (art. 4.3 LCTTM).

Como puede observarse, el destinatario no forma inicialmente parte del contrato, pero se convierte en acreedor del derecho a recibir la mercancía si, una vez llegada al lugar de destino convenido, manifiesta su voluntad de recibirla299.

\subsection{El contrato de seguro}

El desarrollo tecnológico al que se ha llegado hoy día genera situaciones de riesgo, y de ahí la importancia de ofrecer la debida protección a quien las soporta. En este contexto surge el contrato de seguro que trata principalmente de proteger el patrimonio de una persona frente a una necesidad económica, consecuen-

297 A. EMPARANZA Sobejano, El concepto de porteador..., cit., pp. 415 y ss.

${ }^{298} \mathrm{Y}$ es que la cuestión que debe formularse a la hora de determinar la posición jurídica del destinatario en el contrato de transporte es, precisamente, qué figura jurídica es la que permite al destinatario participar en la relación contractual nacida originariamente entre el cargador y el transportista.

299 F. MARTíneZ SANZ, «Transporte de mercancías por carretera (II). Transporte internacional», en id. (dir.) y A. Puetz (coord.), Manual de Derecho del transporte, Marcial Pons, Madrid, 2010, p. 175. 
cia de un siniestro que cause daños en las cosas o las personas ${ }^{300}$. Conforme a lo dispuesto en el artículo 1 LCS, «el contrato de seguro es aquel por el que el asegurador se obliga, mediante el cobro de una prima y para el caso de que se produzca el evento cuyo riesgo es objeto de cobertura a indemnizar, dentro de los límites pactados, el daño producido al asegurado o a satisfacer un capital, una renta $u$ otras prestaciones convenidas».

\section{a) Seguros de daños}

El seguro de daños es una de las dos grandes modalidades de contrato de seguro. Tiene por objeto cubrir un riesgo capaz de producir un daño en el patrimonio del asegurado, por lo que la cobertura prestada por el asegurador se concretará, en caso de producirse el siniestro, en el pago de un resarcimiento a favor del asegurado. El fundamento en el que se basa este tipo de seguro es la valoración de los daños ${ }^{301}$ a posteriori, para que pueda ajustarse el pago de la prestación que pesa sobre el asegurador302.

Un ejemplo muy relevante de seguro contra daños es el contrato de seguro de transporte de mercancías, cuya finalidad es cubrir los diversos riesgos que pueden ocasionarse durante el transporte de la carga y donde el principio resarcitorio se concreta en el valor de las mercancías.

En este tipo de seguros puede suceder que un sujeto (p.ej., el transportista), en cuanto tomador303, estipula el contrato de seguro por cuenta de otro, el asegurado (v.gr., el propietario de la mercancía), es decir, obra por cuenta aje-

300 R. BERCOVITZ Rodríguez-CANO, Manual de derecho civil, Bercal, Madrid, 2011, p. 349. Obsérvese que, a través del seguro, puede protegerse, tanto a quien sufre el daño (p.ej., un seguro de incendio o de robo, o de transporte terrestre de mercancías), como el patrimonio de quien lo causa (a través de un seguro de responsabilidad civil).

301 Conforme la art. 26 LCS, los seguros contra daños no pueden dar lugar al enriquecimiento del asegurado, por lo que el criterio decisivo a la hora de valorar el daño ha de ser de índole objetiva, sin que las intenciones, los proyectos y las circunstancias subjetivas del asegurado afecten a la tasación pericial, ni para aumentar ni para disminuir la indemnización.

302 R. BERCOVITZ RodríGUEZ-CANO, Manual..., cit., p. 358.

${ }^{303} \mathrm{El}$ tomador es parte contratante del seguro y asume obligaciones frente al asegurador, y puede estipular el contrato de seguro en interés propio o ajeno, por ejemplo, del destinatario final (comprador). El asegurado, por su parte es el titular del interés asegurado. Véase, en lugar de muchos, J. GARRIGUES, Contrato de seguro terrestre, Madrid, 1982, p. 75 . 
na304. Se estaría, entonces, ante una estipulación a favor de tercero en el ámbito de los seguros de daños por cuenta ajena. Como es obvio, las relaciones entre asegurado y tomador no se regulan ya sólo por lo dispuesto en la LCS, sino también por lo que se hubiera acordado en el contrato que ha dado lugar a que el tomador concluyera el contrato de seguro de transporte de mercancías por cuenta del asegurado305. La hipótesis aquí analizada de seguro por cuenta ajena es muy frecuente en el ámbito mercantil, en particular, en todos aquellos casos en que alguien ostenta la posesión transitoria de bienes ajenos ${ }^{306}$.

Como regla general, el contrato de seguro de daños es nulo si no existe un interés del asegurado al resarcimiento del perjuicio en el momento de su conclusión (art. 25 LCS). El interés del asegurado es, pues, un elemento contractual esencial307 que es definido como la relación, valorable económicamente, entre el asegurado y el objeto asegurado; «la relación jurídica entre dicho asegurado y el bien objeto de seguro»308, pues la titularidad de dicha relación es necesaria para poder cubrir el riesgo de que el acontecimiento dañoso se produzca y así aprovecharse de la indemnización del daño sufrido309. Como consecuencia, la desaparición del interés del asegurado con posterioridad a la conclusión del contrato y la extinción consiguiente del riesgo excluyen la posibilidad de que se materialice el riesgo previsto en la póliza, quedando extinguido el deber de indemnización del asegurador y, con ello, el contrato de seguro. Tal desaparición del inte-

304 El seguro por cuenta ajena puede configurarse también como seguro «por cuenta de quien corresponda», si no se designa expresamente al titular del interés pero sí, al menos, los criterios para su determinación (p.ej., un seguro por cuenta del «propietario de la carga»). Ello puede influir, incluso, en la propia caracterización del seguro como por cuenta propia o ajena. Valga el siguiente ejemplo: cuando tras la venta es el vendedor quien asegura la mercancía mediante un contrato de seguro de transporte, se asegura el interés eventual tanto del vendedor como del comprador, pues ambos son propietarios sucesivos de la cosa. Vid. J. Boquera MATARREDona, El contrato de seguro de transporte de mercancías por carretera, Tirant lo Blanch, Valencia, 2002, pp. 73 y ss.

305 J. BOQUERA MATARREDONA, El contrato de seguro..., cit., p. 72.

${ }^{306}$ J. GARRIGUES, Contrato de seguro terrestre, cit., p. 74.

307 Vid. SAP Vizcaya (Sección 4a) núm. 299/2010, de 14 de abril (AC 2010, 1581).

${ }^{308}$ SsTS núm. 479/2000, de 16 de mayo (RJ 2000, 3579), y núm. 997/2002, de 23 de octubre (RJ 2002, 8971); SsAP Córdoba (Sección $3^{\text {a }) ~ n u ́ m . ~ 224 / 2006, ~ d e ~} 18$ de octubre (AC 2007, 1046); Segovia (Sección 1a) núm. 9/2007, de 29 de enero (JUR 2007, 250660); y Madrid (Sección 25a) núm. 241/2007, de 8 de mayo (JUR 2007, 210653).

309 J.A. BADILLO ARIAS (coord.), Ley de Contrato de Seguro: jurisprudencia comentada, $2^{\text {a }}$ ed., Aranzadi, Cizur Menor, 2011, pp. 611 y ss. 
rés puede producirse, por ejemplo, con la pérdida de la propiedad sobre el bien asegurado, o cuando se termina el viaje que había sido objeto de seguro310.

\section{b) Seguros de personas}

El concepto de seguro de personas se encuentra en el artículo 80 LCS, que señala que «el contrato de seguro sobre las personas comprende todos los riesgos que puedan afectar a la existencia, integridad corporal o salud del asegurado». Este precepto comprende la regulación común de los seguros de personas, teniendo por objeto la cobertura de aquellos «riesgos» que afectan a la «existencia, a la integridad corporal o a la salud del asegurado». Quedan englobados, pues, los seguros de personas en sentido estricto - seguro sobre la vida311- y los seguros de personas en sentido amplio, que comprenden el seguro de accidentes y el de enfermedad ${ }^{312}$.

La diferencia entre los seguros de personas y los de daños consiste, en consecuencia, en que en el primer caso se considera a la persona como objeto esencial del contrato de seguro, que pretende cubrir el riesgo de que un siniestro afecte a la vida, la integridad o la salud de la persona; en el segundo, en cambio, el interés asegurado es el eje fundamental del seguro que, en caso de que suceda un daño que afecte al objeto -y, por ende, al interés- asegurado, obliga al asegurador a resarcirlo. Partiendo de esta distinción, el contrato de seguro de personas se define como aquel seguro que, oponiéndose al seguro sobre cosas, considera a la persona como el objeto amenazado por un siniestro313.

En el marco de la amplia tipología de contratos a favor de tercero en el artículo 1.257 , párrafo $2^{\circ} \mathrm{Cc}$, se puede afirmar que el contrato de seguro de vida

${ }^{310}$ J. GARRIGUES, Contrato de seguro terrestre, cit., p. 127.

${ }^{311} \mathrm{El}$ contrato de seguro de vida ha sido configurado como un contrato a favor de tercero en las legislaciones de finales del siglo XIX y principios del XX. La referencia al tercero beneficiario se encuentra actualmente en los arts. 84 y ss. LCS, que contiene un régimen similar al de los ordenamientos próximos al nuestro, p.ej., en el Code des Assurances francés de 1976, modificado en múltiples ocasiones (arts. L132-8 y ss.); el Codice civile italiano (arts. 1920 y ss); o la Versicherungsvertragsgesetz alemana de 2007 ( $\S 159$ y ss.). Vid. C. Boldó RODA, «El seguro de vida como contrato a favor de tercero», en Aa.Vv., Homenaje al profesor Vidal Guitarte: Estudios jurídicos, Diputació de Castelló, Valencia, 1999, p. 106.

312 J. A. BADIllo ARIAS (coord.), Ley de Contrato de Seguro..., cit., p. 1431.

313 J. GARRIGUes, Contrato..., cit., p. 485. 
es un contrato aleatorio en interés de tercero (al menos cuando se establezca para caso de muerte314), mercantil e inter vivos, en el cual una persona, el asegurador, a cambio de una suma y para el caso de que sobrevenga la muerte de otra persona ${ }^{315}$, el asegurado, se obliga a satisfacer un capital, una renta u otras prestaciones a la persona designada como beneficiaria en el contrato (art. 83 LCS).

Como puede apreciarse, el beneficio estipulado por el asegurador y el tomador en el contrato de seguro de vida para caso de muerte del asegurado va destinado a una tercera persona que no sea parte contratante. Ha de distinguirse, así, entre el asegurador, el tomador, el asegurado y el beneficiario. De entre ellos, las partes contratantes serán el asegurador y el asegurado -o, de no celebrarse el contrato por quien es titular del interés asegurado, el tomador-, que es quien asume las obligaciones derivadas del contrato.

Por el contrario, en función de cuál sea el contenido del contrato (principalmente, en función de si el seguro se contrata para caso de muerte o para caso de supervivencia), quien obtiene el pago de la prestación comprometida por el asegurador es el asegurado o, en su caso, el beneficiario. $\mathrm{Y}$ es que, en esta relación compleja que es el seguro sobre la vida, el asegurado es el titular del interés asegurado ${ }^{316}$, razón por la cual, cuando se estipule para caso de muerte, es precisamente la muerte del asegurado la que desencadena la obligación de pagar.

En lo que se refiere a la persona del beneficiario, se trata de un tercero ajeno al contrato317 que aparece frente al asegurador como beneficiario, distinto tanto del tomador como del asegurado. Siendo tercero ajeno al contrato, el beneficiario queda exonerado de cualquier obligación contractual (señaladamente,

$314 \mathrm{Su}$ carácter aleatorio se justifica porque -aun siendo inevitable la realización del siniestro (certus an) - no lo es el momento en que se va a producir, es decir, se desconoce cuándo se va a producir la muerte - segura- del asegurado (incertus quando). En este contexto, el seguro de vida se parece al contrato de renta vitalicia. Vid. J. I. CANO MARTínEZ DE VELASCO, El contrato..., cit., p. 135.

315 El siniestro previsto en el seguro de vida (para caso de muerte) es la muerte del asegurado, pues lo que cuenta en este tipo de contratos es el riesgo que se asegura, ni la cosa como objeto del seguro ni la persona como objeto del contrato. Vid. J. GARRIGUES, Contrato..., cit., p. 484.

${ }^{316}$ Que puede ser diferente del tomador, si este último celebra el contrato de seguro por cuenta ajena, aunque ambos sujetos suelen coincidir.

317 P. JimÉneZ BlanCo, El contrato..., cit., p. 74. 
la de satisfacer las primas al asegurador), ni tampoco interviene en la celebración del contrato de seguro, pero se convierte en acreedor de la prestación frente al asegurador una vez que se materialice el evento estipulado en el contrato318.

\section{Excurso: El contrato a favor de tercero en el Derecho comparado}

El presente epígrafe tiene como propósito mostrar cómo el principio de la relatividad contractual y una de sus principales excepciones, la estipulación a favor de tercero, ha merecido una especial atención en la doctrina científica, un hecho que propició la admisión de la plena validez del contrato a favor de tercero. Conviene por ello detenerse, siquiera brevemente, en el estudio del Derecho comparado, con especial referencia a los ordenamientos alemán, francés e italiano, dada la gran similitud que guardan con el español319.

\section{En el Derecho alemán}

En el ordenamiento jurídico alemán, el contrato a favor de tercero se regula en los $\S 328$ a 335 BGB («Vertrag zugunsten Dritter») ${ }^{320}$. El primer apartado del § 328 BGB se refiere al contrato a favor de tercero como aquel en que hay una estipulación por virtud de la cual se compele a un obligado (el promitente) a que haga efectiva una prestación a favor de una persona extraña al contrato, habiéndose este promitente comprometido con el estipulante, para que a través del negocio estipulado, el tercero o esa persona ajena ostente un derecho propio de

${ }^{318}$ R. BERCOVITZ RODRÍGUEZ-CANO, Manual..., cit., p. 359.

319 Con detalle sobre esta cuestión puede verse S. CÁMARA LAPUENTE, «El contrato en favor de tercero a la luz de la armonización del Derecho privado europeo», en J. M. Abril Campoy y M.E. Amat Llari (coord.), Homenaje al profesor Lluís Puig i Ferriol, Valencia, 2006, pp. 647 y ss.

${ }^{320}$ Los parágrafos referidos al Vertrag zugunsten Dritter se sitúan en el Título III del Libro II. Concretamente, en el $\S 328.1$ BGB se dispone lo siguiente: «Durch Vertrag kann eine Leistung an einen Dritten mit der Wirkung bedungen werden, dass der Dritte unmittelbar das Recht erwirbt, die Leistung zu forden» («Por medio de un contrato se puede pactar una prestación para un tercero, con el efecto de que el tercero adquiere directamente el derecho a exigir la prestación»). Vid. C. PÉREZ CONESA, El contrato..., cit., p. 54. 
crédito, al que se le atribuye inmediatamente la facultad de pedir de aquél el cumplimiento de esta prestación ${ }^{321}$.

En el segundo apartado del mismo artículo se dispone que, a falta de pacto entre las partes, ciertos extremos de la estipulación han de derivarse de las circunstancias, especialmente la finalidad del contrato, concretamente en lo que se refiere a la forma y el mecanismo por virtud del cual se concede el derecho al tercero y las facultades reservadas a los contratantes sin que aquél preste su consentimiento322. En relación a este precepto, PACCHIONI opina que parece sencillo, claro y adecuado, aunque el legislador alemán ha prescindido del criterio de la voluntas contrahentium para resolver los problemas relativos al derecho del tercero. A su juicio, la equivocación fundamental del legislador alemán radica, formalmente, en que la institución de los contratos a favor de tercero da lugar a una esfera de aplicación que no corresponde con su real ámbito de aplica-

${ }^{321}$ C. Boldó RodA, El beneficiario en el seguro de vida, Bosch, Barcelona, 1998, p. 37.

322 «En defecto de una disposición especial, se deducirá de las circunstancias y, en especial, el fin del contrato, si el tercero adquiere el derecho, si el derecho del tercero surge inmediatamente o sólo al cumplirse determinadas condiciones, y si debe reservarse a los contratantes la facultad de revocar o modificar el derecho del tercero sin su consentimiento» ( «In Ermangelung einer besonderen Bestimmung ist aus den Umständen, insbesondere aus dem Zwecke des Vertrags, zu entnehmen, ob der Dritte das Recht erwerben, ob das Recht des Dritten sofort oder nur unter gewissen Voraussetzungen entstehen und ob den Vertragschließenden die Befugnis vorbehalten sein soll, das Recht des Dritten ohne dessen Zustimmung aufzuheben oder zu ändern»). Véase C. PÉREZ CONESA, El contrato..., cit., p. 54. La norma se cita con frecuencia en las obras que analizan la regulación de la figura en el Derecho comparado, p.ej., J. M. MARTÍn BERNAL, La estipulación..., cit., p. 83; C. Boldó RodA, El beneficiario..., cit., p. 37; G. PACCHIONI, Los contratos..., cit., p. 139; y D. DE BUEN LOZANO, «La estipulación..., cit., p. 207.

El artículo $331 \mathrm{BGB}$ regula un caso de especial importancia en relación al derecho de revocar la estipulación (así, L. ENNECCERUS y H. LEHMANN, Derecho de obligaciones, I, trad. esp. de B. Pérez González y J. Alguer, Bosch, Barcelona, 1954, p. 179): el caso en que la prestación ha de tener lugar después de la defunción del estipulante, un supuesto habitual en el seguro de vida y frecuente en el de las rentas vitalicias. A su tenor, el tercero no adquiere su derecho hasta aquel momento, o sea, el fallecimiento de quien recibió la promesa (el estipulante). De tal modo que, hasta que éste se produzca, los contratantes pueden modificar el contenido del pacto. El fin perseguido con este precepto es el de configurar el régimen jurídico propio del contrato de seguro de vida a favor de tercero (C. BOLDÓ RODA, El beneficiario..., cit., p. 32). Estos contratos pueden contener, a su vez, un convenio en virtud del cual se atribuye al estipulante la facultad de revocar unilateralmente la promesa a favor del tercero, subrogando a otro en el lugar del beneficiario, sin necesidad de que lo acepte el promitente. Salvo que otra cosa se hubiera pactado, esta sustitución realizada por el estipulante puede hacerse mediante disposición testamentaria (art. 332 BGB). Al respecto, J.M. MARTÍN BERNAL, La estipulación..., cit., p. 84. 
ción en la práctica, pudiendo así pensarse que cuando dos partes contratantes pueden hacer o querer con un contrato, deban hacerlo o quererlo en realidad ${ }^{323}$.

El tenor antes mencionado en el apartado segundo del $\S 328$ BGB deja patentes los esfuerzos del legislador alemán por favorecer un mecanismo en virtud del cual se puede otorgar inmediatamente un derecho de crédito independiente a un tercero, sin que éste haya de intervenir para que se produzca la consecuencia jurídica deseada: la atribución de este derecho324. Dicha fórmula vino a poner fin a disputas doctrinales sobre la «teoría de la adhesión», ya que, según esta última, el origen del derecho del tercero se encuentra en la promesa que le favorece, reconociendo de tal manera la independencia y originalidad del derecho referente al tercero 325 .

El precepto que le sigue en el Código, el $§ 329$ BGB, establece una regla de interpretación cuando lo que se pacta es la asunción de una obligación de pago. En efecto, cuando una de las partes contratantes se obliga en un contrato a satisfacer un pago al acreedor de la otra parte, pero sin asumir la deuda, en caso de duda no se presume la adquisición directa por el acreedor de un derecho a pedir su cumplimiento al promitente. El contenido de la norma se justifica en atención a la consideración de que el interés del estipulante consiste en quedarse liberado de una obligación, y no en la atribución de un derecho de crédito a su acreedor. Esta regla hermenéutica se refiere, pues, a una especie de asunción de deuda (pero sin serlo), que se conoce en el Derecho alemán como una asunción de cumplimiento (Erfüllungsübernahme). Obviamente, no se impide que

323 G. Pacchioni, Los contratos..., cit., p. 114 y 142. M. Casals ColldeCarrera, «El contrato...», cit., p. 35, por su parte, afirma que «[e]sta fórmula es evidentemente más sencilla que el criterio de la voluntad de las partes para dilucidar la existencia de la acción para el tercero». Vid. 4.

324 En el § 330 BGB se regula esta cuestión en relación a la renta vitalicia, donde se presume, salvo pacto en contrario, que la voluntad de las partes es la de otorgar inmediatamente un derecho de crédito al tercero y que este último adquiere la facultad de reclamar su cumplimiento. En efecto, a tenor del precepto citado, «si en un contrato de seguro de vida, o de renta vitalicia, se pacta el pago de una cantidad asegurada o de una renta a un tercero se ha de creer, en caso de duda, que el tercero debe tener directamente el derecho a exigir la prestación» (la traducción es de G. PACCHIONI, Los contratos..., cit., p. 140). Y este mismo criterio se aplica a los contratos de carácter gratuito en los que se impone al beneficiario el deber de realizar una prestación a favor de un tercero, o cuando al adquirir un patrimonio o una fina se se promete una prestación a favor de un tercero en concepto de indemnización.

325 C. PÉrez Conesa, El contrato..., cit., p. 56. 
en un caso concreto las partes dispongan que el tercero-acreedor pueda reclamar, a quien frente a él se ha comprometido, que cumpla la prestación, ya que no se trataría de un supuesto de asunción de cumplimiento sino de deuda ${ }^{326}$.

No debe sorprender que, en el ordenamiento jurídico alemán, la asunción de cumplimiento no pueda equipararse a la figura del contrato a favor de tercero $^{327}$. Y ello por cuanto, en el contrato a favor de tercero, el tercero-acreedor adquiere el derecho por el mero acuerdo entre quien asume la deuda y el deudor. En la asunción de cumplimiento, en cambio, se produce un efecto limitado a las relaciones entre el deudor y quien asume el pago de la deuda (que no se produce hasta que el tercero-acreedor no lo reclame), obligándose el «promitente» ante el deudor a pagar a su acreedor ${ }^{328}$.

Para atribuir el derecho al tercero es prescindible una manifestación de la voluntad de éste en el sentido de aceptarlo. No obstante, ello no impide que ese tercero tenga el derecho de oponerse a que dicho dicho derecho ingrese en su patrimonio, dado que no se le puede obligar a adquirirlo si lo rechaza voluntariamente ( $\$ 333 \mathrm{BGB}$ ). En el supuesto de que el tercero se haya adherido ya al contrato, señala BERNAL que ya no podrá rechazar el derecho que se le concede por una sola declaración unilateral, pero sí que podrá hacerlo a través de un acto de remisión convenido con el deudor.

En el artículo siguiente del Gesetzbuch (§ 334 BGB), en fin, se regula el régimen de las excepciones que deriven del contrato a favor de tercero, pudiendo el promitente invocarlas también frente al tercero. Además, aun cuando el estipulante puede invocar frente al promitente el cumplimiento del contrato ${ }^{329}$,

${ }^{326}$ J. LÓPEZ RICHART, Los contratos..., cit., p. 99.

327 Según la regla enunciada, la «asunción de cumplimiento», en caso de duda, no ha de considerarse un contrato a favor de tercero (del acreedor). En efecto, si alguien me promete satisfacer a mi acreedor, ante la duda, este último no obtiene derecho alguno en ese respecto, porque ese derecho me corresponde a mí exclusivamente. Vid. L. ENNECCERUS y H. Lehmann, Derecho de obligaciones, I (trad. esp. B. Pérez González y J. Alguer), Bosch, Barcelona, 1954, p. 178.

${ }^{328}$ C. PÉrez CONESA, El contrato..., cit., pp. 56-57.

329 Así lo establece claramente el $\S 335$ BGB, a cuyo tenor el estipulante puede exigir la realización de la prestación al tercero también cuando sea éste el acreedor de la misma. La regla parece adecuada, no sólo porque el estipulante tiene un interés patrimonial indirecto (ya sea donandi, solvendi o credendi causa) en la prestción al tercero, sino también porque 
sólo podrá hacerlo en interés del tercero, que es el único que tiene derecho a la prestación. Por ello, es inadmisible la reclamación del cumplimiento para sí mismo ${ }^{330}$, un aspecto que podrá invocarse por el promitente como excepción.

\section{En el Derecho francés}

El régimen de los contratos a favor de tercero en el Código civil francés ha sido objeto de una profunda revisión que entró en vigor el pasado 1 de octubre de 2016331, a la que seguidamente nos referiremos. Sin embargo, conviene comenzar con el análisis de la normativa previgente, pues constituye la base sobre la que se ha construido la teoría general de los contratos a favor de tercero en el Derecho francés.

En este sentido, la normativa gala constituía un claro ejemplo del principio romano «alteri stipulatio nemo potest», que según BAUDRY LACANTINÉRIE se plasma en el artículo 1.119 del Code, a cuyo tenor, por regla general, sólo se podía estipular en su propio nombre para sí mismo332. El precepto citado refleja cómo las ideas de POTHIER sobre este principio influyeron en los redactores del Código francés, obligándoles a buscar una excepción que permita extender el círculo de afectados por el contrato, que no es otra que la estipulación a favor de tercero, contenida en el entonces artículo 1.121 del Code. Éste reconocía la validez de tal estipulación al señalar que «se puede estipular en provecho de un tercero cuando ello es condición de una estipulación que se hace para sí mismo, o de una donación que se hace a otro. El que ha hecho la estipulación no puede revocarla si el tercero declara querer aprovecharse de ella»333.

puede suceder que el tercero es incapaz o le resulte imposible hacer valer por sí mismo el derecho de crédito. Véase J.M. MARTín BERNAL, La estipulación..., cit., p. 85.

330 C. PÉrez CONESA, El contrato..., cit., p. 59.

${ }^{331}$ Con anterioridad, el contrato con estipulaciones a favor de tercero y la promesa del hecho de un tercero se hallaban regulados en los arts. 1.119 a 1.121 del Code civil. Hoy día lo están en los art. 1.203 a 1.209 del mismo texto legal.

${ }^{332}$ El texto original del artículo 1119 del Code disponía que «[o]n ne peut, en general, s'engager, ni stipuler en son propre nom, que pour soi-même».

$333 \mathrm{Al}$ respecto vésaes M. CASALS COLLDECARRERA, El contrato..., cit., p. 354; C. LARROUMET y D. MONDOLONI, «Stipulation pour autrui», en P. Raynaud (dir.), Répertoire de droit civil, Paris, 1998, pp. 2-3. En su versión original, el artículo 1121 del Code establecía que «[o]n peut stipuler au profit d'un tiers, lorsque telle est la condition d'une stipulation que l'on fait 
Impulsada por necesidades prácticas diversas, la doctrina francesa, al interpretar los preceptos citados, llegó a admitir varias figuras contractuales que constituyen aplicaciones del esquema que conlleva una estipulación para una persona que no toma parte en la conclusión del contrato334, tales como el transporte de mercancías y de personas o el contrato de seguro de vida, que propiciaron asimismo la consolidación jurisprudencial de su régimen jurídico. A partir de ahí, se extrajo de la estipulación a favor de tercero un patrón capaz de explicar aquellos casos en los que un tercero adquiere un derecho derivado de un contrato en el que no ha tenido parte335.

A la luz de cuanto se establecía en el antiguo artículo 1.121 del Code, parece conveniente dedicar unas líneas al análisis de las dos excepciones contempladas en él al principio antes enunciado. La primera excepción la constituyen aquellos casos en que la estipulación «es condición de una donación que se hace a otro». Aquí, la palabra «condición» se utilizaba, según BunFoIR, en un sentido impropio, como sinónimo de «carga»336. De este modo, la estipulación sería válida si se apoyara en una cláusula penal, es decir, una prestación accesoria del negocio principal, en virtud de la cual el promitente queda obligado frente al estipulante. Se reconocía, pues, la validez de la estipulación a favor de tercero si ese tercero se encontraba asimismo en la obligación de realizar una prestación accesoria, sea para el promitente en el contrato a título oneroso, o bien para el donatario en un contrato de donación ${ }^{337}$. De no efectuarse esta «carga», podía revocarse la donación.

La segunda excepción, por su parte, alcanza aquellas situaciones en que «ello es condición de una estipulación que se hace para sí mismo». La estipula-

pour soi-même ou d'une donation que l'on fait à un autre. Celui qui a fait cette stipulation ne peut pas plus la révoquer, si le tiers a déclaré vouloir en profiter».

334 Entre las aplicaciones referidas que implican una estipulación a favor de tercero, se puede clasificarlas a dos tipos, aquellas que están previsto por la ley o por el propio Code, como la donación o el legado con cargas, la carga impuesta a un contratante a título oneroso, inversión efectuada por el marido, estipulación en las compras de obras públicas y de mercancías; otras que fueron acuñadas por vía jurisprudencial, como el seguro de vida y el transporte de mercancías y de personas. Vid. J. M. Martín Bernal, La estipulación..., cit., p. 112.

335 J. LÓPEZ RICHART, Los contratos..., cit., pp. 70-71.

336 M. CASAlS COLLDECARRERA, El contrato..., cit., p. 353.

337 J. LÓPEZ RICHART, Los contratos..., cit., p. 73. 
ción referida en este párrafo no era sino una cláusula que figura en un contrato que uno celebra para sí mismo, para que sea parte en él como deudor o acreedor. Por lo tanto, la estipulación a favor de tercero insertada en un contrato se reputaba válida cuando el estipulante resultara obligado suficientemente frente al promitente. El estipulante, por su parte, gozaba de acción para pedir la realización de la prestación al tercero338.

A resultas de un largo proceso evolutivo en la jurisprudencia339, y debido a la falta de una regulación jurídica concreta sobre esta materia, la estructura del contrato a favor de tercero se basaba en las características indicadas en el artículo 1.121 del Code, anteriormente transcrito. Entre tales características, destacaba el hecho de que el derecho del estipulante a revocar la estipulación permanecía vigente mientras el tercero no declarase su consentimiento para aceptar la prestación estipulada en su interés. Para la validez de la aceptación del tercero no se prescribía ninguna forma especial y, una vez declarada por el beneficiario, la prestación devenía irrevocable. También se dictaminó que dicha aceptación podía provenir de los herederos del tercero beneficiario. En fin, se consideraba también que el estipulante podía revocar unilateralmente la estipulación, sin necesidad de que lo consintiera el promitente, por lo que bastaba con notificar la revocación al promitente por cualquier medio de comunicación340.

La nueva regulación de los contratos a favor de tercero en los artículos 1.203 a 1.208 del Code refleja fielmente los resultados de la evolución descrita. Así, el primero de los preceptos que se ocupan de esta cuestión se limita ahora a señalar que «[o]n ne peut s'engager en son propre nom que pour soi-même», esto es, que fuera de los supuestos de representación no se puede vincular válidamente a un tercero mediante un negocio en el que no ha participado. Esto ya lo decía también el anterior artículo 1.119 del Code, pero desaparece ahora del tenor de la norma el segundo inciso, que prohibía realizar en propio nombre

${ }^{338}$ M. CASAls ColldeCARRERA, El contrato..., cit., p. 353.

339 Después de muchos esfuerzas interpretativos por parte de los tribunales franceses, sobre todo de la Cour de Cassation, al respecto de las dos excepciones contenidas en el artículo 1121 del Code, se llegó a declarar la inutilidad del viejo dogma del principio de la relatividad contractual romano, sustituyéndolo por otro que abiertamente reconoce la estipulación a favor de tercero.

$340 \mathrm{Al}$ respecto véase J.M. MARTÍn BERNAL, La estipulación..., cit., p. 117; C. BOLDÓ RODA, El beneficiario..., cit., p. 40. 
una estipulación a favor de tercero. Como consecuencia, los contratos a favor de tercero no constituyen ya una excepción a lo que con anterioridad a la reforma era el principio general (alteri stipulatio nemo potest), sino una categoría específica, dotada de un régimen jurídico especial.

Y así se confirma en el artículo 1.205 del Code, cuando reconoce que «[o]n peut stipuler pour autrui», atribuyendo así un derecho directo a la prestación que, si bien es libremente revocable por el estipulante, no podrá serlo ya una vez que el beneficiario haya declarado (expresa o tácitamente) su aceptación y ésta haya llegado al promitente o al estipulante (art. 1.206). Cuando la revocación no vaya acompañada de la designación de un nuevo beneficiario, la estipulación revierte al estipulante, y se considera que el tercero inicialmente designado no ha sido nunca beneficiario de la estipulación hecha en su favor, es decir, la revocación tiene efectos ex tunc.

\section{En el Derecho italiano}

La regulación de la figura del contrato a favor de tercero en el Derecho italiano se inspiró en un principio en el modelo francés y el Código civil italiano de 1865 contenía una regla muy restrictiva, incluso prohibitiva de este tipo de contratos. En efecto, el principio de que no se podía concluir ninguna estipulación en nombre propio si no era para sí mismo («Nessuno può stipulare in suo proprio nome, fuorchè per se medesimo») hacía que no se otorgasen efectos a esta estipulación más allá de la esfera de las partes contratantes. Ello sólo era posible si la estipulación se hallaba amparada por una las excepciones establecidas en la norma, que eran las mismas que las que contemplaba en el Derecho francés el anterior artículo 1.121 del Code civil 341 .

${ }^{341}$ C. PÉREz CONESA, El contrato..., cit., p. 6o. En efecto, las dos excepciones se tomaron literalmente del artículo 1.121 del Code civil. La primera excepción contemplaba dos supuestos, uno de ellos previsto por la ley, para el caso de que la prestación a favor de tercero fuera objeto secundario de ese contrato; el segundo se refería a aquellos casos en que la consecuencia jurídica del contrato realizar una prestación a favor del estipulante, pero el promitente podía quedar liberado efectuando otra operación a favor de tercero. En la segunda excepción se incluían todos aquellos supuestos en que la obligación del promitente provenía ex re stipulantis, como por ejemplo en el seguro de vida, donde el estipulante conviene que a su fallecimiento la suma asegurada se ingrese a un tercero. Al respecto, con detalle, C. BOLDÓ RODA, El beneficiario..., cit., p. 42; J.M. MARTÍN BERNAL, La estipulación..., cit., p. 112. 
Al igual que sucedía en las normas del Derecho francés anterior a la reforma, el artículo $1.1282^{\mathrm{a}}$ del Codice civile de 1865 sólo admitía la estipulación a favor de tercero que fuera la condición de una estipulación hecha para sí mismo, o de una donación que se hacía para otro342. En estos supuestos, el tercero beneficiario adquería su derecho no sólo como un efecto principal de un contrato pactado entre las partes, sino por la sola voluntad de éstas, de modo que su aceptación de querer aprovechar los efectos de esta prestación tenía como único objeto salvar su derecho de cualquier acción revocatoria de una de las partes contratantes 343 .

Impulsado posteriormente por las tendencias de la doctrina germánica que propugnaban un cambio en el viejo principio de prohibición de la estipulación en provecho de otro, el Código civil italiano de 1942 terminó por admitir el contrato a favor de tercero como una institución de aplicación general344, como contratos cuyos efectos se extienen más allá de la esfera de las partes contratantes. Así, el vigente Codice recoge la figura del contrato a favor de tercero como una institución genérica y le dedica una regulación somera en los artículos 1.411 a 1.413 del Capítulo IX, situado en el Libro IV, bajo la rúbrica «Dei contratti a favore di terzi».

La regulación concreta de la figura del contrato a favor de tercero se determina en el artículo 1.411, que establece que «es válida la estipulación a favor de tercero siempre que el estipulante tenga en ello interés». De ello se infiere con claridad que el legislador italiano logró superar con éxito la anacrónica disposición del artículo 1.128 del Codice de 1865, admitiendo la validez general del contrato a favor de tercero, con el interés del estipulante como única condición345.

342 Vide C. BOLDÓ RodA, El beneficiario..., cit., p. 42.

$343 \mathrm{El}$ tema de la revocación se hallaba establecida en el segundo párrafo del art. 1128 del Codice civile de 1865, a cuyo tenor «[c]hi ha fatta questa stipulazione, non può rivocarla, se il terzo ha dichiarato di volerne profittare».

344 El propio Codice regula, además, casos particulares de aplicación de la figura de los contratos a favor de tercero: el transporte de cosas a favor de un tercero (art. 1.689), la renta vitalicia a favor de tercero (art. 1.875), el seguro de vida a favor de tercero (1920), el depósito, específicamente bancario, en interés de un tercero (art. 1.773), y la asunción de deuda por parte de un tercero, a favor del acreedor (art. 1.273).

345 J. LÓPEZ RICHART, Los contratos..., cit., p. 131-132. 
Con todo, la doctrina italiana posterior al Código mussoliniano ha concluido que el interés del estipulante como requisito de validez del contrato es una limitación más aparente que real, en la medida en que no es sino una aplicación particular del principio general según la cual toda prestación debe siempre responder a un interés del estipulante. Siguiendo esta doctrina, el interés del estipulante en el artículo 1.411 y el interés del acreedor del artículo 1.174 del $\mathrm{Co}^{-}$ dice346 serían así una misma cosa, pues en virtud de ese último artículo el requisito del interés en la prestación es común a todas las obligaciones, sin perjuicio de que el interés pueda ser no patrimonial (p.ej., moral o de afección) ${ }^{347}$. Resulta obvio, en todo caso, que la estipulación a favor de tercero en el Código italiano sería nula si el estipulante carece de interés en la atribución del derecho al tercero, lo que no supone vaciar el contenido del contrato de las restantes relaciones que unen al estipulante con el promitente. Además, en casos excepcionales, por ejemplo, en el caso de la revocación de la estipulación o bien del rechazo del tercero de querer aprovecharse de ella, el interés en la prestación al tercero puede descansar en la disposición del promitente.

El inciso segundo del mismo artículo dispone que, «[s]alvo pacto en contrario, el tercero adquiere el derecho contra el promitente por efecto de la estipulación». La característica más destacada de este inciso radica en la autonomía del derecho del tercero, del que deriva el poder de éste para hacer valer su derecho inmediatamente frente al promitente, sin que sea obligada a tal fin la solicitud de intervención del estipulante para reclamar el cumplimiento de la prestación 348 .

${ }^{346} \mathrm{El}$ artículo 1.174 establece que «la prestación que forma parte del objeto de la obligación debe ser susceptible de valoración económica y corresponder a un interés, aunque no fuera patrimonial, del acreedor».

347 Vid. C. PÉREZ CONESA, El contrato..., cit., p. 61.

348 J.M. MARTÍN BERNAL, La estipulación..., cit., p. 106-107. En el mismo sentido, señala MESSINO que «[e]s una figura mediante la cual se realiza la necesidad práctica de extender la eficacia activa del contrato (expansión de los efectos subjetivos del contrato) fuera del círculo restringido de las partes contratantes. Tal extensión tiene lugar por el hecho de determinar la adquisición directa y autónoma de un derecho por un tercero, a la que corresponde un sacrificio patrimonial a cargo del promitente». También BARASSI entiende que esta figura consiste en atribuir un derecho inmediatamente a favor del tercero, aunque advierte de que el derecho atribuido al tercero es un derecho provisional, pues es revocable (ambos citados por J.I. RODRÍGUEZ GONZÁLEZ, El principio..., cit., p. 256). 
También se refiere el Codice a la revocación de la estipulación, pues ésta «puede ser revocada o modificada por el estipulante hasta que el tercero no haya declarado al promitente su voluntad de querer aprovecharla» (art. 1.411

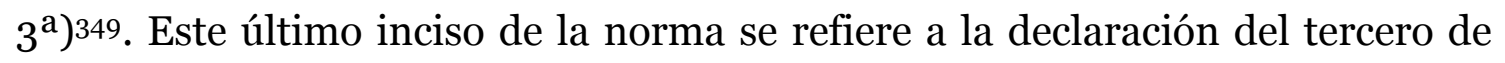
querer aprovecharse de la prestación estipulada en su favor, que puede también ser tácita, aunque tal declaración no es necesaria para atribuir el derecho, dado que éste se atribuye directamente por efecto mismo de la estipulación, esto es, en virtud del contrato y no por la aceptación de tercero. En definitiva, es una condicio iuris cuyo cumplimiento extingue el poder de las partes contratantes para revocar o modificar la estipulación350.

Por último, la autonomía del derecho que se atribuye al tercero y su origen obligacional se explica si se tiene en cuenta lo dispuesto en el artículo 1.413 del Codice, último de los que se ocupan del contrato a favor de tercero, referido a las excepciones oponibles al tercero. A tenor de este precepto, el promitente podrá oponer al tercero las excepciones que deriven del propio contrato del que recibe su derecho el tercero, pero no aquellas que surjan de otras relaciones entre promitente y estipulante ${ }^{351}$. Y ello porque tales relaciones son ajenas al contrato del cual el tercero obtiene inmediatamente su derecho352.

$349 \mathrm{El}$ artículo 1.412 del Codice se refiere, en su primer apartado, a un supuesto particular de contrato a favor de tercero, el contrato de seguro sobre la vida en beneficio de tercero, en el que la prestación a favor de tercero ha de cumplirse después del fallecimiento del estipulante. Según lo dispuesto en este precepto, la estipulación en tal caso podrá revocarla el estipulante, aun cuando el tercero haya manifestado previamente su aceptación, salvo que aquél hubiera renunciado por escrito a su derecho de revocar el beneficio. Al respecto véase F. BONET RAMÓN, «Los contratos..., cit., p. 15. A tenor del segundo párrafo de la misma norma, el beneficio de la prestación, si consiste en un derecho patrimonial, se extiende a los herederos del tercero en el caso de que éste muera antes que el estipulante, con tal que este beneficio no haya sido revocado por el estipulante o éste hubiera dispuesto de otra manera. Vide J.M. MARTÍn BERNAL, La estipulación..., cit., p. 110.

$35^{\circ}$ C. BOLdó RodA, El beneficiario..., cit., pp. 44-45.

${ }^{351} \mathrm{El}$ ejemplo que cita J.M. MARTín BERNAL, La estipulación..., cit., p. 111, es el de la compensación con un crédito nacido de otra causa distinta.

$35^{2}$ Así, J.I. Cano Martínez De Velasco, El contrato..., cit., p. 33; C. Pérez Conesa, El contrato..., cit., p. 65 . 


\section{CAPÍTULO III}

\section{EL CONTRATO DE TRANSPORTE DE MERCANCÍAS POR CARRETERA}





\section{Introducción}

La actividad de transporte en general y, en particular, el transporte de mercancías, constituye un eslabón de singular importancia en el desarrollo económico de todos los países. En efecto, el transporte es indispensable en cualquier ámbito económico, tales como la industria, la agricultura o el comercio353. Resulta imprescindible, por ello, para la actividad de las organizaciones empresariales y de los particulares por igual.

Lo que hace viable la explotación de esta actividad económica es el negocio jurídico que se enmarca en el tipo denominado «contrato de transporte». Es el núcleo negocial que muestra la gran trascendencia que ha logrado tanto en el ámbito económico (por la exigencia de enormes inversiones como autopistas, instalaciones portuarias y aeroportuarias, grandes buques y aeronaves, etc.), como en el jurídico que, inter alia, tiene como objeto racionalizar un régimen jurídico unificador y armonizado para todos los tipos de transporte, tanto más importante cuanto el transporte muchas veces implica el recurso a distintos medios. Tampoco hace falta advertir el papel relevante del Derecho del transporte a la hora de determinar las responsabilidades que pueden surgir durante el desplazamiento de la carga, que justifica la intervención legislativa para reformular un Derecho unificado a nivel nacional e internacional.

La trascendencia económica del transporte - que interviene en todas las fases del ciclo económico, desde la fabricación, pasando por la comercialización (abastecimiento y distribución) hasta el consumo- justifica la intervención estatal y administrativa354, con el fin de organizar el ejercicio de la actividad, vigi-

353 Así lo estableció en su día BROSETA, cuando señaló que a través del transporte se «aproximan las materias primas a los centros de producción y de éstos los productos manufacturados a los centros de distribución y a los consumidores». Vid. J. GómEZ CALERO, El transporte internacional de mercancías, Civitas, Madrid, 1984, p. 15.

354 Esta intervención sobre la explotación empresarial se manifiesta en muchos ámbitos del transporte. Baste mencionar el transporte ferroviario, donde RENFE-Operadora sigue operando en algunas parcelas en régimen de monopolio legal a pesar de la liberalización progresiva; la privatización de Iberia o la liberalización del cabotaje intracomunitario en el transporte por carretera a instancias de la Unión Europea (que permite a los transportistas rentabilizar los transportes internacionales, aprovechando el trayecto de vuelta para realizar transportes puramente internos en Estados distintos del de su domicilio), o la eliminación de las tarifas obligatorias en el transporte de mercancías. Al respecto puede 
lar el acceso a la misma y asegurar la correcta realización del servicio355. Con todo, el contrato de transporte en sí es de naturaleza jurídico-privada.

El presente capítulo se ocupará del contrato de transporte en general, poniendo de relieve su importancia como negocio del que deriva el derecho del destinatario, pues el contrato de transporte constituye un ejemplo legalmente típico del contrato a favor de tercero.

\section{Naturaleza jurídica y caracteres del contrato}

\section{Naturaleza y caracteres}

Es unánimemente reconocido que el contrato de transporte es una subespecie del contrato de arrendamiento de obra - es decir, genera una obligación de hacer de resultado- y no del arrendamiento de servicios - donde el deudor cumpliría con realizar la actividad pactada con la diligencia debida, pero sin estar obligado a alcanzar ningún resultado concreto-. La obligación es de resultado porque el porteador cumple la prestación cuando ofrece a la contraparte el resultado comprometido, que no es otro que el traslado de cosas o personas de un lugar a otro. Con ello, la obligación que asume el porteador se anuda al traslado de las mercancías en cuanto acto de ejecución del contrato, pero también a la entrega al destinatario como resultado final, a cambio de un precio. Es por ello por lo que la operación en su conjunto se considera una locatio operis ${ }^{356}$ : la prestación que se exige del porteador no es la mera actividad, desarrollada con la diligencia de un ordenado porteador (no es, por tanto, de medios), sino la consecución de un resultado357.

verse M. Broseta Pont / F. MarTínez SAnZ, Manual de derecho mercantil, Vol. II, $20^{\text {a }}$ ed., Tecnos, Madrid, 2013, p. 156.

355 R. Padilla GonZález, M. Clavero Ternero y M.Á. Pendón Meléndez, «Transportes», en G.J. Jiménez Sánchez (coord.), Lecciones de derecho mercantil, Tecnos, Madrid, 2010, p. 516.

356 A. DíAz MoRENo, «El contrato de transporte terrestre», en G.J. Jiménez Sánchez (coord.), Derecho Mercantil II, Marcial Pons, Madrid, 2010, p. 640.

357 La doctrina es unánime al respecto. Vid., en lugar de muchos, J. PuTZEYs, Droit des trasnports et droit maritime, Bruylant, Bruxelles, 1993, p. 129; F. MARTínez SANZ, «Transporte de mercancías por carretera (I). Transporte internacional», en id. (dir.) y A. 
A pesar de que el contrato de transporte pertenece a la categoría legal de los arrendamientos de obra, no es permisible identificar los dos contratos, porque hay una serie de caracteres que diferencian el uno del otro. Entre ellos destaca la presencia de un tercero - el destinatario- que, una vez solicitada la entrega de las mercancías, puede ejercitar en nombre propio las acciones que dimanan del contrato de transporte. Además, en el contrato de transporte se presentan otras características significativas, como es la recepción de las mercancías por parte del porteador, que deriva en una obligación de custodia y la correspondiente responsabilidad ex recepto del porteador 358 .

Junto a estos aspectos, son muchas las características diferenciales del contrato de transporte. De entre ellas cabe mencionar la mercantilidad de esa figura contractual, así como otros caracteres a los que se hará una breve referencia en los epígrafes que siguen.

\subsection{Mercantilidad del contrato}

La mercantilidad del contrato de transporte no halla ya apoyo legal en ninguna norma del ordenamiento jurídico español, desde que la norma que a ella se refería en el Código de comercio fuera derogado, junto con los demás preceptos en materia de transporte, por la Ley 15/2009. Concretamente, en el Derecho previgente, el artículo 349 Ccom señalaba que «[e]l contrato de transporte por vías terrestres o fluviales de todo género, se reputará mercantil: 1. Cuando tenga por objeto mercaderías o cualesquiera efectos del comercio. 2. Cuando, siendo cualquiera su objeto, sea comerciante el porteador, o se dedique habitualmente a verificar transportes para el público». Con todo, no parece que, con la desaparición del precepto, haya desaparecido también la coexistencia y dualidad de transporte civil-mercantil359. Por ese motivo, se hace preciso determinar cuándo el contrato es mercantil para abordar el problema de su concepción y sus lími-

Puetz (coord.), Manual de derecho del transporte, Marcial Pons, Madrid, 2010, p. 158; A. DíAZ MORENO, «El contrato...», cit., p. 640.

$35^{8}$ J. GómEZ CALERO, El transporte..., cit., pp. 26 -27.

359 El contrato civil de transporte se regula en el Código Civil en los art. 1.601 a 1.603, al tratar la responsabilidad del transportista. 
tes, de manera similar a como sucede en otros negocios jurídicos que cuentan con una doble regulación 360 .

Según el criterio adoptado por los legisladores del Código de comercio de 1885, se consideraban «actos de comercio» aquellos que estuvieran comprendidos en el propio Código y los que fueran de naturaleza análoga. Y ello sucedía con el contrato de transporte. Al estar contemplado en los artículos 349 y ss. ${ }^{361}$, resultaba indudable que el contrato de transporte regulado por el Código de comercio era mercantil. Y para ello el transporte debía tener por objeto mercaderías o cualesquiera efectos de comercio ${ }^{362}$ o, cualquiera que fuera su objeto, realizarse en el marco de una actividad empresarial organizada (esto es, de forma profesional), incluso si fuera ejecutado por un empresario que no se dedica habitualmente a realizar transportes para el público, pero se encuentra obligado a hacerlo por una sola vez 363.

Sensu contrario, eran considerados civiles aquellos transportes que no estaban incluidos en los supuestos indicados, quedando regulados por el Código civil en sus artículos 1.601 a 1.603. Concretamente, ello sucedía cuando no se cumplían las condiciones establecidas en el artículo 349 Ccom, o sea, cuando se trataba de un transporte aislado, esporádico o «de cortesía»364, ejecutado por un sujeto que no tenía la consideración de empresario, generalmente como consecuencia de relaciones de amistad o de mera cortesía 365, y cuyo objeto eran efec-

360 Sobre este tema puede verse, p.ej., J.L. García-PITA y LASTRES, Derecho mercantil de obligaciones, Parte General, Marcial Pons, Madrid, 2003, p. 331.

${ }^{661}$ J.L. García-Pita y LASTRES, Derecho mercantil de obligaciones..., cit., p. 349.

${ }^{362}$ Lo cual sucede también en otros países de nuestro entorno: véase J. PUTZEYs, Droit des transports..., cit., p. 129.

363 M. Broseta Pont y F. Martínez SAnZ, Manual de Derecho mercantil, Vol. II, $15^{\mathrm{a}}$ ed., Tecnos, Madrid, 2008, p. 154.

$364 \mathrm{El}$ transporte de cortesía (también llamado, en ocasiones, «benévolo») tiene como objeto ofrecer un servicio de transporte gratuito o de mera cortesía. Cabe dudar, incluso, de su naturaleza contractual, pues no existe voluntad alguna de asumir una relación obligacional, es decir, no existe, ni relación de cobertura de ninguna índole -como sí sucede en el contrato de transporte mercantil, donde concurren dos voluntades (la del porteador y la del cargador) para pactar la consecución de un resultado a cambio de una remuneración pecuniaria-, ni tampoco contraprestación de ningún tipo.

365 Sobre el transporte de mera cortesía, vid. E. MAPELLI LÓPEZ, Régimen jurídico del transporte, Ministerio de Justicia, Madrid, 1987, pp. 46 y ss. 
tos personales u otros bienes que no encajaban en la descripción del artículo 349 Ccom (mercaderías y efectos de comercio) ${ }^{366}$.

De lo anterior se deduce que la mercantilidad del contrato de transporte se establecía básicamente en atención a la realización habitual de la actividad, basada desde el principio en el concepto de contrato de empresa. $\mathrm{Y}$ esta parece seguir siendo la orientación después de la entrada en vigor de la Ley del Contrato de Transporte Terrestre de Mercancías, esto es, que el contrato es mercantil cuando sea ejecutado por quien habitualmente realice transportes para el público: una empresa de transporte367. Todo ello sin perjuicio de que, en el marco del presente estudio, no tiene mucha importancia la caracterización del contrato como civil o mercantil. Y ello por cuanto los supuestos en que adquiere relevancia la figura de un tercero beneficiario, el destinatario, se inscriben prácticamente siempre en la realización profesional de transportes a cambio de una contraprestación y son, por ello, indudablemente mercantiles.

\subsection{Carácter consensual}

El consentimiento es el primer requisito que ha de concurrir para perfeccionar el contrato (art. 1.261 Cc). La importancia del consentimiento, señala MANRESA, se basa en la conformidad de los sujetos que van a contratar sobre lo que ha de ser el contrato. El hecho de aceptar uno de ellos la oferta que el otro le hace es el «concurso» de voluntades a que se refiere el artículo 1.262 del Código Civil, que ha de abarcar tanto el objeto como la causa del contrato 368 .

Es imprescindible la voluntad de los contratantes cuando hablamos del contrato de transporte, así que su validez está supeditada al acuerdo de las partes -es decir, al consenso mutuo-, perfeccionándose el negocio por el simple consentimiento manifestado por ambas partes contratantes 369 . En otras pala-

${ }^{366}$ F. J. SÁnChEZ-GAMborino y J. GAITÁn RebOllo, Factbook. Transportes de mercancías por carretera, Aranzadi, Cizur Menor, 2010, p. 72.

367 M. Broseta Pont y F. Martínez SAnZ, Manual..., Vol. II, $23^{\mathrm{a}}$ ed., Tecnos, Madrid, 2016, p. 159.

368 E. MAPELLI LÓPEZ, Régimen jurídico del transporte, cit., p. 73.

369 Es lugar común afirmar el carácter consensual del contrato de transporte al amparo de la legislación y la jurisprudencia, tanto para el transporte nacional [STS núm. 465/1993, de 17 de mayo (RJ 1993, 3555)] como para el transporte internacional [art. 4 CMR y STS de 14 
bras, no se exige forma alguna para demostrar la existencia y el contenido del contrato370. Ello significa que, en caso de que se haya expedido una carta de porte, que la formalización documental de ese contrato se hace ad probationem y no ad solemnitatem, es decir, que sirve sólo como un instrumento para probar la existencia del acuerdo y no para confirmar su validez jurídica ${ }^{371}$, siendo un contrato consensual y no formal ${ }^{372}$. Es, por ello, innecesario extender documento alguno en el contrato de transporte, cuyo cumplimiento se produce con la entrega de las mercancías al destinatario, lo cual no sucede en algunos contratos que necesitan otorgarse en escritura pública como son, p.ej., los contratos de sociedad, la compraventa de inmuebles, etc. 373 .

\subsection{Otras características}

Además de las características anteriores, cabe mencionar otras. En primer lugar, el contrato de transporte es un contrato sinalagmático en el sentido de que las partes se obligan recíprocamente la una (a dar) frente a la otra (a hacer), dando así lugar a una relación bilateral con obligaciones a cargo de ambas partes: el transportista se obliga a cumplir la prestación comprometida de transportar las mercancías y ponerlas a la disposición del destinatario, a cambio de una remuneración a satisfacer por la contraparte en el contrato. De ahí que el contrato sea, normalmente, oneroso, pues se realiza para obtener el precio correspondiente. Ello no obsta, claro está, para que existan transportes gratuitos, pero

de julio de 1987 (RJ 1987, 5489)]. Vid. R. Padilla González, M. Clavero Ternero y M.Á. PENDÓN MELÉNDEZ, «Transportes...», cit., p. 532.

370 R. ILLESCAS ORTIZ (dir.), El transporte terrestre nacional e internacional, Consejo General del Poder Judicial, Madrid, 1997, p. 196.

${ }^{371}$ J. Gómez CALERo, El transporte..., cit., pp. 28-29.

372 Como se decía, el carácter consensual del contrato de transporte ha sido reconocido desde antiguo por el Tribunal Supremo, p.ej., además de las decisiones antes citadas, en sus sentencias de 12 de diciembre de 1968 y 8 de marzo de 1982. Vid. J. M. Ribelles ARELLANO, «El transporte nacional de mercancías por carretera», en J.L. Concepción Rodríguez (dir.), El contrato de transporte, Manual de Formación Continuada 21, Vol. I, Consejo General del Poder Judicial, Madrid, 2003, p. 307.

373 F.J. SÁNCHEZ-GAMBORINO y J. GAITÁN REBOllo, Factbook..., cit., pp. 91-92. 
resulta discutible que queden sometidos a la legislación mercantil (cfr. art. 2.1 LCTTM) 374.

En segundo lugar, también se entiende que el contrato de transporte es conmutativo, en el sentido de que implica la equivalencia de las prestaciones mutuas entre las partes contratantes, de manera que cada una de esas partes asume su obligación a dar o a hacer como equivalente a lo que le va a dar o hacer la contraparte 375 .

\section{Definición del contrato de transporte}

Con carácter general, todas las clases de transporte comparten el mismo concepto y naturaleza jurídica, con independencia de que sean nacionales o internacionales ${ }^{376}$, pues comparten una misma finalidad: trasladar. En el Derecho positivo español falta aún una definición del contrato de transporte de mercancías que sea válida para todos los modos de transporte. Por eso, son muchos los esfuerzos dedicados en la doctrina a la búsqueda de esa definición.

Entre tales nociones puede mencionarse, por ejemplo, la de SÁNCHEZGAMBORINO que lo define como «un acuerdo jurídico entre dos partes, mediante el cual una de ellas - llamada 'transportista'- se compromete, mediante precio, a trasladar una cosa material o mercancía de un lugar a otro, bajo su propia custodia, siguiendo las instrucciones de la otra parte -llamada 'remitente'-, y a entregar esa misma mercancía a un tercero - llamado 'destinatario'- designado por el remitente, en las mismas condiciones que el transportista la recibió, den-

374 Y ello es así no sólo en España. Por ejemplo, para L. PEÑA NossA, De los contratos mercantiles nacionales e internacionales -Negocios del empresario-, $2^{\mathrm{a}}$ ed., ECOE Ediciones, Bogotá, 2006, p. 259, las prestaciones mutuas inter partes aportan un elemento patrimonial susceptible de valoración económica, excluyendo en este sentido todos aquellos transportes que se realizan gratuitamente o con afán de cortesía. Este es el caso de los transportes que vienen denominándose «transportes benévolos», que estarán sometidos a la aplicación del Derecho civil y no mercantil, salvo si se contrata con carácter accesorio a un acto de comercio.

375 J. PUTZEYs, Le contrat de transport routier de marchandise, Bruylant, Bruxelles, 1981, pp. 20-21; A. DÍAZ MORENO, «El contrato...», cit., p. 639; J. GÓMEZ CALERO, El transporte..., cit., p. 28.

${ }^{376}$ La internacionalidad, como señala J. GómEz CALERo (El transporte..., cit., p. 25), «solamente significa que el itinerario discurre por territorio de dos o más naciones (implicando un cruce de frontera) y en consecuencia no afecta al contrato sino a la actividad». 
tro de un determinado plazo de tiempo, si así se hubiere acordado; y ambas partes, a cumplir las restantes obligaciones que el Derecho tuviere establecidas»377.

La ausencia de una definición normativa que sea igualmente válida para todos los supuestos de transporte no impide que el legislador sí haya consagrado una noción legal de transporte en algunas leyes especiales. Este es el caso, señaladamente, de la Ley 15/2009, que contiene una definición en su artículo 2.1, que configura el contrato de transporte terrestre de mercancías como un negocio consensual de naturaleza mercantil, por virtud del cual un empresario (porteador) se compromete, a cambio de un precio, a llevar a cabo el traslado de las mercancías que tiene a bajo su propia custodia de un lugar a otro, poniéndolas a disposición de la persona designada en el contrato para recibirla (el destinatario) 378 .

\section{Marco legal del contrato de transporte}

Es notoria la existencia de diversos medios de transportes, cada uno con sus propias particularidades, razón por la cual conviene ofrecer una visión, siquiera somera, de la diversidad legislativa a nivel nacional e internacional. En el ordenamiento interno, la regulación del contrato de transporte estaba contenida, hasta hace pocas fechas, básicamente en algunos preceptos del Código de Comercio de 1885, concretamente, en el Título VII del Libro II, en los artículos 349 a 379. Estas normas han quedado derogadas por la Ley 15/2009, de 11 de noviembre, del contrato de transporte terrestre de mercancías, que desde su entrada en vigor disciplina los aspectos jurídico-privados de este tipo de transportes en España. La actual Ley actualiza el régimen jurídico del transporte terrestre de mercancías, por carretera y por ferrocarril; con todo, quedó al margen del texto legal, finalmente, la regulación del transporte público de pasajeros379.

Volviendo a los antecedentes del marco jurídico actual, resulta que una de las piedras fundamentales de la regulación española del transporte por carre-

377 F.J. SÁnChez-GAmborino, El contrato de transporte internacional. CMR, Tecnos, Madrid, 1996, p. 26.

378 Véase F. MARTínEz SANZ, «Transporte de mercancías...», cit., p. 157.

379 F. MARTínEZ SANZ, «Transporte de mercancías...», cit., p. 168. 
tera ha sido (y, para los aspectos administrativos, sigue siendo) la Ley 16/1987, de 30 de julio, de Ordenamiento de los Transportes Terrestres (en adelante, LOTT), que, entre otros cometidos, vino a regular en normas administrativas de carácter imperativo algunos aspectos que, con anterioridad a la aprobación de la norma, se encontraban reguladas con carácter dispositivo en el Código de Comercio ${ }^{380}$. Su contenido normativo se completó con el Reglamento de la Ley, aprobado por Real Decreto 1211/1990, de 28 de septiembre. Tampoco debe olvidarse que, diez años después, se aprobó un contrato-tipo o, mejor, unas condiciones generales de contratación de los transportes de mercancías por carrete$\mathrm{ra}^{381}$, que incorporaban al ordenamiento nacional muchas reglas derivadas del Convenio CMR para el transporte internacional de mercancías por carretera382. Con todo, tras la entrada en vigor de la Ley 15/2009, la relevancia tanto de la LOTT y del ROTT como de las condiciones generales, de las que se ha elaborado una nueva versión en $2012^{383}$, ha quedado relegada a un segundo plano.

En el ámbito internacional, resulta aplicable al transporte de mercancías por carretera el Convenio relativo al Contrato de Transporte Internacional de Mercancías por Carretera, hecho en Ginebra el 19 de mayo de 1956 (en adelante CMR, según sus siglas en francés), que es considerado uno de los mejores ejemplos de Derecho uniforme y que se aplica directamente sin que haga falta la in-

380 Sobre esta cuestión puede verse A. EMPARANZA SOBEJANO, «El alcance normativo de la proyectada regulación del contrato de transporte terrestre», en F. Martínez Sanz y M ${ }^{\mathrm{a}}$.V. Petit Lavall (dirs.), Aspectos jurídicos y económicos del transporte: Hacia un transporte más seguro, sostenible y eficiente, Vol. I, Servicio de Publicaciones de la Universitat Jaume I, Castellón, 2007, p. 203.

381 Orden del Ministerio de Fomento de 25 de abril de 1997. En el mismo sentido, SÁNCHEZGAMBORINO muestra la trascendencia de esas condiciones generales de 1997 para matizar la regulación del contrato de transporte, indicando que «tanto en la LOTT como en el ROTT estaba -y sigue estando- previsto que el Ministerio de Transportes - hoy, 'de Fomento'puede aprobar unos denominados contratos-tipo o condiciones generales. Es decir, modelos de cláusulas uniformes de aplicación subsidiaria a lo que libremente acuerden los contratantes, para la regulación más detallada de cada contrato específico, según la clase de mercancías, o el régimen de carga completa o fraccionada - paquetería o grupaje-». Vid. F.J. SÁNCHEZ-GAMBORINO y J. GAITÁN REBOLLO, Factbook..., cit., p. 58.

382 F.J. SÁnChez-Gamborino y J. Gaitán Rebollo, Factbook..., cit., p. 56; F.J. SÁnChEZGAMBORINO, El contrato..., cit., p. 19.

383 Aprobadas por Orden FOM/1882/2012, de 1 de agosto, por la que se aprueban las condiciones generales de contratación de los transportes de mercancías por carretera. 
tervención del legislador nacional384. El Convenio establece una serie de requisitos que definen su ámbito de aplicación. Cuando concurran aquéllos, el CMR se aplica imperativamente ${ }^{385}$, una de las características más importantes del CMR. De esta forma, queda prohibida cualquiera estipulación en el contrato que modifique sus preceptos por medio de acuerdos particulares entre las partes contratantes, salvo que así lo autorice el propio Convenio (art. $41 \mathrm{CMR}$ ).

\section{Relación del contrato de transporte con otros contratos}

\subsection{Compraventa internacional de mercancías}

El nexo que liga el contrato de transporte con el de compraventa ha de buscarse en el papel desempeñado por aquél, en el sentido de que cumple una función auxiliar para acercar las mercancías adquiridas al comprador. Suele hablarse en estos casos de un tipo de venta especial, la venta de plaza a plaza o a distancia, considerándose el contrato de transporte como un instrumento esencial al servicio de la buena ejecución del contrato de compraventa, es decir, que ambos negocios están ligados cuando la entrega de la mercancía requiere su traslado al lugar donde tiene su domicilio el comprador386.

También se manifiesta ese vínculo entre ambos contratos, por ejemplo, en el contrato de transporte marítimo, donde el conocimiento de embarque 387 atribuye el «derecho a controlar» las mercaderías a la persona designada como consignatario o destinatario. Esa atribución del derecho a controlar las mercancías representadas por el documento suele ser descrito como un eslabón necesario que establece un vínculo entre el contrato de transporte, cuyas partes son el

\footnotetext{
384 F. MARTínez SANZ, «Transporte de mercancías por carretera (II). Transporte internacional», en id. (dir.) y A. Puetz (coord.), Manual de derecho del transporte, Marcial Pons, Madrid, 2010, p. 187.

385 F.J. SÁNCHEZ-GAMBORINO, El contrato..., cit., p. 44.

386 E. SECO CARO, «Compraventas especiales y contratos afines en derecho mercantil», en G.J. Jiménez Sánchez (coord.), Derecho Mercantil II, Marcial Pons, Madrid, 2010, p. 341.

387 Como es sabido, el conocimiento de embarque es de uso (casi) exclusivo en el transporte marítimo y tiene unas características especiales que no se presentan en los documentos de transporte en otros modos, estos es, la carta de porte, tanto en el transporte terrestre como en el aéreo (air waybill).
} 
cargador y el porteador, y el de compraventa, establecido entre el cargador (vendedor) y el consignatario o el destinatario (comprador) 388 .

En este mismo sentido, el derecho de disposición en el transporte terrestre faculta a su titular (que suele ser el vendedor-cargador ${ }^{389}$ ) para interrumpir el desplazamiento de las mercancías si el comprador-destinatario, por ejemplo, comunica su intención de incumplir su obligación de pagar; o para venderlas mientras el transporte se está efectuando a otro comprador que sí está en condiciones de cumplir su compromiso de pago frente a él. El uso del derecho de disposición se erige, así, en un instrumento de garantía para el vendedor en las transacciones mercantiles sobre mercancías ${ }^{390}$. Para ejercitarlo, el vendedorcargador dará órdenes al porteador, quien debe ejecutarlas sin poder oponerse más que cuando se lo permite la normativa rectora del contrato que lo liga con el vendedor-cargador (cfr. art. 30.1 CMR).

Antes de volver sobre el tema de la interacción entre el contrato de transporte y el de compraventa internacional, es conveniente resaltar qué es el contrato de compraventa y su marco jurídico y cuáles son los aspectos que lo relacionan con el contrato de transporte.

\section{a) Concepto de la compraventa internacional de mercancías}

El régimen jurídico de la compraventa internacional de mercancías está contenido en la Convención de las Naciones Unidas sobre los Contratos de Compraventa Internacional de Mercaderías, hecha en Viena el 11 de abril de 1980 (en adelante, CISG, según sus siglas en inglés). En rigor, la CISG no llegó a concretar la noción de «compraventa», como sí había sido el caso en las Leyes unifor-

388 A. MADRID PARRA, «Regulación uniforme de UNCITRAL del uso de medios electrónicos en relación con los contratos de transporte de mercancías», en id. (coord.), Derecho uniforme del transporte internacional: Cuestiones de actualidad, McGraw-Hill, Madrid, 1998, p. 87.

389 Como es conocido, el contrato de compraventa no es sino un negocio jurídico constitutivo de obligaciones recíprocas que se ejecutan mediante actos de disposición sobre la cosa y el precio, respectivamente. Así, A. VON THUR, Tratado de las obligaciones, traducido por W. Roces, Comares, Granada, 2007, p. 116.

390 A. RECALDE CASTELLS, «El derecho a disponer de la mercancía», en A. Emparanza Sobejano y A. Recalde Castells, El contrato de transporte internacional de mercancías por ferrocarril, Thomson-Civitas, Cizur Menor, 2008, p. 140. 
mes de La Haya de 1964391. El hecho de que se guardase silencio sobre la noción de «contrato de compraventa internacional» en la Convención se debe a distintas causas. Así, se ha señalado que las dificultades halladas para alcanzar un compromiso general sobre la adecuada posición dogmática sobre este contrato desmotivaron a los legisladores internacionales para plasmar un concepto jurídico de compraventa internacional. También se ha sostenido que el argumento que explica la ausencia de una definición de la compraventa es el hecho de que el contrato de compraventa es similar en la mayoría de los sistemas jurídicos, por lo que sería innecesario afrontar la definición de una institución que funciona prácticamente en todo el mundo de la misma manera y forma ${ }^{392}$.

La razón de no proponer una definición concreta del contrato de compraventa internacional había de buscarse, por tanto, en evitar el conflicto con las legislaciones internas. $\mathrm{Y}$ es que la compraventa se encuentra definida en todos los Códigos civiles, y además de manera parecida, como aquel contrato por virtud del cual una de las partes se obliga a dar o a transmitir la propiedad de una cosa a la otra parte que, a su vez, se compromete a pagar el precio estipulado en dinero393. Ante la ausencia de particularidades respecto del concepto de «com-

${ }^{391}$ Vid. el «Análisis de las respuestas y estudios recibidos de los gobiernos» en el Informe del Secretario General: Venta internacional de bienes. Convenciones de la Haya de 1964, Comisión de las Naciones Unidas para el derecho mercantil internacional, segundo período de sesiones Ginebra, 3 de marzo de 1969, Tema 4 a) del programa provisional (disponible en www.uncitral.org), pp. 21-22.

392 F. OlIVA BLÁZQUEZ, Compraventa internacional de mercaderías (Ámbito de aplicación del Convenio de Viena de 1980), Tirant Lo Blanch, Valencia, 2002, pp. 163-164. La razón de que el legislador optara por guardar silencio y no formular un concepto jurídico de la compraventa es que su coincidencia a nivel mundial con muchas figuras le indujo a abandonar la tarea de determinar una concepción jurídica de compraventa internacional. Así lo entiende también RIGAUX (citado por F. OlIVA BLÁZQUEZ, ibidem) cuando señala que "[i]l a paru aux rédacteurs des deux lois uniformes, comme l'avaient dejá estimé les auteurs de la Convention du 15 juin 1955 sur la loi aplicable, que le concept 'vente' était suffisamment clair pour qu'il ne dût pas être défini dans l'acte international lui-même».

393 Por ejemplo, en el artículo 1.582 del Código Civil francés el contrato de compraventa viene definido como aquel por virtud del cual una parte se obliga a entregar una cosa mientras la contraparte se compromente a pagarla ( $«$ La vente est une convention par laquelle l'un s'oblige à livrer une chose, et l'autre à la payer. Elle peut être faite par acte authentique ou sous seing privé»). El Código Civil italiano, por su parte, establece en su artículo 1.470 que el contrato de compraventa es aquel que tiene como objeto la transmisión de la propiedad de una cosa o un derecho a cambio de un precio ( LL vendita è il contratto che ha per oggetto il trasferimento della proprietà di una cosa o il trasferimento di un altro diritto verso il corrispettivo di un prezzo». En España, la definición legal del contrato de compraventa se encuentra en el artículo $1.445 \mathrm{Cc}$, a cuyo tenor, "por el contrato de compra y venta uno de los contratantes se obliga a entregar una cosa 
praventa», el carácter internacional de ese tipo de contrato se refiere al hecho de que las partes contratantes, el comprador y el vendedor, tienen sus establecimientos en Estados diferentes; sólo en este caso el contrato queda sometido a las normas de la Convención. Sobre la base de estas consideraciones, la doctrina ha elaborado una definición de la compraventa internacional según los artículos 30 y 53 de la Convención, afirmando que es el acuerdo convencional concertado entre dos partes, denominadas comprador y vendedor y con establecimientos en estados diferentes, a través del cual el vendedor transfiere la propiedad de mercancías que se transportarán a otro país, a cambio de comprometerse el comprador a pagar el precio por dichas mercancías y a recibirlas 394.

\section{b) Régimen jurídico de la compraventa internacional}

Como se decía, el contrato de compraventa internacional se rige por la Convención de Viena de 1980. En resumen, la Convención se adoptó después de muchos esfuerzos legislativos para armonizar y facilitar las transacciones entre los países, considerando que la adopción de normas uniformes aplicables al contrato de compraventa internacional de mercaderías contribuiría a disminuir las dificultades jurídicas y promovería el desarrollo del comercio internacional395. Como complemento del Convención, y dirigidos a disciplinar los aspectos relacionados con el traslado de la mercancía una vez vendida ésta, han de tenerse en cuenta los INCOTERMS de la Cámara de Comercio Internacional (CCI), cuya última versión data del año $2010^{396}$.

determinada y el otro a pagar por ella una precio cierto, en dinero o signo que lo represente». Como puede apreciarse, todos los códigos comparados están de acuerdo en que el contrato de compraventa genera una obligación de transmitir la propiedad de una cosa a cambio de pagar una cantidad en dinero. Por lo tanto, queda el carácter internacional como condición específica del contrato, dando lugar a que las cosas o mercancías hayan de ser transportadas de un Estado a otro, o sea, de un país a otro diferente.

394 F. OlIVA BlázQUEZ, Compraventa..., cit., p. 165.

395 L. DíEZ-PiCAZo (dir.), La compraventa internacional de mercaderías: comentario de la Convención de Viena, Civitas, Madrid, 1998, p. 15.

396 La Convención de Viena en su artículo 9 reconoce a las partes del contrato de compraventa como expresión de su autonomía de la voluntades recurrir a los usos y prácticas comerciales, como son los INCOTERMS, e integrarlas al contrato o a los documentos que dan origen a la formación de éste. Vid. B. CAMPuZANO DíAZ, La repercusión del Convenio de Viena de 11 de abril de 1980 en el ámbito de la compraventa internacional de mercaderías, Secretariado de Publicaciones de la Universidad de Sevilla, 
La Convención establece un conjunto de normas que regulan el contrato de compraventa internacional. Su primera parte contiene reglas relativas a su ámbito de aplicación y la segunda reglamenta la formación del contrato, mientras que los derechos y obligaciones de las partes contratantes (comprador y vendedor), además de las acciones en caso de incumplimiento, se hallan regulados en la tercera parte de la Convención397.

\section{c) Conexión entre los contratos de compraventa y de transporte}

En el supuesto del contrato de compraventa internacional de mercaderías destinadas a cruzar las fronteras, se deberá tener en cuenta que para transportar esas mercaderías será necesario contratar los servicios de transporte que facilitan en gran medida la buena ejecución de la compraventa, lo cual implica una interacción entre los derechohabientes - comprador o destinatario y vendedor o cargador- en caso de que se produzca un incumplimiento de la operación o un daño en las mercancías a lo largo del viaje.

De ahí que las consecuencias se produzcan en la intersección entre los efectos jurídicos del contrato de compraventa y los del contrato de transporte, en atención al hecho de que la obligación exige el cumplimiento de la prestación en su integridad: los dos contratos tienen por objeto el mismo deseo de entregar las mercancías a su destinatario, que es el comprador. En la medida en que el incumplimiento de ambos contratos se produce, en su caso, por no entregar las mercancías comprometidas, por entregarlas dañadas o por entregarlas fuera de plazo, ello puede ser también un motivo de disputa entre las partes del contrato de compraventa. Particular relevancia tiene en este contexto la entrega de las mercancías y las vicisitudes relacionadas con ella, de manera que debe concretarse el momento en el que se produce la transmisión del riesgo al comprador.

En efecto, este epígrafe tiene por propósito destacar, dentro del marco de la regulación del contrato de compraventa internacional, aquellas modalidades

Sevilla, 2000, p. 197; A.L. Calvo CARAvaCA, «Comentario del artículo 9», en L. Díez-Picazo (dir.), La compraventa internacional de mercaderías..., cit., p. 132.

397 Vid. Ma ${ }^{\text {a }}$. PERAlES VISCASIllas, «El contrato de compraventa internacional de mercancías (Convención de Viena de 1980)», Madrid, 2001 (disponible en http://www.cisg.law.pace.edu/cisg/biblio/perales1.html). 
en las que la entrega deba hacerse al transportista. Tales modalidades suelen tener su reflejo en la práctica internacional en el uso de los denominados INCOTERMS a los que ya se ha hecho referencia, en relación con la entrega de las mercancías (al transportista) como consecuencia de la celebración de un contrato de compraventa internacional que implica el transporte de la carga 398 .

\section{aa) La entrega de las mercancías}

Como se decía, la entrega de las mercancías que implica su transporte se disciplina a través de términos comerciales normalizados (que no dejan de ser modalidades del contrato de compraventa), generalmente los INCOTERMS399, que «si bien no se regulan en [la CISG] sí derivan de su regulación»400.

En los INCOTERMS, las modalidades de entrega se organizan en cuatro categorías401, que se pueden a su vez aplicar según el modo de entrega. Por ejemplo, en el grupo «E» $\mathrm{y}$ «D» se encuentran los términos que se aplican a la

398 En este sentido, el artículo 58.2 CISG distingue entre el contrato de compraventa que implica el transporte del que no lo implique, afirmando que en la compraventa que implica transporte el vendedor se obliga a contratar un transporte, o bien cuenta con la autorización del comprador para entregarlas a un transportista determinado. Por el contrario, se considera compraventa internacional que no implica transporte aquella en la que el vendedor traslada las mercaderías usando sus propios medios de transporte para entregarlas al comprador, o bien cuando el comprador las recoge en el establecimiento del vendedor. Vid. J.D. ENRIQUE ROSAS, Transporte internacional de mercancías: una introducción al régimen jurídico general del transporte de mercancías. especial incidencia en el ámbito internacional, Porrúa, México, 1999, pp. 271-276.

399 Tales términos comerciales (su denominación proviene de su acrónimo en inglés: INternational COmmercial TERMS) tienen como objeto principal «el dotar de certidumbre en las transacciones internacionales que se sirvan de los mismos, permitiendo a las partes referirse a un juego de reglas preestablecidas que puedan integrarse en el contrato, y primordialmente, determinar la interpretación de los principales términos o cláusulas utilizadas en las ventas internacionales» (J.A. TAMAYO CARMONA, Responsabilidad y riesgo contractual: normas de la Convención de Viena, sobre venta internacional de mercaderías e Incoterms 2000, Tirant Lo Blanch, Valencia, 2002, pp. 28-29.

400 J.D. EnRIQUE RosAs, Transporte..., cit., pp. 273-274. Por el contrario, y como se vio, hay entrega directa cuando el vendedor entrega la mercancía al mismo comprador, es decir, que el vendedor no está obligado a entregar la mercancía en un lugar determinado. Es entonces el comprador quien tiene que acudir al lugar donde se encuentra la mercancía, o al propio establecimiento del vendedor para recogerla, debiendo éste ponerla a su disposición su propio almacén o fábrica. Vid. también J.A. TAMAYO CARMONA, Responsabilidad..., cit., p. 22.

${ }^{401} \mathrm{Si}$ bien en la actualidad se utilizan los INCOTERMS 2010, éstas no derogan la versión anterior de 2000, que se puede seguir usando, salvo si se trata de una modificación sustancial que puede sufrir alguna regla, en cuyo caso ha de hacerse referencia a la que se acuerda, es decir, a la de 2010. Vid. A. CABRERA CÁNOVAS, El transporte internacional por carretera, Marge, Barcelona, 2013, p. 51. 
compraventa con entrega directa. En cambio, los términos incluidos en los grupos «F»y «C» son los que nos interesan en este epígrafe pues son los que se refieren a la compraventa con entrega indirecta, precisamente cuando la compraventa incluye el transporte 402 .

Efectivamente, son compraventas que implican transporte todas aquellas que llevan implícitas un desplazamiento de bienes de un lugar a otro, en el sentido de que el vendedor ${ }^{403}$ pasa a contratar un servicio de transporte, en virtud del cual ese vendedor entrega las mercaderías a un porteador para su transporte ${ }^{404}$. En este supuesto, dispone el artículo 31.a) CISG que el contrato de compraventa implica el transporte de las mercancías con entrega indirecta, que consistirá en ponerlas en poder del primer porteador ${ }^{405}$.

\section{bb) La transmisión del riesgo}

El tema de la transmisión del riesgo 406 es uno de los temas de mayor importancia y complejidad en la regulación internacional de la compraventa407, más si se

402 R. BESES MigUel y $\mathrm{M}^{\mathrm{a}}$.D. BESES MigUeL, Transporte, compraventa y responsabilidades (aspectos nacionales e internacionales), Edisofer, Madrid, 2005, p. 106.

403 Según lo dispuesto en los grupos «F» $\mathrm{y}$ «C» de los INCOTERMS, el transporte puede contratarlo el comprador (FOB) o el vendedor (CIF o CFR). De esta manera, el transportista en este modo de entrega tiene que ser necesariamente una persona distinta de las partes de la compraventa (comprador y vendedor). Así, J.D. ENRIQUE ROSAS, Transporte..., cit. p. 276.

404 C.A. EsPlugues Mota, Compraventa internacional de mercaderías, Impiva, Valencia, 1993, p. 44.

405 Concretamente, el art. 31 CISG establece que, «[s]i el vendedor no estuviere obligado a entregar las mercaderías en otro lugar determinado, su obligación de entrega consistirá: [...] a) cuando el contrato de compraventa implique el transporte de las mercaderías, en ponerlas en poder del primer porteador para que las traslade al comprador».

${ }^{406}$ La delimitación del riesgo en la compraventa pretende determinar a quién perjudica el deterioro o la destrucción fortuitos de las mercaderías (es decir, por causas no imputables al vendedor ni al comprador), una vez perfeccionado el contrato. Así, M. BROSETA PONT y F. MARTínez SANZ, Manual..., Vol. II, $23^{\text {a }}$ ed., cit., p. 83. De forma distinta se define el riesgo en los contratos de seguro, donde se refiere a «la posibilidad de que por azar ocurra un hecho que produzca una necesidad patrimonial, pues el riesgo es un estado que se produce como consecuencia de un hecho» (A. BADIA, El seguro de las mercancías en el transporte. Manual para conocer en profundidad el seguro de las mercancías en el transporte por vía marítima, terrestre y aérea, Marge, Barcelona, 2009, p. 25).

407 Así, señala Olivencia que «[e]l tema del riesgo constituye una cuestión delicada en todo contrato traslativo en que exista una diferencia de tiempo entre el momento en que se celebra o perfecciona y aquel en que la cosa llega a poder del adquirente. Pero esa importancia aumenta en las compraventas internacionales, en función del tiempo normalmente largo- que ese lapso representa y en función de los riesgos reales a que las 
está ante una compraventa con entrega indirecta, es decir, que implique el transporte de las mercaderías.

El artículo 67 CISG prevé dos reglas distintas sobre la transmisión del riesgo en relación con la compraventa que incluye un transporte de mercancías. Sólo procede la aplicación de este artículo si el encargado del transporte de las mercancías es una persona distinta de las partes del contrato de compraventa, es decir, si el comprador o el vendedor se compromete a concluir un contrato de transporte con un tercero, en virtud del cual este tercero (en cuanto sujeto independiente de las partes del contrato de compraventa) se obliga a trasladar las mercaderías a su destino. Quedan excluidos, por tanto, aquellos casos en los que el vendedor se compromete a transportar personalmente la mercancía al comprador y aquellos otros en que el comprador se obliga a acudir al establecimiento del vendedor o donde se encuentren las mercancías para recogerlas con sus propios medios de transporte 408 .

Este precepto se refiere, pues, a los casos en los que el contrato de compraventa incluye el transporte, diferenciando en función de si el vendedor no se encuentra obligado a entregar la mercancía en un lugar fijado o si está obligado a ponerla en poder del porteador en un determinado lugar. En el primer supuesto, el riesgo se transmitirá al comprador en el momento en que las mercancías se ponen en poder del primer porteador. Por el contrario, en el segundo caso el traslado del riesgo al comprador queda condicionado a que las mercancías se pongan en poder del porteador en el lugar convenido409.

En ambos casos, una vez transmitido el riesgo al comprador, es a este último a quien perjudican los daños o la destrucción de las mercancías sobrevenidas durante el transporte. Y ello porque, producida la efectiva puesta en poder de la cosa al porteador, ésta sale de la esfera inmediata de poder y disposición del vendedor. De la redacción de la norma se infiere también que, en caso de

mercaderías están expuestas» (citado por E. SECO CARO, El contrato mercantil de compraventa, Marcial Pons, Madrid, 2009, p. 332).

408 G. Minero AlEJANDRE, «El traslado del riesgo en la compraventa internacional de mercaderías», en Á. Carrasco Perera (Dir.), Tratado de la compraventa, en Homenaje al profesor Rodrigo Bercovitz, T. II, Aranzadi, Cizur Menor, 2013, pp. 1714- 1715.

409 J. CAFFARENA LAPORTA, «Transmisión del riesgo (Comentario a los artículos 66 a 70)», en L. Díez-Picazo (dir.), La compraventa internacional de mercaderías..., cit., p. 524. 
que intervengan varios porteadores en el traslado, la transmisión del riesgo al comprador tiene lugar con la entrega de las mercancías al primero de dichos porteadores ${ }^{410}$.

El apartado segundo del artículo 67 CISG, en su referencia a las compraventas en las que las mercancías son genéricas, establece la necesidad de que esas mercancías sean debidamente identificadas a los efectos del contrato para que se transmita el riesgo al comprador ${ }^{411}$. En cuanto a la manera de esta identificación, se puede emplear cualquier procedimiento: señales en las mercancías, documentos de expedición, mediante una comunicación enviada al comprador o de otro modo, siempre que esos procedimientos determinen claramente y de manera indudable las mercancías afectadas al cumplimiento del contrato.

En el caso de un cargamento colectivo a varios compradores, es obvio que el traslado del riesgo al comprador requiere sólo la identificación de las mercancías que forman parte de ese cargamento, sin asumir él solo el riesgo, porque todos los compradores se comprometen en proporción a la parte de cada uno de ellos en cubrir ese riesgo ${ }^{412}$.

\subsection{El contrato de seguro de transporte}

El transporte internacional de mercancías va unido de forma prácticamente indisoluble a la institución del seguro. Dado que la llegada incólume a destino es la finalidad última perseguida con la operación, no puede hablarse de un transporte moderno sin que esté supeditado a un contrato de seguro, suscrito por el transportista o por el cargador ${ }^{413}$, que garantice una buena llegada de las mercancías a su destino414. La Ley del Contrato de Seguro de 1980 se ha encargado, como es sabido, de deslindar las líneas elementales del seguro en cualquiera de sus modalidades al señalar que, por el contrato de seguro, el asegurador se obli-

${ }^{410}$ G. Minero AlEJANDRE, «El traslado...», cit., p. 1715.

${ }^{411}$ En el ámbito interno, se encuentra una solución similar en el art. 334.1 $\mathrm{Ccom}$.

412 J. CAfFarena Laporta, «Transmisión...», cit., p. 535; G. Minero AlEJANDRE, «El traslado...», cit., p. 1716.

413 Como señala F.J. TiRAdo SuÁREz, «Los seguros de daños», en G.J. Jiménez Sánchez (coord.), Derecho Mercantil II, Marcial Pons, Madrid, 2010, p. 750, «la legitimación para la contratación del seguro se extiende al comisionista y a las agencias de transporte».

414 J.D. ENRIQUE Rosas, Transporte..., cit., p. 279. 
ga, a cambio de una prima, a resarcir un daño o a pagar una suma de dinero en caso de que se verifique la eventualidad prevista en el contrato (art. 1 LCS).

En cuanto al seguro de transporte terrestre de mercancías, la Ley lo define como aquel contrato en virtud del cual «el asegurador se obliga, dentro de los límites establecidos por la Ley y en el contrato, a indemnizar los daños materiales que pueden sufrir con ocasión o como consecuencia del transporte las mercancías porteadas, el medio utilizado u otros objetos asegurados» (art. 54 LCS). Como puede observarse, el seguro de transporte de mercancías se basa en la cobertura por parte del asegurador del riesgo de que las mercancías sean destruidas o dañadas durante el transporte, aun cuando el siniestro tuviera lugar por causas accidentales o fortuitas. En tales casos, la finalidad del seguro consiste en compensar un perjuicio, es decir, cubrir una necesidad patrimonial que el siniestro ha causado al asegurado, pero siempre con el límite del importe del daño, de manera que no se produzca un enriquecimiento injusto en éste ${ }^{415}$.

La relación que liga el seguro al transporte es, por un lado, la complementariedad a la hora de reparar los daños causados por el siniestro e indemnizarlos (el perjudicado puede solicitar el resarcimiento de los daños causados del asegurador y del transportista). Por otro, ambos contratos se enmarcan en la misma tipología de los llamados contratos a favor de tercero, por cuanto ambos contratos tienen como objeto realizar una prestación a favor del destinatario, bien sea la de entregar las mercancías, bien la de asegurarlas y cubrir los daños sobrevenidos en caso de que se materialice el riesgo cubierto en la póliza.

Por su parte, las pólizas de seguro de transporte de mercancías varían según el modo de transporte empleado ${ }^{416}$, pero incluso dentro de un mismo modo

415 J. Munar Martínez y A. Gallego VARA, El seguro de transporte de mercancías: Análisis de riesgos y coberturas, Plus Ultra, Madrid, 1987, p. 59.

${ }_{416}$ En cualquier póliza de seguro se ha de indicar, además de los riesgos cubiertos, la persona por cuya cuenta se efectúa ese contrato de seguro (que suele ser el destinatario), pero ello, como se decía, varia según las modalidades del transporte. Por ejemplo, en la póliza de seguro marítimo de mercancías suele dejar sin determinarse el destinatario o la persona por cuyo interés se hace el seguro (porque puede no estar determinada en el momento de contratarse el seguro y, además, la persona del interesado en las mercancías puede variar con la transmisión del conocimiento de embarque), razón por la cual, en tal caso, el seguro se contrata "por cuenta de quien corresponda». Vid. F. SÁnCHEZ CALERo, Instituciones de Derecho mercantil, Vol. II., Títulos y valores, contratos mercantiles, derecho concursal y marítimo, 21 ${ }^{\mathrm{a}}$ ed., EDERSA, Madrid, 1998, p. 544. Cabe añadir 
existen distintos tipos de pólizas. En efecto, en el seguro de transporte existen varios tipos de cobertura, como es la póliza «por viaje» o «término», que se caracteriza por cubrir un único viaje u operación417. Pero también cabe $-\mathrm{y}$, de hecho, es de uso frecuente en la práctica - la llamada póliza «abierta», que «regula unas condiciones marco que se van a aplicar a una serie continuada de embarques u operaciones de transporte [...]. Se deriva de este tipo de póliza lo que viene llamado la póliza 'flotante' en la que la prima se fija como depósito para un volumen estimado de operaciones, regularizándose el uso real de la póliza al final de cada ejercicio en función de los transportes efectuados»418.

Resumiendo puede decirse que el seguro de transporte terrestre de mercancías es un seguro de daños que cubre el riesgo de que fortuitamente se causen daños materiales a las mercancías transportadas producidos con ocasión del transporte 419 .

\subsection{La comisión de transporte}

De las normas que sobre mandato mercantil o comisión contiene el Código de comercio (arts. 244 y ss.) se desprende que el contrato de comisión es aquel por virtud del cual el «comisionista, en su condición de empresario mercantil, se obliga a prestar su actividad consistente en realizar un acto u operación de comercio por cuenta del comitente». Intervienen pues, de un lado, el comitente o dueño del negocio; y el comisionista, de otro, que se encarga de realizar alguna operación comercial, actuando frente a terceros de dos formas distintas: en

también que los tipos de seguro de transporte se pueden clasificar según diversos criterios, de entre los que destacan: "1. El tipo que se puede clasificar en función del medio de transporte: terrestre, marítimo, fluvial, aéreo o multimodal. 2. En función del objeto asegurado: seguro de mercancías, de vehículos, de daños a terceros, etc. 3. En función de la duración del seguro: por viaje o temporal» (A. CABRERA CÁNOVAS, Transporte..., cit., p. 53). 417 Véase J. SÁncheZ-GAmborino, «Contrato de transporte y contrato de seguro de transporte», en J.L. Concepción Rodríguez (dir.), El contrato de transporte, Manual de Formación Continuada 21, Vol. I, Consejo General del Poder Judicial, Madrid, 2003, p. 511. 418 A. CABrera CÁnovas, Transporte internacional de mercancías, Icex, Madrid, 2011, p. 55 .

419 J. BOQUERA MATARREDONa, El contrato..., cit., pp. 36-37. 
nombre de su comitente o en el suyo propio, por medio de representación indirecta $^{420}$, pero siempre por cuenta de aquél.

Con relación al contrato de comisión, este último puede tener por objeto un contrato de transporte y, en efecto, hay comisión de transporte cuando el objeto de la misma sea la conclusión por el comisionista de un contrato de transporte por cuenta de su comitente. Por su importancia y también por su frecuente utilización en la práctica, el legislador le ha prestado una atención especial. Su marco legal se encuentra actualmente en la Ley 15/2009, de 11 de noviembre del Contrato de Transporte Terrestre de Mercancías, así como en la LOTT y en la legislación que la desarrolla421. La legislación administrativa (LOTT y ROTT) contemplan distintos tipos de intermediarios como son, sobre todo, las agencias de transporte y los transitarios, sin perjuicio de que la Orden del Ministerio de Fomento de 21 de julio de 200o, que regula el acceso a la profesión, prevea una única autorización de «operador de transporte».

En la práctica se tiende a concluir un contrato de comisión de transporte 422 cuando un interesado en hacer trasladar una mercancía no acude directamente al transportista que efectivamente lleva a cabo el desplazamiento de las mercancías, sino a otro operador profesional que interviene como mero intermediario en la contratación del transporte. Éste elegirá entonces un porteador, teniendo en cuenta los elementos característicos y circunstanciales de la expedición como: la necesidad de almacenajes, de contratar las operaciones de carga y descarga, de contratar porteadores en otros modos, etc. En tales casos, podría pensarse que la responsabilidad del comisionista que contrata en nombre ajeno se limita a la adecuada elección del transportista. Mas ello no es posible, pues el artículo 5.2 LCTTM obliga a los intermediarios a contratar con el transportista

\footnotetext{
420 En la representación indirecta el comisionista oculta el nombre del comitente, de manera que es él quien se obliga de manera directa frente el tercero, como si el negocio fuera suyo. Con todo, en el plano interno - es decir entre comisionista y comitente-, deberá transmitir las consecuencias jurídicas del negocio de realización (el precio, la cosa comprada) a su comitente. Vid. M. Broseta Pont y F. Martínez SAnZ, Manual..., Vol. II, $23^{\text {a }}$ ed., cit., p. 114.

${ }^{421}$ L. ANGUlo RodRíGuez, «El contrato de comisión», en G.J. Jiménez Sánchez (coord.), Derecho Mercantil II, Marcial Pons, Madrid, 2010, p. 279-280.

422 Como se decía, en la legislación administrativa (LOTT y ROTT) existen varias tipos de intermediarios, tales como: agencia de transportes, transitario, almacenista-distribuidor, etc. Vid. F.J. SÁNCHEZ-GAMBORINO y J. GAITÁN REBOLLO, Factbook..., cit., p. 75.
} 
que finalmente llevará a cabo el transporte en nombre propio. Si bien la Ley 15/2009 no establece otra sanción distinta en caso de incumplimiento que la de que «[l]os contratos de transporte de mercancías se presuponen [sic] celebrados en nombre propio», el artículo 140.31 LOTT sanciona «la contratación de servicios de transporte terrestre de mercancías por parte de transportistas, agencias de transporte, transitarios, almacenistas distribuidores, operadores logísticos o cualquier otro profesional del transporte incumpliendo la obligación de hacerlo en nombre propio» como infracción muy grave, con multa de entre 1.001 y 2.000 euros [art. 143.1.g) LOTT]. Por otra parte, nada impide que el intermediario efectúe él mismo el transporte si dispone de título administrativo y material móvil que se lo permita423, en cuyo caso responderá sin duda como porteador.

$\mathrm{Al}$ margen de estas normas, que son las que actualmente rigen la comisión de transporte, ésta se menciona todavía en el artículo $275 \mathrm{Ccom}$, a cuyo tenor el comisionista de transporte deberá contratarlo cumpliendo las obligaciones que incumben al cargador en el transporte terrestre o marítimo y, si actúa en nombre propio, responderá frente al porteador de tales obligaciones. También se hacía referencia al comisionista de transporte en el -hoy derogadoartículo 379 Ccom que, al contrario de cuanto sucede con el artículo 275 (que sujeta al comisionista a las mismas obligaciones que al cargador o remitente), equiparaba al comisionista con el porteador.

La diferencia estaba, se decía, en que el artículo 275 Ccom se refiere a un verdadero comisionista que se encarga de remitir efectos a otro lugar, mientras que el artículo 379 Ccom hacía referencia a un auténtico porteador, pues prometía hacer transportar las mercancías («contrataren hacerlo», decía el precepto), siquiera sea empleando estructuras o medios ajenos ${ }^{424}$. Por ello se le considera-

423 F.J. SÁnCHEZ-GAMborino y J. GAITÁn REBOllo, Factbook ..., cit., p. 75.

424 M. Broseta Pont y F. Martínez Sanz, Manual..., Vol. II, $15^{\mathrm{a}}$ ed., cit., p. 118. Al respecto de la controversia sobre la interpretación de los artículos 275 y 379 Ccom, señalan LEIÑENA e IRÁKULIS que «el art. 275 es el relativo a la relación entre el comisionista y el porteador, mientras que el art. 379, que subroga al comisionista en la posición del portador, es el relativo a la relación entre un comisionista de transporte y el cargador en una comisión de transporte» (E. LEIÑENA y N. IRÁKULIS, El régimen jurídico unificado de la comisión mercantil y el mandato en el derecho de obligaciones y contratos, Dykinson, Madrid, 2007, pp. 159-160. 
ba, en ocasiones, un comisionista de garantía, en la medida en que respondía frente a su comitente, no sólo de la obligación de celebrar un contrato de transporte, sino también de responder de su ejecución al quedar subrogado en el lugar del mismo porteador 425 .

Por último, el artículo $274 \mathrm{Ccom}^{426}$ responsabiliza al comisionista de los daños sobrevenidos a las mercancías transportadas cuando estuviera encargado de contratar un seguro de daños y no lo hiciera, siempre y cuando estuviese hecha la provisión de fondos para pagar la prima de seguro o se hubiere obligado a anticiparlos y no hubiese notificado inmediatamente al comitente la imposibilidad de contratarlo427. En el caso (harto improbable) de que el asegurador sea declarado en concurso antes de concluir la operación, tendrá el comisionista la obligación de contratar un nuevo seguro, salvo que el comitente le haya ordenado otra cosa (art. 274.2 Ccom).

\subsection{El contrato de depósito}

El contrato de depósito es un contrato que genera para el depositario la obligación de custodiar la cosa objeto del contrato y devolverla más tarde al depositan-

425 F.C. LÓPEZ RUEDA, El régimen jurídico del transporte multimodal, La Ley, Madrid, 2000, p. 380.

${ }^{426}$ La norma se refiere al caso en que el contrato de transporte y el de seguro sean concluidos por virtud de un pacto complementario o accesorio a otra comisión, bien sea de venta, de compra o de cualquier otra clase, a cuyo tenor el comisionista debe remitir a otra parte los efectos. En tales casos, se dice, el comisionista únicamente queda obligado a estipular el contrato (de transporte o de seguro), pero sin ausmir la garantía de su realización. Cfr. la STS de 14 de octubre de 1985 (RJ 1985, 4843), así como L. ANGUlO RODRÍGUEZ, «El contrato...», cit., p. 280, y E. LEIÑENA y N. IRÁKULIS, El régimen..., cit., p. 159. En cambio, los - hoy derogados- arts. 378 y 379 Ccom, por un lado, obligaban al comisionista a llevar un registro especial (art. 378) y, por otro, consideraban al comisionista (esto es, una agencia de transporte u otro comisionista que actuase profesionalmente por cuenta de transportistas) garante del cumplimiento de las obligaciones, responsabilidades y derechos correspondientes al porteador. Así, L. ANGULO RODRÍGUEZ, «El contrato...», cit., p. 280; cfr. también la STS núm. 381/2001, de 19 de abril (RJ 2001, 6884).

427 La provisión de fondos viene regulada en los arts. 250, 251 Ccom y 1.728 Cc. Este último precepto se refiere a las cantidades necesarias para la ejecución del contrato de mandato o de comisión. Como quiera que es el comisionista quien ha de cumplir el encargo, podrá por precaución suspender su ejecución en el supuesto en que para cumplirlo necesita una provisión de fondos y el comitente no los anticipa (ni se ha pactado tampoco que el comisionista los anticipe o supla), prosiguiendo con la ejecución una vez que el comisionista reciba la cantidad necesaria del comitente. Vid. E. LEIÑENA y N. IRÁKULIS, El régimen..., cit., pp. 105106. 
te ${ }^{428}$, aunque el Código de comercio no proporciona ninguna definición del contrato. Ante este silencio, debe acudirse al Código civil, que lo define en su artículo 1.758 como aquel contrato por cuya virtud del cual una de las partes, el depositario, recibe una cosa ajena (mueble: art. $1.761 \mathrm{Cc}$ ) para que se encargue de guardarla y de restituirla una vez que la otra parte, el depositante, la reclame ${ }^{429}$.

El contrato de depósito es un contrato independiente del contrato de transporte cuando se celebra de forma principal, pero ello no es óbice para considerar que, en ocasiones, constituye un deber accesorio al mismo430. Un supuesto parcialmente distinto es el que contempla el artículo $1.774 \mathrm{Cc}$, que se refiere a aquellas situaciones en que el depósito se constituye indicando que la devolución de la cosa dada en depósito debe efectuarse en un lugar distinto a aquel en que fue depositada. En este caso, el depositario debe transportar la cosa depositada al lugar indicado por el depositante, sobre quien recae la obligación de asumir los gastos de transporte. Surge así la necesidad de delimitar los contratos de transporte y de depósito, que pueden en alguna ocasión llegar a confundirse. Como no puede ser de otra forma, el criterio diferenciador es la causa del consentimiento de las partes, esto es, la finalidad perseguida a la hora de contratar, que es distinta en uno y otro caso: mientras que en el depósito la obligación principal del depositario es la de guardar y conservar la cosa, en el transporte es el desplazamiento de la cosa al lugar de su entrega431.

La confusión que puede darse entre ambos contratos queda manifiesta si se tiene en cuenta lo dispuesto en el artículo $1.094 \mathrm{Cc}$, que impone al obligado a dar una cosa el deber de cuidarla y mantenerla. Pero se trata de un deber instrumental y accesorio, como sucede con el depósito en el marco de un contrato

${ }^{428} \mathrm{El}$ contrato mercantil de depósito se halla regulado en el Código de comercio (Título V, Libro II), en los artículos 303 a 310, complementados en caso de laguna con los arts. 1.758 a 1.789 del Código Civil. El contrato de depósito reviste carácter mercantil se presentan los tres requisitos siguientes, establecidos en el art. 303 Ccom: 1) que el depositario, al menos, sea comerciante; 2) que las cosas depositadas sean objeto de comercio; y 3) que el depósito constituya por sí una operación mercantil. Vid. F.J. ALONSO ESPINOSA, Derecho mercantil de contratos: un curso de iniciación, Aranzadi, Cizur Menor, 2011, p. 95.

429 C. Llorente Gómez DE SEgurA, «Contratos del mercado de servicios (III). Depósito. Transporte. Servicios turísticos», en J.M ${ }^{\mathrm{a}}$. de la Cuesta Rute (dir.), Derecho mercantil II, Huygens, Barcelona, 2014, p. 145.

430 J. PUTZEYs, Le contrat..., cit., p. 39.

${ }^{431}$ F. OZCÁRIZ MARCO, El contrato de depósito: Estudios de la obligación de guarda, Bosch, Barcelona, 1997, p. 159. 
de transporte, por cuya virtud el porteador está obligado a custodiar la mercancía y conservarla para poder entregarla en buen estado al destinatario. Si comúnmente se afirma que del deber de entregar se deriva en la ley un deber de conservar, durante la operación del transporte la mercancía queda bajo la custodia y tutela del porteador, quien debe mantenerla en buena condición porque debe entregarla al destinatario.

En definitiva, el contrato de transporte busca el traslado y la entrega de la mercancía al destinatario. Así, el deber de custodiar la mercancía durante el transporte no es una obligación en sentido técnico sino un simple deber de protección de la carga, o sea, la obligación de custodiarla y protegerla no es más que una deber genérico, accesorio a la prestación de dar. De ahí que el porteador quede obligado únicamente en los términos del artículo $1094 \mathrm{Cc}$, ya que no se está ante dos contratos, de transporte y de depósito, sino ante uno solo, que es de transporte ${ }^{432}$.

\section{Perfección del contrato}

\section{Modo y momento de la perfección del contrato}

Como se ha tenido ocasión de señalar, el contrato de transporte es un contrato consensual, o sea, su conclusión está sometida a las reglas generales, al igual que todos los contratos que se perfeccionan con el acuerdo de voluntades sobre los objetos esenciales de sus prestaciones respectivas 433 .

A pesar de que una primera lectura de la normativa en materia de transporte pudiera inducir a pensar lo contrario, el contrato de transporte no exige una forma especial para su validez. Así se desprende de lo dispuesto en el artículo 13 LCTTM, a cuyo tenor «la ausencia o irregularidad de la carta de porte no

$43^{2}$ R. Beses Miguel y Ma ${ }^{\mathrm{a}}$.D. Beses Miguel, Transporte..., cit., pp. 267-268. En el mismo sentido señala ViCENT CHULiá que «el depósito no puede ser, como contrato, más que principal o sustantivo, existiendo en el transporte obligación de custodia y devolución, sin albergar en su seno un contrato 'auxiliar' de depósito" (citado por F. OZCÁRIZ MARCO, El contrato..., cit., p. 161. Cfr. también la STS de 10 de junio de 1987 (RJ 1987, 4276).

433 J. PUTZEYs, Le contrat..., cit., p. 111. 
producirá la inexistencia o la nulidad del contrato»434, sin perjuicio del papel fundamental que despliega la documentación del contrato como un instrumento probatorio privilegiado en el ámbito del transporte de mercancías 435 .

En efecto, la perfección del contrato de transporte implica un concurso de voluntades, el consentimiento, bastando la simple voluntad de las partes contratantes, pues la conclusión puede manifestarse de cualquier modo. Ya se ha dicho que para su validez no se exige una forma especial, razón por la cual el contrato de transporte es válido si se celebra de forma verbal, como así lo confirma la jurisprudencia 436 .

En cuanto al momento de su perfección, ésta se produce con la declaración por las partes de su voluntad de aceptar las condiciones esenciales de la prestación de transporte, y no en el momento en que la carga se entrega al transportista. La entrega de la mercancía no es, pues, un elemento constitutivo del transporte y no condiciona su perfección (no es, por ello, un contrato real). Se trata más bien, como señala GARRIGUES437, del primer acto de la primera fase de su ejecución. En el mismo sentido, afirma URía que «dicha entrega sólo es esencial en la fase ejecutiva del contrato, no en la formativa» 438 .

\section{Las partes del contrato}

\subsection{El cargador o remitente}

El cargador o remitente es el sujeto que celebra en nombre propio el contrato de transporte y frente al cual el porteador asume la obligación de ejecutarlo439. Es, por tanto, acreedor de la prestación de transporte, razón por la cual no se le de-

\footnotetext{
434 Véase también el art. 4 CMR. Además, así lo tiene declarado la jurisprudencia, p.ej., en las SsTS núm. 465/1993, de 17 de mayo (RJ 1993, 3555); y núm. 558/2001, de 18 de junio (RJ 2001, 4345); o la SAP Madrid núm. 439/2000, de 19 de junio (AC 2000, 1987). Vid., asimismo, F. MARTÍNEZ SANZ, «Transporte...», cit., p. 175.

435 C. Llorente Gómez DE SEgurA, «Contratos...», cit., p. 150.

${ }_{436}$ SsTS de 12 de diciembre de 1968 (RJ 1968, 5842); y de 15 de julio de 1983 (RJ 1983, 4234).

437 Cfr. F.J. SÁncheZ-Gamborino y J. GaitÁn Rebollo, Factbook..., cit., p. 91.

$43^{8}$ R. URÍA, Derecho Mercantil, 24 a ed., Marcial Pons, Madrid, 1997, pp. 720-721.

439 Así lo define el artículo 4.1 LCTTM: «Cargador es quien contrata en nombre propio la realización de un transporte y frente al cual el porteador se obliga a efectuarlo».
} 
be confundir con el llamado «expedidor», que según lo dispuesto en el artículo 4.4 LCTTM, es «el tercero que por cuenta del cargador haga entrega de las mercancías al transportista en el lugar de recepción de la mercancía». Se entiende de esta definición del expedidor que es un tercero ajeno al contrato que actúa en interés del cargador, pero que no contrata el transporte con el porteador en su propio nombre (sin perjuicio de la posibilidad, claro está, de que cargador y expedidor sean la misma persona). De ahí que el cargador sea la persona en cuyo nombre se estipula el contrato de transporte: en caso de actuación en nombre propio y por cuenta ajena ${ }^{440}$, el remitente será quien contrató en su nombre y no el titular del negocio441.

También puede coincidir la persona del cargador con la del destinatario, como sucede, por ejemplo, en el supuesto en que un empresario hace desplazar sus propias mercaderías desde el establecimiento central a una sucursal442. En este caso, como es natural, no existe tercero beneficiario de la prestación de transporte, sino que quien contrata el desplazamiento con el porteador es el (único) acreedor del transporte.

Ahora bien, a efectos de concretar el conjunto de derechos y obligaciones del cargador en el contrato es irrelevante su relación con las cosas objeto del transporte. No importa, en efecto, la clase de derecho real que lo relaciona con la carga, y tampoco adquiere mayor relevancia su vinculación con el destinatario, esto es, si los efectos se trasladan en ejecución de una compraventa, una donación, un préstamo, etc., ya que se trata de operaciones que no afectan en absoluto al contrato de transporte en su regulación principal 443 .

Como se decía, el acreedor del transporte en su etapa inicial es el cargador, quien se obliga a entregar las mercancías objeto del transporte al porteador

440 Como sucede en el caso de la comisión de transporte (vid. art. $274 \mathrm{Ccom}$ ), donde el comisionista-expedidor se compromete a hacer trasladar las mercancías en interés de su comitente-cargador, y también facilita todas las transacciones relacionadas con el transporte, tales como la entrega a otros transportistas, almacenamiento, seguros, aduana, etc. Vid. J. PUTZEYs, Le contrat..., cit., p. 35. También puede ser el cargador en este sentido una agencia de transportes, esto es, un empresario de intermediación en el mercado del transporte. Cfr. F.J. Alonso EsPINOSA, Derecho..., cit., p. 107.

${ }^{441}$ A. DÍAZ MORENO, «El contrato...», cit., p. 651.

$44^{2}$ F.J. SÁnCHEZ-GAMBorino, El contrato..., cit., p. 27.

443 A. DÍAZ Moreno, «El contrato...», cit., p. 651. 
y, en principio, a pagarle el precio por la realización del transporte444. No obstante, una vez que las mercancías han llegado a su destino y el destinatario ha ejercido su derecho según lo estipulado en el contrato de transporte, el cargador deja de ser acreedor del mismo y pierde ese carácter445. Es por ello por lo que, tradicionalmente, se ha defendido que no puede concurrir simultáneamente legitimación activa en el cargador y en el destinatario: una vez la adquiere el segundo la pierde el primero ${ }^{446}$.

En caso de que el transporte sea pactado a portes debidos y el precio no sea satisfecho por el destinatario, incluso habiendo aceptado las mercancías, es el cargador quien debe proceder a su abono, siendo contraparte del porteador en el contrato de transporte, quien siempre podrá reclamar el precio frente al remitente para obligarle 447 al pago (arts. 37-41 LCTTM) ${ }^{448}$.

\subsection{El porteador o transportista}

Es la persona que asume la obligación de ejecutar el transporte, conforme a las condiciones pactadas 449 . La primera definición legal del término «transportista» proviene de las Condiciones generales de contratación de los transporte de mercancías por carretera, aprobadas por Orden del Ministerio de Fomento de 25 de abril de 1997, a cuyo tenor se trata de toda persona física o jurídica habilitada para la ejecución material de transportes de mercancías. Como puede apreciarse, la norma se refiere al titular de una empresa que se encarga por cuenta ajena

444 F.J. AlONSO ESPINOSA, «Derecho...», cit., p. 107.

445 J.D. ENRIQUE RoSAS, Transporte..., cit., p. 222.

446 En lugar de muchos, A. DíAz Moreno, «El contrato...», cit., p. 652. Con mayor detalle sobre esta cuestión, así como sobre los intentos de superar la interpretación clásica, vide infra, Cap. IV, sub X.1.

447 Se trata aquí de una obligación subsidiaria de pago del cargador, que asume la responsabilidad del pago del porte cuando le corresponda al destinatario y éste no haya procedido a cumplirlo. Es eso a lo que se refiere el inciso final del art. 37.2 LCTTM, y también es esta la regla que viene consagrada en el § 421.4 del Handelsgesetzbuch alemán (HGB), donde se afirma que, aunque el pago corresponda al destinatario, «[e]l cargador sigue siendo sujeto obligado al pago de los importes adeudados según el contrato». Vid. A. EMPARANZA SOBEJANO, «Obligación de pago de porte y consecuencias de su incumplimiento», en F. Martínez Sanz y Ma.V. Petit Lavall (dirs.), Régimen del transporte en un entorno económico incierto, Marcial Pons, Madrid, 2011, p. 104.

448 C. Llorente GómEZ DE SEGURA, «Contratos...», cit., p. 152.

449 F.J. SÁNCHEZ-GAMBORINO, El contrato..., cit., p. 27. 
con sus propios medios al traslado de mercancías450. La expresión "porteador», en cambio, se empleaba para designar «al transportista que, en virtud del contrato, asume, en nombre propio, la obligación de transportar las mercancías de un lugar a otro»451.

Este último es el concepto que ha pasado, con escasas variaciones, a la normativa actual. En efecto, a tenor del artículo 4.2 LCTTM, «[p]ortador es quien asume la obligación de realizar el transporte en nombre propio con independencia de que lo ejecute por sus propios medios o contrate su realización con otros sujetos». Al no proporcionarse otra definición distinta del término «transportista», nada debería obstar para que ambas expresiones sean utilizadas con carácter sinónimo, como de hecho sucede en la práctica452.

Así, el porteador o transportista es la parte que se compromete frente al cargador a efectuar el transporte en beneficio de un tercero, es decir, el destinatario o consignatario. En rigor, es la asunción de la obligación contractual de transportar o hacer transportar y custodiar que caracteriza la posición legal del porteador, de manera que resulta innecesario que ese porteador ejecute tales prestaciones de forma efectiva, ya que puede encargárselas a otro porteador 453 . Sobre la base de esta consideración se ha desarrollado la distinción entre la figu-

450 Véase la definición de «transportista» en el Anexo A, cláusula 1.1, y Anexo B, cláusula 1.1.

${ }^{451}$ Cfr. las cláusulas 1.3 de ambos Anexos.

452 Téngase presente, con todo, que al calor de lo dispuesto en las Condiciones generales de 1997 aún se señalaba que ambos términos se usaban de manera y con un significado distinto. Concretamente, la palabra «transportista» se usaba para designar a la empresa autorizada para concertar el transporte, el término «porteador» en cambio se empleaba para designar a quien física o materialmente lo ejecutaba cuando intervenían comisionistas o mediadores (agencias de transporte, transitarios, etc.), que actuaban en nombre propio, pero por cuenta del porteador efectivo. Al respecto puede verse F.J. SÁNCHEZ-GAMBORINO y J. Gaitán Rebollo, Factbook..., cit., p. 8o. Con carácter monográfico sobre el concepto de porteador, A. EMPARANZA SOBEJANO, El concepto de porteador en el transporte de mercancías, Comares, Granada, 2003, passim.

453 C. Llorente Gómez DE SegurA, «Contratos...», cit., p. 151. Idéntico resultado se desprende, a contrario sensu, de lo dispuesto en el art. $1.161 \mathrm{Cc}$, a cuyo tenor «[e]n las obligaciones de hacer el acreedor no podrá ser compelido a recibir la prestación o el servicio de un tercero, cuando la calidad y circunstancias de la persona del deudor se hubiesen tenido en cuenta al establecer la obligación». Es decir, salvo que otra cosa derive de las circunstancias, cabe la subcontratación en las prestaciones y servicios que sean fungibles. 
ra del porteador contractual y la del porteador efectivo o de hecho454, con el objeto, inter alia, de mejorar la protección de los intereses de la carga y promover la defensa de los intereses del transporte 455 .

\section{a) Porteador contractual y efectivo}

La intervención de distintos porteadores en una única operación de transporte puede articularse de distintas formas. La más frecuente en la práctica es el llamado transporte unitario con subtransporte, en el que el contrato de transporte se celebra con un único porteador, que subcontrata todo o parte del desplazamiento con otro u otros porteadores ${ }^{456}$. En tales casos, como no existe ningún vínculo contractual que una al cargador o destinatario con el porteado efectivo, se plantean problemas complejos a la hora de determinar frente a quién puede dirigirse la reclamación en caso de que se produzcan daños cuando la mercancía se encontraba bajo la custodia de éste. Para resolverlos, la jurisprudencia457 y legislación más modernas establecen una suerte de solidaridad especial entre porteador efectivo y contractual, facultando al cargador o al destinatario para hacer valer sus derechos tanto frente al porteador contractual como frente al porteador efectivo ${ }^{48}$. Con todo, es notorio que la acción directa contra el porteador de hecho desapareció del texto de la Ley 15/2009 que finalmente se aprobó en las Cortes.

454 Concretamente, el art. 4.2 LCTTM se refiere al porteador contractual, esto es, aquel que se compromete y asume la ejecución del transporte frente al cargador, mientras que el porteador efectivo es quien efectivamente ejecuta la operación de trasladar, siguiendo las instrucciones del porteador contractual, normalmente a través de un mecanismo de subcontratación. Así, C. LLORENTE GómEZ DE SEGURA, «Contratos...», cit., p. 151.

455 Sobre la figura del porteador efectivo puede verse, con detalle, J.L. PULIDo BEGINES, $E l$ concepto de porteador efectivo en el Derecho uniforme del transporte, Marcial Pons, Madrid, 2012, passim.

${ }^{456}$ Señala el art. 6 LCTTM que, «[c]uando el porteador que haya contratado directamente con el cargador contrate, a su vez, la realización efectiva de la totalidad o una parte del transporte con otro porteador, quedará obligado frente a éste como cargador conforme a lo dispuesto en esta Ley y en el contrato que con él haya celebrado».

457 En ocasiones, los tribunales de justicia declaran responsable al porteador efectivo frente al derechohabiente de las mercancías en caso de que se produzcan daños daños en la carga. Así, p.ej., la SAP Cantabria (Sección 2aa) núm. 698/2012, de 21 diciembre (AC 2013, 1911), donde se declara la responsabilidad del porteador efectivo por falta de prueba de que el incendio se produjera por caso fortuito o fuerza mayor.

${ }^{45} 8$ Véase las references en C. LLORENTE GómEZ DE SEGURA, «Contratos...», cit., p. 151; J.L. PUlido BEgINES, El concepto..., cit., pp. 51 y ss. 


\section{b) Porteadores sucesivos}

Pero la intervención de distintos porteadores puede articularse también mediante el llamado «transporte sucesivo o cumulativo», que es un contrato único en cuya ejecución varios porteadores efectuarán físicamente el transporte de las mercancías, por itinerarios parciales, hasta el lugar de su entrega459, adhiriéndose al contrato mediante la aceptación de las mercancías y de la carta de porte, y respondiendo todos ellos frente al cargador o el destinatario460.

\section{c) El papel de los intermediarios en la contratación del transporte}

Junto a la persona del porteador es posible que intervengan otros sujetos en la contratación del transporte, los intermediarios, que realizan actividades auxiliares o complementarias del transporte ${ }^{461}$. Como se vio, en todos los supuestos de intermediación, el intermediario resulta obligado a asumir frente al usuario la posición de transportista (contractual), y frente al transportista efectivo la de cargador ${ }^{462}$. De entre las entidades físicas o jurídicas que desempeñan el papel de mediador en el transporte, cabe señalar las siguientes actividades auxiliares y complementarias del transporte terrestre a las que se refiere la LOTT463:

En primer lugar, las agencias de transporte ${ }^{464}$ aparecen reguladas en el artículo 120.1 LOTT465 como aquellas empresas que realizan actividades interpuestas o de mediación entre los usuarios y los transportistas466. Las agencias

459 Véase F. JUAN Y MATEU, «El contrato de transporte continuado», RDT, núm. 2, 2009, pp. 21-22.

${ }^{460}$ F.C. LÓPEZ RUEDA, El régimen..., cit., p. 165. Con detalle, infra, Cap. IV, sub X.2.2.

${ }^{461}$ I. QUINTANA CARLO, «Contrato de transporte terrestre», en R. Bercovitz Rodríguez-Cano (dir.), Tratado de contratos: Contratación del transporte y la navegación, Tomo V, Tirant lo Blanch, Valencia, 2009, p. 5093.

462 F J. SÁNCHEZ-GAMBORINO, El contrato..., cit., p. 29.

463 Véase J.M. Ribelles ARELLANO, «El transporte...», cit., pp. 310 y ss.

464 Con detalle sobre esta figura, L.M. PiloñEta Alonso, Las agencias de transporte de mercancías, Bosch, Barcelona, 1997.

465 Conforme a su tenor actual, tras la reforma por la Ley 9/2013, el art. 120 LOTT define las agencias de transporte como aquellas «empresas especializadas en intermediar en la contratación de transportes de mercancías, como organización auxiliar interpuesta entre los usuarios y los transportistas. En el ejercicio de su actividad las agencias podrán desarrollar todas las actuaciones previas de gestión, información, oferta y organización de cargas y servicios necesarias para llevar a cabo la contratación de los transportes».

466 F.J. SÁNCHEZ-GAMBORINO y J. GAITÁN REBOLLO, Factbook..., cit., p. 248. 
han de contratar en nombre propio tanto con el transportista como con el usuario o cargador, asumiendo las responsabilidades y las obligaciones del cargador frente al transportista, y las del transportista frente al usuario o al cargador 467.

En segundo lugar, los transitarios 468 tienen por objeto organizar los transportes internacionales, $y$, en todo caso, aquellos que se efectúen en régimen de tránsito aduanero, realizando en relación con ellos actividades como la contratación en nombre propio con el porteador, o la recepción de las mercancías y su puesta a disposición del transportista designado por el cargador (art. 126 LOTT) 469.

En tercer lugar, los almacenistas-distribuidores son, según el tenor reformado del artículo 125 LOTT, personas físicas o jurídicas que reciben en depósito en sus locales mercancías ajenas para su almacenaje, ruptura de carga, u otras funciones complementarias que resulten necesarias, y llevan a cabo o gestionan la distribución de las mismas, de acuerdo con las instrucciones de los depositantes 470 .

En cuarto lugar, los centros de información y distribución de cargas, cuya finalidad es la de «contribuir a un mejor ajuste de la oferta y la demanda de transporte, en las plazas o zonas económicas que así lo requieran» (art. 124.1 LOTT). Se añade en el mismo precepto que estos sujetos «servirán fundamen-

467 E. MAPELLI, El régimen jurídico del transporte, Madrid, 1987, p. 569; I. QuINTANA CARLO, «Contrato...», cit., p. 5093.

468 Con detalle sobre esta figura, A.Ma . ToBío RIVAS, Los transitarios en el transporte nacional e internacional: régimen jurídico privado, Comares, Granada, 2007.

469 F.J. SÁNCHEZ-GAMBORINO y J. GAITÁN REBOllo, Factbook..., cit., pp. 250 y ss. Véase también F.J. SÁNCHEZ ORTIZ, "Régimen jurídico de los transitarios en los países de la Comunidad Económica Europea», RGD, 1986, pp. 3.827 y ss.; y A.M. ToBío RIVAS, Los transitarios..., cit. El actual art. 126 LOTT define los transitarios como aquellas «empresas especializadas en organizar, por cuenta ajena, transportes internacionales de mercancías, recibiendo mercancías como consignatarios o entregándolas a quienes hayan de transportarlas y, en su caso, realizando las gestiones administrativas, fiscales, aduaneras y logísticas inherentes a esa clase de transportes o intermediando en su contratación».

470 Vid. también F. JuAn y Mateu, Los contratos de logística, Marial Pons, Madrid, 2009, pp. 36-37. Según su nueva regulación recogida en la LOTT tras la reforma por la Ley 9/2013, se trata de «empresas especializadas en actuar como depositarias de mercancías ajenas que, además, se encarguen de distribuirlas o de gestionar su distribución, conforme a las instrucciones recibidas del depositante. En el ejercicio de su función, el almacenista-distribuidor podrá desarrollar otras tareas tales como consolidación o ruptura de cargas, gestión de existencias u otras que resulten preparatorias o complementarias del transporte y distribución de las mercancías almacenadas». 
talmente de punto de encuentro entre oferentes y demandantes de transporte, realizando funciones de información y canalización de ofertas y demandas y prestando servicios encaminados a propiciar las fases preparatorias del contrato de transporte, en cuya conclusión en ningún caso podrán participar directamente dichos centros en nombre propio» (art. 124.2 LOTT). Del tenor de la norma se desprende que los centros de información y distribución de cargas son considerados «auténticos mediadores o corredores», dado el papel típico que desempeñan en acercar y poner en contacto a oferentes y demandantes de transporte, además de realizar labores de información y prestar servicios encaminados a facilitar las etapas preparatorias del transporte 471 .

Por último, el operador logístico, o «proveedor de servicios logísticos» como se le denomina a veces, realiza, como su propio nombre indica, una actividad empresarial especializada en la prestación de servicios logísticos. La figura del operador logístico como intermediario ha surgido de la evolución de otras entidades tradicionales, como transportistas, depositarios y los intermediarios antes mencionados ${ }^{42}$. En cuanto a la función que realiza el operador logístico, el artículo 122 LOTT señala que se ocupa de organizar, gestionar y controlar, por cuenta ajena, todas las operaciones de aprovisionamiento, transporte, almacenaje o distribución de mercancías, utilizando para ello las infraestructuras, tecnología y medios propios o ajenos que facilitan el ejercicio de su actividad.

\subsection{El destinatario}

Como se ha tenido ocasión de señalar, en el contrato de transporte es frecuente que aparezca un tercero ajeno a la relación contractual, la persona a la que va dirigida la mercancía y a cuya disposición debe ponerla el porteador en el lugar de destino pactado (art. 4.3 LCTTM). Este tercero recibe el nombre de destinatario o consignatario473. La persona del destinatario, así como sus derechos y

${ }^{471}$ A.M ${ }^{\text {a }}$. TOBÍo RIVAS, Los transitarios..., cit., p. 128.

472 F. JuAn y Mateu, Los contratos..., cit., p. 35.

$473 \mathrm{El}$ «consignatario» en cuanto destinatario de la expedición no debe confundirse con el «consignatario de buques» en el Derecho marítimo, que es un representante del fletador o el armador, que efectúa por cuenta de éste todas las gestiones, negocios y gastos producidos por las mercancías en puerto. Cfr. el art. 319 de la Ley 14/2014, de 24 de julio, de Navegación Marítima (LNM). 
obligaciones serán objeto de estudio más adelante en el texto, al analizar la posición jurídica del destinatario en el contrato de transporte terrestre de mercancías, poniendo de relieve el mecanismo jurídico por medio del cual éste puede ejercitar los derechos que deriven del contrato de transporte 474 .

\section{La documentación del contrato de transporte terrestre de mercancías: la carta de porte}

\section{Aspectos generales}

La explicación del mecanismo por medio del cual se configura la posición jurídica del destinatario en el contrato de transporte ha dado lugar a un cierto debate doctrinal475. De entre las opiniones vertidas al respecto, cabe mencionar aquella que afirma que la posición jurídica del destinatario se sustenta sobre su mención en la carta de porte (o el conocimiento de embarque) ${ }^{476}$. Esta postura ha sido descartada por muchos autores, debido a su inconsistencia y al hecho de que en la práctica a veces sucede que la carta de porte no se expide o no indica la persona del destinatario. Y ello porque el consignatario de la carga puede determinarse después, durante el transporte, mediante indicaciones del cargador o remitente al porteador, en ejercicio del derecho de disposición, lo cual se opone a esta postura que hace de la carta de porte la fuente legal de la que surge y a través de la que se configura la posición jurídica del destinatario. Es más, como podrá comprobarse en el epígrafe siguiente, la carta de porte no es más que un

474 Como se ha tenido ocasión de señalar, el mecanismo mediante el cual se le permite al destinatario ejercitar los derechos que deriven del contrato de transporte es la estipulación a favor de tercero (art. $1.2572^{\mathrm{a}} \mathrm{Cc}$ ), de manera que, por lo general, se entiende que el de transporte es un «contrato a favor de tercero». De hecho, el contrato de transporte es una de las manifestaciones típicas y más frecuentes en la práctica de est tipo contractual.

475 Véase el segundo capítulo, que se ocupa del contrato a favor de tercero y explica el mecanismo que permite al tercero (aquí, el destinatario) exigir en su propio nombre el derecho de crédito estipulado a su favor.

${ }^{476} \mathrm{Y}$ ello por entender que el documento cumple la función de identificar al destinatario al figurar entre las menciones que conforman el contenido mínimo de la carta. En aquellos casos en que el documento se hace llegar al destinatario (el conocimiento de embarque, fundamentalmente), éste faculta al destinatario, además, para exigir la entrega de las mercancías, previa presentación del original del documento que haya recibido del cargador. 
instrumento probatorio de la existencia del contrato y su ausencia no afecta a su validez 477 .

\section{Naturaleza jurídica de la carta de porte y ejemplares a emitir}

En el transporte terrestre de mercancías es habitual emitir un documento escrito denominado «carta de porte», cuya finalidad es acreditar el hecho de la celebración del contrato y su contenido478. En efecto, según el artículo 4 CMR, la carta de porte es un documento que hace fe de la existencia de un contrato de transporte y reviste, además, la calidad de un instrumento probatorio privilegiado, por la dificultad de probar, en su ausencia, los términos habitualmente incluidos en ella. Pero ello no obsta para constatar que su naturaleza jurídica es meramente declarativa y no constitutiva del contrato479.

La emisión de este documento en la reglamentación del transporte no significa necesariamente que el contrato de transporte terrestre de mercancías sea un contrato de carácter formal. Antes al contrario, es prescindible documentarlo por escrito, siendo un contrato consensual que se perfecciona por el mero

477 La carta de porte es el documento que se expide en el transporte terrestre de mercancías y su régimen jurídico difiere del de los documentos empleados en otros modos, señaladamente, el transporte marítimo, donde el conocimiento de embarque es un títulovalor que proporciona a su poseedor el derecho a obtener y a reclamar en destino las mercancías mencionadas en el documento, sin perjuicio de servir también como título contractual en el que se reflejan los derechos y obligaciones de las partes, además de las cláusulas y estipulaciones que se tengan por conveniente. Vid. A. EMPARANZA SOBEJANO y J.M. MARTíN OSANTE, «El transporte marítimo (II) contrato de transporte marítimo de mercancías en régimen de conocimiento de embarque», en F. Martínez Sanz (dir.) y A. Puetz (coord.), Manual de Derecho del transporte, cit., pp. 119 y ss. Por su parte, y hasta la derogación de los preceptos correspondientes por la Ley 15/2009, el transporte ferroviario interno comportaba la emisión de dos documentos diferentes, la llamada «declaración de expedición» (arts. 351 Ccom y 111 del Reglamento de Policía de Ferrocarriles, de 8 de septiembre de 1878) y el llamado "talón» (art. $113.4^{\circ}$ del Reglamento). Vid. C. LLORENTE GÓMEZ DE SEGURA, «El contrato de transporte de mercancías», en J.M ${ }^{\mathrm{a}}$. de la Cuesta Rute (dir.) y E. Valpuesta Gastaminza (coord.), Contratos mercantiles, T. II, Bosch, Barcelona, 2009, p. 374. Desde la entrada en vigor de la LCTTM (que en este punto no distingue en función del modo de transporte, siempre que éste sea terrestre), también en el transporte ferroviario se emplea un único documento, la carta de porte.

478 M. Broseta Pont y F. Martínez Sanz, Manual..., 23 a ed., cit., p. 166. Cfr. también la cl. 2.1 de las Condiciones generales de contratación de los transportes de mercancías por carretera, aprobadas por Orden FOM/1882/2012, de 1 de agosto: «Se denomina carta de porte al documento en que se hagan constar todas o una parte de las condiciones de realización del transporte contratado».

479 F.J. SÁNCHEZ-GAMBORINO, El contrato..., cit., p. 78. 
acuerdo de voluntades entre las partes, así que no se exige para su prefección el cumplimiento de ningún requisito documental o formal480.

En cuanto al número de ejemplares en que debe emitirse, tanto el artículo 5.1 CMR como el artículo 11.1 LCTTM indican que la carta de porte se expedirá en tres ejemplares originales, que firmarán el remitente y el transportista. El hecho de que se exijan «originales» pone de manifiesto la relevancia que tienen todos ellos como medio de prueba de la existencia del contrato y de su contenido, a pesar de que, como habrá ocasión de comprobar, no todos los ejemplares cumplen la misma función ${ }^{481}$. Concretamente, el primer ejemplar de la carta de porte se entregará al cargador, el segundo viaja con las mercancías y el tercero permanece en poder del transportista.

Añade el artículo 5 CMR en su apartado segundo que, en caso de que se empleen diferentes vehículos para el transporte o cuando así lo aconseje el hecho de que se transporten mercancías de clases diferentes o distintos lotes (es decir, razones relacionadas con las dimensiones o volumen de las mercancías u otras circunstancias), las partes contratantes tienen derecho a exigir la emisión de varias cartas de portes, una por cada vehículo o lote, o clase de mercancías (cfr. art. 10.4 LCTTM). Sin embargo, el transporte sucesivo no es alcanzado por esta norma, pues el mero hecho de que participen varios porteadores no justifica que se emitan más ejemplares de la carta de porte de las que deban emitirse conforme al artículo 5.1 CMR482.

Con anterioridad a la derogación de los preceptos correspondientes por la Ley 15/2009, la regulación en el Código de comercio resultaba poco precisa y nada se decía acerca del sujeto sobre el que recaía el deber de emitir y formalizar la carta de porte, limitándose en su artículo 350 a indicar que «[t]anto el cargador como el porteador de mercaderías o efectos, podrán exigirse mutuamente que se extienda una carta de porte», indicación que subraya el carácter consensual del contrato de transporte («podrán»). Idéntico es el criterio empleado en el artículo 10.1 LCTTM, que igualmente faculta (que no obliga) a las partes a

480 C. LLORENTE GÓMEZ DE SEGURA, «El contrato...», cit., p. 374.

${ }^{481}$ C. LLORENTE GómEZ DE SEGURA, «El contrato...», cit., p. 377.

482 J. PUTZEYS, Le contrat..., cit., p. 123. 
exigir a la otra que se extienda una carta de porte, que será firmada por ambas partes (art. 11.1 LCTTM). El Convenio CMR, en cambio, guarda silencio al respecto. De ello deriva que el documento puede ser expedido por cualquiera de las partes, pues el contrato se perfecciona con el consentimiento de las partes contratantes que son libres de decidir el sujeto que debe emitir la carta de porte, sin que sea este un derecho exclusivo de ninguna de las dos. Su expedición puede corresponder, así, tanto al transportista como al cargador, aunque la emisión de dicho documento suele situarse, dada su función de recibo de la carga, en la esfera del transportista 483 .

Por lo que respecta a la firma de la carta, será válido, además de la firma autógrafa, el empleo de medios mecánicos, p.ej., sellos, o de cualquier otro medio que resulte conveniente ${ }^{484}$. En efecto, según el artículo 5.1 CMR, las firmas podrán estar impresas o ser sustituidas mediante sello del remitente o del transportista «si la legislación del Estado en el que se haya expedido la carta de porte» lo permite ${ }^{485}$, y la española sí lo hace (art. 11.2 LCTTM).

Resulta obvio que la firma de los contratantes no constituye un elemento necesario para la validez del contrato, es decir, su ausencia no afecta en absoluto a la existencia de éste, pues es consensual y no exige observar para su perfección ningún requisito formal. Ahora bien, la firma de las partes sí es necesaria para que las declaraciones de voluntad y otras menciones incluidas en la carta de porte sean oponibles frente a terceros, incluido el destinatario, es decir, para conseguir que la carta de porte despliegue todos sus efectos como instrumento probatorio486. Así, en defecto de firma o de los sellos correspondientes, la carta

\footnotetext{
483 F.J. SÁnChez-GAMborino y J. Gaitán Rebollo, Factbook...cit., p. 99 y 100; C. LLORENTE GÓMEZ DE SEGURA, «El contrato...», cit., p. 376.

$484 \mathrm{M}^{\mathrm{a}}$.J. GUERRERO LEBRÓN, «La carta de porte: requisitos de emisión y funciones», $R D T$, núm. 6, 2010, p. 91.

485 C. LLORENTE GÓMEZ DE SEGURA, «El contrato...», cit. p. 378.

486 A.J. RECALDE CASTELLS, «La firma de las partes del contrato en la carta de porte (firma manual y firma impresa, mecánica o electrónica): El régimen del Código de Comercio y del Convenio Internacional sobre Transporte por Carretera (CMR)», RGD, núm. 606, 1995, p. 2238.
} 
de porte se convierte en un documento irregular487, que queda desprovisto del valor probatorio pleno del que gozaría si estuviera firmada 488 .

\section{Contenido de la carta de porte}

La comparación de los catálogos de menciones a incluir en la carta de porte en los artículos 10 LCTTM y 6 CMR revela una coincidencia prácticamente total 489. Concretamente, de acuerdo con el artículo $6 \mathrm{CMR}$, «[l]a Carta de Porte debe contener las indicaciones siguientes:

a) Lugar y fecha de su redacción.

b) Nombre y domicilio del remitente.

c) Nombre y domicilio del transportista.

d) Lugar y fecha de la toma de carga de la mercancía y lugar previsto para la entrega.

e) Nombre y domicilio del destinatario.

f) Denominación corriente de la mercancía y del modo de embalaje, así como denominación generalmente reconocida de la mercancía, si ésta es peligrosa.

g) Número de paquetes, sus marcas particulares y sus números.

h) Cantidad de mercancía, expresada en peso bruto o de otra manera.

487 Así lo indica el art. 4.1 CMR en su inciso segundo. Al respecto, CLARKE entiende que, también en el caso de que se omita alguna de las menciones de inserción obligatoria (las del art. 6, apartados 1 y 2 CMR), se estaría ante una carta de porte de irregular. Sin embargo, esta irregularidad en nada afecta a la existencia o a la validez del contrato de transporte, como así lo indica el propio art. 4 CMR. Vid. M.A. CLARKE, International..., cit., p. 61; así como J.F. DUQUE DOMÍnGUEZ, «Irregularidad o inexistencia de la carta de porte», en id. y F. Martínez Sanz (dirs.), A. Emparanza Sobejano y M ${ }^{\mathrm{a}}$.V. Petit Lavall (Coords.), Comentarios a la Ley de Transporte Terrestre, Aranzadi, Cizur Menor, 2010, p. 174.

488 C. Llorente Gómez DE Segura, «El contrato...», cit. p. 378; M.A. Clarke, International..., cit., p. 63.

489 Obsérvese que también en el -hoy derogado- art. 350 Ccom se especificaba el contenido de la carta, aunque el número de menciones a incluir es considerablemente más reducido. Concretamente, a tenor de la norma debían incluirse en la carta: «1. El nombre, apellido y domicilio del cargador. 2. El nombre, apellido y domicilio del porteador. 3. El nombre, apellido y domicilio de la persona a quien o a cuya orden vayan dirigidos los efectos, o si han de entregarse al portador de la misma carta. 4. La designación de los efectos, con expresión de su calidad genérica, de su peso y de las marcas o signos exteriores de los bultos en que se contengan. 5. El precio del transporte. 6 . La fecha en que se hace la expedición. 7. El lugar de la entrega al porteador. 8. El lugar y el plazo en que habrá de hacerse la entrega al consignatario. 9. La indemnización que haya de abonar el porteador en caso de retardo, si sobre este punto mediare algún pacto». Las diferencias que esta norma presenta con las más modernas regulaciones en el CMR y en la LCTTM no son sino consecuencias de la evolución del sector de transporte. Así, C. LLORENTE GÓMEZ DE SEGURA, «El contrato...», cit. p. 378 . 
i) Gastos relativos al transporte (precio del mismo, gastos accesorios, derechos de Aduana y otros gastos que sobrevengan desde la conclusión del contrato hasta el momento de entrega de la mercancía).

j) Instrucciones exigidas por las formalidades de Aduana y otras.

k) Indicación de que el transporte está sometido, aunque se haya estipulado lo contrario, al régimen establecido por el presente Convenio.

2. En su caso, la Carta de Porte debe contener, además, las indicaciones siguientes:

a) La prohibición de transbordo.

b) Gastos que el remitente toma a su cargo.

c) Suma del reembolso a percibir en el momento de la entrega de la mercancía.

d) Valor declarado de la mercancía y la suma que representa el interés especial en la entrega.

e) Instrucciones del remitente al transportista concernientes al seguro de la mercancía.

f) Plazo convenido en que el transporte ha de ser efectuado.

g) Lista de documentos entregados al transportista.

3. Las partes del contrato pueden añadir en la Carta de Porte cualquier otra indicación que juzguen útil».

De su redacción -que, como se decía, coincide en lo esencial con la enumeración contenida en el artículo 10 LCTTM - se desprende que las menciones a incluir están divididas en tres clases: el primer apartado recoge las menciones obligatorias que toda carta de porte sujetada al CMR deberá contener (las que identifican a las partes del contrato y al destinatario, así como a la mercancía cuyo traslado constituye el objeto del contrato); el segundo enumera las menciones que resulta necesario incluir sólo si las partes deciden pactarlas, en cuyo caso deberán figurar en la carta (son «condicionalmente obligatorias); el tercer apartado, en fin, faculta para introducir en la carta de porte cualquier otra indicación o mención que las partes consideren conveniente incluir.

Como así se desprende de lo dispuesto en los preceptos citados, debe incluirse todas las menciones previstas en ellos con respecto al contenido de la carta de porte. No obstante, la ausencia o insuficiencia de dichas menciones no privará a ésta de eficacia respecto a los datos que sí se han incluido, puesto que la Ley niega el carácter formal al contrato de transporte. Así, la carta de porte resulta eficaz, aunque no contenga todas las indicaciones que debiera contener. 
Y ello es perfectamente razonable, como señala DíAz MoREno, «si se tiene en cuenta que hay circunstancias sobre las que la Ley ni siquiera exige terminantemente un acuerdo de las partes por cuanto suple su voluntad»490.

Del contenido de la carta de porte lo que resulta más problemático es la posición jurídica del destinatario. Aun cuando éste se designe en la propia carta, no forma parte de la relación contractual subyacente; no firma la carta de porte; ni tampoco adquiere ningún derecho propio por la mera inclusión de su nombre en ésta. Por ello, al integrarse el destinatario como sujeto ajeno posteriormente al contrato, su designación en la carta en esta primera fase de la ejecución del contrato no desvela el fundamento y el alcance de la eficacia probatoria del documento; al menos hasta que acepte la entrega de las mercancías y la reciba con el segundo ejemplar de la carta de porte, devolviendo firmado el tercer ejemplar un un recibo de la entrega al porteador. Con la solicitud de entrega, el destinatario se convierte en acreedor directo del porteador y adquiere legitimación activa frente a éste en caso de no estar de acuerdo sobre el estado de la mercancía o las causas que hayan ocasionado los menoscabos ${ }^{491}$.

Por último, ha de advertirse que, en ocasiones, el destinatario es también el cargador, esto es, coinciden en una persona. En este caso, será necesario indicar ese hecho en la carta de porte, de lo contrario le resultaría imposible al porteador saber a quién debe entregar la mercancía en destino ${ }^{492}$.

\section{Funciones de la carta de porte}

Como se decía, la importancia de la carta de porte reside básicamente en su condición de documento probatorio que hace fe de la existencia y del contenido del contrato de transporte, así como de la recepción de las mercancías por el transportista (arts. 4 y 9.1 CMR, 14.1 LCTTM). De ello se deduce que la carta cumple una función probatoria iuris tantum de la existencia del contrato de

\footnotetext{
490 Así sucede, p.ej., si no se ha pactado el precio del transporte -en cuyo caso se aplicará el art. 39.4 LCCTM - o si las partes no han fijado plazo de entrega -debiendo aplicarse entonces el art. 33.1 de la Ley-. Así, A. DíAz MORENO, «El contrato...», cit., p. 658.

491 R. Padilla González, M. Clavero ternero y M.Á. Pendón Meléndez, «Transportes...», cit., p. 532.

492 J. PUTZEYS, Droit..., cit., p. 141.
} 
transporte y sus condiciones493, y también una función económica en el sentido de que sirve como un recibo de la mercancía entregada. Existe una coincidencia total entre la Ley del Contrato de Transporte Terrestre de Mercancías y el CMR a la hora de identificar la función básica y esencial de la carta de porte como un instrumento probatorio, que -al generar una presunción iuris tantum-goza de un carácter privilegiado respecto a otros instrumentos probatorios.

En cuanto al papel que desempeña la carta de porte como un medio probatorio privilegiado, éste ya se deducía de lo dispuesto en el artículo 353 Ccom, que adopta el mismo criterio que el artículo 9.1 CMR, matizado por la STS de 12 de diciembre de 1968 (RJ 1968, 5842), en el sentido de que «las cartas de portes son documentos que, salvo prueba en contrario, dan fe de las condiciones del transporte»494. A este respecto, la STS de 17 de mayo de 1993 (RJ 1993, 3555) señaló que el uso de la carta de porte como instrumento probatorio ha de ser racional y que no puede ser el único medio de prueba que pueda utilizarse de manera absoluta. Así, «en defecto de carta de porte, se estará al resultado de las pruebas jurídicas»495, teniendo en consideración las justificaciones que sean

493 C. LLORENTE GÓMEZ DE SEGURA, «Contratos...», cit., p. 153.

494 A tenor del art. 353 Ccom, "[l]os títulos legales del contrato entre el cargador y porteador serán las cartas de porte, por cuyo contenido se decidirán las contestaciones que ocurran sobre su ejecución y cumplimiento, sin admitir más excepciones que las de falsedad y error material en su redacción». De este precepto se ha inferido que en el sistema del Código de Comercio la carta de porte constituía un elemento probatorio «privilegiado» sobre los demás medios de prueba [STS de 12 de diciembre de 1968 (RJ 1968, 5842); SAP Valencia de 12 de abril de 1995 (AC 1995, 796)]. Así, C. LLORENTE GómEZ DE SEGURA, «Contrato...», cit., p. 389.

495 A tal efecto, puede utilizarse cualquier medio de prueba admitido en derecho. Obsérvese que, conforme a lo dispuesto en el art. $51 \mathrm{Ccom}$, y siendo generalmente de naturaleza mercantil el contrato de transporte, la declaración de testigos como único instrumento de prueba no es suficiente si la cuantía del contrato excede la - hoy irrisoria- cifra de 1.500 ptas. (unos 9 euros), debiendo aportarse otras pruebas admitidas en el Derecho. No obstante, la vigencia del precepto es discutida al ser anterior a la entrada en vigor de la actual Ley de Enjuiciamento Civil, que obliga a valorar la prueba testifical conforme a los criterios de la sana crítica [cfr. la STS núm. 919/2011, de 23 de diciembre (RJ 2012, 1895)].

Por su parte, no pueden resultar ya de aplicación - por haber sido derogados por la propia Ley de Enjuiciamiento Civil- los artículos 1214 y 1244 a 1248 Cc, citados aún por I. QUINTANA CARLO, «Contrato de transporte», en A.B. Rodríguez-Cano (dir.) y Ma aÁ. Calzada Conde (dir. adj.), Contratos mercantiles, Aranzadi, Cizur Menor, 2001, p. 671; F. J. SÁNCHEZ-GAMBORINO, El contrato..., cit., p. 83. 
precisas, tanto respecto a las personas mencionadas en dicha carta, como a los demás efectos dimanados del contrato de transporte 496 .

En segundo lugar, también hace prueba la carta de porte de la recepción de la mercancía por parte del transportista en el lugar de origen, es decir, cumple la función de un recibo de ésta. Así lo establece claramente el artículo 14.1 LCTTM, al señalar que «[l]a carta de porte firmada por ambas partes hará fe [...] de la recepción de las mercancías por el porteador, salvo prueba en contrario». Es más, acto seguido se establece en el apartado segundo del artículo 14 LCTTM que, «[e]n ausencia de anotación en la carta de porte, o en documento separado firmado por el porteador y el cargador o expedidor, de las reservas suficientemente motivadas del porteador, se presumirá que las mercancías y su embalaje están en el estado descrito en la carta de porte y con los signos y señales en ella indicados». Es decir, la falta de reconocimiento de la mercancía en origen y, consecuentemente, de anotaciones en la carta de porte sobre el estado divergente de la mercancía en el momento de su recepción, hace nacer una presunción (si bien refutable) de que las mercancías se han recibido por el porteador en el estado descrito en la carta de porte, con todo lo que ello implica desde el punto de vista de la responsabilidad de aquél. Por tanto, aun cuando no exista una «obligación» en sentido técnico-jurídico del porteador de revisar la carga en origen (por mucho que así parezca establecerlo el art. 25.1 LCTTM), éste sí soporta una «carga» de examinar las mercancías, so pena de sufrir las consecuencias de la presunción de haber recibido las mercancías en buen estado aparente.

En tercer lugar, la carta de porte puede servir, asimismo, como recibo de la mercancía en el lugar de destino. Al llegar la mercancía a su destino, el destinatario (o persona que actúe en su nombre) podrá exigir la entrega del segundo ejemplar de la carta de porte (el que viaja con la mercancía) (art. 12, primer inciso LCTTM). Al propio tiempo, el porteador podrá exigir de aquél que «extienda en su ejemplar de la carta de porte [es decir, el tercero, el que permanece en poder del porteador497], o en documento separado firmado por ambos, un reci-

496 I. QUINTANA CARLO, «Contrato...», cit., p. 671.

$497 \mathrm{O}$, incluso, en un cuarto ejemplar que acompañará también a la carga, emitido en el mismo momento en que se expiden los otros tres. Así, J.F. DUQUE DomíngUEZ, «Documen- 
bo sobre las mercancías entregadas» (art. 12, segundo inciso LCTTM). Puede decirse que la firma de este ejemplar por el destinatario es el acto que cierra la operación de transporte, al servir como recibo sobre las mercancías llegadas 498 . Es más, también aquí se establece una presunción de que las mercancías se han recibido por el destinatario en el estado descrito en la carta de porte a no ser que éste manifieste "por escrito sus reservas al porteador o sus auxiliares [señaladamente, el conductor] describiendo la pérdida o avería en el momento de la entrega» o, en el caso de pérdidas o averías no manifiestas, dentro de los siete días naturales siguientes (art. 60.1 y 2 LCTTM)499.

Como se decía, en estos casos puede extenderse el recibo en la propia carta (en el ejemplar del porteador), pero nada obsta para se haga en un documento o recibo separado, firmado por el destinatario. Se constata así, nuevamente, que la carta de porte no es un documento necesario en los contratos de transporte, sino que únicamente despliega efectos probatorios.

Por el contrario, no cumple la carta de porte otra de las funciones que son propias de los conocimientos de embarque, en cuanto documentos de transporte empleados en el transporte marítimo. $Y$ es que la carta no tiene la consideración de título de tradición o título-valor ${ }^{500} \mathrm{y}$, en consecuencia, no concede a su titular la condición de poseedor mediato de la carga. Por ello, éste no podrá

tación de la entrega en destino», en id. y F. Martínez Sanz (dirs.), A. Emparanza Sobejano y $\mathrm{M}^{\mathrm{a}}$.V. Petit Lavall (coords.), Comentarios a la Ley de Transporte Terrestre, cit., p. 170.

${ }^{498}$ Véase, además del art. 12 LCTTM ya citado, el art. 13.1 CMR. En el Derecho previgente, el art. 353 Ccom señalaba que, «cumplido el contrato se devolverá al porteador la carta de porte que hubiere expedido, y en virtud del canje de este título por el objeto porteado, se tendrán por canceladas las respectivas obligaciones y acciones, salvo cuando en el mismo acto se hicieren constar por escrito las reclamaciones que las partes quisieran reservarse, excepción hecha de lo que se determina en el art. 366». De ello se infería que el legislador había incluido la carta de porte, conforme al papel que jugaba como prueba del cumplimiento del contrato, entre los llamados títulos de «rescate», es decir, "rescatada" por aquel que la expidió (el porteador) prueba el cumplimiento de la obligación de entrega de las mercancías y, en consecuencia, del cumplimiento del contrato». Vid. C. LLORENTE GÓMEZ DE SEGURA, «El contrato...», cit., p. 391; I. QUINTANA CARLO, «Contrato...», cit., p. 671.

499 Véase Ma ${ }^{\text {a }}$.J. GUERRERO LEBRÓN, «La carta...», cit., p. 95.

${ }^{500}$ Véase, con detalle sobre esta cuestión (si bien sobre la regulación en el Código de comercio, hoy derogada), A.J. RECALDE CASTELLS, «La firma...», cit., p. 2232, quien se oponía a la opinión a la sazón mayoritaria de que los caracteres de la carta de porte eran los de un título-valor representativo o de tradición. Más recientemente, $\mathrm{M}^{\mathrm{a}}$.J. GUERRERO LEBRóN, «La carta...,» cit., pp. 92 y s. 
transmitir la propiedad de las mercancías durante el transporte mediante la entrega de la carta de porte (art. $609 \mathrm{Cc}$ ), es decir, la entrega de la carta carece de eficacia traslativa.

En el comercio internacional, particularmente en relación a la compraventa internacional que implica el transporte de las mercancías, la carta de porte tiene singular importancia cuando se trata de articular la compra a través de un crédito documentario501. En este caso, dado que el primer ejemplar de la carta de porte permanece en posesión del cargador (que en el contrato de compraventa habrá ocupado la posición de vendedor), la solicitud de cobro ante la entidad bancaria señalada exigirá la presentación, además de otros documentos, de dicho ejemplar de la carta de porte. La carta de porte cumple, así, una importante función de bloqueo, pues encontrándose dicho ejemplar en poder de la entidad bancaria, no puede el cargador-vendedor ya ejercer el derecho de disposición sobre la mercancía y el comprador-destinatario podrá estar seguro de que el contrato de transporte no será modificado unilateralmente por el cargado502.

Junto a la carta de porte, por razones de inspección y control de la circulación de las mercancías en general, existe un documento administrativo, el llamado Documento de Control, cuyo propósito es facilitar el control administrativo de cada transporte y detectar anomalías en el cumplimiento de las normas reguladoras del transporte terrestre y sus actividades auxiliares y complementarias ${ }^{503}$. Dicho documento cumple una función preventiva $\mathrm{y}$, al mismo tiempo, probatoria, al igual que la carta de porte $y$, de hecho, no existe inconveniente para que la propia carta de porte actúe como documento de control, pues éste es «de libre edición» (art. 5 Orden FOM/2861/2012). Y así lo confirma el artículo 2.2 de la Orden, cuando señala que, «[e]n aquellos supuestos en los que el transporte se documente en una carta de porte u otra documentación acreditativa ajustada a la legislación nacional, de la Unión Europea o internacional

${ }^{501}$ Véase F.J. SÁNCHEZ-GAMBORINO y J. GAITÁN REBOLLO, Factbook..., cit., p. 99.

${ }^{502} \mathrm{Al}$ respecto, M ${ }^{\mathrm{a}} . J$. GUERRERO LEBRÓN, «La carta...», cit., p. 96.

503 Véase la Orden FOM/2861/2012, de 13 de diciembre, por la que se regula el documento de control administrativo exigible para la realización de transporte público de mercancías por carretera. Dictada en ejercicio de la facultad concedida por los arts. 147 LOTT y 222 ROTT, la Orden sustituye a otra anterior de 2003, la Orden FOM/238/2003, de 31 de enero. 
vigente en la materia, ésta servirá como documento de control administrativo siempre que contenga todos los datos recogidos en el artículo 6 de esta orden» (y que coinciden, en buena medida, con los que han de figurar en la carta de porte conforme a lo dispuesto en los arts. 10 LCTTM y 6 CMR).

\section{La carta de porte emitida electrónicamente}

Ante el auge de las nuevas tecnologías, cabe preguntarse si se puede emitir una carta de porte electrónicamente, es decir, si se autoriza a las partes contratantes que intercambien o realicen el envío del documento mediante la utilización de técnicas digitales en la contratación, sustituyendo el modo tradicional de las menciones literales por claves, con la incorporación de la firma también transferida por el mismo medio electrónico504. En efecto, debido al desarrollo del comercio internacional y su relación con el transporte, sería positivo poder beneficiarse de las ventajas que introduce la tecnología electrónica en el mundo actual, como la seguridad y la rapidez en la transacción, aumentando así la capacidad de los proveedores de servicios de transporte para poder participar y competir en el mercado global505. Tales consideraciones llevaron al legislador a permitir la emisión electrónica de la carta de porte, si bien condicionada al previo acuerdo de los contratantes506.

En efecto, sólo puede emitirse la carta en este formato si las partes así lo acuerdan, de manera que el uso de este medio digital no surte efecto alguno si ha sido impuesto por una sola de las partes. Con respecto a las consecuencias de tal forma de obrar, parece que sean las mismas que las que se anudan a la negativa de una de las partes a emitir la carta de porte en formato papel, esto es, la

504 F.J. SÁNCHEZ-GAMBORINO, «El nuevo modelo IRU-2007 de carta de porte 'CMR'», en F. Martínez Sanz y Ma . V. Petit Lavall (dirs.), Estudios sobre derecho y economía del transporte: reforma y liberalización, Tecnos, Madrid, 2009, p. 378.

505 J.A. ECHEBARRÍA SÁENZ, «La carta de porte emitida electrónicamente», en J.F. Duque Domínguez y F. Martínez Sanz (dirs.), A. Emparanza Sobejano y Ma .V. Petit Lavall (coords.), Comentarios a la Ley de Transporte Terrestre, cit., 2010, p. 186.

${ }^{506}$ Así lo exige el art. 15 LCTTM cuando establece lo siguiente: «1. Si las partes están de acuerdo, podrán emitir la carta de porte por medios electrónicos con arreglo a la legislación vigente. 2. En este supuesto, la carta de porte deberá consistir en un registro electrónico de datos que puedan ser transformados en signos de escritura legibles». 
contraparte podrá considerarla desistida del contrato (art. 10.6 LCTTM)507. Sin embargo, debe recordarse que estamos ante un contrato no formal, de manera que la carta de porte no es sino un instrumento declarativo y no constitutivo del contrato. El contrato de transporte, por su parte, puede concertarse siempre por vía electrónica, aunque no se haya pactado previamente la utilización de medios electrónicos, pues así lo autoriza el artículo 23.2 de la Ley 34/2002, de 11 de julio, de servicios de la sociedad de la información y de comercio electrónico508.

En el contexto internacional, la posibilidad de emitir una carta de porte electrónica fue admitida a través de un protocolo complementario del CMR509, hecho en Ginebra el 20 de febrero 2008. En su artículo primero, este Protocolo define la carta de porte electrónica como aquella «emitida mediante comunicación electrónica por un transportista, un remitente o cualquier otra parte interesada en la ejecución de un contrato de transporte al que le sea de aplicación el Convenio, incluyendo las indicaciones digitales relativas a la comunicación electrónica en forma de datos adjuntos o unidas de otra forma a dicha comunicación electrónica, en el momento de su expedición o posteriormente, de manera a ser parte integrante de la misma» [sic $]^{510}$. El artículo 2.2 del Protocolo, por su parte, le confiere la misma fuerza probatoria y eficacia que la de la carta de porte escrita y firmada manualmente. Así pues, según este protocolo es equivalente a la tradicional carta de porte, emitida conforme a lo establecida en el Convenio CMR, la carta emitida por medios electrónicos, a la que deberá darse el mismo tratamiento ante los tribunales de justicia511.

${ }^{507}$ Así, J.A. ECHEBARRÍA SÁENZ, «La carta...», cit., p. 192.

${ }^{508} \mathrm{M}^{\mathrm{a}}$. J. GUERRERO LEBRÓN, «La carta...», cit., p. 96.

509 Publicado en el B.O.E. núm. 141, de 14 de junio de 2011.

${ }^{510}$ Parece evidente que, en el último inciso de la traducción española, se ha omitido un verbo. Su versión en inglés, por ejemplo, se refiere a «parcticulars logically associated with the electronic communication by attachments or otherwise linked to the electronic communication contemporaneously with or subsequent to its issue, so as to become a part of the electronic consignment note» (la redonda es nuestra).

${ }^{511}$ F.J. SÁnCHEZ-GAMBORINo y J. GAITÁN REBOlLO, Factbook..., cit., p. 104. 


\section{Ausencia, pérdida o irregularidad de la carta de porte}

\subsection{Ausencia o pérdida}

La carta de porte no es más que un instrumento probatorio que hace fe del consentimiento de las partes sobre el objeto del contrato, que no es otro que el de desviar una prestación, el transporte de cosas, hacia otro sujeto, el destinatario. Como se ha visto, es un instrumento cuya función principal es la de probar la existencia de este contrato y su contenido, pero sin que se erija en elemento constitutivo. Como no puede ser de otra forma, cabe incluso que el contrato se formalice por escrito y, con posterioridad, se emita además una carta de porte, en cuyo caso «nada [prueba ésta] contra el documento en que [el contrato hubiese sido consignado], si por exceso u omisión se apartaren de él, a menos que conste expresamente la novación del primero» (art. 1.224 Cc). En caso de discordancia prevalece, por ello, el documento contractual original (lo que no priva a la carta de porte, como enseguida se verá, de su valor probatorio).

Como consecuencia, ni la ausencia inicial de la carta de porte ni su pérdida posterior invalidan el contrato de transporte, ni afectan a su existencia o validez (arts. 4 CMR y 13.1 LCTTM), que en ambos supuestos seguirá sujeto al régimen jurídico que le es propio, esto es, el CMR en caso de que se trate de un transporte internacional (Art. 4 CMR).

Como quiera que el cometido de la carta de porte es hacer fe del contenido del contrato, en caso de pérdida o ausencia de sus tres ejemplares, el juez tendrá que atender a otras pruebas, disponiendo para ello de un amplio margen de discrecionalidad512. Además, y como se vio, el carácter probatorio privilegiado de la carta de porte no es de índole absoluta, sino que puede quedar desvirtuado por otras pruebas («salvo prueba en contrario», reza el artículo 14.1 i.f. LCTTM).

${ }^{512}$ J. PuTZEYS, Le contrat..., cit., p. 126. 


\subsection{Irregularidad}

En el párrafo primero del artículo 13 LCTT se establece una norma relevante, referente a la emisión de cartas irregulares (y, como se vio, a los transportes que se efectúan en ausencia de carta de porte). De su lectura se concluye que la irregularidad de la carta de porte no afecta en absoluto a la existencia o validez del contrato. Y es una norma lógica pues, como se ha visto, el contrato de transporte no es un negocio formal, de manera que su formalización en un documento escrito no es necesaria ni constituye un elemento fundamental para la perfección del contrato. Como consecuencia, la emisión de la carta de porte no es una obligación de las partes, salvo que una de ellas lo pida expresamente (art. 10.1 y 6 LCTTM), sino una mera carga (cuyo incumplimiento priva a las partes de un medio de prueba privilegiado), razón por la cual la Ley contempla la desvinculación entre la documentación y el contrato513.

La carta es irregular si falta alguna de las menciones que han de incluirse en ella, o cuando carece de la firma de las partes contratantes o de una de ellas, o cuando el modo de firmarla no se corresponde con el previsto por la ley en el artículo 11.2 LCTTM, es decir, en caso de que la carta haya sido firmada, por ejemplo, mediante estampación de un sello514. En general, se entiende que es irregular la carta de porte en caso de «no adecuación del documento a las exigencias» de la Ley515. Ahora bien, como ya se ha dicho, ni la inexactitud, ni la irregularidad o la insuficiencia de la carta de porte afectan por sí solas a la existencia del contrato de transporte ni a su validez. De hecho, la carta mantiene su eficacia respecto de las menciones que sí se han incluido (art. 13.1 LCTTM), aunque para preservar su carácter probatorio debe al menos haberse firmado válidamente por ambas partes.

Ello no significa, como es natural, que la irregularidad de la carta no tenga consecuencia alguna (más allá de la que puedan derivarse en el plano administrativo si la carta cumple, al propio tiempo, la función del documento de con-

513 J.F. DUQue DomíngueZ, «Irregularidad...», cit., p. 173 y ss.

${ }^{514}$ Recuérdese que, a tenor del precepto citado, «[s]erá válida la firma de la carta de porte por medios mecánicos, mediante estampación de un sello, o por cualquier otro medio que resulte adecuado, siempre que quede acreditada la identidad del firmante».

515 F.J. SÁNCHEZ-GAMBORINO y J. GAITÁN REBOLLO, Factbook..., cit., p. 100. 
trol al que antes se aludía). Y es que, en caso de que existan irregularidades en la carta, la Ley 15/2009, en su artículo 10.7, prevé el resarcimiento de los daños y gastos causados por la existencia de tales vicios, a cargo de la parte a la que corresponda incluir los datos inexactos o insuficientes en la carta de porte, ya sea el porteador o el cargador 516 .

\section{Comprobación de las menciones de la carta de porte con anterioridad a la recepción de las mercancías en el lugar de origen}

De todo lo anterior se desprende que la carta de porte se considera un título legal entre el cargador y el porteador, que contiene la descripción de las mercancías objeto del contrato. Para desplegar los efectos que le son propios, la carta de porte tiene que ser firmada en todo caso por el porteador, quien asume, junto con la posesión física de la carga, la obligación de restituirla en el lugar convenido517. De ahí que el transportista deba comprobar y verificar las mercancías, ya que es el responsable de las que están bajo de su custodia, conforme a las declaraciones del cargador incluidas en la carta de porte en el momento de la toma en carga de las mercancías. Y así lo reconoce el artículo 8 CMR cuando establece, en su primer párrafo, que el transportista queda obligado a verificar la exactitud de los datos de la carta de porte respecto al número de bultos, sus marcas y números, además de revisar el estado aparente de la mercancía y de su embalaje.

Dicha revisión permite al porteador formular reservas, esto es, poner de relieve los defectos y los menoscabos que tuvieran las mercancías con respecto a su descripción. Y es que, de no efectuar tales reservas, se presumirá (salvo prueba en contrario) que las mercancías se han recibido en el estado descrito en la carta de porte. Es por ello por lo que, si detecta algún tipo de incongruencia entre el contenido de la carta y el estado de la mercancía, deberá indicarlo en la carta de porte, so pena de que se presuma en su contra el buen estado aparente de la carga. En definitiva, con la formulación de la reserva el porteador deja

${ }^{516}$ Cfr. J.F. DUQue DomínGUEZ, «Irregularidad...», cit., p. 175.

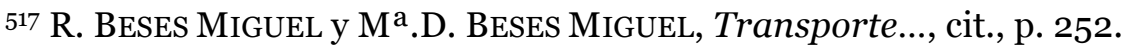


constancia de que la mercancía «a él ya se le entregó mal»518. La comprobación de la carga no es, por ello, una obligación en sentido técnico-jurídico sino una carga, cuyo incumplimiento empeora la situación procesal del transportista, quien deberá probar por otros medios que ya en origen la mercancía no se correspondía con lo que indicaba la carta de porte (lo cual, de ordinario, le resultará muy difícil o incluso imposible).

En cuanto a la exactitud de las menciones insertas en la carta de porte en relación con el número de bultos, sus marcas y números, el cargador ha de incluir en la carta de porte todas las menciones que detallan la naturaleza de las mercancías, la cantidad de bultos, sus marcas identificativas y el peso bruto. Deberá, en consecuencia, hacer entrega de la mercancía al transportista en buen estado físico y, sobre esta base, le incumbe al transportista controlar y comprobar externamente - es decir, visualmente o, en su caso, de forma táctil, pudiendo eventualmente abrir los bultos para comprobar el contenido de éstos (art. 8.3 CMR)519- las indicaciones incluidas en la carta de porte por el cargador (art. 8.1 CMR). Así, la comprobación y control de la mercancía implica una verificación ordinaria de su estado aparente y no intrínseco.

En este mismo contexto, señala SÁNCHEZ-GAMBORINo que el transportista «no es -ni tiene por qué ser- un experto en embalaje», por lo que le bastará con comprobar lo que está al alcance de los ojos de una persona normalmente prudente y atenta520. En otras palabras, la revisión que va a realizar el transportista no implica una comprobación en profundidad o interna de la mercancía, ni tampoco de su calidad intrínseca; el control se centrará en general sobre el estado aparente, salvo si se trata de un tipo de mercancía que está sometido según su particular naturaleza a un tratamiento específico. Ello sucede, por ejemplo, cuando debe controlarse la temperatura por medio de termómetros o cualquier

${ }^{518}$ F.J. SÁNCHEZ-GAMbORINO, El contrato..., cit., p. 108.

${ }_{519}$ Aunque el contrato de transporte entre cargador y transportista está basado en la buena fe, para prevenir litigios futuros en caso de se produzca un siniestro, el remitente puede exigir del transportista que compruebe el contenido de los bultos (art. 8.3 CMR).

${ }^{520}$ F.J. SÁnchez-GAmborino, El contrato..., cit., p. 108; J. PutzeYs, Le contrat..., cit., p. 139. 
otro aparato especial521, donde se le atribuye al porteador o a sus auxiliares un deber especial de prevención para garantizar el traslado sin daños de la carga ${ }^{522}$. También será responsable el transportista estará si ha firmado la carta de porte que contiene alguna cláusula que le atribuye y le obliga a ello523.

Si el transportista no es experto en ese tipo de verificaciones podría recurrir a la ayuda de otros (expertos o especialistas) para que comprueben también el contenido de la mercancía y su naturaleza, a cambio de poder exigir del cargador el reembolso de los gastos asociados a dicha verificación (art. 8.3 CMR), comprendida una indemnización por el tiempo de paralización del vehículo524. En tales casos, el resultado de estas verificaciones deberá hacerse constar en la carta de porte, como prueba de que la carga se ha entregado en buen estado, quedando el remitente liberado frente al transportista de cualquiera responsabilidad que le pueda incumbir después de la entrega (art. 8.3 CMR).

Como se decía, la verificación es una carga que incumbe al transportista, y éste deberá anotar en la carta de porte las reservas respecto de las menciones en la carta en el momento de la recepción de las mercancías. De esta forma, se desvirtúa la presunción iuris tantum de que el porteador ha recibido la mercancía en buen estado aparente (art. 9.2 CMR)525, quedando así libre de responsabi-

${ }^{521}$ Como por ejemplo en el caso del transporte frigorífico. En algún supuesto, el porteador ha alegado el hecho de la estiba en el camión frigorífico como causa específica de exoneración de responsabilidad frente al cargador, cuando esta actividad se había realizado por sus empleados (art. 17.4.c CMR) y, como consecuencia de la misma -estiba defectuosa-, se causaron daños y averías a la mercancía por no alcanzarle correctamente el frío a toda ella. Vid. M.F. Clavero TERNERO, «La responsabilidad del transportista internacional por carretera», en Aa.Vv., Homenaje en memoria de Joaquín Lanzas y de Luis Selva, T. I, Madrid, 1998, p. 81. Con detalle sobre este tema puede verse también F. MARTÍNEZ SANZ, «Transporte terrestre internacional en régimen de temperatura controlada y responsabilidad del porteador», en Aa.Vv., Diez Años de Derecho Marítimo Donostiarra, Servicio Central de Publicaciones del Gobierno Vasco, Vitoria-Gasteiz, 2003, pp. 103-122.

522 Vid. la STS de 20 de junio de 1989 (RJ 1989, 4705). En la doctrina, M.F. Clavero TERNERO, «La responsabilidad...», cit., pp. 81-82.

523 En la doctrina francófona se ha reprochado al transportista el no verificar el embalaje, cuando el deber de verificar figuraba en una cláusula añadida por el cargador en las menciones de la carta de porte. Vid. J. PUTZEYs, Le contrat..., cit., p. 140.

524 J. PUTZEYs, Droit..., cit., p. 157.

525 Dispone el citado precepto que, «[e]n ausencia de anotación en la Carta de Porte de las reservas motivadas del transportista, se presumirá que las mercancías y sus embalajes estaban en buen estado aparente en el momento en que el transportista se hizo cargo de la mercancía, y que el número de bultos, así como sus marcas y números, eran conformes a 
lidad en aquellos supuestos en que el estado real de la carga, sus marcas o números no se corresponden, ya en origen, con el que deriva de la carta de porte. Tales reservas se inscriben en la carta de porte, pero nada obsta para que se hagan constar en un documento aparte, firmado por las dos partes contratantes, esto es, el porteador y el cargador (o, en su caso, el expedidor) ${ }^{526}$.

Lo habitual es que el cargador acepte las reservas inscritas en la carta de porte por el porteador, con lo que tales reservas le comprometen, quedando exonerado el porteador de su responsabilidad respecto de los menoscabos descritos en la reserva. Si ello no es así y el cargador rechaza las reservas, ello pone de relieve una discrepancia entre ambas partes en torno al estado de las mercancías en el momento de su recepción por el transportista. En tales casos, es recomendable consultar con expertos (comisarios de averías o peritos) que se encarguen de dictaminar el estado real de las mercancías527 o, en todo caso, que el transportista se niegue a aceptar la carga (art. 27.2 LCTTM).

\section{El derecho de diposición}

\section{Concepto}

Según una regla tradicional en materia de contratos privados, éstos son ley entre las partes desde el momento de su perfección, de manera que cualquier modificación posterior del contrato será inválida sin un acuerdo recíproco de voluntades. Sin embargo, esta regla conoce una excepción relevante en el ámbito de los contratos de transporte de mercancías: no se aplica a la persona del cargador como parte contratante, que puede impartir instrucciones al transportista con posterioridad a la celebración del contrato y, así, modificar unilateralmente el contenido del contrato. En efecto, a lo largo del viaje es el cargador quien re-

los mencionados en la Carta de Porte». Al respecto véase F.J. SÁnCHEZ-GamboRino, El contrato..., cit., p. 109.

${ }^{526}$ Así lo reconoce el art. 14.2 LCTTM, cuando admite la posibilidad de que las reservas hechas por el porteador se incluyan en otro documento distinto de la carta de porte: «En ausencia de anotación en la carta de porte, o en documento separado firmado por el porteador y el cargador o expedidor, de las reservas suficientemente motivadas del porteador, se presumirá que las mercancías y su embalaje están en el estado descrito en la carta de porte y con los signos y señales en ella indicados» (la redonda es nuestra).

${ }^{527}$ F. MARTíneZ SANZ, «Transporte...», cit., p. 177. 
tiene el control, salvo pacto en contrario528, desde la entrega de las mercancías al porteador hasta el momento en que éstas se ponen a disposición del destinatario. Se trata de una facultad que deriva de la ley, que concede al cargador el poder de modificar el contenido del contrato. No se trata, por ello, de modificar el contrato en sí mismo, como extinguirlo o cambiar su naturaleza, o sustituir una de sus partes contratantes529.

En el contrato de transporte, como se decía, se concede al cargador un derecho que le faculta, antes de que la mercancía haya sido entregada al destinatario530, a modificar por su sola voluntad los términos del contrato, por ejemplo, alterando el destino previsto de la entrega o sustituyendo la persona del destinatario que figura en la carta de porte por otra diferente. La modificación se efectúa a través de impartir instrucciones y órdenes al porteador quién ha de ejecutarlas a cargo del cargador 531 .

El derecho que faculta al cargador (o, en su caso, al destinatario) para detener el transporte o modificar el lugar de destino o la persona del destinata-

528 Ello sucede cuando se hace constar en alguna de las cláusulas del contrato que es el destinatario quien ostenta el derecho de disposición y tiene plena legitimación para disponer de las mercancías durante su transporte. No puede descartarse que el cargador y el destinatario sean la misma persona, en cuyo caso no hará falta designar a quién se atribuye este derecho, pues pertenecerá durante todo el transporte al cargador-destinatario. Sin embargo, deberá hacerse constar en la carta de porte el hecho de que el destinatario y el cargador son misma persona, a fin de evitar cualquiera confusión por parte del porteador.

529 En cuanto a la extinción del contrato, es inadmisible legalmente que una de las partes contratantes ponga fin unilateralmente al contrato, pues este modo de proceder daría lugar a un supuesto de responsabilidad contractual. Cuando se habla de cambiar la naturaleza del contrato, en cambio, nos referimos, por ejemplo, a convertir el contrato de transporte terrestre en otro de transporte aéreo o marítimo. Por último, la sustitución de una de las partes contratantes originales (del cargador o del porteador, por tanto) exige una novación del contrato, que no es posible sin el consentimiento de la contraparte original.

${ }^{530} \mathrm{Y}$ ello por cuanto el derecho de disposición se transmite al destinatario una vez que éste reciba el segundo ejemplar de la carta de porte del porteador y la mercancía se ponga a su disposición (art. 12.2 CMR). Al respecto se señala, con acierto, que «[l]os derechos de uno y otro (el cargador y el destinatario) [...] no se yuxtaponen sino que son correlativos en el tiempo. En efecto, el derecho de disposición se extingue para el cargador y nace para el destinatario» [ «La Ley 15/2009, de 11 de noviembre, del contrato de transporte terrestre de mercancías» ( $\sin$ autor), circular informativa de diciembre de 2009, disponible en http://www.uria.com].

${ }^{531}$ En el Derecho previgente, el derecho de disposición se regulaba en el art. 360 Ccom, cuyo tenor no coincidía plenamente con el del art. 12 de CMR. Así, a la hora de concretar el contenido del «derecho de disposición», aunque ambos preceptos permitían cambiar la persona del destinatario, en el Código de Comercio se establecía que «[e]l cargador podrá, sin variar el lugar donde deba hacerse la entrega, cambiar la consignación de los efectos que entregó al porteador [...]». 
rio532 viene recibiendo tradicionalmente el nombre de derecho «de disposición». Es el derecho que ostenta el cargador en cuanto titular original de la mercancía, cuya finalidad es disponer de ésta durante su transporte533. También se le denomina en ocasiones «derecho de contraorden», puesto que su ejercicio implica la impartición de órdenes contrarias a las originalmente contenidas en otras instrucciones534. En efecto, el derecho de disposición o de contraorden no afecta al contrato de transporte en sí mismo, sino sólo consiste en modificar alguno de sus términos, razón por la cual en el seno de FIATA se ha recomendado hablar de un «derecho de dar nuevas instrucciones al transportista» en vez de un «derecho de disposición»535.

Este derecho de disposición existe en todos los regímenes positivos que regulan las distintas modalidades de transporte ${ }^{536}$, tanto en el Derecho interno español (arts. 29 y 30 LCTTM537 y cl. 5.6 y 5.8 del anexo a la Orden FOM/1882/2012, de 1 de agosto, por la que se aprueban las condiciones generales de contratación de los transportes de mercancías por carretera), como en las

532 Desde el momento en que el derecho de disposición pertenezca al destinatario, por virtud de la solicitud de recepción de la carta de porte y de la mercancía, su ejercicio quedará restringido: sólo podrá designarse por aquél otro destinatario que, a su vez, no podrá designar nuevos destinatarios (arts. 29.2 i.f. LCTTM y 12.4 CMR).

533 A. DÍAZ MORENO, «El contrato...», cit., p. 668.

534 A. ReCAlde CASTELls, «El 'derecho de disposición' en el transporte internacional de mercancías por carretera», InDret, 2006, p. 5 .

535 Cfr. F.J. SÁNCHEZ-GAMBORINO, El contrato..., cit., p. 125.

${ }^{536}$ En el ámbito del transporte aéreo, el derecho de disposición o a variar los términos del contrato se halla regulado en el art. 112 de la Ley 48/1969, de 21 de julio, de Navegación Aérea, a cuyo tenor «[e]l expedidor tiene derecho de disposición sobre las cosas objeto del transporte, pudiendo, después de haber suscrito el contrato, de acuerdo con el transportista, retirarlas del aeropuerto de salida o destino, detenerlas en el curso del viaje a un aeropuerto, cambiar el lugar de destino o la persona del destinatario o pedir su retorno al aeropuerto de salida. Los gastos que ocasione el ejercicio de este derecho serán por cuenta del expedidor». Para los fletamentos de un buque completo por viaje, el art. 275 de la Ley 14/2014, de 24 de julio, de Navegación Marítima, por su parte, señala que «el fletador podrá ordenar la descarga en puerto distinto del convenido, siempre que ello no exponga al buque a riesgos superiores de los previstos al contratar, pagando el flete total contratado y los mayores gastos que se originen».

537 Los preceptos actualmente vigentes regulan el derecho de disposición de forma prácticamente idéntica a como lo hace el CMR. Recuérdese, sin embargo, que bajo la vigencia del Derecho anterior, el art. 360 Ccom únicamente facultaba para cambiar la persona del destinatario o consignatario, pero sin variar el lugar donde debía hacerse la entrega. Cfr. J. GARRIGUES, Curso de Derecho mercantil, II, $8^{\mathrm{a}}$ ed., a cargo de F. Sánchez Calero, Madrid, 1983, p. 220. 
convenciones internacionales ratificadas por España (véase arts. 12 CMR y 30 y 32 de las Reglas Uniformes CIM538)539.

No existe concepto definición legal del derecho de disposición, pero puede concretarse su noción con base en el contenido de los regímenes internos e internacionales que lo regulan. Así, puede definirse el derecho de disposición como la facultad que se atribuye a su titular (cargador o destinatario) para dirigir instrucciones y órdenes al porteador, cuya obligada atención conlleven la alteración unilateral del contenido sustancial del contrato, ordenándose al porteador para tal efecto que paralice el transporte, que restituya la mercancía a su punto de origen o que la entregue en un lugar o a un destinatario distintos a los inicialmente pactados, si bien dentro de los límites marcados por la Ley540.

\section{Naturaleza jurídica del derecho de disposición}

No cabe duda de que la naturaleza jurídica del derecho de disposición se enmarca en el esquema de los derechos potestativos o de configuración jurídica541, que legitima a su titular -el cargador primero, después el destinatario- para alterar unilateralmente algún aspecto de la prestación configurada en el contrato, respetando los límites marcados por la Ley. La modificación puede referirse a dos elementos sustanciales del contrato: en primer lugar, el objeto del transporte, cuando el cargador da órdenes al porteador para detener el desplazamiento de las mercancías o restituirlas al lugar de origen542; en segundo lugar, el sujeto al que van destinados los efectos transportados (esto es, el destinatario), sustitu-

${ }_{538}$ Reglas Uniformes relativas al contrato de transporte internacional por ferrocarril de mercancías (CIM), Apéndice B del Convenio relativo a los transportes internacionales por ferrocarril (COTIF) de 9 de mayo de 1980 según la redacción que figura en el Protocolo de modificación de 3 de junio de 1999 (en adelante, RU CIM).

539 A. RECALDE CASTELLS, «El 'derecho de disposición'...», cit., p. 4.

540 M.Á. PENDÓN MELÉNDEZ, «El derecho de disposición», RDT, núm. 6, 2010, p. 178; A. DÍAZ MORENO, «El contrato...», cit., p. 668.

${ }^{541} \mathrm{~F}$. JUAN Y MATEU, Los impedimentos para la entrega en el transporte de mercancías por carretera, Comares, Granada, 2005, p. 75; A. RECAlDE CASTELls, «El 'derecho de disposición'...», cit., p. 4.

${ }^{542} \mathrm{Y}$ es que el derecho de disposición sirve como una garantía del cargador (generalmente el vendedor en el contrato de compraventa subyacente) frente al destinatario (el comprador), en el caso de que éste muestre su intención de incumplir el contrato, en cuyo caso el cargador podrá detener o interrumpir el viaje de las mercancías y ordenar al porteador que las devuelva a su punto de partida. 
yéndolo por otro. Generalmente, la facultad de modificar el contrato pertenece al cargador, salvo pacto en contrario, por ejemplo, cuando se otorga ab initio al destinatario, haciéndolo constar así en la carta de porte543; o cuando el destinatario esté en poder del primer ejemplar de la carta de porte (el que permanece con el cargador), con lo que queda «bloqueado» el derecho de disposición del cargador, quien no podrá ejercitarlo al no estar en posesión del primer ejemplar de la carta544.

Como se decía, el derecho de disposición reviste la naturaleza jurídica de un derecho potestativo. En efecto, pertenecen a esta categoría aquellos derechos que confieren a su titular la facultad de constituir, con una declaración propia, una relación jurídica ya existente, de concretar y determinar su contenido, o de extinguir o modificar aquella relación con otro tercero545. Más específicamente, el derecho de disposición se enmarca entre los derechos potestativos que otorgan a su titular la posibilidad de alterar el contenido y las condiciones sustanciales del contrato (ius variandi), en este caso, cambiar la consignación de los efectos entregados por el cargador al porteador o designar un nuevo destinatario546.

El derecho de disposición es una institución tradicional y clásica en la regulación legal del transporte de mercancías, que generalmente se otorga al cargador-remitente. El derecho de disposición no se puede transmitir de manera autónoma, sino que su adquisición por el destinatario es consecuencia de la caracterización del contrato de transporte como un contrato a favor de tercero, en virtud del cual se atribuye directamente al destinatario los derechos sobre las mercancías una vez que éste declare su aceptación para recibir los efectos de la prestación: en este momento se incorpora al contrato y se convierte en titular del derecho de disposición, que desde este momento ya no puede ser revocado por el cargador 547.

543 Así lo dispone el art. 12 CMR en su apartado tercero, cuando establece que «[e]l derecho de disposición pertenece en todo caso al destinatario desde el mismo momento de emisión de la carta de porte, si así se hizo constar en dicha carta de porte por el remitente».

544 A. DÍAZ MORENO, «El contrato...», cit., p. 669.

545 A. VON TUHR, Tratado..., cit., p. 12.

546 F. JUAN Y MATEU, Los impedimentos..., cit., p. 75.

547 A. RECALDE CASTELls, «El 'derecho de disposición'...», cit., p. 11. 
También se encuentran relacionadas con el derecho de disposición otras instituciones que tienen en común la misma facultad de impartir instrucciones, tal como sucede en el contrato de comisión o de mandato, que faculta al comitente o al mandante, con el fin de gestionar y controlar sus intereses en tales actividades, dar órdenes al comisionista o mandatario (arts. 254 Ccom y 1.719 Cc). Lo mismo sucede en el contrato de agencia [art. 9.2.c) LCA], en el marco del cual el principal tiene derecho a impartir instrucciones y órdenes al agente. Dado que la realización de todas las operaciones que se efectúan por el comisionista, el mandatario o el agente gira en torno al interés de sus representados, surge un derecho del comitente-mandante o el principal a dar instrucciones, alterando o revocando algunos términos del contenido del contrato (arts. 254, 255 y 279 Ccom, y arts. 1.719 y $\left.1.7321^{\circ} \mathrm{Cc}\right)^{548}$.

\section{Función del derecho de disposición}

El ejercicio del derecho de disposición puede resultar útil en diferentes situaciones549, pues tiene por objeto hacer la ejecución del transporte más flexible y a distintas situaciones que pueden surgir durante la fase de ejecución del contrato550. Por lo tanto, las instrucciones y órdenes que alteran el contenido del contrato frecuentemente se deben a negocios dispositivos sobre la mercancía, en razón a los cuales se ha celebrado el contrato de transporte551.

La función que cumple el derecho de disposición en el tráfico de mercancías es puramente económica, en atención a las circunstancias que rodean el comercio o la especulación con las mercancías objeto del transporte. Por ejem-

548 Cfr. A. ReCAlde CASTELls, «El 'derecho de disposición'...», cit., p. 9; F. JuAN y Mateu, «Derecho de disposición», en J. F. Duque Domínguez y F. Martínez Sanz (dirs.), A. Emparanza Sobejano y $\mathrm{M}^{\mathrm{a}}$.V. Petit Lavall (coords.), Comentarios a la Ley de Transporte Terrestre, cit., p. 365.

549 Como, por ejemplo, discrepancias comerciales entre el cargador y el cliente destinatario (impago o retraso en el pago), resolución de errores, programación logística que aconseja entregar en otro almacén, o incidentes sobrevenidos después del inicio del transporte (huelga, inclemencias meteorológicas, etc.). Así, A. CABRERA CÁNOVAS, El contrato de transporte por carretera (Ley 15/2009), Marge, Barcelona, 2010, p. 67.

$55^{\circ}$ F. JUAN Y MATEU, «Derecho...», cit., p. 365.

551 A. RECALDE CASTELLS, «El derecho a disponer de la mercancía», en A. Emparanza Sobejano y A. Recalde Castells (dirs.), El contrato de transporte internacional de mercancías por ferrocarril, Thomson-Civitas, Cizur Menor, 2008, p. 143. 
plo, si se modifica el lugar de entrega, ello puede deberse al deseo de disponer de ella en un lugar donde la carga es más demandada. Así, el cargador puede impartir órdenes e instrucciones al porteador para que el envío sea encaminado a un nuevo lugar de consignación donde se pueda conseguir un mejor precio552.

Además, a través del derecho de disposición el cargador puede protegerse frente al incumplimiento de la obligación de pago por el destinatariocomprador, ya que la facultad que tiene el remitente-vendedor de retener la entrega o de recuperar las mercancías es un instrumento que puede ejercitarse por éste siempre y cuando el destinatario-comprador no cumpla su obligación de satisfacerle el precio de las mercancías. De esta manera, el derecho de disposición juega un papel esencial para garantizar la operación comercial relativa a las mercancías frente al riesgo de impago por parte del destinatario a quien va dirigido el envío553.

Por último, conviene advertir que el derecho de disposición sirve también para solucionar ciertos obstáculos que frenan la ejecución del transporte, esto es, cuando el porteador se encuentre con impedimentos al transporte o a la entrega de las mercancías al destinatario. En efecto, ante tales impedimentos que se pueden presentar tanto para el transporte como para la entrega, el transportista queda obligado a solicitar instrucciones al cargador que ostente el derecho a disponer de la mercancía, una solicitud que se produce siempre antes de que la mercancía sea reclamada por el destinatario554, es decir, durante el viaje555. El deber de pedir instrucciones y órdenes al cargador surge para remover el obstáculo que impide al transportista cumplir con su obligación contractual, de

${ }^{52}$ F. JUAN Y MATEU, «Derecho...», cit., p. 365.

553 A. RECAlDE CASTELlS, «El 'derecho de disposición'...», cit. p. 6; ID., «El derecho a disponer...», cit., p. 142.

554 Es decir, antes de que el derecho de disposición se transmita al destinatario, pues una vez llegada la mercancía al destino y aceptado el envío por el destinatario, éste se incorpora al contrato y se convierte en acreedor de la prestación y titular del derecho de disponer de la mercancía.

555 Vid. el art. 14 CMR, así como F.J. SÁNCHEZ-GAMBORINO, El contrato..., cit., pp. 134 y ss. 
manera que las instrucciones que pueden impartirse consistirán en un cambio del lugar de entrega o en el retorno de las mercancías a su punto de partida556.

\section{Contenido del derecho de disposición y límites a su ejercicio}

El contenido del derecho de disposición reside en la impartición de órdenes e instrucciones que tienden a modificar el contenido del contrato de transporte. Como se indicó más arriba, el derecho de disposición reviste la naturaleza de un derecho potestativo que faculta al cargador (o, en su caso, al destinatario) para modificar de manera unilateral el contrato de transporte. Así, nada obsta para que el derecho pueda ampliarse, en el sentido de que la enumeración de instrucciones posibles efectuada por el legislador no tiene carácter exhaustivo, pudiendo adoptar otras formas diferentes de las previstas por la Ley557. En efecto, señala el artículo 29.1 LCTTM (y, de forma similar, el art. 12.1 CMR) que el remitente o el cargador pueden impartir una serie de instrucciones al porteador, solicitándole, en particular, «que detenga el transporte, que devuelva la mercancía a su origen o que la entregue en un lugar o a un destinatario diferente de los indicados en la carta de porte» 558 .

Este catálogo de instrucciones se limita a establecer con carácter enunciativo una serie de instrucciones que tanto el remitente como, en su caso, el destinatario podrán transmitir al porteador 559 . La primera de las posibles órdenes citadas en la norma va destinada a detener la ejecución del transporte. En tales casos, es probable que la orden de detención sea reflejo de la intención del remitente (en cuanto estipulante) de revocar la estipulación hecha a favor del destinatario, recuperando aquél el derecho a poseer las mercancías560.

${ }^{556}$ Sobre la actuación del porteador ante los impedimentos para la entrega, vid. F. JUAN Y MATEU, Los impedimentos..., cit., pp. 65 y ss.; A. RECALDE CASTELLS, «El derecho a disponer...», cit., p. 142.

557 En otras palabras, «sin constituir un numerus clausus». Así, A. RECALDE CASTELls, «El 'derecho de disposición'...», cit., p. 19.

${ }^{558} \mathrm{El}$ art. 29.1 de la Ley 15/2009 no hace más que reproducir lo ya establecido en el art. 12.1 CMR. Sostiene A. RECALDE CASTELlS, «El 'derecho de disposición'...», cit., p. 19, sin embargo, que este precepto resulta más detallado, inter alia, porque remarca claramente que la enumeración lo es a título de ejemplo («en particular»).

559 M.Á. PENDÓN MELÉNDEZ, «El derecho...», cit., p. 185.

560 A. RECALDE CASTELLS, «El 'derecho de disposición'...», cit., p. 19. 
La segunda instrucción mencionada en el artículo 29.1 LCTTM supone la devolución de las mercancías a su punto de partida o a otro lugar de entrega. Aunque este tipo de orden no está prevista expresamente en el artículo 12.1 CMR, ninguna duda cabe de que puede también darse en un transporte internacional, por hallarse incluida en la orden más general que implica la modificación del lugar previsto para la entrega ${ }^{561}$.

La referencia a este tipo de orden - esto es, la modificación del lugar de consignación de las mercancías- es lo bastante extensa como para comprender situaciones distintas: así, el nuevo lugar de consignación puede encontrarse no sólo en el territorio nacional, sino también en otro país extranjero562. La duda que se plantea en este último caso es si el cambio unilateral del contenido del contrato implica asimismo una modificación del régimen legal aplicable (es decir, de un régimen nacional a un régimen internacional), porque el nuevo lugar de entrega se encuentra ahora más allá de las fronteras nacionales y se sitúa en el territorio de un país extranjero.

Estando ante un contrato de transporte terrestre de mercancías, algunos autores han señalado que el transporte estaría sometido al Derecho nacional y no al Convenio CMR, por la razón de que el lugar relevante para determinar la aplicación del Convenio es el lugar de consignación indicado en el contrato (art. 1 CMR), y no el que pueda determinarse posteriormente a través del derecho de disposición563. En sentido diverso, otros autores sostienen que el contrato podría resultar en todo caso sujeto al ámbito de aplicación del CMR, por el hecho de que la instrucción solicitada para entregar la mercancía en un estado diferente puede no ser vinculante para el porteador, en la medida en que rebase los límites legales del derecho de disposición564.

${ }^{561}$ M.Á. PENDÓN MELÉNDEZ, «El derecho...», cit., p. 186.

${ }^{562}$ A. ReCAlde CASTELLS, «El 'derecho de disposición'...», cit., p. 20.

${ }^{563}$ Así, J. BASEDOW, «Art. 12 CMR», en Aa.VV., Münchener Kommentar zum HGB, Vol. 7, número marginal 3, quien advierte, sin embargo, de que que sí resultará de aplicación el CMR cuando las partes hayan simulado un transporte nacional para convertirlo después en internacional mediante nuevas instrucciones, con el fin de evitar el régimen del convenio (citado por F. JUAN Y MATEU, «Derecho...», cit., p. 370).

564 R. HERBER y H. PIPER, CMR, Art.1 CMR, número marginal 53, citado nuevamente por F. JUAN Y MATEU, «Derecho...», cit., p. 370. 
Por último, puede ordenarse al porteador que entregue la mercancía a un destinatario distinto de aquel indicado inicialmente en la carta de porte. Esta posibilidad de cambiar la persona del destinatario puede analizarse conjuntamente con la anterior, referida a la modificación del lugar previsto de la entrega, en la medida en que la orden que implica un cambio del lugar de consignación supone (generalmente) también la designación de un nuevo destinatario565. También aquí, la finalidad perseguida con el ejercicio del derecho de disposición es eminentemente económica, que le permitirá al titular de aquél atender un negocio ajeno al transporte - por ejemplo, un contrato de compraventa o de distribución-, sin perjuicio de que pueda servir también como una garantía ante un incumplimiento por parte del destinatario566.

En cuanto a las condiciones que limitan el ejercicio del derecho de disposición, este último se halla subordinado al cumplimiento de ciertos límites y condiciones. En primer lugar, las instrucciones impartidas por el remitente han de ir referidas al contrato de transporte ya concertado, así que se excluyen del ámbito en el que son válidas estas instrucciones todas aquellas que pretenden modificar unilateralmente 567 los elementos fundamentales del contrato de transporte como, por ejemplo, la alteración de la naturaleza de la obligación asumida por el transportista o el cambio del régimen jurídico que determinan las normas fundamentales de responsabilidad 568 .

En relación con los límites al ejercicio del derecho de disposición, los artículos 30.1 LCTTM y 21.5 CMR coinciden al establecer los requisitos para el ejercicio del derecho. En efecto, para ello es necesaria la presentación del primer ejemplar de la carta de porte, en el que se anotarán las nuevas instrucciones, con la condición de que el transportista cuente con la «posibilidad material de atender la petición», debiendo el titular del derecho (el remitente o el destinata-

565 A. RECALDE CASTELLS, «El derecho a disponer...», cit., p. 148.

566 M.Á. PENDÓN MELÉNDEZ, «El derecho...», cit., p. 187.

567 En este sentido, no se admite las instrucciones y órdenes que supongan una esencial modificación del contrato original, a no ser que exista consenso mutuo para novarlo. Vid. A. RECALDE CASTELLS, «El 'derecho de disposición'...», cit., p. 20.

${ }^{568}$ A. RECALDE CASTELLS, «El derecho a disponer...», cit., p. 149. 
rio) reembolsar al transportista los gastos y perjuicios que le pueda ocasionar el cumplimiento de tales instrucciones 569 .

Es en este primer requisito donde la carta de porte aparece nuevamente como un documento que cumple una importante función de bloqueo para paralizar el ejercicio del derecho de disposición por parte del remitente. De esta forma, se garantiza que, una vez que éste se desprenda del primer ejemplar de la carta de porte (p.ej., remitiéndolo por otra vía al destinatario), no podrá ya modificar el contrato de transporte, de manera que las mercancías seguirán su camino hasta el lugar de consignación en los términos previstos en el contrato de transporte. Por ello, y como no puede ser de otra forma, el transportista responderá en caso de que ejecute las instrucciones emitidas por quien no le presentó el primer ejemplar de la carta de porte570.

En cuanto a la segunda condición que limita el ejercicio del derecho de disposición, el artículo 12.5.b) CMR, al igual que el artículo 30.1.b) LCTTM, dispone, por un lado, que la ejecución de estas nuevas instrucciones debe ser posible en el momento en que se imparten al transportista y, por otro, que no deben dificultar la explotación normal de la empresa de transporte, ni ocasionar perjuicios a terceros (señaladamente, los cargadores o destinatarios de otras expediciones). Este precepto puede invocarse ante la imposibilidad de atender las nuevas instrucciones en el tiempo debido, lo cual, en la época en que se redactó el Convenio, sucedía por ejemplo cuando el vehículo había salido ya hacia su destino y no había medios para comunicar con el conductor571 (un supuesto hoy superado en buena medida gracias a los métodos modernos de telecomunicación). Aún hoy puede suceder, por ejemplo, cuando la instrucción impartida supone modificar el lugar de destino a un país para el que el transportista no cuenta con la autorización necesaria.

569 F.J. SÁNCHEZ-GAMBORINO, El contrato..., cit., p. 127.

570 A pesar del silencio del legislador, el cargador recupera de nuevo el derecho de disposición cuando el destinatario no acepta la entrega de las mercancías, aun sin disponer del primer ejemplar de la carta de porte, cuya función paralizadora ha de considerase decaída en estos supuestos, a consecuencia de la falta de interés del destinatario. Vid. A. DÍAZ MORENO, «El contrato...», cit., p. 669.

${ }^{571}$ F.J. SÁNCHEZ-GAMBORINO, El contrato..., cit., p. 127. 
La imposibilidad de llevar a cabo las órdenes no es sino una consecuencia de un obstáculo que impide el transportista realizar la entrega del envío. En efecto, la imposibilidad, como se ha indicado, puede tener un alcance objetivo (p.ej., instrucciones para entregar la mercancía en un lugar inaccesible por carretera) y otro subjetivo (esto es, cuando las instrucciones superan la capacidad de este transportista concreto, que no puede cumplirlas), además de que puede ser material, cuando es imposible la entrega de las mercancías debido, por ejemplo, a motivos meteorológicos, o jurídica, cuando se imparten instrucciones para entregar las mercancías en un sitio donde las autoridades han prohibido el acceso a los camiones572.

Tampoco resulta aceptable que el transportista deba seguir instrucciones que dificulten su explotación empresarial, por ejemplo, si las órdenes dadas al transportista le obligan a volver en vacío desde su nuevo destino. En fin, el porteador podrá rehusar seguir las instrucciones cuya realización pudiera perjudicar a terceros u otros clientes del transportista, o a otras mercancías que hubieran sido enviadas, o cuando la ejecución de tales instrucciones produce un retraso o demora en sus envíos 573.

La última condición que restringe el ejercicio del derecho de disposición es que las instrucciones no pueden tener como efecto la división del envío. Es inadmisible impartir instrucciones al porteador que supongan la división de la expedición, por ejemplo, cuando este último recibe órdenes para que entregue una parte de las mercancías que componen el envío a un destinatario y otra parte del cargamento a otro destinatario distinto574. La división del cargamento haría nacer un nuevo contrato o varios contratos (pues, de lo contrario, se produciría una dispersión del envío por la pluralidad de destinatarios, que afectará, a buen seguro, a la actividad del porteador), salvo en el supuesto en que «se emitan varias cartas de portes (art. 5.2 CMR) correspondientes a varias remesas en diferentes vehículos, o para mercancías de varias clases o agrupadas en

${ }^{572}$ A. ReCAlde CASTELls, «El 'derecho de disposición'...», cit., p. 20.

573 F.J. SÁNCHEZ-GAMbORINO, El contrato..., cit., p. 127; A. RECALDE CASTELlS, «El 'derecho de disposición'...», cit., p. 20.

574 A. DÍAZ MORENO, «El contrato...», cit., p. 670. 
distintos lotes»575. En este último supuesto, no debería existir inconveniente para que el derecho de disposición se ejerza respecto de cada uno de los envíos documentados en una carta de porte.

Como se vio, ante instrucciones que perturben la ejecución del transporte, el porteador no resulta obligado a seguirlas por razones de seguridad y de buena ejecución. Sin embargo, el transportista cuando rechaza el cumplimiento de estas instrucciones ha de comunicarlo enseguida a quien las emitió (art. 12.6 CMR). Es más, es el transportista quien debe probar los hechos que le impiden cumplir las instrucciones que le impartió el cargador o el destinatario, o que tales instrucciones eran difíciles, irrazonables, imposibles o perjudicaban a terceros, para lo que puede servirse del contenido original de la carta de porte576.

\section{Titularidad del derecho de disposición}

\subsection{El derecho de disposición del cargador o remitente}

La facultad de modificar unilateralmente el contenido del contrato de transporte suele atribuirse, en primer lugar, al cargador o remitente577 como titular primario del derecho de disposición, ya que esta facultad ingresa en su patrimonio gracias a su posición como parte original en el contrato578, y así se prevé en los artículos 29.1 LCTTM y 12.1 CMR579.

La única excepción en el transporte terrestre la constituye el transporte ferroviario internacional, donde el artículo 18 de las Reglas Uniformes CIM atribuyen dicho derecho al destinatario, salvo que otra cosa se haya pactado en el contrato580. Obsérvese, con todo, que la cuestión acerca del titular «original»

575 Advierte de ello F.J. SÁNCHEZ-Gamborino, El contrato..., cit., p. 129.

576 A. RECALDE CASTELLS, «El 'derecho de disposición'...», cit., p. 27.

577 Mientras que la Ley 15/2009 emplea la primera expresión, el CMR utiliza el término «remitente». A lo largo de los epígrafes siguientes se usarán como sinónimos.

${ }_{578}$ M.Á. PEndón MELÉndeZ, «El derecho...», cit., p. 178; A. RECALDE CASTELLS, «El derecho a disponer...», cit. p. 143 y ss.

579 También se contemplaba así, en el Derecho previgente, en el art. 360 Ccom.

580 Según lo dispuesto en el art. 18 RU CIM, se puede atribuir el derecho de disposición tanto al remitente (art. 18.1) como al destinatario (art. 18.2). Sin embargo, el titular «natural» (es decir, salvo que otra cosa de acuerde) del derecho de disposición será el destinatario, desde que se emita la carta de porte. Al respecto puede verse, con detalle, $\mathrm{A}$. 
del derecho de disposición fue objeto de debate durante la elaboración del Convenio CIM en cuanto precursor inmediato de las Reglas Uniformes homónimas, ante la multitud de regímenes presentes en los distintos países europeos. Por un lado, la delegación suiza opinó que el destinatario debía ser el titular del derecho a impartir órdenes, a menos que se reservara este derecho en la carta de porte a favor del remitente. Por otro, el proyecto alemán preveía una solución distinta, que otorgaba el derecho de disposición con carácter exclusivo al remitente, pero sólo hasta el momento en que el segundo ejemplar de la carta de porte se entregase al destinatario o éste aceptase la recepción de las mercancías581.

En el transporte (nacional e internacional) de mercancías por carretera es, pues, el cargador el titular primario del derecho de disposición, y lo es desde que se concluye el contrato de transporte, con independencia de que se emita una carta de porte. De ello deriva que el cargador recibe su derecho a disponer de las mercancías del contrato en sí y no de la carta de porte. Queda descartada, así, la idea de que el derecho de disposición surge al emitir una carta de porte, por mucho que los artículos 30.1.a) LCTTM y 12.5.a) CMR parecen condicionar el ejercicio del derecho a dar órdenes a la presentación del primer ejemplar de la carta de porte. Ha de entenderse, más bien, que esta condición adquiere virtualidad práctica sólo en aquellos supuestos en los que se ha emitido efectivamente una carta de porte. En ausencia de tal, el cargador ha de acreditar su derecho a dar instrucciones al porteador mediante otros medios de prueba582.

En conclusión, la facultad que se otorga al remitente para modificar el contrato de transporte le posibilita ejercer, por iniciativa propia, su derecho a detener la ejecución del transporte, a ordenar la devolución de las mercancías a su punto de partida y, también, a cambiar el lugar de entrega o la persona del destinatario indicados en la carta de porte.

RECALDE CASTELLS, «El derecho a disponer...», cit., p. 134; F. JUAN Y MATEU, «Derecho...», cit., pp. 366 y ss.

${ }^{581}$ L.-É. MATILE, Le droit du destinataire dans le transport international de marchandises par chemin de fer, Jaunin, Lausanne, 1958, p. 35.

${ }^{882}$ F. JUAN Y MATEU, «Derecho...», cit., p. 367. 


\section{a) La impartición de instrucciones en caso de impedimentos al transporte y para la entrega}

Cabe advertir que el tema del derecho de disposición del cargador es un tema amplio y complicado, en el sentido de que se halla íntimamente relacionado con la impartición de instrucciones en caso de que se presente un impedimento al transporte o para la entrega. Tales impedimentos están regulados en los artículos 31, 38, 44 y 45 LCTTM, para el transporte nacional, así como en los artículos 14,15 y 16 CMR, para el transporte internacional 583.

\section{aa) Impedimentos al transporte}

La solicitud e impartición de instrucciones cuando el transporte se enfrenta a algún obstáculo o impedimento forma parte del derecho de disposición. Sin embargo, la diferencia entre ambos modos de impartir instrucciones reside en el hecho de que, de presentarse un impedimento al transporte, el porteador deberá consultar al remitente sobre cómo proceder, mientras que el ejercicio del derecho de disposición en sentido estricto implica la modificación sobrevenida del contrato de transporte mediante la impartición de órdenes o instrucciones por la propia voluntad del remitente -o sea, espontáneamente-, sin que el porteador pueda sin más rechazarlas o negarse a cumplirlas 584 .

El concepto «impedimento para el transporte» no se define en los artículos referidos. No obstante, ante esta carencia legislativa, se puede extraer una definición sencilla de los preceptos que tratan de los impedimentos al transporte, entendiendo por tales aquellos acontecimientos o cualquier motivo que hace que la finalización del transporte en las condiciones previstas en la carta de porte sea imposible (art. 14.1 CMR). Es decir, los «impedimentos para el transpor-

\footnotetext{
583 Debe señalarse que el -hoy derogado- art. 369 Ccom sólo regulaba los impedimentos para la entrega, careciendo de cualquier disposición sobre los impedimentos al transporte. $\mathrm{Al}$ respecto puede verse, F. JUAN Y MATEU, «Impedimentos al transporte», en J.F. Duque Domínguez y F. Martínez Sanz (dirs.), A. Emparanza Sobejano y $\mathrm{M}^{\mathrm{a}}$.V. Petit Lavall (coords.), Comentarios a la Ley de Transporte Terrestre, cit., p. 384. En cambio, sí están previstos los impedimentos tanto al transporte como a la entrega en los arts. 20 a 22 RU CIM, que se corresponden en mayor o menor medida con los preceptos de la LCTTM y el CMR antes reseñados.
}

584 L.-É. MATILE, Le droit..., cit., pp. 40-41. 
te» son aquellas causas o motivos que vuelven imposible su ejecución. Concretamente, se trata de cualquier impedimento que se produce después de la recepción de las mercancías por el porteador y antes de que lleguen las mercancías al lugar previsto para su entrega, es decir, durante el periodo en que se efectúa su desplazamiento, con independencia de que sea debido o no a culpa del porteador (que sólo influye, en su caso, a la hora de solicitar el reembolso de los gastos causados por la ejecución de las instrucciones) 585 .

Son muchos los obstáculos al transporte que pueden surgir durante su realización: pueden ser imprevistos e inevitables (es decir, supuestos de fuerza mayor), como los fenómenos naturales (incendio, inundación, terremoto etc.) ${ }^{586}$; pueden deberse a una interrupción física del tráfico en determinadas vías, o a medidas administrativas de los poderes públicos, o a huelgas del personal de aduana, al cierre de fronteras (en el transporte internacional) o, en fin, a la culpa de un tercero587.

En el caso de que se presente un impedimento o cualquier interrupción en el curso del transporte, el transportista está obligado a comunicarle al remitente o, en su caso, al destinatario ${ }^{58}$ o a la persona legitimada para impartir órdenes, los obstáculos que impiden la continuación del transporte y solicitarle instrucciones, proporcionándole toda la información útil para impartir las órdenes más adecuadas al caso determinado. Como no puede ser de otra forma, los gastos y perjuicios que se devenguen por la ejecución de las instrucciones ha-

585 Vid. el art. 14.1 CMR, así como F. JUAN Y MATEU, «Los impedimentos para la ejecución del contrato», en A. Emparanza Sobejano y A. Recalde Castells (dirs.), El contrato de transporte internacional de mercancías por ferrocarril, cit., p. 162; L.-É. MATILE, Le droit..., cit., p. 41; B. MERCADAL, Droit des transports terrestres et aériens, Dalloz, Paris, 1996, p. 108.

${ }^{886}$ Con detalle sobe esta cuestión, F. MARTínEz SANZ, La responsabilidad del porteador en el transporte internacional de mercancías por carretea -CMR-, Comares, Granada, 2002, pp. 202 y ss.

${ }^{587}$ F. J. SÁNChEZ-GAMBorino, El contrato..., cit., p. 134; J. PUTZEYS, Droit..., cit., p. 173.

588 Siempre y cuando sea él el titular del derecho de disposición, p.ej., por disponer del primer ejemplar de la carta de porte, o por haberse pactado expresamente que dicho derecho se le atribuye a él directamente (art. 29.2 LCTTM). Vid. F. JUAN Y MATEU, «Impedimentos...», cit., p. 387. 
brán de ser debidamente resarcidos por el titular del derecho de disposición, salvo si ha intervenido culpa del porteador 589 .

Ni el CMR ni tampoco la Ley 15/2009 determinan el momento exacto en el que el porteador ha de solicitar las instrucciones. Ello es debido, probablemente, al amplio abanico de situaciones posibles que imposibilitan la realización del transporte. De esta forma, enfrentado con una circunstancia imprevista, el transportista habrá de actuar diligentemente y pedir instrucciones tan pronto como le sea posible, sea por teléfono u otro medio de comunicación, teniendo en cuenta la continua evolución de la tecnología. Cualquier retraso o demora injustificada en comunicar tal circunstancia al derechohabiente impedirá al transportista solicitar el reembolso de los gastos y perjuicios por las instrucciones emitidas. Sin embargo, hay quien opina que hubiera sido adecuado determinar un límite de tiempo máximo para pedir instrucciones al cargador590.

La imposibilidad para seguir ejecutando el transporte no permite al transportista, según lo dispuesto en la Ley, desentenderse de su exclusiva responsabilidad por la custodia y conservación de las mercancías. De ahí que no pueda abandonarlas sin más, ni tampoco aplicar un menor nivel de diligencia en su custodia, aun cuando el impedimento sea debido a caso fortuito o fuerza mayor. Antes al contrario, continúa respondiendo por cualquier daño ocasionado en las mercancías, conforme a las reglas sobre responsabilidad del porteador en caso de pérdida o avería. Por su parte, es el transportista quien soporta la carga de la prueba de demostrar que los impedimentos para el transporte no han tenido como causa su culpa u omisión591.

A veces sucede que el transportista no recibe en tiempo útil las instrucciones que pidió del cargador, o que las mercancías pueden sufrir por su propia naturaleza daños durante la espera de instrucciones. Para remediar esta situación, los artículos 14.2 CMR y 31.2 LCTTM facultan (y obligan) al porteador, en

\footnotetext{
589 F. Juan y Mateu, «Impedimentos...», cit., pp. 387 y ss.; M.A. Clarke y D. Yates, Contracts..., cit., p. 33.

590 Así, F.J. SÁnChez-Gamborino, El contrato..., cit., p. 136; F. JuAN y Mateu, «Impedimentos...», cit., p. 387.

${ }^{591}$ J. PUTZEYS, Droit..., cit., p. 166 y 167; J.D. ENRIQUE RosAS, Transporte..., cit., p. 235 y ss; F. JUAN Y MATEU, «Los impedimentos...», cit., p. 163.
} 
ausencia de órdenes, para adoptar aquellas medidas que juzgue adecuadas en interés del derechohabiente.

En línea con lo que disponen los preceptos citados, puede concluirse que se está en este caso ante una forma excepcional del derecho de disposición. Y es que en este último caso parece que el propio porteador adquiere, de forma sobrevenida y dentro de los estrechos márgenes marcados por la ley, su propio poder de disposición sobre las mercancías. Es decir, se le confiere la facultad de adoptar aquellas medidas que vea razonables y adecuadas, cambiando las condiciones del transporte por su propia cuenta, como precaución tomada diligentemente y de buena fe, posibilitando el buen fin de la operación592.

En cuanto a la idoneidad de la medida que ha de adoptar el transportista, se ha señalado que no cabe exagerar la intervención del transportista en tomar enseguida todas las medidas que agotan su capacidad, ya que el transportista no tiene por qué adentrarse en los detalles de la operación subyacente; pero tampoco debe el transportista tratar este asunto con negligencia en lo que concierne a la elección de la medida más conveniente, pudiendo incluso considerarse un supuesto de dolo o fraude. Es suficiente, entonces, con que aproveche su experiencia y sus conocimientos respecto a las circunstancias del caso, y que se comporte diligentemente y de buena fe, tal y como se espera de un transportista profesional593.

Como se ha visto, el porteador podrá actuar según su propio criterio si no recibe instrucciones del cargador (o de quien fuera titular del derecho de disposición) «en tiempo útil». Ciertamente, el legislador no ha fijado ningún período concreto que puede considerarse «útil», ni tampoco un plazo de tiempo máximo para esperar las instrucciones. Y está bien que no lo haya hecho, dada la gran diversidad de casos posibles que pueden darse en la práctica, puesto que cada caso concreto implica otro tiempo conveniente, según las reglas discrecionales de prudencia y diligencia 594 .

${ }^{592}$ F. JUAN Y MATEU, «Impedimentos...», cit., p. 389.

593 F.J. SÁNCHEZ-GAMBORINO, El contrato..., cit., p. 137.

594 F.J. SÁNCHEZ-GAMBORINO, El contrato..., cit., p. 138. 
No cabe duda, con todo, de que ante una demora en la impartición de instrucciones el transportista no tiene por qué aguantar indefinidamente la llegada de las órdenes, en particular, cuando es consciente de que el hecho de esperar instrucciones puede dañar las mercancías si no se actúa con prontitud. A este respecto señala el artículo 31.3 LCTTM que, en caso de producirse un retraso en la emisión de tales instrucciones, estando el cargador (o quien ostente el derecho de disposición) obligado a impartirlas en un tiempo razonable, deberá éste abonar los gastos y perjuicios causados al transportista595.

Por último, las medidas descritas en párrafos anteriores han de ser razonables, proporcionadas y adecuadas al buen fin del transporte, atendiendo a la diversidad de las circunstancias que pueden producirse en la práctica596. Entre otras medidas, el transportista puede, conforme a las facultades concedidas por la Ley, descargar la mercancía (art. 16.2 CMR), proceder a su venta (art. 16.3 CMR) o devolverla a su lugar de origen. También podrá, según dispone la Ley 15/2009, depositar la mercancía en almacén seguro o llevar a cabo la operación de transporte, pero en otras condiciones diferentes de las establecidas en el contrato597.

\section{bb) Impedimentos para la entrega}

Bajo el Derecho previgente, el Código de comercio no proporcionaba ninguna definición concreta del término «impedimento para la entrega», y ni siquiera mencionaba este término en su articulado. Sin embargo, el legislador sí enumeró, en el artículo 369 Ccom, algunas de las hipótesis más relevantes que perte-

595 F. JUAN Y MATEU, «Impedimentos...», cit., p. 389.

596 Como se vio, son muchos los supuestos que pueden darse, tales como el cierre de fronteras, la interrupción física del tráfico, errores en la denominación de las personas interesadas, o en la descripción de la propia mercancía, o de la ruta a seguir, etc. Son todos ellos hechos o circunstancias que frenan la actividad normal del transporte y la consecución del objetivo perseguido con la operación.

597 Ello sucede, por ejemplo, si debido a una avería que sufre el vehículo resulta difícil continuar el transporte. El transportista en este caso puede solucionar el impedimento con un transbordo de la mercancía a otro vehículo, salvo pacto en contrario. De forma similar, cuando se halla en una ruta completamente bloqueada por cualquier motivo, podrá superarse el impedimento cambiando el itinerario, salvo si se hubiera acordado que la ruta paralizada es el itinerario obligado por el cual debe efectuarse el transporte. Al respecto, $\mathrm{F}$. JUAN Y MATEU, «Los impedimentos para la ejecución...», cit., p. 165; ID., «Impedimentos...», cit., p. 386. 
necen a la categoría de los impedimentos para la entrega: la ausencia del destinatario, o si éste no fuera hallado en el domicilio expresado en la carta de porte; el impago de los portes y gastos del transporte por parte del destinatario; y, por último, el rechazo por parte del destinatario de efectos transportados 598 . Diferente es la situación en las legislaciones más modernas. Valga como el ejemplo el CMR, que no sólo regula la figura de los impedimentos para la entrega en su artículo 15, sino también los denomina así, al señalar que «[c]uando, después de la llegada de la mercancía al lugar de destino, se presentan impedimentos para la entrega...».

En efecto, el término «impedimento para la entrega» suele referirse en el Derecho del transporte a aquellos hechos o circunstancias de origen diverso599 que surgen en el momento previsto para la entrega, esto es, después de la llegada del envío al punto de destino. La presencia de tales hechos o circunstancias impide al porteador entregar los efectos transportados al destinatario. No obstante, al igual que sucede con los impedimentos para la ejecución del transporte, el porteador sigue obligado a custodiar las mercancías y responderá de los daños que pudieran ocasionarse a las mercancías según las reglas generales ${ }^{600}$. Sobre la base de tales consideraciones, el impedimento para la entrega se ha definido como aquel evento o hecho por virtud del cual la entrega de las mercancías en el lugar de destino se hace imposible ${ }^{601}$.

598 Véase F. JUAN Y MATEU, «El régimen jurídico de los impedimentos para la entrega en el transporte nacional por carretera», en F. Martínez Sanz (dir.) y $\mathrm{M}^{\mathrm{a}}$. V. Petit Lavall (coord.), I Congreso Internacional de Transporte: los retos del transporte en el siglo XXI, T. I, Tirant lo Blanch, Valencia, 2005, p. 942.

599 Tales hechos o circunstancias se han clasificado en tres grupos, en atención a su pertenencia a la esfera de los sujetos intervinientes en el transporte. En primer lugar, los hechos o circunstancias que se producen en la esfera del destinatario, por ejemplo, cuando éste rehúsa la recepción de la mercancía; o cuando se niega a abonar el pago de los gastos o los portes debidos por el transporte. En segundo lugar, existen hechos y circunstancias que surgen en la esfera del porteador, por ejemplo, cuando se estropean los mecanismos con los que se halla dotado su vehículo para la descarga. En último lugar, los impedimentos para la entrega pueden pertenecer también a la esfera del cargador, por ejemplo, cuando el porteador no encuentra el destinatario o no consigue localizarlo en el lugar previsto en la carta de porte, debido a que el cargador había incluido datos incorrectos. Así, F. JUAN Y MATEU, «Los impedimentos para la entrega...», cit., p. 11.

${ }^{600}$ F. JUAN Y MATEU, «Los impedimentos para la entrega...», cit., p. 9.

${ }^{601}$ L.-É. MATILE, Le droit..., cit., p. 44. 
La diferencia que existe entre el impedimento para el transporte y el impedimento para la entrega ha de buscarse en el hecho de que en este último los impedimentos surgen después de la arribada de las mercancías al punto de destino, esto es, el lugar previsto para la entrega. Por ello, el hecho de que el destinatario se niegue a recibir las mercancías antes incluso de que éstos lleguen al lugar de su consignación se haya calificado como un supuesto de «impedimento para la entrega anticipado»602.

En cuanto a sus consecuencias, cuando se producen impedimentos que imposibilitan la entrega de la mercancía al destinatario, al igual que ocurre en los impedimentos al transporte, los artículos 15.1 CMR y 36.1 LCTTM imponen al porteador la obligación de pedir inmediatamente instrucciones, describiendo con exactitud el hecho o la circunstancia que impide la entrega, al objeto de poder emitir instrucciones adecuadas al respecto. Ahora bien, si el impedimento acabara mientras el porteador está esperando la llegada de las instrucciones (o sea, antes de haberlas recibido), entregará las mercancías al destinatario, dando aviso enseguida al remitente ${ }^{603}$. Aunque la ley no lo exigiese, la solicitud de instrucciones tan pronto como sea posible resulta la solución más conveniente para el porteador para liberarse de su obligación de conservar y custodiar las mercancías. En efecto, aun a pesar de que se haya presentado un impedimento para la entrega, el transportista sigue sujeto al deber de custodia de la carga ${ }^{604}$.

De entre los impedimentos que impiden la entrega destaca el rehúse del destinatario a recibir la mercancía. Es el impedimento más acuciante de todos los previstos en la Ley, ya que, con la llegada de las mercancías a destino, aparece en escena el destinatario como tercero cuya actuación puede generar una diversidad de situaciones jurídicas en la esfera del porteador. Recuérdese a este respecto que este sujeto no está obligado en virtud del contrato de transporte a recibir las mercancías, de manera que tampoco será responsable en caso de que

${ }^{602}$ F. JUAN Y MATEU, «Los impedimentos para la ejecución...», cit., pp. 166-167.

603 Así, para el transporte ferroviario, P.M.-F. DURAND, Les transports internationaux (ferroviares et mixtes): Etude comparée des nouvelles conventions de Berne mises en application le 1 mars 1956, Sirey, 1956, p. 176. Cfr. también el art. 36.2 LCTTM.

604 A. DíAz MORENo, «El contrato...», cit., p. 671; F. JUAN y MATEU, «Los impedimentos para la ejecución...», cit., pp. 20 y ss. 
las rehusara ${ }^{605}$. Ello no obsta, como es natural, para que el destinatario resulte obligado a recibir la carga en virtud de otra relación jurídica (señaladamente la de valuta, generalmente un contrato de compraventa, que propició la celebración del contrato de transporte), pero no lo será frente al transportista (sino, probablemente, frente al cargador).

En efecto, la recepción de la mercancía nunca ha sido una obligación para el destinatario sino una mera ventaja que se le atribuye en virtud de la estipulación hecha en su favor. De ahí que pueda negarse libremente a aceptar los géneros transportados sin que incurra en responsabilidad alguna surgida del contrato de transporte, ni tampoco necesita presentar justificación de ningún tipo para su conducta. La libertad del destinatario para optar entre aceptar o rehusar el envío se deriva de su posición jurídica como tercero ajeno al contrato de transporte, tipificada en el régimen de los contratos a favor de tercero606. Conviene recordar al respecto que el destinatario ocupa la posición del beneficiario en un contrato a favor de tercero que, en virtud de la estipulación hecha en su provecho, goza del derecho de aceptar o de repudiar la prestación prometida.

Se entiende que se está ante un rechazo implícito de la carga cuando el destinatario manifiesta su aceptación para recibirla, pero se niega a pagar las cantidades devengadas (esto es, los portes debidos, los gastos o el reembolso) con ocasión del transporte y previstas en la carta de porte607. En tal caso, se puede deducir tácitamente de la conducta de aquel destinatario que no se aviene a pagar los costes del transporte que rechaza el recibo de los géneros transportados, pues el porteador gozará del derecho que le concede el artículo 40.1 LCTTM a detener la entrega de las mercancías, negándose a ponerlas en mano del destinatario ${ }^{608}$. Idéntica es la solución en el transporte internacional, donde

605 F.J. SÁNCHEZ-GAMBORINO, El contrato..., cit., p. 139.

${ }^{606}$ F. JUAN Y MATEU, «Los impedimentos para la entrega...», cit., pp. 32 y ss.

${ }^{607}$ Así, para la situación en el ámbito de aplicación del CMR, F.J. SÁNCHEZ-GAMBORINO, El contrato..., cit., p. 139.

${ }^{608} \mathrm{El}$ art. 40 LCTTM se ocupa de la suerte de las mercancías en caso de impago del precio del transporte por parte del destinatario, estableciendo en su párrafo primero que, «[s]i llegadas las mercancías a destino, el obligado no pagase el precio u otros gastos ocasionados por el transporte, el porteador podrá negarse a entregar las mercancías a no ser que se le garantice el pago mediante caución suficiente». Al respecto de esta hipótesis, que implica la aceptación de la mercancía, pero sin pagar el reembolso o el precio del transporte, DÍAZ MORENo señala que, desde un punto de vista abstracto, se puede incluir 
el porteador, de acuerdo a lo establecido en el artículo 13.2 CMR, tampoco se encuentra obligado a efectuar la entrega del envío al destinatario, a menos que éste preste garantía suficiente ${ }^{609}$.

Por su parte, si por una omisión del porteador no ha llegado a efectuarse el cobro del reembolso según lo pactado en el contrato, y aun así las mercancías han sido entregadas al derechohabiente, el transportista queda obligado a resarcir al remitente en cuantía no supuerior al precio del reembolso, sin perjuicio de su derecho para repetir contra el destinatario (art. $21 \mathrm{CMR}$ ).

A la luz de lo dispuesto en el artículo 15.2 $\mathrm{CMR}^{610}$, parece conveniente señalar ciertos problemas que pueden surgir entre el destinatario y el remitente, conectados generalmente con la relación de valuta (el contrato de compraventa sobre las mercancías que después se transportan al comprador), en el marco de la cual se discute sobre la calidad de la mercancía, o sobre el precio a fin de rebajarlo, etc. En la medida en que tales dificultades habrán de ser solventadas finalmente por el vendedor y el comprador, el precepto citado protege al porteador, que es un tercero ajeno al contrato de compraventa, frente a inconvenientes surgidos de éste que pueden afectarle directamente si el destinatario decide rehusar la carga. Así, en caso de que el requerimiento por el destinatario no concuerda con las órdenes del remitente, el porteador deberá atender la solici-

esta hipótesis entre los impedimentos para la entrega, ya que el destinatario no se encarga de las mercancías según lo previsto en el contrato. Sin embargo, desde un punto de vista de legislación positiva, el supuesto difiere de cuando se está ante una situación que tiene un tratamiento específico en los arts 36 y 44 LCTTM. Puesto que en esta situación el porteador que detiene la mercancía no tiene por qué pedir instrucciones ni esperarlas, al discurrir el plazo máximo de diez días computados desde el día del impago, el porteador deberá solicitar al órgano judicial o arbitral (Junta Arbitral del Transporte) el depósito de las mercancías y la enajenación de las necesarias para cubrir las cantidades y los gastos del transporte (A. DÍAZ MORENO, «El contrato...», cit., pp. 671-672).

${ }^{609} \mathrm{El}$ artículo 374 Ccom aún preveía otra solución: con intención de proteger al porteador frente al impago, el Código le reconocía el derecho a solicitar, cuando el destinatario no procedía al pago y después de transcurridas veinticuatro horas desde la entrega, el depósito judicial de los géneros que había conducido e interesar la venta judicial para el cobro de lo debido. Al respecto puede verse E. MAPELLI LÓPEZ, Régimen..., cit., p. 112.

610 «Incluso en el caso de que el destinatario haya rehusado la mercancía, éste puede requerir, sin embargo, la entrega de la misma; siempre que el transportista no haya recibido instrucciones contrarias del remitente.» 
tud de entrega del destinatario, siempre que no reciba instrucciones contrarias del remitente con anterioridad ${ }^{611}$.

Al hilo de lo dicho, cabe preguntarse sobre el régimen aplicable al impedimento para la entrega que sobreviene después de que el destinatario haya aceptado el recibo de las mercancías, es decir, qué sucede en esta situación en relación con la solicitud de instrucciones y a quién debe el transportista pedirlas. De lo dispuesto en los artículos 36.4 LCTTM y 15.3 CMR se infiere que, cuando el destinatario haya dado orden al porteador de entregar la mercancía a un tercero, aquél se subroga en el derecho de disposición del remitente, de manera que es de él de quien deberán solicitarse instrucciones en caso de impedimentos para la entrega a dicho tercero. En definitiva, el porteador queda obligado a pedir órdenes al destinatario una vez que éste se haya incorporado al contrato del transporte mediante su aceptación de recibir los efectos transpor$\operatorname{tados}^{612}$. En este mismo contexto, el artículo 12.4 CMR restringe la cadena de subrogaciones entre destinatarios, por motivos de seguridad jurídica y para evitar confundir al porteador con respecto a su responsabilidad frente a varios destinatarios. En efecto, y como se vio, a tenor del precepto citado se prohíbe al tercero que sustituye al destinatario original designar nuevos destinatarios ${ }^{613}$.

\section{b) La extinción del derecho de disposición del cargador o remitente}

El derecho de disposición del cargador o remitente se extingue cuando empieza el del destinatario, saliendo de su órbita patrimonial y entrando en la del destinatario ${ }^{614}$. No obstante, el remitente recupera su derecho de disposición cuando se está ante algún impedimento para la entrega, por ejemplo, el rechazo de reci-

611 A. CABRERA CÁNOVAS, El transporte internacional por carretera, Marge, Barcelona, 2013, p. 104; F.J. SÁNCHEZ-GAMBORINO, El contrato..., cit., p. 140.

${ }^{612}$ A. DÍEz MORENO, «El contrato...», cit., p. 673; F.J. SÁNCHEZ-GAMBORINO, El contrato..., cit., p. 140.

${ }^{613} \mathrm{Al}$ respecto véase F.J. SÁNCHEZ-GAMBORINO, El contrato..., cit., p. 140.

$614 \mathrm{Al}$ respecto señala RECALDE con acierto que la pérdida del derecho de disposición por el remitente no siempre conduce a que lo adquiera el destinatario. Y es que, como se ha visto con anterioridad, el ejercicio del derecho de disposición por el remitente queda sujeto a ciertas condiciones, entre las que se encuentra la obligación de presentar el primer ejemplar de la carta de porte. Así, el remitente, una vez enviada la carta de porte al destinatario, queda desprovisto de su derecho a disponer de la carga, aunque en este caso no se produzca (aún) la transmisión del derecho al destinatario. Vid. A. RECALDE CASTELLS, «El 'derecho de disposición'...», cit., p. 15. 
bir las mercancías por parte del destinatario, o la imposibilidad de localizarlo en el domicilio indicado en la carta de porte ${ }^{615}$.

En efecto, la extinción del derecho del remitente a modificar el contrato y a disponer de la mercancía se produce, según lo previsto en los artículos 12.2 CMR y 30.3 LCTTM, una vez entregado al destinatario el segundo ejemplar de la carta de porte (el que viaja con las mercancías) o cuando éste manifieste su voluntad de reclamar la entrega de las mercancías. Obviamente, sólo puede hablarse en estos supuestos de una extinción del derecho de disposición cuando éste no pertenecía ya desde el principio al destinatario, por haberse hecho constar así en la carta de porte ${ }^{616}$.

Volviendo al supuesto del rehúse de la mercancía por el destinatario, también este acto puede encuadrarse en la teoría general del contrato a favor de tercero. Si se equipara la situación del destinatario a la del tercero beneficiario, la aceptación de la prestación estipulada en su provecho hace que adquiera inmediatamente los efectos beneficiosos del contrato a su favor. En el caso del contrato de transporte, se refiere al derecho a la entrega de las mercancías, que desde la aceptación estará protegido frente a cualquier acto de revocación que pueda privarle del fruto de la estipulación concluida en su interés ${ }^{617}$.

En consecuencia, una vez atribuido el derecho de disposición al destinatario, éste será legitimado para reclamar sus derechos frente al porteador y se convierte en titular del derecho de disposición. Así, el porteador a partir de ese momento estará obligado a pedir y recibir instrucciones emitidas por el destina-

615 E. MAPELli LÓPEZ, Régimen..., cit., p. 107; F. JUAN Y MATEU, «Los impedimentos para la entrega...», cit., pp. 30 y ss.

${ }^{616}$ Este es el supuesto contemplado en el art. 12.3 CMR. Su homólogo español en el art. 29.2 LCTTM, sin embargo, no exige que la atribución de este derecho al destinatario se haga constar en la carta de porte, sino que se le puede atribuir mediante pacto expreso entre las partes contratantes, reconociendo al destinatario, desde el momento de la formalización del contrato de transporte, la titularidad del derecho de dar órdenes y de disponer de las mercancías. Ello sucede a menudo cuando el transporte se contrata en ejecución de un contrato de compraventa, con el destinatario como comprador y el remitente como vendedor, ya que cuando este último recibe el pago del comprador, atribuirá la facultad de disponer del envío al destinatario-comprador quien, a su vez, se asegura de que efectivamente recibirá la mercancía, evitando así cualquier intento de desviar el transporte a otro destinatario. Vid. A. DÍAZ MORENO, «El contrato...», cit., p. 668; F. JUAN Y MATEU, «Derecho...», cit., p. 367.

617 A. ReCAlde CASTELls, «El ‘derecho de disposición'...», cit., p. 15. 
tario que toma las decisiones sobre el envío, ya que a través de esta atribución se le sitúa en una situación directa frente al envío, asumiendo todos los derechos y obligaciones dimanadas de ello ${ }^{618}$.

\subsection{El derecho de disposición del destinatario}

Habrá ocasión de analizar el derecho de disposición del destinatario más adelante, concretamente, en el siguiente capítulo de esta obra, que será dedicado a la posición jurídica del destinatario. Pero ello no impide que se haga una breve referencia él. Como se decía, el derecho de disposición se transmite al destinatario mediante una operación subrogada, al sustituirse al remitente por el destinatario en la facultad de impartir instrucciones y reclamar frente al porteador todos los derechos correspondientes a la entrega. Y tal transmisión del derecho al destinatario puede realizarse por dos modos: por un lado, con la entrega al destinatario del segundo ejemplar de la carta de porte o con la solicitud por éste de entrega de la carga (arts. 12.2 CMR y 30.3 LCTTM); por otro, mediante pacto expreso entre las partes en el contrato que atribuya el derecho de disposición al destinatario (art. 29.2 LCTTM), haciéndolo constar, en su caso, en la carta de porte (art. 12.3 CMR).

\subsection{Sobre la posibilidad de transmitir el derecho de disposición a un tercero}

En cuanto a la posibilidad de atribuir el derecho de disposición a un tercero, la ley prohíbe expresamente que ese derecho se transmita de manera sucesiva del destinatario a otra persona (arts. 12.4 CMR y 29.2 LCTTM). Y ello porque el derecho de disposición del destinatario se extingue una vez que nombre un nuevo destinatario quien, a su vez, no podrá ejercer el derecho de disposición en relación con esta carga recibida por el destinatario primitivo.

El objetivo perseguido por la norma es, probablemente, el aumento de la seguridad jurídica en beneficio del transportista, previniendo la concatenación de destinatarios que impida que el transportista pueda finalizar la operación de transporte, aparte de que éste no necesariamente estará seguro de a quién debe

618 M.Á. PENDÓN MELÉNDEZ, «El derecho...», cit., p. 196. 
entregar definitivamente las mercancías y cuál es su último destinatario, y quién le abonará los gastos y los portes del transporte ${ }^{619}$.

Sin embargo, la posibilidad de atribuir el derecho de disposición a un tercero que no sea ni el cargador ni el destinatario no es un caso excepcional, ya que nada obsta para que en el contrato se pacte que el transportista deba informar del arribo de las mercancías a una persona determinada y en una dirección concreta (la llamada notify address) ${ }^{620}$.

${ }^{619}$ F.J. SÁNCHEZ-GAMBORINO, El contrato..., cit., p. 127.

620 Es este el criterio de RECALDE CASTELLS cuando señala que «no cabe extrañar el caso en que, en el contrato, se designa como destinataria de la mercancía a la entidad de crédito que financia la operación de exportación, mientras que el destinatario real se menciona en la carta de porte como aquél a quien debe notificarse la llegada de las mercancías, eventualmente atribuyéndole la facultad de determinar dónde debe efectuarse la entrega para poder atender a las circunstancias comerciales concurrentes. En este caso será aplicable el régimen del derecho de disposición previsto para cuando se atribuye dicho derecho al destinatario» (A. RECALDE CASTELLS, «El 'derecho de disposición'...», cit., p. 19). 


\section{CAPítulo IV}

\section{LA POSICIÓN JURÍDICA DEL DESTINATARIO EN EL CONTRATO DE TRANSPORTE TERRESTRE DE MERCANCÍAS}





\section{Los posición del destinatario en la configuración legal del contrato de transporte}

\section{Antecedentes históricos de la configuración de las operaciones de transporte}

Desde una dimensión histórica se advierte que la forma primitiva del transporte implicaba una actividad porteadora que no requería aún la celebración de contrato alguno, pues los comerciantes transportaban personalmente las mercancías que ellos mismos compraban y vendían. El vendedor viajaba con su mercancía para ofrecerla a sus clientes eventuales, comerciantes y no comerciantes, mientras que el comprador iba a buscar la mercancía que necesitaba a su lugar de origen, o acudían ambos a las ferias donde se solía especular con bienes y mercancías ${ }^{621}$. Cada uno de ellos llevaba a cabo por su propia cuenta la actividad de transporte de las mercancías desde su domicilio hasta el lugar donde se comercializaban y viceversa.

Esta forma de organizar la circulación de las mercancías en la vida económica primitiva era debida a muchas razones, entre ellas la pobreza de los medios de transporte, la escasez de los medios de comunicación y la falta de seguridad. Este último motivo justificaba que los viajeros acompañaran las mercancías en sus itinerarios con el fin de protegerlas contra las incursiones de salteadores de caminos ${ }^{622}$.

Poco a poco se fueron produciendo avances importantes en el ámbito del comercio, tras la revolución de los medios de telecomunicación, junto a la del transporte, sobre todo después de la invención del ferrocarril y de los automóviles en el siglo XIX, que propiciaron un aumento importante de la rapidez y la

${ }^{621}$ Señala DíAz DomínguEZ al respecto que «[e]n la Edad Antigua el transporte es un acto económico pero no un contrato jurídico, porque el comerciante en general carga por su cuenta las mercancías y recorre con ellas los lugares que escoge como campo de sus especulaciones» (citado por J. GómEZ CALERO, El transporte..., cit., p. 14).

622 Así ya A. PERrinjaquet, Droit de disposition du destinataire dans le contrat de transport suisse, Imprimerie de la Société de la Gazette de Lausanne, Lausanne, 1929, p. 15 . 
seguridad en el transporte ${ }^{623}$. Paralelamente, la actividad de los comerciantes empezó a cambiar gradualmente y a volverse más especializada, por cuanto algunos se especializaron en la compra o en la venta de mercancías, mientras que otros se dedicaron a trasladar las mercancías de aquéllos.

Desde entonces, el transporte se ha convertido en una actividad casi exclusiva de empresas privadas e independientes. Con esta nueva forma de organización comercial, el vendedor, o en su caso el fabricante, dejó de efectuar por sí el transporte de sus productos, confiándolo a un transportista especializado, al tiempo que resultó innecesario que el comprador se desplazara para recibir su mercancía, pues este último, a su vez, confía en que el vendedor adopte todas las medidas necesarias para asegurar el buen fin del viaje y para que las mercancías lleguen en buen estado a su destino 624 .

Partiendo de estos antecedentes históricos se puede concluir que el transporte pasó de ser en su forma primitiva una actividad efectuada de forma privada por el dueño de las mercancías, quien las transportaba por sus propios medios, a una actividad pública en la que remitente y porteador son personas distintas. Son dos, por tanto, las partes contratantes que inicialmente acuerdan el transporte de las mercancías ${ }^{625}$.

\section{La aparición del destinatario en las operaciones de transporte}

Las referencias anteriores dan cuenta del hecho de que, en la actualidad, el vendedor-remitente tiende a dejar sus mercancías en manos de un transportista profesional, con el que celebrará un contrato de transporte. El vendedor, en

\footnotetext{
${ }^{623}$ En efecto, el avance tecnológico tuvo mucha influencia en el sector del transporte, quizás más que en cualquier otro en materia de comercio, hasta el punto de transformar la realidad económica y social, ya que cambiaron la utilización de la clásica navegación a vela a la de vapor, y del motor de combustión a la energía nuclear. En cuanto al transporte terrestre, la tracción animal se sustituyó por el ferrocarril y el automóvil, mientras en el transporte aéreo se pasó en poco tiempo de la hélice al turborreactor. Vid. M. OlivenciA RuIZ, «La tarea unificadora en materia de transporte», en A. Madrid Parra (coord.), Derecho uniforme del transporte internacional: Cuestiones de actualidad, McGraw-Hill, Madrid, 1998, p. 10.

624 A. PERrinJaQuet, Droit de disposition..., cit., p. 16.

625 J. Gómez CALERo, El transporte..., cit., p. 14.
} 
consecuencia, deja de operar por sí el transporte y de entregar las mercancías personalmente a su comprador (o a su derechohabiente). Al objeto de poder cumplir con sus obligaciones dimanantes del contrato de compraventa, el vendedor-remitente deberá por ello indicar en el contrato de transporte a quién desea dirigir el envío, o sea, el tercero-comprador.

De cuanto antecede se comprende de qué forma el destinatario surge como sujeto distinto del remitente: aparece como un tercero extraño al contrato de transporte del que, sin embargo, deriva derechos aun sin haber intervenido en su celebración. Ello no impide que el destinatario se adhiera posteriormente al contrato, una vez que acepte las mercancías tras su llegada al punto de destino y se proceda a la entrega de las mismas. Por esta razón, el contrato de transporte se caracteriza por no repercutir sólo en la esfera de las partes contratantes, el cargador y el transportista ${ }^{626}$, sino también despliega algunos de sus efectos frente al destinatario.

En efecto, la aparición del destinatario en el contrato de transporte vino acompañada en el Derecho moderno por dos características: la primera, que el traslado de las mercancías pasa a efectuarse por cuenta del destinatario, que se convierte en acreedor principal de la prestación estipulada a su favor; la segunda, la obligación del destinatario de abonar, en su caso, los gastos del transporte una vez terminado éste y aceptada la entrega de las mercancías por aquél627.

\section{Consecuencias derivadas de la aparición del destinatario en el contrato de transporte}

Como se decía, las principales consecuencias de la aparición del destinatario en el marco estructural del contrato de transporte son su ejecución por cuenta del destinatario y la carga de satisfacer, en su caso, el precio del transporte y los gastos si quiere recibir las mercancías. Ambos aspectos han marcado la evolución del contrato de transporte en torno a la participación del destinatario, concretamente, la atribución al destinatario de una acción personal y directa frente

${ }^{626}$ J. Garrigues, Curso..., cit., p. 214.

627 A. PERrinJaQuet, Droit de disposition..., cit., p. 17. 
al transportista para exigir el cumplimiento del contrato (o de solicitar el resarcimiento de los daños y perjuicios causados en caso de que ello no sea posible).

\section{El marco estructural de la posición jurídica del destinatario: la estipulación a favor de tercero}

\subsection{La transmisión del derecho de disposición del expedidor al destinatario}

Como regla general, el derecho de disposición nace en la esfera patrimonial del cargador, debido a la posición que ocupa en el contrato de transporte. En efecto, salvo que otra cosa se pacte, la ley atribuye al cargador, en cuanto parte contratante, el derecho de disposición. Como se vio, este último derecho se caracteriza por su peculiar función y contenido, concediendo a su titular el poder de modificar, por su propia y única voluntad, el contenido del contrato de transporte. Ello implica que el porteador se encuentra en una cierta relación de subordinación, pues deberá cumplir todas las instrucciones y órdenes del (cargador o destinatario) que cumplan con las condiciones que establece la ley para el ejercicio del derecho de disposición.

Como se ha indicado con anterioridad, el derecho de disposición es un derecho que nace ex lege, de manera que se configura como un elemento esencial y típico del contenido del contrato de transporte. De ahí que no haya lugar para que las partes contratantes puedan excluirlo, ni tampoco disponen de autoridad para decidir sobre su nacimiento, ni limitarlo más allá de lo dispuesto en la Ley. Así, el único pacto que puede alcanzarse en relación con ese derecho es la transmisión, por acuerdo expreso, de su titularidad a otra persona, esto es, al destinatario ${ }^{628}$.

Según lo previsto en los artículos 12.3 CMR y 29.2 LCTTM, el destinatario adquiere el derecho de disposición que le transmite el cargador de forma inmediata cuando se hace constar esta transmisión en el primer ejemplar de la carta

${ }^{628}$ En este sentido, se señala que la transmisión del derecho de disposición en la práctica no necesita de ningún acuerdo, ya que basta con su atribución al destinatario unilateralmente por el expedidor-cargador y su reconocimiento por el porteador. Vid. M.Á. PENDón MELÉNDEZ, «El derecho...», cit., p. 178. 
de porte. Aunque la atribución de este derecho se hace de forma voluntaria por el cargador, su ejercicio por el destinatario queda condicionado a la presentación de este primer ejemplar de la carta de porte, cuya posesión se erige así en requisito imprescindible para atribuirle legitimación para ejercer su derecho a disponer de los efectos enviados. Y ello porque la adquisición de este ejemplar del documento de transporte es el medio de prueba legalmente reconocido que atribuye al destinatario su legitimación, que es asignado ya en la propia carta de porte que se presenta al porteador. En ausencia de este documento, el derecho de disposición permanece en la esfera patrimonial del cargador, de manera que lo único que puede solicitar el destinatario en virtud del contrato de transporte es, entonces, la entrega de las mercancías, a condición de que manifieste su consentimiento para aceptarlas una vez que éstas hayan llegado a destino ${ }^{629}$.

La atribución del derecho de disposición al destinatario hace de su ejercicio una tarea complicada. $\mathrm{Y}$ es que el destinatario ha de cumplir las mismas condiciones que se imponen al cargador para poder ejercer su derecho de disposición: no cabe duda alguna de que el derecho de disposición que se transmite del cargador al destinatario permanece igual, es decir, su naturaleza, su contenido esencial y los requisitos para su ejercicio son los mismos que los que correspondan al cargador ${ }^{63}$. En efecto, según se establece expresamente en los artículos 12.5 CMR y 30.1.a) LCTTM, el ejercicio del derecho de disposición por el destinatario - de forma igual a como sucede en caso de que lo ejercite el cargador- está condicionado, desde el momento en que se hizo constar su titularidad de este derecho en la carta de porte, a que el destinatario presente el primer ejemplar de la carta de porte, en la que deben figurar las nuevas órdenes emitidas al transportista ${ }^{63}$. De ello deriva claramente que la falta de presentación de

629 Sobre la base de esta afirmación se ha planteado en ocasiones que la posición jurídica del destinatario deriva de su identificación en la carta de porte, adquiriendo de ella el derecho de disposición. Sin embargo, la mayoría de los autores niegan esta afirmación, en atención al hecho de que «el origen de la posición del destinatario no está en la carta de porte, sino en el contrato", porque "si se admite que el fundamento de la posición del destinatario se halla en la carta de porte [...] queda sin explicación cómo adquiere el destinatario esa posición cuando la carta de porte no se emite». Vid. J. GómEZ CALERO, El transporte..., cit., p. 26.

${ }^{630}$ A. RECALDE CASTELLS, «El 'derecho de disposición'...», cit., p. 16.

${ }_{631}$ Todo ello sin perjuicio, claro está, del derecho del transportista a solicitar el resarcimiento por los gastos y daños que se puedan ocasionar en la fase de ejecución de 
este ejemplar de la carta de porte impide al destinatario modificar el contrato con anterioridad a la llegada de las mercancías al lugar de destino.

Ahondando más en el mecanismo por el cual se atribuye el derecho de disposición al destinatario, conviene recordar que la ley prevé dos maneras para transmitirlo al destinatario. La primera de ellas tiene lugar cuando se entrega el segundo ejemplar de la carta de porte al destinatario antes que las propias mercancías o cuando éste reclama la entrega de la carga. En tales casos, el destinatario se adhiere al contrato de transporte con la aceptación de la carta de porte $o$ la solicitud de entrega, momento a partir del cual el transportista estará sujeto a las instrucciones impartidas por él (arts. 12.2 CMR y 30.3 LCTTM) ${ }^{632}$. Idéntica es la consecuencia - esto es, la transmisión del derecho de disposición- cuando el destinatario hace valer los derechos que le corresponden en caso de pérdida o retraso en la entrega de la mercancía (art. 30.3 i.f. LCTTM).

La segunda manera de atribuir el derecho de disposición al destinatario es la prevista en el artículo 29.1 LCTTM (que en buena medida reproduce lo dispuesto en el art. 12.3 CMR), a cuyo tener el derecho de disposición puede atribuírsele directamente «cuando así se hubiese pactado expresamente»633. Por ello se entiende, a diferencia de lo que indica su modelo en el artículo 12.3 $\mathrm{CMR}^{634}$, que la transmisión del derecho de disposición al destinatario no se condiciona a que se haga constar en la carta de porte, siempre y cuando la atribución al destinatario se haya pactado de forma expresa entre las partes.

Este último supuesto tiene su eco específico en la práctica cuando el cargador es el vendedor y el destinatario el comprador en el contrato de compra-

estas órdenes, que surge con independencia de quién resulte ser titular del derecho de disposición

${ }^{632}$ Véase A. RECALDE CASTELLS, «El 'derecho de disposición'...», cit., p. 17.

633 En este caso, la transmisión del derecho de disposición al destinatario se realiza mediante un pacto expreso en el contrato de transportista celebrado entre cargador y porteador. Este pacto no es sino un acuerdo jurídico-privado como manera indirecta para cumplir una obligación contractual, cediendo al destinatario una acción para exigir el cumplimiento de esta estipulación pactada en su provecho.

634 En su apartado tercero, el art. 12 CMR dispone que «[e]l derecho de disposición pertenece en todo caso al destinatario desde el mismo momento de redacción de la Carta de Porte, si así se hizo constar en dicha Carta de Porte por el remitente». Como puede apreciarse, se exige expresamente que la atribución del derecho de disposición al destinatario ha de hacerse constar en la carta de porte para poder ejercer las facultades que se derivan de él. 
venta con expedición que proporciona la relación de valuta del contrato de transporte, esto es, cuando la venta implica el transporte de los efectos y su puesta a disposición del destinatario-comprador ${ }^{635}$. El hecho de atribuir el derecho de disposición directamente al destinatario-comprador sirve a éste de garantía de que la entrega se realizará a él, bloqueando la posibilidad de que el cargador-vendedor modifique el itinerario y desvíe el transporte a otro destinatario en ejercicio del derecho de disposición, o que ordene la detención del transporte y la devolución de las mercancías a su punto de partida ${ }^{636}$.

\subsection{La estipulación a favor de tercero}

Como ya se ha indicado en el segundo capítulo de este trabajo, uno de los temas que más han preocupado tradicionalmente a la doctrina ha sido el diseño del marco jurídico aplicable al destinatario. No sorprende así la existencia de diferentes teorías ${ }^{637}$ para explicar la posición jurídica que éste asume en el contrato de transporte. El análisis de los distintos esfuerzos realizados por la doctrina indica que la opinión que mayor consenso concita en esta materia es la que considera el contrato de transporte como un subtipo de los negocios jurídicos que contienen una estipulación a favor de tercero ${ }^{638}$. Y ello porque es la más cohe-

${ }^{635}$ M.Á. PENDÓN MELÉNDEZ, «La obligación de entrega en la venta con expedición», en A. Madrid Parra (coord.), Derecho uniforme del transporte internacional: Cuestiones de actualidad, McGraw-Hill, Madrid, 1998, pp. 356 y ss.

${ }^{636}$ F.J. SÁNCHEZ-GAMBORINO, El contrato..., cit., p. 125; F. JUAN Y MATEU, «Derecho...», cit., p. 367; A. RECALDE CASTELLS, «El 'derecho de disposición'...», cit., p. 16.

637 Como se vio, el segundo capítulo está dedicado en su totalidad al estudio de la teoría del contrato a favor de tercero como forma para determinar el régimen jurídico del destinatario en un contrato de transporte de mercancías, a nivel tanto nacional como internacional. Puesto que el destinatario es un tercero que no interviene en la conclusión del contrato entre cargador y transportista, su situación jurídica deriva de una estipulación a favor de tercero, que determina la pertenencia de los contratos de transporte al género mayor de los contratos a favor de tercero.

${ }^{638}$ En efecto, es esta la teoría que mayoritariamente se defiende en la doctrina española. Vid. M. Broseta Pont y F. MarTínez SANZ, Manual de Derecho mercantil, cit., p. 161; A. RECALDE CASTELLS, «El contrato de transporte...», cit., pp. 49 y ss.; C. LLORENTE Y GÓMEZ DE SEGURA, «El contrato de transporte terrestre de mercancías», cit., pp. 1004 y ss.; F. MarTínez Sanz, «Sujetos», en J.F. Duque Domínguez y F. Martínez Sanz (dirs.), A. Emparanza Sobejano y $\mathrm{M}^{\mathrm{a}}$.V. Petit Lavall (coords.), Comentarios a la Ley de Transporte Terrestre, cit., p. 81. Distinta aún la opinión en J. GARRIGUES, Curso de Derecho mercantil, cit., p. 214 ( «La explicación de este fenómeno ha sido muy debatida. Sin necesidad de recurrir a construcciones más o menos ingeniosas, hemos de ver aquí un ejemplo legal de la concesión de derechos contractuales a terceros no contratantes»); así como R. URÍA, Derecho mercantil, Madrid, 1985, p. 534, citado por E. MAPELLI LÓPEZ, El régimen..., cit., 
rente a la hora de dar una explicación del mecanismo en virtud del cual el destinatario se adhiere posteriormente al contrato de transporte y se convierte en acreedor de la prestación estipulada en su favor, adquiriendo todos los derechos derivados del contrato una vez que acepte la estipulación que le favorece, pudiendo invocar todas las pretensiones relevantes del contrato de transporte frente al transportista.

\section{El concepto de «destinatario» en el Derecho del transporte}

\section{Definición del destinatario}

Como se decía, el destinatario no es parte en el contrato de transporte, ni tampoco interviene de ninguna manera en su celebración, sino que es un mero beneficiario de la prestación estipulada en su provecho. No llega, por tanto, a intervenir en él como parte originaria (simplemente porque no ha participado en su conclusión), pero ello no impide que se incorpore posteriormente como acreedor frente al transportista, una vez las mercancías lleguen al punto de destino y el destinatario reclama todos los derechos que derivan del contrato ${ }^{639}$. No obstante, cuando se habla del destinatario se refiere a un sujeto que tiene, junto al cargador y al transportista, una gran transcendencia en la configuración contractual del transporte, tanto desde el punto de vista de su ubicación en el propio contrato de transporte como respecto de su intervención para finalizar la operación, pudiendo recibir los efectos trasladados, sin perjuicio de sus derechos y de la acción que le faculta para reclamar la indemnización de los daños que hayan podido sufrir las mercancías ${ }^{640}$.

Con arreglo al artículo 4.3 LCTTM, el destinatario es la persona a quien el porteador se compromete a entregar las cosas objeto del transporte en el lugar

p. 111, a cuyo juicio «la verdadera causa o razón está en la naturaleza de título de tradición que tiene la carta de porte».

${ }_{39}$ A. Antonini, Corso di diritto dei trasporti, $2^{\mathrm{a}}$ ed., Giuffrè, Milano, 2008, p. 184; F. MARTÍNEZ SANZ, «Sujetos», cit., pp. 81-82.

640 A.Y. RODRÍGUEZ BURBANO, Transporte multimodal: Régimen jurídico y responsabilidad del porteador, tesis doctoral, Castellón de la Plana, 2010, p. 353. 
fijado para la entrega. Dicho de otra manera, es a quien van dirigidas las mercancías ${ }^{641}$. Es, pues, el acreedor de la prestación en su etapa ejecutiva, ya que una vez realizado el transporte, tiene derecho a recibir las mercancías ${ }^{642}$.

Encontramos otras definiciones del destinatario, llamado en ocasiones «consignatario», en el Derecho previgente. Así, las Condiciones Generales de 1997 (Anexo A, cl. 1.6 y Anexo B, cl. 1.6) entendían por «consignatario» o «destinatario» aquella "persona, física o jurídica, a la que el porteador ha de entregar las mercancías objeto del transporte una vez finalizado éste», una definición que coincidía con la que proporcionaba el artículo 22.1 LOTT antes de su modificación por la Ley 9/2013. Ya entonces se entendía, pues, que los términos «destinatario» y «consignatario» eran sinónimos ${ }^{643}$. Sin embargo, en el ámbito del transporte comercial, se utiliza con preferencia el vocablo «destinatario», por la razón de ser este el que actual y frecuentemente se usa no sólo en el círculo empresarial de transporte y sus actividades auxiliares (mediadores), sino también por todas las entidades que de una manera u otra se relacionan con el transporte, tales como aseguradoras, bancos y clientes. Para evitar confusiones, debe advertirse que el «consignatario» del que se trata aquí es un sujeto distinto del consignatario de buques en el transporte marítimo, que tiene asignadas unas funciones distintas 644 .

En la práctica, el destinatario de las mercancías puede ser el mismo remitente o cargador ${ }^{645}$, por ejemplo, cuando un comerciante hace trasladar sus mercaderías desde el establecimiento central a los distintos sitios de venta don-

${ }^{641} \mathrm{C}$. VIGNALI, Il trasporto terrestre: verso una responsabilità oggettiva del vettore, Giuffrè, Milano, 2000, p. 170.

${ }^{642}$ A. DÍAZ MORENO, «El contrato...», cit., p. 652.

${ }^{643}$ En este sentido, E. MAPELLI, El régimen..., cit., p. 109, se refiere al «consignatario» como «la persona a la que se consiga el destino de la expedición porteada», mientras que el «destinatario» es «la persona a la que se destina la expedición». Como puede apreciarse, nada impide que los términos se utilicen de forma indistinta, al coincidir su significado.

644 F.J. SÁnCHEZ-GAMbORINO y J. GAITÁN REBOllo, Factbook..., cit., p. 83.

645 Así lo señalaba expresamente el tenor previgente del art. 22.1 LOTT, cuando establecía que "[p]odrá ser consignatario de las mercancías el propio cargador o una persona distinta». En el mismo sentido, la STS de 2 diciembre 1975 (RJ 1975, 4319), que admite la posibilidad de que el destinatario sea la misma persona que figura como cargador o remitente, como por ejemplo en el caso del usuario de un transporte de mudanza. 
de tiene sucursales ${ }^{646}$, donde sus representantes o empleados retirarán en su nombre las mercancías. No obstante, en la práctica actual lo más frecuente es que se designe otra persona para recibir las mercancías, por lo tanto, el comerciante (cargador-vendedor) suele remitir sus mercancías a sitios donde no tenga sucursales ni representantes 647.

El CMR, en cambio, no proporciona ninguna definición del destinatario, aunque sí obliga a las partes contratantes a identificarlo, mencionando su nombre y su domicilio en la carta de porte ${ }^{648}$. La falta de inscripción del nombre del destinatario en la carta de porte puede plantear un problema de gran importancia a la hora de entregar las mercancías, ya que puede resultar imposible conocer a quién ha de entregarse los efectos enviados ${ }^{649}$, por una parte, y determinar quién tendrá el derecho a reclamar frente al porteador cuando se produzcan daños a las mercancías, por otro. También puede suceder que el cargador, por necesidades prácticas, mencione únicamente el domicilio o la dirección del destinatario, permaneciendo el destinatario desconocido. En este caso, lo que se discute es a quién se puede considerar jurídicamente como destinatario. Al respecto, DORRESTEIN sostiene que, como regla general, el destinatario será la persona a la que las mercancías sean finalmente entregadas de acuerdo con la intención de las partes contratantes, aunque no sea el destinatario «original» (como, p.ej., el transitario que, en cuanto consignatario inscrito en la carta de porte, recibe las mercancías por cuenta del destinatario final, art. 121 LOTT) ${ }^{650}$.

${ }^{646}$ F.J. SÁnCHEZ-GAMBORINO y J. GAITÁn REBOLlo, Factbook..., cit., p. 83.

647 En tal supuesto, el comerciante dirigirá las mercancías a otra persona a la que ha de entregarlas como consecuencia de las relaciones jurídicas que median entre los dos como, por ejemplo, un contrato de compraventa. Vid. J. GARRIGUES, Curso..., cit., p. 214.

${ }^{648} \mathrm{En}$ su art. 6.1, letra e), el CMR establece que «la carta de porte debe contener las indicaciones siguientes: [...] e) Nombre y domicilio del destinatario».

649 En el supuesto en que coincidan cargador y destinatario en una misma persona, esta circunstancia ha de hacerse constar claramente en la carta de porte para evitar cualquier confusión.

${ }^{650}$ Th.H.J. DORRESTEIN, Recht van het internationale wegvervoer, Tjeenk Willink, Zwolle, 1977, citado por K.J. HAAK, The Liability of the Carrier under the CMR, Stichting Vervoeradres, The Hague, 1986, p. 256. Obsérvese, con todo, que no se trata de una opinión unánimente aceptada. En este sentido, el Rechtbank Ámsterdam se ha negado a respetar estas necesidades prácticas de no consignar el nombre del destinatario en la carta de porte, manteniendo indicado en ésta el consignatario como destinatario principal que resulta facultado para reclamar frente al porteador (sentencia de 18 de marzo de 1981, $S \& S, 1981$, pp. 83 y 84, citada igualmente por K.J. HAAK, op. y loc. cit.). 


\section{La distinción entre partes y terceros}

La particularidad del contrato de transporte reside, pues, en la participación de tres sujetos, dos intervinientes en su conclusión, y un tercero que se incorpora posteriormente a él, una vez cumplidas las condiciones exigidas a tal efecto. Con ocasión de esta configuración peculiar que caracteriza el contrato, resulta obligado distinguir entre las partes contratantes y el o los terceros ${ }^{651}$. A la vista de la configuración tripartita del contrato de transporte, se analizará a continuación el proceso que da lugar a la mutación de la posición del destinatario a lo largo de las fases de ejecución del contrato, en particular, el momento a partir del cual el destinatario deja de ser un tercero respecto del contrato y se adhiere a él. Pero antes de ello, debe estudiarse la distinción conceptual entre «parte» $\mathrm{y}$ «tercero».

\subsection{La noción de «parte» y su posición en el contrato}

La noción de «parte» y su posible ampliación más allá del concepto tradicional ha sido objeto de estudio principalmente en la doctrina francesa ${ }^{652}$, que buscó expandir el significado del término más allá de su alcance tradicional, un aspecto que se analizará brevemente a continuación.

A juicio de GHESTIN, la noción de «parte» puede obedecer a un concepto amplio y otro restringido ${ }^{653}$. En cuanto al concepto estricto de «parte», éste hace referencia a una concepción individualista del contrato, en el sentido de que alcanza las personas que se han unido voluntariamente para concluir un acto654.

${ }^{651}$ Recuérdese que el contrato de transporte pertenece al grupo de los contratos a favor de tercero, cuya construcción dogmática nació como excepción al principio de relatividad contractual.

652 Véase, por ejemplo, J. GHESTIN, «Nouvelles propositions pour un renouvellement de la distinction des parties et des tiers», Revue Trimestrielle de Droit Civil (RTDciv.), núm. 4, octubre-diciembre de 1994; C. GuELfUCCI-ThIBIERGE, «De l'élargissement de la notion de partie au contrat... à l'élargissement de la portée du principe de l'effet relatif», RTDciv., núm. 2, abril-junio de 1994; J.-L. AUBERT, «À propos d'une distinction renouvelée des parties et des tiers», RDTciv., núm. 2, abril-junio de 1993; M.-L. MATHIEU-IzORCHE, «Une troisième personne bien singulière», RDTciv., núm. 1, enero-marzo de 2003.

653 J. GHESTIN, «La distinction entre les parties et les tiers au contrat», citado por C. GUELFUCCI-THIBIERGE, «De l'élargissement de la notion de partie au contrat...».

654 Este concepto de «parte» alcanza dos categorías de personas. Por un lado, aquellos que concluyan el negocio a través de sus representantes; por otro, los herederos de las partes contratantes. Vid. C. GUELFUCCI-ThIBIERGE, «De l'élargissement de la notion de partie au 
Trasladado al ámbito español, este concepto estricto no contradice en absoluto lo dispuesto en el artículo 1258 del Código civil, que por regla general exige el mero consentimiento de las partes para perfeccionar un contrato, es decir, la concordancia de dos (o más) voluntades en obligarse mutuamente (art. 1.254 Cc), siempre que el objeto y la causa del contrato sean lícitos (arts. 1271-1277 Cc). De ahí que el criterio que atribuya la cualidad de parte resida principalmente en la voluntad de contratar 655 .

En cuanto al concepto amplio de parte, para GHESTIN comprende también a aquellas personas que se hallan vinculadas por su consentimiento a los efectos obligacionales del contrato. Esta definición amplía la noción de parte porque la cualidad de tal reside en la voluntad, no de concluir el contrato, sino de estar subordinado a sus efectos obligatorios. Y esta voluntad puede manifestarse tanto durante la conclusión del negocio como durante su ejecución. Como puede apreciarse, el círculo de partes se extiende más allá del encuentro inicial de voluntades ${ }^{656}$ (p.ej., al cesionario en caso de que se haya producido una cesión del contrato).

Si ello es así, la definición de «parte» puede subdividirse en atención a un criterio cronológico. De un lado, las partes en el momento de la celebración del contrato son los sujetos que participaron, en persona o por medio de representante, en su conclusión. De otro, las partes en el momento de la ejecución del contrato, que son aquellos sujetos que inicialmente eran terceros, pero han adquirido la cualidad de parte después de celebrado aquél ${ }^{657}$. Y esto último sucede, por ejemplo, en los supuestos de «cesión de la posición contractual», cuando el titular del derecho cede a un tercero su posición jurídica con respecto a una obligación que tiene prestaciones mutuas, de manera que este tercero se con-

contrat...», cit., p. 277 y ss. Así lo prevé también, en definitiva, el art. 1.257 del Código civil español.

655 Véase nuevamente las referencias en C. GuELfUCCI-ThIBIERGE, «De l'élargissement de la notion de partie au contrat...», cit., pp. 277 y ss.

${ }^{656}$ Vid. C. Guelfucci-Thibierge, «De l'élargissement de la notion de partie au contrat...», cit., p. 278.

657 J. GHESTIN, «Nouvelles propositions...», cit., p. 784. 
vierte en parte del contrato en lugar de quien lo era inicialmente, esto es, el titular originario del derecho de crédito (cedente) ${ }^{658}$.

A la vista de cuanto antecede, puede resumirse que lo relevante para determinar quién es parte en un contrato es el consentimiento a resultar sujeto al contrato. Así, el concepto de «parte» quedaría circunscrito a aquellos sujetos que prestaron su consentimiento a la conclusión del contrato, así como a aquellos otros que con posterioridad y mediante otro acuerdo de voluntades han adquirido el derecho de modificarlo o de ponerle fin. Dado que tales facultades no concurren en la persona del destinatario en el contrato de transporte (que no deja de ser el beneficiario en un contrato a favor de tercero), éste no se puede reputar parte del contrato concluido a su favor, sino un mero beneficiario que, eso sí, adquiere un auténtico derecho de crédito que ingresa definitivamente en su esfera patrimonial mediante la aceptación ${ }^{659}$.

\subsection{La noción de «tercero» y su posición en el contrato}

La noción clásica de «tercero» se define por oposición a la de parte ${ }^{660}$ : tercero es toda persona que no ostenta la cualidad de «parte»661. Entonces, son terceros aquellos que no han intervenido de ninguna manera en la perfección del contrato, ni por sí ni por medio de representante ${ }^{662}$. Y ello incluye, como señala GHESTIN, aquellas personas que resultan sujetos, de manera activa o pasiva, a los efectos obligatorios de un contrato, desde el momento en que pierden o no disponen de los privilegios característicos de la cualidad de parte, tales como el poder de modificar o poner fin al contrato mediante un nuevo acuerdo de voluntades 663 .

Partiendo de esta concepción jurídica de tercero, su posición no es equiparable a la de las partes por no gozar de sus prerrogativas (modificar, poner

${ }^{65} 8$ S. HidAlgo GARCÍA, El contrato y los terceros; seguro, edificación, crédito al consumo, pactos de exclusiva y subcontratación, Lex Nova, Valladolid, 2012, p. 10 de la introducción.

659 J. LÓPEZ RICHART, Los contratos..., cit., p. 337.

${ }^{660}$ S. HIDALGO GARCÍA, El contrato..., cit., p. 9 de la introducción y autores ahí citados.

${ }^{661}$ J. GHESTIN, «Nouvelles propositions...» cit., p. 796.

${ }^{662}$ S. HidAlgo GARCÍA, El contrato..., cit., p. 9.

663 J. GHESTIN, «Nouvelles propositions...» cit., p. 796. 
fin, ejercer la acción resolutoria en caso de incumplimiento), pero sí puede beneficiarse de un derecho de crédito que le hayan transmitido las partes contratantes, cediéndole además su derecho de exigirlo y reclamarlo frente al promitente en caso de incumplimiento o cumplimiento defectuoso del contrato. Es lo que sucede con el destinatario en el contrato de transporte: es un tercero extraño al contrato que, sin embargo, puede extraer derechos de él mediante la aceptación de la oferta hecha por las partes contratantes, sustituyendo al cargador en la facultad para solicitar la entrega o para reclamar frente al porteador en caso de siniestro. Por mucho que el destinatario se sitúe parcialmente en el lugar del cargador al reclamar sus derechos frente al promitente, el transportista, ello no elimina a aquél del contrato, sino que permanece como parte contratante. Así, la incorporación del destinatario al contrato mediante la aceptación de la entrega de las mercancías no supone más que la paralización de la posibilidad de revocar la estipulación hecha por el cargador-estipulante en su favor; revocación que, en el caso del contrato de transporte, se materializaría en el ejercicio del derecho de disposición que, por regla general, surge en cabeza de este último.

Retomando lo que se acaba de exponer acerca del tercero-beneficiario, resulta conveniente advertir que éste adquiere únicamente un derecho a beneficiarse del contrato concluido a su favor entre el promitente y el estipulante, de manera que se integra en la órbita contractual con el carácter de tercero: no se le atribuye ninguna prerrogativa dimanada del contrato, lo que le impide hacer valer su voluntad para cambiar el fundamento contractual o invocar otra disposición contractual que no se identifique con aquellas referidas a la atribución del provecho 664 .

Ciertamente, y como hubo ocasión de señalar, el destinatario adquiere en algunos casos el derecho a «modificar» el contrato en ejercicio del derecho de disposición. Mas ello no parece suficiente para atribuirle la condición de parte, pues, «[e]n virtud del contrato, el destinatario no adquiere más que el derecho a la entrega de las mercancías y ello siempre que éstas hubiesen llegado a destino y las hubiese reclamado al transportista»665, de manera que el derecho de

664 J. LÓPEZ RICHART, Los contratos..., cit., p. 339.

665 A. ReCAlde CASTELls, «El 'derecho de disposición'...», cit., p. 16. 
disposición sólo le corresponde, por regla general ${ }^{666}$, al cargador o remitente. Es más, incluso aunque el destinatario puede, siempre y en todo caso, «disponer» de la mercancía desde que le fue entregado el segundo ejemplar de la carta de porte o hubiera reclamado la entrega de las mercancías (arts. 12.2 CMR y 30.3 LCTTM), resulta dudoso que ello comporte realmente una modificación del contrato - no puede modificarse algo que ya se ha ejecutado- y que las «órdenes» o «instrucciones» que pueda emitir el destinatario en estos casos «sean realmente algo más que una forma de hacer valer el derecho a la entrega de la mercancía que deriva del contrato de transporte»667. Así, el tercero no sería más que un beneficiario del privilegio (que se convierte en acreedor de la deuda asumida por el promitente, una vez declarada su voluntad de aceptar la prestación estipulada entre éste y el estipulante ${ }^{668}$ ), y tan sólo cabría discutirse la posibilidad de que el tercero-destinatario se convierta en parte contractual si el derecho de disposición se le concede $a b$ initio. Pero incluso en este caso su intervención se limitaría al ejercicio de un derecho que le ha sido concedido por las partes del contrato.

No puede sorprender, así, que con frecuencia se niegue la posibilidad de que el tercero beneficiario se convierta en parte con la aceptación de la estipulación hecha en su favor. En efecto, algunos autores sostienen que la incapacidad para cambiar o resolver el contrato, inherente a la estipulación a favor de tercero, es el criterio que en este caso permite distinguir entre «parte» $\mathrm{y}$ «tercero». No obstante, hay quien señala que este es un criterio inútil para diferenciar ambas categorías. El tercero se reputaría parte, se dice, no desde un punto de vista formal (no hay desde luego intervención por su parte en la conclusión del con-

${ }^{666}$ Recuérdese que la solución es distinta en el ámbito del transporte internacional de mercancías por ferrocarril, donde el derecho de disposición, a pesar de pertenecer ex lege al remitente (art. 18.1 RU CIM), corresponde al destinatario salvo que otra cosa se pacte en el contrato y se haga constar así en la carta de porte (art. 18.3 RU CIM).

${ }^{667}$ Nuevamente, A. RECALDE CASTELLS, «El 'derecho de disposición'...», cit., p. 18.

668 Es esta la distinción que mayor predicamento tiene entre la doctrina francesa a la hora de separar las posiciones de «parte» y de «tercero», esto es, la que diferencia entre el «efecto obligatorio» del contrato (parte) y la «oponibilidad» de éste (terceros). Vid. J.-L. AUBERT, «À propos...», cit., pp. 267 y ss. 
trato), sino por el objeto del contrato que tiene como finalidad atribuir al beneficiario la titularidad del derecho de crédito surgido de él669.

A medio camino entre ambas propuestas se encuentra la de quienes proponen una posición dual del tercero-beneficiario, que sería tercero en lo que se refiere al derecho de crédito estipulado en su favor, pero sería parte en lo que se refiere a las obligaciones que se le puedan $\operatorname{imponer}^{670}$ (v.gr., la de pagar el precio en un transporte a portes pagados, que se convierte de carga en obligación con la aceptación de la entrega por el destinatario).

Y esta es, entre nosotros, la opinión de CANO MARTínez DE VELASCO, para quien el límite a partir del cual el tercero deja de serlo para convertirse en parte ha de situarse en la carga que se le pueda imponer para recibir la prestación. En este sentido, señala que el tercero sigue siendo un extraño al contrato a pesar de la carga (y aunque el gravamen sea superior al derecho otorgado) si de ello no resulta un sinalagma contractual. En este caso, la aceptación manifestada por el tercero no es suficiente para convertir a éste en parte, porque su consentimiento no se refiere a la aceptación del contrato en su totalidad, como un objeto de derecho y de obligación, sino a la aceptación de la carga junto con el derecho671. Por el contrario, cuando el tercero favorecido recibe junto con el derecho una obligación que dimana del contrato - en particular, la de pagar la contraprestación al promitente-, el hecho de que el tercero acepte se configura en este caso como una operación jurídica completa en la que se obtienen derechos y obligaciones y en la que, consecuentemente, el tercero pasa a ser parte y deja paralelamente de ser un extraño al contrato. A esta categoría de ejemplos pertenecería el transporte a portes debidos. Como quiera que el contrato de transporte es celebrado entre cargador y transportista, siempre que el destinatario sea un sujeto distinto de aquél, el tercero beneficiario (destinatario) es inicialmente un

${ }^{669}$ Con detalle sobre las reflexiones de GHESTIN acerca de la posición del tercero como parte puede verse J. GHESTIN, «La distinción...», cit., p. 520; ID. «Les effets du contrat», Paris, 1992, publicado por el propio GHESTIN en colaboración con M. BILLIAU, así como la «Introducción» realizada por GHESTIN a la obra colectiva M. Fontaine y J. Ghestin (dirs.), Les effets du contrat à l'egard des tiers (comparaisons franco-belges), Paris, 1992, pp. 28 y ss., citado por J. LÓPEZ RICHART, Los contratos..., cit., p. 334; J. GHESTIN, «Nouvelles propositions...», cit., p. 797.

${ }^{670}$ Véase las referencias en J. GHESTIN, «Nouvelles propositions...», cit., p. 798.

${ }^{671}$ J.I. CANO MARTÍNEZ DE VELASCO, El contrato..., cit., p. 120. 
perfecto extraño en un contrato concluido sin su intervención. Mas siendo el transporte a portes debidos, el destinatario debe satisfacer el precio del transporte si quiere hacer valer sus derechos (en particular, exigir la entrega de las mercancías), con lo que, de forma sobrevenida, deviene parte en el contrato.

De cuanto antecede deriva que la cuestión acerca de si el tercero beneficiario adquiere o no la cualidad de parte contratante es un tema polémico que, a la vista de la descripción exhaustiva de las facultades del destinatario en la legislación sectorial, no afecta a las conclusiones que más adelante se expondrán sobre el contenido de su posición contractual. No cabe duda de que nuestro Códigos civil (y también los códigos de nuestro entorno más próximo: el italiano y el francés) contempla la estipulación a favor de tercero como una excepción al principio de la relatividad de los contratos y autoriza el recurso a esta figura en el tráfico tanto mercantil como civil. Pero ello no es óbice para constatar que las partes del contrato son las que son (el estipulante y el promitente), y siguen siéndole aun después de la aceptación de la prestación por el tercero, con independencia de que éste se considere también «parte» o no.

\section{Distinción de figuras afines}

\section{El expedidor}

El punto que tiene en común la figura del expedidor con la del destinatario es el hecho de que, en ambos casos, se trata de un «tercero» respecto del contrato de transporte ${ }^{672}$. Por supuesto existe una gran diferencia entre ambas figuras que trasluce también en la noción de «expedidor» en el artículo 4.4 LCTTM, que lo define como un tercero que por cuenta del cargador hace entrega materialmente de las mercancías al transportista en el lugar de su recepción por éste.

${ }^{672} \mathrm{El}$ expedidor es quien materialmente entrega las mercancías al porteador y, por ello, ocupa una posición de intermediario, interviniendo -en cuanto representante del cargador- en el momento inicial de la ejecución del transporte. En todo caso, salvo que cargador y expedidor coincidan en una misma persona, es un tercero ajeno al contrato de transporte. $\mathrm{Y}$ es que la relación que une al cargador con el expedidor se rige por otro contrato [probablemente de comisión, por cuanto el expedidor, como comisionista, se compromete por cuenta del cargador (comitente) a entregar las mercancías al transportista (art. 4 LCTTM); o, en su caso, de prestación de servicios]. 
Cuando se habla de expedidor se refiere a una figura relativamente nueva, que ha aparecido sólo recientemente por necesidades prácticas. Surge como un comisionista que media entre el cargador y el transportista, ya que a veces, por las circunstancias que sea, el cargador se encuentra imposibilitado para entregar personalmente las mercancías al transportista, lo que le obliga a designar un expedidor-comisionista para encargarle esta tarea. Al propio tiempo, puede convenirle al transportista que la entrega se haga desde el establecimiento del expedidor. De la definición apuntada se deriva que el expedidor desempeña el papel de un delegado en la posición contractual de una de las partes -en este caso, del cargador-, efectuando por mandato de éste una parte determinada de la operación contractual: la entrega de las mercancías al porteador ${ }^{673}$.

La figura del expedidor suele tener, además, mucha transcendencia en lo relativo a las operaciones de carga y descarga, puesto que su actuación por cuenta y riesgo del cargador incide de forma notable en el régimen de responsabilidad del porteador, en particular, cuando la realización de estas operaciones genera un menoscabo o daño a las mercancías ${ }^{674}$.

\section{El consignatario de buques}

El consignatario de buques es uno de las figuras que, por una cuestión meramente terminológica, puede confundirse con la del consignatario-destinatario en el contrato de transporte. Conviene, por ello, dedicarle cierta atención, subrayando las diferencias que existen entre ambos sujetos.

Históricamente, el consignatario de buques apareció en las transacciones en torno a la explotación del buque (en el contrato de fletamento o de transporte marítimo) como un intermediario representante del armador o del fletador del buque en un puerto675. En efecto, el papel que desempeña el consignatario de buques ha surgido en proporción a las necesidades del comercio, asumiendo

673 F. MARTínEZ SANZ, «Sujetos», cit., p. 82.

${ }^{674}$ Con detalle sobre las operaciones de carga y descarga puede verse la obra de B. GARCíA ÁlvAREZ, La carga y descarga en el contrato de transporte de mercancías, Marcial Pons, Madrid, 2011.

675 E. Silvestre MARTí, Manual del consignatario marítimo; Obligaciones y responsabilidades, Iberediciones, Madrid, Colegio de Oficiales de la Marina Mercante Española, 1993, p. 11. 
progresivamente todas aquellas tareas de las que solía encargarse el Capitán tras la arribada, lo cual pone de relieve una relación de delegación o, mejor dicho, de colaboración entre naviero y consignatario. De ahí que se entienda que la relación esté basada en un contrato de mandato (aunque con características específicas) ${ }^{676}$, por cuanto el consignatario de buques se encarga por cuenta de su mandante (el naviero o capitán del buque) de los actos u operaciones comerciales que rodean la explotación del buque; actos que, dada su naturaleza, se rigen por la normativa en materia, no de mandato civil, sino de comisión mercantil (art. 244 Ccom) ${ }^{677}$.

En cuanto a las funciones características del consignatario de buques, éste se encarga de todas las funciones que estaban antes atribuidas al capitán del buque en el puerto. A la vista de la legislación marítima española, estas funciones consisten en la realización de todas las gestiones y actuaciones necesarias para el pronto despacho del buque en puerto678 $\mathrm{y}$, salvo órdenes expresas del naviero, se encuentra obligado a cumplir estas funciones con la misma diligencia con la que actuaría el naviero para defender su propio interés679.

Así, el consignatario asume la responsabilidad por el rápido despacho documental frente a las autoridades locales o a la administración portuaria ${ }^{680}$, prestando atención a la tripulación y al buque, pertrechándolo con los suministros que precise. Efectuará también todas las operaciones de gestionar, negociar, liquidar los fletes y gastos producidos por las mercancías, firmar los conocimientos de embarque de las mercancías de exportación y recibe los conoci-

${ }^{676}$ Véase las referencias en R.A. GONZÁLEZ-LEBRERO, El agente consignatario de buques en España, Bosch, Barcelona, 1989, p. 27.

677 R.A. GONZÁLEZ-LEBRERO, El agente consignatario..., cit., p. 27. Cfr. también el art. 320 de la Ley 14/2014, de 24 de julio, de Navegación Marítima (LNM), que somete el contrato de consignación a las reglas de la agencia comercial «[c]uando se trate de consignaciones continuadas o estables».

678 Dispone el art. 319 LNM que «[s]e entiende por consignatario a la persona que por cuenta del armador o del naviero se ocupa de las gestiones materiales y jurídicas necesarias para el despacho y demás atenciones al buque en puerto».

679 E. SilveSTRE MARTí, Manual..., cit., p. 35.

${ }^{680}$ Realizando actividades tales como «obtener la autorización de entrada y salida, avisos a prácticos, sanidad, amarradores y remolcadores; correr el Manifiesto ante la aduana, anunciar la llegada y presentar ante la Autoridad portuaria la solicitud de atraque y una copia del Manifiesto o relación de la mercancía a efectos de la liquidación de las Tarifas Portuarias» (E. SILVESTRE MARTí, Manual..., cit., p. 35). 
mientos canjeables por las mercancías descargadas de importación ${ }^{681}$, pero siempre (en nombre y) por cuenta del armador o naviero (art. 321 LNM).

De cuanto antecede se desprende con facilidad que existe una diferencia sustancial entre el «consignatario» como destinatario de las mercancías que van dirigidas a él y el consignatario de buques, que cumple con el mandato de su representado las funciones de gestión y ejecución de las operaciones de despacho y atención al buque en puerto. Ello no obsta, con todo, para que el consignatario de buques intervenga también en la relación entre porteador marítimo y destinatario. Así, podrá, en particular, «tomar posesión del cargamento y cuidarlo bajo su responsabilidad hasta que el destinatario lo reciba o, en el caso de que no aparezcan o se nieguen a recibirlo, depositarlo judicialmente; reconocer la mercancía para delimitar el alcance de los daños o faltas; fijar la cantidad y peso de la mercancía calculando el flete, si se estableció según estos datos; y cobrar el flete debido»682, pero lo hará, en todo caso, por cuenta del porteador y no del destinatario.

\section{El transitario}

El término transitario suele usarse exclusivamente en el tráfico internacional, ámbito en que su actuación venía siendo más característica, ya que este profesional no podía intermediar en operaciones nacionales, salvo cuando estas operaciones fueran el principio o el final de una operación internacional ${ }^{683}$.

En el panorama legislativo actual, los transitarios vienen definidos en el artículo 121 de la LOTT como aquellas «empresas especializadas en organizar, por cuenta ajena, transportes internacionales de mercancías, recibiendo mercancías como consignatarios o entregándolas a quienes hayan de transportarlas y, en su caso realizando las gestiones administrativas, fiscales, aduaneras y logísticas inherentes a esa clase de transportes o intermediando en su con-

${ }^{681}$ J. BAENA, Transporte internacional: Manuales de formación de transporte, Logis Book, Barcelona, 2002, p. 25.

682 E. SilveSTRE MARTí, Manual..., cit., p. 34.

683 F.J. SÁnChEZ-GAMBorino y J. GaItÁN REBOllo, Factbook..., cit., p. 250; A. CABRERA CÁNOVAS, El transporte..., cit., p. 131. 
tratación»684. De este precepto se infiere que la función que se atribuye al transitario es la de organizar el transporte por cuenta de su cliente; es, por tanto, principalmente un intermediario. En efecto, la figura del transitario reviste gran importancia por el papel fundamental que desempeña en el transporte multimodal ${ }^{685}$. Se trata de un auténtico «arquitecto del transporte»686, una descripción que precisa la actuación del transitario como organizador que cuenta con las facultades necesarias para proceder a cumplir las formalidades aduaneras, al depósito y almacenaje de mercancías, a reexpedir, recibir, consignar y poner a disposición de los transportistas o de los destinatarios las mercancías procedentes o destinadas al transporte internacional, etc. ${ }^{687}$

${ }^{684}$ Es este el tenor de la versión dada por la Ley 9/2013, de 4 de julio, por la que se modifica la Ley 16/1987, de 30 de julio, de Ordenación de los Transportes Terrestres y la Ley 21/2003, de 7 de julio, de Seguridad Aérea. Siendo la LOTT una norma administrativa, y en ausencia de una definición de la figura en el Derecho mercantil, la doctrina ha procurado elaborarla, señalando que «los transitarios son los intermediarios u organizadores de las operaciones de transporte internacional por cualquier medio» (R. Alonso SoTO, «El contrato de transporte», en R. Uría y A. Menéndez (dirs.), Curso de Derecho Mercantil, T. II, $2^{\text {a }}$ ed., Civitas, Cizur Menor, 2006, p. 332), o los ha definido como un «empresario, colaborador autónomo de otros empresarios, encargado de organizar los transportes internacionales de mercancías, para lo cual generalmente celebra contratos de transporte, por cualquier medio, en nombre propio y por cuenta ajena, así como otras actividades complementarias de diversa índole, necesarias para su correcto desarrollo» (A.M ${ }^{\text {a }}$. ToBío RIVAS, Los transitarios en el transporte nacional e internacional: régimen jurídico privado, Comares, Granada, 2007, p. 32, con referencia a otras definiciones doctrinales).

${ }^{685}$ Existen diversas asociaciones de transitarios que, a nivel nacional, están agrupadas en la Federación Española de Asociaciones de Transitarios (FETEIA). A nivel internacional, destaca la Fédération Internationale des Associations de Transitaires et Assimilés (FIATA), que incluso ha elaborado modelos de documentos para el transporte multimodal internacional: el FIATA Multimodal Transport Bill of Lading (FBL) que, como cualquier conocimiento de embarque, es negociable; y el FIATA Multimodal Transport Waybill (FWB), que -al igual que la carta de porte- no lo es.

686 F.C. LÓPEZ RUEDA, El régimen..., cit., p. 386.

${ }^{687} \mathrm{El}$ art. 167 ROTT (que, aun siendo anterior a la última reforma de la LOTT, conserva su vigencia hoy día) enumera las funciones que ejerce el transitario en las operaciones del transporte "1. Los transitarios, en el ejercicio de sus funciones de intermediación y organización de los transportes internacionales y de los que se efectúen en régimen de control aduanero podrán realizar las siguientes actividades, siempre referidas a dichos tipos de transporte: a) Cumplir las formalidades administrativas ligadas al transporte internacional o al régimen de tránsito aduanero. b) Depositar o almacenar mercancías procedentes o destinadas al transporte internacional o en régimen de tránsito aduanero. c) Consolidar y desconsolidar mercancías. d) Coordinar las diversas fases del transporte con destino o procedencia internacionales, y, en particular, el tránsito, la reexpedición, el transbordo y las diferentes operaciones terminales. e) Contratar la realización de los portes, con las Empresas de transporte. f) Recibir, consignar y poner a disposición de los transportistas o de los destinatarios mercancías procedentes o destinadas al transporte internacional o en régimen de control aduanero. 2. Los transitarios, salvo que se limiten a 
En cuanto a la distinción entre la figura del transitario y la del destinatario, lo cierto es que no existe mayor riesgo de confusión entre ambas. Sucede, sin embargo, que el transitario puede figurar, por designación del cargador, como consignatario o destinatario de una expedición ${ }^{688}$. En estos casos, parece que deba entenderse que el transitario es un destinatario intermedio, esto es, un comisionista que actúa en nombre e interés del cargador o el destinatario para reexpedir o continuar el transporte de las mercancías, y no es el derechohabiente final de las mercancías ${ }^{689}$.

\section{El destinatario como comprador en un contrato de compraventa de mercaderías: el caso particular de las ventas EXW y FOB}

En un contrato de compraventa con expedición, que implica la celebración de un contrato de transporte para permitir la ejecución de la obligación de entrega, el comprador suele ocupar la posición del destinatario en el transporte de las cosas vendidas ${ }^{690}$. Desempeña, así, un doble papel: es parte contratante en el contrato de compraventa y se halla vinculado, al propio tiempo, al contrato de transporte (como parte, en caso de haberlo concertado él; como tercero beneficiario, en caso contrario). No obstante, las obligaciones que surgen de uno y otro contrato deben separarse claramente, pues aun cuando el de compraventa constituya la relación de valuta que da lugar a la celebración del de transporte, se trata de negocios independientes. Ello queda patente si se tiene en cuenta que una de las partes del contrato de transporte, el porteador, es un tercero completamente ajeno a la compraventa. Como consecuencia, el transportista sólo se obliga frente a su contraparte en el contrato de transporte a hacer llegar los bie-

poner las mercancías a disposición del transportista designado por el cargador, deberán contratar el transporte en nombre propio, de acuerdo con idénticas reglas a las establecidas en relación con las agencias de transporte». De este segundo apartado de la norma se desprende que el transitario puede perfectamente actuar como expedidor en una operación de transporte concertada por el cargador.

688 Así lo reconoce el propio art. 121 LOTT, cuando establece que una de las funciones típicas de los transitarios es la recepción de las mercancías transportadas como consignatarios.

689 J. PUTZEYS, Droit..., cit., p. 60.

690 A. RECALDE CASTELLS, El conocimiento de embarque y otros documentos del transporte: función representativa, Civitas, Madrid, 1992, p. 234. 
nes vendidos al comprador-destinatario, pero no es parte en el contrato de compraventa, concluido entre vendedor y comprador ${ }^{691}$. Si se producen daños en las mercancías, sólo responde frente a quien ostente legitimación activa en virtud de la normativa sobre transportes, con independencia de cuáles sean las consecuencias en el ámbito de la compraventa.

$\mathrm{Y}$, sin embargo, no puede negarse la relación entre ambos contratos, que surge de la necesidad de trasladar las mercancías sin incidentes desde las instalaciones del vendedor hasta las del comprador. El elemento que liga el uno al otro es la inclusión en el contrato de compraventa de uno de los INCOTERMS elaborados por la Cámara de Comercio Internacional, referidos a las obligaciones y responsabilidades de las partes con ocasión del transporte de la mercancía del vendedor al comprador. En este contexto, nos referiremos únicamente a los INCOTERMS del tipo EXW o FOB, en los que el comprador se encarga de contratar el transporte principal, de manera que el destinatario será al propio tiempo el cargador que contrata con el transportista692.

En lo que respecta a esos dos tipos de INCOTERMS, el comprador quedará obligado a concertar el transporte (terrestre o marítimo, dependiendo del INCOTERM que se utilice), asumiendo en este contrato el papel de cargador. Para la venta ex works o EXW, el vendedor, aun sin ser cargador (pues lo es el comprador-destinatario) entrega la carga al transportista en sus propias instalaciones. En el supuesto de la compraventa FOB, el porteador ha de emitir el conocimiento de embarque y entregar un ejemplar del mismo al cargadordestinatario, que por su virtud tendrá derecho a pedir la entrega de las mercancías en el puerto de destino. También aquí, la situación difiere de la normal, en la que es el vendedor quien concierta el transporte, en el sentido de que la entrega de las mercancías al porteador no la realiza el cargador (esto es, el comprador-destinatario), sino el vendedor. De hecho, este último no podría tampoco efectuarla, porque en tanto las mercancías no se encuentren a bordo del buque, el cargador (comprador-destinatario) no será, ni su propietario ni su poseedor (mediato), pues no se le habrá podido entregar todavía el conocimiento

${ }^{691}$ M. Remond-Goullloud, Droit maritime, $2^{\mathrm{a}}$ ed., Pedone, Paris, 1993, p. 412.

692 O. LLAMAZARES GARCÍA-LOMAS, Guía práctica de los INCOTERMS 201O, $2^{\mathrm{a}}$ ed., Global Marketing Strategies, Madrid, 2011, pp. 51-52. 
de embarque. Se está, por ello, ante una circunstancia anormal, ya que lo habitual es que quien entregue las mercancías al porteador sea el cargador693. Para evitar cualquier confusión, esta circunstancia deberá hacerse constar en el conocimiento de embarque ${ }^{694}$.

\section{Los derechos del destinatario}

\section{Aspectos generales}

El destinatario, como ya se ha indicado anteriormente, pasa a ser acreedor en la fase ejecutiva del contrato de transporte, una vez que reciba las mercancías en el lugar y en el momento determinado, es decir, cuando acepte la estipulación hecha en su favor mediante la solicitud de entrega de las mercancías. Es, por tanto, en este momento cuando el destinatario adquiere la titularidad de los derechos que derivan del contrato de transporte.

Como regla general, los derechos derivados del contrato de transporte pueden reclamarlos frente al transportista ambos sujetos, tanto el cargador como el destinatario. Sin embargo, debe advertirse de que, en su gran mayoría, la doctrina y jurisprudencia españolas niegan que esta reclamación pueda hacerse simultáneamente por uno y otro, es decir, que no pueden exigir tales derechos al mismo tiempo. Y ello porque, se dice, las facultades del cargador se extinguen, inter alia, cuando nacen en cabeza del destinatario. Por tanto, se transmiten de cargador a destinatario, en virtud de la naturaleza misma del contrato hecho a favor del destinatario, así que este último recibe del primero los derechos a exigir el cumplimiento de la prestación contractual prometida ${ }^{695}$.

693 Como no puede ser de otra forma, en caso de que el INCOTERM elegido señale al vendedor como obligado a contratar el transporte, ocupará éste la posición de cargador y, al propio tiempo, de encargado de realizar la entrega al porteador. No existiría, pues, ninguna desviación del sistema habitual.

694 F. SÁNChez CAlero, El contrato..., cit., p. 200-201; D. BoYeras SCHUMANN, La compraventa internacional de mercancías: la modalidad $F O B$, tesis doctoral, Barcelona, 2013, p. 216.

695 Concretamente, la facultad para reclamar suele anudarse al derecho de disposición, y ya hemos señalado con anterioridad que, por regla general, el destinatario adquiere dicho derecho cuando, una vez llegadas las mercancías a su destino, solicita que éstas le sean entregadas junto con el segundo ejemplar de la carta de porte. También es posible, como se vio, que el cargador indique en la carta de porte la pertinencia ab initio del derecho al 


\section{El contenido y los límites de los derechos del destinatario}

Los preceptos básicos en materia de derechos del destinatario son los artículos 35 LCTTM y 13 CMR. El primer apartado de ambos se dedica a regular el ejercicio de ciertos derechos emanados del contrato de transporte por el destinatario, a pesar de ser ajeno a la relación contractual que une a cargador y transportista. El segundo, por su parte, establece algunos límites que se imponen al destinatario a la hora de ejercitar los derechos derivados del contrato, esto es, la obligación de satisfacer, en su caso, los portes y los gastos del transporte al objeto de reclamar la entrega.

\subsection{El derecho a la entrega de las mercancías}

La entrega de las mercancías al destinatario es la fase final de la operación de transporte, ya que una vez llegadas las mercancías a su destino y entregadas al destinatario se puede afirmar que la operación ha concluido: el hecho de entregar las mercancías al destinatario es el objeto esencial y final perseguido con la celebración del contrato de transporte. En efecto, generando dicho contrato una obligación de hacer de resultado a cargo del transportista, éste promete alcanzarlo, esto es, poner las mercancías en manos del destinatario como resultado final, a cambio de un precio696.

La obligación de entregar la mercancía al destinatario se halla recogida expresamente tanto en la LCTTM (art. 35.1) como en el Convenio CMR (art. 13.1). En dichos preceptos, la obligación de resultado tiene su reflejo en uno de los derechos del destinatario, en el sentido de que éste, tras la llegada de las mercancías, está facultado para exigir la entrega ${ }^{697}$ de las mercancías, reclamándosela al transportista quien, a su vez, queda obligado a ejecutarla.

Así pues, al destinatario le corresponde, sobre todo, el derecho a que se le entregue el envío en buen estado, sin menoscabo ni daño alguno. Sin embargo,

destinatario, quedando así paralizados los intentos de modificar las condiciones del contrato por parte del cargador.

${ }^{696}$ A. DÍAz MORENO, «El contrato...», cit., p. 640.

697 Obsérvese que la mera petición por el destinatario de que se le entregue las mercancías se reputa como aceptación de la prestación estipulada por el cargador en su favor, y así pasa a incorporarse como acreedor en el contrato de transporte. 
la entrega puede llegar a suscitar ciertos problemas en relación a la responsabilidad del porteador frente al destinatario. Y ello porque el porteador no se libera de su responsabilidad, que tiene su fundamento en la custodia de las mercancías, si no llega a garantizar el buen fin de la operación de transporte. Esto es, debe entregar adecuadamente las mercancías a la persona correcta en el lugar y en el tiempo acordados, aún más cuando estas indicaciones se insertan expresamente en el contrato o en la carta de porte ${ }^{698}$.

El primer aspecto que puede resultar problemático es la entrega de las mercancías a la persona correcta. No suelen plantearse muchas dudas al respecto, ya que basta para que la entrega sea efectuada correctamente que se conozca la persona legitimada para recibir las mercancías según lo previsto en el contrato o en la carta de porte, sin perjuicio de que la entrega se realice válidamente si se efectúa a quien actúa como representante del destinatario. Aun así, pueden presentarse ciertas incidencias en esta materia como, por ejemplo, el que la entrega se efectúe por error a una persona diferente de aquella que está designada en el contrato o en la carta de porte, en otras palabras, que no es la persona a quien iba dirigida la mercancía. En este caso, la entrega por error se reputa por lo general una pérdida que no exime al transportista de su responsabilidad 699 .

En lo que se refiere a la entrega en el lugar y en el tiempo estipulados, estos elementos se encuentran entre los contenidos esenciales que han de figurar en el contrato y que han de reflejarse en la carta de porte conforme a lo dispuesto en los artículos 33.1 y 10.1.e LCTTM. Recuérdese que también cabe la posibilidad de que haya cambiado el lugar previsto para la entrega por el cargador, a través del ejercicio del derecho de disposición sobre las mercancías (art. 12.1 CMR), debiendo el cargador en este caso incluir las nuevas instrucciones respecto de la modificación del lugar de entrega en la carta de porte [art. 33.1.a) LCTTM]. No obstante, en el caso en que no se haya determinado el lugar para la entrega en el contrato ni tampoco en la carta de porte, el porteador habrá que

698 F. MARTÍNEZ SANZ, La responsabilidad..., cit., p. 132.

699 F. MARTínez SANZ, La responsabilidad..., cit., p. 133. 
pedir al destinatario las oportunas instrucciones para que le indique el lugar donde le va a remitir las mercancías ${ }^{700}$.

También puede suceder que se concluye el contrato de transporte sin que se fije la fecha prevista para la entrega. Cuando así fuera, y la fecha no consta en el contrato ni tampoco en la carta de porte, el artículo 33.1 LCTTM prevé que la mercancía ha de ser entregada al destinatario dentro del plazo que razonablemente emplearía un porteador diligente para efectuar la operación de transporte, teniendo en cuenta las circunstancias del caso701. Si no es así -esto es, la entrega no se realiza en el tiempo previsto-, se estaría ante un supuesto de retraso: la duración efectiva del transporte supera el tiempo pactado o el que es razonable exigir a un transportista diligente, atendiendo a las circunstancias particulares de cada caso ${ }^{702}$.

En efecto, el tema del momento de la entrega en relación con la aceptación del destinatario puede llegar a plantear alguna complicación pues, en ocasiones, aquél decide no aceptar el recibo de las mercancías si se trata, por ejemplo, de una entrega extemporánea. Y es que el destinatario no soporta ninguna obligación de recibir ese tipo de entrega703, ni ningún otro, porque es - por regla general, y salvo que cargador y destinatario sean la misma persona- un tercero

${ }^{700}$ A. RECALDE CASTELLS, «La posición jurídica del destinatario en el contrato de transporte de mercancías», RDT, núm. 6, 2010, p. 206.

${ }^{701}$ Especial atención ha prestado el legislador a la determinación del momento de entrega en el transporte ferroviario, en cuanto establece en el art. 33 LCTTM un método conreto para su cálculo: «En el transporte ferroviario, en ausencia de acuerdo y sin perjuicio de lo establecido en los apartados 3 y 4, los plazos de transporte no podrán superar los siguientes límites: a) Para vagones completos: Plazo de expedición: 12 horas. Plazo de transporte, por cada fracción indivisible de 400 kilómetros: 24 horas. b) Para envios en régimen de paquetería: Plazo de expedición: 24 horas. Plazo de transporte, por cada fracción indivisible de 200 kilómetros: 24 horas. 3. En el transporte ferroviario, el porteador podrá ampliar el plazo de duración del transporte en lo estrictamente necesario cuando: a) Los envíos se transporten por líneas con diferente ancho de vía, por mar o por carretera cuando no exista conexión ferroviaria. b) Circunstancias extraordinarias entrañen un aumento anormal del tráfico o dificultades anormales de explotación. 4. El plazo de entrega empieza a correr con la recepción de las mercancías para su transporte. Se prorrogará por el tiempo que las mercancías estén paradas por causa no imputable al porteador y su cómputo se suspenderá los días festivos y los inhábiles para circular».

${ }^{702}$ Como ejemplo, el art. 19 CMR menciona el caso de una carga parcial, debiendo tenerse en cuenta el tiempo necesario para reunir un cargamento completo en condiciones normales.

${ }^{703}$ F. MARTínez SANZ, La responsabilidad..., cit., p. 137. 
beneficiario de una estipulación realizado en su favor, de manera que no soporta ningún deber frente al porteador de aceptar la prestación hecha en su interés, independientemente de si la entrega ha sido ejecutada en el plazo convenido o no. La situación ni siquiera cambia cuando, como es habitual en la práctica, el destinatario es el comprador en el contrato de compraventa, es decir, en la relación de valuta con el vendedor-estipulante, que ocupa la posición de cargador en el contrato de transporte. Ciertamente, el contrato de compraventa obliga al destinatario a aceptar la entrega del envío, pero ello no trasciende al contrato de transporte, por lo que nada impide que el destinatario rechace la carga. Ello puede suceder, por ejemplo, cuando el estado de las mercancías no satisface sus expectativas como consecuencia de averías; porque el género de las mercancías no se corresponde con el que fuera objeto del contrato de compraventa; porque la entrega es extemporánea (tanto porque llega antes de lo previsto, como cuando lo hace con retraso); o, en fin, porque no había solicitado ningún envío704.

\subsection{El derecho a exigir la entrega del segundo ejemplar de la carta de porte}

Habitualmente, el desplazamiento de las mercancías exige que las mismas vayan acompañadas de determinados documentos, entre ellos, el segundo ejemplar de la carta de porte. La entrega de ese segundo ejemplar de la carta de porte es uno de los derechos esenciales del destinatario, por cuanto una vez reclamada la entrega de la mercancía frente al porteador, el destinatario tiende a pedirle simultáneamente la entrega de este ejemplar (art. 12 LCTTM), que cumple una función probatoria ${ }^{705}$.

La solicitud de entrega de este documento no tendrá lugar hasta que lleguen las mercancías a su distinto. En ese momento, el destinatario puede reclamar al porteador que le entregue el segundo ejemplar de la carta de porte, momento a partir del cual se transmite al destinatario el derecho a disponer sobre las mercancías, con la consiguiente pérdida de ese derecho por parte del

704 A. PUETz, «Derechos del destinatario», en J.F. Duque Domínguez y F. Martínez Sanz (dirs.), A. Emparanza Sobejano y $\mathrm{M}^{\mathrm{a}}$.V. Petit Lavall (coords.), Comentarios a la Ley de Transporte Terrestre, cit., p. 436.

705 A. RECALDE CASTELLS, «La posición...», cit., p. 207. 
cargador, sin perjuicio de lo que dispuesto en el artículo 13.1 CMR (art. 12 CMR)706.

Como se decía, la entrega del segundo ejemplar de la carta de porte se produce de ordinario en el mismo momento en que las mercancías son puestas a disposición del destinatario. Y ello porque su función radica en permitir al destinatario verificar y comprobar el estado que tenía la mercancía en el lugar de origen y en el momento en el que se procedió a la carga, por cuanto la mercancía debe entregarse en buen estado, sin averías ni perjuicios707, conforme a las condiciones y a la descripción que resultan de la carta de porte (art. 34.1 LCTTM). Las menciones de la carta de porte resultan, por ello, de interés fundamental para el destinatario.

\subsection{El derecho al resarcimiento de los daños y perjuicios causados}

En efecto, según lo dispuesto en los artículos 13.1 CMR y 35.1 LCTTM, el destinatario podrá ejercer frente al porteador una serie de derechos derivados del contrato de transporte, y podrá hacerlo «desde el momento en que, habiendo llegado las mercancías a destino o transcurrido el plazo en el que deberían haber llegado, solicite su entrega» (art. 35.1 LCTTM)708. De entre tales derechos destaca el de reclamar el resarcimiento de los daños y perjuicios derivados del incumplimiento o cumplimiento defectuoso de la operación de transporte, esto es, cuando el transportista no cumple con su obligación de trasladar y conservar la mercancía objeto del transporte ${ }^{709}$.

A estos efectos, el destinatario puede ejercitar sus pretensiones indemnizatorias frente al porteador desde que acepte la estipulación hecha en su favor. Es decir, no hace falta que el destinatario esté legitimado para el ejercicio del

\footnotetext{
${ }^{706}$ J. PUTZEYs, Le contrat..., cit., p. 118.

$707 \mathrm{Al}$ respecto puede verse $\mathrm{M}^{\mathrm{a}}$.J. GuERRERO LEBRÓN, «La carta...», cit., p. 95; A. RECALDE CASTELLS, «La posición...», cit., p. 207.

${ }^{708} \mathrm{El}$ art. 13.1 CMR, a pesar de su tenor diverso, prevé una regulación muy similar. Obsérvese, con todo, que este último precepto faculta expresamente al destinatario para ejercer los derechos que resulten del contrato de transporte en caso de que «llegara a declararse perdida la mercancía», una precisión que está ausente en la norma homóloga de la Ley 15/2009.

${ }^{709}$ A. PUETZ, «Derechos...», cit., p. 437.
} 
derecho de disposición o que se halle en poder de algún ejemplar de la carta de porte (no es un título de necesario rescate). Y es que la adhesión del destinatario al contrato de transporte no exige más que su aceptación para reclamar la entrega de las mercancías. De ello se infiere que el derecho del destinatario a la indemnización nace en el momento en que, llegada la mercancía a su punto de destino, el destinatario solicita su entrega; o, en caso de que se produzca un retraso en la entrega de la mercancía, cuando haya transcurrido el plazo en el que debería haber llegado a su destino ${ }^{710}$.

Es conveniente señalar - como regla que es general a todo transporteque si las incidencias o daños experimentados por las mercancías han sobrevenido por un supuesto que resulta amparado por una causa de exoneración de responsabilidad711, el transportista no tendrá que indemnizar al destinatario (ni tampoco al cargador) por el valor de los géneros entregados para el transporte, pero tampoco tiene derecho a reclamar el abono del precio del transporte por un opus no conseguido (la llegada de la mercancía a destino en perfecto estado y su puesta a disposición del derechohabiente). Por su parte, si se presenta una avería, el porteador tendrá derecho a cobrar el precio de transporte, pero reduciéndose su importe en proporción al resultado obtenido ${ }^{712}$.

\subsection{La facultad de rehusar las mercancías}

Conforme a la naturaleza jurídica del contrato de transporte, que forma parte del grupo de contratos a favor de tercero, el nacimiento del derecho a favor del beneficiario-destinatario es inmediato ${ }^{713}$. No obstante, tiene un carácter provisional por cuanto puede ser revocado por el cargador-estipulante y rechazado por el tercero, esto es, el destinatario.

${ }^{710}$ A. RECALDE CASTELls, «La posición...», cit., p. 208.

${ }^{711}$ Como es notorio, tales causas figuran en los artículos 17.2 y 4 CMR y 48 y 49 LCTTM y pueden reconducirse, en su mayoría, a causas de alcance general como son la fuerza mayor, el caso fortuito o la culpa de la víctima.

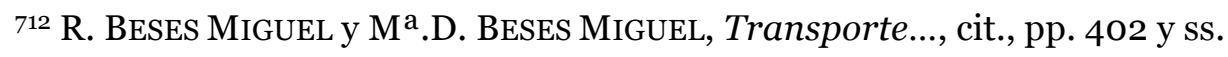

${ }^{713}$ Como se vio a lo largo del segundo capítulo de la presente obra, el derecho del destinatario nace en el momento de la celebración del contrato de transporte, sin perjuicio de que, para que surta los efectos que le son propios, el destinatario deba declarar, de forma tácita o expresa, su voluntad de hacer valer dicho derecho. 
No resulta necesario recordar que, por regla general, el destinatario no participa en la celebración del contrato de transporte, y su incorporación al mismo se produce con posterioridad, durante la fase final de la ejecución del transporte, esto es, cuando acepta los efectos del envío. Asimismo, no asume ninguna obligación frente a los contratantes, y su intervención en el contrato queda condicionada a su aceptación, por cuanto nada le impide que rehúse dicha intervención, absteniéndose a recibir la mercancía. Así pues, el destinatario es libre de aceptar o de rechazar el recibo de las mercancías, sin que resulte sujeto a carga alguna de justificar o alegar motivos que expliquen su rechazo. Aun así, el acto de rehusar las mercancías por el destinatario no figura entre los casos de negligencia ni de imprudencia culposa que exoneran de responsabilidad al porteador conforme a lo establecido en el artículo 48 LCTTM714.

Junto a la facultad de rechazar el recibo de las mercancías, el destinatario también puede dejarlas de cuenta del porteador. Ello puede suceder en el caso de pérdida parcial, averías o retrasos prolongados (art. 54 LCTTM), pero no hay que confundir ambos supuestos (por mucho que el precepto citado hable también de «rehusar»). La diferencia entre uno y otro supuestos se halla en la relación que une al destinatario con el contrato de transporte. Rehusada la recepción de las mercancías, el destinatario no entra en el contrato y no adquiere, por tanto, derecho alguno derivado de él, de manera que ni estará autorizado para impartir instrucciones al porteador, ni adquirirá un derecho de disposición frente a éste. Por el contrario, si el destinatario acepta la entrega, se adherirá al contrato de transporte y, por lo tanto, pasará a ser titular de los derechos que resultan de tal relación, entre ellos el de dejar la mercancía de cuenta del porteador715. También son distintas, en fin, las consecuencias: a nada tiene derecho el destinatario que haya rehusado sin justificación la aceptación de la mercancía, mientras que el que haya declarado el deje de cuenta, podrá exigir del porteador la indemnización por pérdida total de la carga (art. 54 LCTTM).

Aun después de declarar el rehúse de las mercancías, no parece que al destinatario se le prive definitivamente del ejercicio de su derecho, pues puede

${ }^{714}$ Así, A. DÍAZ MORENO, «El contrato...», cit., p. 653.

715 P. MARTínez GonZÁLEZ, El transporte terrestre de mercancías, Díaz de Santos, Madrid, 2006, p. 69. 
reconsiderar su negativa dentro de un plazo conveniente y reclamar la entrega de las mercancías ${ }^{716}$. Ello se infiere de lo dispuesto en el artículo 36.2 LCTTM, a cuyo tenor, «[s]i el impedimento [aquí, el rehúse de las mercancías por el porteador] cesa antes de que el porteador haya recibido instrucciones [del cargador], entregará las mercancías al destinatario, notificándolo inmediatamente al cargador». Así, el plazo «conveniente» al que antes se hizo referencia viene marcado por el tiempo que necesita el cargador para impartir instrucciones al transportista.

En cuanto a la forma del rehúse de la mercancía, lo cierto es que la Ley no establece ninguna forma especial para su eficacia. Así, aquél puede declararse de manera expresa o tácita, es decir, puede resultar también de hechos concluyentes como, por ejemplo, la negativa a descargar la mercancía cuando tal operación le incumbe al destinatario 717 .

\subsection{El derecho de retención del transportista}

El derecho de retención es uno de los derechos del porteador que recaen sobre las mercancías transportadas, cuyo objeto es garantizar el cobro de sus créditos derivados del contrato de transporte, de manera que suele hablarse del «privilegio del porteador». Desde una perspectiva económica, el derecho de retención del transportista constituye un instrumento intrínseco al Derecho del transporte que resulta adecuado para disminuir los riesgos del incumplimiento de la obligación de pagar el precio del desplazamiento que soporta el empresario transportista. En efecto, este privilegio que ostenta el porteador no es sino una medida legal que cautelarmente protege los intereses de quien, habiendo cumplido su obligación de llevar a cabo el traslado de las mercancías a su punto de destino, pretende de buena fe que la contraparte, en este caso el destinatario, cumpla la suya, en el marco de sus respectivas prestaciones negociales ${ }^{718}$.

\footnotetext{
716 A. PERrinjaquet, Droit..., cit., p. 96.

717 Cfr. A. Recalde CASTElls, «La posición...», cit., p. 210; A. DÍAZ Moreno, «El contrato...», cit., p. 653.

${ }^{718}$ L.M. PILOÑETA ALONSO, «El privilegio del porteador terrestre y su derecho de retención sobre la mercancía transportada», en Aa.Vv., Actualidad jurídica del transporte por carretera. In memoriam F. M. Sánchez Gamborino, Madrid, 2005, p. 239.
} 
Ese tipo de garantía del pago de los portes y gastos se ha venido regulando en normas de distinta procedencia y rango ${ }^{719}$, que facultaban y facultan al porteador para retener las cosas transportadas y denegar su entrega al destinatario si este último se niega a pagar el flete o precio del transporte o, en su caso, a satisfacer el reembolso debido para la entrega, si así figura en la carta de porte. Sin embargo, este derecho de retención está condicionado a que el porteador deposite la mercancía ante un órgano judicial o ante la correspondiente junta arbitral del transporte. Así, hay que entender que el porteador no tiene el derecho de retener la mercancía por sí y ante sí (art. 40.2 LCTTM), evitando así toda clase de problemas y complicaciones, incluida una posible acusación por «apropiación indebida»720 según lo establecido en el Código Penal en sus artículos 253 y $254^{721}$.

Del tenor del artículo 35.2 LCTTM se desprende que, con la reclamación de la entrega de la mercancía por parte del destinatario, la que inicialmente fuera una mera carga de abonar el precio del transporte ${ }^{722}$ se convierte en obligación en sentido técnico-jurídico. En aras de garantizar el cumplimiento de esta obligación que incumbe al destinatario, el artículo 40 LCTTM - de igual forma que el artículo 13.2 CMR - otorga al porteador una protección eficaz en forma de un derecho de retención sobre los efectos transportados para forzar al desti-

719 Concretamente, en España, los arts. 375 Ccom y 9.2 de la Orden del Ministerio de Transportes, Turismo y Comunicaciones de 30 de noviembre de 1981, por la que se aprueba el Reglamento-Tipo regulador de los servicios de transporte público de mercancías por carretera con carga fraccionada (B.O.E. núm. 294, de 9 de diciembre de 1981), ambos hoy derogados, así como en el art. 40 LCTTM.

$720 \mathrm{Al}$ respecto señala el art. 253.1 del vigente Código Penal que «[s]erán castigados con las penas del artículo $249 \mathrm{o}$, en su caso, del artículo 250, salvo que ya estuvieran castigados con una pena más grave en otro precepto de este Código, los que, en perjuicio de otro, se apropiaren para sí o para un tercero, de dinero, efectos, valores o cualquier otra cosa mueble, que hubieran recibido en depósito, comisión, o custodia, o que les hubieran sido confiados en virtud de cualquier otro título que produzca la obligación de entregarlos o devolverlos, o negaren haberlos recibido».

${ }^{721}$ F.J. SÁNCHEZ-GAMBORINO y J. GAITÁN REBOLLO, Factbook..., cit., pp. 118 y ss.

${ }^{722}$ Obsérvese que el principio de relatividad de los contratos impide establecer obligaciones a cargo de quien no las haya aceptado. Por ello, en tanto el destinatario no declare su voluntad de aceptar las mercancías, tan sólo soporta una carga, en el sentido de que no resulta obligado a pagar el precio del transporte, pero no podrá exigir la entrega sin hacerlo efectivo. 
natario a pagar los gastos derivados del transporte, «a no ser que se le garantice el pago mediante caución suficiente» (art. 40 LCTTM)723.

Ahora bien, precisamente donde más interés puede tener el derecho de retención - esto es, en sede concursal-, su ejercicio queda suspendido en virtud del artículo 59 bis de la Ley 22/2003, de 9 de julio, Concursal724.

\subsection{Ejercicio del derecho a la comprobación del destinatario después de la llegada de las mercancías al lugar de destino}

Con la llegada de la mercancía y su entrega al destinatario se supone que el porteador ha cumplido con su deber de transportar. No obstante, la entrega ha de efectuarse correctamente, es decir, previo cumplimiento de la obligación de custodiar adecuadamente las mercancías: éstas han de ser entregadas en perfecto estado, íntegras e incólumes, tal y como figuran descritas e identificadas en el documento de transporte (art. 34.1 LCTTM). No obstante, a veces sucede que esta entrega no se produce en las condiciones previstas725.

La falta de identidad entre las mercancías descritas en la carta de porte y las efectivamente entregadas al destinatario hará surgir la responsabilidad del porteador, por cuanto éste responde de cualquier daño o menoscabo producido a las mercancías frente al derechohabiente, sea el cargador o el destinatario. Este último interviene en el momento de la llegada de las mercancías para verificar y comprobar su estado, esto es, para determinar si coinciden con las condiciones y la descripción de las mismas que resultan del documento de transporte.

723 Véase A. DíAz Moreno, «El contrato...», cit., p. 653; A. PUETZ, «Derechos...», cit., p. 448. Al respecto, el Código de Comercio señalaba en su art. 374, hoy derogado, que «el transportista no puede retener la mercancía por sí y ante sí, sino que ha de depositarla a disposición de la Autoridad judicial». Hoy, dicha regla figura en el art. 40.2 LCTTM, a cuyo tenor, «[c]uando el porteador retenga las mercancías, deberá solicitar al órgano judicial o a la Junta Arbitral del Transporte competente el depósito de aquéllas y la enajenación de las necesarias para cubrir el precio del transporte y los gastos causados, en el plazo máximo de diez días desde que se produjo el impago».

724 A tenor del artículo 59 bis.1 de la Ley Concursal, «[d]eclarado el concurso quedará suspendido el ejercicio del derecho de retención sobre bienes y derechos integrados en la masa activa». El apartado segundo, por su parte, continúa diciendo que «[s]i en el momento de conclusión del concurso esos bienes o derechos no hubieran sido enajenados, deberán ser restituidos de inmediato al titular del derecho de retención cuyo crédito no haya sido íntegramente satisfecho».

725 F.J. SÁnChez-Gamborino, El contrato..., cit., p. 257; Ma .P. MarTín CASTRO, El transporte multimodal: concepto y sujetos, EDICIP, Puerto Real, 2001, p. 362. 
Si no fuera así, la Ley obliga al destinatario que haya ejercido su derecho a la comprobación a hacer constar por escrito sus reservas al porteador o, en su caso, a los auxiliares de éste (arts. 6o LCTTM y 30 CMR), consignando si existe avería o alteración del estado de la mercancía en el momento de la entrega. Para ello, dispone del plazo legalmente previsto, que es de siete días desde la fecha de entrega si se trata de averías y pérdidas ocultas o no manifiestas. En cambio, tratándose de averías o pérdidas fácilmente constatables (es decir, manifiestas), deberá formular tales reservas en el mismo momento en que las mercancías le sean entregadas.

El Convenio CMR emplea en su artículo 30.1 el término «contradictoriamente», de lo que se infiere que la comprobación es de carácter bilateral, es decir, que ha de ser efectuada conjuntamente por el porteador (o su auxiliar) y el destinatario726; una regla que tiene su reflejo en el apartado segundo del artículo 34 LCTTM. Con ese examen contradictorio o bilateral de las mercancías, la reserva por parte del destinatario deviene innecesaria, sobre todo si existe acuerdo sobre su estado y las causas que lo motivan. En caso contrario, las partes podrán proceder al reconocimiento de las mercancías según lo establecido en el artículo 26.3 LCTTM727 o disponer el reconocimiento de la mercancía «por un perito designado a tal efecto por ellos mismo o por el órgano judicial o la Junta Arbitral del Transporte que corresponda» (art. 34.2 i.f. LCTTM).

Si el destinatario recibe las mercancías sin poner de relieve menoscabo o pérdida alguna durante el acto de la verificación contradictoria y sin formular reservas al porteador, se presumirá salvo prueba en contrario que las mercancías le fueron entregadas en buen estado, o sea, en el mismo estado que figura en la carta de porte (arts. 30.1 CMR y 60.1 LCTTM)728. Obsérvese que la regla es fiel reflejo de la que se aplica al porteador en el momento de recibir las mercancías del cargador o expedidor: en ausencia de reservas hechas por el transportista en el momento de la recepción en origen, se presume que las mercancías se hallan en el estado descrito en la carta de porte. De ahí que se presuma que cualquier menoscabo o daño que se constate en el momento de su entrega al

${ }^{726}$ F. J. SÁNCHEZ-GAMBORINO, El contrato..., cit., p. 258.

${ }^{727}$ Así lo indica el artículo 60.2 i.f. LCTTM.

${ }^{728}$ Ma.P. MARTÍN CASTRO, El transporte..., cit., p. 362. 
destinatario es imputable al porteador. No sorprende, en suma, que la verificación del estado de la mercancía sea un tema crucial para el ejercicio de los derechos respectivos de las partes intervinientes en el transporte, que se completa con un marco probatorio legalmente establecido al objeto de manifestar reservas y reclamaciones frente al porteador ${ }^{729}$.

Cuando no se constata ningún daño o pérdida en la mercancía después de realizada la verificación contradictoria por el transportista y el destinatario, se presume finalizada la relación contractual entre porteador y destinatario. Por ello, no es admisible reclamación alguna frente al porteador sobre los perjuicios producidos a las mercancías durante el traslado, salvo que se trate de una reclamación referida a un menoscabo o avería que no ha podido descubrirse por ambas partes en el momento del examen contradictorio (art. 30.2 CMR)730.

\section{Obligaciones del destinatario}

\section{La entrega contra reembolso}

\subsection{Concepto y naturaleza jurídica de la entrega contra reembolso}

Si volvemos la vista atrás y centramos nuestra atención en la evolución histórica de una cuestión compleja como es la naturaleza jurídica de la entrega contra reembolso, merece destacarse el papel desempeñado por la Corte de Casación francesa, aunque tampoco faltan aportaciones doctrinales sobre el tema clásico de si la instrucción de entregar la mercancía contra reembolso constituye un mandato distinto del contrato de transporte o si se integra en él731. En efecto, la Cour de Cassation coadyuvó a través de sus decisiones a alcanzar la conclusión

\footnotetext{
729 A. EMPARANZA SOBEJANO, «Estado de las mercancías en el momento de la entrega al destinatario», en J. F. Duque Domínguez y F. Martínez Sanz (dirs.), A. Emparanza Sobejano y $\mathrm{M}^{\mathrm{a}}$.V. Petit Lavall (coords.), Comentarios a la Ley de Transporte Terrestre, cit., pp. 426 y ss.

${ }_{730}^{\circ} \mathrm{M}^{\mathrm{a}}$.P. MARTín CASTRO, El transporte..., cit., p. 363. El el derecho interno, aun cuando se hubiera realizado una verificación contradictoria, también cabe probar por otros medios que la carga se entregó en un estado no conforme con la descripción en la carta de porte (recuérdese que la presunción reviste naturaleza iuris tantum), pues, al contrario de cuanto sucede en el CMR, el art. 60.2 LCTTM no veda esta posibilidad.
}

${ }^{731} \mathrm{Al}$ respecto puede verse, p.ej., A. COOLEN, «La livraison contre le remboursement», en Jacques Putzeys, Liber amicorum, Bruylant, Bruselas, 1996, p. 230. 
de que, cuando el porteador se compromete a no entregar la mercancía al destinatario hasta que éste pague el reembolso, tal operación no es sino una condición accesoria y previa a la operación de entrega, que se enmarca en el contrato de transporte, al que queda indisolublemente unido ${ }^{732}$.

La operación de entregar la mercancía al destinatario contra reembolso es usada frecuentemente en la práctica. Al margen de su gran importancia en el transporte postal, también tiene su reflejo en el comercio internacional, donde abundan los negocios de compraventa a distancia y se emplea el equivalente en inglés «COD» (cash on delivery) o «POD» (pay on delivery) ${ }^{733}$. Se trata, en definitiva, de una forma de pagar el precio de compra de la mercancía transportada conforme al acuerdo establecido entre el vendedor-cargador y el porteador, que estipulan este pacto bajo la forma de una cláusula incorporada al contrato de transporte734. Este sistema de entrega contra reembolso tiene una función instrumental, cuyo objeto es equilibrar la situación en que se hallan las partes distantes entre sí del contrato de compraventa.

Así, cuando se celebra un contrato de compraventa a distancia en el que se aplace el pago hasta después de la entrega de las mercancías al comprador735, el vendedor comienza a cumplir su obligación antes de que el comprador empiece a efectuar la suya: el vendedor contrata el transporte de las cosas objeto de la venta al comprador, asumiendo a tal efecto unos gastos e, incluso, ciertos riesgos, sin antes recibir el precio de las mercancías vendidas. Es esta la primera razón que puede llevar al vendedor a incluir en el contrato de transporte la cláusula «COD», esto es, para asegurarse con la ayuda del porteador el cobro del

${ }_{732}$ Véase J. PUTZEYS, Le contrat..., cit., p. 236. Dada su estrecha relación con el Derecho francés, es esta también la solución adoptada por la doctrina y la jurisprudencia belgas, por entender que es lo más correcto desde un punto de vista lógico y por confirmarlo así la realidad económica. $\mathrm{Al}$ respecto, A. COOLEN, «La livraison...», cit., p. 232.

${ }_{733} \mathrm{La}$ entrega contra reembolso se ha definido como un instrumento o una técnica de pago que exige la participación de un intermediario «financiero» particular, que no es otro que el mismo porteador, quien asume la responsabilidad de realizar el cobro por cuenta del cargador y, a tal efecto, deberá negarse a entregar las mercancías al destinatario hasta que éste pague las cantidades debidas en concepto de reembolso (traducción libre de Le dico du commerce international, disponible en http://www.glossaire-international.com).

734 F.J. SÁNCHEZ-GAMBORINO, El contrato..., cit., p. 199.

735 Obsérvese que existen otras formas de garantizar el pago de las mercancías, señaladamente, la apertura de un crédito documentario a favor del vendedor, un aspecto en el que no se puede profundizar aquí. 
destinatario de las cantidades debidas por éste. Quiere decirse con ello que la entrega contra reembolso se utiliza como una medida de garantía frente al incumplimiento del comprador de pagar el importe de la venta, de manera que el comprador-destinatario no va a poder recibir los efectos transportados hasta que satisfaga el importe que le debe al vendedor-cargador ${ }^{736}$.

Aun tratándose de un servicio accesorio 737 y adicional al transporte, su naturaleza jurídica se corresponde con la de un pacto de comisión o gestión de cobro, en el que el cargador es el comitente y el porteador ocupa la posición del comisionista738. De esta forma se aplicarán supletoriamente las normas del Código de comercio en materia del contrato de comisión mercantil (arts. 244 y ss. Ccom)739. Y es que, a través de tal cláusula incorporada al contrato de transporte, el remitente encarga al porteador la tarea de cobrar el reembolso, debiendo negarse a realizar la entrega si el destinatario no cumple con su obligación de pagar la cantidad indicada en la carta de porte.

El cobro del reembolso se considera uno derecho del porteador quien, aparte de su derecho al precio y los gastos del transporte, tendrá derecho también a una remuneración a cambio de la comisión asumida, a satisfacer con independencia del importe del transporte. Es decir, el transportista va a percibir una cantidad de dinero como premio de su comisión, conforme a lo previsto en el artículo 277 del Código de Comercio740. Y así lo establecen asimismo las Condiciones generales para el transporte de mercancías por carretera de 2012,

736 A. Emparanza Sobejano, «Entrega contra reembolso», en J. F. Duque Domínguez y F. Martínez Sanz (dirs.), A. Emparanza Sobejano y $\mathrm{M}^{\mathrm{a}}$.V. Petit Lavall (coords.), Comentarios a la Ley de Transporte Terrestre, cit., p.512.

737 F. J. SÁnCheZ-GAMborino y J. GAITÁn REBOLlo, Factbook..., cit., p. 143.

738 F.J. Sánchez-Gamborino, El contrato..., cit., p. 199; F. JUAN y Mateu, Los impedimentos para la entrega..., cit., p. 46.

739 En las condiciones generales de 1997, en ausencia de una mención específica en el Código de comercio, la entrega contra reembolso encontraba una regulación detallada en las condiciones 1.9 y 2.30 del Anexo B que, sin embargo, eran aplicables únicamente al transporte de carga fraccionada. La regulación actual en la cláusula 6.4 de las Condiciones generales de 2012 resulta aplicable tanto al transporte de carga completa como al de carga fraccionada y reproduce en buena medida el contenido del art. 42 LCTTM.

740 A. RECALDE CASTELLS, «La entrega de las mercancías contra el reembolso en el transporte internacional por carretera», en F. Martínez Sanz y $\mathrm{M}^{\mathrm{a}}$.V. Petit Lavall (dirs.), Aspectos jurídicos y económicos del transporte: Hacia un transporte más seguro, sostenible y eficiente, T. I, Servicio de Publicaciones de la Universitat Jaume I, Castellón, 2007, p. 773. 
cuando señalan que «[e]l pago de la prima de reembolso, que se facturará separadamente del precio del transporte, corresponderá al obligado al pago del transporte» (cl. 6.4, $5^{\mathrm{a}}$ ). Como puede apreciarse, se trata de un aspecto no regulado en el artículo 42 LCTTM, pues no sólo se menciona la prima de reembolso, sino se deja claro también quién debe asumir su pago. Otra innovación respecto de lo dispuesto en la Ley, contenida igualmente en la cláusula 6.4 de las condiciones generales, es la referencia a la anulación del reembolso o la modificación de su cuantía por el cargador, que «se regirán por las reglas sobre el ejercicio del derecho de disposición» contenidas en las propias condiciones generales.

\subsection{Régimen de responsabilidad}

\section{a) La responsabilidad del cargador}

El régimen jurídico de la responsabilidad en el marco de la entrega contra reembolso puede abordarse, en primer lugar, desde la posición jurídica del cargador por cuanto éste, según lo previsto en los artículos 7.1.b) CMR y 10.7 LCTTM, responde de todos los gastos y daños irrogados al porteador por la inexactitud o insuficiencia de la indicación de la suma del reembolso a percibir en el momento de la entrega de la mercancía en la carta de porte. Además, tal inexactitud e insuficiencia puede plantearse también por el porteador como causa de exoneración de su responsabilidad en aplicación de los artículos 17.2 CMR y 48.1 LCTTM (culpa del cargador) ${ }^{741}$.

Cuando la carta de porte no contenga indicación alguna sobre el reembolso, nada obsta a la validez del pacto (incluso verbal) entre cargador y transportista (la inscripción en la carta de porte no tiene carácter constitutivo), mas el cargador tendrá que probar que el porteador estaba efectivamente obligado a entregar las mercancías a cambio del cobro de determinadas cantidades del destinatario, así como la cuantía exacta del reembolso, la forma de pago y, en su caso, la moneda en que ha de cobrarse ${ }^{742}$.

${ }^{741}$ F.J. SÁNCHEZ-GAMBORINO, El contrato..., cit., p. 200.

${ }^{742}$ F. Juan y Mateu, Los impedimentos..., cit., pp. 47-48; F.J. SÁncheZ-Gamborino, El contrato..., cit., p. 200. 
Por lo tanto, para evitar las complicaciones eventuales que pueden producirse, es aconsejable que la mención del pacto referido a la «suma del reembolso a percibir por el porteador en el momento en que proceda a la entrega de la mercancía al destinatario» sea incluida con precisión en la carta de porte (art. 6.1.c. CMR y 10.2. c LCTTM). A los efectos de determinar el contenido de la prestación exigible del porteador es conveniente que la carta de porte contenga claramente todos los datos relevantes, esto es, la cuantía que el destinatario debe pagar en concepto de reembolso, la moneda en la que ha de satisfacerse el pago, si el reembolso ha de cobrarse en efectivo o si son admisibles otros medios de abono distintos de la entrega de dinero, etc. ${ }^{743}$

\section{b) La responsabilidad del porteador}

El porteador, a su vez, habiéndose comprometido a realizar dicho encargo a cambio de una remuneración, responderá frente el cargador si no cumple su obligación de percibir la cantidad pactada en concepto de reembolso. Este incumplimiento por parte del porteador comportará la indemnización del cargador hasta la cuantía total del reembolso, sin perjuicio del derecho del porteador a repetir contra el destinatario (arts. 42.3 LCTTM y 21 CMR). El importe de la indemnización será, pues, como máximo, una cantidad equivalente a la del reembolso no percibido. Este importe constituye un límite cuantitativo del pago indemnizatorio, de conformidad con lo que establecen los preceptos indicados744, lo cual parece lógico si se tiene en cuenta que, en línea de principio, el cargador no sufre otro daño distinto del de no percibir el importe de la venta. Sin embargo, cabe señalar que si el porteador, en el supuesto en que el reembolso incluya dos importes distintos (el primero en concepto de precio de venta de los bienes y el segundo por el precio del transporte), no percibe el importe del reembolso mencionado en la carta de porte en su totalidad (o sea, cuando percibe únicamente el primer importe), no se libera de su responsabilidad por in-

743 A. Emparanza Sobejano, «Entrega...», cit., p. 514; A. Recalde Castells, «La entrega...», cit., pp. 774-775; F.J. SÁNCHEZ-GAMBORINO, El contrato..., cit., p. 200.

744 F.J. SÁNCHEZ-GAMBORINO, El contrato..., cit., p. 201. 
cumplimiento del pacto suscrito, aunque haya percibido una parte sustancial de dicho importe745.

En cuanto al supuesto de que el destinatario se niegue a pagar la suma del reembolso, se entenderá que éste rechaza la recepción de las mercancías, con lo que ha de aplicarse las normas correspondientes a los impedimentos a la entrega (art. 42 LCTTM, que remite expresamente al art. 36 LCTTM) ${ }^{74}$.

\subsection{Cuantía del reembolso y comisión de cobro}

La cuantía a percibir del destinatario en concepto de reembolso deriva de lo pactado entre cargador-vendedor y destinatario-comprador. En la práctica, se refiere al importe global del precio de las mercancías vendidas objeto del transporte, aunque su determinación en la carta de porte corresponde al cargador. Por ello, dicha cuantía no tiene por qué coincidir estrictamente con el valor de estas mercancías, y el resarcimiento debido en caso de pérdida o avería puede ser distinto, ya a que son dos conceptos independientes en materia de indemnización, por mucho que ambos resulten del contrato de transporte747. Es más, el importe del reembolso se puede extender asimismo a otros conceptos distintos del precio de compraventa, tales como el precio del transporte cuando éste se realice a portes pagados, el precio de la comisión, el precio del seguro del

745 Véase A. RECAlde CASTElls, «La entrega...», cit., p. 777; A. EMPARANZA SobEJANO, «Entrega...», cit., p. 515 .

746 Así ya, para la situación anterior a la entrada en vigor de la Ley 15/2009, F. JUAN Y MATEU, Los impedimentos..., cit., pp. 52-53.

747 Señala al respecto SÁNCHEZ-GAMBORINO con acierto que «la estipulación de cantidad de reembolso no tiene efecto de declaración de valor por las razones siguientes: $1^{\circ}$ ) porque esta cuantía obedece a relaciones económicas que el transportista no tiene por qué conocer (y así, pudiera incluir descuentos, acumulación de cargos o compensación entre operaciones, etc.); $2^{\circ}$ ) porque, aun acreditando que la cuantía indicada correspondiera exacta y únicamente a esa mercancía, siempre se referirá a su valor en destino (lugar de su entrega al destinatario) mientras que el previsto en el artículo 23.1 [CMR] como indemnizable es el valor en origen, por tanto siempre distinto al indicado, pues al menos siempre el transporte aporta un 'valor añadido' a la mercancía; $3^{o}$ ) porque, aun cuando hipotéticamente tales dos valores de origen y de destino coincidiesen, no se cumpliría el requisito de cobro por el transportista de un suplemento en los portes -que exige el artículo 24-, rompiéndose entonces el equilibrio entre precio del transporte y responsabilidad que supuestamente asumiría». Así, F.J. SÁnchEZ-GAmborino, El contrato..., cit., p. 202-203; véase también ID. y J. GAITÁN REBOLLO, Factbook..., cit., p. 144. 
transporte, los costes de embalaje, o cualesquiera otros gastos o créditos pendientes que el cargador tuviera contra el destinatario ${ }^{748}$.

El cobro del importe indicado en su totalidad es el objeto perseguido mediante el encargo que hubiera pactado el porteador con el cargador, así que el porteador responde frente a este último si no ha podido percibir el importe total del abono que debía satisfacer del destinatario. No se da mucha importancia, a estos efectos, al hecho de si la comisión de cobro se había efectuado diferenciando los distintos conceptos que integraban la cuantía del reembolso. En otras palabras, el pacto en su totalidad se cumple de forma defectuosa cuando sólo se ha percibido una parte (por muy sustancial que fuera) de dicho cobro, ya que el reembolso se refiere a un importe único que puede comprender, según la cláusula de entrega contra reembolso, también el precio del transporte 749 .

Por la gestión de cobro, el porteador gozará de remuneración específica que corresponde al premio de la comisión (art. 277 Ccom). Para la determinación de su cuantía a de estarse a los criterios pactados por las partes, aunque lo habitual es que el cálculo se realice en forma de una cantidad mínima fija y un porcentaje sobre la cuantía del cobro750. Además, en la cláusula 6.4 de Condiciones generales de la contratación de los transportes de mercancías por carretera de 2012 se establece que la facturación del pago de la prima del reembolso ha de ser pagado separadamente del precio de transporte.

En fin, también la determinación de la forma de pagar el importe del reembolso depende de lo que se haya pactado entre el cargador-vendedor y el comprador-destinatario de las mercancías expedidas aunque, nuevamente, lo determinante a efectos del contrato de transporte es el contenido de éste (y no del de compraventa, que para el transportista es res inter alios acta). Como regla general, el pago se ha de satisfacer al porteador en efectivo, por lo que su realización por otro medio de pago (p.ej., mediante cheques) ha de ser

${ }^{748}$ F. JUAN Y MATEU, Los impedimentos..., cit., p. 49.

749 A. ReCalde Castells, «La entrega...», cit., p. 777; A. Emparanza Sobejano, «Entrega...», cit., p. 515 .

750 A. RECALDE CASTELls, «La entrega...», cit., p. 773; A. EMPARANZA Sobejano, «Entrega...», cit., pp. 514-515. 
expresamente autorizada (art. 42.1 LCTTM). Como se ha señalado en el epígrafe anterior, para evitar los problemas que pueden producirse respecto de la forma de pagar, es recomendable que se incluya en el contrato toda clase de instrucciones y precisiones acerca del modo específico de abono del reembolso. En caso de autorizarse otros medios de pago, tales como el cheque, letras de cambio, pago mediante tarjeta, etc., no siempre será suficiente con mencionar esos otros medios de pago, debido a las complicaciones que pueden ocasionarse a la hora del cobro por el hecho de que el porteador tal vez no sea un experto en tales transacciones comerciales. Hay que destacar en la cláusula, más bien, las características concretas que han de revestir tales medios de pago para que cumplan con lo estipulado al efecto de prevenir cualquier equívoco a la hora de realizar el encargo correctamente ${ }^{751}$.

Es admisible también que se modifique la forma de pago mediante instrucciones emitidas al porteador, comunicándole que entregue los envíos al destinatario cuando se le presente otro tipo de documentos que justifiquen el pago, tales como un justificante bancario de la transferencia de la cuantía del reembolso al cargador, o cuando se acredita que el pago está garantizado de manera suficiente (por ej., cuando se presenta una copia de una carta de crédito abierto por el banco a favor del cargador) ${ }^{752}$.

La diversidad de las fórmulas de pago a veces puede suscitar problemas, ya que el conductor no está cualificado necesariamente para poder analizar el contenido de ciertos documentos, sobre todo si están redactados en un idioma extranjero. La responsabilidad del porteador se limita aquí a ejecutar las instrucciones emitidas por el cargador753. Por ello, no se pide al porteador que sea un experto en transacciones de pago, sino que más bien se le exige que sea diligente y no acepte cualquier documento, sobre todo si el documento ya en apariencia no se corresponde con las instrucciones impartidas por el cargador. El patrón de diligencia a la hora de examinar la veracidad de dichos documentos no será la de un comerciante profesional, sino la de un porteador que efectúa el

751 F. Juan y Mateu, Los impedimentos..., cit., p. 50; A. Emparanza Sobejano, «Entrega...», cit., p. 515.

${ }^{752}$ J. PutZeYs, Le contrat..., cit., p. 237; A. RECALDE CASTELLS, «La entrega...», cit., p. 778.

753 A. COOLEN, «La livraison...», cit., p. 235. 
transporte, con lo cual éste no puede ser garante del valor del documento en sí mismo 754 .

Consecuentemente, el porteador no responde frente al cargador cuando se encuentra ante un medio de pago que carece de la preceptiva provisión de fondos o que es simplemente falso. En efecto, no debe descartarse la posibilidad de que el porteador sea objeto de una estafa, si a la hora de la entrega al destinatario se presenta otra persona, entregándole un cheque bancario con el nombre del destinatario, según las instrucciones emitidas por el cargador. En este caso, el porteador no tiene culpa si no ha comprobado la identidad de aquél, así que no asumirá la responsabilidad si luego resulta que la recuperación de las mercancías es imposible debido a dicha estafa755.

En cambio, nada impide que el porteador se abstenga de entregar las mercancías si la documentación presentada parece sospechosa o dudosa respecto de su autenticidad, solicitando al cargador nuevas instrucciones que se pueden tomar a tal respecto756; si la solicitud no fuera posible, el porteador habrá de actuar como comisionista de la forma más prudente y que sea más favorable para los intereses de su comitente, conforme a las normas aplicables en materia de comisión mercantil (art. 255 Ccom) 757.

\subsection{Cumplimiento e incumplimiento del encargo de cobrar el reembolso}

\section{a) El transportista ha cumplido su encargo de percibir el reembolso del destinatario}

Se entiende cumplida la obligación del porteador, en cuanto comisionista de cobro, cuando ejecuta correctamente el encargo que le hizo el cargador a percibir la cantidad de dinero convenida del destinatario. Una vez realizado dicho encargo, parece que el porteador quede liberado de la obligación que

\footnotetext{
754 F.J. SÁnchez-Gamborino, El contrato..., cit., p. 203; A. ReCalde Castells, «La entrega...», cit., p. 778.

755 A. COOLEN, «La livraison...», cit., p. 237.

756 F.J. SÁNCHEZ-GAMBORINO, El contrato..., cit., p. 203.

757 F. JUAN y MATEU, Los impedimentos..., cit., p. 51.
} 
tuviera frente al cargador. No obstante, el hecho de actuar como comisionista le obliga, como no puede ser de otra forma, a entregar al cargador la cantidad que recibió del destinatario en concepto de reembolso. Cabe recordar en este contexto que no hay que confundir el precio del transporte a portes debidos y la cuantía del reembolso, pues no resultará obligado el porteador a entregar al cargador dicho porte, ni tampoco cualquier premio por la gestión efectuada con éxito758.

El artículo 42.2 LCTTM y la condición 6.4 de las Condiciones generales de 2012 prevén para tal caso que el porteador transfiera la suma cobrada al cargador o a la persona designada por él en el plazo de diez días desde que lo hubiera recibido, salvo que se hubiera pactado un plazo más largo. En caso contrario, el cargador tendrá derecho a la indemnización de los daños y perjuicios causados por no haberse puesto a su disposición las cantidades percibidas, al haberse incumplido la obligación del porteador según lo previsto en el contrato de transporte 759 .

Ante el silencio que guarda el CMR sobre las consecuencias de no entregar al cargador la cantidad cobrada en concepto de reembolso, la responsabilidad del porteador por dicho incumplimiento se rige por el Derecho nacional760; en España, por tanto, según las reglas antes enunciadas.

\section{b) Incumplimiento del encargo de cobrar el reembolso}

Como se vio, la negativa del destinatario a abonar el importe del reembolso al porteador faculta a éste para denegar la entrega de las mercancías, aunque más que de una facultad se trata de una obligación, derivada de la relación de comisión que el porteador asume frente al cargador. Como consecuencia, si el porteador, a pesar de la negativa del destinatario y el correspondiente impago del reembolso, lleva a cabo la entrega, se produce un incumplimiento por su parte. Por virtud de dicho incumplimiento del porteador, éste pierde la remuneración

\footnotetext{
758 A. Recalde CASTElls, «La entrega...», cit., p.780; A. EMParanza SobeJano, «Entrega...», cit., p. 517.

759 F. JUan y Mateu, Los impedimentos..., cit., p. 52.

${ }^{760}$ Así, para la situación anterior a la entrada en vigor de la LCTTM, A. RECALDE CASTELLS, «La entrega...», cit., p. 781; F. JUAN Y MATEU, Los impedimentos..., cit., p. 52.
} 
por la comisión de cobro y, además, responderá frente al cargador de los daños que la falta de cobro del reembolso haya generado a éste, sin perjuicio de su derecho de repetir posteriormente contra el destinatario que rehusó cumplir la obligación de pagar el reembolso (art. 42.3 LCTTM) ${ }^{761 .}$

El incumplimiento del que se trata aquí deriva de la negligencia del porteador que no ha exigido el pago del reembolso del destinatario, con lo que es prima facie responsable de la falta de cumplimiento del encargo asumido frente al cargador ${ }^{762}$. La responsabilidad del porteador por entregar las mercancías sin cobrar la cuantía del reembolso que el destinatario debe al cargador viene regulada en el artículo 21 CMR, al igual que en el artículo 42.3 LCTTM, como un supuesto especial de responsabilidad del porteador, pues no figura entre los supuestos de responsabilidad mencionados en el Capítulo IV del Convenio (y el Capítulo V de la Ley) que se ocupa de la responsabilidad del porteador. En efecto, no se trata de un supuesto «propio» de responsabilidad del porteador (por pérdidas, averías y retrasos) sino de la vulneración de la cláusula de reembolso incluida en el contrato de transporte: ésta se incumple si la mercancía se consigna sin obtener el pago, y se cumple defectuosamente si se produce el cobro parcial de lo debido en concepto de reembolso ${ }^{763}$.

A este respecto es indiferente que el incumplimiento del porteador se hubiera producido por un hecho culposo o alguna conducta dolosa o no, de manera similar a como sucede en el contrato de comisión cuando el comisionista debe ejecutar correctamente la comisión, sin que sea necesario a tal efecto que concurra conducta alguna de las que hemos señalado (art. $252 \mathrm{Ccom}$ ). Y ello porque el artículo 42 LCTTM no prevé criterio alguno de imputación y se estima que se está ante una responsabilidad objetiva derivada de la falta de consecución del resultado, de manera que la prueba de la diligencia o de cualquier estado subjetivo, por muy complicada que resulte, no exime al porteador de la responsabili-

${ }^{761} \mathrm{Al}$ respecto véase F. JUAN y MATEU, Los impedimentos..., cit., p. 52-53; A. RECALDE CASTElls, «La entrega...», cit., p. 781; A. EMPARANZA SOBEJANO, «Entrega...», cit., p. 518.

762 A. COOLEN, «La livraison...», cit., p. 236.

763 C. GóRriz López, La responsabilidad en el contrato de transporte de mercancías; carretera, ferrocarril, marítimo, aéreo y multimodal, cit., pp. 387 y 388. 
dad por su incumplimiento, que radica en no obtener el cobro del reembolso encomendado 764 .

La cuestión puede resultar más compleja cuando la realización material del transporte se encomienda a un porteador efectivo, subcontratado por el porteador contractual que haya recurrido a sus servicios para la ejecución del transporte. Pues bien, si el porteador efectivo no cumple la obligación de cobrar el reembolso, el cargador no estará legitimado frente al porteador efectivo (subporteador) para reclamar a éste el incumplimiento de dicho encargo, sino sólo frente al porteador contractual con quien ha contratado el transporte, ya que el subporteador no es sino un mandatario del porteador principal que no tiene ninguna relación contractual con el cargador 765 . Sin embargo, nada impide que el porteador contractual, en el ámbito interno, pueda regresar contra el porteador efectivo, reclamándole el resarcimiento de los daños y perjuicios causados por el incumplimiento de las obligaciones derivadas del pacto de reembolso ${ }^{766}$ (siempre y cuando, claro está, la cláusula de reembolso se había reflejado también en el subcontrato de transporte).

\subsection{El límite indemnizatorio y la prescripción de las reclamaciones por reembolso}

El resarcimiento que le incumbe prestar al porteador por su incumplimiento de la obligación de obtener el reembolso depende de los daños efectivamente causados, aunque está cuantitativamente limitado. En efecto, el importe del reembolso no es una cuantía que deba satisfacerse automáticamente por el mero hecho del incumplimiento, como si de una cláusula penal se tratara, sino que constituye un techo máximo indemnizatorio que puede o no alcanzarse. Es esto lo que se desprende del tenor literal del artículo 42.3 LCTTM, a cuyo tenor, por la falta de la percepción del cobro del reembolso, «responderá [el transportista\} frente al cargador hasta el importe del reembolso».

764 A. ReCAlde Castells, «La entrega...», cit., pp. 782-783; A. Emparanza Sobejano, «Entrega...», cit., pp. 518-519; C. GÓRRIZ LÓPEZ, La responsabilidad..., cit., p. 388.

765 A. EMPARANZA SobeJANo, «Entrega...», cit., p. 519.

${ }^{766}$ A. RECALDE CASTELLS, «La entrega...», cit., p. 783. 
Menos diáfana se plantea la cuestión acerca del cálculo de la indemnización en el ámbito del CMR, donde existe una discusión doctrinal sobre si el cargador goza de forma automática de un derecho a obtener la cantidad debida por el destinatario o si deberá probar los daños que le ha generado el incumplimiento del porteador. Ciertamente, el artículo 21 CMR establece en la versión española que «el transportista quedará obligado a indemnizar al remitente hasta la suma total del reembolso»767. Ahora bien, una opinión autorizada afirma que las versiones oficiales (el inglés y el francés, según la antefirma del Convenio) autorizan ambas soluciones.

En la doctrina gala parece predominar la idea de que en la versión francesa inclina la balanza a favor de la primera hipótesis. De la expresión «indemniser l'expediteur a concurrence du montant du remboursement» se infiere que el porteador debe siempre satisfacer al remitente la cantidad que debió obtener del destinatario. Otros autores patrocinan la misma opinión, basando sus argumentos en el hecho de que el porteador tendrá el derecho de regreso frente al destinatario ${ }^{768}$. Sin embargo, la aplicación consecuente de esta opinión podría llevar a que el cargador obtenga una suma superior a la que recibiría en caso de pérdida total cuando la suma del reembolso sobrepasa ampliamente el valor que tenía mercancía con arreglo al artículo 23 CMR769.

Otra solución es la que trasluce en algunas de las traducciones del Convenio, entre ellos la alemana y española, a cuyo tenor el porteador deberá satisfacer la indemnización hasta el límite de la suma que debía obtener770. En este sentido, al cargador le corresponderá la carga de alegar y probar los daños producidos por el incumplimiento del porteador y la cuantía de los mismos para que pueda ser indemnizado, hasta el límite fijado en la normativa aplicable (que, en el caso de la Ley española y el CMR, coincide con el importe del reembolso no abonado por el destinatario). Así, si los daños sufridos por el cargador resultan menores que la cifra del reembolso, la responsabilidad estará limitada

\footnotetext{
${ }^{767}$ Véase F.J. SÁNCHEZ-GAMBORINO, El contrato..., cit., p. 202.

${ }^{768}$ Cfr. las referencias en C. GóRRIZ LóPEZ, La responsabilidad..., cit., p. 388.

769 A. RECALDE CASTELLS, «La entrega...», cit., p. 784.

${ }^{770}$ C. GÓRRIZ LÓPEZ, La responsabilidad..., cit., pp. 388-389.
} 
al importe del daño ${ }^{771}$. En cambio, si los daños superan el importe señalado, no deberá pagar el porteador más que éste. Con todo, este límite indemnizatorio no será de aplicación, en el ámbito internacional, cuando el daño hubiera sido causado por dolo o culpa equiparable del porteador (art. $29 \mathrm{CMR}$ )772; o, a nivel nacional, cuando éste hubiera actuado de forma dolosa o con una infracción consciente del deber jurídico asumido (art. 62 LCTTM)773.

Para el transporte internacional, el artículo 32.1 CMR establece un plazo de prescripción de un año para las acciones dirigidas a reclamar el daño patrimonial frente al porteador por haber dejado de obtener el reembolso pactado. Dicho plazo se alarga hasta los tres años en caso de dolo o falta equivalente por parte del causante del daño según la Ley del foro. El plazo corre a partir de la expiración de un plazo de tres meses desde la conclusión del contrato de transporte [art. 32.1.c) CMR]. A nivel nacional, por su parte, la regla es misma, aunque el plazo de prescripción en caso de causación dolosa del daño se fija en dos (y no tres) años (art. 79.1 LCTTM) 774.

\subsection{La acción de repetición del porteador frente al destinatario}

El artículo 21 CMR en su último inciso prevé que el porteador tiene derecho a repetir contra el destinatario para recuperar lo que tuvo que indemnizar al car-

771 A. EMPARANZA SOBEJANO, «Entrega...», cit., p. 521; F. JUAN Y MATEU, Los impedimentos..., cit., p. 54; C. GÓRRIZ LÓPEZ, La responsabilidad..., cit., p. 389.

772 F. JUAN Y MATEU, Los impedimentos..., cit., p. 54. Con detalle sobre la culpa equiparable al dolo en el ámbito del CMR, F.J. SÁnCHEZ-GAMBORINo, La llamada culpa grave en el transporte de mercancías por carretera, Marge, Barcelona, 2016, pp. 295 y ss.

773 A. Emparanza Sobejano, «Entrega...», cit., p. 521; F. MARtínez SANZ y A. Puetz, «Pérdida del beneficio de limitación», en J.F. Duque Domínguez y F. Martínez Sanz (dirs.), A. Emparanza Sobejano y $\mathrm{M}^{\mathrm{a}}$.V. Petit Lavall (coords.), Comentarios a la Ley de Transporte Terrestre, cit., pp. 748 y s. La interpretación del circunloquio reproducido en el texto, que el art. 62 LCTTM emplea junto a la expresión «actuación dolosa» del porteador o de sus auxiliares, no resulta en absoluto sencilla, pero parece consolidada la opinión según la que el inciso se refiere al llamado dolo «eventual». Así, nuevamente, F. MARTínEz SANZ y A. PUETZ, «Pérdida del beneficio de limitación», cit., pp. 738 y ss.; así como F.J. ARIAS VARONA, «El comportamiento subjetivo del porteador como causa para la pérdida de los beneficios de responsabilidad», $R d T$, núm. 6, 2010, pp. 283 y ss.

774 El artículo 32.1.c) CMR determina el cómputo del plazo de prescripción para casos distintos de la pérdida, la avería o el retraso [para los que el dies a quo se determina conforme a los apartados a) y b) del art. 32.1 CMR], como por ejemplo el precio del transporte, indemnización por paralizaciones o de otros gastos del transporte, etc. El art. 79.2.c) LCTTM, por su parte, se refiere expresamente a los supuestos de entrega contra reembolso. 
gador por la falta de cumplimiento del encargo de cobro. La acción de repetición del porteador no deriva de una subrogación en las acciones del cargador, sino representa un derecho propio del porteador, derivado del pago de la deuda nacida a su cargo por el incumplimiento de su obligación frente al cargador ${ }^{775}$.

El carácter subjetivo del derecho del porteador para ejercer la acción de repetición impide al destinatario oponer excepciones que puedan derivar del contrato subyacente o del contrato de transporte. En cuanto al primero, el destinatario estará obligado a indemnizar al porteador el importe que haya pagado al cargador sin poder oponer, por ejemplo, el hecho de que la calidad de la mercancía no se corresponda con la calidad pactada en el contrato de compraventa. Es esta una acción que sólo puede oponerla frente al cargador, dado que el porteador no forma parte del contrato de compraventa celebrado entre aquél y el destinatario. Por ello, el destinatario deberá entregar la cuantía del reembolso que le debe al porteador, y sólo después podrá hacer valer su derecho a repetir frente al cargador en el marco de este contrato subyacente776. Tampoco está legitimado el destinatario para oponer las excepciones que pudieran resultar del contrato de transporte por averías o pérdidas en la mercancía, ya que son reclamaciones de responsabilidad cuyo régimen jurídico está regulado en los artículos 17 y ss. del CMR777.

Lo cierto es que la atribución al porteador del derecho a repetir contra el destinatario por la indemnización pagada al cargador en el último inciso de los artículos 21 CMR y 42.3 LCTTM no debería plantear excesivos problemas. No obstante, la actuación del porteador contra el destinatario parece estar condicionada a que se haya emitido una carta de porte en la que se haya hecho constar todos los conceptos que se reclaman en concepto de reembolso, para que éste sepa cuáles son las eventuales consecuencias de aceptar la carga sin satisfacer el reembolso. Es más, la acción que reconocen los preceptos citados al porteador para reclamar frente al destinatario lo que ha pagado al cargador es una acción especial y diferente de la que resulta de la mera facultad del porteador

775 J. PUTZEYs, Le contrat..., cit., p. 240; A. COOLEN, «La livraison...», cit., p. 242.

776 A. COOLEn, «La livraison..., cit., p. 242; F.J. SÁNCHEZ-GAMBorino, El contrato..., cit., p. 204.

777 F.J. SÁNCHEZ-GAMBORINO, El contrato..., cit., p. 204. 
para negar la entrega si no se satisface el importe del reembolso. Por ello, en el ámbito del CMR se ha defendido con acierto que el artículo 21 viene a colmar una laguna muy importante al regular este tipo de acción, cuyo fundamento legal con arreglo al Derecho interno habría de buscarse, con anterioridad a la entrada en vigor de la Ley 15/2009 (que, como se vio, reconoce idéntica acción al porteador), en la figura del enriquecimiento sin causa, debido al incremento que experimenta el destinatario en su patrimonio al recibir la mercancía sin pagar su precio al porteador. Y dicho incremento patrimonial viene acompañado de un correlativo empobrecimiento del porteador, cuyo patrimonio disminuye como consecuencia de haber satisfecho una indemnización al cargador, lo cual proporciona una causa justa que lo legitima para reclamar contra el destinatario778.

\section{Otras obligaciones del destinatario}

\subsection{Expedición de un justificante que documente la entrega}

Como correlato lógico a la solicitud del destinatario para que le sea entregada la mercancía acompañada del segundo ejemplar de la carta de porte, el porteador tendrá derecho a exigir al destinatario que le extienda un documento justificativo o un recibo firmado por él que pruebe que las mercancías han sido entregadas (art. 12 LCTTM). Este documento tiene como objeto probar el cumplimiento de la obligación del porteador frente al cargador y al destinatario. Como quiera que la prueba de la entrega de las mercancías corresponde suministrarla al porteador779, hará bien en exigir un justificante que lleve la firma y el nombre del destinatario o el sello de su empresa, sin perjuicio de que, en ausencia de este documento o recibo, el porteador conserva su derecho a probar el acto de la recepción por cualquier otro medio de prueba ${ }^{780}$.

${ }^{778}$ A. RECALDE CASTELLS, «La entrega...», cit., p. 787.

779 De estimarse lo contrario, habría de exigirse al destinatario la prueba de que no le ha sido entregada la carga, lo cual, tratándose de un hecho negativo, no resulta en absoluto sencillo (diabolica probatio).

${ }^{780}$ B. MERCADAL, Droit..., cit., p. 112. 


\subsection{El pago del precio y de los gastos del transporte}

No está de más recordar que, entre las notas características que integran la naturaleza y el concepto del contrato de transporte, figura su carácter bilateral. En efecto, el porteador se compromete a trasladar la mercancía de su punto de partida a su punto de llegada, a cambio de recibir, del cargador o del destinatario, el pago del precio establecido en el contrato de transporte ${ }^{781}$. Ciertamente, nada obsta para que se concierte un contrato gratuito, pero en este caso no resultará sujeto a lo dispuesto en la Ley 15/2009 (cfr. arts. 2.1 y 39.4 LCTTM), ni tampoco al CMR, cuyo ámbito de aplicación se extiende únicamente al transporte «a título oneroso» de mercancías por carretera (art. 1.1 CMR).

El precio del transporte es uno de los elementos fundamentales del contrato de transporte, ya que representa la contraprestación del cargador o, en su caso, del destinatario, que tiene derecho a recibir el porteador o la empresa porteadora por las obligaciones y el riesgo que asume ${ }^{782}$. El precio del transporte puede ser abonado de distintas formas, dependiendo de cómo se efectúa el transporte: a «portes pagados», en cuyo caso el importe del transporte será satisfecho por el cargador ${ }^{783}$, o a «portes debidos», donde la obligación de pago se impone al destinatario.

A la vista del carácter dispositivo de la LCTTM y la ausencia de tarifas obligatorias en el transporte de mercancías, no hay inconveniente alguno en que el precio del transporte y los demás gastos sean libremente fijados por las partes contratantes, pues éstas pueden pactar el precio que quieran784. Tampoco nada

${ }^{781}$ E. MAPELLI, Régimen..., cit., p. 243.

782 R. URÍA, A. MENÉndez y R. AlONSO SOTO, «El contrato de transporte», en R. Uría y A. Menéndez (dirs.), Curso de Derecho Mercantil, T. II, $2^{\mathrm{a}}$ ed., Thomson-Civitas, Cizur Menor, 2006, p. 334.

783 Ciertamente, la expresión «a portes pagados» puede llevar a confución, pues parece indicar que el precio del transporte ha sido satisfecho antes de iniciarse el desplazamiento. Que ello no es así queda patente si se tiene en cuenta lo dispuesto en el art. 39.1 LCTTM, a cuyo tenor, "[c]uando otra cosa no se haya pactado, el precio del transporte y los gastos exigibles en virtud de una operación de transporte deberán ser abonados una vez cumplida la obligación de transportar y puestas las mercancías a disposición del destinatario».

784 Así lo pone de manifiesto el art. 18 LOTT, estableciendo que «El precio de los transportes discrecionales de [...] mercancías [...] será libremente fijado por las partes contratantes». 
obsta para que las partes estipulen incluso una modalidad mixta de pago, en la que éste se reparte, por partes iguales o no, entre el cargador y el destinatario 785 . Sin embargo, el marco legal cambia cuando el transporte es gratuito, o sea, cuando no existe contraprestación a cargo del remitente o destinatario. Como se vio, a este transporte gratuito no se aplica la Ley del contrato de transporte terrestre de mercancías, ni tampoco el CMR, pues queda excluido de su ámbito de aplicación por no cumplir el requisito de onerosidad del contrato. En efecto, la relación jurídica obligacional que une a las partes en el transporte mercantil se halla sujeto al principio de que el transporte por parte del porteador se realiza a cambio de un precio, que será pagado por el cargador o por el destinatario en función de la modalidad de pago ${ }^{786}$, tal y como lo pone de relieve hoy el artículo 2.1 LCTTM. En este sentido, el transporte efectuado por el porteador será remunerado a través del pago del precio establecido, cuestión que queda aún más clara en el artículo 39.4 LCTTM, que establece que el transporte es un servicio remunerado y «en ningún caso se presumirá que el transporte es gratuito», confirmando con ello la onerosidad del contrato de transporte sujeto a la Ley787.

En relación con las obligaciones que asume el destinatario frente al porteador, aquél deberá satisfacer el precio del transporte sólo cuando se concierta su prestación a portes debidos (art. 37.2 LCTTM). Es decir, el porteador tendrá el derecho de exigir el pago del precio de la prestación que realizó en el momento de hacer la entrega de las mercancías al destinatario (cfr. art. 39.1 LCTTM). La atribución de la obligación de pago al destinatario tendrá que estar pactada de forma expresa en el contrato concertado entre el cargador y el porteador, aunque no necesariamente debe también figurar en la carta de porte. Además, y como no puede ser de otra forma, dicha forma de satisfacer los portes ha de ser acordada previamente entre el cargador y el destinatario (p.ej., en el correspondiente contrato de compraventa), pues de lo contrario no tendrá ningún efecto frente a éste que, como es sabido, es una parte ajena al contrato de transporte y

785 F. JuAn y Mateu, Los impedimentos..., cit., p. 40.

${ }^{786}$ Así ya, para el régimen anterior, E. MAPELLI, Régimen..., cit., pp. 243 y ss.

${ }^{787}$ A. EMPARANZA SOBEJANO, «Obligación...», cit., p. 99. 
no intervino en su conclusión, de manera que los pactos en este sentido entre el cargador y el porteador no le son oponibles ${ }^{788}$.

Mas aún en el caso de que el transporte a portes debidos se haya acordado en la relación de valuta (de manera que efectivamente existe una obligación del destinatario - frente al cargador- de hacerse cargo del precio del transporte), la de pagar los portes no es una «obligación» en sentido técnico jurídico derivada del contrato de transporte, pues no puede válidamente obligarse a una persona - el destinatario- en un contrato - el de transporte- que no ha consentido. Es en el momento en que el destinatario preste su aceptación a recibir la mercancía y reclamar sus derechos frente al porteador, cuando se incorpora al contrato de transporte y resulta obligado (ahora sí, en sentido técnico-jurídico) «a hacer efectivo el precio del transporte y los gastos causados» (art. 35.2 LCTTM). Si se trata de encuadrar esta situación en la teoría general de los contratos a favor de tercero, resulta que el destinatario, siendo un tercerobeneficiario, se adhiere voluntariamente a la relación negocial una vez que acepte la estipulación hecha a su favor. En este sentido, la atribución al destinatario de la obligación de pagar el precio del transporte no es sino una consecuencia de la aceptación de la prestación por parte del destinatario y presupuesto o carga para poder ejercer su derecho a la entrega, en las condiciones, precisamente, de la estipulación acordada inicialmente por el promitente y el estipulante ${ }^{789}$.

La adhesión del destinatario a la relación contractual se produce en el momento de aceptar la entrega de las mercancías y asumir el compromiso de pagar el porte que le debe al porteador, ya que la entrega y el pago son dos operaciones que deben realizarse simultáneamente (do ut des). De esta manera, tratándose de obligaciones recíprocas, si el destinatario se niega a pagar el porte al porteador, éste podrá negarse a cumplir su obligación de entregarle la mer-

788 A. Emparanza Sobejano, «Pago del precio del transporte», en J. F. Duque Domínguez y F. Martínez Sanz (dirs.), A. Emparanza Sobejano y $\mathrm{M}^{\mathrm{a}}$.V. Petit Lavall (coords.), Comentarios a la Ley de Transporte Terrestre, cit., p. 470.

${ }^{789} \mathrm{Al}$ respecto puede verse, con detalle, A. RECALDE CASTELLS, «Otras obligaciones derivadas del contrato de transporte: pago del precio y de otros gastos; embalaje; carga y descarga; formalidades administrativas», en A. Emparanza Sobejano y A. Recalde Castells (dirs.), El contrato de transporte internacional..., cit., pp. 87 y ss. 
cancía hasta que se le pague el precio79o, sin perjuicio de que el destinatario tendrá el derecho de dirigirse al cargador para reclamar la devolución del porte abonado si no le correspondía pagarlo791.

Sin embargo, al menos a nivel nacional, el precio del transporte no tiene por qué aparecer, necesariamente, en la carta de porte (no lo exige el art. 35 LCTTM)792. Así, el destinatario soportará la carga de pagar el precio aun cuando éste no se haya fijado en la carta de porte o cuando ésta no se haya emitido. Con ello, trata de evitarse al transportista los problemas que pueda significar para él tal omisión, sin perjuicio de las dificultades en materia probatoria. Cabe añadir que en aquellos casos en que el transportista y el destinatario no lleguen a un acuerdo sobre la cuantía de los portes o sobre la obligación del destinatario de realizar el pago, el destinatario podrá prestar caución suficiente para garantizar que le sea entregada cuanto antes la mercancía, con independencia de cuál sea el resultado del posterior conflicto sobre el pago ${ }^{793}$.

Por último, cabe recordar que la posición jurídica del porteador como parte contratante no le faculta para obligar al destinatario a satisfacer el precio del transporte, cuando éste no ha prestado su consentimiento a la aceptación de las mercancías. De conformidad con el régimen jurídico aplicable a los contratos a favor de tercero, el destinatario no es sino un tercero-beneficiario que goza del derecho de aceptar o de rehusar la prestación hecha en su favor. En este sentido, su rechazo a recibir el envío impide que llegue a adherirse al contrato, por lo que tampoco habrá de pagar el precio ni puede obligársele a abonarlo. La situación

\footnotetext{
${ }^{790}$ La exceptio non adimpleti contractus no se halla reconocida de manera expresa en nuestro Código civil. No obstante, es generalmente admitida la opinión según la cual, en las obligaciones recíprocas, cada parte puede rehusar el cumplimiento de la obligación a su cargo mientras la otra no cumpla la suya, con fundamento, bien en el art. $1.466 \mathrm{Cc}$ (que prevé tal excepción en sede de compraventa), bien en el art. 1.100 Cc («[e]n las obligaciones recíprocas ninguno de los obligados incurre en mora si el otro no cumple o no se allana a cumplir debidamente lo que le incumbe»). Al respecto véase L. DíEz-PICAZO, Fundamentos..., T. II, pp. 803 y ss.

${ }^{791}$ A. EMPARANZA SobEJANO, «Pago...», cit., pp. 470-471.

${ }^{792} \mathrm{Al}$ contrario de lo que dispone el art. 13.2 CMR, por virtud del cual el destinatario «está obligado a hacer efectivo los créditos que resulten de la carta de porte». De ello se infiere que el destinatario tiene que pagar el precio del transporte, pero sólo si está determinado en la carta de porte, para poder recibir las mercancías y ejercer los derechos que le correspondan.
}

793 A. PUETZ, «Derechos...», cit., p. 446. 
cambia si acepta el recibo del envío, pidiendo la entrega de las mercancías, en cuyo caso se adhiere al contrato y, en base a ello, asumirá todas las obligaciones correspondientes si así se ha acordado, y así se establece claramente en el artículo 37.2 LCTTM.

Cuestión distinta son las consecuencias en aquellos casos en que el destinatario solicita la entrega de las mercancías, pero no abona el porte o los gastos adicionales al porteador. En tales supuestos, y después de agotar todas las posibilidades de pedir el pago y confirmando así la imposibilidad de realizar la entrega (esto es, cuando el destinatario se niegue a pagar y tampoco puede o quiere ofrecer caución suficiente al porteador para hacerle entregar las mercancías), al porteador no le quedará otro remedio que reclamar su derecho al cobro de los portes y otros gastos frente al cargador que, según lo dispuesto en el artículo 37.2 LCTTM, «responderá subsidiariamente en caso de que el destinatario no pague». Y es que el mero hecho de que se haya atribuido el pago al destinatario no debe exonerar totalmente al cargador de la obligación de pagar el porte y los gastos al porteador, protegiéndosele a éste frente a un eventual incumplimiento del pago correspondiente.

\section{a) Las condiciones para la reclamación de portes y gastos}

Como se ha tenido ocasión de señalar, la reciprocidad es un carácter esencial de los contratos mercantiles de transporte, pues generan obligaciones para ambas partes. De ahí deriva el derecho del porteador de reclamar al destinatario el pago de los portes y de otros gastos ocasionados por la realización del transporte. Sin embargo, la reclamación del transportista se condiciona al cumplimiento de su obligación de entregar las mercancías y ponerlas a disposición del destinatario: una vez cumplida la obligación de desplazamiento y ofrecida la entrega al destinatario, nace el derecho a percibir la retribución (ex art. 1157 Cc)794. Por esta razón, sólo procede reclamar el porte en su totalidad si se ha logrado íntegramente el resultado prometido (la ejecución del transporte) y, en caso contrario - esto es, en los supuestos de ejecución parcial-, el transportista no tendrá

794 A. EMPARANZA SOBEJANO, «Obligación de pago del precio y los gastos del transporte», en J. F. Duque Domínguez y F. Martínez Sanz (dirs.), A. Emparanza Sobejano y Ma .V. Petit Lavall (coords.), Comentarios a la Ley de Transporte Terrestre, cit., p. 486. 
derecho a exigir todo el precio y los gastos del transporte, sino sólo los que correspondan a la parte ejecutada, siempre que ésta reporte algún provecho para el destinatario (art. 39.2 LCTTM).

De ello puede inferirse que, en caso de pérdida total o extravío de la mercancía, el transportista perderá el derecho a reclamar el porte y los gastos debido a la desaparición del objeto del contrato y, con ello, la imposibilidad sobrevenida de alcanzar el resultado prometido. Y así parece reconocerlo también la Ley, cuando establece que el precio del transporte y los gastos deberán ser pagados una vez cumplida la obligación de transportar y puestas las mercancías a disposición del destinatario (39.1 LCTTM)795. Es más, en caso de que el extravío o la pérdida total le sean imputables, el porteador responderá por el incumplimiento de la obligación de resultado que había asumido (la entrega de los efectos transportados al derechohabiente) ${ }^{796}$.

\section{b) El contenido de la obligación de pagar los portes y gastos}

El contenido de la reclamación del transportista se extiende, desde luego, al precio del transporte (o, en su caso, una indemnización a cargo del cargador en una cantidad equivalente al precio del transporte si éste no entrega las mercancías al transportista en el lugar y en el tiempo pactados en el contrato: art. 19.2 LCTTM). Pero también comprende aquellos gastos que se puedan originar entre la fase inicial de contratación y la finalización de la fase ejecutiva del transporte, como, por ejemplo, gastos de aduana, depósitos, impuestos, etc. Asimismo, el concepto incluye otros gastos suplementarios que resultan de la ejecución de las órdenes e instrucciones dadas al transportista en ejercicio del derecho de disposición, sea por el cargador o en su caso el destinatario [art. 30.1.a) LCTTM]797.

795 A. ReCAlde CASTELlS, «La posición...», cit., p. 211. En la medida en que el contrato de transporte constituye un subtipo del contrato de arrendamiento de obra, resulta también pertinente la cita de los arts. 1.589 y 1.590 Cc. Así, A. DíAz MORENO, «El contrato...», cit., p. 608; A. Puetz, Derecho de vagones, Marcial Pons, Madrid, 2012, p. 224.

796 Para tales casos, la Ley dispone - ahora expresamente- que, «además de la indemnización a que haya lugar, serán reintegrados en su totalidad el precio del transporte y demás gastos devengados con ocasión del mismo» (art. 58.1 LCTTM).

797 A. RECALDE CASTELLS, «La posición...», cit., p. 212. 
Los gastos referidos en el artículo 35.2 LCTTM deben estar inscritos junto al precio del transporte en la carta de porte (art. 10.1. lit. k)798. No obstante, como así lo pone de relieve el propio artículo 35.2 LCTTM, el derecho de reclamar las cantidades desembolsadas por el porteador con ocasión de la realización del transporte no proviene dde el hecho que estén inscritas en la carta de porte, sino la obligación de abonarlas por el destinatario surte como consecuencia de que éste se prevalga de los derechos que derivan del contrato de transporte (art. 35.2 LCTTM y art. 13.2CMR)799.

Las partes del contrato de transporte pueden estipular libremente la forma del pago del precio de transporte, incluidos los gastos generados, y también quién será el obligado a satisfacerlos al transportista. Ello significa que no se puede reclamar del destinatario el pago del precio o los gastos, ni siquiera por vía de excepción, cuando la carta de porte incluye una cláusula del tipo «portes prepagados» o «portes pagados», pues en tales casos asume la obligación del pago el cargador ${ }^{80 o}$. En este supuesto, la entrega de las mercancías debe efectuarse sin que el transportista pueda reclamar el pago del destinatario en el lugar de destino.

No obstante, del tenor del artículo 35.2 LCTTM deriva que la facultad del transportista para pedir del destinatario que cumpla con su obligación de pago no queda condicionada a que se trate de conceptos incluidos en la carta de porte (como sí sucede en el art. 13.2 CMR). De ello podría inferirse que la inserción de las cláusulas mencionadas (señaladamente, la de «portes pagados») no impide que el destinatario resulte obligado desde el momento en que ejerza sus derechos derivados del contrato, siempre que el transportista demuestre que el precio y los gastos del transporte no le fueron abonados. Esta conclusión resulta discutible por razón de la confianza puesta por el destinatario en el contenido de la carta de porte (en este caso, los conceptos debidos), que puede verse defraudada por el transportista cuando éste reclama la percepción de conceptos imprevisibles. A la vista de cuanto antecede, resulta más razonable entender que no debe permitirse al transportista accionar contra el destinatario para obligarle

798 A. PUETZ, «Derechos...», cit., p. 447.

799 A. RECALDE CASTELLS, «La posición...», cit., p. 212.

800 F. J. SÁNCHEZ-GAMBORINO y J. GAITÁN REBOLLO, Factbook..., cit., p. 115 y ss. 
al pago de portes y gastos que ya se expresaron en el contrato como pagados o asumidos personalmente por el cargador, sobre todo cuando el porteador es consciente y ha aceptado ese hecho mediante su inserción en la carta de porte (art. 37.2 LCTTM) ${ }^{801}$.

Por el contrario, el derecho del transportista a retener las mercancías parece proceder incluso si el pago del precio se atribuye al cargador y no al destinatario, de manera que, si el destinatario no satisface los portes y los gastos al transportista, éste puede rehusar la entrega de las mercancías al destinatario. Si ello es así, el incumplimiento del pago del precio y los gastos del transporte podría oponerse como excepción, aplicando lo dispuesto en el artículo 35.2 LCCTM (a cuyo tenor el destinatario tiene la carga de satisfacer el precio del transporte y los gastos para hacer valer sus derechos derivados del contrato). En tales casos, si el destinatario satisface los portes y gastos al objeto de obtener la entrega de las mercancías, gozará de un derecho a repetir del cargador lo que hubiese satisfecho, reclamando el pago del importe del que el cargador debía responder frente al transportista (art. $1.158 \mathrm{Cc}$, que se ocupa del pago hecho por quien cumpla por cuenta del obligado) ${ }^{802}$.

Por otro lado, quedan excluidos de los portes y gastos que resultan de la ejecución del contrato, los importes de cualquier indemnización por daños imputables al cargador, o sea, cuando se trata de resarcimientos debidos al incumplimiento de obligaciones que incumben al cargador. Señaladamente, éste es el responsable de embalar adecuadamente las mercancías, ya que en el caso de un embalaje defectuoso responderá frente al transportista de los daños causados a él y al material de transporte (su vehículo), con lo que deberá indemnizarle los gastos que hubiera incurrido por tal circunstancia803. Por último, en caso de desacuerdo sobre los conceptos debidos, el transportista puede exigir que se preste caución suficiente (art. 35.2 LCTTM).

${ }^{801}$ A. RECALDE CASTELLS, «La posición...», cit., p. 212.

802 Así, A. RECALDE CASTElls, «La posición...», cit., p. 213.

803 A. DÍAz MORENO, «El contrato...», cit., p. 276; A. RECALDE CASTELls, «La posición...», cit., p. 213. 


\section{c) La prestación de caución suficiente}

La prestación de caución suficiente, prevista en los artículos 13.2 CMR y 35.2 LCTTM, es un medio para acelerar y asegurar la entrega de las mercancías que ha sido denegada por el porteador. Según los preceptos citados, se puede recurrir a este mecanismo cuando existe un desacuerdo sobre el precio del transporte o sobre el sujeto obligado a su pago. En su virtud, el destinatario que garantice el pago de forma suficiente al porteador, podrá solicitarle la entrega de las mercancías ${ }^{804}$.

Se trata, pues, de una garantía de pago que presta el destinatario ofreciendo caución suficiente. Este aspecto viene recogido también en el artículo 40.1 LCTTM, que regula la enajenación de las mercancías por impago del precio, estableciendo que el porteador podrá negarse a entregar las mercancías cuando el obligado no satisface el precio u otros gastos causados por la ejecución de transporte, salvo que se le presente una garantía para afianzar el referido pago a través de una caución suficiente. El segundo apartado del artículo 40 LCTTM está basado en el primero, en el sentido de que, cuando el porteador retenga las mercancías, deberá pedir al órgano judicial o a la Junta Arbitral del Transporte competente el depósito de las mismas y la enajenación de las necesarias para cubrir el precio del transporte y los gastos ocasionados, un procedimiento que se somete a un plazo máximo de diez días desde el día en el que se produjo el impago ${ }^{805}$.

Este tipo de garantía resulta novedosa en el ámbito del transporte, cuya importancia radica en que anteriormente se procedía previamente a la entrega de las mercancías y posteriormente se reclamaba el pago correspondiente. Sin

\footnotetext{
804 A. CABRERA CÁNOVAS, El contrato..., cit., p. 73.

805 Con anterioridad a su sustitución por las Condiciones generales de 2012, las de 1997 establecían, en este mismo sentido, en la condición 2.3 del Anexo A), que cuando se trataba de un transporte a portes debidos, el transportista tenía el derecho a exigir su pago en el momento de entregar las mercancías al destinatario; por su parte, en caso de impago del precio del transporte por el destinatario, la misma norma, junto a la condición 2.4 del Anexo B), facultaba al transportista para exigir la venta por la Junta Arbitral del Transporte que corresponda, o autoridad judicial competente, de aquella parte de las mercancías que integran el envío que fuera suficiente para cubrir el precio del transporte y los gastos que hubiera causado, después de transcurrir el plazo de veinticuatro horas desde que hizo entrega de las mercancías al destinatario. Vid. P. MARTínEZ GONZÁLEZ, El transporte terrestre..., cit., p. 128-129.
} 
embargo, la enajenación forzosa de las mercancías no se puede instar, en la Ley 15/2009, cuando el transportista ya no las tiene en su poder, puesto que una vez entregadas ya no puede exigir su restitución, al contrario de lo que ocurría en el marco del artículo 375 Ccom (hoy derogado). A su tenor, la reclamación del precio del transporte y los gastos causados durante el traslado o hasta el momento de la entrega podía efectuarse hasta ocho días después de haberse hecho la entrega, momento a partir del cual el transportista perdía su derecho especial y pasaba a considerarse un acreedor ordinario para reclamar el pago frente al obligado. De ello se infería que la enajenación forzosa de las mercancías al amparo del precepto citado podía solicitarse aun después de hacer la entrega, pero dentro de un plazo de ocho días desde que tuviera lugar8o6.

En la práctica, el derecho de retención de las mercancías por el transportista asegura que el cobro del precio de transporte quede garantizado. No obstante, este derecho no se extiende a la percepción del precio y gastos derivados de transportes anteriores, aunque se trate de las mismas partes contractuales. Si aun así el transportista retuviese la carga en garantía de créditos nacidos de otros contratos distintos, habría de entenderse que comete un delito de apropiación indebida (arts. 253 y 254 CP) 807.

Por último, conviene mencionar que la caución es una garantía accesoria que procede en caso de incumplimiento del destinatario de la carga de pagar los portes y gastos debidos. Nada se dice en la Ley sobre cuándo tal caución es «suficiente», por lo que puede resultar adecuado cualquier tipo de garantía, sea personal o real 808 .

\subsection{Desestiba, descarga y manipulación de las mercancías}

Las operaciones previas y posteriores a la ejecución del traslado - esto es, las de carga y descarga, y de estiba y desestiba- revisten una importancia singular en

\footnotetext{
${ }^{806}$ E. MAPELLI, El régimen jurídico..., cit., p. 247; M. BADA DE COMINGES, «Enajenación de las mercancías por impago del precio del transporte», en J. F. Duque Domínguez y F. Martínez Sanz (dirs.), A. Emparanza y $\mathrm{M}^{\mathrm{a}} \mathrm{V}$. Petit Lavall (coords.), Comentarios a la Ley de Transporte Terrestre, cit., p. 498.

807 M. BADA DE COMINGES, «Enajenación...», cit., p. 497.

${ }^{808}$ A. PUeTZ, «Derechos...», cit., p. 448; A. RECALDE CASTELlS, «La posición...», cit., p. 213.
} 
el ámbito del transporte, tanto por su coste, como por los efectos negativos de su defectuosa ejecución. Sin perjuicio de lo previsto en relación con las obligaciones del porteador, la Ley 15/2009 establece, en su artículo 20, que, salvo pacto en contrario ${ }^{809}$, la obligación de carga y estiba, así como la de descarga y desestiba, incumbirán respectivamente al cargador y al destinatario. Concretamente, según la fase de la realización del transporte, estas operaciones serán repartidas entre ambos sujetos: la operación previa de carga y estiba corresponderá al cargador, y la operación posterior de desestiba y descarga al destinatario ${ }^{810}$. Cuando tales operaciones corresponde realizarlas, efectivamente, al cargador y al destinatario, cualquier daño ocasionado como consecuencia de alguna deficiencia en dichas operaciones será de cuenta del cargador y del destinatario, respectivamente, salvo que dicho daño sea sufrido por causa de una estiba inadecuada que hubiere ejecutado el cargador siguiendo las instrucciones dadas por el porteador (art. 20.2 LCTTM). En cuanto a la manipulación del vehículo para su carga, las operaciones que se hayan de efectuar en él o sus accesorios para facilitar su adecuada carga o para asegurar la integridad del envío durante su transporte (p.ej., desentoldado y entoldado, desmontaje o montaje de cartolas, etc.), corresponderán al porteador, si bien el cargador, o en su caso el destinatario, deberá suministrarle todos los medios personales o materiales necesarios para hacerle posible la realización de dichas operaciones (cl. 4.15 de las Condiciones generales de 2012).

Siendo esta la regla general en los transportes de carga completa, en lo relativo al transporte de paquetería y similares que impliquen la recogida o reparto de envíos, la Ley establece que las operaciones de carga y descarga correrán, salvo pacto en contrario, por cuenta del porteador (art. 20.3 LCTTM), y so-

${ }^{809} \mathrm{Al}$ objeto de prevenir ciertos abusos cometidos por la industria cargadora en el pasado, la Ley especifica ahora expresamente que el pacto por el que el porteador asume la realización de las operaciones descritas debe producirse necesariamente «antes de la efectiva presentación del vehículo para su carga o descarga» para que pueda serle válidamente opuesto.

810 Las operaciones de carga y descarga, estiba y desestiba han encontrado su regulación, sucesivamente, en el art. 22 LOTT (al que hoy se ha dotado de otro contenido distinto), el art. 4 ROTT, las Condiciones generales de 1997 (condición 2.33 del Anexo A), así como, por último, la LCTTM (art. 20) y a su remolque las Condiciones generales de 2012, en igual sentido, pero con distinto grado de detalle. Vid. F.J. SÁnChEZ-GAMborino y J. GaITÁn REBOLLO, Factbook..., cit., p. 140. 
bre él recae, en consecuencia, la responsabilidad por los daños que puedan ocasionarse a resultas de las operaciones que le incumbe realizar.

Conforme a la cláusula 6.10 de las Condiciones generales de 2012, el tiempo del que dispone el destinatario para realizar la descarga estará limitado a dos horas, calculadas a partir de la llegada del vehículo al lugar de destino, salvo que las partes hubieran estipulado que la entrega se realizaría en una hora determinada, en cuyo caso se computarán las dos horas a partir de aquélla, aunque el vehículo haya llegado con anterioridad. También se establece que, si el cargador no ha precisado los horarios de descarga en el lugar previsto a tal efecto y el límite temporal de dos horas antes referido no se hubiera superado completamente a las dieciocho horas (o a la hora de cierre del establecimiento si fuera posterior), su cálculo se suspenderá hasta las ocho horas (o el momento de apertura del establecimiento si fuera anterior) del primer día laborable siguiente.

En caso de que se incumplan los plazos señalados, el porteador podrá solicitar del destinatario una indemnización en concepto de paralización del vehículo (art. 22.1 LCTTM). Al contrario de cuanto sucedía bajo la vigencia de las Condiciones generales de 1997, a cuyo tenor el destinatario quedaba exonerado del pago de la indemnización si demostraba que dicho incumplimiento no le fue imputable (por concurrir un supuesto de fuerza mayor, caso fortuito o culpa del porteador) (cl. 2.35 del Anexo A), ni la Ley ni tampoco las Condiciones actuales se refieren a este supuesto. De ello puede inferirse que, al menos, la fuerza mayor y el caso fortuito no proporcionan ya una causa de exoneración al destinatario. Y parece razonable que sea así, pues el porteador no tiene por qué asumir el riesgo de que no pueda procederse a la descarga por causas no imputables a ninguna de las partes, que ahora pesa sobre el destinatario.

En el transporte de paquetería y similares, la legislación previgente (cl. 2.27 de las Condiciones generales de 1997) establecía que, cuando el destinatario no se hallase en el domicilio en el que debía realizarse la entrega, el porteador estaba obligado a dejarle un aviso fechado por escrito, determinando el lugar y el plazo para proceder a la recogida del envío, o señalando una fecha y hora precisas en las que el porteador volverá a pasar por su domicilio para realizar 
la entrega ${ }^{811}$. A pesar de que las actuales Condiciones generales no contienen ninguna indicación en este sentido, parece razonable seguir exigiendo, sobre la base del deber de buena fe contractual (arts. 1.258 Cc y $57 \mathrm{Ccom}$ ), que el porteador avise al destinatario de la llegada del envío, eso sí, empleando cualquier medio de comunicación a su alcance (aviso escrito, correo o mensaje electrónico, etc.). En todo caso, transcurridos tres meses desde que se intentó la primera entrega al destinatario, el porteador podrá considerar abandonado el envío y proceder a la enajenación o destrucción de las mercancías, quedando libre de cualquier reclamación formulada, no sólo por el cargador o el destinatario, sino también por terceros que tengan algún derecho sobre la mercancía, señaladamente, su propietario (art. 44.3 LCTTM).

\section{Incidencia de los impedimentos para el transporte y la entrega}

Sobre todo cuando la operación de transporte reviste carácter internacional, no es infrecuente que surjan problemas durante su ejecución, debidos inter alia a la longitud de los trayectos, que darán lugar a impedimentos u obstáculos de todo orden para la realización del transporte y la puesta de las mercancías a disposición del destinatario ${ }^{812}$. Con todo, tampoco se descartan (y no son mucho menos frecuentes) los impedimentos en el transporte interno. Debido a la estrecha relación que guardan con la posición jurídica del destinatario, serán objeto preferente de atención los impedimentos para la entrega (sub 2.), pero sin desconocer la posible existencia de otros obstáculos, surgidos durante el desplazamiento, es decir, los impedimentos para el transporte (sub 1.).

\section{Los impedimentos para el transporte}

El legislador no se ha preocupado de ofrecer una definición precisa de qué debe entenderse por «impedimentos al transporte» y el artículo 31 LCTTM no formula un concepto jurídico de los mismos. Su noción ha de elaborarse, pues, a partir del contenido de la norma, y puede afirmarse que se trata de obstáculos que

\footnotetext{
${ }^{811} \mathrm{Al}$ respecto véase P. MARTíNEZ GONZÁLEZ, El transporte terrestre..., cit., p. 130.

812 Así, para el art. 14 CMR, F.J. SÁNCHEZ-GAMBORINO, El contrato..., cit., p. 134.
} 
comportan la imposibilidad de llevar a cabo el transporte hasta el punto de destino en las condiciones previstas en el contrato. No obstante, al contrario de lo que sucede en relación a los impedimentos para la entrega, sobre los que enseguida se volverá, el precepto no ofrece ejemplo alguno de impedimento al transporte ${ }^{813}$. En términos generales, se refiere a los motivos que impiden la ejecución del transporte - es decir, hechos y circunstancias sobrevenidos después de la concertación del contrato de transporte y que se producen antes de la arribada de las mercancías al lugar fijado para la entrega-, por virtud de los cuales el traslado de las mercancías por el itinerario previsto, de un modo seguro y dentro la fecha prevista para la entrega se vuelve imposible ${ }^{814}$. En otras palabras, el concepto de «impedimento» se limita a aquellos hechos que imposibilitan al transportista cumplir su obligación bajo las condiciones inscritas en la carta de porte, con exclusión de aquellos casos en los cuales la prestación de transporte únicamente deviene más onerosa, o más complicada ${ }^{815}$.

Los impedimentos al transporte pueden tener su origen en diversas circunstancias producidas en la esfera del transportista (como, p.ej., en el caso de huelga de sus empleados o una avería en el vehículo), o ser extrañas a él, como en el caso de una interrupción o bloqueo de carreteras por catástrofes naturales, o por una orden del gobierno de cierre de fronteras. De ello se infiere que los obstáculos al transporte constituyen un numerus apertus, para comprender distintos supuestos que pueden constituir un impedimento al transporte ${ }^{816}$.

Nada obsta para que sean considerados impedimentos al transporte aquellos obstáculos que ya existían $a b$ initio, esto es, en el momento de contratar. Se trata, en definitiva, de condiciones previstas en el documento de transporte (art. 14.1 CMR) que, al comenzar la ejecución, convierten la prestación bajo dichas condiciones en irrealizable o imposible, debiendo el porteador en-

${ }^{813}$ F. JUAN Y MATEU, «Impedimentos...», cit., p. 384.

814 Obsérvese que la traducción al español del art. 20 RU CIM utiliza la expresión «impedimento para proceder al transporte». Aun así, debe interpretarse que la norma se refiere no sólo a los obstáculos que se produzcan al inicio del transporte, sino a todas aquellas circunstancias que se produzcan durante el desplazamiento, esto es, entre el lugar de origen y el de destino. Así, F. JuAn y MATEU, «Los impedimentos para la ejecución...», cit., p. 162.

815 F.J. SÁNCHEZ-GAMBORINO, El contrato..., cit., p. 135.

816 F. JUAN Y MATEU, «Impedimentos...», cit., p. 384. 
tonces solicitar instrucciones al derechohabiente (cargador o destinatario). Con todo, la imposibilidad de realizar el transporte en los términos acordados en la carta de porte no faculta al transportista para desentenderse de su obligación de custodia y conservar las mercancías con la diligencia de un ordenado transportista, aunque el origen del impedimento sea un fortuito liberatorio que le eximiría de su responsabilidad en caso de siniestro. El transportista en este supuesto estará obligado a pedir instrucciones de quien ostenta el derecho de disposición y seguirlas sin perder el contacto con él, informándole oportunamente sobre los eventuales cambios de las circunstancias, de modo que puedan impartirse nuevas órdenes e instrucciones más adecuadas al respecto ${ }^{817}$.

\section{Los impedimentos para la entrega}

Las incidencias que imposibilitan la entrega vienen reguladas, a nivel interno, en el artículo 36 LCTTM, aunque también están previstas, si bien de forma parcial, en el artículo 15 CMR para el transporte internacional de mercancías por carretera, así como en el artículo 21 RU CIM para el transporte ferroviario transfronterizo.

$\mathrm{Al}$ igual que sucede en relación a los impedimentos para el transporte, no existe definición legal de qué debe entenderse por «impedimentos para la entrega», por lo que debe estarse al contenido de las respectivas normas para deducir su noción. En este sentido, se entiende que son impedimentos para la entrega aquellos hechos o circunstancias que se producen después de la llegada de las mercancías a su destino que impiden que el porteador cumpla con su obligación de entregar las mercancías al destinatario. Estos impedimentos para la entrega se pueden diferenciar de los que se presentan durante la ejecución del transporte en un aspecto fundamental: el momento en que se producen. Al contrario de cuanto sucede con los impedimentos al transporte, que afectan a la obligación de trasladar las mercancías al lugar de destino, los impedimentos para la entrega se refieren a aquellas circunstancias que imposibilitan la entrega del envío al destinatario, es decir, se presentan después de la llegada al lugar determinado en la carta de porte. Ahora bien, también aquí el mero hecho de que se presente

817 F.J. SÁNCHEZ-GAMBORINO, El contrato..., cit., p. 135. 
un impedimento para la entrega no exonera al porteador de su responsabilidad por la custodia de las mercancías ${ }^{818}$.

Está ultima característica proporciona un criterio para diferenciar los impedimentos para la entrega de otros obstáculos que imposibilitan al porteador la entregar de la mercancía, señaladamente, cuando ésta se pierde después de la llegada a destino, por ejemplo, en caso de que se produzca un robo en el mismo lugar de destino. A tales supuestos se aplica, no el régimen jurídico de los impedimentos para la entrega, sino el de responsabilidad del porteador ${ }^{819}$. En base a ello, se entiende que sólo constituye un impedimento para la entrega aquel hecho que impide la entrega al destinatario, pero siendo todavía posible la entrega de las mercancías a una tercera persona que no sea el destinatario o devolverla al cargador ${ }^{820}$. A lo largo de los siguientes epígrafes se abordará algunas de las incidencias que el propio artículo 36.1 LCTTM considera impedimentos para la entrega.

\subsection{El transportista no logra localizar el domicilio del destinatario o éste no se encuentra en él}

La primera circunstancia mencionada en el artículo 36.1 LCTTM se refiere a aquellos supuestos en que la entrega no puede realizarse "por no hallarse el destinatario en el domicilio indicado en la carta de porte». Así, representa un impedimento para la entrega el hecho de que el destinatario no se encuentre en el domicilio previsto para la entrega, pues es una incidencia que imposibilita al

${ }^{818}$ F. JUAN Y MATEU, Los impedimentos..., cit., pp. 11 y ss.

819 Dada su frecuencia, el robo de las mercancías es uno de los supuestos que ha recibido especial atención por parte de la jurisprudencia. De las decisiones recaídas al respecto se infiere que, por regla general, el robo no exonera al porteador de su responsabilidad frente al derechohabiente, salvo si excepcionalmente fue de verdad inevitable, lo cual sucede pocas veces en la práctica, ya que siempre podrá reprocharse al porteador el no haber dejado el vehículo en un lugar más seguro. Cfr., en lugar de otras muchas, la SsAP Barcelona (Sección $15^{\mathrm{a}}$ ) de 13 de febrero de 2003 (JUR 2004, 14188), en un caso de robo tras dejar el vehículo aparcado durante dos días en la calle; y Alicante (Sección $6^{\mathrm{a}}$ ) núm. 332/2004, de 4 de junio (AC 2004, 1935); así como la STS núm. 918/2003, de 8 de octubre (RJ 2003, 7383), a cuyo tenor la simple denuncia no exonera al porteador cuando de ella no se puede probar que el porteador ha tomado todas las medidas de seguridad exigibles para evitar el robo. Vid. F. MARTÍNEZ SANZ, «Transporte de mercancías por carretera (II)...», cit., pp. 198 y ss.

${ }^{820}$ F. JUAn y Mateu, «Impedimentos a la entrega», en J. F. Duque Domínguez y F. Martínez Sanz (dirs.), A. Emparanza Sobejano y Ma .V. Petit Lavall (coords.), Comentarios a la Ley de Transporte Terrestre, cit., p. 455. 
porteador cumplir con su obligación. Pero también lo es, aunque la Ley no lo mencione, la imposibilidad de localizar dicho domicilio. En efecto, la imposibilidad de localizar el domicilio del destinatario no figura de modo expreso en ningún texto legal entre los impedimentos para la entrega, pero ello no obsta para que este supuesto pueda subsumirse bajo la circunstancia antes enunciada pues, efectivamente, imposibilita al transportista la entrega de las mercancías $^{821}$.

Entre los datos obligatorios que han de mencionarse en la carta de porte se encuentran los datos identificativos del destinatario de la mercancía y su dirección [arts. 10.1.f) LCTTM y 6.1.e) CMR]. Tales indicaciones debe incluirlas el cargador, pudiendo hacer constar, asimismo, un domicilio o, por lo menos, un medio de contacto para recibir notificaciones (notify address) que permita al transportista informar sobre el lugar y el momento de la entrega ${ }^{822}$.

La imposibilidad de localizar el domicilio del destinatario puede surgir por varias razones, por ejemplo, por un error a la hora de facilitar la dirección del destinatario, porque la información es incompleta, o porque el destinatario ha modificado su domicilio sin avisar de ese cambio al cargador. También es posible que la imposibilidad de localizar el domicilio del destinatario sea imputable a mala fe de éste, por ejemplo, cuando no tiene ningún interés en recibir las mercancías, facilitando al transportista una dirección falsa o inexistente en aras de diferir la entrega o, incluso, desembarazarse de las mercancías.

Lo cierto es que la identificación del domicilio del destinatario tiene que figurar precisamente con el nombre completo del destinatario [ex arts. 10.1 f) LCTTM y 6.1 e) CMR], con el fin de evitar cualquier confusión en el caso de que el transportista se encuentre con distintas personas que tienen el mismo domicilio. En caso contrario, puede afirmarse que se está ante un impedimento para la entrega, debido a que la identificación a partir de los datos facilitados ha sido imposible. Y es que el transportista no tiene por qué arriesgarse a entregar las

${ }^{821}$ Así, con base en el -hoy derogado- art. 369 Ccom, F. JUAN y MATEU, Los impedimentos..., cit., p. 27. Véase también F.J. SÁNCHEZ-GAMBORINO, El contrato..., cit., p. 139; y J. GÓMEZ CALERO, El transporte..., cit., p. 513.

${ }^{822}$ Esta última posibilidad viene recogida expresamente sólo en el art. 10.1.f), pero ello no significa que no pueda indicarse una notify address también en un transporte sujeto al CMR. 
mercancías si no está seguro de su destinatario legítimo, pues de equivocarse puede declararse su responsabilidad frente al cargador ${ }^{823}$.

Ciertamente, la imposibilidad referida no se entiende como un impedimento para la entrega hasta que el transportista no haya agotado todos los medios razonables para localizar el domicilio del destinatario, ya que el primer intento fracasado no le exime de que se siga informando y trate de averiguar cuál es el domicilio donde debe efectuarse la entrega de las mercancías ${ }^{824}$. Pero tampoco es lógico, por otra parte, que el transportista se encuentre sometido a un deber absoluto de localizar el domicilio del destinatario. Quiere decirse con ello que los esfuerzos del transportista en este caso se limitan a lo que puede considerarse razonable atendidas las circunstancias del caso concreto, así que no está obligado a hacer lo imposible. Este supuesto se produce con mayor frecuencia en el transporte internacional, donde el deber de localizar el destinatario se puede atenuar en atención a los obstáculos que suscita la ignorancia del idioma del país extranjero.

La consecuencia de que el cargador incluya una indicación errónea o falsa de los datos del destinatario y su dirección en la carta de porte da lugar a la responsabilidad de éste frente al porteador por todos los perjuicios y daños que dicha indicación le hubiera ocasionado. Dicha responsabilidad queda establecida en los artículos 10.7 LCTTM y 7.1.a) CMR, a cuyo tenor el cargador o remitente, por motivo de la inexactitud o insuficiencia de la indicación del nombre y el domicilio del destinatario en la carta, responderá de todos los gastos y perjuicios que padece el transportista. A título de ejemplo, el cargador se ve obligado a indemnizar al transportista en concepto de paralización, al perder tiempo para averiguar la dirección correcta del destinatario ${ }^{825}$. En efecto, según lo previsto en el artículo 22.1 LCTTM, el transportista podrá exigir una indemnización cuando el cargador o destinatario se demora en la ejecución de las operaciones de carga, estiba, desestiba o descarga ${ }^{826}$. E igual razonamiento habría de apli-

\footnotetext{
823 F. JUAN y MateU, Los impedimentos..., cit., pp. 27 y ss.

824 M.A. ClARKe, International Carriage..., cit., p. 101.

825 F. JUAN Y Mateu, Los impedimentos..., cit., p. 30.

${ }^{826}$ Concretamente, el art. 22 LCTTM establece que «1. Cuando el vehículo haya de esperar un plazo superior a dos horas hasta que se concluya su carga y estiba o desestiba y
} 
carse al tiempo invertido por el transportista para conseguir la localización del destinatario. Es más, el transportista se libera de cualquier responsabilidad por el retraso en el cumplimiento de su obligación de entrega, simplemente porque este retraso es imputable al cargador, debido a la inclusión de datos inexactos o insuficientes en la carta de porte (arts. 48.1 LCTTM y 17.2 CMR).

\subsection{El destinatario no se hace cargo de la mercancía en las condiciones establecidas en el contrato}

El artículo 36.1 LCTTM se limita a señalar que el hecho de «no hacerse cargo de la mercancía en las condiciones establecidas en el contrato» constituye un impedimento para la entrega. Sin embargo, son muchos los supuestos específicos que pueden subsumirse bajo esta regla; supuestos a los que nos referiremos a continuación.

\section{a) El destinatario se retrasa en la aceptación de la entrega}

Como ya se ha visto, el destinatario está facultado para aceptar o rechazar unilateralmente la recepción de las mercancías llagadas a destino, es decir, para manifestar al porteador su voluntad de querer aprovechar la prestación hecha en su favor o no. Sin embargo, dicha manifestación está condicionada a que se realice en un tiempo adecuado, o sea, con prontitud ${ }^{827}$. Y es que no es exigible al transportista que esté pendiente indefinidamente de que el destinatario decida sobre si acepta o no la entrega. Por ello, si se produce un abuso en el tiempo para declarar la aceptación o el rechazo del envío - esto es, cuando se haya superado el

descarga, el porteador podrá exigir al cargador una indemnización en concepto de paralización. 2. Dicho plazo se contará desde la puesta a disposición del vehículo para su carga o descarga en los términos requeridos por el contrato. 3. Salvo que se haya pactado expresamente una indemnización superior para este supuesto, la paralización del vehículo por causas no imputables al porteador, incluidas las operaciones de carga y descarga, dará lugar a una indemnización en cuantía equivalente al Indicador Público de Renta de Efectos Múltiples/día multiplicado por 2 por cada hora o fracción de paralización, sin que se tengan en cuenta las dos primeras horas ni se computen más de diez horas diarias por este concepto. Cuando la paralización del vehículo fuese superior a un día el segundo día será indemnizado en cuantía equivalente a la señalada para el primer día incrementada en un 25 por ciento. Cuando la paralización del vehículo fuese superior a dos días, el tercer día y siguientes serán indemnizados en cuantía equivalente a la señalada para el primer día incrementada en un 50 por ciento».

827 M. ClARKE, International carriage..., cit., p. 101. 
plazo de tiempo que se considere razonable para ello- parece que se está ante un impedimento para la entrega.

No obstante, hay que tener en cuenta que el cálculo del plazo para que se pronuncie el destinatario, es decir, la determinación del momento a partir del cual el silencio de éste califica como impedimento para la entrega, dependerá de las circunstancias del caso concreto. Ese cálculo deberá tener en cuenta, por ejemplo, el tiempo que necesita el destinatario para verificar las mercancías y asegurar que su estado se corresponde con el indicado en la carta de porte. También influye el lugar previsto para la entrega, en el sentido de que el cómputo difiere cuando la entrega se hace en el propio domicilio del destinatario o cuando la misma está prevista en otro lugar. En el primer caso, el tiempo se calcula a partir del momento de la puesta a disposición de las mercancías al destinatario, mientras que, en el segundo, el cómputo del plazo empezará desde el momento en que se avise al destinatario de la llegada de las mercancías al lugar de destino ${ }^{828}$.

\section{b) El destinatario rechaza la entrega de las mercancías}

El rehúse de la recepción de las mercancías puede entenderse como el supuesto más relevante de impedimento para la entrega que se produce en la esfera del destinatario. De hecho, es el único supuesto al que se refiere expresamente el artículo 15.1 del CMR (mientras que, en el art. 36.1 LCTTM, habría de subsumirse bajo la negativa a «hacerse cargo de la mercancía en las condiciones establecidas en el contrato»). Ese tipo de impedimento se produce cuando el destinatario ejercita su derecho de rechazar el envío, que es una facultad intrínseca a todo transporte en el que el destinatario sea un tercero ajeno al contrato. No siendo éste sino el beneficiario de una estipulación concertada en su favor, puede aceptarla o no con libertad, sin estar obligado a hacerlo y sin necesidad de ofrecer justificación alguna al respecto.

La opción de repudiar el envío no acarrea para el destinatario ninguna responsabilidad derivada del contrato de transporte, pero si existe, como suele ser el caso, alguna vinculación jurídica entre él y el cargador sobre la base de

${ }^{828}$ F. JUAN Y MATEU, Los impedimentos..., cit., p. 32. 
otro contrato distinto al contrato de transporte (generalmente, un contrato de compraventa a distancia), puede llegar a responder sobre la base de la relación de valuta. Como se ha tenido ocasión de señalar al analizar la posición jurídica del destinatario en el contrato de transporte, el fundamento en que se basa la libertad del destinatario para aceptar o rechazar la recepción de las mercancías es la posición que ocupa en relación al contrato, que se califica por la mayoría en la doctrina como un contrato a favor de tercero ${ }^{829}$. Salvo cuando ocupe al propio tiempo la posición de cargador, el destinatario es un tercero extraño al contrato de transporte que en modo alguno ha intervenido en su celebración, por lo tanto, no se considera una parte del mismo sino un beneficiario favorecido contractualmente por las partes originales del contrato. Y la configuración del beneficiario en el contrato a favor de tercero le faculta para libremente aceptar la estipulación hecha en su favor o para renunciar a ella (art. 1.257 $2^{\mathrm{a}} \mathrm{Cc}$ ): el rehúse de la entrega por parte del destinatario no es otra cosa que la renuncia del beneficiario a la estipulación hecha en su interés.

El hecho de repudiar la entrega es una declaración de voluntad unilateral del destinatario, a través de la cual muestra su intención de no aceptar que ingresen en su patrimonio los efectos transportados. Puede también servirle al porteador, advirtiéndole de la presencia de un impedimento para la entrega, que surte efectos desde el momento en que dicha declaración llega a su conocimiento. Ciertamente, si la renuncia se declara antes incluso de que la mercancía haya llegado al lugar de destino, no se da uno de los requisitos característicos de los impedimentos para la entrega, la llegada al lugar de destino ${ }^{830}$. Mas siendo idéntica la consecuencia, no parece que exista necesidad de decidir si se trata de un impedimento al transporte o la entrega. Sea como fuere, el porteador se encuentra ante un impedimento desde el momento en que recibe la declaración, pues no tiene la obligación de esperar un tiempo en el lugar de entrega por si el destinatario cambia de parecer aceptando posteriormente la recepción de las

829 Así lo reconoce también la doctrina civilista. Véase, en particular, L. DíEz-PICAzo, Fundamentos del derecho civil patrimonial, T. IV, Las particulares relaciones obligatorias, Thomson-Civitas, Cizur Menor, 2010, p. 411.

830 Así, F. JUAN Y MATEU, «Impedimentos...», cit., p. 455, duda de si se trata de un impedimento al transporte o una suerte de «impedimento a la entrega anticipado». 
mercancías, ni tampoco tiene por qué insistir o si quiera intentar convencerle para que acepte el envío ${ }^{831}$.

Por último, y como ya se ha advertido en otro lugar, conviene subrayar que el deje de cuenta y el rechazo de las mercancías son dos actos distintos que no se deben confundir, aunque ambas facultades forman parte del conjunto de derechos que para el destinatario resultan del contrato de transporte. La diferencia entre ellas radica en que, en el deje de cuenta o abandono, el destinatario deberá justificar el rechazo en atención, por ejemplo, al retraso excesivo o el mal estado de las mercancías. Quiere decirse con ello que el destinatario debe haber aceptado la entrega de las mercancías, pero al comprobarlas descubre que no satisfacen su expectativa o no se corresponden con las indicaciones de la carta de porte. De ahí que el rechazo en este caso se produzca después de aceptar el destinatario la entrega y no antes, como ocurre en el caso del rehúse a recibir las mercancías.

\section{c) El destinatario se niega a pagar el precio del transporte}

El precio que abona el cargador, o en su caso el destinatario, al porteador por el traslado de las mercancías constituye un elemento esencial del contrato de transporte, por lo que un transporte benévolo o de cortesía no se reputa un contrato de transporte en sentido técnico-jurídico. Es el carácter oneroso el que caracteriza el contrato de transporte mercantil, en el que el porteador percibe una cantidad de dinero por cumplir con su obligación frente al cargador, ya que el transporte de las mercancías a cambio de un precio es la causa final que persigue cada parte en el contrato ${ }^{832}$. En fin, como es sabido, el precio del transporte debe incluirse como una de las menciones que figuran en la carta de porte [arts. 6.1.i) CMR y 10.1.k) LCTTM], aunque no existe inconveniente para que las par-

${ }^{831}$ M.A. ClARKE, International carriage..., cit., p. 101.

$8_{32}$ E. MAPELLI, Régimen..., cit., p. 46. Véase también R. URÍA, A. MENÉNDEZ y R. AlONSO SOTO, «El contrato...», cit., p. 334. En rigor, en el contrato de transporte internacional, para que resulte de aplicación el CMR, la prestación ha de realizarse a título oneroso (art. 1 CMR). De ello se infiere que no necesariamente debe pactarse la percepción de un precio en dinero, y nada obsta para que el porteador pueda aceptar cualquier otra ventaja en concepto de contraprestación. 
tes contratantes lo fijen verbalmente, sin hacerlo constar en el documento de transporte ${ }^{833}$.

También se ha visto ya que las partes pueden estipular libremente quién debe pagar el precio del transporte. En caso de que se haya concertado el transporte «a portes pagados» será el cargador; en cambio, corresponderá al destinatario pagar el precio cuando las mercancías viajan «a portes debidos». En defecto de pacto sobre este particular, se entenderá que el transporte lo es a portes $\operatorname{pagados}^{834}$.

Pero la misma posibilidad de pactar un transporte a portes debidos ha sido invocada por algún autor como argumento para criticar la teoría de que el contrato de transporte sea un contrato a favor de tercero. En particular, se dice, de este último tipo contractual no pueden derivarse obligaciones para el beneficiario, siendo un contrato a favor y no a cargo de tercero, de manera que de él derivan solamente derechos para quienes no han intervenido en su conclusión. Dicha crítica ha sido y debe ser descartada por dos motivos. En primer lugar, el hecho de que el pago por el destinatario en el contrato de transporte no se considera una obligación en sentido técnico-jurídico, sino una carga que el destinatario tiene que cumplir en aras de recibir la entrega de las mercancías. Así, de rechazarse el cumplimiento de la carga, negándose el destinatario a pagar los costes del transporte, el porteador tiene a su vez el derecho de negarse a entregarle las mercancías. En segundo lugar, el contrato a favor de tercero no necesariamente aporta únicamente privilegios para el tercer-beneficiario, sino también se pueden derivar de él cargas, que pueden llegar a convertirse en obligaciones cuando se trata de un contrato sinalagmático como es el caso del transporte.

Por ende, en lo que aquí interesa, cabe advertir de que, si se hubiera pactado la modalidad de transporte a portes debidos (o sea, a cargo del destinatario), será un impedimento para la entrega si el destinatario manifiesta la aceptación de recibir la entrega, pero sin querer pagar (íntegramente) el precio del transporte ${ }^{835}$. En definitiva, se trataría de un supuesto en el que el destinatario

833 F. J. SÁNCHEZ-GAMBORINO, El contrato..., cit., p. 31.

834 F. J. SÁnChEZ-GAMborino y J. GAITÁn REBOLLO, Factbook..., cit., p. 108.

835 F. JUAN Y MATEU, Los impedimentos..., cit., pp. 39 y ss. 
no se hace cargo de la mercancía «en las condiciones establecidas en el contrato» (art. 36.1 LCTTM).

\section{d) El destinatario se niega a pagar los gastos del transporte}

Con todo, ya se ha dicho que el precio del transporte no es el único desembolso al que, en su caso, debe hacer frente el destinatario. Y ello porque, entre los derechos que corresponden al porteador, se encuentra el de exigir el reembolso de los gastos generados por el traslado de los efectos hasta su entrega. Tales gastos son los que se ocasionan entre la salida en el lugar de origen hasta la llegada al de destino y comprenden distintos conceptos, como, por ejemplo, el embalaje, almacenaje, aduanas, descarga, comprobación de mercancías, etc. También se incluyen los gastos generados con ocasión de la ejecución de las instrucciones dadas por el cargador o, en su caso, por el propio destinatario, según quién ostente el derecho de disposición [arts. 30.1.a), 31.3, 32.2 y 36.3 LCTTM], y, asimismo, los que se generen por la propia iniciativa del porteador, cuando ello sea necesario y en interés del transporte (art. 31.2 LCTTM). A falta de criterios fijos para el cálculo de dichos gastos, su cuantía es, en principio, ilimitada, pudiendo incluso superar la cuantía de los portes.

En algunos preceptos, el legislador establece que será el cargador quien deba satisfacer los gastos del transporte (aunque ello no impide que en el contrato se identifique al sujeto que resulta obligado a su reintegro), por ejemplo, si éstos han sido generados por el ejercicio de su derecho de disposición, impartiendo instrucciones relativas al transporte al porteador [art. 30.1.a) LCTTM]. También recaen sobre el cargador los gastos producidos por la verificación de los bultos realizada a causa de sospechas de falsedad en la declaración de su contenido que se confirman tras el examen (art. 26.1 LCTTM), o cuando es el cargador quien solicita expresamente la verificación (art. 26.2 LCTTM). Lo mismo sucede cuando ha de procederse al pesaje de la carga en aras de concretar el precio del transporte, incluido el coste del desplazamiento del vehículo, si es el cargador quien solicitó el pesaje (cl. 3.2 de las Condiciones generales de 2012). De existir una prima por el servicio de reembolso, su satisfacción incumbe al cargador cuando se efectúa el transporte a portes pagados, y al destinatario 
si lo es a portes debidos (ex cl. 6.4 de las Condiciones generales, que vinculan el pago de la prima a la obligación de pagar el precio del transporte).

Pues bien, a los gastos les es de aplicación el mismo régimen jurídico que al pago del precio del transporte cuando el traslado de las mercancías se ejecuta a portes debidos: al aceptar el destinatario el recibo de las mercancías, se compromete también a satisfacer dichos gastos accesorios al porteador. En efecto, de negarse a pagar los gastos, el transportista podrá a su vez denegar la entrega de las mercancías. Así, la negativa a pagar estos gastos constituye un impedimento para la entrega, tanto en el transporte nacional (art. 35.2 LCTTM) como en el transporte internacional (art. 13.2 CMR) ${ }^{836}$ : nuevamente, el destinatario no se hace cargo de la mercancía «en las condiciones establecidas en el contrato» (art. 36.1 LCTTM).

\section{e) El destinatario se niega a pagar el reembolso}

Como se ha tenido ocasión de señalar al analizar el régimen jurídico de la entrega contra reembolso ${ }^{837}$, ésta se utiliza como una medida de garantía frente al incumplimiento del destinatario de abonar el precio de las mercancías vendidas, de manera que el destinatario no va a poder recibir las mercancías hasta que satisfaga dicho precio a través del porteador y por cuenta del cargador que, en el supuesto de la compraventa a distancia, será el vendedor ${ }^{838}$. Así, el reembolso es un servicio accesorio y adicional al transporte, que reviste la naturaleza jurídica de una comisión o gestión de cobro, en la que el cargador es el comitente y el porteador el comisionista ${ }^{839}$.

La negativa del destinatario a satisfacer el pago del reembolso al porteador, o el hecho de que no se haya efectuado el pago correctamente o en la forma debida, faculta al porteador para denegar la entrega las mercancías, con base en su posición jurídica en la relación de comisión como mandatario del cargador. En consecuencia, esta negativa es un hecho suficiente para afirmar que se está

${ }^{836}$ F. JUAN Y MATEU, Los impedimentos..., cit., p. 44 y ss.

837 Véase supra, sub VI.1.

${ }^{83}$ A. EMPARANZA SOBEJANO, «Entrega contra...», cit., p. 512.

839 En este sentido, F.J. SÁNCHEZ-GAMBORINo, El contrato..., cit., p. 199; ID. y J. GAITÁN REBOLLO, Factbook..., cit., p. 143. 
ante un impedimento para la entrega, de forma idéntica a como sucede en los casos en que el destinatario se niega a sufragar el precio o los gastos del transporte que fueran de su cuenta. Las Condiciones generales de 2012 (cl. 6.4) incluso equiparan abiertamente el hecho de negarse a pagar el reembolso al rehúse del envío por parte del destinatario, como ya sucedía bajo las Condiciones generales de 1997 (cl. 2.30 del Anexo B, que se remitía a la cl. 2.28 sobre rechazo del envío por parte del destinatario) ${ }^{840}$. Queda patente, pues, que nuevamente se está ante un supuesto de negativa del destinatario a «hacerse cargo de las mercancías en las condiciones establecidas en el contrato» (art. 36.1 LCTTM).

\section{f) El destinatario pretende aplazar la fecha de entrega}

Entregar las mercancías al destinatario y ponerlas a su disposición en el momento previsto en el contrato constituye una obligación fundamental del transportista. El momento previsto para la entrega puede concretarse en una fecha, y también es posible fijar un horario durante el cual el transportista habrá de proceder a la entrega de las mercancías. La fecha de entrega pactada por el cargador y el transportista es una de las menciones que se deben incluir en la carta de porte [arts. 10.1.e) LCTTM y 6.2.f) CMR], pero la inscripción no es constitutiva (puede no haberse hecho referencia al término en el documento, o puede no haberse expedido carta de porte, o haberse perdido o destruido ésta) y, además, el plazo puede ser modificado mediante el ejercicio del derecho de disposición ${ }^{841}$.

En muchas ocasiones, existe en el contrato un acuerdo sobre la determinación del horario habilitado para la entrega (por ejemplo, «entrega entre las seis y las doce horas»), que no tiene por qué coincidir con el horario comercial normal del destinatario. Sin embargo, esta determinación del horario adecuado tiene que ser flexible y equilibrado, ponderando los intereses de ambas partes y según las circunstancias del caso concreto. En la práctica, debe poder presumirse la buena fe en los negocios comerciales (art. 57 Ccom), evitando cualquier abuso del derecho, de manera que no se permite al destinatario negar la entrega de las mercancías cuando se efectúa con poca antelación o pocos minutos más

840 S. RodRíGUEZ SÁNCHEZ, «Depósito y enajenación de las mercancías», RdT, núm. 6, 2010, p. 241; F. JUAN Y MATEU, Los impedimentos..., cit., pp. 52-53.

${ }^{841}$ F.J. SÁNCHEZ-GAMBORINO y J. GAITÁN REBOLLO, Factbook..., cit., p. 146. 
tarde de la hora estimada para esa tarea, especialmente cuando se trata, por ejemplo, de transportes de larga distancia, en los que es muy difícil estimar la hora exacta de llegada ${ }^{842}$.

No es imputable al transportista ninguna responsabilidad si la recepción de las mercancías al destinatario tiene efectivamente lugar, con independencia de que coincida o no con el horario indicado. Es decir, siempre que el destinatario acepte la entrega, se puede afirmar que el transporte ha sido realizado correctamente y que el transportista ha cumplido con su obligación hasta el final. Por el contrario, no debe entenderse que el destinatario renuncia al transporte o que se está ante un impedimento para la entrega en caso de que rechace la recepción de las mercancías debido a que la entrega se pretende realizar fuera del horario concordado. Y es que, en tales casos, el destinatario tiene derecho a exigir que la entrega sea realizada en horario hábil, ni más ni menos. En cambio, sí puede constituir un impedimento para la entrega el hecho de que el destinatario pida al transportista que aplace la entrega de las mercancías hasta otro momento, cuando éste ya se había dispuesto a hacer entrega en el horario previsto. Ese aplazamiento de la entrega a pesar de haberse presentado el transportista en el horario pactado supone, de nuevo, una negativa del destinatario a aceptar la entrega de las mercancías «en las condiciones establecidas en el contrato» (art. 36.1 LCTTM), con lo que es innegable la existencia de un impedimento para la entrega 843 .

\subsection{El destinatario se niega a desestibar o a descargar las mercancías}

En principio, la obligación de realizar las operaciones de carga y descarga (y también las de estiba y desestiba) se atribuye al cargador o al destinatario, respectivamente, «salvo que expresamente se asuman estas operaciones por el porteador antes de la efectiva presentación del vehículo para su carga o descarga» (art. 20.1 LCTTM) ${ }^{844}$. La situación cambia en el transporte de paquete-

842 F. JUAN Y MATEU, Los impedimentos..., cit., p. 57.

843 F. MARTínez SANZ, La responsabilidad del porteador..., cit., pp. 142-143.

844 Con detalle sobre esta cuestión, B. GARCíA ÁlvAREZ, La carga y descarga..., cit., p. 75; F. MARTÍNEZ SANZ, «Transporte de mercancías por carretera (I)...», cit., p. 178. 
ría y asimilados 845 , donde la presunción es la inversa, es decir, la carga y la descarga corresponde realizarlas al porteador, salvo que otra cosa se pacte (art. 20.3 LCTTM); la estiba y desestiba, por su parte, corresponden en todo caso al transportista, de forma que no cabe el pacto en contrario. Bajo la vigencia del Derecho anterior, el artículo 22.3 LOTT aún distinguía entre transporte de carga completa, en el que las operaciones de carga y descarga corrían de cuenta del cargador y el destinatario, respectivamente, mientras que en el transporte de carga fraccionada dicha responsabilidad se atribuía el transportista, salvo pacto en contrario en uno y en otro caso ${ }^{846}$.

Con respecto al transporte internacional, nada se dice en el CMR sobre la determinación de los sujetos que están obligados a realizar las operaciones de carga y descarga, ni tampoco sobre quién recae la responsabilidad por los daños que se pueden ocasionar durante o a consecuencia de estas operaciones. No obstante, sí se señala como causa privilegiada de exoneración de responsabilidad del transportista la «manipulación, carga o descarga de las mercancías y operaciones complementarias realizadas por el remitente o el destinatario o personas que obren por cuenta de uno y otro» [17.4.c) CMR]. Ante esta laguna normativa debe acudirse a la legislación nacional que resulte aplicable supletoriamente, conforme a las normas de conflicto del foro ${ }^{847}$. Si fuera la española,

845 De conformidad con el art. 20.3 LCTTM, son aquellas que «impliquen la recogida $o$ reparto de envíos de mercancías consistentes en un reducido número de bultos que puedan ser fácilmente manipulados por una persona sin otra ayuda que las máquinas o herramientas que lleve a bordo del vehículo utilizado».

${ }^{846}$ Esos dos conceptos de transporte de «carga completa» $\mathrm{y}$ «carga fraccionada», de las que se hacían eco también las Condiciones generales de 1997, se han eliminado del Derecho vigente y la Ley 15/2009 únicamente se refiere a los servicios «de paquetería y cualesquiera otros similares» para establecer la distinción apuntada en materia de carga y descarga. Con todo, ha de reconocerse que el fondo de la cuestión no ha cambiado de forma sustancial, aunque la norma actual pone más énfasis en el reducido número de bultos que resultan fáciles de manipular por una sola persona. Al respecto véase $\mathrm{F}$. MARTínEZ SANZ, «Transporte de mercancías por carretera (I)...», cit., p. 178; y J.M ${ }^{\mathrm{a}}$. SÁNCHEZ ÁlvAREZ, «Responsabilidad por los daños en las mercancías durante las operaciones de carga/descarga, estiba/desestiba, por insuficiencia o defecto en el embalaje. Tratamiento por los Tribunales», ponencia para la Fundación Francisco Corell, 28 de abril de 2016, disponible a través de la página web de la fundación (http://www.fundacion-fcorell.es).

847 De conformidad con el Reglamento (CE) no 593/2008 del Parlamento Europeo y del Consejo, de 17 de junio de 2008, sobre la ley aplicable a las obligaciones contractuales (Roma I), a los contratos de transporte de mercancías les resultará de aplicación, «[e]n defecto de elección de la ley aplicable [..., ] la ley del país donde el transportista tenga su residencia habitual, siempre y cuando el lugar de recepción o el lugar de entrega, o la residencia habitual del remitente, también estén situados en ese país. Si no se cumplen estos requisi- 
procede la aplicación del artículo 20 LCTTM que, siendo de carácter dispositivo, admite pactos sobre la atribución de las obligaciones de carga y descarga (y, salvo en el transporte de paquetería, de estiba y desestiba), siempre que sean ex$\operatorname{presos}^{848} \mathrm{y}$, en su caso, se alcancen antes de la presentación del vehículo para su carga en el lugar de origen.

Cuando la obligación de efectuar las operaciones de desestiba y descarga pesa sobre el destinatario y éste se niega a realizarlas aun después de reclamar la entrega, o exige que las realice el porteador o un tercero, concurre un impedimento para la entrega. Y es que el consentimiento a la entrega por el destinatario implica la aceptación de todos los términos que derivan de la ley y el contrato; términos que comprenden la atribución de las operaciones de desestiba y descarga al destinatario ${ }^{849}$.

\subsection{El destinatario se niega a expedir o firmar el documento de entrega}

Como se indicó en el momento oportuno ${ }^{850}$, el porteador está facultado para exigir y el destinatario obligado a expedir o firmar un documento justificativo de la entrega (art. 12 LCTTM). En la medida en que dicho recibo es la principal prueba de la que puede valerse el transportista para justificar la realidad de la entrega, parece lógico que pueda negarse a entregar la carga si no se le facilita el documento en cuestión. No sorprende, por ello, que el artículo 36.1 LCTTM contemple expresamente la negativa del destinatario a firmar el documento de en-

tos, se aplicará la ley del país donde esté situado el lugar de entrega convenido por las partes» (art. 5.1).

848 B. García Álvarez, La carga y descarga..., cit., p. 75; F. JUAN y MateU, Los impedimentos..., cit., p. 58.

849 F. JUAN Y MATEU, Los impedimentos..., cit., p. 58. Obsérvese que, en este mismo contexto, el art. 2 b) de la Orden del Ministerio de Fomento de 30 marzo de 2001 por la que se establecen normas para la realización por las Juntas Arbitrales del Transporte de funciones de depósito y enajenación de mercancías (B.O.E. núm. 90, de 14 de abril de 2001), disponía que la negativa del destinatario a realizar la descarga, cuando le correspondía a él realizarla, equivalía a un rehúse del envío (véase la referencia en F. JUAN y MATEU, «Impedimento a...», cit., p. 460). No obstante, dicha precisión ha desaparecido de la norma actual [art. 2.c) de la Orden FOM/3386/2010, de 20 de diciembre, de idéntico título], que se limita a reproducir el contenido del art. 36.1 LCTTM.

850 Véase supra, sub VI.2.1. 
trega como un impedimento para la entrega que obliga al porteador a solicitar instrucciones del porteador.

\section{La responsabilidad del porteador: hechos que dan lugar a su responsabilidad frente al destinatario}

El porteador, desde que acepta la mercancía para su traslado, asume una obligación de resultado, es decir, de entregar las mercancías al destinatario, incólumes y dentro del plazo convenido (si lo hubiere) o calculado conforme a las reglas legales supletorias. Con carácter general, la responsabilidad del porteador gira en torno a dos supuestos básicos de responsabilidad en el transporte de mercancías: por un lado, la responsabilidad de custodia o responsabilidad ex recepto, dado que responderá de los daños o perjuicios que puedan sufrir las mercancías encontrándose éstas bajo su tutela (concretamente, pérdida y avería); por otro, la responsabilidad por retraso, que opera cuando, aun llegando las mercancías a su destino en buen estado y bien custodiadas, sin pérdida ni menoscabo alguno, lo hagan con retraso y fuera del plazo acordado o razonable (de ahí que se hable también de responsabilidad ex contractu). En caso de incumplimiento de las obligaciones de custodia y de observar el plazo de transporte, el porteador responde, salvo que pueda probar la concurrencia de una causa de exoneración (arts. 17 y 18 CMR) ${ }^{851}$.

El principio o fundamento de la responsabilidad del transportista viene regulado en los artículos 17 CMR y 47 LCTTM, aunque las opiniones acerca de cuál sea este principio o fundamento están divididas ${ }^{852}$. Además, y como se ha tenido ocasión de señalar, la obligación que asume el transportista es de resultado, de forma que sólo se produce el cumplimiento exacto si éste entrega la mercancía a su destinatario en perfecto estado, íntegra y dentro del plazo fijado.

${ }^{851}$ F. MARTínEz SANZ, La responsabilidad..., cit., p. 183, quien por ello señala, con buen criterio, que la responsabilidad del porteador se presume.

${ }^{852}$ En particular, tanto para el art. 17 CMR, como para los arts. 47 LCTTM y 23 RU CIM se defiende, bien que se trata de un ejemplo de responsabilidad cuasi-objetiva del transportista, bien que éste responde por culpa (si bien con inversión de la carga probatoria), bien, en fin, que la responsabilidad de aquél se presume, pudiendo exonerarse alegando y probando que el daño ha resultado (o, en su caso, ha podido resultar) de algún hecho que la ley califica como exoneratorio. 
Así lo establece el artículo 17.1 CMR, cuando afirma que el transportista «es responsable de la pérdida total o parcial y de las averías que se produzcan entre el momento de recepción de la mercancía y de la entrega, así como del retraso en la entrega» 853 .

Son tres, por tanto, los hechos que son susceptibles de desencadenar la responsabilidad del transportista: las averías (o sea, una merma de calidad), las pérdidas (mermas de cantidad) y el retraso en la entrega.

\section{Averías}

A veces sucede que el porteador cumple con su obligación de hacer llegar la mercancía a su punto de destino, pero no en el mismo estado en que la recibió del cargador o expedidor, en cuyo caso se estaría ante una «avería». Ahora bien, al igual que sucede con la pérdida, a la que seguidamente nos referiremos, no existe una definición legal de avería. Ante la ausencia de una noción legal, la doctrina española define la avería con referencia al valor de las cosas transportadas: son averías aquellos daños que provocan una alteración substancial de la mercancía, causando una disminución en su valor con respecto al estado en que el transportista la recibió del cargador ${ }^{854}$.

En la práctica se suele usar el término «daño» como un sinónimo de avería. Ambas expresiones significan lo mismo, un detrimento o menoscabo de la mercancía objeto del transporte, el que hace que dicha mercancía pierda valor ${ }^{85}$. El deterioro que altera la calidad de la mercancía puede ser parcial, si por efecto de la avería se estropea una parte de la mercancía; o total, cuando el daño

${ }^{853}$ No hay diferencia alguna con respecto a lo que se dispone en el art. 47.1 LCTTM, a cuyo tenor el porteador «responderá de la pérdida total o parcial de las mercancías, así como de las averías que sufran, desde el momento de su recepción para el transporte hasta el de su entrega en destino. Asimismo, el porteador responderá de los daños derivados del retraso en la ejecución del transporte conforme a lo previsto en esta ley».

854 J.L. CONCEPCIÓN RODRÍGUEZ, «El transporte internacional de mercancías por carretera», en id. (dir.), El contrato de transporte, Manual de Formación Continuada, 21, Vol. I, Consejo General del Poder Judicial, Madrid, 2003, p. 265; C. GóRrIZ LÓPEZ, La responsabilidad..., cit., p. 358 y ss.

855 F. J. SÁnCheZ-GAMBORINo y J. GAITÁN REBOLlo, Factbook..., cit., p. 157. 
afecta a la totalidad de la carga ${ }^{856}$. En términos cualitativos, la avería puede ser, además, relativa, cuando a pesar de producirse una pérdida de valor, la mercancía sigue siendo apta para su comercialización; o absoluta, cuando los géneros afectados quedan totalmente inútiles para su comercialización, en cuyo caso la avería queda asimilada a la pérdida (art. 54.2 LCTTM) ${ }^{857}$.

En fin, en atención a la visibilidad de la avería, a tenor de lo dispuesto en los artículos 60.1 LCTTM y 30.1 CMR, la avería puede ser interna o externa, según si se detecta o no a simple vista. Esta última clasificación de las averías es la que más interesa al destinatario, que estará obligado a inspeccionar la mercancía para descubrir los eventuales daños causados durante el transporte. Y es que difiere el plazo del que dispone el destinatario para poner de relieve frente al porteador la existencia de tales averías, que es de siete días naturales para las averías no aparentes, mientras que no existe beneficio de plazo cuando las averías son manifiestas (arts. 60.1 LCTTM y $30.1 \mathrm{CMR}$ ) $^{85}$. Como se ha adelantado en otro lugar, la ausencia de reservas en tiempo útil hace que se presuma, salvo prueba en contrario, que las mercancías han sido entregadas al destinatario en el estado descrito en la carta de porte. En cambio, si puede demostrarse la realidad de la avería y que ésta se ocasionó durante el período de responsabilidad del transportista (esto es, desde la recepción en origen hasta la entrega en destino), el porteador responderá frente al derechohabiente, en su caso el destinatario, por los daños causados, debiendo satisfacer una indemnización equivalente a la

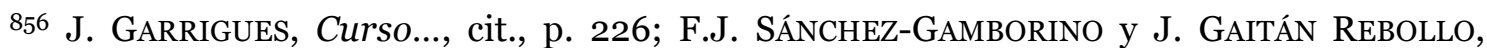
Factbook..., cit., p. 157. Al respecto, se añade que el concepto de avería guarda una íntima relación con la naturaleza de los bienes, por ejemplo, cuando las mercancías aparecen mojadas, rotas, o descongeladas e inservibles, muy especialmente en relación a la denominada "carga en frío», que suele aplicarse a los productos perecederos (véase $\mathrm{P}$. MARTÍNEZ GONZÁLEZ, El transporte terrestre..., cit., p. 72). Y es que no todas las mercancías acusan ciertas contingencias con la misma intensidad.

857 En efecto, existen casos en los que la avería total se puede equiparar a la pérdida total, concretamente, cuando resulta difícil diferenciar entre avería y pérdida. Véase J.L. CONCEPCIÓN RODRÍGUEZ, «El transporte...», cit., p. 265-266. Para que ello suceda, el art. 54.2 LCTTM exige que las averías «hagan que las mercancías resulten inútiles para su venta o consumo, atendiendo a la naturaleza y uso corriente de los objetos de que se trate».

${ }^{85}$ F. J. SÁnchez-Gamborino y J. Gaitán Rebollo, Factbook..., cit., p. 158. 
pérdida de valor experimentada por las mercancías (arts. 53 LCTTM y 25 CMR) 859 .

\section{Pérdidas}

El término «pérdida» no se encuentra tampoco definido legalmente, de manera que su concepto ha debido ser elaborado por la doctrina sobre la base de los preceptos que de ella se ocupan en la Ley 15/2009 y en el CMR. Se trataría de aquel supuesto en el que le es imposible al porteador entregar materialmente en destino lo que se había comprometido a transportar, en todo o en parte, con independencia de la causa, si es interna, externa o debida a que la mercancía se ha entregado a otro destinatario diferente del que figura en el contrato o en la carta de porte ${ }^{860}$.

$\mathrm{Al}$ contrario de lo que se sucede en caso de avería, la pérdida conlleva una falta en cuanto a la cantidad de lo transportado y no en su estado físico, que es propio de la avería. Se distingue entre pérdida total y parcial, según si se ha perdido la totalidad de los efectos confiados al porteador o sólo una parte de la carga ${ }^{861}$. La distinción tiene cierta importancia si se repara en que alguna norma, como por ejemplo el artículo $32 \mathrm{CMR}$, se sirve de ella para determinar el momento a partir del cual comienza a contar el plazo de prescripción: en el supuesto de pérdida parcial, la prescripción corre a partir del día de la entrega [arts. 79.2.a) LCTTM y 32.1.a) CMR], mientras que en el supuesto de pérdida total la prescripción empieza al transcurso de veinte días después de la expiración del plazo de transporte estipulado (treinta días en el transporte internacional) o, caso de no existir éste, a los treinta (sesenta) días desde que el porteador se hizo

\footnotetext{
859 A. DÍAz Moreno, «El contrato...», cit., p. 681; A. EMPARANZA SOBEJANO, «Estado de las mercancías en el momento de la entrega al destinatario», en J. F. Duque Domínguez y F. Martínez Sanz (dirs.), A. Emparanza Sobejano y $\mathrm{M}^{\mathrm{a}}$.V. Petit Lavall (coords.), Comentarios a la Ley de Transporte Terrestre, cit., p. 424.

$860 \mathrm{M}^{\mathrm{a}}$.V. PETIT LAVALL, La responsabilidad por daños en el transporte aéreo internacional de mercancías, Comares, Granada, 2007, p. 74; A. PUETZ, «Supuestos de responsabilidad», en J. F. Duque Domínguez y F. Martínez Sanz (dirs.), A. Emparanza Sobejano y Ma ${ }^{a}$.V. Petit Lavall (coords.), Comentarios a la Ley de Transporte Terrestre, cit., 2010, p. 560; C. GÓRRIZ LÓPEZ, La responsabilidad..., cit., pp. 356-357; J. GARRIGUES, Curso..., cit., p. 226.

861 J.L. CONCEPCIÓN RODRÍGUEZ, «El transporte...», cit., p. 264; A. PUETZ, «Supuestos...», cit., p. 560; C. GÓRRIZ LÓPEZ, La responsabilidad..., cit., p. 358.
} 
cargo de las mercancías objeto del transporte [arts. 79.2.b) LCTTM y 32.1.b) $\mathrm{CMR}]^{862}$.

$\mathrm{Al}$ respecto de determinar la existencia de una pérdida de la mercancía, hay que tener en cuenta la importancia del artículo 54 LCTTM, que prevé la equiparación a pérdida total de varios supuestos, como cuando se pierde una parte de las que componen el envío y el uso del conjunto sin la parte no entregada es imposible; o cuando las mercancías llegan averiadas de tal forma que resulten inútiles para su venta o consumo. En fin, también puede considerarse perdida la mercancía cuando se produce un retraso en la entrega de más de veinte días sobre el plazo convenido o, a falta de plazo, cuando transcurran treinta días desde que el porteador se hizo cargo de las mercancías (art. 54.3 LCTTM) ${ }^{863}$. Concretamente, la presencia de cualquiera de estos supuestos de equiparación a pérdida total concede al destinatario el derecho de rehusar la recepción de las mercancías y dejarlas por cuenta del porteador, reclamándole la indemnización correspondiente a la pérdida de la carga.

\section{Retraso}

Conforme a lo previsto en los artículos 47.1 LCTTM y 17.1 CMR, el porteador también responde frente al destinatario de los daños causados por el retraso en la entrega. Se entiende por retraso en la entrega la puesta de la mercancía a disposición del destinatario después del plazo previsto en el contrato o calculado conforme a lo dispuesto en la Ley (que se refiere ahora al «término que razonablemente emplearía un porteador diligente en realizar el transporte, atendiendo a las circunstancias del caso", art. 33.1 LCTTM) ${ }^{864}$. En consecuencia, tanto el artículo 33 LCTTM como el artículo 19 CMR se refieren a las dos situaciones posibles: por un lado, que se haya fijado plazo en el contrato; por otro, que este no sea el caso, debiendo estarse entonces al tiempo que razonablemente em-

\footnotetext{
862 C. GÓRRIZ LÓPEZ, La responsabilidad..., cit., p. 358; J.L. CONCEPCIÓN RODRÍGUEZ, «El transporte...», cit, p. 264.

$863 \mathrm{El}$ art. $20 \mathrm{CMR}$ establece plazos sustancialmente más largos, en atención al carácter internacional del transporte: treinta días desde la finalización del plazo de entrega o sesenta días desde que el porteador se hizo cargo de la mercancía. Al respecto véase A. PUETz, «Supuestos...», cit., p. 561.

${ }^{864}$ A. DÍAZ MORENO, «El contrato...», cit., p. 683; J. GARRIGUES, Curso..., cit., p. 227.
} 
plearía un transportista diligente. Ahora bien, en ambas situaciones el transportista responde cuando rebase el plazo (fijado o razonable) de entrega, siempre que ello no sea debido a una causa que la propia Ley considera como liberatoria de responsabilidad (arts. 48 LCTTM y 17.2 CMR).

\subsection{Se ha fijado un plazo de entrega}

En la práctica, es habitual que las partes contratantes hayan fijado en la carta de porte un plazo determinado para la entrega de la mercancía objeto del transporte (arts. 33 LCTTM y 19 CMR). En tales casos, se está ante un retraso cuando la mercancía no sea entregada al destinatario en el término concertado. Aunque no se haya producido por el retraso un daño en los efectos (lo cual puede suceder, por ejemplo, cuando lo que se transporta son mercancías perecederas, en cuyo caso la responsabilidad lo es por averías y no por retraso), el retraso en sí puede dar lugar a un perjuicio económico que dará lugar a la responsabilidad del transportista, siempre y cuando, claro está, pueda acreditarse que efectivamente se ha causado un daño al destinatario 865.

En cuanto a la forma de documentarse el pacto referido, éste se puede fijar sin ninguna exigencia formal, ya que será permisible, en defecto de su mención en la carta de porte, acudir a otros medios de prueba que indiquen su existencia y contenido. Además, recuérdese que la falta de mencionar el plazo de entrega en la carta de porte no afecta a la validez ni a la existencia del acuerdo correspondiente ${ }^{866}$. Sin embargo, el hecho de que el contrato de transporte no esté sujeto a requisito de forma alguna no supone que su documentación a través de la carta de porte (en cuanto medio privilegiado de prueba) sea irrelevante para la ejecución del mismo. Así, en su ausencia las partes se enfrentarán a ciertas dificultades para el ejercicio de los derechos y las acciones que correspondan

\footnotetext{
865 Por ello, los daños causados por el retraso son, por definición, daños indirectos o «consecuenciales», por ejemplo, el perjuicio que se causa al destinatario por la imposibilidad de entregarlas a tiempo a un tercero, con quien se había comprometido. En este sentido, véase la SAP Asturias (Sección $5^{\text {a }}$ ) núm. 25/2004, de 14 de enero (JUR 2004, 79845), así como F. MARTínEZ SANZ, «Transporte...», cit., p. 202.

866 F.J. SÁNCHEZ-GAMbORINO, El contrato de transporte..., cit., p. 189; A. PUETZ, «Lugar y plazo de entrega de la mercancía al destinatario», en J. F. Duque Domínguez y F. Martínez Sanz (dirs.), A. Emparanza Sobejano y M ${ }^{\mathrm{a}}$.V. Petit Lavall (coords.), Comentarios a la Ley de Transporte Terrestre, cit., p. 409.
} 
en caso de incumplimiento contractual, debiendo estarse al régimen general de la prueba en la Ley de Enjuiciamiento Civil867. En efecto, como quiera que el destinatario no tiene por qué conocer el contenido del contrato de transporte, la mención del plazo en la carta de porte resulta ser el medio más efectivo para alertarlo sobre su existencia y facilitarle el ejercicio de los derechos que correspondan en caso de retraso.

El plazo de entrega puede estipularse en forma absoluta, concretando un día exacto para efectuar la entrega de la mercancía al destinatario, o bien de manera relativa, disponiendo que las mercancías han de ser entregadas en un cierto período de tiempo, por ejemplo, en un plazo de siete días a partir de la fecha de la toma en carga ${ }^{868}$.

Un problema particularmente espinoso se plantea en relación a la fijación de plazos excesivamente cortos, o sea, imposibles de cumplir. Ciertamente, tales situaciones no deberían darse en la práctica, pues el transportista es un profesional que debería conocer el plazo que necesita para desplazar las mercancías al lugar de destino. No obstante, si aun así sucediese, parece que dicho pacto resultaría nulo por imposibilidad del objeto si resulta objetivamente imposible (esto es, para cualquier porteador, y no sólo para ese concreto) respetar el plazo (art. 1.272 Cc) $)^{869}$.

La superación del plazo acordado de entrega implica un incumplimiento contractual, que dará lugar a la responsabilidad del transportista si de ello ha derivado algún daño y el retraso le es imputable. Si no existiese pacto, o éste no pudiera probarse, se estará al plazo que razonablemente emplearía un porteador diligente, habida cuenta de las circunstancias del caso (arts. 33 LCCTM y 19 CMR), un aspecto al que se dedica el epígrafe siguiente.

\footnotetext{
${ }^{867}$ Así, para el Derecho previgente, donde el art. 354 Ccom ordenaba estar «al resultado de las pruebas jurídicas que haga cada parte en apoyo de sus respectivas pretensiones, conforme a las disposiciones generales establecidas en este Código para los contratos de comercio», F.C. LÓPEZ RUEDA, El régimen jurídico..., cit., p. 414.

868 F. J. SÁncheZ-GAMborino y J. GAITÁn REBOLlo, Factbook ..., cit., p. 160

869 Con detalle sobre esta cuestión, F. MARTínez SANZ, La responsabilidad..., cit., pp. 448 y ss.; A. PUETZ, «Lugar y plazo...», cit., pp. 409 y ss.
} 


\subsection{No se ha pactado plazo de entrega: el plazo «razonable»}

En el caso de que no haya llegado a fijarse ningún plazo de entrega en el contrato de transporte, la entrega deberá realizarse dentro del plazo que razonablemente emplearía un transportista diligente, atendiendo a las circunstancias del caso. Como ejemplo de tales circunstancias, el artículo 19 CMR menciona el caso de carga parcial, donde deberá tenerse en cuenta el tiempo necesario para poder reunir un cargamento completo ${ }^{870}$.

En efecto, el parámetro para calcular el tiempo razonable para el transporte es el tiempo medio que suele efectivamente emplearse en determinado recorrido, esto es, el tiempo realmente utilizado por el transportista debe cotejarse con el que habría empleado un transportista diligente, para lo que puede estarse, bien al tiempo habitualmente consumido por el mismo transportista en la ejecución de transportes similares en ocasiones precedentes, bien al empleado por otros transportistas en la misma ruta y con los mismos medios, o bien al tiempo que emplearía un transportista diligente ${ }^{871}$. Ello obliga a tener en consideración las circunstancias específicas que rodean la operación de transporte en cuestión, por ejemplo, la dificultad del recorrido con mal tiempo (no es lo mismo realizar un mismo trayecto en verano que en invierno), la clase de mercancía (perecedera o no), además de la normativa sobre tiempos de conducción y descanso, así como las instrucciones e informaciones dadas por el cargador o el destinatario, otros obstáculos previsibles, etc. ${ }^{872}$.

En definitiva, la determinación del plazo razonable queda, en última instancia, a la apreciación del juzgador, que deberá determinar si el tiempo empleado por el transportista es o no excesivo (aplicando, en su caso, por analogía lo dispuesto en el art. $1.128 \mathrm{Cc}$, que concede al juez la potestad de fijar la duración del plazo cuando no existe fecha señalada para la entrega, «pero de [la]

\footnotetext{
870 Otras circunstancias a tener en cuenta a la hora de calcular el plazo razonable de transporte serían, por ejemplo, la distancia, obstáculos en el itinerario, el clima, la velocidad que puede alcanzarse con los medios a disposición del transportista, la naturaleza (perecedera $o$ no) de la carga, etc. Véase F.J. SÁNCHEZ-GAMBORINO, El contrato de transporte..., cit., p. 189.

${ }^{871}$ Así, para el transporte aéreo de mercancías, Ma ${ }^{\mathrm{a}}$.V. PetiT LAVALL, La responsabilidad..., cit., p. 87.

${ }^{872}$ A. PUETZ, «Lugar y plazo...», cit., p. 414; J. PUTZEYS, Le contrat..., cit., pp. 232 y 233.
} 
naturaleza y circunstancias [de la obligación] se dedujere que ha querido concederse al deudor», o cuando la determinación del plazo haya quedado a voluntad de éste). En todo caso, la prueba del retraso (y, como prius, del plazo «razonable» si éste no se hubiera fijado en el contrato) corresponde al destinatario, en cuanto hecho sobre el que éste fundamenta su pretensión (art. 217.2 LEC), lo que pone de relieve la conveniencia de pactar un plazo de entrega.

\subsection{El llamado «deje de cuenta»}

Como se ha indicado arriba en el texto, el retraso puede equipararse a pérdida total de las mercancías cuando transcurran los plazos fijados en la Ley, que son de veinte días a partir de la fecha de entrega si ésta se hubiera fijado en el contrato (art. 54.3 LCTTM), un plazo que se amplía a treinta días en el transporte internacional (art. 20.1 CMR). Por el contrario, en el supuesto de que no se haya concertado ni fijado de otro modo la fecha en la que habrá de entregarse las mercancías, el límite será de treinta o sesenta días después de que el transportista recibió el cargamento (arts. 54.3 LCTTM y 20.1 CMR, respectivamente) ${ }^{873}$. A la vista de lo que antecede, el retraso puede equipararse a una pérdida de las mercancías cuando se superen los plazos indicados sin efectuarse la entrega, hecho que faculta al destinatario para abandonar las mercancías, o sea, para dejarlas de cuenta del transportista874. Debe advertirse que el llamado «deje de

873 J. PUTZEYS, Le contrat..., cit., p. 233; C. GÓRRIZ LÓPEZ, «Supuestos de equiparación a pérdida total», en J.F. Duque Domínguez y F. Martínez Sanz (dirs.), A. Emparanza Sobejano y $\mathrm{M}^{\mathrm{a}}$.V. Petit Lavall (coords.), Comentarios a la Ley de Transporte Terrestre, cit., pp. 666 y ss.; A. PUETZ, «Lugar y plazo...», cit., p. 414.

874 Obsérvese que se trata de un derecho del destinatario, no de una consecuencia necesaria de la superación de los plazos señalados en la Ley, de manera que puede declarar el abandono o no. Ese derecho al «deje de cuenta» es una institución antigua que tenía su reflejo ya en el Código de comercio. En efecto, el (hoy derogado) art. 371 Ccom establecía que, «[e]n los casos de retraso por culpa del porteador, a que se refieren los artículos precedentes, el consignatario podrá dejar por cuenta de aquél los efectos transportados, comunicándoselo por escrito antes de la llegada de los mismos al punto de su destino. Cuando tuviera lugar este abandono, el porteador satisfará el total importe de los efectos como si se hubieran perdido o extraviado". Siguiendo con el Derecho previgente, también en la condición 2.26 del Anexo A de la Orden de 25 de abril de 1997 se hacía referencia al deje por cuenta del porteador en las operaciones de carga completa, estableciendo que «cuando el porteador sólo hiciese entrega de una parte de las cosas que componen el envío, el consignatario podrá rehusar el hacerse cargo de éstas cuando pruebe que no puede utilizarlas con independencia de las no entregadas». 
cuenta»875 supone un derecho privilegiado del destinatario, quien podrá, una vez transcurridos los plazos legalmente establecidos (o ante pérdidas parciales o averías que cumplan lo dispuesto en el art. 54 LCTTM), rehusar el recibo de la carga, reclamando del transportista que sea responsable del hecho causante del daño la indemnización que corresponda en caso de pérdida total ${ }^{876}$.

\section{a) Ejercicio del derecho}

Respecto del ejercicio del deje de cuenta, conviene recordar que éste no debe confundirse con el rechazo o rehúse de la entrega a que antes se hizo referencia. En efecto, como se decía, se trata de facultades bien distintas, sobre todo en relación a la necesidad de motivar la negativa del destinatario a recibir la carga. $Y$ es que éste podrá rehusar la recepción de las mercancías sin proporcionar justificación o explicación alguna, mientras que el deje de cuenta implica que se cumplan los requisitos establecidos taxativamente en la Ley (esto es, que las mercancías no pueden usarse sin la parte perdida o son inútiles para su venta o consumo debido a una avería, o que se han superado los límites temporales establecidos en la norma).

La diferencia entre ambas instituciones debe buscarse en la naturaleza del contrato de transporte. El destinatario, según el esquema del contrato a favor de tercero, no es sino un beneficiario al que va dirigida la prestación estipulada en su favor, de manera que, para adquirir el derecho a reclamar la prestación, habrá que prestar su aceptación para recibirla. Mediante la aceptación se adhiere al contrato de transporte y gozará de los derechos derivados de éste, entre los que se halla el deje de las mercancías por cuenta del transportista ${ }^{877}$. En cambio, si no acepta la prestación (rehusando la entrega de las mercancías), no puede extraer ningún derecho del contrato y, por ende, tampoco procede la indemnización que le concede el artículo 54.3 LCTTM.

875 La Ley 15/2009 no emplea el término referido, sino que regula la institución bajo la rúbrica «equiparación a pérdida total» (art. 54 LCTTM), que además abarca supuestos no previstos en el Código de comercio (concretamente, las pérdidas parciales y las averías).

876 E. MAPELLI LÓPEZ, Régimen jurídico..., cit., p. 299.

877 P. MARTíneZ GonZÁLEZ, El transporte..., cit., p. 69. 
En los supuestos de retraso excesivo, al no tratarse de percibir un determinado resarcimiento por daños y averías ocasionados, sino que depende de la exclusiva voluntad del destinatario, la equiparación de dicho retraso a la pérdida total difiere de los otros casos de equiparación, la pérdida parcial y la avería (art. 54.1 y 2 LCTTM). En efecto, es innecesario demostrar la inutilidad de las mercancías entregadas, como sucede en los supuestos de pérdida parcial y avería, de manera que podrá declararse el abandono incluso cuando las mercancías se encuentran en buen estado y son aptos para su comercialización ${ }^{878}$. La cuantía de la indemnización será aquella que corresponda por la pérdida del envío, calculada en función del valor de las mercancías abandonadas (art. 52 LCTTM) ${ }^{879}$. En fin, declarado el abandono por sobrepasarse los plazos indicados en la Ley, el destinatario podrá aún recuperarlas en caso de que reaparezcan, en cuyo caso deberá restituir la indemnización recibida (art. 59 LCTTM).

\section{b) Consecuencias}

Según GARRIGUES, el deje de cuenta implica una verdadera compra forzosa de la mercancía por el transportista ${ }^{880}$, pero es una compra que carece de fundamento jurídico, ya que es impropia a la prestación incumplida. No existe en otros modos de transporte distintos del terrestre, y al transportista tampoco le interesa mantener las mercancías bajo su custodia después de llevar a cabo el transporte, pues su cometido se agota con el traslado de éstas. Supone, en definitiva, mezclar dos contratos diferentes ya cabalmente organizados por la ley: por una parte, el contrato de compraventa que une al remitente con el destinatario; por otra, el de transporte, concluido por el remitente y el transportista, para que después intervenga en éste un tercero, que es el destinatario, con su decisión de abandonar los efectos transportados en cabeza del transportista ${ }^{881}$.

Es más, el hecho de que el deje de cuenta sea una facultad del destinatario hace que éste pueda convertir a su arbitrio el simple retraso en pérdida. Dis-

878 C. GÓRRIZ LÓPEZ, «Supuestos de equiparación...», cit., p. 669.

879 Según lo dispuesto en el art. 55 LCTTM, «[e]l valor de las mercancías se determinará atendiendo al precio del mercado o, en su defecto, al valor de mercancías de su misma naturaleza y calidad».

880 Citado por E. MAPELLI LÓPEZ, Régimen jurídico..., cit., p. 301.

${ }^{881}$ F. J. SÁNCHEZ-GAMBORINO y J. GAITÁn REBOLLO, Factbook..., cit., p. 207. 
pondrá, por ello, de una doble opción: podrá aceptar la mercancía con retraso, sin por ello perder su derecho a reclamar del porteador la indemnización por su cumplimiento defectuoso por temporalmente inexacto, pero podrá también exigir del transportista la satisfacción del importe íntegro correspondiente al valor de las mercancías, como si éstas se hubieran perdido ${ }^{882}$.

\section{Efectos de la entrega y de la falta de entrega de las mercancías al destinatario}

\section{Efectos para el porteador, en particular, su actuación en caso de impedimentos al transporte o a la entrega}

La principal actuación que el transportista debe realizar frente al destinatario es poner a su disposición las mercancías transportadas, que deben estar en las mismas condiciones en las que las recibió al tiempo de su carga, y ello por cuanto la prestación asumida por él -en particular, la obligación de custodia - termina en el momento en que se efectúa la entrega ${ }^{883}$. Es al destinatario a quien va destinada la mercancía objeto del contrato de transporte, de manera que la entrega debe hacerse a quien ostenta la condición de tal, o sea, a quien aparece como consignatario de la mercancía en la carta de porte, si es que se ha expedido, o según lo pactado entre el cargador y transportista sobre quién debe recibir la mercancía. Ya se ha visto que el destinatario designado en la carta de porte puede sustituirse por otro, de forma unilateral por el cargador, mediante el ejercicio del derecho de disposición. En este caso, el cargador deberá comunicar este cambio al transportista e impartirle la orden de entregar la mercancía a otro destinatario distinto del indicado en la carta de porte. En caso de entregar la mercancía a quien no estuviera legitimado para recibirla, el transportista res-

882 E. MAPElli LóPez, Régimen jurídico..., cit., p. 301; F.J. SÁNCHEZ-GAMborino y J. GAITÁN REBOLLO, Factbook..., cit., p. 207.

${ }^{883}$ I. SANCHO GARGALLO, «Transporte marítimo de mercancías en régimen de conocimiento de embarque», en J.L. Concepción Rodríguez (dir.), El contrato de transporte, cit., p. 58. 
ponderá frente al cargador o frente al destinatario designado por la pérdida que ello de ordinario implica 884.

Otras actuaciones del porteador surgen como respuesta frente a ciertos obstáculos que tienen su causa en comportamientos del propio destinatario, o surgen durante el desplazamiento de la carga al lugar de destino: los impedimentos al transporte y para la entrega, a los que ya se ha hecho referencia. En caso de que se presenten, la Ley establece unos procedimientos precisos que han de seguirse por el porteador, un aspecto del nos ocuparemos en los siguientes epígrafes.

La finalidad principal del procedimiento que el porteador debe seguir cuando surgen impedimentos al transporte o a la entrega es permitirle que se libere de su obligación de custodiar las mercancías. A tal efecto, los artículos 31, 32, 36, 40, 44 y 45 LCTTM contienen ciertas previsiones inspiradas, a su vez, en los artículos 13.2, 15 y 16 CMR. Las medidas a seguir pueden considerarse adecuadas al objetivo perseguido y se traducen en: una solicitud de instrucciones al cargador, el depósito de las mercancías y, en su caso, su enajenación en caso de que éstas corran el riesgo de perderse o de sufrir daños (art. 32 LCTTM) 885.

\subsection{La petición de instrucciones al cargador}

La petición de instrucciones al cargador es una de las medidas que tiene que tomar el transportista cuando se encuentra frente a cualquier impedimento. Concretamente, debe ponerse en contacto con el cargador para informarle de los problemas producidos, para que éste, a su vez, pueda impartir las instrucciones oportunas atendiendo a la solicitud del porteador. Su finalidad es la de superar

884 F. JUAN Y MATEU, «La entrega de la mercancía», en A. Emparanza Sobejano y A. Recalde Castells (dirs.), El contrato de transporte internacional de mercancías por ferrocarril, cit., p. 125 .

885 C. GÓRRIZ LÓPEZ, «Algunas consideraciones sobre las novedades de la Ley 15/2009, de 11 de noviembre, del contrato de transporte terrestre de mercancías», en F. Martínez Sanz y $\mathrm{M}^{\mathrm{a}}$.V. Petit Lavall (dirs.), Régimen del transporte en un entorno económico incierto, Marcial Pons, Madrid, 2011, p. 145. 
el obstáculo, sea por la modificación de la consignación o la devolución de las mercancías al lugar de origen (art. 36.1 LCTTM) ${ }^{886}$.

Cabe recordar que el cargador pierde su derecho de disposición una vez que el destinatario se adhiera al contrato de transporte, es decir, desde el momento en que éste declara su aceptación para recibir el envío tras su llegada a destino. De este modo, el destinatario ostentará el derecho de disposición de la mercancía frente al porteador. Pues bien, en caso de que surja un impedimento, el destinatario inicial asume el papel del cargador con respecto a la facultad de dar instrucciones al porteador $u$ ordenarle que entregue las mercancías a otra persona, en su caso, al destinatario final. Se entiende con ello que el destinatario sustituye al cargador y el tercero al destinatario (art. 36.4 LCTTM) ${ }^{887}$.

Recibidas las oportunas instrucciones por parte del cargador o destinatario, el transportista está obligado a cumplirlas, a no ser que sean inejecutables o excedan los límites para el ejercicio del derecho de disposición. Como consecuencia, el incumplimiento de las instrucciones representa una vulneración del contrato de transporte que dará lugar a la responsabilidad del transportista conforme a lo dispuesto en los artículos 30.2 LCTTM y 12.7 CMR. El transportista al que sea imputable la pérdida o avería de la mercancía por no cumplir las instrucciones recibidas para superar el hecho impeditivo del transporte responderá, asimismo, sobre la base de su deber de custodia (ex recepto), conforme a lo dispuesto en los artículos 47 y ss. LCTTM y 17 y ss. CMR 888.

En fin, si solicitadas órdenes al cargador, éstas no fueran recibidas, o no lo fueran en tiempo útil889, el porteador podrá tomar otra de las medidas previstas en la legislación sectorial, concretamente, depositar él mismo las mercancías o encomendar su depósito a un tercero (en cuyo caso sólo responderá de la dili-

886 Véase F.J. SÁnCheZ-GAMbORino y J. GAITÁn REBOlLO, Factbook..., cit., p. 198; así como supra, Cap. III, sub IV.5.a).

887 F. J. SÁNCHEZ-GAMBORINO y J. GAITÁN REBOLlo, Factbook. Transporte..., cit., p. 198.

888 F. JUAN Y MATEU, Los impedimentos..., cit., pp. 80-81.

${ }^{889}$ A este respecto, la cl. 6.6 de las Condiciones generales de 2012, tras reconocer que el plazo para emitir instrucciones puede ser establecido por pacto entre las partes, señala que, «[c]ando nada se hubiese pactado al efecto, el porteador podrá apreciar la falta de instrucciones del cargador si transcurren más de dos horas desde que las solicitó sin haberlas recibido». 
gente elección del depositario), o solicitar el depósito de la mercancía ante una autoridad judicial o ante la Junta Arbitral del Transporte (art. 44.1 LCTTM, al que remite el 36.5 de la Ley).

\subsection{El depósito de las mercancías}

El porteador, según establece el artículo 44 LCTTM $^{890}$, puede depositar él mismo las mercancías, entregarlas a un tercero para su depósito o acudir al depósito judicial o arbitral para descargar las mercancías con ocasión de algún impedimento al transporte o la entrega ${ }^{891}$. La solicitud de depósito judicial o arbitral sólo procede después de agotados los intentos para comunicar con el cargador (o, en su caso, el destinatario), pidiéndole nuevas instrucciones (siempre que ello sea posible), si éstas no se reciben, o no se reciben en el plazo pactado o en el que establece la condición 6.6 de las Condiciones generales de 2012 o, en fin, si las instrucciones recibidas no pudieran ejecutarse por ser de cumplimiento imposible o inexigible (art. 36.5 LCTTM).

Así pues, son tres los supuestos en que el porteador podrá recurrir al depósito judicial o arbitral de las mercancías transportadas, que surtirá los efectos de la entrega, dándose por concluido el transporte ${ }^{892}$. En primer lugar, puede suceder que el porteador no pueda comunicarse con el cargador y que, como consecuencia, no pueda solicitar ni recibir instrucciones. Con todo, parece difícil que, en un mundo interconectado como el en que vivimos, este supuesto pueda aún darse hoy día, pero no debe descartarse esa posibilidad cuando, por ejemplo, un suceso catastrófico interrumpe las comunicaciones. En segundo lugar, el porteador también puede recurrir al depósito judicial cuando transcurra el

\footnotetext{
${ }^{890} \mathrm{El}$ contenido del precepto se reproduce en la cl. 6.6 de las Condiciones generales de 2012, de forma similar a como sucedía en las de 1997, donde la cuestión encontraba su regulación en las cl. 2.31 del Anexo A (transporte de carga completa) y $2.282^{\text {a }}$ del Anexo B (transporte de carga fraccionada).

${ }^{891}$ En el ámbito internacional, la constitución del depósito judicial no aparece regulado en el CMR ni tampoco en las Reglas Uniformes CIM, razón por la cual debe estarse a las normas internas sobre esta cuestión. Así, C. GÓRRIZ LÓPEZ, «Algunas consideraciones...», cit., p. 147.

892 M. BADA DE COMINGES, «Depósito de las mercancías en los supuestos de impedimentos al transporte o a la entrega», en J.F. Duque Domínguez y F. Martínez Sanz (dirs.), A. Emparanza Sobejano y $\mathrm{M}^{\mathrm{a}}$.V. Petit Lavall (coords.), Comentarios a la Ley de Transporte Terrestre, cit., p. 535.
} 
tiempo pactado o un plazo razonable desde la solicitud de instrucciones sin que éstas fueran recibidas ${ }^{893}$. En tercer y último lugar, también procede el depósito si, después de recibidas las instrucciones impartidas por el cargador, éstas resultan inejecutables, bien porque su ejecución es objetivamente imposible o puede dar lugar a un daño en las mercancías, bien porque son inexigibles al exceder de las facultades que corresponden al titular del derecho de disposición ${ }^{894 .}$

Sabido es que el porteador al que se encomienda el transporte de la mercancía asume la responsabilidad por su custodia desde su recepción en origen hasta su entrega en destino. Como consecuencia, en los casos de impedimentos antes señalados, el transportista no puede simplemente descargar las mercancías y abandonarlas mientras se hallan bajo su custodia. Resulta obvio que de ello puede derivar una serie de perjuicios y gastos para el porteador, que se encuentra ante la apremiante necesidad de desembarazarse de la carga ${ }^{895}$. De ahí que se le faculte para depositar las mercancías judicialmente o ante la Junta Arbitral correspondiente, como así lo indica claramente la Ley 15/2009.

Nada se dice, en cambio, en el CMR al respecto, y la ausencia de regulación en el Derecho uniforme del transporte internacional acerca del depósito judicial de la carga constituye una laguna que ha de colmarse con recurso al Derecho nacional. En efecto, al contrario de cuanto sucede en el Derecho interno, los preceptos del CMR no se refieren, ni expresa ni implícitamente, en ningún momento al depósito judicial. Es más, el propio Convenio contiene dos normas aparentemente contradictorias entre sí. Por un lado, los artículos 14.1 y 15.1 CMR obligan al porteador, ante la presencia de impedimentos para la entrega, a solicitar instrucciones al cargador y actuar conforme a éstas. Por otro, ante estos mismos impedimentos al transporte o a la entrega, el artículo 16.2 CMR le faculta para «descargar inmediatamente la mercancía por cuenta del que tenga derecho sobre la misma», custodiándola él mismo o confiándola a un tercero. El análisis en profundidad de la cuestión excede con creces el ámbito del presente estudio y afecta, sobre todo, al cargador. Baste por ello con reproducir las prin-

893 Recuérdese que, de acuerdo con la cl. 6.6 de las Condiciones generales de 2012, este plazo razonable se fija en dos horas a contar desde la solicitud de instrucciones.

894 F. JUAN Y MATEU, Los impedimentos..., cit., pp. 83 y ss.

895 M. BADA DE COMINGES, «Depósito de las mercancías...», cit., p. 535. 
cipales soluciones ofrecidas por parte de la doctrina científica para salvar la contradicción entre el deber del porteador de pedir instrucciones al cargador y el derecho de éste a descargar de modo inmediato las mercancías ${ }^{896 .}$

Por un lado, se afirma que el porteador ostenta un derecho de opción entre solicitar instrucciones al cargador y descargar las mercancías. No obstante, esta interpretación no convence porque no se puede elegir entre un derecho facultativo (descargar) y un deber obligacional (solicitar instrucciones). Por otro, se argumenta que la solicitud de instrucciones y la descarga son procedimientos complementarios que no se excluyen mutuamente. Según esta postura, el porteador podrá descargar las mercancías sin pedir antes órdenes al cargador, lo que le posibilita para recuperar la disponibilidad del vehículo con mayor celeridad. Sin embargo, el hecho de descargar la mercancía no significa que el porteador quede exonerado de su obligación de comunicar e informar posteriormente al cargador y que no deba estar a las instrucciones que reciba de este último (que podrán implicar, por ejemplo, cargar nuevamente la mercancía, entregarla a otro destinatario o devolverla al lugar de origen del transporte). Esta segunda interpretación, sin embargo, es incompatible con lo dispuesto en el artículo 16.2 CMR, a cuyo tenor, "después de esta descarga, el transporte se considerará terminado».

En fin, la propuesta más ponderada parece ser la de conceder prioridad a la obligación de solicitar instrucciones frente al derecho a descargar las mercancías, y ello porque al porteador se le obliga siempre a pedir nuevas órdenes y sólo puede proceder a la descarga como remedio secundario, cuando le es imposible solicitar dichas instrucciones o cuando éstas no le lleguen en tiempo útil o sean irrealizables o inexigibles. Aun siendo esta última postura la más plausible, tampoco está exenta de críticas, pues el artículo 16.2 CMR establece claramente que el porteador puede descargar «inmediatamente» la mercancía, sin hacer referencia a que esta operación de descarga se halle subordinada o sometida a la petición previa de órdenes.

${ }^{896}$ Para un resumen de las distintas posturas puede verse, entre nosotros, F. JUAN Y MATEU, Los impedimentos..., cit., p. 84 y ss. En la doctrina comparada, H. JESSER-HUSS, «Übereinkommen über den Beförderungsvertrag im internationalen Straßengüterverkehr», en Aa.Vv., Münchener Kommentar zum Handelsgesetzbuch, Vol. 7, $3^{\text {a }}$ ed., 2014, pp. 1617 y s. 
Como se decía, esta disyuntiva no se plantea cuando el transporte resulta sujeto a la Ley 15/2009, pues tanto el artículo 31.2 como el artículo 36.5 exigen claramente que el transportista solicite instrucciones al cargador antes de proceder a la adopción de otras medidas distintas, señaladamente, el depósito de la carga. A ello no obsta, a nuestro juicio, el que también el artículo 44.1 LCTTM autoriza al porteador para descargar «inmediatamente» las mercancías por cuenta de quien tenga derecho sobre ellas pues, como se decía, sólo se permite invocar dicho precepto después de agotadas las medidas previstas en los artículos 31 y 36 LCTTM.

\section{a) El depósito judicial y notarial}

El artículo 44 LCTTM reconoce al porteador la facultad de depositar las mercancías transportadas ante un órgano judicial o ante la Junta Arbitral del Transporte competente ${ }^{897}$. Ante la ausencia de controversia litigiosa, resulta evidente que la constitución del depósito se caracteriza por ser un acto de jurisdicción voluntaria ${ }^{898}$. El procedimiento para promover el depósito se hallaba regulado en los artículos 2.119 y ss. de la Ley de Enjuiciamiento Civil de 1881, bajo el título «depósito y reconocimiento de efectos mercantiles», hasta que ésta fue derogada en virtud de la disposición derogatoria única de la Ley 15/2015, de 2 de julio, de la Jurisdicción Voluntaria (en adelante, LJV).

A tenor del artículo 2.119 de la LEC de 1881, el porteador que deseaba proceder al depósito judicial debía solicitárselo formalmente al Juez, describiendo con detalle el depósito solicitado e indicando el depositario, cuya designación, sin embargo, no vinculaba al órgano judicial, sino que se trataba de una simple propuesta que permanecía sujeta a la discreción del Juez, quien decidía teniendo en cuenta los datos sobre el depositario designado ofrecidos por quien hacía el depósito. Para que procediera el acto judicial de depósito, debía avisarse al cargador y al destinatario del procedimiento que, a su vez, podían contestar a

897 R.D. NATERA HIDALGO, Fiscalidad de los contratos civiles y mercantiles, CISS, Bilbao, 2007, p. 1241.

898 Conforme al art. 1.2 de la Ley 15/2015, de 2 de julio, de la Jurisdicción Voluntaria, son actos de jurisdicción voluntaria «todos aquellos que requieran la intervención de un órgano jurisdiccional para la tutela de derechos e intereses en materia de Derecho civil y mercantil, sin que exista controversia que deba sustanciarse en un proceso contencioso". 
la reclamación, presentando las alegaciones y pruebas que considerase oportunas. El juez gozaba de plena discreción para ponderar los hechos que fundamentasen el proceso del depósito y lo justificasen ${ }^{899}$.

Este sistema de depósito judicial de las mercancías regulado en la LEC no era lo suficientemente flexible para las exigencias y el desarrollo del transporte terrestre presente, sobre todo porque el procedimiento ante el órgano judicial, aparte de oneroso, era lento y no llegaba a satisfacer la necesidad del transportista de disponer con prontitud de su vehículo y liberarse de la obligación de custodiar la carga. Por estos motivos los transportistas en España no recurrían al depósito judicial y sí al depósito ante las Juntas Arbitrales, a las que igualmente se refiere el artículo 44 LCTTM y sobre el que se volverá en el epígrafe siguiente, como modalidad alternativa de depósito de las mercancías ${ }^{900}$.

Es más, la actual Ley de Jurisdicción Voluntaria, que vino a derogar la vetusta regulación en la Ley de Enjuiciamiento Civil de 1881, ni siquiera se refiere al depósito judicial de las mercancías transportadas, aunque modifica la Ley del Notariado en el sentido de permitir el depósito ante notario cuando, «por disposición legal o pacto, proceda el depósito de bienes muebles, valores o efectos mercantiles». Este recurso, que se hallaba presente ya en la Ley 14/2014, de 24 de julio, de Navegación Marítima (LNM), se nos antoja adecuado, dada la mayor celeridad que cabe esperar del procedimiento ante el fedatario público. Como más adelante se verá, también en sede de enajenación forzosa de la mercancía para cubrir el precio y los gastos del transporte la Ley se inclina ahora también por la vía notarial y no judicial.

\section{b) El depósito ante las Juntas Arbitrales del transporte}

Las Juntas Arbitrales del Transporte provienen de las antiguas «Juntas de Detasas»901. Son órganos de naturaleza administrativa creados por la Ley de Orde-

899 Sobre el procedimiento anterior de depósito véase F. RAMOS MÉNDEZ, La jurisdicción voluntaria en negocios de comercio, Civitas, Madrid, 1978, p. 61.

900 F. JUAN Y MATEU, Los impedimentos..., cit., p. 88.

${ }^{901}$ Con este término se designaba a las precursoras de las actuales Juntas Arbitrales del Transporte, que fueron creadas en el año 1932, modificándose su régimen en 1938. La intervención de estos órganos fue obligatoria en aquellos conflictos cuya cuantía no superara 
nación de los Transportes Terrestres que, además de la función propiamente arbitral, realizan otras funciones, de entre las que destaca el depósito y, en su caso, la enajenación de mercancías en los casos en que corresponda conforme a la normativa reguladora del contrato de transporte (art. 38.3 LOTT). El marco jurídico de las funciones de depósito y enajenación está contenido en la actualidad, además de en el artículo 6.1.c) ROTT, en la Orden FOM/3386/2010, de 20 de diciembre, por la que se establecen normas para la realización por las Juntas Arbitrales del Transporte de funciones de depósito y enajenación de mercancías. Creadas como un instrumento de protección y defensa de las partes intervinientes en el contrato de transporte terrestre ${ }^{902}$, las Juntas están compuestas por un presidente, como representante de la Administración, y por entre dos y cuatro vocales, designados para representar tanto a las empresas de transporte como a los cargadores, nombrados todos ellos por sus respectivas asociaciones empresariales (art. 8 ROTT) ${ }^{903 .}$

La función fundamental de las Juntas Arbitrales consiste en resolver los litigios de carácter mercantil ocurridos en relación con el cumplimiento de los contratos de transporte terrestre nacional e internacional904 cuando, de común acuerdo, sean sometidas a su conocimiento por las partes intervinientes u otros sujetos que ostenten un interés legítimo (art. 38 LOTT, art. 6.2 ROTT). Siendo cierto lo anterior, no lo es menos que el éxito de las Juntas Arbitrales se explica por la presunción de sometimiento a su jurisdicción que establece el tercer párrafo del artículo 38.1 LOTT, a cuyo tenor «[s]e presumirá que existe el referido acuerdo de sometimiento al arbitraje de las Juntas siempre que la cuantía de la controversia no exceda de 15.ooo euros y ninguna de las partes intervinien-

el límite de las 3.000 pesetas. Vid. L. ORRIOLS AROCAS, Las juntas arbitrales de transporte: Manual práctico, IVET, núm. 7, Valencia, 2002, pp. 13-14.

${ }_{902}$ Sobre este aspecto, L. ORRIOLS AROCAS, Las juntas..., cit., p.13.

903 Cfr. F.J. SÁNCHEZ-GAMBORINO, El contrato de transporte..., cit., p. 310 y ss.

904 La sumisión a arbitraje de los conflictos surgidos de transportes internacionales habrá de respetar lo dispuesto en el art. 33 CMR que obliga, inter alia, a aplicar imperativamente las normas contenidas en el Convenio. A tenor de este precepto, el contrato de transporte puede incluir una cláusula que atribuya competencia a un Tribunal arbitral, siempre y cuando, como se decía, dicha cláusula prevea que el Tribunal arbitral aplique las normas del Convenio. Con detalle sobre esta cuestión, A. PUETZ, «Transporte internacional de mercancías por carretera y sumisión a arbitraje: problemas en la aplicación del art. 33 CMR», Arbitraje, núm. IV-3, 2011, pp. 869 y ss. 
tes en el contrato hubiera manifestado expresamente a la otra su voluntad en contra antes del momento en que debiera haberse iniciado la realización del transporte o actividad contratado».

Al objeto de determinar la competencia territorial de las Juntas Arbitrales y el órgano concreto ante el que debe realizarse el depósito de las mercancías, el Reglamento de la Ley de Ordenación de los Transporte Terrestre declara competente la Junta Arbitral del territorio donde se ubican las mercancías [art. 7.3 con relación con art. $6.1 \mathrm{c}$ ) ROTT]. Por su parte, de conformidad con lo establecido en el artículo 8 de la Orden FOM/3386/2010, el depósito material de los efectos se llevará a cabo en los locales de los que disponga la Junta, es decir, que sean de su propiedad o que tenga arrendados. No obstante, al amparo de un acuerdo o convenio concertado con empresas o entidades públicas o privadas, a cambio de una percepción pecuniaria905, se puede realizar el depósito de las mercancías utilizando los recintos, locales, naves o espacios adecuados de esas empresas o entidades colaboradoras. Incluso puede asumirse el depósito por el propio transportista, responsabilizándose éste de la custodia y conservación de las mercancías (art. $81^{\text {a }}$ de la Orden FOM/3386/2010). En fin, puede denegarse la realización del depósito de las mercancías por falta de locales adecuados para la constitución del mismo (art. 83 de la Orden FOM/3386/2010).

Lo que caracteriza al depósito arbitral es la simplicidad y la ausencia de formalidades especiales ${ }^{906}$, dado que el procedimiento es ágil y tiene lugar ante un órgano profesionalmente experto y especializado en la materia. El procedimiento en sí (pero no el depósito) es gratuito907, y cualquier usuario, cargador,

905 Estas entidades percibirán una remuneración con arreglo a las tarifas, que deberán ser
conformes con los usos comerciales y aceptadas por el Presidente de la Junta, así como el
coste diario del seguro que cubra los distintos riesgos de pérdida o deterioro de las mercan-
cías depositadas (art. $82^{\text {a }}$ de la Orden FOM/3386/2010, de 20 de diciembre).
${ }^{906}$ Lo pone de relieve M. BADA DE COMINGES, «El arbitraje en el transporte terrestre: Las
juntas arbitrales del transporte», en F. Martínez Sanz (dir.) y M ${ }^{a}$.V. Petit Lavall (coord.), I
Congreso Internacional de Transporte: Los retos del transporte en el siglo XXI, T. II,
Tirant lo Blanch, Valencia, 2005, p. 1823 .
907 F. JUAN Y MATEU, Los impedimentos..., cit., p. 90 y ss. Algo similar sucede con la función
propiamente arbitral, donde la intervención de abogado y procurador no es preceptiva,
cualquiera que sea el importe de la reclamación, lo que puede suponer un ahorro relevante.
Así, L. ORRIOLS AROCAS, Las juntas..., cit., p. 36 . Para iniciar el procedimiento arbitral es
suficiente, además, con un simple escrito de reclamación dirigido a la Junta, y un único 
transportista o intermediario que tenga interés en el contrato de transporte puede comparecer ante las Juntas Arbitrales.

En cuanto al procedimiento de depósito de las mercancías ante las Juntas Arbitrales del Transporte, la parte solicitante (esto es, el porteador que promueve el depósito) ha de presentar la correspondiente solicitud mediante escrito dirigido a la junta. La reclamación interpuesta anta la junta arbitral ha de detallar los requisitos necesarios, como son: los datos identificativos del solicitante (nombre o razón social y domicilio) y del destinatario y del cargador (nombre y domicilio), así como la descripción detallada de las mercancías y las características del contrato de transporte celebrado. También debe consignarse todo lo relacionado con el lugar de entrega, pago, plazo del transporte y otros pactos incluidos, así como el motivo por el que se solicita el depósito (art. 5.1 de la Orden). En fin, deberá adjuntarse todas las pruebas o peritajes que tengan relevancia para el asunto en cuestión ${ }^{908}$, en particular, aquellas que acrediten el impedimento al transporte a la entrega, o el impago del precio o de los gastos del transporte (art. 5.2 de la Orden).

Previamente a aceptar la solicitud de cualquier depósito, el Presidente o Secretario de la Junta deberá realizar un examen de las mercancías, comprobando el tipo y las características de las mercancías cuyo depósito se solicita, también su estado de conservación y la concordancia de estos extremos con los que, en su caso, figuren en la carta de porte u otra documentación que se hubiera aportado. Si el estado o las características de las mercancías impiden o desaconsejan su depósito, éste se rechazará (notificándoselo al solicitante), pudiendo incluso destruirse las mercancías cuando se trate de mercancías que se encuentren en mal estado para el uso o consumo. En caso de estimarse necesario, podrá solicitarse previamente informe al órgano de la Administración Pública con competencias relacionadas con la clase de mercancía de que se trate (art. 7 de la Orden).

trámite de vista, rápido y antiformalista, bastará para resolver las reclamaciones planteadas (A. CABRERA CÁNOVAS, Transporte internacional..., cit., p. 145).

908 R. ESCRIG MORENO, «Arbitraje nacional e internacional», en F. Martínez Sanz (dir.) y $\mathrm{M}^{\mathrm{a}}$.V. Petit Lavall (coord.), I Congreso Internacional de Transporte..., T. II, cit., p. 1834; F. JUAN Y MATEU, Los impedimentos..., cit., p. 92. 
Después de la aceptación de la solicitud, el presidente de la Junta dirigirá notificaciones de la solicitud del depósito simultáneamente al cargador y al destinatario, concretando un plazo no superior a diez días para que hagan las alegaciones y pruebas que estimen oportunas para contestar a la reclamación interpuesta. En el supuesto del destinatario, se le indicará en la notificación que, dentro de ese mismo plazo, podrá abonar los portes y gastos de las mercancías recibidas o cuya entrega se pretende. $\mathrm{Y}$ al igual que sucede en el artículo 35.2 LCTTM, también podrá manifestar su aceptación de las mercancías previa constitución de un aval o garantía de los portes y gastos causados (art. 9.1 de la Orden). Con ello parece concederse una suerte de «segunda oportunidad» al destinatario para solicitar la entrega de las mercancías, incluso aunque las hubiera rechazado en un primer momento909.

La resolución de la Junta Arbitral del Transporte sobre la procedencia del depósito de las mercancías deberá adoptarse en el plazo máximo de seis meses desde que se presentó la solicitud (art. 17.1 de la Orden). Ciertamente, este plazo de seis meses para que decida la Junta Arbitral parece demasiado largo y se compadece mal con los intereses del porteador, sobre quien recae la responsabilidad por la custodia y conservación de las mercancías según las reglas establecidas en la propia Ley 15/2009 (art. 44.1 LCTTM) y no en concepto de depositario910, ya que no quedará liberado de dicha obligación de custodia mientras la Junta no haya acordado aún la constitución del depósito911. La resolución tomada por la Junta Arbitral en el ejercicio de las competencias reguladas en la Orden pondrá fin a la vía administrativa, aunque cabe, como no puede ser de otra forma, la interposición de un recurso contencioso-administrativo (art. $172^{\mathrm{a}} \mathrm{de}$ la Orden).

En fin, ningún depósito de las mercancías podrá ser levantado sin autorización expresa del Presidente de la Junta y sin previo pago de los gastos, dere-

909 Así, F. JuAn y Mateu, Los impedimentos..., cit., p. 93.

910 Distinta era la situación bajo el derecho previgente, donde la posición jurídica del porteador que había procedido al depósito de la carga era la de un depositario, de manera que respondía por todos los daños y menoscabos que las cosas depositadas padecieran por alguna imprudencia o malicia por su parte, pero también de los perjuicios causados a las mercancías por culpa de su naturaleza o un vicio de las mismas, si en estos casos no actuó con la diligencia suficiente para evitarlos (art. $2062^{\mathrm{a}} \mathrm{Ccom}$ ).

911 Véase la crítica en F. JUAN y MATEU, Los impedimentos..., cit., p. 93. 
chos y honorarios que se hubieran devengado (art. 11 de la Orden). Es decir, aunque el procedimiento ante la Junta es gratuito, el depósito no lo es ${ }^{912}$, y los gastos correspondientes habrán de ser satisfechos por quien solicite el levantamiento del depósito (que puede ser el propio transportista que lo solicitó, pero también el cargador o el destinatario, pues tienen un «interés legítimo»).

De conformidad con lo dispuesto en el artículo 44 LCTTM, la constitución del depósito de las mercancías surtirá, para el transportista, todos los efectos de la entrega y se dará por finalizado el transporte. Es decir, el depósito es un subrogado de la entrega que produce sus mismos efectos cuando concurren los requisitos previstos en la norma, esto es, cuando su constitución era correcta conforme al régimen jurídico de los impedimentos para (el transporte o) la entrega. De ahí que el porteador quede liberado, desde el momento de la constitución del depósito913, de la obligación de custodia de las mercancías y de su responsabilidad por los daños y perjuicios que las mercancías pudieran sufrir a partir de entonces: el depósito ante la Junta, al igual que la entrega, pone fin al período de responsabilidad del transportista, que se había iniciado con la recepción de la carga en el lugar de origen. Por el contrario, y como se vio, si el porteador procede él mismo al depósito de las mercancías, seguirá respondiendo sobre la base de lo dispuesto en el Capítulo V de la Ley 15/2009, esto es, de conformidad con las reglas sobre la responsabilidad del transportista.

\section{c) Entrega de las mercancías en depósito a un tercero}

El porteador, según el tenor de los artículos 44.1 LCTTM y 16.2 CMR, puede entregar las mercancías en depósito a un tercero. Es otra posible alternativa para la constitución del depósito que se confiere al porteador. En este caso, el porteador sólo asumirá la responsabilidad por culpa in eligendo, esto es, por la

${ }_{912}$ Lo indica claramente el art. 4 de la Orden 3386/2010, cuando señala que «[e]l que promueva la actuación de la Junta deberá responder de todos los gastos causados por el depósito [...], sin perjuicio de su derecho al reintegro».

913 Obsérvese que el porteador sí responde de las pérdidas o averías ocurridas con anterioridad a la constitución del depósito. Al objeto de determinar si los daños existían o no en el momento de su entrega a la Junta, su Presidente queda obligado a comprobar la carga, en particular, "el tipo y las características de las mercancías cuyo depósito se solicita, su estado de conservación y la concordancia de estos extremos con los que, en su caso, consten en la carta de porte u otro documento que se hubiera aportado» (art. 7 de la Orden FOMR/3386/2010). 
elección adecuada del tercero depositario914. Por ello, el porteador que elige descargar las mercancías y entregarlas a un tercero depositario ha de ser razonable y prudente en su elección, debiendo tener en cuenta ciertos datos como, por ejemplo, la reputación y solvencia profesional de este depositario, o la adecuación de sus instalaciones a la naturaleza de las mercancías915. Así pues, el porteador será responsable de su elección y de la prueba del buen estado de las mercancías antes de que proceda a entregarlas al depositario, pero no de las averías y pérdidas que sufran las mercancías mientras se encuentren en poder del depositario. De ellas responde el depositario frente al derechohabiente, con arreglo a las normas de responsabilidad aplicables al depósito de mercancías ${ }^{916}$.

Así, resulta imposible dirigir una reclamación frente al porteador una vez constituido el depósito, a no ser que se trate de una reclamación por la inadecuada elección del depositario. Esta imposibilidad tiene su fundamento en la transmisión del riesgo que provoca la constitución del depósito, que se traslada junto con las mercancías al depositario e implica la responsabilidad de éste por los daños o pérdidas que se ocasionaron en ellas durante el depósito. Por ello, desde ese momento será el depositario quien asuma la custodia de las mercancías depositadas. Sin embargo, a diferencia de cuanto sucede en el depósito judicial o arbitral, el que se efectúe ante un tercero depositario no produce los efectos de la entrega ni de la conclusión del transporte, sino sólo la transmisión del riesgo de pérdida de los efectos depositados ${ }^{917}$.

\subsection{La venta de las mercancías}

Cuando la constitución del depósito no brinde una solución adecuada para resolver el problema causado por las circunstancias que imposibilitan la entrega, el reclamante puede instar, como alternativa al depósito, la enajenación de las mercancías depositadas por la vía judicial o arbitral, siempre y cuando se dé una

914 S. RODRÍGUEZ SÁNCHEZ, «Depósito y enajenación...», cit., p. 243.

915 F.J. SÁNCHEZ-GAMBORINO, El contrato de transporte..., cit., p. 143.

916 M. BADA DE COMINGES, «Depósito de las mercancías...», cit., p. 535.

917 S. RodRÍGUEZ SÁNCHEZ, «Depósito y enajenación...3», cit., p. 243 y 244. 
de las circunstancias determinadas por la Ley 15/2009 en su artículo 44.2, que reproduce de forma casi textual lo establecido en el artículo 16.3 CMR918.

La única diferencia ha de verse en el hecho de que, mientras que el artículo 16.3 CMR le faculta al porteador para proceder a la venta, el artículo 44.2 LCTTM únicamente le permite solicitar del órgano judicial o arbitral la enajenación. Que ello no supone contradicción alguna queda patente si se tiene en cuenta que, a tenor de la norma de conflicto del artículo 16.5 CMR, «[e]l modo de proceder en este caso de venta estará determinado por la ley o la costumbre del lugar donde se encuentra la mercancía». Encontrándose ésta en España, ha de procederse, pues, conforme a lo previsto en el artículo 44.2 LCTTM, que exige la venta judicial o arbitral de la carga.

Conforme a lo previsto en ambos preceptos, el porteador podrá recurrir a la venta de la mercancía ante el órgano judicial y arbitral competente, «sin esperar instrucciones del que tiene derecho sobre la misma, si así lo justifican la naturaleza perecedera o el estado de la mercancía en que se encuentren o si los gastos de custodia son excesivos en relación con su valor». Aparte de tales circunstancias, el porteador podrá también proceder a la venta si en un plazo razonable no recibió, del que ostenta el derecho de disposición sobre la mercancía, las instrucciones solicitadas al objeto de superar el impedimento al transporte o a la entrega que se hubiera presentado.

\section{a) Supuestos en los que procede la venta de las mercancías}

aa) Riesgo de pérdida de la carga por su naturaleza perecedera o por su estado

El porteador puede solicitar la enajenación (o proceder a la venta) ${ }^{119}$ de las mercancías, en primer lugar, si los efectos trasladados son de naturaleza perecedera y se encuentran en un estado que les haga correr el riesgo de perderse (art. 44

${ }^{918}$ Una circunstancia que pone de relieve M. BADA DE COMINGES, «Depósito de las mercancías...», cit., p. 536.

919 Como se decía, el art. 16.3 CMR permite que el transportista venda las mercancías, mientras que el art. 44.2 LCTTM únicamente le faculta para solicitar la enajenación judicial o arbitral. 
LCTTM y 16 CMR). Hay que entender que la venta urgente de las mercancías no procede solamente si hay peligro de que éstas se pierdan, sino también de que sufran averías que comporten una alteración en la sustancia de las mercancías, provocando una disminución de su valor. No son, sin embargo, de naturaleza perecedera aquellas mercancías que experimentan con el paso del tiempo una depreciación en el mercado, pues este hecho por sí sólo no autoriza al porteador para que acuda a la venta de los efectos ${ }^{920}$.

Asimismo, la ley faculta al porteador para recurrir a la enajenación de las mercancías, sin estar obligado a esperar la remisión de instrucciones o que reciba nuevas órdenes del titular del derecho de disposición, cuando el estado de dichas mercancías así lo justifique (art. 44.2 y 16.3 CMR). Queda claro que, en este caso, la normativa no hace referencia a mercancías que se consideran de naturaleza perecedera, sino a aquellas que están amenazadas de deteriorase en un tiempo muy corto por la intervención de ciertos factores accidentales o circunstancias climáticas que pueden dañar las mercancías (como, por ejemplo, cuando se trata de un cargamento de hierro o de acero que, debido al frío o a la humedad, puede oxidarse). Este supuesto implica la existencia de un peligro concreto para la carga y no se justifica por su naturaleza perecedera en sí. También será aconsejable que el porteador acuda a un perito profesional para comprobar y verificar el estado de las mercancías y se provea así de una prueba del estado de las mercancías, para empezar el proceso de venta sin incertidumbres en cuanto al estado de la carga921.

\section{bb) Gastos de custodia desproporcionados}

En segundo lugar, la enajenación inmediata de las mercancías puede promoverse también si los costes de custodia de las mercancías son excesivos en relación a su valor. Ahora bien, ni el Convenio ni tampoco la Ley española ofrecen criterio alguno para determinar cuándo tales gastos son «excesivos». Esta carencia legal abre la puerta a diversas interpretaciones, teniendo en cuenta la diversidad de mercancías a que puede afectar la norma. Sin embargo, como punto de parti-

\footnotetext{
920 S. RodRíGUEZ SÁNCHEZ, «Depósito y enajenación...», cit., p. 241; F. JUAN Y MATEU, Los impedimentos..., cit., p.102.

${ }^{921}$ F.J. SÁNCHEZ-GAMBORINO, El contrato de transporte..., cit., p. 145.
} 
da parece razonable entender que son excesivos los gastos si es dudoso si, una vez ejecutada la enajenación, podrán abonarse los costes a que están afectas las mercancías $^{922}$.

En este caso, será exigible que el porteador haga una comparación de los gastos y ventajas del depósito con los costes y ventajas de la enajenación. Se trata de una valoración aproximada de la rentabilidad de cada una de las posibilidades, de manera que sólo podrá elegir la enajenación si ésta resulta económicamente más favorable que el depósito923.

\section{cc) Falta de instrucciones}

En fin, el porteador puede solicitar la venta de las mercancías si en un plazo razonable no ha recibido instrucciones del sujeto que tiene el derecho a disponer de las mercancías cuya ejecución sea proporcionada a las circunstancias del caso ${ }^{924}$. La aplicación de esta regla, en relación con la que prevén los artículos 36 LCTTM y 15 CMR, presupone que el porteador ya había pedido instrucciones para superar un impedimento para la entrega. Partiendo de esta petición, el porteador estará facultado para solicitar la enajenación o la venta de las mercancías cuando, después de transcurrir un plazo espera razonable según los usos y costumbres comerciales, no ha recibido las instrucciones pedidas ${ }^{925}$.

$\mathrm{Al}$ no establecerse, ni en el Convenio ni en la Ley española, ninguna regla para fijar dicho plazo ${ }^{926}$, dada la diversidad de situaciones que pueden concurrir en la práctica, se propone adoptar el criterio de la razonabilidad, teniendo en cuenta las circunstancias del caso. Este criterio obliga al intérprete a estimar de manera aproximada cuál sería el tiempo máximo que el porteador debe esperar desde el momento en el que haya solicitado las instrucciones ${ }^{927}$. A tal efecto,

922 M. BADA DE COMINGES, «Depósito de las mercancías...», cit., p. 537.

923 F. JUAN Y MATEU, Los impedimentos..., cit., p.104.

924 M. BADA DE COMINGES, «Depósito de las mercancías...», cit., p. 537.

925 F. JUAn y MATEU, Los impedimentos..., cit., p.104.

${ }^{926}$ No resulta de aplicación en esta sede el plazo de dos horas previsto en la cl. 6.6 de las Condiciones generales de 2012, pues como así lo pone de relieve la remisión a la cl. 5.10 del mismo clausulado, la venta no figura entre los remedios contemplados por la norma.

927 F.J. SÁNCHEZ-GAMBORINO, El contrato de transporte..., cit., p. 145; F. JUAN Y MATEU, Los impedimentos..., cit., p.104. 
deberá valorarse todas las circunstancias que afecten al transporte, a las mercancías y al cargador ${ }^{28}$.

Como así se desprende del tenor de la norma, la venta procede no sólo en ausencia de instrucciones, sino también cuando éstas no sean proporcionadas a las circunstancias del caso (art. 44.2 i.f. LCTTM). Se trata, en definitiva, de instrucciones cuya ejecución no puede ser exigida equitativamente del porteador, esto es, cuando el titular del derecho de disposición abusa de su derecho de dar órdenes, de modo que se sobrepasan los límites previstos en los artículos 30.1.b) LCTTM y 12.5 b) CMR929.

\section{b) Venta judicial o notarial}

Como ya hemos señalado con anterioridad, en caso de que el impedimento consista en la negativa del destinatario a satisfacer el precio y los gastos del transporte, el porteador, conforme a lo que le concede el artículo 40.2 LCTTM, tendrá el derecho de retener las mercancías para obtener el pago. Ahora bien, también se advirtió de que no puede simplemente apropiárselas, so pena de incurrir en el hecho ilícito tipificado en el artículo $252 \mathrm{CP}$ (apropiación indebida). Es por ello por lo que el porteador estará obligado a poner las mercancías a disposición de un órgano judicial o de la Junta Arbitral competente para promover la enajenación y satisfacer así su derecho de cobro ${ }^{930}$.

La Ley de Jurisdicción Voluntaria regula el procedimiento de subasta voluntaria en sus Título VII (arts. 108 y ss.). No obstante, puede recurrirse también al expediente de venta notarial, oportunamente introducido en la Ley del Notariado (LN) con ocasión de la entrada en vigor de la Ley 15/2015. El recurso a la venta notarial se justifica desde el momento en que también la Ley 14/2014, de 24 de julio, de Navegación Marítima (LNM) ordena que todos los expedientes de jurisdicción voluntaria en el ámbito del Derecho marítimo se ventilen ante un notario, «a elección de los interesados» (art. 501 LNM). No sorprende, por

${ }_{928}$ M. BADA DE COMINGES, «Depósito de las mercancías...», cit., p. 537.

929 F. JUAN Y MATEU, Los impedimentos..., cit., p. 104.

$93^{\circ}$ F. J. SÁNCHEZ-GAMBORINO y J. GAITÁN REBOLlo, Factbook..., cit., p. 200. 
ello, que el legislador haya optado por esta alternativa también al regular los expedientes de enajenación en ámbitos distintos del marítimo.

Por su parte, la Ley del Notariado obliga, en su artículo 79.3, a proceder «según lo previsto en esta Ley para las actas notariales de subasta». El procedimiento se inicia con una solicitud presentada por el porteador ante el notario, acreditando su legitimación para disponer sobre la mercancía y su valoración para la subasta (art. 73.2 LN). Obsérvese que, según dispone el artículo 40.2 LCTTM, únicamente puede procederse a la venta de aquellas que sean necesarias para cubrir el precio del transporte y los demás gastos. Pues bien, finalizada la subasta de los efectos, que se realizará de forma electrónica (art. $73.12^{\mathrm{a}} \mathrm{LN}$ ), y comprobado que se ha alcanzado el tipo mínimo establecido, con el precio logrado se pagará las cantidades pendientes, debiendo entregarse el remanente al titular de las mercancías.

\section{c) Venta por vía arbitral}

La actuación ante las juntas arbitrales para instar la venta de las mercancías es una opción alternativa que la Ley la concede al porteador cuando se dan las circunstancias pertinentes. Atendiendo a lo que se establece en la norma, el porteador podrá reclamar la enajenación de las mercancías ante estos órganos: a) cuando el porteador hubiera retenido las mercancías por impago del precio del transporte conforme a lo dispuesto en el artículo 40.2 LCTTM, siempre que la solicitud de enajenación se formule dentro de un plazo de diez días desde el momento de la retención; b) cuando se presenten impedimentos al transporte o a la entrega y los gastos de depósito sean excesivos en relación al valor de la carga o el porteador no hubiera recibido instrucciones de quien ostenta el derecho de disposición o éstas no resulten proporcionadas a las circunstancias del caso; y c) cuando las mercancías corrieran el riesgo de perderse o de sufrir daños graves, sin que hubiera tiempo para entregarlas ni para que sus dueños dispusieran de ellas o impartieran instrucciones al respecto (art. 3 de la Orden FOM/3386/2010).

El procedimiento para la enajenación de las mercancías por vía arbitral es el mismo que el que se establece para la constitución de depósito (art. 5.1 de la Orden FOM/3386/2010). De este modo, el porteador deberá solicitar la ena- 
jenación de las mercancías presentando un escrito dirigido a la Junta competente, haciendo constar todos los datos necesarios (identificación del solicitante, del destinatario y del cargador, descripción del envío, el motivo por el que se solicita la enajenación y proposición de las pruebas pertinentes). Dicha solicitud deberá ir acompañada de cualquier documento que acredite los hechos impeditivos del transporte o de la entrega que sirven de base a la pretensión (art. 5.1 de la Orden FOM/3386/2010). También aquí, el Presidente de la Junta someterá las mercancías a un examen para comprobar su estado (art. 7 de la Orden) y, realizado éste, mandará notificaciones de la solicitud interpuesta, incluido el importe reclamado, simultáneamente al cargador y al destinatario, siempre y cuando lo permitan las circunstancias del caso (art. 9 de la Orden FOM/3386/2010). Recibida la notificación, el destinatario podrá manifestar su deseo de recibir las mercancías objeto del transporte, previo pago del precio y los gastos del transporte, o constituyendo aval o garantía al efecto (supuesto al que antes nos hemos referido como «segunda oportunidad» del destinatario).

En respuesta a la solicitud presentada, la junta resolverá proceder o no a la enajenación, previo peritaje de las mercancías si así lo estima necesario el Presidente de la Junta (art. 12.1 de la Orden). Examinando las disposiciones de la Orden FOM/3386/2010, llama la atención el hecho de que se prevén tres modalidades de enajenación diferentes (arts. 13, 14 y 16, en relación con lo que dispone el art. 15):

a) La modalidad principal a través de la cual se efectúa la enajenación de las mercancías, es la subasta, cuyo objetivo es alcanzar el precio más alto posible y que viene regulada detalladamente en el artículo 13 de la misma Orden931. El procedimiento de subasta de las mercancías será determinado por la Junta, y deberá dársele la publicidad que se estime conveniente, que está en función del valor de las mercancías a subastar (art. 13.1)932. La Junta fijará la primera fecha

${ }^{931}$ Véase F. JUAN Y MATEU, Los impedimentos..., cit., p.107.

${ }_{932} \mathrm{El}$ anuncio de subasta se expondrá necesariamente en el tablón de anuncios que, a estos efectos, tenga la Junta en su sede y se enviará, para su difusión, a las instituciones, asociaciones y entidades con interés en la materia. Si el valor previsible a obtener en la licitación lo permitiera, podrán publicarse, además, anuncios en los correspondientes boletines oficiales (art. 13.5 de la Orden FOM/3386/2010). El anuncio de subasta contendrá necesariamente los siguientes extremos: a) Referencia al expediente y al acuerdo de la Junta de enajenar las mercancías depositadas por el procedimiento de subasta pública. b) Descripción 
de la celebración de subasta, que será pública (art. 13.7), con la posibilidad de retomar la subasta en un segundo y tercer intento cuando sea necesario (art. 13.2)933. El acto de subasta comenzará con una descripción detallada de las mercancías y del tipo de licitación (art. 13.7) y finaliza con el pago del precio por parte del rematante, que deberá acreditarse dentro del siguiente día hábil a la celebración de la subasta. El pago sólo podrá realizarse en metálico o por medio de cheques conformados por la entidad financiera librada (art. 13.8)934.

b) La segunda modalidad viene recogida en el artículo 14 de la Orden FOM/3386/2010 como una primera excepción al modelo de subasta, ya que la Junta podrá proceder a la venta directa de las mercancías depositadas cuando concurra alguno de los tres supuestos mencionados en los párrafos a), b) y c) del precepto: cuando por la naturaleza, el estado de conservación de las mercancías o por cualquier otra incidencia ocurrida, no sea posible promover la subasta sin riesgo de que las mercancías se pierdan (párr. a); cuando la subasta hubiera resultado desierta, o cuando el licitador hubiera renunciado a la adjudicación con pérdida, en su caso, de la fianza (párr. b); o cuando el escaso valor de las mercancías en relación con los gastos del procedimiento de subasta desaconsejen promover la subasta correspondiente (párr. c). Esta modalidad se considera la más conveniente para los supuestos de venta urgente, y la Junta deberá proceder a la venta de las mercancías por el precio más alto y en el menor tiempo posible, procurando tomar todas las medidas necesarias para que dicha venta se

sumaria de las mercancías u objetos de que se trata, con su contraseña de identificación, lugar donde se encuentran depositadas y valoración de las mismas. c) Lugar, día y hora de la subasta. d) Tipos de licitación de la subasta. e) En su caso, fianza en metálico que deben depositar los licitadores (art. 13.6 de la Orden FOM/3386/2010).

933 A tenor de lo dispuesto en el art. 13.3 de la Orden FOM/3386/2010, «[e]l tipo de licitación para la primera subasta será el precio de las mercancías fijado en la valoración que al efecto se realice. Para la segunda subasta el tipo de licitación será del 75 por 100 de la primera y para la tercera bastará con que cubra la deuda y los gastos».

934 De no verificarse el pago en la forma y fecha indicadas, el adjudicatario perderá su derecho, así como, en su caso, la cantidad depositada como fianza previa a la licitación. Con el importe del precio de remate, la Junta pagará los gastos soportados por ella como consecuencia de estas actuaciones, los de peritación y las cantidades que, en su caso, se adeuden a las entidades depositarias colaboradoras. Una vez liquidados dichos gastos, pagará las cantidades obtenidas a las personas que tengan acreditado su derecho, según el procedimiento que se haya instado, acordando la consignación del resto (art. 13.8 de la Orden $\mathrm{FOM} / 3386 / 2010)$. 
realice en los diez días hábiles siguientes a aquél en que se adoptó el acuerdo de enajenación935 (art. 14. 2 de la Orden FOM/3386/2010).

Además, la norma añade que la Junta podrá proponer al solicitante de la venta la propiedad de las mercancías cuando el precio ofrecido por el comprador directo sea menor al importe de los gastos y derechos a satisfacer, corriendo por su cuenta los gastos en que se hubiera incurrido. Si el solicitante no responde dentro de los tres días siguientes a la oferta de entrega, se llevará a cabo su venta directa al comprador inicial (art. $14.23^{\text {a }}$ de la Orden FOM/3386/2010).

c) Finalmente, como tercera modalidad y segunda excepción al procedimiento de subasta, también cabe la enajenación por persona o entidad especializada, pública o privada. Tal venta se realiza previa solicitud del solicitante de la enajenación, o a petición del propietario de las mercancías acompañada del consentimiento del solicitante, y cuando las características de las mercancías así lo aconsejen (art. $161^{\text {a }}$ de la Orden FOM/3386/2010). La Junta acordará el plazo máximo para la realización de esta modalidad de enajenación, plazo que no podrá superar los tres meses, y también determinará las condiciones en que deberá llevarse a cabo la enajenación, de modo que pueda conseguirse el mayor precio posible (art. $162^{\mathrm{a}}$ de la Orden).

Las cantidades que se obtengan con la venta por cualquiera de las modalidades mencionadas se reparten de acuerdo con lo dispuesto en el artículo 13.8 o, en su caso, en el artículo 15 (art. $164^{\text {a }}$ de la Orden FOM/3386/2010). En primer lugar, una parte del precio obtenido de la venta corresponderá al pago de los gastos que estas actuaciones hubieran supuesto para la Junta, así como los de peritación y, en su caso, los gastos incurridos por el depósito de las mercancías por entidades depositarias colaboradoras (arts. $13.83^{\text {a }}$ y 15.1). En segundo lugar, tendrán derecho a cobrar aquellas personas que tengan acreditado su derecho (arts. $13.84^{\mathrm{a}}, 15.1$ y $164^{\mathrm{a}}$ de la Orden FOM/3386/2010), esto es, princi-

935 Por lo que se refiere al plazo indicado arriba, se ha dicho que los redactores del precepto no quisieron establecer un plazo menor, ni señalaron la obligatoriedad de cumplirlo, por la razón de que no será siempre posible observarlo. Así, F. JUAN y MATEU, Los impedimentos..., cit., p. 108. 
palmente el porteador, por el importe del precio y los gastos del transporte936, teniendo en cuenta que las mercancías se encuentran especialmente obligadas al pago del precio y demás gastos del transporte conforme a los artículos 37 y 39 LCTTM. Una vez satisfechas las cantidades que correspondan por los conceptos anteriores, la Junta procederá a la consignación del remanente, si lo hubiera (arts. $13.84^{\mathrm{a}}, 15.1$ y $164^{\mathrm{a}}$ de la Orden FOM/3386/2010)937.

Por último, conviene mencionar que, si el precio obtenido en la subasta (a través de alguna de las alternativas de enajenación) no cubre el importe de la deuda por razón del transporte, el porteador podrá reclamar la diferencia del cargador (art. 45 LCTTM) ${ }^{938}$.

\section{Efectos para el destinatario}

\subsection{Aspectos generales}

Una vez realizada la entrega de la mercancía al destinatario por el transportista concluye la operación del transporte. Es la fase última del transporte, que se consuma con la llegada del transportista al lugar de destino y la entrega de los efectos transportados al destinatario, en perfecto estado y dentro del plazo fijado o razonable. En caso contrario, no se podrá afirmar que el transporte se ha efectuado correctamente. En caso de incumplimiento se podrán formular reclamaciones y reservas al transportista por cualquier evento dañoso, pérdida, avería o retraso en relación a la mercancía939. En base a dichas incidencias el destinatario podrá interponer una acción frente al transportista, cuyo ejercicio se halla limitado temporalmente mediante la prescripción.

${ }^{936}$ En caso de que el importe obtenido de la venta directa no alcanzara para cubrir todos los gastos y derechos, se respetará la siguiente prelación en los pagos: a) Los gastos soportados por la Junta Arbitral como consecuencia de estas actuaciones. b) Los derechos y gastos de peritación. c) Los gastos de almacenaje y actividades complementarias a éste. d) El precio y gastos del transporte. e) Las paralizaciones ocasionadas al porteador. f) Otras clases de gastos y derechos (art. 15.2 de la Orden FOM/3386/2010).

937 Véase F. JUAN Y MATEU, Los impedimentos..., cit., pp. 108 y 109.

938 Obsérvese que, a tenor del art. 10.4 ROTT, es el cargador quien responde de la diferencia. Sobre la base de lo dispuesto en la Ley 15/2009, este mismo resultado puede alcanzarse si se tiene en cuenta que «el cargador responderá subsidiariamente en caso de que el destinatario no pague» (art. 37.2 i.f. LCTTM).

939 F.J. SÁNCHEZ-GAMBORINO, El contrato de transporte..., cit., p. 257. 


\subsection{Reservas y reclamaciones}

Ante la ausencia de una definición legal de lo que debe entenderse por «reservas», del contenido de las normas que se refieren a ellas se infiere que son reservas o protestas 940 todas aquellas reclamaciones y observaciones que se realizan en algún momento de la ejecución del transporte, indicando la deficiencia o inadecuación de los elementos a que se refiere la reserva. Principalmente, son dos los sujetos que pueden formular reservas sobre el estado de las mercancías: el transportista y el destinatario, así como, en su caso, los auxiliares que actúen por cuenta de uno u otro941.

En el caso del transportista, por ejemplo942, éste debe efectuar un reconocimiento externo de las mercancías y puede no aceptar la recepción de la carga si descubre que el embalaje de la mercancía es insuficiente o en condiciones inadecuadas (art. 27.1 LCTTM). Si aun así las acepta, conviene que haga constar en la carta de porte o en un documento separado las deficiencias detectadas, para evitar que, finalizado el desplazamiento, se declare su responsabilidad, en

940 Vid. art. 68.2 LCTTM. También la doctrina utiliza indistintamente los términos «protesta», «aviso» y «denuncia», con un significado idéntico al de «reserva». Vid., entre otros, C. GÓRRIZ LÓPEZ, La responsabilidad..., cit., p. 868; A. EMPARANZA SOBEJANO, «Las reservas o protestas en destino en el transporte terrestre y marítimo: contenido y alcance», $R d T$, núm. 1, 2008, pp. 77 y ss.; I. SANCHO GARGALLO, «Transporte marítimo...», cit., p. 58.

941 P. MARTÍNEZ-GiJÓN MACHUCA, «Reservas y reclamaciones en la Ley 15/2009, de 11 de noviembre, del contrato de transporte terrestre de mercancías», $R d T$, núm. 6, 2010, p. 370. Sin embargo, también el cargador parece poder formular reservas en algunos supuestos. Concretamente, éste se puede negar a entregar las mercancías al transportista si considera que el vehículo no es apto para que se carguen en él las mercancías objeto del transporte, y, en todo caso, podrá realizar una anotación sobre las condiciones insuficientes del vehículo que podrían afectar al estado de la carga durante el traslado en la carta de porte (J.F. ÁlvAREZ OCHOA, Transporte internacional de mercancías, Paraninfo, Madrid, 2016, p. 75). En fin, en el ámbito del transporte internacional se le permite al cargador también formular las reservas por retraso (suponiendo que es él quien conoce el plazo en que se entregó las mercancías al transportista y puede conocer exactamente en qué fecha deberían haber sido entregadas en destino), si se entera por el destinatario de que las mercancías no se han puesto a disposición de éste en la fecha indicada. Así, P. MARTínEZ-GIJÓN MACHUCA, «Reservas...», cit., p. 370; A. EMPARANZA SOBEJANO, «Las reservas...», cit., p. 92.

${ }_{942}$ Las reservas del transportista y las consecuencias de su realización o ausencia están reguladas en distintos lugares de la Ley, concretamente, en los arts. 14, 21, 24, 25 y 27 LCTTM. 
defecto de reservas o anotaciones hechas previamente, por las averías y los daños causados por el embalaje inadecuado943.

Finalizado el desplazamiento de las mercancías, y verificada la carga tras su llegada al lugar de destino, el destinatario puede aceptarla sin más o formular reservas, si las mercancías no se corresponden con la descripción de las mercancías realizada por el cargador. En este último caso, mediante la formulación de la reserva el destinatario manifiesta su desacuerdo con el estado de la mercancía (por ejemplo, porque sólo se entrega una parte, o porque presenta averías), cuyo efecto será la modificación del valor probatorio del documento en este extremo944. Y es que la existencia de reservas, aun cuando no constituya una prueba del daño, sí destruye la presunción de que las mercancías se han entregado en el estado descrito en la carta de porte (art. 60.1 i.f. LCTTM).

En efecto, en caso de que se hayan producido incidencias en relación a las mercancías, el destinatario tendrá que manifestar por escrito las oportunas reservas al transportista945, haciendo constar una descripción general de lo sobrevenido. Si las pérdidas o averías pueden descubrirse a simple vista, el destinatario deberá formular las reservas en el momento de la entrega, y si los daños no son aparentes, en los siete días naturales (hábiles en el CMR) siguientes a la en-

943 La obligación (rectius, la carga) del transportista de revisar y comprobar el estado de las mercancías y el contenido de la carta de porte, debiendo en su caso formular las oportunas reservas (justificadas), aparece regulado, a nivel internacional, en el art. 8.2 CMR. En sentido similar, establece el art. 25 LCTTM que el transportista deberá para proceder, en el momento de hacerse cargo de las mercancías, al reconocimiento externo de las mercancías, comprobando «su estado aparente y el de su embalaje, así como la exactitud de las menciones de la carta de porte relativas al número y señales de los bultos». Y sigue estableciendo la norma: «2. Los defectos apreciados se anotarán por el porteador en la carta de porte, mediante la formulación singularizada de reservas suficientemente motivadas. 3. El porteador que carezca de medios adecuados para verificar la coincidencia del número y las señales de los bultos lo hará constar justificadamente en la carta de porte».

944 F.C. LÓPEZ RUEDA, El régimen jurídico..., cit., p. 485.

945 También se puede aceptar las reservas verbales, aunque resultan casi imposibles de probar por el destinatario. Vid. A. EMPARANZA SOBEJANO, «Las reservas...», cit., p. 83; F.J. SÁnCHEZ-GAMBORINO, El contrato de transporte..., cit., p. 264. Ciertamente, el art. 60.1 LCTTM exige que las reservas se manifiesten por escrito, pero también es cierto que idéntica consecuencia se anuda a la prueba por otros medios de que las mercancías no se entregaron en el estado descrito en la carta de porte (la presunción que establece el segundo párrafo del art. 60.1 LCTTM admite prueba en contrario); y aquí es donde podrían tener cabida las reservas verbales. 
trega de la mercancía946. De no hacerlo, se presumirá, como se vio, que las mercancías se entregaron en el estado descrito en la carta de porte, salvo que lo contrario pueda demostrarse por otros medios (art. 60.1 i.f. LCTTM). Sin embargo, en caso de retraso, el derecho a la indemnización estará condicionado a que el destinatario dirija reservas escritas al transportista en un plazo de veintiún días (naturales947) desde el siguiente al de la entrega de las mercancías (art. 30.3 CMR y 60.3 LCTTM). De ello se infiere que el plazo es de caducidad, perdiéndose el derecho al resarcimiento si no se formula reserva en el plazo indicado.

Cabe destacar, con arreglo a lo previsto en los preceptos mencionados, que las reservas deben figurar por escrito, en la propia carta de porte o en cualquier otro documento. A falta de formularse las reservas en los plazos fijados por la Ley (arts. 60.1 LCTTM y 30.1 CMR), ya se ha dicho que se presumirá, salvo prueba en contrario, que el destinatario ha recibido las mercancías en el mismo estado escrito en la carta de porte (arts. 8 y 9 CMR). El objetivo que se persigue con las reservas es eminentemente probatorio, pues desvirtúan la presunción iuris tantum de que dichas mercancías se entregaron correctamente por el transportista en las mismas condiciones y en el estado descrito en el documento de transporte (arts. 60.1 LCTTM y 30.1 CMR) 948 .

En caso de verificación contradictoria -es decir, un examen realizado conjuntamente por el porteador y el destinatario-, las reservas no son necesarias (art. 60.2 LCTTM) ${ }^{949}$, y su resultado sí puede constituir una prueba de que

${ }^{946}$ Véase J.M. RUIZ RoDRÍGUEZ, Transporte de mercancías por carretera: Manual de competencia profesional, Marge Books, 2013, Barcelona, p. 34.

947 Así, J.F. DuQue Domínguez, «Reservas», en id. y F. Martínez Sanz (dirs.), A. Emparanza Sobejano y M $\mathrm{M}^{\mathrm{a}}$.V. Petit Lavall (coords.), Comentarios a la Ley de Transporte Terrestre, cit., p. 713.

948 M. SACRISTÁN REPRESA, «Rechazo de bultos», en J.F. Duque Domínguez y F. Martínez Sanz (dirs.), A. Emparanza Sobejano y $\mathrm{M}^{\mathrm{a}}$.V. Petit Lavall (coords.), Comentarios a la Ley de Transporte Terrestre, cit., p. 345; A. EMPARANZA SOBEJANO, «Las reservas...», cit., p. 80.

949 Del tenor del art. 30.1 CMR se infiere que, por regla general, la verificación o comprobación del estado de las mercancías habría de realizarse bilateralmente, o sea, en presencia del transportista, pues comienza señalando que «si el destinatario recibe la mercancía sin verificar su estado contradictoriamente con el transportista [...]». Vid. F.J. SÁNCHEZGAMBORINO, El contrato de transporte..., cit., p. 258. Además, se añade en el art. 30.2 CMR que «la prueba contraria al resultado de esta verificación no podrá ser realizada más que si se trata de pérdidas o averías no claras y siempre que el destinatario haya dirigido reservas escritas al transportista en el plazo de siete días, descontados los domingos y festivos, a partir de esta constatación». 
el daño fue causado durante el período de responsabilidad del transportista, al contrario de cuanto sucede con las reservas unilaterales formuladas por el destinatario. En efecto, y como se ha tenido ocasión de señalar, estas últimas no constituyen una prueba de que la pérdida o la avería se originó mientras la carga se hallaba bajo la custodia del transporte (piénsese en las averías no manifiestas, donde la reserva puede formularse hasta siete días después de la entrega), de manera que este extremo ha de ser probado por el destinatario950.

Además, las reservas cumplen una función informativa, en el sentido de que sirven para «advertir al transportista» de que podrá ser demandado por el destinatario por los daños sufridos en las mercancías durante su traslado, reclamando la indemnización correspondiente. Esta advertencia da al transportista la oportunidad de recabar las pruebas necesarias que le permitan demostrar que el daño no le es imputable, es decir, que concurre una causa de exoneración de responsabilidad 951.

A partir de aquí, y demostrado que los daños ocurrieron durante el período de responsabilidad del transportista, sobre éste pesa la carga de la prueba de que la pérdida, avería y/o retraso en la entrega de las mercancías no le son imputables, es decir, que son debidos a culpa del cargador o del destinatario (incluidas las instrucciones de éstos no motivados por un acto u omisión negligente del porteador), a un vicio propio de las mercancías o a un hecho inevitable cuyas consecuencias no haya podido impedir (arts. 48.1 LCTTM y 17.2 CMR, que regulan las llamadas «causas ordinarias» de exoneración del porteador); o que concurría un riesgo especial cuya materialización ha podido verosímilmente dar lugar al daño causado a las mercancías (arts. 49.1 LCTTM y 17.4 CMR), esto es, una «presunción» o «causa privilegiada» de exoneración (lo cual es posible sólo en caso de pérdidas o averías, pero no de retraso en la entrega).

De cuanto ha quedado dicho se infiere sin dificultad que el destinatario, cuando detecta en el momento de la entrega algún tipo de anomalía en las mercancías, tendrá el derecho para elegir entre dos opciones: someter la carga a una verificación contradictoria junto con el transportista (arts. 60.2 LCTTM y 30.2

950 Así, JESSER-HuSs, «Übereinkommen...», cit., p. 1804.

${ }^{951}$ A. EMPARANZA SOBEJANO, «Las reservas...», cit., p. 79. 
CMR), que sin duda es la opción preferible, siempre que sea posible (no lo será, de ordinario, en caso de averías o pérdidas no manifiestas); o bien formular una reserva unilateral al porteador o a sus auxiliares, en cuyo caso habrá de aclararse si los daños son aparentes o no952.

Así, cuando se trata de pérdidas o averías manifiestas, que resultan fáciles de descubrir desde el exterior a simple vista953, la formulación de reservas por el destinatario ha de hacerse en el momento de la entrega en destino. Para las reservas establecidas en los artículos 60.1 LCTTM y 30.1 CMR, la descripción de los daños realizada por el destinatario ha de realizarse de forma general, teniendo en cuenta la naturaleza de las mercancías, su carácter peligroso, etc., y que no es necesario que sea extremadamente detallada. No quiere decirse con ello que baste con que la descripción sea muy superficial, sino que ha de proporcionar suficientes datos que permitan al transportista tomar nota con consciencia de lo ocurrido para poder hacerse con las pruebas que le permitan exonerarse de su responsabilidad en caso de que el destinatario le reclame el resarcimiento de los daños causados954. Por último, cabe señalar que las reservas carecen de sentido en caso de pérdida total de la mercancía, ya que no se entrega en destino objeto alguno sobre en el que puedan versar las reservas955.

\subsection{Prescripción de las reclamaciones nacidas del contrato de transporte}

La prescripción constituye una figura jurídica que impone un límite temporal previsto por la Ley al ejercicio de las acciones y reclamaciones, transcurrido el cual se extingue la posibilidad de actuar por un supuesto de incumplimiento956. La reclamación, una vez interpuesta, se desestima automáticamente y queda

$95^{2}$ A. EMPARANZA SOBEJANO, «Las reservas...», cit., p. 81.

953 Los daños en las mercancías pueden detectarse incluso por el oído (por ejemplo, en caso de material frágil que «suena a roto») o a través del tacto (por ejemplo, cuando «el leve peso de un paquete no se corresponde con el del aparato que se dice lleva dentro»). Así, F.J. SÁNCHEZ-GAMBORINO, El contrato de transporte..., cit., p. 263.

954 F.J. SÁNCHEZ-GAMBORINO, El contrato de transporte..., cit., p. 262; A. EMPARANZA SOBEJANO, «Las reservas...», cit., p. 84; C. GÓRRIZ LÓPEZ, La responsabilidad..., cit., p. 868.

955 A. EMPARANZA SOBEJAno, «Las reservas...», cit., p. 79; F.J. SÁNCHEZ-GAMBORINO, El contrato de transporte..., cit., p. 263.

956 J.L. CONCEPCIÓN RODRÍGUEZ, «El transporte internacional...», cit., p. 298. 
archivada por los tribunales, tan pronto sea alegada por el demandante y aceptada por el juez. Por motivos de seguridad jurídica, el ejercicio de las acciones se somete a un plazo de prescripción determinado, para evitar que la acción se halle indefinidamente pendiente y alguien modifique después de mucho tiempo las situaciones jurídicas, por ejemplo, las que deriven de un contrato de transporte957. En efecto, no es asumible que el transportista permanezca sujeto sine die a la eventualidad de ser demandado por el cargador que le había confiado el traslado de sus mercancías (o por el asegurador de la carga que haya indemnizado a a éste) en ejercicio de una acción resarcitoria958. El destinatario, por su parte, adquiere legitimación para reclamar sus derechos frente al transportista con la aceptación de las mercancías y, tratándose de una acción contractual basada en el contrato de transporte, estará también sometido al plazo de prescripción impuesto por la Ley.

La prescripción, como señala EmPARANZA SOBEJANo, busca depurar el ejercicio intempestivo de derechos patrimoniales y es, por ello, una herramienta esencial para garantizar la seguridad jurídica en el tráfico. En el transporte terrestre, precisamente, la función instrumental que cumple dicha institución tiene un mayor protagonismo, dado que la operación de transporte está caracterizada por su elevado dinamismo, que exige resolver a la mayor brevedad cualquier eventual reclamación derivada de él959.

La prescripción de las acciones nacidas del contrato de transporte se halla regulada en los artículos 79 LCTTM y 32 CMR. En ambas normas se establece un único plazo para ejercer las acciones y reclamaciones surgidas del contrato. Este plazo general es de un año, aunque excepcionalmente se alarga en los supuestos expresamente previstos en la Ley. Puesto que se trata de normas de carácter imperativo e inderogable, la duración del plazo no estará sujeto a la voluntad de las partes contratantes y cualquier estipulación en contrario será

957 F.J. SÁNCHEZ-GAMBORINO, El contrato de transporte..., cit., p. 285.

958 J.L. CONCEPCIÓN RODRÍGUEZ, «El transporte internacional...», cit. p. 298.

959 A. EMPARANZA SobEJANO, «La prescripción de las acciones en el Convenio relativo al contrato de transporte internacional de mercancías por carretera (CMR)», RGD, núm.. 579, 1992, p. 11713. 
nula de pleno derecho, en aplicación de los artículos 78 LCTTM en relación con el artículo 6.3 Cc y 41.1 CMR960.

El plazo se amplía excepcionalmente a dos (en el Derecho nacional) y tres años (en el Derecho uniforme) cuando las acciones que se ejercitan tienen su origen en una actuación dolosa del legitimado pasivo, o a) cuando éste haya infringido deliberadamente alguno de los deberes jurídicos asumidos en el contrato de transporte, provocando con tal manera daños que, sin ser directamente queridos, sean consecuencia necesaria de la acción, como así se desprende para el ámbito interno de lo dispuesto en el artículo 79.1 LCTTM961; o b) cuando el porteador haya actuado con culpa equivalente al dolo, para el transporte internacional (art. 29 CMR). La determinación de si existe o no un grado de culpa equivalente al dolo en Derecho español no resulta en absoluto sencilla962 y no puede analizarse aquí. Baste por ello señalar que, ante la apuesta decidida del legislador español de restringir la exclusión del beneficio de limitación de responsabilidad del transportista a los supuestos de causación dolosa (siquiera en grado eventual) del daño, parece razonable entender que no existe tal culpa equiparable en España. Lo que sí es seguro es que, para que sea aplicable el plazo de dos o tres años habrá de demostrarse el nexo causal entre el comportamiento doloso y el daño causado. Así, por poner un ejemplo, el retraso debido a que el transporte ha sido detenido por incumplimiento de la normativa en materia de tiempos de conducción y descanso no parece guardar ninguna conexión causal con los perjuicios causados por una estiba defectuosa.

La calificación de una conducta como dolosa es, en muchas ocasiones, una cuestión que no puede resolverse hasta el final de un litigio, es decir, en la sentencia. En tales casos, no podrá determinarse si la acción está prescrita o no

960 M.F. Clavero TERNERO, «La responsabilidad del transportista...», cit., p. 93; P. MARTÍNEZ-GIJÓN MACHUCA, «Reservas...», cit., p. 381; F.J. SÁNCHEZ-GAMbORINO, El contrato de transporte..., cit., p. 289.

${ }_{961}$ Como puede apreciarse, el art. 79.1 LCTTM reproduce de forma literal lo dispuesto en el art. 62 LCTTM que, como se ha tenido ocasión de señalar, hacer decaer las limitaciones a la responsabilidad del transportista en estos mismos casos, es decir, cuando su comportamiento subjetivo merezca calificarse como directa o eventualmente doloso. Al respecto véase P. MARTínEZ-GIJÓN MACHUCA, «Reservas y reclamaciones...», cit., p. 381.

962 Con detalle sobre la culpa equiparable al dolo en el ámbito del CMR, F.J. SÁNCHEZGAMBORINO, La llamada culpa grave..., cit., pp. 295 y ss. 
en tanto no se produzca el fallo. También puede suceder que el reclamante confía en la existencia de dolo y presenta la demanda antes del transcurso del plazo de dos o tres años señalado en la norma, y que finalmente resulte que Tribunal declare la procedencia de la excepción de prescripción, con la consecuencia de que la demanda en su conjunto será rechazada963.

Una vez determinado el plazo de prescripción, deberá fijarse acto seguido el momento en el que se inicia el cómputo de dicho plazo, esto es, el dies a quo. En el CMR, a este aspecto del cómputo de la prescripción se le ha dado mucha importancia por cuanto es esencial a la hora de aplicar el plazo de prescripción de las acciones, y lo mismo sucede en otros convenios internacionales en la materia, que también regulan con detalle el momento a partir del cual dará comienzo el cómputo de dicho plazo ${ }^{964}$.

El artículo 79.1 LCTTM, al igual que su homólogo en el CMR, determina el inicio del cómputo del plazo dependiendo del caso concreto, esto es, según si se ha producido una pérdida total, una pérdida parcial, una avería o un retraso en la entrega. Esta técnica normativa se emplea, pues, tanto en el ámbito del transporte nacional como en el transporte internacional965 y busca ofrecer una solución legal adecuada al caso concreto, evitando así que se traten todos los casos por igual, ya que el tiempo afecta mucho a la forma en que se ejercita la reclamación.

Esta forma de determinar el dies a quo podría inducir a pensar que hay diferentes plazos de prescripción, cuando este no es el caso. Sucede, sin embargo, hay que tener en cuenta varios factores que influyen en el cómputo, como

963 En similar sentido, F.J. SÁNCHEZ-GAMBORINO, El contrato de transporte..., cit., p. 289.

964 A. EMPARANZA SOBEJANO, «La prescripción de las acciones...», cit., p. 11718. Valga como ejemplo el art. 48.2 RU CIM, a cuyo tenor "[e]l plazo de prescripción correrá: a) para la acción de indemnización por pérdida total: a partir del trigésimo día siguiente al de expiración del plazo de entrega; b) para la acción de indemnización por pérdida parcial, avería o por sobrepasar el plazo de entrega: a partir del día en que hubiera tenido lugar la entrega; c) en todos los demás casos: desde la fecha en que pueda ejercitarse el derecho. El día indicado como punto de partida de la prescripción nunca estará comprendido en el plazo».

965 A. EMPARANZA SOBEJANO, «Artículo 78: carácter imperativo, artículo 79: plazos generales», en J.F. Duque Domínguez y F. Martínez Sanz (dirs.), A. Emparanza y Ma.V. Petit Lavall (coords.), Comentarios a la Ley de Transporte Terrestre, cit., p. 892; ID., «La prescripción de las acciones...», cit., p. 11719. 
también son distintos los supuestos que pueden dar lugar a una reclamación nacida del contrato de transporte. Valga como muestra el siguiente ejemplo. Supongamos que las mercancías deben llegar dentro de un plazo fijado, pero, al finalizar éste, aún no han sido entregadas al destinatario. En este caso, el destinatario desconoce la naturaleza de esta incidencia, es decir, si se trata de un retraso o de una pérdida total y en base a qué dirigir su reclamación indemnizatoria contra el porteador 966 . Por otro lado, tampoco es lo mismo un supuesto de pérdida total, donde nada queda que pueda entregarse al destinatario, y otro de avería, donde las mercancías sí se le entregan, pero en un estado distinto a aquel en que los recibió el porteador. Parece acertada, por ello, la decisión del legislador de establecer un dies a quo distinto para cada supuesto de daño o perjuicio, aun manteniendo idéntico el plazo de prescripción ${ }^{967}$. A lo largo de las siguientes líneas, se van a examinar los diferentes supuestos previstos en los artículos 79.2 LCTTM y 32.1 CMR, ya que en cada uno de estos supuestos el momento en que se inicia el cómputo varía, dependiendo de la naturaleza del hecho que motiva la reclamación: pérdida parcial o total, avería o retraso, u otra acción basada en el contrato de transporte.

\section{a) Supuestos de pérdida parcial, avería de la mercancía y retraso en la entrega}

Al igual que en el Convenio CMR [art. 32.1.a)], también en la LCTTM [art.79.2.a)] se hace referencia, en primer lugar, a aquellas acciones que tienen su origen en la pérdida parcial o avería de las mercancías, o en una demora en la entrega. De conformidad con estas normas, el plazo de prescripción comienza a

\footnotetext{
${ }_{966}$ Recuérdese que el mero transcurso de los plazos previstos en la Ley permite equiparar el retraso a una pérdida total aunque en realidad las mercancías no se han perdido (art. 54.3 LCTTM). En este sentido, como hemos visto anteriormente al analizar el llamado «deje de cuenta», el plazo que establece el art. 54.3 LCTTM para equiparar el retraso a pérdida total es de veinte días desde la fecha convenida para la entrega sin que ésta se haya efectuado cuando exista un pacto sobre el plazo de transporte. En cambio, cuando no se ha fijado ningún plazo para la entrega de las mercancías, el retraso puede equipararse a pérdida total una vez transcurridos treinta días desde que el porteador se hizo cargo de las mercancías.

967 Véase, p.ej., la SAP Valencia (Sección 9a) núm. 89/2009, de 16 de abril (JUR 2009, 258527), en la que se determinó que el plazo de prescripción por impago de los portes empezaba a correr después de la entrega de la mercancía al destinatario porque había un pacto de pago diferido entre las partes. Al respecto, A. EMPARANZA SOBEJANO, «Artículo 78...», cit., p. 892.
} 
contarse desde que se produzca la entrega al destinatario ${ }^{968}$. El criterio que se tiene en cuenta para el inicio del cómputo es, pues, el acto de la entrega de la mercancía al destinatario, razón por la cual, si ésta no se produce (pérdida total), no se aplica el apartado a) de ambos preceptos ${ }^{969}$.

El motivo por el que el legislador ha agrupado estos tres supuestos bajo un mismo apartado radica en la relativa facilidad para determinar el dies a quo: al haber tenido lugar la entrega de las mercancías, se podrá fijar con precisión el momento a partir del cual el plazo de prescripción comenzará a contarse. Y es que en los tres supuestos indicados la entrega ha sido concluida, aun de forma defectuosa, incompleta o con retraso, hechos en base de los cuales el destinatario puede ejercer su derecho de reclamar la indemnización correspondiente 970 . En efecto, la fecha de la entrega es el momento a partir del cual el destinatario puede ejercitar su acción, que es el criterio general fijado en el Código civil para el cómputo de los plazos de prescripción ${ }^{971}$.

De ordinario, dicha fecha no resultará difícil de determinar, pues figurará en el recibo de entrega que tiene derecho a exigir el porteador (art. 12 LCTTM). Puede suceder, sin embargo, que el porteador no entrega directamente las mercancías al destinatario, sino que las consigna a otro sujeto, por ejemplo, una empresa de carga y descarga, que a su vez se compromete a trasladarlas al destinatario. Si este otro sujeto actúa por cuenta del porteador, no hay duda de que la entrega no se produce hasta que la mercancía se ponga a disposición del destinatario designado en el contrato ${ }^{972}$. En caso contrario - esto es, cuando ha sido contratado por el destinatario-, la regla habría de ser también la contraria, pues para el transportista el contrato de transporte ha concluido y no tiene por

968 F.J. SÁNCHEZ-GAMBORINO y J. GAITÁN REBOLlo, Factbook..., cit., p. 213.

969 F.J. SÁNCHEZ-GAMBORINO, El contrato de transporte..., cit., p. 291.

970 A. EMPARANZA SOBEJANO, «Artículo 78...», cit., p. 892-893.

${ }^{971}$ Así, el art. 1.969 Cc, a cuyo tenor «[e]l tiempo para la prescripción de toda clase de acciones, cuando no haya disposición especial que otra cosa determine, se contará desde el día en que pudieron ejercitarse».

972 P. MARTÍNEZ-GiJÓN MACHUCA, «Reservas y reclamaciones...», cit., p. 382. 
qué soportar el riesgo de que, por las razones que fueran, el tercero retrasa la entrega definitiva al destinatario 973.

\section{b) Supuestos de pérdida total de la mercancía}

A diferencia de lo que ocurre en los supuestos arriba indicados, en el caso de pérdida total del envío nada se entrega al destinatario y no resulta tan sencillo identificar el día «en que pudieron ejercitarse» las acciones derivadas del contrato. Así, la razón por la que la pérdida total se regula separadamente de los supuestos de pérdida parcial, avería o retraso, y por la que recibe un tratamiento singular, estriba en el hecho de que no hubo entrega de la mercancía, y se carece de un elemento determinante que sirve como una referencia fija desde de la cual empezar a computar el plazo prescriptivo. Asimismo, la pérdida implica que no se ha alcanzado, ni siquiera parcialmente, el resultado prometido, de modo que se está ante un incumplimiento total de la prestación, a diferencia de los tres casos antes referidos, que se ocupan de un cumplimiento defectuoso del contrato de transporte974.

El legislador no es ajeno a esta cuestión y, por ello, la ha tenido en cuenta al fijar el método de cómputo del plazo de prescripción de la reclamación por pérdidas975, que se determina de la misma manera en el transporte nacional e internacional: con respecto al plazo de entrega, si lo hubiera, y la toma en carga en caso contrario. En lo que ya no coinciden ambas normativas es en el tiempo que debe haber transcurrido desde dichas fechas para que comience a contar la prescripción que, por razones evidentes, es más largo en los desplazamientos transfronterizos. En efecto, mientras que en el transporte internacional el plazo comienza a contar una vez superados los treinta días desde la expiración del plazo de entrega acordado, o sesenta días desde que el porteador se hizo cargo de la mercancía cuando no se ha convenido ningún plazo al respecto [art. 32.1.b) CMR], en el artículo 79.2.b) LCTTM el plazo correrá a partir de los veinte días

973 Por ello, no compartimos la opinión de P. MARTínEZ-GiJÓN MACHUCA, op. y loc. ult. cit., a cuyo juicio ha de estarse al caso concreto, pudiendo adelantarse el dies a quo al momento de la entrega a la empresa de carga y descarga sólo si el destinatario obró de mala fe.

974 A. EMPARANZA SOBEJANO, «La prescripción de las acciones...», cit., p. 11725; ID., «Artículo 78 ...», cit., p. 894.

975 A. EMPARANZA SOBEJANO, «La prescripción de las acciones...», cit., p. 11726. 
después de transcurrir del plazo de entrega convenido, o, en ausencia de pacto sobre el particular, a partir de los treinta días desde el momento en que el porteador se hizo cargo de la mercancía.

En fin, ya se ha visto que la pérdida total no siempre implica la desaparición total o que la mercancía se haya extraviado durante el transporte, que imposibilitaría su entrega al destinatario ${ }^{976}$. Habrá que tener en cuenta, asimismo, aquellos supuestos que se mencionan en el artículo 54 LCTTM como supuestos asimilables y equiparables a dicha pérdida total. Recuérdese que, según el precepto mencionado, son equiparables a la pérdida total aquellos supuestos en que el destinatario se niega a recibir las mercancías cuando le sea entrega tan sólo una parte si prueba su inutilidad sin la parte faltante; cuando las averías ocasionadas a la mercancía obstaculizan su comercialización o la hacen inútil para su consumo; o cuando se haya superado veinte días desde el plazo previsto para la entrega, o cuando transcurran treinta días en ausencia de pacto sobre el plazo del transporte 977 .

En tales casos, cabe plantearse el momento a partir del cual comienza a correr el plazo de prescripción, pues el cálculo difiere en uno y otro supuesto (pérdida total y pérdida parcial, avería o retraso). Pues bien, lo más razonable parece entender que, en los casos en que el destinatario deje las mercancías de cuenta del porteador por averías o pérdidas parciales, el plazo se compute desde el día en que se entregan (parte de) las mercancías (averiadas), pues también aquí existe una referencia temporal clara como es la fecha de entrega. Si el abandono se declara, en cambio, por el retraso excesivo en la entrega, podría dudarse de cuál de los métodos de cálculo habría de emplearse, el previsto para la pérdida total o el que se señala para los retrasos en la entrega. Sin embargo, el problema no puede llegar a plantearse por cuanto (seguramente no de forma casual) los plazos para que comience la prescripción y para poder considerar perdida la mercancía coinciden (20/30 días en el Derecho nacional, 30/60 días en el CMR).

976 F.J. SÁNCHEZ-GAMBORINO, El contrato de transporte..., cit., p. 291.

977 A. EMPARANZA SOBEJANO, «Artículo 78...», cit., p. 893. 


\section{c) Inicio del cómputo en los restantes supuestos de reclamación}

Finalmente, tanto el artículo 79.2.c) LCTTM como el artículo 32.1.c) CMR hacen referencia de forma genérica a «todos los demás casos», es decir, a cualquier otro supuesto de incumplimiento o cumplimiento defectuoso del contrato de transporte que pueda dar lugar a una reclamación por parte, tanto del porteador (p.ej., por impago del precio de transporte), como por parte del destinatario o del cargador. Pues bien, el artículo 79.2.c) establece que, en tales casos, el plazo prescriptivo empezará a correr una vez transcurrido tres meses desde la celebración del contrato de transporte o desde el día en el que la acción pudiera ejercitarse, si fuera posterior978. La regla es la misma que la del artículo 32.1.c) CMR, con la única diferencia de que este último precepto no facilita ninguna orientación acerca de cuáles podrían ser esas otras acciones (de modo que todo lo que no está previsto expresamente en las letras anteriores se incluirá en la letra c)979. Por el contario, el artículo 79.2.c) LCTTM sí enumera -si bien a modo de ejemplo y con carácter no exhaustivo- varios supuestos que tienen cabida en esta norma, como son «la reclamación del precio del transporte, la indemnización por paralizaciones o la derivada de la entrega contra reembolso y de otros gastos de transporte».

Son muchos, pues, los supuestos que pueden englobarse bajo la letra c) como, por ejemplo, la indemnización de los daños ocasionados por el retraso imputable al porteador en la puesta a disposición del vehículo (art. 18.2 LCTTM) ${ }^{980}$, el impago de los portes y gastos ${ }^{981}$, la indemnización por paralización del vehículo (art. 22.1 LCTTM), la indemnización por no haber hecho efectivo el reembolso (art. 42.2 LCTTM), o la debida por el porteador en caso de ejecutar las instrucciones impartidas en ejercicio del derecho de disposición sin haber exigido la presentación del primer ejemplar de la carta de porte (art. 30.2 LCTTM), etc. Se pretende agrupar, así, todos aquellos casos que pueden ser objeto de una reclamación que no sean los que tienen acomodo en los apartados a) y b) de los dos artículos mencionados. Sin embargo, quedarían excluidos de su

\footnotetext{
978 A. EMPARANZA SOBEJANO, «Artículo 78...», cit., p. 894-895.

979 F.J. SÁNCHEZ-GAMBORINO, El contrato de transporte..., cit., p. 292.

980 P. MARTÍNEZ-GiJón MACHUCA, «Reservas y reclamaciones...», cit., pp. 382-383.

981 Vid. la STS núm. 624/2007, de 6 de junio (RJ 2007, 5423).
} 
ámbito de aplicación aquellos otros supuestos que no se corresponden con las obligaciones emanadas del contrato de transporte, tales como el depósito de las mercancías, la formalización de documentos, etc.982, que prescribirán conforme a las reglas correspondientes previstas en el Código de comercio, el Código civil o la normativa sectorial específica.

\section{d) Problemas derivados de la fijación de un único plazo de prescrip-} ción para todas las acciones nacidas del contrato de transporte

Este mecanismo legislativo de unificar los plazos de prescripción con independencia del fundamento de la reclamación presenta indudables ventajas, pero también es cierto que puede lugar a ciertos conflictos, al igual que ya sucedía en el ámbito del artículo $32 \mathrm{CMR}$, precepto que constituye la principal fuente de inspiración para la regulación en la Ley 15/2009.

En primer lugar, la hipótesis de que haya un único plazo prescriptivo aplicado a todos los supuestos da lugar a una disparidad de plazos, puesto que no todos comienzan a correr en el mismo momento, razón por la cual incluso se ha propuesto su uniformización ${ }^{983}$. Ello puede tener consecuencias prácticas por cuanto, en segundo lugar, nada impide que se ventilen en un mismo litigio diversas reclamaciones relacionadas entre sí, por ejemplo, cuando el destinatario reclame por pérdida total de las mercancías frente al porteador, el cual, a su vez, exige del reclamante el pago de los portes ${ }^{984}$. En este caso, el dies a quo no es el mismo para las dos acciones, lo cual puede resultar injusto si, en el momento de interponerse la demanda, una ha prescrito y la otra no, cuando ambas tienen su fundamento en un mismo contrato de transporte. Por último, la remisión genérica al momento en que pueda ejercitarse la acción en los artículos 79.2.c) LCTTM y 32.1.c) CMR puede generar notable inseguridad jurídica, por no de-

982 A. EMPARANZA SOBEJANO, «Artículo 78...», cit., p. 895.

983 Así lo destaca A. EMPARANZA SOBEJANO, «La prescripción de las acciones...», cit., p.11722.

984 F.J. SÁNCHEZ-GAMBORINO, El contrato de transporte..., cit., p. 293; A. EMPARANZA SOBEJANO, «Artículo 78...», cit., p. 895. 
terminarse precisamente el momento en que el derecho a reclamar puede ejercitarse ${ }^{985}$.

Esto último sucede, por ejemplo, a la hora de precisar el momento en que surge la obligación de pago del porte al porteador. Y es que, por un lado, el artículo 39 LCTTM establece que, salvo pacto contrario, «el precio del transporte y los gastos exigibles en virtud de una operación de transporte deberán ser abonados una vez cumplida la obligación de transporte y puestas las mercancías a disposición del destinatario». Por otro, el artículo 41 LCTTM señala que «el obligado al pago del transporte incurrirá en mora en el plazo de treinta días, en los términos previstos en la Ley 3/2004, de 29 de diciembre, por la que se establecen medidas de lucha contra la morosidad en las operaciones comerciales». Lo cierto es que la cuestión no admite fácil solución, pues a tener del primer precepto citado, la obligación de pago vence y es exigible desde el momento en que las mercancías son puestas a disposición del destinatario.

El segundo, por su parte, se refiere en realidad a una cuestión distinta, la mora (y no el vencimiento), mas para ello remite a otra norma, la Ley 3/2004, que, sin duda, regula la mora, pero lo hace en relación al vencimiento (pues a él se anuda la mora). En efecto, a tenor de esta última norma, si no se hubiera pactado plazo para el pago986, la mora (y, con ello, la obligación de satisfacer un interés sobre el importe debido) comienza con el transcurso de «treinta días naturales después de la fecha de recepción de las mercancías o prestación de los servicios, incluso cuando hubiera recibido la factura o solicitud de pago equivalente con anterioridad» (art. 5 en relación con el art. 4.1 de la Ley 3/2004), por ser este el plazo de pago que establece con carácter supletorio la Ley. De ahí la contradicción con lo dispuesto en el artículo 39.1 LCTTM: mientras que éste declara el vencimiento de la obligación de pago en el día de la entrega de las mercancías, la Ley 3/2004 concede un plazo de treinta días a partir

985 A. EMPARANZA SOBEJANO, «Artículo 78...», cit., pp. 895-896.

${ }^{986} \mathrm{Si}$ lo hubiera, habrá de estarse a él, siempre que no exceda de sesenta días naturales, que es el máximo permitido por el art. 4 de la Ley 3/2004. Vencido el plazo pactado, la mora es automática (art. 5), una regla que se corresponde con la que se establece con carácter general para todas las obligaciones mercantiles (art. $63.1^{\circ} \mathrm{Ccom}$ ). 
de esa fecha (momento a partir del cual, como no puede ser de otra forma, comienza la mora, que es automática987).

Pues bien, a efectos de determinar el plazo de prescripción, parece lícito entender que, por regla general, éste comienza a computar a los tres meses desde la celebración del contrato de transporte. Y ello porque, al fijarse en el artículo 1.3 de la Ley 3/2004 un aplazamiento máximo de sesenta días naturales después de la fecha de prestación de los servicios (esto es, la entrega de la mercancía al destinatario) - que sería el momento a partir del cual «la acción pudiera ejercitarse», conforme a lo previsto en el art. 79.2 c) LCTTM-, parece poco probable que con ello vaya a superarse el plazo de tres meses establecido con carácter general en la norma. Lo mismo sucede, con mayor razón, en caso de que no se hubiera pactado un aplazamiento del pago donde, o eso parece, la acción puede ejercitarse desde el momento de la entrega de la carga (art. 39.1 LCTTM), por mucho que la perturbadora referencia en el artículo 41.1 LCTTM pueda llevar a pensar lo contrario 988 .

Además, es posible que se acuerde el abono del precio por semanas o meses, y no por traslado efectuado, hecho que dificulta la concreción del momento a partir del cual surge la obligación de pago. Aun cuando se recomienda que, para evitar esta situación, se pacte expresamente la fecha precisa en que se devenga el pago del porte, ello no siempre es así. Cuando nada se diga al respecto, las normas sobre prescripción - señaladamente, el artículo 79.2.c) LCTTMson poco ilustrativas ${ }^{989}$ y habrá de estarse a las circunstancias de cada caso concreto.

\section{e) Interrupción y suspensión de la prescripción}

Fijando la prescripción como instituto jurídico unos límites temporales al ejercicio de las acciones nacidas del contrato de transporte, puede sin embargo ser interrumpida o suspendida cuando se den ciertas circunstancias que justifiquen

\footnotetext{
987 Así lo establece claramente el art. 5 de la Ley 3/2004, que se refiere tanto a los plazos convencionales como a los legalmente establecidos.

988 Otra opinión en A. EMPARANZA SOBEJANO, «Artículo 78...», cit., p. 896, para quien «no parece que el momento inicial de la acción de reclamación sea el del impago tras la entrega de las mercancías, sino treinta días después».
}

989 A. EMPARANZA SOBEJANO, «Artículo 78...», cit., p. 896. 
que el plazo deje de correr. Ello significa que se alarga el plazo durante el cual al reclamante no se le puede oponer la prescripción para que se desestime o rechace la reclamación formulada990.

El artículo 79.3 LCTTM regula dos formas distintas de paralización de la prescripción. Por un lado, dispone que la prescricpión de las acciones surgidas del contrato «se interrumpirá» por las causas previstas en la legislación mercantil991. Por otro, dispone que la reclamación (extrajudicial) por escrito «suspenderá» el curso de la prescripción hasta que el reclamado rechace la pretensión y devuelva los documentos que la hubiesen acompañado. En este último caso, la paralización que puede sufrir la prescripción hace que se detenga su cómputo, sin perjuicio de que cabe su reanudación una vez desaparecidas las causas que causaron dicha paralización992. Como puede apreciarse, en función de cuál sea el fundamento que motiva la paralización las consecuencias son distintas: la interrupción de la prescripción cuando se dé alguno de los supuestos previstos con carácter general en el Código de comercio; la suspensión en caso de reclamación extrajudicial. Y la diferencia es fundamental, pues mientras que la interrupción tiene por efecto que el plazo vuelva a contar en su integridad, tras la suspensión se «reanuda», es decir, la parte del plazo que ya hubiera transcurrido no se recupera ${ }^{993 .}$

Las «causas señaladas con carácter general para los contratos mercantiles» son las del artículo 944 Ccom, que resultarán de aplicación tanto en al ámbito interno (la LCTTM obliga expresamente a recurrir a él), como en el transporte internacional cuando la demanda se presente en España, por cuanto el CMR prevé en su artículo 32.3 que «la suspensión de la prescripción se regirá por la ley del territorio en el que se ejerce jurisdicción. Lo mismo se aplicará

990 F.J. SÁNCHEZ-GAMBORINO, El contrato de transporte..., cit., p. 294.

991 Véase P. MARTÍNEZ-GIJÓN MACHUCA, «Reservas y reclamaciones...», cit., p.383.

992 A. EMPARANZA SOBEJANO, «La prescripción de las acciones...», cit., p. 11734; ID., «Artículo 78 ...», cit., p. 897.

993 Vide A. EMPARANZA SOBEJANO, «Artículo 78...», cit., p. 898, quien subraya que fue la primera vez que esta forma de paralizar la prescripción se recoge en nuestro ordenamiento, donde la regla general es la interrupción. Hoy día, la suspensión de la prescripción se ordena, p.ej., también en el art. 4 de la Ley 5/2012, de 6 de julio, de mediación en asuntos civiles y mercantiles. 
a la interrupción de la prescripción»994. Pues bien, el artículo 944.1 Ccom señala tres causas que provocan la interrupción (que no la suspensión) de la prescripción. Concretamente, establece que «la prescripción se interrumpirá por la demanda u otro cualquier género de interpelación judicial hecha al deudor; por el reconocimiento de las obligaciones; o por la renovación del documento en que se funde el derecho del acreedor».

La «interpelación judicial» a que se refiere la norma no parece quedar limitada a la demanda judicial, sino habría de incluirse también, en primer lugar, la solicitud de conciliación, regulada en el artículo 141 LJV. La conciliación es un procedimiento de jurisdicción voluntaria que busca una conciliación amistosa, previa al pleito, y que, tratándose de una materia atribuida al Juzgado de lo Mercantil, se celebra ante el Secretario judicial de éste (art. 140 LJV). A los efectos que aquí nos interesan, el artículo 143 LJV señala expresamente que "[l]a presentación con ulterior admisión de la solicitud de conciliación interrumpirá la prescripción». Por el contrario, no interrumpe la prescripción la solicitud de inicio de mediación, pues el artículo 4 de la Ley 5/2012, de 6 de julio, de mediación en asuntos civiles y mercantiles, ordena expresamente la suspensión. En segundo lugar, también cabe preguntarse si interrumpe la prescripción la interposición de una demanda arbitral ante la Junta Arbitral del Transporte995. A nuestro juicio, ello está fuera de toda duda, pues el artículo 9.10 ROTT se remite a «las reglas establecidas en la legislación general de arbitraje» para todas aquellas cuestiones no reguladas en el propio Reglamento y su normativa de desarrollo, y la jurisprudencia atribuye efecto interruptivo a la demanda arbitral formulada al amparo de la Ley 60/2003, de 23 de diciembre, de Arbitraje. Para las reclamaciones en el ámbito del CMR, reconoce este mismo efecto a la reclamación ante la Junta Arbitral del Transporte la SAP Valencia de 13 de noviembre de $2003^{996}$.

994 P. MARTíneZ-GiJón MACHUCA, «Reservas y reclamaciones...», cit., p. 383.

995 Ello era posible con las precedentes Juntas de Detasas, como así lo ha destacado la jurisprudencia [SSTS de 30 de octubre 1971 (RJ 1971, 4520) (non vidi) y de 28 de marzo 1984 (RJ 1984, 1465)]. Al respecto puede verse F.J. SÁNCHEZ-GAMBORINO, El contrato de transporte..., cit., p. 295.

${ }_{996}$ SAP Valencia (Sección 6a) núm. 777/20003, de 13 de noviembre (JUR 2004/100029). 
La novedad más destacable que introduce la Ley 15/2009 en sede de paralización de la prescripción es que esta última se suspenderá por una reclamación extrajudicial. Y merece ser destacada por dos razones. En primer lugar, porque reconoce expresamente que la interpelación extrajudicial paraliza el curso del plazo de prescripción, lo cual no está previsto en el artículo 944 Ccom. Ciertamente, la jurisprudencia había anudado ya idéntico efecto paralizador a la reclamación al margen de un procedimiento judicial, partiendo de la interpretación extensiva hecha por el Tribunal Supremo a la luz del artículo 1973 Cc a partir de su importante sentencia de 4 de diciembre de $1995^{997}$, que ha extendido a los contratos mercantiles el mismo tratamiento que se aplica a los contratos civiles; y lo ha hecho también respecto de las reclamaciones que surgen con ocasión de un contrato de transporte ${ }^{998}$. Pero no está demás que se reconozca legalmente dicho efecto, máxime cuando el artículo 32.2 CMR ya establecía que una «reclamación escrita interrumpe [sic] la prescripción»: si ello es posible en el ámbito internacional, también debería serlo a nivel interno999.

En segundo lugar, se establece claramente que la reclamación extrajudicial no interrumpe la prescripción (con lo que el plazo empezaría a computarse ex novo desde el principio), sino que la suspende, es decir, no se resta eficacia al tiempo ya transcurrido, de modo que el cómputo del plazo prescriptivo se reanuda y no comenzará a contarse nuevamente desde el principio ${ }^{1000}$. La solución legal resulta adecuada, no sólo porque la suspensión resulta, por regla general, más apropiada que la interrupción, que puede llevar a plazos muy largos de prescripción en la práctica, sino también porque esta es la regla que establece el artículo 32.2 CMR. Ciertamente, en la versión española del Convenio se lee

997 STS núm. 1046/1995, de 4 de diciembre (RJ 1995, 9157). Véase también las SsTS núm. 1269/1998, de 31 de diciembre (RJ 1998, 9769); núm. 273/2000, de 21 de marzo (RJ 2000, 2022); núm. 309/2001, de 31 de marzo (RJ 2001, 4780); y núm. 189/2006, de 8 de marzo (RJ 2006, 1074).

998 Entre otras, véase las SsAP Barcelona (Sección 15 ${ }^{\mathrm{a}}$ ) de 15 de marzo de 2000 (AC 2000, 3591); Zaragoza (Sección $4^{\text {a }) ~ n u ́ m . ~ 204 / 2003, ~ d e ~} 7$ de abril (AC 2003, 1232); Granada (Sección $4^{\mathrm{a}}$ ) núm. 378/2004, de 18 de junio (AC 2004, 1327); y Alicante (Sección 6a) núm. 284/2004, de 10 de mayo (JUR 2004, 317610).

999 A. EMPARANZA SOBEJANO, «Artículo 78...», cit., p. 898.

1000 P. MARTÍNEZ-GIJÓN MACHUCA, «Reservas y reclamaciones...», cit., p. 384; A. EMPARANZA SOBEJANO, «La prescripción de las acciones...», cit., p.11735; F. J. SÁNCHEZ-GAMBORINO, El contrato de transporte..., cit., p. 296. 
que «[l]a reclamación escrita interrumpe la prescripción», pero ello no ha sido óbice para que se le reconozca efecto suspensivo y no interruptivo, pues sigue estableciendo el mismo precepto que, en caso de aceptación parcial de la reclamación, «la prescripción no vuelve a tomar su curso más que por la parte reclamada que continúa en litigio»1001.

En cuanto a la forma que debe revestir la reclamación para que suspenda la prescripción, las dos normativas únicamente exigen forma escrita ${ }^{1002}$. Sin embargo, al efecto de preconstituir prueba para un eventual litigio posterior, conviene remitir las reclamaciones por un medio fehaciente como, por ejemplo, una carta certificada, o un fax o un télex ${ }^{1003}$, siempre y cuando sean enviados con acuse de recibo para tener constancia de la llegada de dicha reclamación a su destinatario ${ }^{1004}$. Y es que, como así se desprende de lo dispuesto en el artículo 79.3 i.f. LCTTM, «[l]a prueba de la recepción de la reclamación [...] corresponde a la parte que la invoque».

Para que se reanude el plazo de prescripción, el porteador deberá contestar a la reclamación por escrito y devolver los documentos que acompañaron a aquélla. Conjugando esta regla con el efecto meramente suspensivo de la reclamación, se vislumbra el doble objetivo perseguido por el legislador: por un lado, y como se vio, se evitan los alargamientos excesivos de los plazos de prescripción, ya que éstos no comienzan a correr de nuevo, sino que se reanudan desde donde se habían paralizado; por otro, se anima al porteador para que conteste con celeridad a la reclamación, pues de lo contrario la prescripción quedará indefinidamente suspendida1005. También aquí la prueba de la contestación a la reclamación y la devolución de los documentos corresponde a la parte que la invoque y, en caso de que el reclamado acepte parcialmente la reclamación, el

${ }^{1001}$ Además, ello deriva claramente de las versiones francesa e inglesa, únicas fehacientes, que establecen claramente que «[u]ne réclamation écrite suspend la prescription» y que «[a] written claim shall suspend the period of limitation», respectivamente. Así también, A. EMPARANZA SOBEJANO, "Artículo 78...», cit., p. 898.

${ }^{1002}$ Así, para el CMR, la STS de 15 de noviembre de 1993 (RJ 1993, 8913).

1003 Vid. STS de 29 de abril de 1986 (RJ 1986, 2040).

1004 F.J. SÁNCHEZ-GAMBORINO, El contrato de transporte..., cit., p. 297.

${ }^{1005}$ A. EMPARANZA SOBEJANO, «La prescripción de las acciones...», cit., p.11735; ID., «Artículo 78 ...», cit., p. 898. 
cómputo de la prescripción se reanudará respecto de la parte que sigue siendo litigiosa ${ }^{1006}$.

Por último, conviene poner de relieve que, en caso de que se produzca otra reclamación posterior fundada en las mismas causas que la primera reclamación, no se suspenderá nuevamente el cómputo de la prescripción. Quiere decirse con ello que el efecto paralizador se concede sólo una vez, y si se formula otra reclamación posterior, el plazo prescriptivo seguirá corriendo para evitar que el reclamante, por su única voluntad, pueda evitar indefinidamente la prescripción de su acción ${ }^{1007}$.

\section{f) La prescripción entre porteadores}

Conviene destacar por último que el apartado cuarto del artículo 79 LCTTM aporta otra novedad muy importante al abordar el plazo de la prescripción que se aplicará a las reclamaciones entre porteadores. También aquí el plazo de prescripción es de un año, pero no comienza a correr hasta el día en que se haya dictado laudo arbitral o sentencia firme que fije la indemnización a satisfacer o, en caso de que tal fallo no exista, a partir del día en que el porteador haya efectuado el pago al reclamante.

La importancia de esta novedad radica en el hecho mismo de que se establezca una regla especial sobre el dies a quo del plazo de prescripción para entablar reclamaciones en caso de que hayan participado varios porteadores en la operación de transporte, un tema que siempre ha preocupado tanto las empresas de transporte, como a las compañías de seguros. Se trata de aquellos supuestos en que el acreedor, generalmente el destinatario (o, por subrogación, el asegurador de la carga), dirige una reclamación contra uno de los porteadores intervinientes en la operación de transporte y éste paga la indemnización que corresponde. En ausencia de una regla especial, resultaba en ocasiones que la acción de este porteador había prescrito ya cuando pretendía «repetir» contra al auténtico culpable del daño causado en las mercancías. Y ello porque, al menos en el llamado transporte unitario con subtransporte, la acción del porteador

1006 P. MARTÍNEZ-GiJÓN MACHUCA, «Reservas y reclamaciones...», cit., p.384.

1007 F.J. SÁNCHEZ-GAMBORINO, El contrato de transporte..., cit., p. 303. 
contractual que hubiera satisfecho la indemnización al cargador o destinatario contra el porteador efectivo es, en rigor, una acción de responsabilidad (basada en los artículos 47 y ss. LCTTM o 17 y ss. CMR), que prescribe según las reglas antes anunciadas ${ }^{1008}$.

Para solucionar este problema (que persiste en el ámbito del transporte internacional ${ }^{1009}$ ), el artículo 79.4 LCTTM otorga al porteador que haya satisfecho la indemnización al destinatario, la posibilidad de disponer de un plazo suficiente para accionar contra el porteador responsable, reclamándole el reintegro de la cuantía que había pagado al destinatario en concepto de indemnización. Este plazo particular es independiente para cada porteador, de manera que el plazo comienza a computarse, individualmente y no para todos los porteadores, a partir del momento en que se haya satisfecho la indemnización o se haya dictado el laudo o la sentencia.

Queda patente con ello la enorme relevancia de la norma en la práctica, ya que todas las acciones de reclamación entre porteadores antes estaban sometidas a un único plazo de prescripción, lo que dificultaba mucho el regreso entre porteadores. El modelo del que se sirvió el legislador para corregir esta carencia es el régimen previsto en el CMR para el transporte sucesivo. Como es sabido, los porteadores que intervienen en la ejecución de un transporte de estas características asumen conjuntamente la obligación de transportar ante el cargador o el destinatario. Como consecuencia, el artículo 39.4 CMR establece una regla especial para la determinación del dies a quo de la prescripción de las acciones entre porteadores (el día de la sentencia que fija la indemnización o el pago de ésta), que ha sido generalizado por el legislador español para toda forma de colaboración entre porteadores, incluido el transporte unitario con subtransporte.

En efecto, el artículo 79.4 LCTTM se aplica no sólo al transporte sucesivo, sino también a cualquier otro transporte en el que intervenga más de un portea-

${ }^{1008}$ Con detalle sobre esta cuestión, A. PUETZ, «Legitimación y prescripción en el seguro ‘de transporte': ¿conviene reformar la Ley de Transporte Terrestre y la de Contrato de Seguro?», en L.Ma ${ }^{a}$. Miranda Serrano y J. Pagador López (dirs.), Retos y tendencias del Derecho de la contratación mercantil, Marcial Pons, Madrid, 2017, pp. 754 y ss. (en imprenta).

${ }^{1009}$ En efecto, la regla especial que sobre esta materia contiene el art. 39.4 CMR resulta de aplicación únicamente a los transportes sucesivos, pues forma parte del Capítulo VI del Convenio, que se dedica a este tipo de transporte. 
dor, pues ello deriva de la expresión «entre porteadores»1010. De esta forma, la regla especial indicada en la norma se extiende también a las relaciones entre los intermediarios que intervienen en la contratación del transporte (que, conforme a lo dispuesto en el art. 5.2 LCTTM, sólo pueden contratar el transporte en nombre propio y, por ello, tendrán la consideración de porteadores) y los transportistas por ellos subcontratados, y a las que se establezcan entre los propios mediadores si hubiese varios. Se entiende con ello que, para que el intermediario pueda entablar la reclamación de regreso contra el porteador efectivo, se abre un nuevo plazo de prescripción que permite a aquél formular esta segunda reclamación a partir del momento en que pague la indemnización debida al cargador o destinatario. Como se decía, no existía tal regla con anterioridad a la entrada en vigor de la Ley 15/2009, por lo que únicamente podía invocarse lo dispuesto en el artículo $1.969 \mathrm{Cc}$, a tenor del cual «[e]l tiempo para la prescripción de toda clase de acciones [...] se contará desde el día en que pudieron ejercitarse»1011. Y ello no siempre resultaba eficaz en la práctica pues, como se decía, la reclamación entre porteadores es, en rigor, una acción de responsabilidad que puede ejercitarse desde el momento en que se produce el daño y no una acción de repetición que no pueda interponerse hasta después de pagada la indemnización ${ }^{1012}$.

\section{Cuestiones de legitimación en el contrato de transporte}

Resulta conveniente comenzar el estudio de la legitimación en el contrato de transporte indicando brevemente su significado, porque resulta esencial en el marco de la responsabilidad del porteador conocer y determinar los sujetos que tienen derecho a ejercitar una acción como acreedores de la prestación indemnizatoria por daños y perjuicios (legitimación activa), y también aquellos otros

1010 A. EMPARANZA SOBEJANO, «Artículo 78...», cit., p. 899.

${ }^{1011}$ F.J. SÁNCHEZ-GAMBORINO y J. GAITÁN REBOLLO, Factbook..., cit., p. 215.

${ }^{1012}$ Con todo, la jurisprudencia española no siempre lo ha entendido así, y no es infrecuente encontrar sentencias que acuden al art. 37 CMR (que, al igual que el art. 39.4 CMR al que antes se hizo referencia, resulta de aplicación exclusiva a los transportes sucesivos) para fundamentar la acción de «repetición» contra el porteador causante del daño. En este sentido se expresa, p.ej., la reciente STS núm. 611/2014, de 4 de noviembre (RJ 2015, 9); o las SsAP Barcelona (Sección 15 ${ }^{\mathrm{a}}$ ) núm. 407/2012, de 5 de diciembre (JUR 2013, 74139); y núm. 410/2014, de 17 de diciembre (JUR 2015, 11501). Al respecto, con detalle, A. PUETZ, «Legitimación y prescripción...», cit., p. 755. 
frente a los que puede ejercitarse la acción (legitimación pasiva). En términos generales, la legitimación ad causam se define como aquel interés legítimo para intervenir en un proceso judicial como demandante (legitimado activo) - es decir, la «cualidad de un sujeto consistente en hallarse en la posición que fundamenta jurídicamente el reconocimiento de una pretensión que ejercita»1013-, o aquella capacidad para ser parte demandada (el legitimado pasivo) ${ }^{1014}$.

\section{Legitimación activa}

La legitimación activa es un tema controvertido y no resulta fácil determinar quién puede ejercitar una acción frente al transportista ${ }^{1015}$, pues en los transportes internacionales está sujeta a lo dispuesto en la lex fori o a la consideración legal del tribunal que entiende del fondo de la controversia' ${ }^{1016}$. En efecto, no queda siempre claro a quién se atribuye la facultad de interponer una demanda por los perjuicios sobrevenidos durante el transporte de mercancías. Y ello porque la situación en el transporte terrestre difiere de la que se presenta en el transporte marítimo en régimen de conocimiento de embarque, donde la legitimación activa para exigir el resarcimiento corresponde al poseedor legítimo del documento de transporte ${ }^{1017}$. Frente a esta laguna del Convenio, la determinación de la legitimación activa debe efectuarse conforme a la Ley nacional aplicable, y ésta, en el caso español, señala al acreedor de la obligación de realizar la entrega de las mercancías como legitimado activo, con independencia de que sea, al propio tiempo, su propietario o no ${ }^{1018}$. Por ello, en el contrato de trans-

${ }^{1013}$ SsTS núm. 382/1997, de 8 de mayo (RJ 1997, 3876), y núm. 464/1997, de 30 de mayo. En la doctrina, F. SÁNCHEZ CALERO, El contrato de transporte marítimo de mercancías, $2^{\mathrm{a}}$ ed., Aranzadi, Cizur Menor, 2010, p. 514.

1014 C. GóRriz LóPEZ, La responsabilidad..., cit., p. 153; P. MARTínEZ GONZÁLEZ, El transporte..., cit., p. 189.

1015 F. MarTínez SANZ, Manual...., Vol. II, cit., p. 172.

$1016 \mathrm{Al}$ igual que sucede en el Convenio de Varsovia (véase $\mathrm{M}^{\mathrm{a}}$.V. PETIT LAVALL, La responsabilidad..., cit., p. 158), el CMR no menciona expresamente quién resulta legitimado activo para reclamar en caso de daños a las mercancías o retrasos en la entrega. También en el ámbito interno son frecuentes los litigios en que se plantea la legitimación activa del demandante, como así lo pone de relieve, p.ej., la SAP Valencia (Sección 9ª) núm. 94/2011, de 1 de marzo (JUR 2011, 169758).

1017 J. PUTZEYS, Le contrat..., cit., p. 361.

${ }^{1018} \mathrm{M}^{\mathrm{a}}$.V. PetiT LaVALL, La responsabilidad..., cit., p. 158. 
porte la legitimación puede pertenecer, bien al cargador, bien al destinatario, pues ambos son acreedores de la prestación prometida por el transportista.

En lo que se refiere al destinatario, ya se vio que, en cuanto tercero ajeno al contrato, no puede sin más ejercer los derechos que dimanen del contrato. Ciertamente, una vez finalizado el desplazamiento y puestas las mercancías a disposición del destinatario, éste gozará de un derecho propio para reclamar el cumplimiento de su obligación (y, en su caso, su subrogado, la indemnización). Pero para ello deberá previamente aceptar la estipulación hecha en su favor1019. Debe, por tanto, adherirse al contrato de transporte para convertirse en acreedor de la prestación, lo que sucede cuando adquiere el derecho de disposición sobre las mercancías conforme a lo dispuesto en el artículo 30.3 LCTTM. A partir de ese momento, el destinatario estará legitimado activamente frente al porteador para reclamarle los daños que la mercancía haya sufrido durante su traslado. Y lo será para reclamar los derechos que derivan del contrato de transporte y no del documento de transporte, la carta de porte, pues ésta no se reputa un título-valor.

$\mathrm{Al}$ objeto de considerar que el destinatario se ha adherido efectivamente al contrato de transporte y puede, por ende, reclamar los derechos que derivan de él, el artículo 35 LCTTM establece dos modalidades distintas (que reproducen, de forma prácticamente literal, el contenido del artículo 13 LCTTM, si bien con una importante omisión a la que se hará referencia en el párrafo siguiente). En ambos casos, es fundamental la solicitud por parte del destinatario de la entrega de las mercancías, esto es, la aceptación de la estipulación hecha en su favor. Pero el momento en el cual puede formularse dicha solicitud difiere en función del caso concreto: podrá hacerse en el momento en que las mercancías llegan al lugar previsto para la entrega (que será el caso cuando la mercancía presente averías o se haya producido una pérdida parcial), pero también cuando transcurra el plazo previsto al efecto, esto es, cuando las mercancías hubieran debido llegar (en caso de retraso o pérdida total).

1019 Como consecuencia, resulta lógico entender que el destinatario pierde la facultad de reclamar sus derechos derivados del contrato cuando rehúse la entrega de la mercancía por cualquier motivo. Así, P. SCAPEL, Traité théorique et pratique sur les transports par merterre-eau-air-fer: le destinataire des marchandises, Librairie générale de droit et de jurisprudence, Paris, 1958, p.78. 
A estos supuestos, el artículo 13 CMR añade otro, la pérdida de las mercancías. En efecto, una vez declarada ésta, el destinatario podrá ejercitar los derechos que deriven del contrato de transporte sin necesidad de esperar el transcurso del plazo de entrega (fijado o razonable). La omisión del legislador español, que no ha recogido este supuesto en el artículo 35 LCTTM es criticable, porque no tiene ningún sentido obligar al destinatario a aguardar el fin del plazo de transporte si resulta evidente que no se le va a entregar nada. Ciertamente, el que se obligue a éste a esperar tiene sentido en los demás supuestos, pues si se le permitiese actuar antes de adquirir el derecho de disposición y perderlo el cargador, se podría llegar a perjudicar a éste, quien ya no podría invocar ese mismo derecho de disposición. Pero ello no sucede en los casos de pérdida total, donde el derecho de disposición carece de objeto, al haber desaparecido la carga $^{1020}$. Con todo, no parece que ello vaya a plantear mayores dudas en el transporte nacional, donde las distancias a recorrer son de ordinario más cortas (y, en consecuencia, los plazos más breves) que en el transporte internacional.

Además, y a pesar de la aparente sencillez de la regla enunciada, ya se ha dicho que son frecuentes los problemas a la hora de determinar el sujeto que ostente legitimación activa para reclamar frente al porteador. Por poner un ejemplo, a pesar de ser el destinatario la persona que originariamente ostenta la legitimación, el pago de la indemnización por parte del asegurador de la carga hace que éste se subrogue en los derechos de aquél, adquiriendo legitimación activa para interponer una accionar contra el transportista ${ }^{1021}$ y recuperar la suma que anteriormente abonó al asegurado en concepto de indemnización ${ }^{1022}$.

${ }^{1020} \mathrm{Al}$ respecto véase, con detalle, A. PUETZ, «Derechos del destinatario», en J.F. Duque Domínguez y F. Martínez Sanz (dirs.), A. Emparanza Sobejano y Ma ${ }^{\mathrm{a}}$.V. Petit Lavall (coords.), Comentarios a la Ley de Transporte Terrestre, cit., pp. 438 y ss.

${ }^{1021} \mathrm{M}^{\mathrm{a}}$.P. MARTín CASTRO, El transporte multimodal..., cit., p. 365. En el ordenamiento español, la subrogación también en el ámbito del seguro de transporte se produce de conformidad con lo dispuesto en el art. 43 LCS. Así, C. GÓRRIZ LÓPEZ, La responsabilidad..., cit., p. 194. Con detalle sobre la subrogación del asegurador, $\mathrm{M}^{\mathrm{a}}$.R. ISERN SALVAT, El derecho de subrogación en el seguro de transporte terrestre de mercancías por carretera, Marcial Pons, Madrid, 2013, passim.

${ }^{1022}$ En este sentido, el art. 43 LCS establece lo siguiente: «1. El asegurador, una vez pagada la indemnización podrá ejercitar los derechos y las acciones que por razón del siniestro correspondieran al asegurado frente a las personas responsables del mismo, hasta el límite de la indemnización. 2. El asegurador no podrá ejercitar en perjuicio del asegurado los derechos en que se haya subrogado. El asegurado será responsable de los perjuicios que, 
Asimismo, hay que tener presente, en cuanto a la legitimación activa en el contrato de transporte, que en las compraventas ex works (y, en el transporte marítimo ${ }^{1023}$, también en las ventas FOB) es el destinatario como comprador quien ocupa, al propio tiempo, la posición de cargador. Por su parte, el vendedor, en cuanto expedidor, se limita a dejar las mercancías a disposición del comprador en sus almacenes (o en el lugar fijado donde debe entregarlas), para que puedan ser recogidas por el transportista designado en virtud del contrato de transporte firmado con el comprador-destinatario. Así, el vendedorexpedidor no tiene ningún vínculo contractual con el transportista o el destinatario, más allá del contrato de compraventa que únicamente le liga a este último. De ello se infiere que no puede ser legitimado activamente con respecto a un

con sus actos u omisiones, pueda causar al asegurador en su derecho a subrogarse». De ello se infiere que existe un doble límite por lo que se refiere al derecho en que se subroga: uno cuantitativo, que es el importe de la indemnización satisfecha al asegurado, y otro cualitativo, en el sentido de que el ejercicio de la subrogación por el asegurador está condicionado a que no sea realizado en perjuicio del asegurado. Vid. S. MUÑOZ SÁNCHEZ, «Algunas consideraciones en materia de legitimación activa en el transporte terrestre -nacional e internacional», en F. Martínez Sanz (dir.) y Mª.V. Petit Lavall (coord.), I Congreso Internacional de Transporte..., T. I, cit., p. 935.

1023 Otra complicación en relación con la legitimación activa se presenta frecuentemente en la práctica marítima y multimodal. En la medida en que solamente se se halla legitimado quien está designado como consignatario en el documento de transporte -marítimo (conocimiento de embarque) o multimodal (DTM)-, ello puede dar lugar a problemas cuando el destinatario real no es el poseedor del documento de transporte o el destinatario último de las mercancías. Así, es conveniente hacer una clara distinción entre la titularidad formal y la titularidad sustantiva del derecho de crédito (así, J.Ma ${ }^{\mathrm{a}}$. RUIz SOROA, «Problemas de legitimación en la acción de resarcimiento por averías y faltas en el transporte marítimo», $A D M$, vol. I, 1981, p. 234). Tales supuestos podrán generarse cuando el destinatario real no se haya designado en el DTM, lo que puede impedirle el ejercicio de la acción contra el operador de transporte multimodal (o sea, el transportista contractual). La situación se agrava en presencia de un seguro, por cuanto la legitimación activa del asegurador se adquiere por subrogación de éste en la posición del destinatario. En consecuencia, el destinatario real no puede transmitirle al asegurador la legitimación activa porque no la tiene, y así pierde el derecho de reclamar contra el transportista para obtener la indemnización. Para evitar que se complique el ejercicio de la acción de resarcimiento, y que ello redunde en beneficio del transportista, sería exigible que el destinatario formalmente legitimado ceda el derecho de crédito a la entrega al destinatario real de las mercancías o a su asegurador. La doctrina se ha pronunciado respecto de los supuestos en que el endosatario formalmente legitimado sea sólo un agente o mandatario del destinatario real, declarando la legitimación del destinatario real para poder accionar frente al porteador aun cuando no figure en el contrato de transporte. Al respecto véase $\mathrm{M}^{\mathrm{a}}$.P. MARTín CASTRO, El transporte multimodal..., cit., p. 366. 
derecho que proviene del contrato de transporte, simplemente porque no fue parte en su celebración ${ }^{1024}$.

No estará legitimado tampoco quien ejercita un derecho basado en otro título distinto, como por ejemplo la compraventa o la propiedad de las mercancías, porque la causa de la obligación del porteador es únicamente el contrato de transporte, en virtud del cual se obliga a transportar y entregar las mercancías al destinatario ${ }^{1025}$. Ello no impide, como es natural, que el propietario pueda ejercitar una acción de daños contra el transportista, pero ésta será de naturaleza extracontractual (art. $1.902 \mathrm{Cc}$ ), salvo que ocupe la posición de cargador o de destinatario en el contrato de transporte.

En fin, tampoco ostenta legitimación activa aquel destinatario que, después de realizado el desplazamiento y llegadas las mercancías a su destino, rehúse la entrega de éstas. En este caso, el cargador no pierde su derecho de disposición (y puede ejercitarlo sin necesidad de presentar el primer ejemplar de la carta de porte: art. 15.1 CMR) y el destinatario no lo adquiere, de manera que será aquél quien, en su caso, resultará legitimado para reclamar la indemnización de los daños y perjuicios causados.

Una última duda que conviene es despejar es la posible doble legitimación de cargador y destinatario. Como es sabido, el destinatario adquiere dicha legitimación cuando el cargador pierde su facultad de disponer de las mercancías. Como quiera que el derecho de disposición no puede pertenecer simultáneamente al cargador y al destinatario, es lugar común señalar que también la legitimación activa sólo puede corresponder a uno u otro, pero no a ambos a la vez. Es decir, que la legitimación, que el cargador sin duda ostenta por ser contraparte del porteador en el contrato de transporte, se transfiere al destinatario junto con el derecho de disposición, razón por la cual, se dice, no es posible la doble legitimación ${ }^{1026}$, con lo que pretende protegerse al porteador frente al

$1024 \mathrm{Al}$ respecto puede verse, por ejemplo, D. BOYERAS SCHUMANN, La compraventa internacional de mercancías: la modalidad FOB, cit., p. 159

1025 R. Beses Miguel y Mª.D. BeSEs Miguel, Transporte..., cit., p. 424.

${ }^{1026}$ Este supuesto de la doble legitimación activa de cargador y destinatario sí se reconoce en otros ordenamientos, señaladamente el alemán (§ 421.1 HGB), pero también en otros países europeos, como Holanda, Bélgica, Francia e Inglaterra. Lo pone de relieve A. PUETZ, «Derechos y obligaciones del destinatario en la Ley del Contrato de Transporte Terrestre de 
riesgo de tener que indemnizar doblemente los perjuicios ocasionados en las mercancías trasladadas ${ }^{1027}$. Sin embargo, también existen voces en la doctrina que abogan por permitir la doble legitimación del destinatario y del cargador, de manera que éste permanecerá legitimado para formular la pretensión resarcitoria aun a pesar de haberla adquirido aquél ${ }^{1028}$. Al margen de razones basadas en la teoría general de los contratos a favor de tercero (al cargador debería serle posible, no sólo reclamar los daños que a él mismo se le han causado, sino también el cumplimiento de la estipulación hecha a favor del tercero, el destinatario), se aduce también que no existe tal riesgo de doble pago, por ser ambos acreedores solidarios (arts. 1.137, 1.140, 1.142 y $1.1432^{\mathrm{a}} \mathrm{Cc}$ ).

\section{Legitimación pasiva}

\subsection{Aspectos generales}

Como se ha dicho, la legitimación pasiva señala la persona frente a la que debe ejercitarse la reclamación, de manera que su determinación resulta fundamental cuando el destinatario quiera hacer valer sus derechos que deriven del contrato de transporte. Pues bien, según la regulación del contrato de transporte contenida en el CMR y en la legislación positiva española, la legitimación pasiva para el ejercicio de la acción de indemnización corresponderá al transportista que había celebrado con el cargador el contrato de transporte de las mercancías (porteador contractual), asumiendo con ello la responsabilidad por la realización íntegra del traslado y la de entregar la mercancía en el mismo estado en que se recibió en origen ${ }^{1029}$. En el mismo sentido, el artículo 6 en relación con los artículos 47 y 4.2 LCTTM imputa al transportista contractual la responsabilidad por incumplimiento o cumplimiento defectuoso del contrato, sin perjuicio de su derecho a regresar contra el transportista efectivo (art. 6.2 LCTTM) o el resto de los participantes en un transporte sucesivo (art. 65 LCTTM) que, cuan-

Mercancías», en F. Martínez Sanz y Ma ${ }^{\mathrm{a}}$.V. Petit Lavall (dirs.), Régimen del transporte en un entorno económico incierto, Marcial Pons, Madrid, 2011, p. 228.

1027 F. MARTínez SANZ, Manual..., Vol. II, cit., p. 172; V. BELlido CAMBrón, «El contrato de transporte internacional de mercancías por carretea», IberoForo-Castellón, p. 1.

1028 A. PUETZ, «Derechos y obligaciones...», cit., p. 229.

1029 C. GÓRRIZ LÓPEZ, La responsabilidad..., cit., p. 209. 
do el daño les sea imputable, habrán de hacer frente al pago o al reintegro, según los casos, de la indemnización.

De ello se infiere sin dificultad que la legitimación pasiva se otorga en primer lugar al transportista que contrató con el cargador la ejecución del transporte, ya sea empleando sus propios medios, o subcontratando, a su vez, la totalidad o parte del transporte con otros transportistas (art. 6 LCTTM) ${ }^{1030}$. Menos diáfana se plantea la cuestión acerca de la legitimación pasiva de otros sujetos intervinientes en el transporte, esto es, los dependientes del transportista y el transportista efectivo o subcontratado, así como, aun tratándose de un supuesto escasamente utilizado en la práctica, a los distintos transportistas que participen en un transporte sucesivo.

En cuanto a la legitimación pasiva del porteador efectivo, es habitual en la práctica que el transportista contractual subcontrata con otros transportistas, encomendándoles la realización efectiva de una parte o de la totalidad del transporte (art. 6 LCTTM). Estos subtransportistas tendrán la calificación de auxiliares (independientes) del porteador contractual, y lo mismo se aplica a los auxiliares de estos subtransportistas, cuando tales auxiliares se encargaron de realizar el transporte en interés de aquéllos ${ }^{1031}$, y el transportista que hubiera celebrado el contrato con el cargador responde de los actos y omisiones de todos ellos (arts. 47.3 LCTTM y 3 CMR). Ciertamente, ello no impide que el reclamante perjudicado pueda dirigir su reclamación por vía extracontractual contra los auxiliares de aquél, entre ellos el conductor y el o los subtransportista en virtud del principio neminem laedere consagrado en el artículo $1902 \mathrm{Cc}$, cuando éstos hayan causado los daños en las mercancías de forma culposa o negligente ${ }^{1032}$. Pero el régimen de responsabilidad será el que resulte de la propia Ley 15/2009, y no el previsto con carácter general en el Código civil (art. 63 LCTTM). Y ello

${ }^{1030}$ A. PUETZ, «Derechos y obligaciones...», cit., pp. 230 y ss.

${ }^{1031}$ A. PUETZ, «Supuestos...», cit., p. 573.

${ }^{1032}$ En este sentido véase, p.ej., las SsAP Álava (Sección $1^{\text {a }}$ ) núm. 305/2000, de 19 de julio (AC 2000, 2208); SAP Valencia (Sección 11 a) núm. 550/2003, de 29 de septiembre (AC 2003, 2023). La reclamación a estos auxiliares viene justificada por ser quienes materialmente causaron los daños a las mercancías objeto de la reclamación. Así, A. EMPARANZA SOBEJANO, "Aplicación del régimen de responsabilidad a las diversas acciones», en J.F. Duque Domínguez y F. Martínez Sanz (dirs.), A. Emparanza Sobejano y Ma.V. Petit Lavall (coords.), Comentarios a la Ley de Transporte Terrestre, cit., p. 756. 
para que no pueda esquivarse el régimen jurídico contractual de responsabilidad consignado en la Ley, en particular, las limitaciones cuantitativas a la responsabilidad previstas en el artículo 57 LCTTM1033.

En fin, también cabe, a nuestro juicio, que el destinatario dirija una acción contractual contra aquel transportista efectivo que le haya entregado o deba entregarle la mercancía en el lugar de destino. Y ello porque el subcontrato de transporte no deja de ser un contrato de transporte típico (esto es, un contrato a favor de tercero), en el que el transportista contractual ocupa la posición del cargador (art. 6.2 LCTTM) ${ }^{1034}$ y el destinatario la del tercero beneficiado por la estipulación. Si ello es así, nada debería obstar para que el destinatario reclame, no sólo la entrega, sino también la indemnización de los daños y perjuicios causados del subporteador sobre la base de ese subcontrato.

\subsection{La legitimación pasiva en el contrato de transporte sucesivo}

En su artículo 34, el CMR define una modalidad particular de transporte, el llamado «transporte sucesivo», al establecer que, «[s]i un transporte sometido a un solo contrato es ejecutado por sucesivos transportistas por carretera, cada uno de éstos asumirá la responsabilidad por la ejecución del transporte total». A renglón seguido, dispone que «[e]l segundo transportista y cada uno de los siguientes se obligan por la mera aceptación de la carta de porte». A pesar de su gran similitud con el transporte unitario con subtransporte al que antes se hizo referencia, se trata de dos modalidades bien distintas, pues en éste el segundo y sucesivos transportistas no se adhieren al contrato de transporte original, sino que cada uno de ellos actúa sobre la base de un contrato distinto, el subcontrato de transporte. A pesar de que también la Ley 15/2009 se hace eco del transporte sucesivo y le dedica una regulación somera en los artículos 64 a

1033 A. EmParanza SobeJANO, «Aplicación del régimen de responsabilidad...», cit., pp. 761 y s.

1034 Así, para el CMR, A. EMPARANZA SOBEJANO, «Cuestiones de legitimación activa y pasiva en el Convenio de Transporte Internacional de Mercancías por Carretera», en F. Martínez (dir.), Problemas en la aplicación del CMR. Especial referencia a la responsabilidad, Fundación Francisco Corell, Madrid, 2002, pp. 37 y s.; para la LCTTM, A. PUETZ, «Derechos del destinatario», cit., p. 445. Contra, por entender que la subcontratación agota sus efectos en la relación interna entre porteador y subtransportista, A. SÁNCHEZ ANDRÉS, «El transporte combinado de mercancías», RDM, núms. 135-136, 1975, p. 56; A. DÍAZ MORENO, «El contrato...», cit., p. 635 . 
66, es escasamente utilizado en la práctica, donde predomina claramente el transporte con subtransporte ${ }^{1035}$. Es por ello por lo que, por regla general, el destinatario no podrá reclamar sobre la base de estos preceptos, aunque -como seguidamente se verá- resultan mucho más favorables para sus intereses.

Pues bien, los artículos 65 LCTTM y 36 CMR regulan con carácter exhaustivo la legitimación pasiva en el caso de transporte sucesivo. Siguiendo su tenor, la determinación del transportista frente al que puede interponerse la pretensión resarcitoria resulta sencilla en esta modalidad de transporte, ya que la legitimación pasiva se confiere, simultáneamente, al primer porteador, al último o a aquel que haya realizado la parte del trayecto en cuyo curso ocurrió el hecho que motiva la reclamación. Tratándose de un supuesto de responsabilidad cuasi-solidaria (art. 64.1 LCTTM) ${ }^{1036}$, no sorprende que la acción pueda presentarse contra uno o contra varios de los sujetos mencionados a la vez, sin perjuicio de que, una vez interpuesta la acción contra alguno de ellos, ya no se podrá dirigir contra los demás.

Centrándonos en el contenido regulador de los artículos 65 LCTTM y 36 CMR, el «primer transportista» al que se refieren estos preceptos es aquel que ha contratado con el cargador, por lo que la acción contra él es siempre posible ${ }^{1037}$. A este efecto, resulta indiferente que participe en la ejecución material del transporte o no, pues es indudablemente parte en el contrato. Por su parte, también resulta posible demandar a aquel transportista que tuviera encomendada la realización del trayecto en que se originaron los daños, anticipando así el resultado de la liquidación interna del daño entre porteadores [art. 66.1.a)

1035 Como razón fundamental se aduce, además de la aversión de los transportistas a obligarse solidariamente frente al acreedor del transporte, el deseo de no desvelar a los porteadores sucesivas en una cadena de transporte el precio y las demás condiciones del transporte, lo cual sería irremediablemente el caso si el contrato fuera el mismo para todos ellos. Vide, en lugar de muchos, A. ZURIMENDI ISLA, «Contrato con porteadores sucesivos», en J.F. Duque Domínguez y F. Martínez Sanz (dirs.), A. Emparanza Sobejano y Ma.V. Petit Lavall (coords.), Comentarios a la Ley de Transporte Terrestre, cit., p. 766.

${ }^{1036}$ Advierte A. ZuRIMENDI IsLA, «Ejercicio de reclamaciones», en J.F. Duque Domínguez y F. Martínez Sanz (dirs.), A. Emparanza Sobejano y $\mathrm{M}^{\mathrm{a}}$.V. Petit Lavall (coords.), Comentarios a la Ley de Transporte Terrestre, cit., pp. 778 y s., de que no se está en rigor ante un supuesto de responsabilidad solidaria en sentido técnico, pues -como seguidamente se indicará- no se puede reclamar a todos los deudores a la vez, sino sólo a los que señala el art. 65 LCTTM.

1037 F.J. SÁNCHEZ-GAMBORINO, El contrato de transporte..., cit., p. 324. 
LCTTM]. Sin embargo, en ocasiones resulta difícil identificar al porteador causante del daño, por lo que raras veces la demanda se dirigirá contra él1038. En fin, con base en la consideración de que el transportista que más cercano le resulta al destinatario es el último, la acción puede dirigirse también contra él. No obstante, el «último transportista» según los preceptos antes indicados no será el que, según el plan inicial del viaje, hubiera debido entregar la mercancía en destino, sino el último transportista que haya llegado a adherirse al contrato, tras haber aceptado la entrega de las mercancías y de la carta de porte ${ }^{1039}$. Por ello, en caso de pérdida de la mercancía, el último en transportar la mercancía se convierte en último transportista sucesivo.

Desde un punto de vista práctico, resulta conveniente dirigir la acción contra el primer transportista o contra el último, pues no es necesario probar que el daño les sea imputable. En efecto, al cargador le resultará más fácil dirigirse contra el primer transportista, puesto que es con quien ha concluido el contrato de transporte. En el caso del destinatario sucede lo contrario, pues el único con el que habrá tenido contacto es con el último porteador, quien le habrá entregado las mercancías, a no ser que éstas se hubieran perdido ${ }^{1040}$. En comparación con los supuestos anteriores, la legitimación pasiva del porteador intermedio bajo cuya custodia se ha originado el hecho perjudicial se plantea más dificultosa. Y ello por cuanto ha de demostrarse por el destinatario que la causación del daño le es imputable (art. 217.2 LEC), lo cual no siempre será fácil o incluso posible ${ }^{1041}$. Así, se corre el riesgo de que el tribunal desestime la demanda y, para cuando quiera interponerse contra otro porteador en la cadena,

${ }^{1038}$ A. ZURIMENDI ISLA, «Ejercicio...», cit., p. 776; F.J. SÁNCHEZ-GAMbORINO, El contrato de transporte..., cit., p. 325

1039 A. ZURIMENDI ISLA, op. y loc ult. cit. En este sentido, el art. 34 CMR establece que «[e]l segundo transportista y cada uno de los siguientes se obligan por la mera aceptación de la mercancía y de la carta de porte». Según este precepto, no se adhiere al contrato de transporte sucesivo (y no ostenta, por ello, legitimación pasiva) aquel transportista que no hubiera llegado a recibir la mercancía por haberse ésta perdido, o aquel que no haya aceptado la mercancía. Vid. F.J. SÁNCHEZ-GAMBORINO, El contrato de transporte..., cit., p. 325.

1040 F.J. SÁNCHEZ-GAMBORINO, El contrato de transporte..., cit., p. 325; A. ZURIMENDI ISLA, «Ejercicio...», cit., p. 776.

${ }^{1041}$ La determinación del sujeto responsable se facilita si se han realizado reservas conforme a lo dispuesto en el art. 64.3 LCTTM, pero al igual que sucede con las reservas que pueda formular el destinatario tras la llegada de las mercanías (art. 6o LCTTM), éstas no prueban que el daño se ha causado precisamente bajo la custodia del transportista precedente. 
haya prescrito la acción ${ }^{1042}$. Es más, aunque el destinatario se prevalga de lo dispuesto en el artículo 65 i.f. LCTTM e interponga la acción contra varios porteadores a la vez, incluido el que, a su juicio, ha causado el daño, salva el problema de la prescripción, pero corre el riesgo de que la demanda sea desestimada parcialmente, con la consecuente imposición de parte de las costas procesales. En fin, en el caso de que hayan existido distintos hechos perjudiciales originados en varios tramos, o que el retraso se haya acumulado por la acción de varios transportistas, se entenderán legitimados pasivos todos aquellos que han contribuido a la causación del daño ${ }^{1043}$.

Con referencia a los porteadores efectivos que contribuyan a la realización del transporte como subcontratados de los porteadores sucesivos contractuales, no se les puede demandar sobre la base de lo establecido en el artículo 65 LCTTM. Y es que no ocupan lugar alguno en la cadena de adhesiones al contrato, con la consecuencia de que no son, ni el primero o el último transportista, ni tampoco aquel bajo cuya custodia se ha ocasionado el hecho dañoso, sino auxiliares de uno u otro. Solamente tendrán esa consideración sus porteadores contractuales, que son los que se comprometieron de modo sucesivo y que, asimismo, asumirán la responsabilidad por los actos u omisiones de sus subcontratados. No quiere decirse con esto que los sujetos que están legitimados activamente no puedan dirigirse contra los porteadores de hecho, pues sí podrán hacerlo sobre la base de cuanto se expuso en el momento oportuno ${ }^{1044}$, pero no en virtud de lo que prevé el artículo 65 LCTTM ${ }^{1045}$.

Por el contrario, no cabe la posibilidad de que el cargador o el destinatario se dirijan contra los demás porteadores que no están incluidos en los artículos 65 LCTTM y 36 CMR. Ahora bien, si cualquiera de éstos se dirige contra aquéllos pidiéndoles, por ejemplo, el pago de los portes, en este caso, para evitar que estén obligados a cumplir si no han recibido la mercancía o la han recibido con retraso o de forma defectuosa (de manera que no tendrán que abonar los

${ }^{1042}$ Advierte de ello A. ZURIMENDI ISLA, «Ejercicio...», cit., p. 776.

1043 F.J. SÁNCHEZ-GAMBORINO, El contrato de transporte..., cit., p. 325; A. ZURIMENDI ISLA, «Ejercicio...», cit., p. 776.

1044 Vide supra, sub 2.1.

1045 A. EMPARANZA SOBEJANO, «Aplicación del régimen...», cit., p. 756; A. ZURIMENDI IsLA, «Ejercicio...», cit., p. 777 . 
portes, o no en su integridad), el artículo 36 CMR faculta a cargador y destinatario a oponer la acción de responsabilidad vía excepción. Con ello se pretende prevenir una situación de clara inferioridad procesal ${ }^{1046}$ que se produciría si se les impidiese alegar que el hecho de no cumplir con su obligación de pagar los portes se debe al incumplimiento o al cumplimiento defectuoso de la obligación de transporte, custodia y entrega ${ }^{1047}$.

\section{a) Ejercicio de la acción en el transporte sucesivo}

Como se ha tenido ocasión de señalar, tanto el artículo 36 CMR como el artículo 65 LCTTM permiten la acumulación de acciones contra varios porteadores en un mismo proceso. En el ámbito del CMR, también cabe la posibilidad de que, si la demanda contra uno de los porteadores resulte infructuosa el perjudicado se dirija contra otro de los sujetos mencionadas en la norma. Mas ello no es posible a tenor de la norma española, pues el «derecho de opción se extinguirá desde el momento en que el demandante ejercite su acción contra uno de ellos». De ello se infiere que, aunque el demandante podrá elegir contra cuál o cuáles de los porteadores dirige su reclamación, si ésta resultase infructuosa, perderá su derecho a accionar y se queda sin cobrar la indemnización que esperaba.

No obstante, si el demandante se ha equivocado en la identificación del legitimado pasivo y se declara que el demandado no figura entre los sujetos a que se refiere el artículo 64 LCTTM, el derecho de acción no se extingue y el perjudicado podrá interponer una reclamación judicial contra quienes realmente sean legitimados pasivos. Tal solución tiene acomodo en la literalidad del articulo 65 LCTTM, a cuyo tenor el derecho de opción se extinguirá a partir del momento en que el reclamante ejercita su acción contra alguno de los legitimados

${ }^{1046}$ Este supuesto excepcional no se halla regulado expresamente en el art. 65 LCTTM. Como vía de solución se apunta en la doctrina el paralelismo existente con el artículo 406.1 LEC, que permite a los interesados formular reconvención, siempre y cuando haya una «conexión entre sus pretensiones y las que sean objeto de la demanda principal»; y admitido el derecho a reconvenir, con mayor razón debería acogerse una excepción cuando, como aquí sucede, la conexión es evidente. Así, A. ZURIMENDI ISLA, «Ejercicio...», cit., p. 778. En el transporte unitario con subtransporte, resulta igualmente evidente que el destinatario pueda reconvenir contra el transportista contractual por la existencia de averías en las mercancías cuando éste le reclame el pago de los portes, aunque el daño fuera causado por el subtransportista. Así lo reconoce implícitamente la STS de 26 de octubre de 1985 (RJ 1985, 4955), pues no rechaza de plano la reconvención, aunque la desestima por falta de pruebas. 1047 Así, A. ZURIMENDI ISLA, «Ejercicio...», cit., p. 777. 
pasivos determinados por la Ley, y no contra cualquier otro porteador que figure entre los sujetos elegibles. Tampoco en la reclamación extrajudicial se agota el derecho de opción por la misma razón indicada por el precepto citado, por lo que podrán interponerse la demanda judicial contra un sujeto distinto del que haya sido destinatario de la reclamación extrajudicial ${ }^{1048}$.

En fin, parece conveniente recordar que, al tratarse de un contrato de transporte sucesivo, todos los porteadores que intervienen en la realización del transporte asumirán la responsabilidad conjuntamente ante el acreedor (arts. 64.1 LCTTM y 34 CMR), sea el cargador o destinatario. De ahí, si se demanda a alguno de los porteadores legitimados pasivamente conforme a lo dispuesto en los artículos 65 LCTTM y 36 CMR, éste no tendrá la posibilidad de exonerarse alegando que el daño no le es imputable a él, sino a otro porteador que haya intervenido en la cadena de transporte. Sí cabe la exoneración, como no puede ser de otro modo, si se demuestra que el hecho dañoso no es imputable a ninguno de los porteadores implicados. Y también podrá el demandado oponer cualquier excepción basada en el contrato de transporte sucesivo como, por ejemplo, el impago de los portes o de los gastos que derivan del mismo ${ }^{1049}$.

\section{b) Acción de repetición entre porteadores sucesivos}

A pesar de que es una cuestión en cierta medida ajena al objeto del presente estudio, conviene dedicar unas breves consideraciones a la acción de repetición entre porteadores sucesivos, es decir, de qué manera puede el porteador que haya satisfecho la indemnización al destinatario recuperar el importe satisfecho del transportista al que sea imputable el hecho dañoso.

\section{aa) Consideraciones generales}

De la definición del transporte sucesivo se desprende que todos los participantes responden de la correcta ejecución del transporte frente al acreedor de la prestación, con sujeción a las normas de legitimación pasiva que se acaban de enun-

1048 A. ZURIMENDI ISLA, «Ejercicio...», cit., p. 778.

1049 Vid. SAP Cádiz (Sección 5a) de 21 de febrero de 2003 (JUR 2003/157584), si bien referido a un supuesto de transporte ferroviario, donde aún hoy el transporte sucesivo es más frecuente que en el transporte de mercancías por carretera. 
ciar. Sin embargo, dicha definición sólo contempla la vertiente externa de la responsabilidad y no se refiere a las eventuales reclamaciones entre tales porteadores, al margen de las que pueden existir entre estos porteadores sucesivos y el cargador o destinatario. A este supuesto de la repetición entre porteadores sucesivos se consagran los artículos 66 LCTTM y 37 CMR, que facultan al transportista que haya soportado el pago de la indemnización frente al acreedor sin que el daño le fuera imputable para ejercer una reclamación de recobro contra el o los porteadores causantes del daño, en definitiva, para distribuir la carga indemnizatoria entre todos los transportistas sucesivos ${ }^{1050}$.

Los dos preceptos citados prevén ciertos criterios y alguna norma procesal en cuanto al ejercicio del derecho de regreso entre los porteadores sucesivos, pero no resuelven algunos de los problemas que pueden suscitarse en la práctica, p.ej., quién debe cobrar el precio del transporte y cómo se distribuye éste entre los transportistas sucesivos. En caso de que el contrato nada establezca al respecto, cabe acudir al régimen de integración contractual, contemplado en el artículo $1258 \mathrm{Cc}$, de manera que podrá estarse a lo que habitualmente ha venido sucediendo entre los porteadores en este tipo de situación o, en ausencia de relaciones previas, a la costumbre o a la buena fe $\mathrm{e}^{1051}$.

\section{bb) Legitimados pasivos de la acción de repetición}

i. El daño es imputable a un único porteador

La regla general según lo previsto en los artículos mencionados permite al transportista que tuvo que pagar lo que no le correspondía, dirigir una acción de repetición contra el transportista al que efectivamente sea imputable el daño, pudiendo recuperar tanto el principal como los intereses y gastos, así como, en su caso, las costas procesales ${ }^{1052}$. Así pues, según los criterios establecidos en los preceptos referidos, el transportista causante del daño será el único que debe soportar el importe total de la indemnización [arts. 66.1.a) LCTTM y 37.a)

$105^{\circ}$ F.J. SÁNCHEZ-GAMBORINO, El contrato de transporte..., cit., p. 327.

${ }^{1051}$ A. ZURIMENDI ISLA, «Acción de repetición entre porteadores sucesivos», en J.F. Duque Domínguez y F. Martínez Sanz (dirs.), A. Emparanza Sobejano y Ma .V. Petit Lavall (coords.), Comentarios a la Ley de Transporte Terrestre, cit., p. 786.

1052 F.J. SÁNCHEZ-GAMBORINO, El contrato de transporte..., cit., p. 328. 
CMR]. De este modo, si al porteador contra el que se dirigió el acreedor de la prestación le es imputable el daño, evidentemente, no tendrá ningún derecho de regresar contra otro u otros porteadores sucesivos. Así lo indica claramente el artículo 37.a) CMR, cuando señala que este porteador soportará la indemnización íntegra, «ya la haya pagado él mismo» o la haya pagado otro ${ }^{1053}$.

\section{ii. El daño es imputable a varios porteadores}

Según la letra b) de los artículos 66.1 LCTTM y 37 CMR, cuando el hecho perjudicial es imputable a varios transportistas, el que haya satisfecho la indemnización podrá ejercer el derecho de repetición contra todos ellos, y cada uno responderá por la parte de responsabilidad que le corresponda. No se repartirá, por tanto, el pago de la indemnización por partes iguales, sino que cada uno debe hacerle frente en proporción a su cuota de responsabilidad. En caso de que el daño sea imputable a un porteador efectivo que nog merezca la calificación de transportista sucesivo en los términos antes vistos, el transportista que lo haya subcontratado responderá, según los casos, frente al acreedor del transporte o al porteador que haya satisfecho la indemnización a éste, sin perjuicio de su derecho de regreso contra el porteador efectivo ${ }^{1054}$.

Si fuera imposible evaluar la cuota de responsabilidad que se atribuye a cada uno de los transportistas, el importe de la indemnización se prorrateará en función de la parte del precio del transporte que corresponda a cada uno de ellos [arts. 66.1.b) i.f. LCTTM y 37.b) i.f. CMR] ${ }^{1055}$. Si uno de ellos fuera el que ha abonado toda la indemnización al acreedor, tendrá el derecho de reclamar contra los demás la parte que les toque a éstos, y no la totalidad de la indemnización pagada ${ }^{1056}$.

1053 Cfr. A. ZURIMENDI ISLA, «Acción de repetición...», cit., p. 788; F.J. SÁnCheZGAMBORINO, El contrato de transporte..., cit., pp. 328-329.

1054 F.J. SÁNCHEZ-GAMBORINO, El contrato de transporte..., cit., p. 329.

1055 En efecto, así lo establece el art. 66.1.b) LCTTM, cuando señala que «si no cabe valorar dicha responsabilidad, el coste se repartirá en proporción al precio que a cada uno corresponda por el transporte»; y también el segundo inciso del art. 37.b) CMR, a cuyo tenor, «si la evaluación de las partes es imposible, cada uno de ellos será responsable proporcionalmente a la cuota de remuneración del transporte que le corresponda».

${ }^{1056}$ A. ZURIMENDI ISLA, «Acción de repetición...», cit., p. 788. 
iii. Se desconoce el transportista al que es imputable el daño

Cuando no se sabe con certeza a cuál de los transportistas intervinientes le es imputable el daño, la indemnización se repartirá entre todos en función de la parte del precio que corresponde a cada uno de ellos ${ }^{1057}$. También aquí, el que haya satisfecho el importe íntegro de la indemnización podrá repetir contra todos los porteadores sucesivos, pero sin poder reclamar la porción que le toca a él ${ }^{1058}$. Ello puede suceder, por ejemplo, si el daño se descubre a la hora de descargar o desembalar las mercancías, lo cual dificulta enormemente determinar el momento en que se produjo el daño, máxime cuando se trata de daños no manifiestos para los porteadores, respecto de los cuales no habrán podido introducir una reserva conforme a lo dispuesto en el artículo 64.3 LCTTM en el momento de hacerse cargo de la mercancía.

Ciertamente, nada debe obstar para que, incluso en reclamaciones entre porteadores, se realicen alegaciones con fundamento en los artículos 48 y 49 LCTTM, o 17 y 18 CMR al objeto de quedar exonerado de la responsabilidad que inicialmente les incumbía. Con todo, a la vista de que el non liquet acerca de la causa concreta del daño perjudica siempre al deudor de una obligación de hacer de resultado (en este caso, al transportista) ${ }^{1059}$, resulta difícil imaginar que uno de los participantes pueda quedar exonerado y los otros no, pues, de descono-

${ }_{1057}$ Así lo indican los arts. 66.1.c) LCTTM ( Si no se puede determinar quiénes son los porteadores responsables, el coste de la indemnización se repartirá entre todos los que hayan intervenido en el transporte de forma proporcional al precio que corresponda por éste»); y art. 37.c) CMR ( $«$ Si no se puede determinar, entre estos transportistas, a cuáles es imputable la responsabilidad, la carga de indemnizar se repartirá en la proporción fijada en el párrafo b) de este artículo entre dos los transportistas»). El hecho de que, excepcionalmente, la parte de la indemnización a satisfacer en última instancia por cada uno de los porteadores sea la misma, no significa que ello sea siempre así: la regla es otra, pues la contribución de los transportistas depende de su participación en el precio, que no tiene porque ser idéntica. Cfr. F.J. SÁNCHEZ-GAMBORINO, El contrato de transporte..., cit., pp. 330331.

${ }^{1058}$ A. ZURIMENDI ISLa, «Acción de repetición...», cit., p. 788.

1059 L. DíEz-PiCAzo, Fundamentos..., T. II, cit., pp. 745 y ss.; con idéntico resultado, F. JORDANO FRAGA, La responsabilidad contractual, Civitas, Madrid, 1987, pp. 489 y ss.; A. PuETZ, Derecho de vagones..., cit., pp. 270 s. La razón que justifica este planteamiento es la siguiente: si no puede determinarse la causa del accidente, tampoco puede excluirse la posibilidad de que el daño sea imputable al deudor, de manera que la prueba de la diligencia habría de alcanzar todas las posibles causas del daño, lo cual, de ordinario, no será posible en la práctica. 
cerse la causa del daño, no basta con probar la propia diligencia para liberarse de responsabilidad.

iv. Insolvencia de alguno de los porteadores obligados al pago

El legislador ha abordado expresamente el tema de la insolvencia de alguno de los porteadores sucesivos en los artículos 66.1.d) LCTTM y 38 CMR. Concretamente, se señala que, si el legitimado pasivo que debiera soportar en última instancia el pago íntegro de la indemnización es insolvente, el que haya pagado la indemnización al acreedor de la prestación podrá ejercer su derecho de repetición contra los demás porteadores, con independencia de que les sea imputable la producción del daño o no. Y nuevamente, el criterio de reparto es la participación de cada uno en el precio del transporte, descontando la parte proporcional que corresponda a quien haya satisfecho ya la indemnización.

Ahora bien, si son varios los porteadores a las que cabe imputar el daño y uno de ellos es insolvente, serán únicamente los demás porteadores responsables los que deben soportar la insolvencia del corresponsable ${ }^{1060}$. En cambio, si por aplicación del criterio subsidiario del artículo 66.1.c) resultase que todos los porteadores fuesen responsables del daño causado, el que haya abonado el importe indemnizatorio podrá repetir contra los demás porteadores, salvo aquellos que sean insolventes, distribuyendo entre ellos la indemnización que debía el insolvente, descontando la cuantía que a él le correspondía desde el principio, más la proporción de la insolvencia que también debe soportar.

El problema que puede plantear la aplicación práctica de la norma es la de definir el concepto de «insolvencia», es decir, si para considerar que un porteador es insolvente debe haberse declarado el concurso de acreedores o no. Si se considerase necesaria la declaración judicial de concurso, ello puede significar que, cuando por fin se declare éste, la acción de repetición haya ya prescrito en aplicación del artículo 79.4 LCTTM. Tampoco parece adecuado considerar que basta la mera insolvencia de hecho ${ }^{1061}$. Como solución intermedia, se ha propuesto acudir a los hechos indicativos de la insolvencia previstos en el ar-

${ }^{1060}$ M.A. CLARKE, International..., cit., n. 52, c.

${ }^{1061}$ F.J. SÁNCHEZ-GAMBORINO, El contrato de transporte..., cit., p. 331-332. 
tículo 2.4 de la Ley 22/2003, de 9 de julio, Concursal ${ }^{1062}$, pues en ausencia de una declaración formal de concurso, tales situaciones resultan de por sí lo suficientemente significativos a efectos de la aplicación del artículo 66 LCTTM ${ }^{1063}$.

${ }^{1062} \mathrm{El}$ art. 2.4 de la Ley Concursal prevé que, «[s]i la solicitud de declaración de concurso la presenta un acreedor, deberá fundarla en título por el cual se haya despachado ejecución o apremio sin que del embargo resultasen bienes libres bastantes para el pago, o en la existencia de alguno de los siguientes hechos: $10^{\circ}$ El sobreseimiento general en el pago corriente de las obligaciones del deudor. $2 .^{\circ}$ La existencia de embargos por ejecuciones pendientes que afecten de una manera general al patrimonio del deudor. $3 .^{\circ}$ El alzamiento o la liquidación apresurada o ruinosa de sus bienes por el deudor. $4 .^{\circ} \mathrm{El}$ incumplimiento generalizado de obligaciones de alguna de las clases siguientes: las de pago de obligaciones tributarias exigibles durante los tres meses anteriores a la solicitud de concurso; las de pago de cuotas de la Seguridad Social, y demás conceptos de recaudación conjunta durante el mismo período; las de pago de salarios e indemnizaciones y demás retribuciones derivadas de las relaciones de trabajo correspondientes a las tres últimas mensualidades».

1063 Así, con acierto, A. ZURIMENDI ISLA, «Acción de repetición...», cit., pp. 789-790. 



\section{CONCLUSIONES}



PRIMERA. - La caracterización del contrato de transporte como un contrato a favor de tercero es fruto de una importante labor doctrinal, realizada al calor de la necesidad de dotar la entrada del destinatario en el contrato de transporte de una adecuada justificación dogmática. En efecto, hubo de encontrarse el mecanismo a través del cual un tercero extraño a la órbita contractual, el destinatario, adquiere un derecho propio derivado del contrato estipulado entre el cargador-estipulante y el transportista-promitente en su favor, de modo que el transportista resulte obligado a entregar a aquél los efectos transportados una vez preste su consentimiento para recibirlos. Como acreedor de la prestación acordada en su favor, su incumplimiento facultará además al destinatario para ejercer una acción contractual frente al transportista a fin de exigirle en su propio nombre el cumplimiento de lo pactado.

SEGUNDA. - A consecuencia de la aversión que mostraba el Derecho romano a que se desvirtuasen los límites del principio de la relatividad de los contratos, que debían surtir efectos únicamente entre las partes contratantes, la figura del contrato a favor de tercero no se consagró como categoría genérica hasta la época de los códigos. Fue con el auge económico y el aumento de las transacciones en la vida cotidiana que se comenzó a admitir paulatinamente la existencia de tales negocios, primero como excepción al principio de la relatividad contractual, y luego como instrumento propio, como así sucede en el artículo $1.2572^{\mathrm{a}}$ del Código civil español.

TERCERA. - Han sido muchas las teorías con las que se ha tratado de dar una explicación convincente acerca de la adquisición del derecho por el tercero beneficiario que no haya intervenido en modo alguno en la celebración del contrato. Al abordar la determinación de la naturaleza jurídica del contrato a favor de tercero, se han expuesto las distintas teorías que de mayor aceptación gozan en la doctrina, con el fin de comprender mejor la figura del tercero en el contrato que le favorece. Su examen ha revelado que el mecanismo traslativo del derecho tiene su fundamento en la naturaleza misma del contrato a favor de tercero y su configuración dogmática. En efecto, los inconvenientes que presentan las distintas teorías han apoyado en cierta medida que se terminase por consagrar la teoría del contrato a favor de tercero en las normas reguladoras de los negocios que contienen estipulaciones de la misma índole, o sea, a favor de tercero. Sin ir más 
lejos, en España el contrato a favor de tercero comenzó por considerarse una excepción al principio de la relatividad de los contratos y ha pasado a conformar una regla general en el artículo $1.2572^{\mathrm{a}} \mathrm{Cc}$.

CUARTA.-El funcionamiento del contrato a favor de tercero ha tratado de explicarse a través de otras figuras jurídicas, que han causado no poca controversia en la doctrina a la hora de explicar el mecanismo atributivo del derecho al tercero. Entre ellas, sin ánimo de exhaustividad, cabe mencionar la teoría de la oferta; la gestión de negocios ajenos; la adquisición directa y la de la declaración unilateral de voluntad. La primera de ellas es inadmisible, pues descompone el negocio en dos contratos sucesivos, lo cual no se compadece bien con el carácter unitario del contrato a favor de tercero. La teoría de la gestión de negocios ajenos y la de la declaración unilateral de voluntad tampoco resultan satisfactorias para explicar la adquisición del derecho: la primera se refiere, en rigor, a un contrato por cuenta de tercero y no a favor de tercero, mientras que la segunda es inadmisible por diferenciar entre la voluntad unilateral y el contrato, de modo que convierte al derecho del tercero en una promesa desligada de su causa, dando así lugar a la nulidad del contrato por no cumplir uno de sus requisitos esenciales. En fin, tampoco resulta posible que nazca un derecho a favor de tercero de un contrato sin siquiera hacérselo saber y sin que éste manifieste su intención de aprovecharlo, con lo que queda descartada igualmente la teoría de la adquisición directa.

QUINTA.-Como en cualquier otro contrato, son partes del contrato a favor de tercero quienes intervinieron originariamente en su formación, o sea, el estipulante y el promitente. Sin embargo, la peculiaridad de este tipo de contrato estriba en que contiene una estipulación a favor de tercero, en cuya virtud el promitente se obliga a realizar una prestación en beneficio de quien inicialmente no es parte en el contrato, dando lugar a una relación tripartita entre promitente, estipulante y tercero. Como no puede ser de otra manera, las partes contratantes, el estipulante y el promitente, han de gozar de la capacidad suficiente que les permita contratar según lo previsto en la ley.

El estipulante es el sujeto que toma la iniciativa de estipular el contrato en el que se establece la prestación, cuya ejecución se encomienda al promitente frente al tercero. Es, por tanto, el que tiene interés en que el provecho de la pres- 
tación sea atribuido al tercero. A pesar de no ser el acreedor de la prestación acordada con el promitente (pues es el tercero), el estipulante no pierde su condición de parte contratante, ni siquiera después de la adhesión del tercero al contrato a través de su aceptación. Ello justifica que pueda ejercitar una acción frente al promitente, también después de la entrada del tercero, en caso de incumplimiento de su obligación. En su condición de parte, el estipulante podrá modificar la designación del tercero favorecido e incluso revocar el beneficio en tanto no haya sido aceptado por éste. Y también es el estipulante sobre quien, en principio, pesa la obligación de entregar la contraprestación al promitente, en el caso de que el contrato fuera oneroso; si fuese gratuito, se estaría ante un contrato unilateral a favor de tercero.

El promitente es el obligado a realizar la prestación estipulada a favor del tercero, a no ser que sea revocada en tiempo útil o que el tercero la rechace, pues en estos supuestos la prestación ingresa en el patrimonio del estipulante. Así, se desprende de la naturaleza del contrato que el promitente se convierte en legitimado pasivo de la acción interpuesta tanto por el estipulante como por el tercero. Por su parte, en los contratos onerosos a favor de tercero, el promitente ostenta legitimación activa frente al estipulante para reclamar la contraprestación, y también puede exigir del tercero que cumpla las cargas que le hubieran sido impuestas por el estipulante en provecho del promitente.

El beneficiario, en fin, es un tercero ajeno al contrato, es a quien va destinado el objeto del contrato que consiste en atribuirle un derecho de crédito frente al promitente. La aceptación por este tercero del derecho es el momento que marca su adhesión al contrato, y también convierte en irrevocable la prestación. Tras la aceptación de su posición como acreedor, el tercero podrá ejercitar contra el obligado la acción de cumplimiento y, en caso de que éste no se produzca o se realice de forma parcial o defectuosa, reclamar de él la indemnización de los daños y perjuicios que se le hayan causado. Como la aceptación del tercero no es sino una condición para el ingreso en su patrimonio del derecho de crédito frente al promitente y para convertir en irrevocable la estipulación, el rechazo de la prestación no afecta en nada a la validez del contrato, ya que el derecho que se pretendía atribuir al tercero ingresa con carácter retroactivo en el 
patrimonio del estipulante, que hasta entonces no había ostentado su titularidad en ningún momento.

SEXTA.-El contrato a favor de tercero se caracteriza por su configuración singular que comprende tres sujetos, una estructura tripartita que se basa sobre la existencia de distintas relaciones jurídicas de las partes contratantes entre sí y con el tercero. En primer lugar, la relación de cobertura existente entre el estipulante y el promitente es la que nace del contrato a favor de tercero, obligando al promitente a satisfacer el derecho de crédito que se atribuye al tercero. La segunda relación es la de valuta o subyacente que une al estipulante con el tercero beneficiario y que explica la causa que justifica la atribución a éste de la prestación que se obliga a realizar el promitente. Su naturaleza es variable y puede clasificarse según la causa de la atribución patrimonial al tercero (donandi, solvendi o credendi causa). En fin, la relación de ejecución como tercera relación que completa el esquema triangular del contrato, es la consecuencia jurídica perseguida con él, basada en la relación de cobertura que une a estipulante y promitente con el propósito de aumentar el patrimonio del tercero con un derecho de crédito. En efecto, en esta relación de ejecución el tercero es el acreedor de la prestación estipulada en su provecho mientras que el promitente ocupa la posición del deudor, una relación obligatoria que nace a pesar de que promitente y tercero no han celebrado ningún contrato.

SÉPTIMA.-El contrato a favor de tercero ha encontrado reflejo legal también en el Derecho comparado. En Alemania, se halla regulada en los §§ 328 a 335 $\mathrm{BGB}$, a tenor de los cuales el tercero beneficiario adquiere inmediatamente un derecho de crédito frente al promitente de la estipulación concertada a su favor, a no ser que lo rechace, en cuyo caso se entenderá que no lo ha adquirido en ningún momento ( $§ 333 \mathrm{BGB}$ ). Conforme a lo dispuesto en el $\S 334 \mathrm{BGB}$, el promitente puede oponer al tercero todas las excepciones derivadas del contrato. En este mismo precepto se confiere al estipulante la posibilidad de exigir el cumplimiento a favor del tercero, con lo que éste y aquél son acreedores solidarios que pueden dirigir simultáneamente una reclamación frente al promitente, pero únicamente para exigir el cumplimiento al tercero (y no al estipulante).

En el Derecho civil francés anterior a la reforma de 2016, la prohibición de las estipulaciones en nombre propio, pero por cuenta de otro, era un claro 
ejemplo de la perpetuación del principio romano alteri stipulatio nemo potest en el Código napoleónico. En el régimen actualmente vigente se elimina cualquier referencia a esta prohibición y se proporciona una regulación completa de los contratos que contienen estipulaciones a favor de tercero, que reconoce la atribución de un derecho directo al beneficario, de carácter revocable, que habrá de ser aceptado por éste.

La regulación de la figura del contrato a favor de tercero en el Derecho italiano ha sido inspirada en un principio en el modelo francés (antiguo art. 1.121 del Code civil), aunque en el Codice civile de 1942 se admitió en gran medida la estipulación a favor de tercero, pues a tenor de su artículo 1.411 un tercero puede adquirir del contrato celebrado en su provecho de manera directa derechos frente al promitente y no frente al estipulante. Además, con su aceptación del beneficio estipulado en su provecho se extingue el derecho del estipulante a revocar la estipulación. Así, impulsado por las tendencias de la doctrina germánica que propugnaban el abandono del principio alteri stipulatio nemo potest, también el Codice italiano terminó por asumir el contrato a favor de tercero como una institución de aplicación general.

OCTAVA. - La figura del contrato a favor de tercero regulado en el artículo $1.2572^{\text {a }} \mathrm{Cc}$ es la que permite explicar más claramente la intervención de una persona, el destinatario, ajena al cargador que ha concluido el contrato con el transportista, en la fase final de ejecución del transporte, adquiriendo los derechos dimanantes del contrato. Esta intervención del destinatario en la fase final del transporte constituye, sin duda alguna, una de las características esenciales del tipo contractual, que contiene una estipulación a favor de tercero a condición de que éste haga saber su aceptación a la parte obligada antes de que sea revocada por el estipulante (art. 1.257 $2^{\mathrm{a}} \mathrm{Cc}$ ).

En efecto, si se compara el esquema de adquisición de los derechos del destinatario con el esquema general de los contratos a favor de tercero, se observa, de una parte, que tercero beneficiario y destinatario son sujetos ajenos inicialmente al contrato que no han participado en su celebración, pero intervienen en la fase de ejecución; y, de otra, que la adquisición definitiva del derecho queda condicionada a su aceptación de la prestación estipulada en su favor, reclamando, en el caso del transporte, la entrega de las mercancías. Además, el 
ejercicio del derecho de disposición por el cargador-estipulante tiene el efecto de revocar la estipulación hecha a favor de tercero, pues se le concede la facultad de ordenar al transportista que las devuelva a su punto de partida o que las entregue a otro destinatario.

NOVENA. - Tras el estudio de las distintas figuras afines al contrato a favor de tercero se constata que es una institución jurídica que une dos voluntades tendentes a producir un efecto jurídico, cuyo objeto es desviar hacia un tercero beneficiario un derecho de crédito. Así, las obligaciones contractuales se generan en cabeza de las partes que intervinieron en su celebración, mientras que el tercero se beneficia de todos o alguno de los derechos que dimanen de él. Sin embargo, la posibilidad de encuadrar el contrato de transporte en el esquema general del contrato a favor de tercero ha sido negada por algún sector doctrinal, con base en la constatación de que, en el transporte a portes debidos, la adquisición de los derechos por parte del destinatario se condiciona a que éste satisfaga el precio y los gastos del transporte. Y ello, se dice, es incompatible con el contrato a favor de tercero, que genera únicamente genera derechos -mas no obligaciones- para el tercero beneficiario. Esta objeción ha sido rebatida con acierto por quienes defienden la teoría de que el contrato de transporte es un contrato a favor de tercero con el argumento de que el pago de los portes no es una obligación en sentido técnico-jurídico sino una carga o condición que debe satisfacer el tercero-destinatario si quiere recibir las mercancías. Así, nada obsta para que rechace la prestación, aun cuando no concurra justa causa, con la consecuencia de que tampoco deberá pagar el precio del transporte. En cambio, si la negativa a pagar el precio surge una vez aceptada la prestación, el porteador podrá cobrarse del cargador, que responde subsidiariamente frente a aquél. Y esta solución resulta plenamente coherente con la configuración del contrato de transporte como negocio a favor de tercero.

No sorprende, así, que la tesis del contrato a favor de tercero sea la que mayoritariamente se defiende en la doctrina que, además, pone de relieve que el contrato de transporte es uno de los ejemplos más frecuentes de este tipo contractual. Con ello se consigue explicar coherentemente la posición jurídica del destinatario en el contrato de transporte, que se convierte en acreedor del transportista-promitente desde el momento en que acepta la estipulación hecha 
a su favor. En caso de que ésta incumpla, ostentará también legitimación activa para reclamar, en cuanto subrogado del cumplimiento, el resarcimiento de los daños y perjuicios causados por pérdidas o averías en la mercancía, o por un retraso en la entrega.

DÉCIMA.-El contrato de transporte es un elemento muy importante en la cadena de suministro y suele concertarse a raíz de otro negocio jurídico, generalmente una compraventa a distancia, y junto a otros, como el depósito, el seguro o la comisión, aunque se trata de contratos independientes. Se define en el artículo 2.1 LCTTM como un contrato consensual, bilateral y oneroso, por virtud del cual el porteador se obliga, a cambio de una remuneración, a transportar las mercancías objeto del contrato de un lugar a otro y de entregarlas al destinatario previsto en el contrato. El que se defina el contrato en la Ley constituye una novedad, tanto respecto de lo que sucedía en el Código de comercio, como en relación al Derecho uniforme.

UNDÉCIMA.-Son dos los sujetos que intervienen en la conclusión del contrato, el transportista (promitente) y el cargador (estipulante). El destinatario (tercero beneficiario), por su parte, es la persona a la que va dirigida la mercancía objeto del contrato, aunque normalmente no participa en la celebración de éste. Junto a ellos, cabe la posibilidad de que intervengan otros sujetos en la contratación o la ejecución del contrato, como son el expedidor, que entrega las mercancías al transportista; los intermediarios u operadores de transporte; los porteadores efectivos subcontratados por el transportista contractual al objeto de realizar materialmente el desplazamiento; $\mathrm{u}$ otros porteadores que se comprometen en virtud de ese mismo contrato a ejecutar sucesivamente la operación de transporte.

DUODÉCIMA.-El carácter consensual del contrato de transporte es confirmado por el hecho de que la ausencia o irregularidad de la carta de porte no afecta a la validez de aquél. Se trata de un mero instrumento probatorio (privilegiado, eso sí) de la existencia y el contenido del contrato de transporte, con lo que queda descartada aquella postura doctrinal que considera la carta de porte como la fuente de la que surge y a través de la que se configura la posición jurídica del destinatario. Aun cuando la carta sea emitida, es posible que no figure en ella el destinatario, de manera que los derechos de éste derivan del mismo 
contrato y no del documento que, al contrario de cuanto sucede con el conocimiento de embarque, no es un título-valor y no es necesaria su presentación al objeto de reclamar en destino la entrega de las mercancías.

DECIMOTERCERA.-El denominado «derecho de disposición» es una institución ya clásica en la regulación jurídica del transporte de mercancías que faculta al cargador o, en su caso, al destinatario para modificar unilateralmente el contrato de transporte. Desempeña un papel relevante como instrumento de garantía frente al impago por el destinatario del precio de la compraventa que motiva el transporte, pues permite al cargador controlar las mercancías durante su traslado. Su adquisición por el destinatario requiere, al igual que la de todo derecho nacido de un contrato a favor de tercero, la aceptación por parte del tercero, que se produce a más tardar en el momento en que solicita la entrega de las mercancías. Es en este momento cuando se incorpora al contrato, convirtiéndose en acreedor de la prestación y en titular del derecho de disposición, con lo que la estipulación deviene irrevocable para el cargador.

DECIMOCUARTA.-El concepto de destinatario se construye independientemente del título de transporte, o sea, la carta de porte. En efecto, extrae su derecho del propio contrato, pero incluso aunque aparezca identificado en la carta de porte, podrá ser sustituido por el cargador en ejercicio del derecho de disposición, sin su consentimiento y también sin el del transportista, pues no es parte en el contrato. Su inclusión en el documento tampoco acarrea para él ninguna obligación, y hasta que no declare su consentimiento a la adhesión al contrato mediante la solicitud de entrega de las mercancías seguirá siendo un tercero ajeno al contrato. Por ello, no está obligado a recibir las mercancías, ni a pagar el precio del transporte (salvo que, excepcionalmente, el cargador y el destinatario coincidan en una misma persona), y su negativa a integrarse en el contrato no genera para él ningún tipo de responsabilidad derivada del contrato de transporte. La negativa del destinatario a recibir las mercancías o a satisfacer el precio o los gastos del transporte constituye un impedimento para la entrega, en cuya presencia el transportista deberá solicitar instrucciones del cargador y podrá, en su caso, proceder al depósito de la carga para quedar liberado de su deber de custodia. En tales casos, será el cargador quien deba hacer frente a las 
cantidades devengadas con ocasión de la realización del transporte, aun cuando éste sea a portes debidos.

DECIMOQUINTA.-A través de la adhesión del destinatario al contrato de transporte, éste se convierte en acreedor de la prestación y adquiere el derecho de disposición, debiendo el transportista cumplir frente a él su obligación de entregar las mercancías, sin daños y dentro del plazo de transporte. En caso de incumplimiento o de cumplimiento defectuoso de dicha obligación, el destinatario podrá ejercer en su propio nombre la acción de resarcimiento de los daños y perjuicios causados. No obstante, además del destinatario se halla legitimado activamente también el cargador, en cuanto contraparte del transportista en el contrato de transporte, quien podrá reclamar del porteador el cumplimiento de la prestación a favor de aquél y, también, el resarcimiento de los daños causados por el incumplimiento. A pesar de que la doctrina en España suele anudar la legitimación activa a la titularidad del derecho de disposición, de manera que no puede pertenecer simultáneamente al cargador y al destinatario, ante el silencio de la Ley nada debería obstar para sostener lo contrario, pues no existe riesgo de que el transportista deba satisfacer una doble indemnización en la medida en que el cargador y el destinatario son acreedores solidarios.

DECIMOSEXTA.-Por regla general, la acción de responsabilidad deberá dirigirse contra el transportista que haya celebrado el contrato de transporte con el cargador (transportista contractual), pero nada impide que el destinatario actúe frente al porteador efectivo bajo cuya custodia se haya ocasionado el daño a las mercancías por vía extracontractual, debiendo sin embargo sujetarse al régimen jurídico contractual de responsabilidad consagrado en la Ley 15/2009 y en el CMR. También debe considerarse posible que actúe contra el porteador efectivo que le entregue o deba entregarle las mercancías sobre la base del subcontrato de transporte que vincula a éste con el porteador contractual, pues se trata de un contrato de transporte típico en el que el destinatario ocupa la posición del tercero beneficiario de la prestación de transporte. En el transporte sucesivo, por su parte, la legitimación pasiva recae en el primer transportista, en el último, o en aquel que haya efectuado el tramo en el que se ocasionó el siniestro. 



\section{BIBLIOGRAFÍA}

Alonso EsPinosa, F.J., Derecho mercantil de contratos: un curso de iniciación, Aranzadi, Cizur Menor, 2011.

Álvarez OchoA, J.F., Transporte internacional de mercancías, Paraninfo, Madrid, 2016.

Andreoli, M., La cesión del contrato, Editorial Revista de Derecho Privado, Madrid, 1956.

ANGulo Rodríguez, L., «El contrato de comisión», en G.J. Jiménez Sánchez (coord.), Derecho Mercantil II, Marcial Pons, Madrid, 2010, pp. 269-282.

Antonini, A., Corso di diritto dei trasporti, $2^{\mathrm{a}}$ ed., Giuffrè, Milano, 2008.

ARIAS VARONA, F.J., «El comportamiento subjetivo del porteador como causa para la pérdida de los beneficios de responsabilidad», Revista de Derecho del Transporte, núm. 6, 2010, pp. 283-302.

Aubert, J.-L., "À propos d'une distinction renouvelée des parties et des tiers», Revue Trimestrielle de Droit Civil, núm. 2, abril-junio de 1993, pp. 263-278.

BADA DE COMINGES, Ma ., «Enajenación de las mercancías por impago del precio del transporte», en J.F. Duque Domínguez y F. Martínez Sanz (dirs.), A. Emparanza Sobejano y $\mathrm{M}^{\mathrm{a}}$.V. Petit Lavall (coords.), Comentarios a la Ley de Transporte Terrestre, Aranzadi, Cizur Menor, 2010, pp. 495-499.

— «Depósito de las mercancías en los supuestos de impedimentos al transporte o a la entrega», en J.F. Duque Domínguez y F. Martínez Sanz (dirs.), A. Emparanza Sobejano y $\mathrm{M}^{\mathrm{a}}$.V. Petit Lavall (coords.), Comentarios a la Ley de Transporte Terrestre, Aranzadi, Cizur Menor, 2010, pp. 533-541.

— «El arbitraje en el transporte terrestre. Las juntas arbitrales del transporte», en F. Martínez Sanz (dir.) y $\mathrm{M}^{\mathrm{a}}$.V. Petit Lavall (coord.), I Congreso Internacional de Transporte: los retos del transporte en el siglo XXI, Tomo II, Tirant lo Blanch, Valencia, 2005, pp. 1819-1846.

BADIllo ARIAS, J.A., (coord.), Ley de Contrato de Seguro: jurisprudencia comentada, Aranzadi, Cizur Menor, 2011.

BAENA, J., Transporte internacional. Manuales de formación de transporte, Logis Book, Barcelona, 2002.

BELlido CAMBRón, V., «El contrato de transporte internacional de mercancías por carretera», Derecho y Empresa, núm. 4/2001.

Bercovitz Rodríguez-CAno, R., Manual de Derecho civil, Bercal, Madrid, 2011.

Beses Miguel, R., y Beses Miguel, $\mathrm{M}^{\mathrm{a}}$.D., Transporte, compraventa y responsabilidades (aspectos nacionales e internacionales), Edisofer, Madrid, 2005.

Boldó RoDA, C., «El seguro de vida como contrato a favor de tercero», en Aa.Vv., Estudios jurídicos en homenaje al profesor Vidal Guitarte, Tomo I, Castellón-Valencia, 1999, pp. 103-108.

-El beneficiario en el seguro de vida, Bosch, Barcelona, 1998. 
Bonet Ramón, F., «Los contratos a favor de tercero», Anales de la Academia Matritense del Notariado, vol. XII, 1961.

BOYERAS Schumann, D., La compraventa internacional de mercancías la modalidad $F O B$, tesis doctoral, Barcelona, 2013.

CABANILlaS SÁNCHEZ, A., «El contrato con efectos protectores para terceros en el derecho alemán», en Aa.Vv., Estudios jurídicos en homenaje al profesor Luis Díez-Picazo, Civitas, Madrid, 2003, pp. 1492-1523.

CABrera CÁnOvas, A., El transporte internacional por carretera, Marge Books, Valencia-Barcelona, 2013.

-Transporte internacional de mercancías, Icex, Madrid, 2011.

-El contrato de transporte por carretera (Ley 15/2009), Marge Books, Valencia-Barcelona, 2010.

CAFFARENA LAPORTA, J., «Transmisión del riesgo (Comentario a los artículos 66 a 70)», en L. Díez-Picazo (dir.), La compraventa internacional de mercaderías: Comentario de la Convención de Viena, Civitas, Madrid, 1998, pp. 514-537.

Calvo Caravaca, A.L., «Comentario del artículo 9», en L. Díez-Picazo (dir.), La compraventa internacional de mercaderías: Comentario de la Convención de Viena, Civitas, Madrid, 1998, pp. 132-144.

CÁMARA LAPUENTE, S., «El contrato a favor de tercero a la luz de la armonización del Derecho privado europeo», en J.M. Abril Campoy y $\mathrm{M}^{\mathrm{a}}$.E. Amat Llari (coords.), Homenaje al profesor Lluis Puig i Ferriol, Valencia, 2006, pp. 647683.

CAmpuzano DíAz, B., La repercusión del Convenio de Viena de 11 de abril de 1980 en el ámbito de la compraventa internacional de mercaderías, Secretariado de Publicaciones de la Universidad de Sevilla, Sevilla, 2000.

Cano Martínez de Velasco, J.I., El contrato a favor de tercero, El seguro de vida, Cálamo, Barcelona-Mataró, 2005.

Carballo Hidalgo, M., «El contrato a favor de tercero», Actualidad Civil, núm. 47, 2000, pp. 1697-1727.

Carrasco Perera, Á., Derecho de contratos, Aranzadi, Cizur Menor, 2010.

CASAls Colldecarrera, M., «El contrato a favor de tercero», Nueva Enciclopedia Jurídica, Seix Barral, Barcelona, 1956-2, pp. 346-375.

CECChini Rosell, X., La cláusula «por sí o por persona que se designará», Tirant lo Blanch, Valencia, 2000.

Christian, J. (dir.), Traité pratique de droit commercial, Tomo 2, Bruselas, 1990.

Clarke, M.A., International Carriage of Goods by Road: CMR, Sweet \& Maxwell, London, 1991.

- y YATES, D., Contracts of Carriage by Land and Air, $2^{\mathrm{a}}$ ed., Informa, London, 2008. 
Clavero Ternero, M.F., «La responsabilidad del transportista internacional por carretera», en Aa.Vv., Memoria de Joaquín Lanzas y de Luis Selva, Tomo I, Madrid, 1998, pp. 77-95.

CONCEPCIÓN RODRíGUEZ, J.L., «El transporte internacional de mercancías por carretera», en id. (dir.), El contrato de transporte, Manual de Formación Continuada 21, Vol. I, Consejo General del Poder Judicial, Madrid, 2003, pp. 249302.

Coolen, A., "La livraison contre le remboursement», en Aa.Vv., Jacques Putzeys, Liber amicorum, Bruylant, 1996, pp. 229- 243.

DE BuEn, D., «La estipulación en provecho de tercero», Revista General de Legislación y Jurisprudencia, vol. 71, núm. 142, 1923, pp. 193-237.

Díaz Moreno, A., «El contrato de transporte terrestre», en G.J. Jiménez Sánchez (coord.), Derecho Mercantil II, Marcial Pons, Madrid, 2010, pp. 635-695.

DíEz-PICAZO, L., Fundamentos del Derecho civil patrimonial, Vol. IV, Las particulares relaciones obligatorias, Civitas, Cizur Menor, 2010.

-Fundamentos del Derecho civil patrimonial, Vol. II, Las relaciones obligatorias, $6^{\mathrm{a}}$ ed., Civitas, Cizur Menor, 2008.

-Fundamentos del Derecho civil patrimonial, Vol. I, Introducción. Teoría del contrato, $6^{\mathrm{a}}$ ed., Civitas, Cizur Menor, 2007.

- (dirs.), La compraventa internacional de mercaderías: Comentario de la Convención de Viena, Civitas, Madrid, 1998.

DuQue Domínguez, J.F., «Documentación de la entrega en destino», «Irregularidad o inexistencia de la carta de porte» y «Reservas», en id. y F. Martínez Sanz (dirs.), A. Emparanza Sobejano y Ma.V. Petit Lavall (coords.), Comentarios a la Ley de Transporte Terrestre, Aranzadi, Cizur Menor, 2010, pp. 169-171, 173-175 y 711-716.

DUQUE PÉREZ, J.E., «La declaración de voluntad como fuente de obligaciones», Medellín, 1953.

DuRAND, P.M.F., Les transports internationaux (ferroviares et mixtes): Étude comparée des nouvelles Conventions de Berne mises en application le 1 mars 1956, Sirey, Paris, 1956.

ECHEBARRÍA SÁENZ, J.A., «La carta de porte emitida electrónicamente», en J.F. Duque Domínguez y F. Martínez Sanz (dirs.), A. Emparanza Sobejano y Ma.V. Petit Lavall (coords.), Comentarios a la Ley de Transporte Terrestre, Aranzadi, Cizur Menor, 2010, pp. 185-210.

Emparanza Sobejano, A., «Obligación de pago de porte y consecuencias de su incumplimiento», en F. Martínez Sanz y Mª.V. Petit Lavall (dirs.), Régimen del transporte en un entorno económico incierto, Marcial Pons, Madrid/Barcelona, 2011, pp. 99-114.

- «Estado de las mercancías en el momento de la entrega al destinatario», «Pago del precio del transporte», «Obligación de pago del precio y los gastos del transporte», «Entrega contra reembolso», «Aplicación del régimen de responsabilidad a las diversas acciones» y «Artículo 78: carácter imperativo, artículo 
79: plazos generales», en J.F. Duque Domínguez y F. Martínez Sanz (dirs.), A. Emparanza Sobejano y $\mathrm{M}^{\mathrm{a}} . \mathrm{V}$. Petit Lavall (coords.), Comentarios a la Ley de Transporte Terrestre, Aranzadi, Cizur Menor, 2010, pp. 423-430, 465-473, 485-494, 511-522, 755-762 у 887-900.

- «Transporte multimodal», en F. Martínez Sanz (dir.) y A. Puetz (coord.), Manual de derecho del transporte, Marcial Pons, Madrid, 2010, pp. 385-415.

- «Las reservas o protestas en destino en el transporte terrestre y marítimo: contenido y alcance», Revista de Derecho del Transporte, núm. 1, 2008, pp. 7798.

- «El alcance normativo de la proyectada regulación del contrato de transporte terrestre», en F. Martínez Sanz (dir.) y Ma .V. Petit Lavall (coord.), Aspectos jurídicos y económicos del transporte: Hacia un transporte más seguro, sostenible y eficiente, Tomo I, Servicio de Publicaciones de la Universitat Jaume I, Castellón, 2007, pp. 199-215.

-El concepto de porteador en el transporte de mercancías, Comares, Granada, 2003.

-«El art. 2 CMR: ¿un modelo de regulación de transporte multimodal?», en Aa.Vv., Diez años de Derecho Marítimo Donostiarra, Servicio Central de Publicaciones del País Vasco, Victoria-Gasteiz, 2003, pp. 37-53.

- «Cuestiones de legitimación activa y pasiva en el Convenio de Transporte Internacional de Mercancías por Carretera», en F. Martínez (dir.), Problemas en la aplicación del CMR. Especial referencia a la responsabilidad, Fundación Francisco Corell, Madrid, 2002, pp. 29-40.

- «La prescripción de las acciones en el Convenio relativo al contrato de transporte internacional de mercancías por carretera (CMR)», Revista General de Derecho, núm. 579, Valencia, 1992, pp. 11713-11738.

-, y MARTín OSANTE, J.M., «El transporte marítimo (II) contrato de transporte marítimo de mercancías en régimen de conocimiento de embarque», en F. Martínez Sanz (dir.) y A. Puetz (coord.), Manual de derecho del transporte, Marcial Pons, Madrid, 2010, pp. 113-137.

ENRIQUE ROSAS, J. D., Transporte internacional de mercancías: una introducción al régimen jurídico general del transporte de mercancías. Especial incidencia en el ámbito internacional, Porrúa, México, 1999.

Enneccerus, L. y Lehmann, H., Derecho de obligaciones, I, trad. esp. B. Pérez González y J. Alguer, Bosch, Barcelona, 1954.

EsCRIG MoReno, R., «Arbitraje nacional e internacional», en F. Martínez Sanz (dir.) y $\mathrm{M}^{\mathrm{a}} . \mathrm{V}$. Petit Lavall (coord.), I Congreso Internacional de Transporte: los retos del transporte en el siglo XXI, Tomo II, Tirant lo Blanch, Valencia, 2005, pp. 1829-1846.

Espulgues Mota, C.A., Compraventa internacional de mercaderías, Impiva, Valencia, 1993.

ForNer DELAYGUA, J.J., La cesión de contrato, Bosch, Barcelona, 1989. 
GÁlvEZ CRIADO, A., La asunción de deuda en el derecho civil; asunción liberatoria, asunción cumulativa y supuestos concretos, Tirant lo Blanch, Valencia, 2007.

GARCíA Álvarez, B., La carga y descarga en el contrato de transporte de mercancías, Marcial Pons, Madrid, 2011.

García-Amigo, M., La cesión de contratos en el derecho español, Editorial Revista de Derecho Privado, Madrid, 1964.

García-Pita y Lastres, J.L., Derecho mercantil de obligación. Parte General, Marcial Pons, Madrid, 2003.

GARRIGUes, J., Contrato de seguro terrestre, Madrid, 1982.

-Curso de Derecho mercantil, II, $8^{\text {a }}$ ed., a cargo de F. Sánchez Calero, Madrid, 1983 .

Gete-Alonso y Calera, Ma .C., «Eficacia del contrato», en Manual de Derecho Civil II. Derechos de obligaciones. Responsabilidad civil y Teoría del contrato, $3^{\mathrm{a}}$ ed., Marcial Pons, Madrid, 2000.

GHEstin, J., «Nouvelles propositions pour un renouvellement de la distinction des parties et des tiers», Revue Trimestrielle de Droit Civil, núm. 4, octubrediciembre de 1994, pp.777-800.

Gómez CAlero, J., El transporte internacional de mercancías, Civitas, Madrid, 1984.

GonZÁlEZ-LEbrero, R.A., El agente consignatario de buques en España, Bosch, Barcelona, 1989.

GonZÁlez PaCAnowska, I., «Comentario al art. 1275 Cc», en Aa.Vv., Comentarios al código civil y compilaciones forales, XVII, 10 A, 1993, pp. 324-419.

GóRRIZ LÓPEZ, C., «Supuestos de equiparación a pérdida total», en J.F. Duque Domínguez y F. Martínez Sanz (dirs.), A. Emparanza Sobejano y Ma.V. Petit Lavall (coords.), Comentarios a la Ley de Transporte Terrestre, Aranzadi, Cizur Menor, 2010, pp. 661-669.

- «Algunas consideraciones sobre las novedades de la Ley 15/2009, de 11 de noviembre, del contrato de transporte terrestre de mercancías», en F. Martínez Sanz y $\mathrm{M}^{\mathrm{a}}$.V. Petit Lavall (dirs.), Régimen del transporte en un entorno económico incierto, Marcial Pons, Madrid, 2011, pp. 129-155.

- La responsabilidad en el contrato de transporte de mercancías; carretera, ferrocarril, marítimo, aéreo y multimodal, Publicación del Real Colegio de España, Bolonia, 2001

GUELFUCCI-THIBIERCE, C., «De l'élargissement de la notion de partie au contrat... à l'élargissement de la portée du principe de l'effet relatif», Revue Trimestrielle de Droit Civil, núm. 2, abril-junio de 1994, pp. 275-285.

GuerRero LEBRón, Ma . J., «La carta de porte: requisitos de emisión y funciones», Revista de Derecho del Transporte, núm. 6, 2010, pp. 81-97. 
HAAK, K.J., The Liability of the Carrier under the CMR, Stichting Vervoeradres, The Hague, 1986.

Hedemann, J.W., Tratado de Derecho Civil, Vol. II, Derecho de obligaciones, Editorial Revista de Derecho Privado, Madrid, 1958.

HidAlgo GARCía, S., El contrato y los terceros; seguro, edificación, crédito al consumo, pactos de exclusiva y subcontratación, Lex Nova, Valladolid, 2012.

IlLESCAS ORTIZ, R. (dir.), El transporte terrestre nacional e internacional, Consejo General del Poder Judicial, Madrid, 1997.

ISERN SALVAT, Ma .R., El derecho de subrogación en el seguro de transporte terrestre de mercancías por carretera, Marcial Pons, Madrid, 2013.

Jassogne, C. (dir.), Traité pratique de droit commercial, Tomo 2, Bruselas, 1990.

JESSER-Huss, H. «Übereinkommen über den Beförderungsvertrag im internationalen Straßengüterverkehr», en Aa.Vv., Münchener Kommentar zum Handelsgesetzbuch, Vol. 7, $3^{\mathrm{a}}$ ed., 2014, pp. 1445-1890.

JIMÉNEZ BLANCO, P., El contrato internacional a favor de tercero, Universidad de Santiago de Compostela, 2002.

JoRDANO FraGA, F., La responsabilidad contractual, Civitas, Madrid, 1987.

JUAN y MATEU, F., «Derecho de disposición», «Impedimentos al transporte»y «Impedimentos a la entrega», en J.F. Duque Domínguez y F. Martínez Sanz (dirs.), A. Emparanza Sobejano y Ma .V. Petit Lavall (coords.), Comentarios a la Ley de Transporte Terrestre, Aranzadi, Cizur Menor, 2010, pp. 363-371, 383393 y $453-464$.

-Los contratos de logística, Marial Pons, Madrid-Barcelona-Buenos Aires, 2009.

— «l contrato de transporte continuado», Revista de Derecho del Transporte, $\mathrm{n}^{0}$ 2, 2009, pp. 15-22.

— «La entrega de la mercancía» y «Los impedimentos para la ejecución del contrato», en A. Emparanza Sobejano y A. Recalde Castells (dirs.), El contrato de transporte internacional de mercancías por ferrocarril, Civitas, Cizur Menor, 2008, pp.161-175 y 119-137.

-Los impedimentos para la entrega en el transporte de mercancías por carretera, Comares, Granada, 2005.

— «El régimen jurídico de los impedimentos para la entrega en el transporte nacional por carretera», en F. Martínez Sanz (dir.) y Ma . V. Petit Lavall (coord.), I Congreso Internacional de Transporte: los retos del transporte en el siglo XXI, Tomo I, Tirant lo Blanch, Valencia, 2005, pp. 941-964.

Lacruz Berdejo, J.L., Elementos de Derecho Civil II. Derecho de obligaciones, Dykinson, Madrid, 1999. 
-Elementos de Derecho civil, T. II, Vol.1, Parte general. Teoría general del contrato, nueva edición, revisada por Francisco Rivero Hernández, Dykinson, Madrid, 1999.

LEIÑENA, E., y IRÁKULIS, N., El régimen jurídico unificado de la comisión mercantil y el mandato en el derecho de obligaciones y contratos, Dykinson, Madrid, 2007.

LlamaZARes, O., Guía práctica de los INCOTERMS 201O, Global Marketing Strategies, Madrid, 2011.

Llorente Gómez de Segura, C., «Contratos del mercado de servicios (III). Depósito. Transporte. Servicios turísticos», en J.Ma de la Cuesta Rute (dir.), Derecho mercantil II, Huygens, Barcelona, 2014, pp. 145-161.

— «El contrato de transporte de mercancías», en J.Ma . de la Cuesta Rute (dir.) y E. Valpuesta Gastaminza (coord.), Contratos mercantiles, Tomo II, Bosch, Barcelona, 2009, pp. 343-459.

LÓPEZ RICHART, J., Los contratos a favor de terceros, Alicante, 2001.

LÓPEZ RuEDA, F.C., El régimen jurídico del transporte multimodal, La LeyActualidad, Madrid, 2000.

-El régimen jurídico de la carga y descarga en el transporte de mercancías, Servicio Central de Publicaciones del Gobierno Vasco, Vitoria-Gasteiz, 2005.

MAPELLI LÓPEZ, E., Régimen jurídico del transporte, Ministerio de Justicia, Madrid, 1987.

MARTín BERNAL, J.M., La estipulación a favor de tercero, Montecorvo, Madrid, 1985 .

MARTín CASTRO, Ma .P., El transporte multimodal: concepto y sujetos, Ed. Publicaciones Científicas y Profesionales DL, 2001.

MARTíneZ-GiJón MACHUCA, P., «Reservas y reclamaciones en la Ley 15/2009, de 11 de noviembre, del contrato de transporte terrestre de mercancías", Revista de Derecho del Transporte, núm. 6, 2010, pp. 367-386.

Martínez GonzÁlez, P., El transporte de mercancías: responsabilidad por averías, faltas y retrasos, Diaz de Santos, Madrid, 2006.

Martínez Sanz, F., «Sujetos», en J.F. Duque Domínguez y F. Martínez Sanz (dirs.), A. Emparanza Sobjenao y $\mathrm{M}^{\mathrm{a}}$.V. Petit Lavall (coords.), Comentarios a la Ley de Transporte Terrestre, Aranzadi, Cizur Menor, 2010, pp. 75-83.

- «Transporte de mercancías por carretera (I). Transporte interno», en id. (Dir.) y A. Puetz (coord.), Manual de Derecho del transporte, Marcial Pons, Madrid, 2010, pp. 157-185.

-Manual de Derecho mercantil, Vol. II, $23^{\mathrm{a}}$ ed, Tecnos, Madrid, 2016.

-Manual de Derecho mercantil, Vol. II, 15 a ed., Tecnos, Madrid, 2008.

- «Transporte terrestre internacional en régimen de temperatura controlada y responsabilidad del porteador», en Aa.Vv., Diez Años de Derecho Marítimo Do- 
nostiarra, Servicio Central de Publicaciones del Gobierno Vasco, VitoriaGasteiz, 2003, pp. 103-122.

—, y Puetz, A., «Pérdida del beneficio de limitación», en J.F. Duque Domínguez y F. Martínez Sanz (dirs.), A. Emparanza y M ${ }^{a}$ V. Petit Lavall (Coords.), Comentarios a la Ley de Transporte Terrestre, cit., pp. 748 y ss.

Mathieu-Izorche, M.-L., "Une troisième personne bien singulière», Revue Trimestrielle de Droit Civil, enero-marzo de 2003, pp. 51-56.

MATILE, L.-É., Le droit du destinataire dans le transport international de marchandises par chemin de fer, Jaunin, Lausanne, 1958.

Matilla Alegre, R., Contratos de utilización del buque, Bosch, Barcelona, 1988.

Minero ALEJANDRE, G., «El traslado del riesgo en la compraventa internacional de mercaderías», en Á. Carrasco Perea (dir.), Tratado de la compraventa, en Homenaje al profesor Rodrigo Bercovitz, Tomo II, Aranzadi, Cizur Menor, 2013, pp. 1711-1721.

Munar Martínez, J., y Gallego Vara, A., El seguro de transporte de mercancías: Análisis de riesgos y cobertures, Plus Ultra, Madrid, 1987.

MuÑoz SÁNCHEZ, S., «Algunas consideraciones en materia de legitimación activa en el transporte terrestre -nacional e internacional», en F. Martínez Sanz (dir.) y $\mathrm{M}^{\mathrm{a}}$.V. Petit Lavall (coord.), I Congreso Internacional de Transporte: los retos del transporte en el siglo XXI, Tomo I, Tirant lo Blanch, Valencia, 2005, pp. 921-936.

NART FERnÁNDEZ, N., «Notas sobre los contratos a favor de tercero». Anales de la Academia Matritense del Notariado, 1950, pp. 449-475.

Natera Hidalgo, R., Fiscalidad de los contratos civiles y mercantiles, CISS, Bilbao, 2007.

NAVARRo Michel, M., El contrato para persona a designar. Nuevas perspectivas, Dykinson, Madrid, 2004.

Oliva Blázquez, F., Compraventa internacional de mercaderías (ámbito de aplicación del Convenio de Viena de 1980), Tirant Lo Blanch, Valencia, 2002.

Olivencia Ruiz, M., «La tarea unificadora en materia de transporte», en A. Madrid Parra (coord.), Derecho uniforme del transporte internacional: Cuestiones de actualidad, McGraw-Hill, Madrid, 1998, pp.1-22.

ORRIOLS AROCAS, L., Las juntas arbitrales de transporte: Manual práctico, núm. 7, IVET, Valencia, 2002.

OzCÁriz MARCo, F., El contrato de depósito: Estudios de la obligación de guarda, Bosch, Barcelona, 1997.

PACCHIONI, G., Los contratos a favor de tercero. Estudios de Derecho romano, civil y mercantil, trad. de la última edición italiana por F. Javier Osset, Editorial Revista de Derecho Privado, Madrid, 1948. 
Padilla González, R., Clavero Ternero, M., y Pendón Meléndez, M.Á., «Transportes», en G.J. Jiménez Sánchez (coord.), Lecciones de derecho mercantil, Tecnos, Madrid, 2010, pp. 516-568.

PASQUau Liaño, M., La gestión de negocios ajenos, Montecorvo, Madrid, 1986.

PENDón MELÉNDEZ, M.Á., «La obligación de entrega en la venta con expedición», en A. Madrid Parra (coord.), Derecho uniforme del transporte internacional: Cuestiones de actualidad, McGraw-Hill, Madrid, 1998, pp. 325-368.

-«El derecho de disposición», Revista de Derecho del Transporte, núm. 6, 2010, pp. 173-199.

PEÑa Nossa, L., De los contratos mercantiles nacionales e internacionales Negocios del empresario-, $2^{\mathrm{a}}$ ed., ECOE Ediciones, Bogotá, 2006.

PÉrez Conesa, C., El contrato a favor de tercero, Comares, Granada, 1999.

PÉREz Gallardo, L.B., "El contrato a favor de terceros», en Aa.Vv., Derecho de Contratos, Tomo I, Teoría general del contrato, La Habana, 2001.

Perrinjaquet, A., Droit de disposition du destinataire dans le contrat de transport Suisse, Imprimerie de la Société de la Gazette de Lausanne, Lausanne, 1929.

Petit LaVAlL, Ma.V., La responsabilidad por daños en el transporte aéreo internacional de mercancías, Comares, Granada, 2007.

Piloñeta Alonso, L.M., Las agencias de transporte de mercancías, Bosch, Barcelona, 1997.

- «El privilegio del porteador terrestre y su derecho de retención sobre la mercancía transportada», en Aa.Vv., Actualidad jurídica del transporte por carretera. In memoriam F. M. Sánchez Gamborino, Madrid, 2005, pp. 239-258.

PuETz, A., «Legitimación y prescripción en el seguro ‘de transporte’: ¿conviene reformar la Ley de Transporte Terrestre y la de Contrato de Seguro?», en L.Ma . Miranda Serrano y J. Pagador López, Retos y tendencias del Derecho de la contratación mercantil, Marcial Pons, Madrid, 2017, pp. 754 y ss.

-Derecho de vagones: Régimen jurídico-privado de la utilización de vagones de mercancías en tráfico ferroviario, Marcial Pons, Madrid, 2012.

- «Transporte internacional de mercancías por carretera y sumisión a arbitraje: problemas en la aplicación del art. 33 CMR», Arbitraje, núm. IV-3, 2011, pp. 869 y ss.

— «Derechos y obligaciones del destinatario en la Ley del Contrato de Transporte Terrestre de Mercancías», en F. Martínez Sanz y Ma.V. Petit Lavall, Régimen del transporte en un entorno económico incierto, Marcial Pons, Madrid, 2011, pp. 219-236.

— «Lugar y plazo de entrega de la mercancía al destinatario», «Derechos del destinatario» y «Supuestos de responsabilidad», en J.F. Duque Domínguez y F. Martínez Sanz (dirs.), A. Emparanza Sobejano y $\mathrm{M}^{\mathrm{a}}$.V. Petit Lavall (coords.), Comentarios a la Ley de Transporte Terrestre, Aranzadi, Cizur Menor, 2010, pp. 401-419, 431-448 y 553-575. 
Pulido BEgines, J.L., El concepto de porteador efectivo en el Derecho uniforme del transporte, Marcial Pons, Madrid, 2012.

PuTZEYS, J., Droit des transports et droit maritime, Bruylant, Bruxelles, 1993.

-Le contrat de transport routier de marchandise, Bruylant, Bruxelles, 1981.

QUINTANA CARLO, I., «Contrato de transporte terrestre», en R. Bercovitz Rodríguez-Cano (dir.), Tratado de contratos: Contratación del transporte y la navegación, Tomo V, Tirant Lo Blanch, Valencia, 2009, pp. 5087-5162.

- «Contrato de transporte», en A. Bercovitz Rodríguez-Cano (dir.) y Mª́.Á. Calzada Conde (dir. adj.), Contratos mercantiles, Aranzadi, Cizur Menor, 2001, pp. 665-688.

RAMOs MÉNDEZ, F., La jurisdicción voluntaria en negocios de comercio, Civitas, Madrid, 1978.

RECALDE CASTELlS, A., «La posición jurídica del destinatario en el contrato de transporte de mercancías», Revista de Derecho del Transporte, núm. 6, 2010, pp. 201-214.

-«El derecho a disponer de la mercancía», en A. Emparanza Sobejano y A. Recalde Castells (dirs.), El contrato de transporte internacional de mercancías por ferrocarril, Civitas, Cizur Menor, 2008, pp. 139-159.

- «La entrega de las mercancías contra reembolso en el transporte internacional por carretera», en F. Martínez Sanz y $\mathrm{M}^{\mathrm{a}}$.V. Petit Lavall (dirs.), Aspectos jurídicos y económicos del transporte: hacia un transporte más seguro, sostenible y eficiente, Tomo I, Servicio de Publicaciones de la Universitat Jaume I, Castellón, 2007, pp. 771-787.

- «El derecho de disposición en el transporte internacional de mercancías por carretera», InDret, núm. 349, 2006.

- «La firma de las partes del contrato en la carta de porte (firma manual y firma impresa, mecánica o electrónica): el régimen del Código de Comercio y del Convenio Internacional sobre Transporte por Carretera (CMR)», Revista General de Derecho, núm. 606, 1995, pp. 2229-2243.

-El conocimiento de embarque y otros documentos del transporte; función representativa, Civitas, Madrid, 1992.

Remond-Goullloud, M., Droit maritime, $2^{\text {a }}$ ed., Pedone, Paris, 1993.

RiBELLES ARELLANO, J.M ${ }^{\mathrm{a}}$., «El transporte nacional de mercancías por carretera», en J.L. Concepción Rodríguez (dir.), El contrato de transporte, Manual de Formación Continuada 21, Vol. I, Consejo General del Poder Judicial, Madrid, 2003, pp. 303-352.

Roca Sastre, R. Ma., y Puig-Brutau, J., Estudios de Derecho Privado, Vol. I, Editorial Revista de Derecho Privado, Madrid, 1948.

RODRíGueZ BuRBANO, A.Y., Transporte multimodal: Régimen jurídico y responsabilidad del porteador, tesis doctoral, Castellón de la Plana, 2010. 
RodríGuez GONZÁLEZ, J.I., El principio de relatividad de los contratos en el Derecho español, Colex, Madrid, 2000.

RodríGuez SÁncheZ, S., «Depósito y enajenación de las mercancías», Revista de Derecho del Transporte, núm. 6, 2010, pp. 233-253.

Ruiz RodRíguez, J.M., Transporte de mercancías por carretera: Manual de competencia profesional, Marge Books, Barcelona, 2013.

Ruiz SorA, J.M ${ }^{\mathrm{a}}$., «Problemas de legitimación en la acción de resarcimiento por averías y faltas en el transporte marítimo», Anuario de Derecho Mercantil, vol. I, 1981, pp. 213-245.

SACRistán Represa, M., «Rechazo de bultos», en J.F. Duque Domínguez y F. Martínez Sanz (dirs.), A. Emparanza Sobejano y M ${ }^{\mathrm{a}}$.V. Petit Lavall (coords.), Comentarios a la Ley de Transporte Terrestre, Aranzadi, Cizur Menor, 2010, pp. 333-345.

SÁNCHEZ-GAMbORINo, F.J., «El nuevo modelo IRU-2007 de carta de porte 'CMR'», en F. Martínez Sanz y Ma ${ }^{\mathrm{a}}$.V. Petit Lavall (dirs.), Estudios sobre derecho y economía del transporte: reforma y liberalización, Tecnos, Madrid, 2009, pp. 356-381.

- «Contrato de transporte y contrato de seguro de transporte», en J.L. Concepción Rodríguez (dir.), El contrato de transporte, Manuel de Formación Continuada 21, vol. I, Consejo General del Poder Judicial, Madrid, 2003, pp. 462521.

-El contrato de transporte internacional. CMR, Tecnos, Madrid, 1996.

-, y Gaitán Rebollo, J., Factbook. Transporte de mercancías por carretera, Aranzadi, Cizur Menor, 2010.

SÁNCHEZ CALERO, F., El contrato de transporte marítimo de mercancías; Reglas de la Haya-Visby, Hamburgo y Rotterdam, $2^{\mathrm{a}}$ ed., Aranzadi, Cizur Menor, 2010.

-Instituciones de derecho mercantil, Vol. II, Títulos y valores, contratos mercantiles, Derecho concursal y marítimo, $21^{\text {a }}$ ed., Editoriales de Derecho Reunidas, Madrid, 1998.

SÁNChEZ ORTIZ, F.-J., «Impedimentos surgidos en la ejecución del servicio de transporte (Comentario a los artículos 14 a 16 de la Convención CMR)», Revista General de Derecho, 1987, p. 2527-2537.

SANCHO GARGALLO, I., «Transporte marítimo de mercancías en régimen de conocimiento de embarque», en J.L. Concepción Rodríguez, El contrato de transporte, Manuales de Formación Continuada 21, Vol. I, Consejo General del Poder Judicial, Madrid, 2003, pp. 27-83.

SCAPEL, P., Traité théorique et pratique sur les transports par mer-terre-eauair-fer: le destinataire des marchandises, Librairie générale de droit et de jurisprudence, Paris, 1958.

SECO CARO, E., «Compraventas especiales y contratos afines en derecho mercantil», en G.J. Jiménez Sánchez (coord.), Derecho Mercantil II, Marcial Pons, Madrid, 2010, pp. 339-354. 
-El contrato mercantil de compraventa, Marcial Pons, Madrid, 2009.

Silvestre MarTí, E., Manual del consignatario marítimo; Obligaciones y responsabilidades, Iberediciones, Madrid, 1993.

TAmayo CARMona, J.A., Responsabilidad y riesgo contractual: normas de la convención de Viena, sobre venta internacional de mercaderías e incoterms 200o, Tirant Lo Blanch, Valencia, 2002.

Tirado SuÁrez, F.J., «Los seguros de daños», en G.J. Jiménez Sánchez (coord.), Derecho Mercantil II, Marcial Pons, Madrid, 2010, pp. 793-780.

Tobío Rivas, $\mathrm{A}^{\mathrm{a}}$.M., Los transitarios en el transporte nacional e internacional: Régimen jurídico privado, Comares, Granada, 2007.

Truyol y SERRA, A., Historia de la filosofía del Derecho y del Estado, 2. Del Renacimiento a Kant, $3^{\mathrm{a}}$ ed., Alianza Editorial, Madrid, 1988.

URÍA, R., Derecho Mercantil, 24a ed., Marcial Pons, Madrid, 1997.

-, MenÉndeZ, A. y Alonso Soto, R., «El contrato de transporte», en R. Uría y A. Menéndez, Curso de Derecho Mercantil, Tomo II, La contratación mercantil. Derecho de los valores. Derecho concursal. Derecho de la navegación, $2^{\text {a }}$ ed., Civitas, Madrid, 2006, pp. 323-348.

VaQuer Aloy, A., Derecho europeo de los contratos: Libros II y IV del marco común de referencia, Atelier, Barcelona, 2012.

von Tuhr, A., Tratado de las obligaciones, traducido por W. Roces, edición al cuidado de J.L. Monereo Pérez, Comares, Granada, 2007.

VIGNALI, C., Il trasporto terrestre: verso una responsabilità oggettiva del vettore, Giuffrè, Milano, 2000.

ZURIMENDI IsLA, A., «Ejercicio de reclamaciones» y «Acción de repetición entre porteadores sucesivos», en J.F. Duque Domínguez y F. Martínez Sanz (dirs.), A. Emparanza Sobejano y M ${ }^{\mathrm{a}}$.V. Petit Lavall (coords.), Comentarios a la Ley de Transporte Terrestre, Aranzadi, Cizur Menor, 2010, pp. 775-783 y 785-793. 


\section{JURISPRUDENCIA}

\section{Jurisprudencia española}

\subsection{Tribunal Supremo}

STS de 10 de diciembre de 1956 (RJ 1956, 4126).

STS de 28 de junio de 1961 (RJ 1961, 3017).

STS de 18 de diciembre de 1964 (RJ 1964, 5894).

STS de 12 de diciembre de 1968 (RJ 1968, 5842).

STS de 30 de octubre 1971 (RJ 1971, 4520).

STS de 2 diciembre 1975 (RJ 1975, 4319).

STS de 7 de junio de 1976 (RJ 1976, 2634).

STS 15 de julio de 1983 (RJ 1983,4234).

STS de 28 de marzo 1984 (RJ 1984, 1465).

STS de 8 de octubre de 1984 (RJ 1984, 4765).

STS de 26 de octubre de 1985 (RJ 1985, 4955).

STS de 31 de enero de 1986 (RJ 1986, 443).

STS de 29 de abril de 1986 (RJ 1986, 2040).

STS de 10 de junio de 1987 (RJ 1987, 4276).

STS de 14 de julio de 1987 (RJ 1987, 5489).

STS de 6 de febrero de 1989 (RJ 1989, 670).

STS de 6 de marzo de 1989 (RJ 1989, 1998).

STS núm. 465/1993, de 17 de mayo (RJ 1993, 3555).

STS 26 de abril de 1993 (RJ 1993, 2964).

STS de 15 de noviembre de 1993 (RJ 1993, 8913).

STS núm. 1046/1995, de 4 de diciembre (RJ 1995, 9157).

STS núm. 382/1997, de 8 de mayo (RJ 1997, 3876).

STS núm. 464/1997, de 30 de mayo.

STS núm. 1269/1998, de 31 de diciembre (RJ 1998, 9769).

STS núm. 273/2000, de 21 de marzo (RJ 2000,2022).

STS núm. 309/2001, de 31 de marzo (RJ 2001, 4780).

STS núm. 381/2001, de 19 de abril (RJ 2001, 6884).

STS núm. 558/2001, de 18 de junio (RJ 2001, 4345).

STS núm. 918/2003, de 8 de octubre (RJ 2003, 7383). 
STS núm. 1088/2004, de 11 de noviembre (RJ 2004, 6893).

STS núm. 189/2006, de 8 de marzo (RJ 2006, 1074).

STS núm. 624/2007, de 6 de junio (RJ 2007, 5423).

STS núm. 644/2008, de 8 de julio (RJ 2008, 3353).

STS núm. 919/2011, de 23 de diciembre (RJ 2012, 1895).

STS núm. 611/2014, de 4 de noviembre (RJ 2015, 9).

\subsection{Audiencias Provinciales}

\section{Álava}

SAP Álava (Sección $1^{\mathrm{a}}$ ) núm. 305/2000, de 19 de julio (AC 2000, 2208).

\section{Alicante}

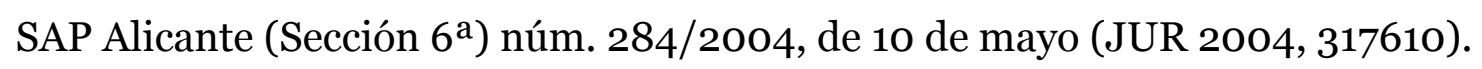

SAP Alicante (Sección 6ª) núm. 332/2004, de 4 de junio (AC 2004, 1935).

\section{Asturias}

SAP Asturias (Sección 5a) núm. 25/2004, de 14 de enero (JUR 2004,79845).

\section{Barcelona}

SAP Barcelona (Sección 15 ${ }^{\mathrm{a}}$ ) de 15 de marzo de 2000 (AC 2000,3591).

SAP Barcelona (Sección 15ª) de 13 de febrero de 2003 (JUR 2004, 14188).

SAP Barcelona (Sección 15 ${ }^{\mathrm{a}}$ ) núm. 407/2012, de 5 de diciembre (JUR 2013, 74139).

SAP Barcelona (Sección 15ª) núm. 410/2014, de 17 de diciembre (JUR 2015, 11501).

\section{Cádiz}

SAP Cádiz (Sección 5a) de 21 de febrero de 2003 (JUR 2003, 157584).

\section{Cantabria}

SAP Cantabria (Sección 2a) núm. 698/2012, de 21 diciembre (AC 2013, 1911).

\section{Granada}

SAP Granada (Sección 4a) núm. 378/2004, de 18 de junio (AC 2004, 1327).

\section{Madrid}

SAP Madrid (Sección 12ª) núm. 439/2000, de 19 de junio (AC 2000, 1987).

\section{Valencia}

SAP Valencia de 12 de abril de 1995 (AC 1995, 796).

SAP Valencia (Sección 11 a) núm. 550/2003, de 29 de septiembre (AC 2003, 2023).

SAP Valencia (Sección 6 ${ }^{\mathrm{a}}$ ) núm. 777/2003, de 13 de noviembre (JUR 2004/100029). 
SAP Valencia (Sección 9 ${ }^{\text {a) }}$ núm. 89/2009, de 16 de abril (JUR 2009, 258527).

SAP Valencia (Sección 9a) núm. 94/2011, de 1 de marzo (JUR 2011, 169758).

\section{Zaragoza}

SAP Zaragoza (Sección 4a) núm. 204/2003, de 7 de abril (AC 2003, 1232).

\section{Jurisprudencia comparada}

Sentencia del BGH de 25 de junio de 1971 ( $B G H Z$ 56, p. 273).

Sentencia del BGH de 28 de febrero de 1977 (BGHZ 69, pp. 82 y ss.).

Sentencia del BGH de 17 de febrero de 1978 ( $B G H Z$ 70, pp. 327 y ss.).

Sentencia del BGH de 12 de noviembre de 1979 ( $B G H Z$ 75, p. 323).

Sentencia del BGH de 10 de mayo de 1984. 